Universidad NACIONAL dE LA PLATA

Facultad de Humanidades y Ciencias de la Educación Secretaría de Posgrado

Tesis de Doctorado:

\title{
Lógicas políticas en tensión: La Tendencia Revolucionaria del Peronismo y su participación en el gobierno constitucional de la provincia de Buenos Aires (1973-1974)
}

\author{
Tesista: Prof. Fernanda Tocho \\ Directora: Dra. Mora González Canosa \\ Co-directora: Prof. Ana Barletta
}

Ensenada, mayo de 2020 


\section{INDICE}

Agradecimientos $\quad 5$

INTRODUCCIÓN 8

1. Presentación del tema, ubicación en el contexto histórico y fundamentación $\quad 8$

2. Algunas definiciones previas de nuestro actor 14

3. Estado de la cuestión y enfoque de la investigación 18

4. Problema, interrogantes y objetivos de la tesis 30

4.1 El problema de investigación $\quad 30$

4.2 Interrogantes e hipótesis de trabajo 32

4.3 Objetivos de la tesis 35

5. Metodología, plan de trabajo y uso de las fuentes 36

6. Contenido de la Tesis 43

\section{CAPÍTULO I: LA TENDENCIA REVOLUCIONARIA EN LA} APERTURA DEMOCRATICA. Actores, estrategias y prácticas frente a la disyuntiva política (1971-1972)

1.1 Del ocaso de la Revolución Argentina al despertar de la democracia: el GAN, Lanusse y Perón.

1.1.2 Perón: del apoyo a las "formaciones especiales" a la reorganización partidaria 50

1.1.3 La Tendencia Revolucionaria del Peronismo en los años 1971-1972. 55

1.2 Experiencias de radicalización movimientistas: $\quad 62$

-Los "oscuros" de las FAP $\quad 62$

-Descamisados: Acción Peronista y el grupo de la JP de Vicente López 66

-La Juventud Peronista de La Plata y la Federación Universitaria de la Revolución $\begin{array}{ll}\text { Nacional (FURN) } & 68\end{array}$

-Montoneros, las UBR y el fenómeno de la JP Regionales 72

1.3 Lecturas y reposicionamientos de las agrupaciones de la Tendencia frente al escenario electoral 75

1.3.1 El GAN y las primeras reacciones generadas $\quad 76$

1.3.2 El apoyo a la vía electoral: táctica y/o estrategia en los grupos de la

$\begin{array}{ll}\text { Tendencia } & 82\end{array}$ 


\section{CAPÍtUlo II: DEL LUCHE Y VUELVE A LA CAMPAÑA}

ELECTORAL. Internas, candidaturas $y$ juego partidario de la Tendencia en la provincia de Buenos Aires

2.1 Activismo electoral temprano: el caso de JP/FURN de La Plata y su integración a Montoneros.

2.2 La reorganización partidaria a nivel nacional: la elección de Cámpora como candidato y los antagonismos al interior del peronismo 95

2.3 La interna bonaerense: del enfrentamiento violento a la verticalidad 102

2.4 La campaña del FREJULI en el verano de 1973 y el lugar de la Tendencia en el triunfo electoral. Tensiones y debates frente al trabajo político partidario

\section{CAPÍTULO III: DE LA RESISTENCIA ARMADA AL DESEMPEÑO} INSTITUCIONAL. La llegada de la TR a la gobernación provincial

3.1 Entre la revolución y la institucionalización: la Tendencia en el gobierno

3.2 De las elecciones a la asunción: los (des)encuentros con Perón.

\section{CAPITULO IV: LA PARTICIPACIÓN DE LA TENDENCIA EN EL MINISTERIO DE BIENESTAR SOCIAL}

4.1 La llegada del Dr. Floreal Ferrara al Ministerio de Bienestar Social

4.1.1 La República de los Niños y el fenómeno de las tomas: cruce de tiempos y metodologías de acción política en el orden institucional

4.1.2 Experiencias innovadoras y/o ¿revolucionarias? en salud, minoridad y desarrollo social

4.2 Primeras voces de alarma: Ezeiza y renuncia de Cámpora

CAPITULO V: LOS "MINISTERIOS ROJOS". EL CASO DE ASUNTOS AGRARIOS Y OBRAS PÚBLICAS 
5.1.2 Política agraria y social: las Unidades Básicas de Producción y Solidaridad Social

5.1.3 "La tierra para quien la trabaja": El Parlamento Agrario

5.1.4 Un "socialismo sui generis"

5.2 "Convertir nuestro lugar de trabajo en una trinchera de lucha". La gestión de Alberto González en el MOP

5.2.1 Hacia una estructura política de masas en el MOP: las Mesas de Trabajo y las Comisiones de Respuesta Inmediata (CERI)

5.2.2 Militancias múltiples: el estado, el barrio y la organización

201

5.2.3 "Por el camino de la reconstrucción y la liberación nacional": El caso del dique de Paso de las Piedras

204

\section{CAPITULO VI: APUESTAS FRENTISTAS DESDE EL MINISTERIO DE GOBIERNO. EL OPERATIVO DORREGO}

6.1 El contexto: La cruzada contra el "enemigo interno" y las reacciones de la Tendencia

6.2 Política frentista: militares y militantes "codo a codo" por la Reconstrucción Nacional 215

6.3 Intervención en el territorio: El Operativo Dorrego y su impacto en la interna peronista

\section{CAPÍTULO VII: LA DESARTICULACION DE UNA EXPERIENCIA}

7.1 Perón presidente: la ofensiva derechista contra la TR se radicaliza 230

7.1.1 La sublevación de los guardiacárceles: ¿un intento de golpe? 235

7.2 Dilemas y quiebres hacia adentro de la TR: el mamotreto y el origen de los Leales

7.3 Los sucesos de Azul: la renuncia de Bidegain y el ocaso del proyecto institucional de la Tendencia $\quad 250$

7.3.1 El Acta de Seguridad Nacional y las Reformas al Código Penal 251

7.3.2 La precipitación de los acontecimientos: el accionar del ERP en Azul 253

7.3.3 Descalabro en la Provincia 257

7.3.4 La despedida de los Ministerios y la "vuelta al llano" 259 
CONCLUSIONES

268

Fuentes y Bibliografía

284 


\section{Agradecimientos}

Esta investigación de largo aliento, si bien implicó un gran esfuerzo en términos individuales -cristalizados en las interminables jornadas de escritura en soledad- es a la vez, como todo proceso intelectual y académico, el resultado de la concurrencia y el apoyo de una gran cantidad de personas, colectivos e instituciones que fueron fundamentales para su concreción.

En primer lugar, quiero reconocer la labor de varias mujeres que, con su enorme inteligencia y bondad, se conviertieron en faros esenciales de esta investigación: comienzo por mis queridas directoras, Mora González Canosa y Ana María Barletta, con quienes me une hoy un vínculo profesional y afectivo trascendente. Ellas fueron quienes desde el primer momento me alentaron a continuar con mi tema y me hicieron ver el sentido valioso de esta investigación, cuando se encontraba aún en los tramos iniciales y yo misma dudaba de su posible concreción. A través de hermosas jornadas de intercambio y debate en nuestra "oficina-café", lograron transmitirme su confianza depositada en mi trabajo, el cual se enriqueció notablemente gracias a sus lecturas precisas, sus comentarios lúcidos, sus observaciones analíticas profundas, y su acompañamiento sensible y cariñoso, todos elementos fundamentales sin los cuales esta tesis no hubiera podido ser escrita. Por todo esto, mi admiración, gratitud y afecto con ambas es infinito.

Otras tres mujeres a las que les quiero agradecer y dedicar unas palabras especiales son Ana Julia Ramírez, Laura Lenci y Lucía Abbattista. Con ellas también me une no solo una relación profesional que ha sido de las cosas más gratificantes que me han sucedido a lo largo de mi carrera, sino una amistad construida sobre lazos de compañerismo y admiración. Con su inagotable generosidad y su capacidad intelectual y política, ellas también a través de numerosos intercambios a lo largo de estos años se conviertieron en un motor muy importante para pensar y volcar por escrito gran parte de las ideas que están aquí presentes.

Con ellas además he compartido varios espacios institucionales y académicos que han sido una cantera ingente de ideas, miradas y discusiones sobre la historia reciente y la política, que han nutrido algunas de las reflexiones más significativas de mi investigación. Me refiero al Equipo de Investigación "La política y sus formas: 19731976”, que dirigió Ana María Barletta y Jorge Cernadas en sus primeros 4 años, y que 
luego continuó Laura Lenci y Roberto Pittaluga, radicado en el Centro de Investigaciones Sociohistóricas (CISH) de la Facultad de Humanidades y Ciencias Sociales de la UNLP. Junto a Horacio Bustingorry, Magdalena Lanteri y Talia Meschiany compartí algunos de los momentos mas estimulantes de mi formación como investigadora, intercambiando lecturas y discusiones que fueron sumamente enriquecedoras, y que me enseñaron algo fundamental: que la práctica de la investigación histórica puede alcanzar altísimos grados de rigurosidad y análisis, y a la vez constituirse en un modo potente de intervención política. Para todxs ellxs mi agradecimiento profundo, al igual que mi reconocimiento por su extraordinaria condición humana e intelectual.

Otros dos espacios y colectivos que me acompañaron en este trayecto y que representaron ámbitos de un notable estímulo intelectual y de compromiso político, son la Maestría en Historia y Memoria y la Revista Aletheia. Gracias especialmente a Laura Codaro por su alegría y su empuje cotidiano, y a todxs y cada unx de mis compañerxs de este hermoso grupo humano de quienes aprendo día a día, y con quienes compartimos el maravilloso trabajo y la militancia de mantener viva la memoria y la defensa por los derechos humanos.

Quisiera agradecer de manera especial a Anibal Viguera, quien no sólo fue uno de los mejores profesores que tuve en mi carrera de grado, y con quien me une una identificación muy estrecha en su forma de pensar y recuperar nuestra historia reciente en el presente, sino que además fue una de las personas que más me apoyó en las instancias iniciales de este proyecto, acompañando la presentación a CONICET, institución pública gracias a la cual obtuve la beca doctoral que me permitió financiar esta investigación durante los primeros 5 años.

También quisiera agradecer a dos compañeros y colegas, Horacio Bustingorry y Juan Besoky, por su inmensa generosidad a la hora de compartir materiales de archivo y sus avances de investigación que fueron también insumos esenciales para mi tesis. Su predisposición al intercambio de ideas y fuentes, de manera franca y abierta, resultaron un aporte invalorable para mis indagaciones, abonando con sus comentarios agudos al desarrollo de algunas reflexiones centrales para mi trabajo. Sumo también mi agradecimiento a Horacio Robles, cuyos trabajos sobre la JP platense fueron muy enriquecedores para mi investigación, y es quien además con su enorme amabilidad me facilitó material de archivo del Ministerio de Obras Públicas que fue clave para complementar el trabajo de entrevistas. 
Por otra parte, merecen una mención especial y mi profundo agradecimiento todas las personas que accedieron a que las entreviste, otorgándome parte de su tiempo y dedicación, junto a sus invaluables recuerdos y viviencias. Sin la colaboración de sus testimonios y documentos, esta tesis tampoco podría haberla escrito.

Agradezco a la Facultad de Humanidades y Ciencias de la Educación, que es ya mi segunda casa y mi lugar de pertenencia, en donde me formé como docente e investigadora, y además aprendí el valor inestimable de la defensa de la Educación Pública y la militancia política por ese derecho. Y es el lugar en el que conocí algunas de las personas que hoy representan los afectos más importantes de mi vida.

A mis queridxs compañeros de la carrera del Profesorado de Historia y del Centro de Investigaciones Sociohistóricas: Leandro Sessa, Marcelo Starcenbaum, Juan Carnagui, Javier Guimet, Cristian Casco que me acompañaron en este camino, haciéndolo mucho más agradable, y siempre me brindaron su palabra de aliento para seguir adelante y poder concluir este proyecto.

A mis compañerxs de la Secretaría de Posgrado de la FaHCE, que convierten cotidianamente mi lugar de trabajo en un espacio agradable de compañerismo y mucho humor, y a Pablo Moro por haberme brindado su ayuda en este último tramo.

Por último, aunque no menos importante, el agradecimiento infinito a mis afectos:

A mis amigas "de la facu" que ya son hermanas de la vida: Mariel Giacomone, Nadia Nieto, Belén Castro, Laura Monacci, Catalina Curcciarelo y Lucía Abbattista. Por hacerme feliz con su presencia, por prestarme el oído en mis momentos de desanimo, por contenerme en mis crisis y darme la confianza necesaria para terminar este trabajo. Las mismas palabras caben para Angie, Carola, Charo y Sole, por el cariño inmenso que nos une, y porque también me bancaron y celebraron alegremente cuando concluí esta larga tarea.

A mi mamá y a mi hermana, que son mi pilar y mi sostén incondicional. Y que junto con mi querido Jaime me enseñaron a no bajar los brazos y a luchar por mis sueños con enorme dedicación y esfuerzo.

A Sebastián, mi amor y compañero de la vida, que nunca dejó de apuntalarme en este camino tan sinuoso, y al que me une el amor más extraordinario: nuestro pequeño Juan Sebastián. Esta tesis no hubiera podido escribirla sin la compañía de ambos, de sus abrazos, besos y sus risas.

La Plata, 22 de mayo de 2020 


\section{INTRODUCCIÓN}

\section{Presentación del tema, ubicación en el contexto histórico y fundamentación:}

El corto pero denso período que va desde 1973 a 1976 constituye un momento central de nuestra historia reciente, el de la experiencia del retorno del peronismo al poder luego de 18 años de proscripción y del exilio de Juan Domingo Perón. Este proceso ha sido interpretado por gran parte de la bibliografía académica como el cierre del ciclo histórico abierto en 1955, signado por la convergencia de diversas crisis producto tanto del agotamiento del modelo de acumulación vigente, como también por los efectos de la proscripción del peronismo, llevando a un profundo distanciamiento entre el Estado y la sociedad civil (Cavarozzi, 1983; Pucciarelli, 1999). Un dato insoslayable de esta etapa que explica en gran parte la extensa inestabilidad institucional que la caracterizó y las transformaciones políticas arriba mencionadas- lo constituye el "juego imposible” en el que se vio atrapado el régimen político durante esos años, al intentar combinar la pretensión de consenso social y legitimidad con la marginación de la fuerza política mayoritaria, siendo a la vez prisionero de factores de poder como las Fuerzas Armadas, las corporaciones empresarias y los sindicatos. Este proceso, sumado a los intentos de implantar un proyecto de reestructuración económica con altos costos sociales (O’Donnell, 1972; James, 2003) tuvo como uno de sus resultados el fuerte descreimiento en el funcionamiento del sistema democrático y de partidos dentro de sectores cada vez más amplios de la sociedad, lo que a su vez contribuyó a que una parte significativa de los actores políticos y sociales del momento asumieran la violencia como una práctica política legítima en la resolución de los conflictos.

Acompañando esta crisis de legitimidad del sistema político y como fruto también de estas tensiones irresueltas, varios estudios han señalado el surgimiento de un proceso de modernización cultural y radicalización política durante estos años, que afectó a amplios sectores de la sociedad civil y política transformando sustantivamente sus identidades de origen, sus discursos y sus prácticas (Altamirano, 2001; Gilman, 2012; Manzano, 2017). Uno de sus efectos más notorios, como señala Tortti (1999; 2009), fue el crecimiento de un campo general de protesta y la emergencia de un nutrido conglomerado de fuerzas sociales y políticas que ha sido denominado "Nueva Izquierda". En este espacio convergieron diversos grupos y actores quienes, más allá de sus diferencias de origenes 
políticos e ideológicos, comenzaron a articular un lenguaje y un estilo político común que giraba en torno a las demandas de "liberación nacional", "socialismo" y "revolución", y que abrazaba nuevas formas de resistencia y de lucha política que iban desde la protesta y la acción directa al activismo armado (Tortti, 1999; 2009; 2014).

La explosiva combinación de estos factores llegó a su clímax con el gobierno militar de la "Revolución Argentina", el cual en su afán de "suspender" la política por tiempo indeterminado (De Riz, 2000) y llevar a cabo un programa autoritario y fuertemente regresivo contra los sectores medios y asalariados, pareció dar fundamento, como un recurso válido y justo, al ejercicio de la "violencia de los de abajo" (O’ Donnell, 1982), sentando las condiciones para el pasaje de una cultura política defensiva y de resistencia, a una etapa ofensiva de activa movilización y confrontación (Gordillo, 2003; RamírezViguera, 2006)

El despliegue de estos sucesos de orden nacional junto con el impacto de otros de carácter internacional (Revolución Cubana; guerra de Vietnam y proceso de descolonización tercermundista; renovación posconciliar de la Iglesia Católica y el diálogo cristianomarxista) derivaron en la emergencia en la escena pública de las organizaciones políticomilitares de signo peronista y marxista, las que guiadas por la idea de una posible e inminente revolución, plantearon bajo diversas estrategias la necesidad de llevar a cabo la lucha armada como vía central para acceder al poder y construir un orden socialista (Rot, 2016). El surgimiento de las organizaciones guerrilleras lejos estuvo de constitur un fenómeno netamente nacional, siendo el contexto de la guerra fría, el mundo bipolar y la instauración de regímenes dictatoriales de nuevo tipo en América Latina (con formas inucitadas de represión) el escenario mayor que alimentó las esperanzas en la lucha armada como vía para lograr una transformación social, en toda una generación de jóvenes a escala continental (Marchesi, 2019)

Paralelamente y en el campo de las transformaciones que durante este periodo se desarrollaron en el peronismo, debemos mencionar el fenómeno de la renovación de su composición social a partir de la incorporación masiva de sectores juveniles de clase media, quienes imbuidos del clima de radicalización social y política -y conscientes del persistente arraigo que entre las clases populares mantenía dicha fuerza política y su líder- emprendieron el tránsito hacia esta identidad, entendiendo al peronismo como el estado mayor de conciencia al que había llegado la clase trabajadora, y por ello mismo como un movimiento potencial -o en sí mismo- revolucionario capaz de llevar adelante el proceso de liberación nacional y social (Gillespie, 1987; Altamirano, 2001; Bozza, 2006; 
Lanusse 2005; Caviasca 2009; González Canosa, 2013; Campos, 2012; Gil, 2018). Este camino de radicalización será emprendido tanto por grupos de jóvenes y militantes provenientes del peronismo de la resistencia (Fuerzas Armadas Peronistas-FAP) como por otros cuyos orígenes se remontan a la izquierda marxista-guevarista (Fuerzas Armadas Revolucionarias-FAR) y el catolicismo posconciliar (Montoneros y Descamisados).

Como corolario de estos hechos, un activo movimiento de contestación social generalizada cobró inusitada fuerza, a partir de los sucesos del Cordobazo y las revueltas populares subsiguientes, que marcaron el comienzo del fracaso del proyecto de la "Revolución Argentina", llevando a una situación caracterizada por algunos autores como “crisis de hegemonía” o de “dominación celular” (Portantiero, 1977; O’Donnell, 1982), o incluso como el inicio de una fase ascendente de lucha de clases y "guerra civil" (Bonavena, 1998; Izaguirre, 2009). Este escenario abrió el camino para la búsqueda de una salida política consensuada desde las Fuerzas Armadas, preocupadas ante el avance del accionar guerrillero y el extendido consenso que sus prácticas encontraban en amplios sectores de la sociedad civil (Svampa, 2003; Anzorena, 1996).

De esta manera surgió el proyecto de salida electoral encabezado por el General Alejandro Agustín Lanusse, que buscó -apelando al "Gran Acuerdo Nacional"reencauzar la protesta y conflictividad social dentro de los marcos institucionales, aislando a los núcleos duros de la "nueva oposición" y reconstituyendo el poder estatal a través de la conciliación con los partidos políticos tradicionales, incluyendo al peronismo (Barletta-Cernadas, 2006; Pucciarelli, 1999; Tortti, 1999).

En este contexto, los sectores de la izquierda peronista nucleados en lo que se denominó Tendencia Revolucionaria cobraron un inusitado protagonismo, al ser reconocidos y reivindicados por Perón, quien no dudaba en incentivar las prácticas y expectativas de la “juventud maravillosa” y las "formaciones especiales" en función del juego de disputas y presiones que lo enfrentaban al gobierno militar (De Riz, 2000; Ollier 1986 y 1989). El activo plan de movilización encabezado por estos grupos en la campaña del "Luche y Vuelve" y el tan ansiado retorno del líder exiliado, en noviembre de 1972, confirmaron la importancia de estos sectores dentro del Movimiento Peronista, en detrimento de los grupos gremiales y de la rama política, fuertemente cuestionados en función del papel negociador que muchos de sus dirigentes habían demostrado durante los gobiernos del período (James, 2003; Bernetti, 1983). 
Finalmente, la asunción de Héctor Cámpora tras la victoria del Frente Justicialista de Liberación (FREJULI) en las elecciones presidenciales del 11 de marzo de 1973 marcó el punto culminante de la influencia de la izquierda peronista en el escenario político nacional, fenómeno que se expresó también en los diversos cargos ministeriales y parlamentarios que quedaron en manos de personas afines o directamente nucleadas en ese sector.

Al respecto, varios autores han señalado la existencia de "provincias montoneras" (Svampa, 2003; Bonavena, 2009; Servetto, 2010; Antúnez, 2015, De Marinis y Abalo, 2005) en relación con la posición cercana -aunque de manera diversa y en diferentes grados- que ligaba a muchos gobernadores peronistas con los militantes de la Tendencia Revolucionaria. Dentro del grupo de provincias mencionadas, además de Salta, Mendoza, Santa Cruz y Córdoba, existe consenso en la literatura en incluir a la provincia de Buenos Aires, siendo la gobernación de Oscar Bidegain reconocida ampliamente (tanto por sus contemporáneos como por la bibliografía académica) por sus simpatías con la izquierda del Movimiento.

Más concretamente, el peso de este actor en dicha experiencia se revela en el papel fundamental que sus organizaciones desempeñaron durante la campaña electoral, a través de la activa movilización y el apoyo explícito otorgado al futuro gobernador dentro de la interna partidaria, como también en la incorporación directa de sus miembros en ámbitos sustantivos de gestión ejecutiva y parlamentaria, junto a los programas y medidas que desplegaron desde el espacio institucional provincial a lo largo de 1973.

Por último y con relación a esto, será el vínculo entre Bidegain y la Tendencia Revolucionaria el sindicado como causa principal de la crisis terminal de su gobierno, en un contexto político adverso y de enfrentamiento abierto con los sectores de la derecha peronista, quienes contaban con el aval de Perón y su proyecto de disciplinar a la fracción dura del Movimiento (Godio, 1986; Gillespie 1987; De Riz 2000; Servetto 2010; Franco, 2012).

Tomando en consideración el tratamiento que durante largo tiempo caracterizó los estudios sobre "los años setenta" y el complejo periodo de 1973-1976, centrados principalmente en tópicos como la violencia política, la militarización de los conflictos y la primacía de la lucha armada (Oberti-Pittaluga, 2006; Acha, 2010), nuestro trabajo se propone reconstruir un fenómeno que ha sido poco abordado por los estudios académicos: la inserción en los aparatos de Estado de sectores del peronismo revolucionario. Más precisamente, y a partir de un estudio de caso centrado en la 
provincia de Buenos Aires, analizaremos los proyectos, las iniciativas y las trayectorias político-institucionales de los/as militantes de la Tendencia Revolucionaria del peronismo en el gobierno constitucional de Oscar Bidegain.

En líneas generales nuestra propuesta apunta a la ampliación del marco analítico del período en cuestión, a través de una perspectiva que busca poner en el centro de la escena la experiencia de la Tendencia Revolucionaria sin reducirla a su dimensión armada, pensando en un sentido amplio y a la vez complejo las múltiples formas de la política (Barletta, 2010; Monasterolo y Pittaluga, 2018) concebidas y desplegadas por este actor en un momento crucial y vertiginoso de nuestro pasado reciente. Así, desde este posicionamiento analítico, lejos de juzgar como "irracionales", "contradictorias" o "excluyentes" las acciones armadas e institucionales emprendidas por sus militantes, se buscará reponer y comprender la lógica política integral que guió sus diferentes apuestas -en sus momentos de mayor articulación y de disputa- volviendo inteligibles sus prácticas y las tensiones implicadas en su devenir.

En este marco entonces será de especial interés para nuestra tesis observar los conflictos y dilemas derivados de un proceso político que llevó a militantes portadores de un ideario revolucionario y de prácticas políticas inscriptas en una estrategia de guerra integral (propaganda y lucha armada, movilizaciones y protestas callejeras, asambleas, tomas de fábricas, establecimientos públicos y poblados, etc) a ocupar espacios institucionales, en lo que fue un intento por compatibilizar lógicas de acción disímiles pero concebidas como parte de un mismo proyecto político: la construcción de la "patria socialista". Asimismo, se atenderá a las resignificaciones que sobre sus prácticas militantes y el vínculo con el compromiso revolucionario realizaron algunos grupos de la Tendencia en ese pasaje a la esfera estatal.

Por lo dicho, estimamos relevante la elección de la Tendencia Revolucionaria como actor principal de nuestra investigación en función no sólo del lugar central que ocupó en el escenario político que definió el triunfo electoral de 1973, sino por el hecho de que condensó las principales tensiones que atravesaron al campo político en su conjunto a lo largo del proceso estudiado: revolución/democracia, insurrección/institucionalización, derecha/izquierda peronista, partido político/movimiento/vanguardia armada.

Por otra parte, la génesis y evolución histórica de este actor nos sitúa de lleno en el terreno de los discursos y prácticas políticas desarrolladas por un amplio espacio político dentro del peronismo, que desde fines de los años sesenta y principios de los setenta se identifica cada vez más con una línea "combativa", "revolucionaria" y de "izquierda" 
dentro del Movimiento (Bozza, 2001). Esto nos permitirá abordar también el problema del conflicto político-ideológico con los sectores denominados de la "ortodoxia" peronista, desde el punto de vista discursivo y fundamentalmente desde las acciones y prácticas políticas.

Otro de los desafíos y a la vez potencialidades que presenta el estudio de la Tendencia Revolucionaria radica en su compleja composición y estructura interna, reuniendo en su seno tanto organizaciones de carácter clandestino-militar (Montoneros, Descamisados, FAR, FAP) junto con otras orientadas al trabajo de superficie en diferentes espacios institucionales dentro del partido justicialista y en los denominados frentes de masas (Juventud Peronista Regionales-JPR, Juventud Trabajadora Peronista-JTP, Juventud Universitaria Peronista-JUP, Movimiento Villero Peronista-MVP, Agrupación Evita-AE, Unión de Estudiantes Secundarios-UES, Movimiento de Inquilinos Peronistas-MIP, Peronismo de Base-PB) y un conjunto de actores individuales como dirigentes políticos, sindicalistas, intelectuales, gente del mundo de la cultura, artistas y universitarios que adherían a lo que genéricamente se consideraba el "socialismo nacional" y se sentían parte de la Tendencia. Reconocer y analizar dicha heterogeneidad permitirá adentrarnos en la amplitud de imaginarios y prácticas que desplegaron los sectores del peronismo revolucionario en un contexto político extremadamente complejo y de alta incertidumbre, como así también abordar las tensiones derivadas del intento de conjugar dentro de un proyecto revolucionario (que incluía como metodología el accionar armado) la participación en las estructuras del gobierno democrático.

Por otra parte, el reconocimiento de la diversidad constitutiva de este actor nos permitirá evitar caer en una lectura unívoca de su desempeño (tanto en una dimensión sincrónica como diacrónica), atendiendo a los matices, cambios y/o diferencias que, tanto a nivel general dentro del Movimiento Peronista, como al interior del espacio político de la Tendencia, se fueron desplegando a medida que avanzaba el año 1973.

En tal sentido, acercarnos desde esta perspectiva a las diversas y numerosas iniciativas institucionales (ejecutivas, parlamentarias, de trabajo territorial-barrial, etc.) desarrolladas por los militantes de la Tendencia en el gobierno de Oscar Bidegain, posibilitará analizar el proceso político en cuestión "sin reducir el ethos de los setenta a su sola faz oscura" (Svampa, 2003:435), considerando las múltiples y cambiantes estrategias y apuestas que desarrollaron los actores involucrados en función de los rumbos también cambiantes que tomaba el proceso político. 
En síntesis, consideramos que la presente investigación puede realizar un aporte relevante al estudio y comprensión del problema de la dificultosa institucionalización de los sectores del peronismo revolucionario en el Movimiento y el Estado, lo cual conlleva analizar la conflictiva relación con Perón y los grupos antagónicos de la derecha políticosindical. Como también reflexionar sobre las tensiones internas de este amplio conglomerado político, derivadas del accionar de las organizaciones armadas peronistas y de sus mútiples agrupaciones de base, en su doble objetivo de retorno del peronismo al poder y de continuación de la estrategia revolucionaria.

Finalmente, el recorrido por esta compleja trama de relaciones, disputas y enfrentamientos político-ideológicos nos permitirá analizar el difícil equilibrio que atravesó la Tendencia Revolucionaria en torno a su necesidad de mantener intacto el vinculo con Perón -lo cual implicaba reconocer su rol como máximo conductor acatando su autoridad en vistas de no perder el lazo político con las masas-, o abandonar esa pretensión para llevar adelante su proyecto revolucionario.

\section{Algunas definiciones previas de sobre nuestro actor}

El nombre Tendencia Revolucionaria (TR) del peronismo se utilizó por primera vez en el Segundo Congreso del Peronismo Revolucionario reunido en Córdoba en enero de 1969, para definir a los grupos que se encontraban a favor de la lucha armada como vía central para enfrentar a la dictadura del General Onganía, creando así lo que consideraban las condiciones necesarias de conciencia y organización del pueblo peronista para la lucha por el retorno de su líder (Gurruchari, 2001; Amorín, 2005). ${ }^{1}$ Más allá de esta denominación nativa, algunos enfoques académicos como el de Laura Lenci (1999) incluyen dentro de la Tendencia a un conjunto más amplio y heterogéneo de actores y organizaciones que se identificaban con el peronismo revolucionario de finales de la década del sesenta y principios del setenta, incluyendo por tanto, además de las

\footnotetext{
1"Estrategia y Táctica Revolucionarias"- Documento presentado en el segundo Congreso del Peronismo Revolucionario en Pajas Blancas, Córdoba, por la Tendencia Revolucionaria del peronismo, Cristianismo y Revolución $\mathrm{N}^{\circ} 12$, marzo 1969. En este Congreso se enfrentaron tres posiciones, una sostenida por el grupo de Gustavo Rearte (MRP) que proponía afianzar primero la organización de la clase trabajadora, para luego iniciar la lucha en el plano militar. Una posición intermedia, sostenida por el grupo de la CGTA, que postulaba afianzar la estructura sindical y lanzar un "frente de resistencia civil" que conjugara diferentes acciones de tipo insurreccional, pero no puntualizaba en la lucha armada; y una última y mayoritaria posición que declaraba la necesidad de lanzar la lucha armada como metodología central para despertar la conciencia revolucionaria de las masas y lograr la toma del poder. Esta postura era sostenida en ese momento por Bernardo Alberte, Alicia Eguren, la agrupación Acción Revolucionaria Peronista de Cooke y el grupo de militantes vinculados a Juan García Elorrio, entre los que se encontraban José Sabino Navarro, Carlos Hobert y Gustavo Lafleur, futuros fundadores de Montoneros (Gurruchari, 2001:253; Amorín, 2005:357)
} 
organizaciones armadas (Fuerzas Armadas Peronistas-FAP, Fuerzas Armadas Revolucionarias-FAR, Montoneros, Descamisados) a los grupos de jóvenes de clase media que desde de diferentes tradiciones político-ideológicas en vías de radicalización se incorporaban al proceso revolucionario a través del peronismo, formando numerosas agrupaciones de base que desarrollaron sus actividades en los frentes de masas, siendo la Juventud Peronista Regionales (JPR) ligada a Montoneros la de mayor peso, pero no la única. Asimismo la autora da cuenta de otros actores menos visibilizados -con diferentes matices ideológicos, diversidad de prácticas políticas y posicionamientos respecto de la lucha armada- que acompañaron este proceso de radicalización y confluyeron en la aspiración de unificarse en torno a una "tendencia revolucionaria" dentro del peronismo, tales como los sindicatos combativos herederos de la CGT de los Argentinos, las organizaciones profesionales de médicos y abogados (entre otras), las Ligas Agrarias del Noroeste Argentino y variadas personalidades del mundo de la cultura que no acordaban necesariamente con la adopción de la lucha armada como principal estrategia revolucionaria, o no por lo menos en todos los momentos y circunstancias en los que se llevó a cabo (Lenci, 1999:174).

Observamos aquí que esta definición amplia y laxa de la Tendencia como un emergente del movimiento de radicalización dentro del campo peronista, logra trascender la focalización exclusiva en sus organizaciones armadas, relevando la heterogeneidad de sus actores, el nexo con otros activismos políticos y la multiplicidad de prácticas políticas encaradas desde la militancia revolucionaria (Gonzalez Canosa y Tocho, 2018). ${ }^{2}$

Por su parte, en el estudio de Lucas Lanusse (2005) sobre los grupos originarios que conformaron la organización armada Montoneros, encontramos una definición de TR diferente, más acotada y específica, y que es utilizada para referir a cuestiones de orden exclusivamente político-ideológico. Este uso surgió y tiene sentido en el marco de las disidencias que comenzaron a perfilarse entre los diferentes grupos de la izquierda peronista, y que hacia 1971-72 se plasmaron como discusiones entre las posiciones movimientistas, tendencistas y alternativistas. Al respecto, y a diferencia de los

${ }^{2}$ Desde la bibiliografía testimonial, José Amorín (2005:361), ex militante de Montoneros, es quien ha definido a la Tendencia en un sentido abarcativo, como expresión de la última etapa en el devenir histórico de los sectores combativos y revolucionarios del Movimiento Peronista, cuyo elemento distintivo, aunque no excluyente hacia 1970 fue la incorporación de los jóvenes de clase media y la conformación de organizaciones guerrilleras. Por otra parte, estudios recientes y pormenorizados dentro del campo académico como los de Antúnez (2015), Pozzoni (2017) y Stavale (2018) utilizan también este significado amplio de la denominación Tendencia, identificando en ella al conjunto heterogéneo de la militancia peronista revolucionaria de los setenta que incluyó además de las organizaciones armadas, a las agrupaciones de superficie y figuras del campo político, sindical, artístico e intelectual no adscriptas necesariamente y de manera orgánica a ninguna de las organizaciones armadas peronistas. 
movimientistas que consideraban al Movimiento Peronista como unido y revolucionario en su conjunto -incluyendo en esa caracterización al mismo Perón como un líder revolucionario-, los tendencistas sostenían que dentro del Movimiento existían diferencias irreconciliables en cuanto a los objetivos estratégicos (enfrentamiento con las burocracias políticas y sindicales), pero reconocían en el mismo una potencialidad revolucionaria y llamaban a dar el combate en su interior. Esta misma posición asumía que si Perón no era revolucionario, por lo menos estaba dispuesto a volcarse en ese sentido, toda vez que la facción que representara a los intereses de la clase obrera hegemonizara la totalidad del Movimiento. De esta forma, se toleraba la convivencia "táctica" con los burócratas y enemigos internos. Asimismo, para este sector, la adopción de metodologías no armadas y la posibilidad de participar de las estructuras institucionales dentro del Movimiento y de las elecciones también se calificaban como apuestas "tácticas" en función del objetivo estratégico mayor. Por último, los alternativistas si bien mantenían la identidad peronista, descartaban de lleno cualquier tipo de convivencia con los "burócratas", adoptando una postura clasista al bregar por la organización política independiente de la clase obrera (Lanusse, 2005:255).

Cabe aclarar que estas clasificaciones deben considerarse como tipos ideales que raramente se daban en estado puro en la realidad, dada la heterogeneidad interna de las organizaciones en cuestión y la variación de sus planteos a lo largo del tiempo. En este sentido, aunque la posición de Montoneros en sus primeros comunicados podría calificarse como cercana al movimientismo, dado su reconocimiento como "brazo armado" del Movimiento en su conjunto, no obstante, al momento de diseñar sus estrategias, Lanusse sostiene que la organización adoptó una postura más "tendencista", es decir, optó por la vía de conformar una tendencia revolucionaria dentro del peronismo, con el objetivo de hegemonizarlo desde adentro (p. 259). De hecho, hacia fines de 1971 en un documento interno de la organización se señala la necesidad de conformar una vanguardia, cuya tarea fundamental sería la construcción de una estrategia revolucionaria dentro del Movimiento Peronista y que reemplazara las estructuras existentes. ${ }^{3}$

Sintetizando ambas definiciones que aluden a dimensiones de análisis diferentes, podemos observar que la primera (Lenci, 1999) es una conceptualización más amplia, mientras que la segunda (Lanusse, 2005) es más restringida. O dicho en otras palabras, mientras que la primera atiende a un continente heterogéneo de actores cuyas fronteras delimitan a organizaciones armadas, grupos de militantes, agrupaciones de base y figuras 
que se identifican como representantes del Peronismo Revolucionario -es decir que en esta acepción se incluye a todos en la TR: movimientistas, tendencistas y alternativistas-, la segunda tiene unas fronteras más acotadas de orden político-ideológico que deslinda las tres posturas en cuestión y define solo a una de ellas como representante de la Tendencia.

Precisamente, este uso más acotado se vincula con una tercera acepción de este término presente en la bibliografía, aquella que solapa o subsume la experiencia de la TR con Montoneros, lo que contribuye también a simplificar la totalidad de las prácticas de la Tendencia a las acciones armadas. El caso más representativo es el del clásico libro de Richard Gillespie (1987), quien identifica como sinónimos a la Tendencia y Montoneros, o el libro de Perdía (1997). En particular estas consideraciones se apoyan en el peso que Montoneros adquirió dentro de la escena política en el año 1973, logrando la integración de otras agrupaciones y organizaciones armadas en su seno. En efecto, la fusión de Descamisados a fines de 1972 y FAR formalmente en octubre de 1973 con Montoneros conservando para la organización el nombre de esta última- contribuyeron a que se identifique sin más Montoneros con la Tendencia (Pozzoni, 2017).

En relación con esto, es importante aclarar que si bien Montoneros fue efectivamente la organización que hacia 1973 logró hegemonizar ese espacio político, consideramos más apropiado a los fines de nuestro trabajo utilizar la denominación TR para definir a nuestro objeto de estudio, en tanto dicho término nos permite conceptualizar un actor y un universo político más extenso y flexible en sus contornos cronológicos, políticos e ideológicos, reconociendo en él la multiplicidad de formas y experiencias que revistió la militancia revolucionaria peronista en la década del setenta en diferentes contextos.

A lo largo de este trabajo estarán presentes las definiciones de Lenci (1999) y de Lanusse (2005), en tanto ambas habilitan a pensar la heterogeneidad y tensión que caracterizaba a este conglomerado político en su devenir histórico, es decir, en su doble expresión de colectivo mayor que condensaba diferentes discursos y prácticas identificadas con el peronismo revolucionario en los primeros años de la década del setenta- lo que incluye diversas organizaciones (y por ende a diversos grupos de militantes, experiencias, trayectorias) con distintas maneras de pensar la contradicción principal (clase, nación), el proceso revolucionario (nacional o nacional y social), la estrategia armada (foco/insurrección/guerra popular y prolongada/ejército revolucionario), la relación con Perón (líder revolucionario/ líder a secas/ líder burgués), el Movimiento (revolucionario en su conjunto/ tendencia revolucionaria/organización independiente)- sin que ninguna de 
ellas represente de manera excluyente dicha tradición. Y a la vez como caracterización del alineamiento tendencista y posicionamiento político específico que adoptó Montoneros hacia el año 1972.

En este complejo entramado de alineamientos, expectativas y formas de entender y poner en práctica el ideario de la "patria socialista" por el que pugnaba la Tendencia, se expresaron con inusitada intensidad muchas de las tensiones que atravesaron la dinámica política del período 73-76, condicionando la evolución de este actor y su participación institucional en el gobierno de Oscar Bidegain.

\section{Estado de la cuestión y enfoque de la investigación}

El papel de la Tendencia Revolucionaria del peronismo dentro de la particular coyuntura de los años 1973-76, ha sido abordado de manera general en una bibliografía que, globalmente, analiza un período más amplio que el que concentra nuestro interés, pero que la abarca inevitablemente. El retorno del peronismo al poder no puede estar desligado, entonces, de una periodización que lo incluye desde 1955, cuando Perón fue derrocado por la llamada Revolución Libertadora.

Esta bibliografía más abarcativa a la que nos referimos extiende su mirada al período 1955-1976, incluyendo entre sus temas de interés la evolución del Movimiento Peronista en toda la etapa que transcurre entre la "Resistencia Peronista" y los prolegómenos del golpe de estado de 1976, el proceso de radicalización social y política de los años sesenta y setenta en el que se enmarca el surgimiento de la "Nueva Izquierda" y las organizaciones armadas de signo peronista y marxista, como también de manera particular los vertiginosos tres años del tercer gobierno peronista.

Al respecto, en el transcurso de la década del ochenta y fuertemente influenciados por el clima de restitución democrática, emergieron un conjunto de investigaciones que, poniendo el acento en la esfera política como clave interpretativa fundamental, tendieron a explicar la creciente inestabilidad del período 1955-1976 y su espiral de violencia, a partir del funcionamiento y características del sistema político-institucional (Cavarozzi, 1983; Itzcovitz, 1985; Hilb y Lutzky, 1986; Ollier, 1986; De Riz, 1981 y 2000; Amaral y Plotkin, 1993, entre otros). En estos trabajos, la política adopta un lugar preeminente como dimensión analítica sustancial para explicar los sucesos y la dinámica del período, atendiendo a la interacción entre los actores políticos y sociales, así como a los proyectos que desplegaron y los conflictos y profundos enfrentamientos en que derivó todo el proceso de la tercera experiencia peronista en el gobierno (Barletta, 2010). Consideramos 
que estas investigaciones representaron en aquel entonces, un aporte fundamental en la complejización de las relaciones entre los así llamados "fenómenos estructurales" y las relaciones de poder, en la medida que le otorgaron a la dimensión política una autonomía relativa, contemplando la inluencia que las condiciones estructurales de la sociedad tienen sobre los comportamientos de los actores políticos, pero de manera indirecta. Sin embargo, encontramos en la perspectiva conjunta de estas obras ciertas limitaciones. En líneas generales, podríamos decir que en estos trabajos se desliza un enfoque que arriesga a reducir "la política" a su expresión estrictamente institucional, es decir, centrada casi exclusivamente en el funcionamiento partidario y las reglas de representación del sistema democrático que, a nuestro juicio, son sólo algunos de los elementos constitutivos de la política. Lógicamente, desde esa perspectiva, tienden a identificarse como "no políticas" al conjunto de acciones llevadas a cabo por las organizaciones armadas, que de ese modo son reducidas a su función puramente militar. En este sentido, lo que se observa en esta bibliografía es una fuerte carga normativa, consistente en transformar en categorías de análisis determinadas valoraciones histórico-culturales ("espíritu democrático", política entendida únicamente como "búsqueda de consensos") que muchas veces resultan ajenas al período que se investiga, imponiendo sobre aquel tiempo sentidos anacrónicos que obstaculizan su plena comprensión (Franco, 2005; Oberti-Pittaluga, 2006).

Por otra parte, en las últimas décadas, asistimos a una multiplicidad de escritos y perspectivas donde es clara la influencia del avance de los estudios culturales y análisis del discurso en las ciencias sociales. En este sentido, un conjunto de obras se ha abocado al estudio del campo de las ideas y la cultura política, poniendo el eje en las subjetividades y paradigmas ideológicos que articularon los discursos y las prácticas durante este período, en particular los del campo de la "Nueva Izquierda" (Sarlo, 2001; Altamirano, 2001; Vezzetti, 2006 y 2009; Terán, 2006; Carnovale, 2011). Sin duda, estas obras aportan a la mejor comprensión de ciertos imaginarios y "estructuras de sentimiento" que promovieron la radicalización y violencia de importantes sectores de la sociedad civil en los años setenta. No obstante, se percibe en muchos casos una sobredimensión del rol que las ideas habrían tenido como determinantes de las acciones, estableciendo entre las creencias y las prácticas una relación directa sin más mediación que la de las "pasiones ideológicas" (Terán, 2006). En particular, gran parte de estos trabajos tienden a explicar el golpe de estado de 1976 como consecuencia de la espiral de violencia que resultó del peso que ciertas matrices ideológicas -a las que se atribuye un carácter mesiánico- ejercieron sobre las prácticas de las organizaciones armadas. Así, 
bajo esta perspectiva, se deja fuera del horizonte analítico y explicativo la incidencia que sobre la dinámica política y la escalada de violencia previa al golpe militar tuvieron, por ejemplo, los efectos de la violencia contrarrevolucionaria, tanto en su modalidad clandestina en manos de los grupos paramilitares como en la plasmación de toda una legislación represiva oficial emanada desde el propio Estado democrático, tal como señalan de manera contundente el libro de Marina Franco (2012) y las valiosas investigaciones del campo de estudios sobre la represión (Aguila, Garaño y Scatizza, 2016).

En particular para la coyuntura 1973-76, contamos con obras realizadas contemporáneamente o muy poco tiempo después, muchas de las cuales han sido reeditadas, como los textos de Nicolás Casullo (2008) y los artículos de varios autores escritos entre 1979 y 1981 para la revista Controversia (2009), muchos de los cuales desempeñaron un destacado papel en los acontecimientos que ocupan nuestra investigación. Estos textos, constituyen fuentes significativas para volver sobre las primeras interpretaciones de un período más que controvertido y los análisis sobre el papel jugado por la militancia revolucionaria peronista en aquellos años.

Además de la bibliografía contemporánea al período, numerosos trabajos han elaborado conceptualizaciones precisas sobre la vertiginosa coyuntura de los años 1973-1976, más allá de la diversidad de enfoques y de que en algunos casos su objeto de estudio no se limite únicamente al tercer gobierno peronista. En líneas generales, gran parte de estos trabajos coinciden en interpretar el período que se inicia con la apertura democrática y la vuelta del peronismo al gobierno en 1973 como un proceso de freno y retroceso en el avance de los niveles de conciencia y conflictividad social que se venían desarrollando desde el Cordobazo. Desde esta perspectiva, el retorno del peronismo habría implicado un "dique de contención" y un freno a la radicalización popular que venía produciéndose desde 1969 (De Riz, 1981 y 2000; Cavarozzi, 1983; Tortti, 1999; Svampa, 2003; Ollier, 1986; Itzcovitz, 1985). Incluso algunos puntos de esta interpretación son compartidos por los trabajos inspirados en la perspectiva del CICSO (Centro de Investigaciones en Ciencias Sociales), los cuales a través de la aplicación de un marco teórico marxista entienden la salida electoral de 1973 como un proyecto de la burguesía para neutralizar e institucionalizar el conflicto social (Marín, 2007; Izaguirre, 2009; Bonavena, 2009), o los artículos compilados en Camarero, Pozzi y Schneider (2000).

No obstante, la diferencia entre ambos grupos de trabajos radica en que, para los primeros, el proceso de institucionalización fracasó en cierto modo no por un ascenso del 
nivel de conflictividad y lucha de clases, sino por la profunda inestabilidad política provocada por la lucha interna dentro del partido gobernante. En efecto, la centralidad que adquieren como clave interpretativa fundamental del período los conflictos entre las diversas ramas del Movimiento Peronista y su influencia directa en la marcha tortuosa de los gobiernos nacionales y provinciales, junto con el derrumbe de las instituciones democráticas, constituye un punto común de ese primer y extenso conjunto de obras arriba señaladas, a las que podemos sumar también el ya clásico libro de Julio Godio sobre la presidencia de Perón (1986) junto con análisis políticos más recientes como los de Alejandro Horowicz (2005) y Alicia Servetto (2010).

Sin tomar como objeto de estudio específico la Tendencia Revolucionaria en el tercer gobierno peronista, resultan interesantes los aportes analíticos de tres artículos (Svampa 2003; Barletta-Cernadas, 2006; y Barletta, Lenci y Ramírez, 2013) que abordan de manera general los dilemas de la coyuntura política que se abre en 1973, al señalar las tensiones y conflictos derivados de la dinámica entre un sistema político en recomposición y una sociedad civil altamente movilizada (Svampa, 2003); junto con la existencia de ciertos desfasajes entre las expectativas y los sentidos que los actores atribuían a sus prácticas y a sucesos del orden político general (retorno de Perón, apertura electoral, gobierno de Héctor Cámpora, crecimiento acelerado de las organizaciones de superficie de Montoneros, la construcción de la "patria socialista", etc.), y los modos en que esos procesos eran interpretados por los demás actores sociales y políticos del momento (Barletta-Carnadas, 2006). En esta misma línea, el artículo más reciente de Barletta, Lenci y Ramírez (2013) titulado "Democracias en pugna: un intento de recuperar los sentidos perdidos" resulta sumemente interesante para nuestra investigación. Partiendo de un enfoque alternativo que busca problematizar la polarización analítica hegemónica de "autoritarismo/democracia" que marcó los estudios de los años ochenta -bajo el halo de la Teoría de los dos demonios- y que ubicaba tanto al Terrorismo de Estado de la dictadura como a la etapa democrática inmediatamente anterior (1973-1976) dentro de un mismo proceso signado por la violencia política y el autoritarismo, las autoras proponen "devolverle historicidad a aquellos años, para redescubrir 'lo que no fue, pero podría haber sido",", recuperando así la existencia de múltiples apuestas, discursos y prácticas impugnadoras del orden y de sentidos disruptivos en torno al escenario democrático que, aunque terminaron en fracaso, dotaron a la etapa en cuestión de una complejidad y singularidad propia, lo cual no debería quedar 
al margen de las caracterizaciones que sobre esa coyuntura se formulen a posteriori desde el análisis histórico.

Aquí se retomará este tipo de acercamientos en tanto permiten dar cuenta de los desafíos que marcaron un momento histórico muy particular donde la institucionalidad democrática recuperada se articuló -no sin tensiones- con formas de la política armada y no armada altamente cuestionadoras del orden social, cargando así de nuevos sentidos la etapa formal "democrático burguesa" que encabezó el gobierno de Héctor Cámpora.

Acercándonos más al actor que constituye nuestro objeto de estudio, existen numerosas investigaciones que realizan un análisis exhaustivo del surgimiento y evolución de las agrupaciones de la Tendencia Revolucionaria del peronismo, y/o de su organización político-militar más importante, Montoneros (Ollier, 1986; Gillespie, 1987; Gil, [1989] 2018; Lanusse, 2005; Sigal y Verón, 2004; Caviasca 2009; Salcedo, 2011; Bartoletti, 2011; Campos, 2016; Pacheco 2013; Gonzalez Canosa, 2012; Slipak, 2015; Seminara, 2015; Pozzoni, 2017; Confino, 2018; Stavale, 2018; Otero, 2019). Dichos trabajos ofrecen hipótesis divergentes sobre variados temas y aspectos que tratan sobre el origen, la trayectoria y las disidencias de esta agrupación a lo largo de la década del setenta, su programa político y la vinculación con el Movimiento Peronista y su líder: la incidencia del nacionalismo mayormente de derecha (Gillespie, 1987) o del catolicismo renovador tercermundista (Lanusse, 2005; Campos, 2016; Lenci, 1998) en la conformación de los grupos originarios; el carácter "burgués y reformista" de su programa (Pacheco, 2013) acompañado también por la "ingenuidad política" e "inmadurez ideológica" de la organización al creer en un "Perón revolucionario" (Gillespie, 1987; Sigal y Verón, 2004); o por el contrario, los objetivos revolucionarios de su estrategia desde sus orígenes (Lanusse, 2006; Salcedo 2011) y una tendencia cada vez más vanguardista de su accionar en función del peso originario de la ideología marxista-guevarista (Ollier, 1986 y 2005) junto con la incidencia negativa que en este mismo sentido habría provocado la fusión con las FAR (Amorín, 2005; Peyrou, 2008; Duzdevich, Raffoul y Beltramini, 2015).

Desde otro angulo, numerosas investigaciones han destacado la amplitud y flexibilidad de las estrategias desarrolladas por Montoneros en diferentes coyunturas políticas a lo largo de su trayectoria, en función del carácter dual de la organización (político-militar) y de su integración al peronismo y al juego electoral, recuperando sus vínculos con las llamadas “agrupaciones de superficie" y otros activismos legales (Flaskamp, 2002; Lorenz, 2007 y 2013; Caviasca, 2009; Bartoletti, 2011; Robles, 2011; Salas, 2014; Friedemann, 2015; Dip, 2017; Otero, 2019). En este último grupo, podemos incluir también el exhaustivo 
trabajo de González Canosa (2013) sobre la trayectoria específica de las FAR y su integración con Montoneros como así también el trabajo de Castro-Salas (2011) sobre la organización Descamisados.

Algunas de las obras mencionadas, como las de Ollier (2005) y Bartoletti (2011) tienden a explicar la derrota del proyecto revolucionario de Montoneros en función del supuesto "déficit político" que habría carcaterizado a la organización en su derrotero, poniendo el énfasis en lo que denominan el "desvío militarista". También podemos incluír aquí al libro de Pilar Calveiro (2005), el libro de Amorín (2005), el de Gasparini (1999) y el artículo de Pastoriza (2006) quienes subrayan el predominio de la militarización por sobre la búsqueda de construcción política dentro de Montoneros, y la separación entre una lógica militar imperante en la conducción triunfalista y bélica, del conjunto de los principios originales de participación política y justicia social sostenidos por el grueso de la militancia. Este esquema del quiebre en su trayectoria, en lo que sería una sustracción de la política (Pastoriza, 2006) por el imperativo de la violencia, es rebatido de forma sugestiva por la tesis de Slipak (2015) sobre la conformación identitaria de Montoneros. En este interesante trabajo, la autora discute la teoría del desvío militarista a partir del análisis de sus publicaciones. En ese marco, Slipak revela cómo desde su constitución, la política montonera apareció ligada a un imaginario bélico, planteando una fusión entre la lógica militar y la lógica política, aspectos que además habrían estado presentes en el conjunto de su militancia y no sólo en la cúpula de la organización (p. 15). Enfoques similares que escapan al tópico de la inflexión militarista y a consideraciones sobre lógicas contradictorias y excluyentes, podemos encontrar también en la tesis de González Canosa ya citada (2013) y en la tesis de Confino (2018) sobre la Contraofensiva Estratégica de Montoneros. Bajo un análisis y reconstrucción profunda, el autor propone un acercamiento novedoso al tema de la Contraofensiva en donde lejos de pensarla como el paradigma más acabado del militarismo intrínseco de la organización, busca situar dicha experiencia en una trama histórica de más larga duración atendiendo a los repertorios políticos previos y a la lógica política de Montoneros dentro de la cual aquella operación se inscribió, sin por ello negar el fuerte componente militar que impregnó sus acciones. Su interpretación en definitiva rompe con las miradas hegemónicas sobre este acontecimiento que durante mucho tiempo tendieron sólo a definirla en su dimensión militar e irracional, como una "locura" y un "suicidio" causante de la derrota (p.13)

Por su parte, y en el marco también de los nuevos enfoques que han renovado el campo historiográfico sobre la Tendencia Revolucionaria en los últimos años, encontramos 
estudios muy valiosos que se han preguntado por las disidencias y rupturas en su itinerario, echando luz sobre la heterogeneidad de este espacio político y de un recorrido mucho menos monolítico. Investigaciones como las de Mingrone (2010), Seminara (2015), Pozzoni (2017) y Stavale (2018) han reconstruído con rigor analítico la historia de esos debates y/o desprendimientos, visibilizando las tempranas discusiones políticoideológicas que se dieron en su seno y que serán retomadas en esta tesis.

En esta revisita sobre la historia de Montoneros y las organizaciones revolucionarias del peronismo, debemos mencionar también el valioso aporte de los estudios realizados bajo una perspectiva de género y feminista. Así, trabajos como los de Oberti (2015), Noguera (2013), Viano (2011) y Grammatico (2011) han iluminado diversos aspectos de la participación de las mujeres dentro de las organizaciones armadas, como también su extendida presencia en las llamadas "agrupaciones de superficie" y su vínculo con la estructura militar y clandestina, atendiendo a los diversos modos en que el género interviene y resulta configurador de toda su experiencia militante.

Por otra parte, contamos en la actualidad con una abundante bibliografía de corte testimonial sobre "los setenta" y en particular sobre las organizaciones revolucionarias del peronismo (Jauretche, 1997; Chavez-Lewinger, 1998; Anguita-Caparrós, 2007 [1998]; Gasparini, 1999; Vaca Narvaja-Frugoni, 2002), parte de la cual hace mención específica al rol jugado por la Tendencia Revolucionaria en espacios de gestión administrativa y parlamentaria durante el tercer gobierno peronista (Amorín; 2005; Perdía, 1997). En un registro similar, existe un conjunto amplio de trabajos de corte periodístico y con fuerte impronta de reconstrucción de la memoria histórica, que partiendo del estudio de ciertos actores y sucesos relevantes del período como la campaña electoral de 1973 y el gobierno de Héctor Cámpora (Bernetti, 1983; Bonasso, 1997); la masacre de Ezeiza (Verbitsky, 1988); la trayectoria del dirigente de la Juventud Peronista Rodolfo Galimberti (Larraquy y Caballero, 2000); el asesinato del líder de la CGT José Rucci por Montoneros (Reato, 2008); la trayectoria de los jóvenes peronistas platenses (Amato y Boyanovsky Bazán, 2008); o la prensa montonera (Esquivada, 2004; Grassi, 2015), complementan con rigor empírico nuestro conocimiento sobre momentos claves y puntos de quiebre de la coyuntura política del tercer gobierno peronista que influyeron de manera directa en la adopción de ciertos cambios de estrategia y reposicionamientos de los actores en pugna. Al respecto, el libro de Verbitsky, Ezeiza, se ha vuelto una versión ya clásica de lo sucedido en torno a la masacre del 20 de junio de 1973, sentando las bases de una cronología sobre la ruptura temprana y definitiva de Perón con los jóvenes 
de la Tendencia y el comienzo del accionar de la violencia paraestatal en manos de sectores de derecha del Movimiento. Otras dos publicaciones destacadas para nuestro trabajo son sin dudas el citado libro de Miguel Bonasso, El presidente que no fue, y el de Jorge Bernetti, El peronismo de la victoria, obras que apelando a la memoria histórica de sus protagonistas -en este caso, los propios autores- recogen la experiencia de la presidencia de Cámpora y el rol central que la Tendencia Revolucionaria desarrolló en la misma, junto con los imaginarios y expectativas que dicho proceso despertó entre sus militantes, marcando el contraste de esa etapa visualizada desde el presente como una “primavera camporista”, y las presidencias peronistas posteriores de Lastiri, Perón y Estela Martínez de Perón.

No obstante, cabe señalar que en líneas generales se observa en todos estos trabajos de corte periodístico y testimonial, un acercamiento general y uniforme hacia la Tendencia Revolucionaria desde la óptica nacional, en muchos casos homologándola sin más a Montoneros y subordinando el análisis de sus prácticas a las decisiones de su Conducción Nacional, sin dar cuenta de la heterogeneidad y complejidad de ese conglomerado en torno a sus diferentes agrupaciones, ni de su particular implantación en el terreno de la política institucional provincial.

Si bien es difícil establecer un estado de la cuestión específico sobre la Tendencia Revolucionaria, en el último tiempo y con la multiplicación de estudios sobre historia reciente a escala regional en todo el país, han surgido trabajos que se ocupan del papel que desempeñó en el ámbito de los distintos gobiernos provinciales. Estudios como los de Ladeuix (2006), Bonavena (2009), Servetto (2010), Antúnez (2015) y Bustingorry (2015) proveen elementos importantes para la reconstrucción y comprensión del rol clave que jugaron los enfrentamientos entre las distintas ramas del Movimiento Peronista en la crisis terminal de los gobiernos afines a la Tendencia. Al hacer hincapié en el temprano e inestable carácter de las alianzas celebradas durante la apertura electoral -dado el incongruente contenido ideológico que albergaban los diferentes sectores reunidos en su seno-, dichos trabajos nos permiten conocer los lineamientos específicos a escala regional de la dinámica del enfrentamiento en cada peronismo provincial, reconociendo actores y trayectorias disímiles, lo que permite escapar a narraciones más generales que tienden a simplificar la caída de los gobiernos cercanos a la Tendencia como un resultado mecánico y efecto dominó del conflicto de la interna peronista a nivel nacional (De Riz, 2000).

En este sentido, tres de las obras arriba citadas merecen un comentario especial en función del diálogo que nuestra investigación emprende con ellas. El libro de Alicia 
Servetto, 73/76 El gobierno peronista contra las "provincias montoneras", producto de su tesis doctoral, busca esclarecer un escenario conflictivo escasamente estudiado como son las intervenciones dispuestas por el ejecutivo nacional a los gobiernos provinciales y, de este modo, aporta al análisis pormenorizado de fenómenos extra-céntricos en el interior de un país cuyas dimensiones históricas y políticas han sido interpretadas preferentemente desde la óptica de los gobiernos centrales.

Servetto reconstruye minuciosamente los escenarios provinciales describiendo actores y conflictos específicos en las cinco provincias que fueron intervenidas: Formosa, Córdoba, Salta, Mendoza y Santa Cruz, centrando su interpretación en las disputas que se engendraron dentro del peronismo, particularmente lo que denomina como una "guerra de posiciones para ganar espacios de poder" entre la derecha político-sindical y los grupos de la Tendencia Revolucionaria (p. 208). Para la autora, las intervenciones provinciales fueron un instrumento utilizado por Perón y su sucesora para dirimir la contienda interna de su Movimiento a favor de los sectores ortodoxos y "funcionales" a su proyecto de la "democracia integrada" y "concertación social". Bajo la aplicación de ese mecanismo, explica Servetto, se logró liquidar los bastiones de poder de la Tendencia Revolucionaria con la consiguiente reestructuración de los planteles de gobierno a nivel provincial, y la depuración ideológica, la desmovilización y el disciplinamiento social a nivel general (p. 208).

Reconociendo este valioso y pionero aporte, en los capítulos centrales de nuestra tesis pondremos en debate algunos de sus postulados sobre la primacía del "espiral de violencia", la "militarización de la política" y la consiguiente "lógica de guerra" como únicas claves explicativas del conflicto interno en el peronismo, proponiendo una nueva interpretación que desde una reconstrucción centrada en la trayectoria institucional de la Tendencia Revolucionaria en el gobierno bonaerense, nos permita comprender qué prácticas políticas, qué proyectos y qué programas de acción estaban en disputa, más allá de la dicotomía discursiva, la lógica de guerra o la puja instrumental de cargos entre la "patria peronista" versus la "patria socialista".

Una perspectiva similar a la de Servetto encontramos en la tesis doctoral de Damián Antúnez, publicada en su libro "Caras extrañas. La Tendencia Revolucionaria del Peronismo en los gobiernos provinciales. (Buenos Aires, Córdoba, Mendoza, Santa Cruz y Salta, 1973-1974) en el año 2015. En este trabajo se analiza comparativamente la relación conflictiva entre las cinco gobernaciones identificadas como cercanas a la Tendencia Revolucionaria, con el sector de la ortodoxia peronista y el gobierno nacional 
de Juan Domingo Perón. Bajo un enfoque que pone el énfasis en el carácter discursivo del conflicto entre la derecha y la izquierda del Movimiento, por sobre la distinción de las prácticas y proyectos políticos en juego, el autor identifica como un factor central en la caída de los mencionados gobiernos la ruptura de las relaciones entre Perón y Montoneros hacia la segunda mitad del año 1973. En tal sentido, para Antúnez, los cuestionamientos, las denuncias y el hostigamiento desatado contra los mandatarios que encabezaban las "provincias montoneras" respondían menos al desafío políticoideológico por izquierda que sus programas de gobierno y practicas de acción política pudieran representar, y más a la lógica instrumental del enfrentamiento entre la Tendencia y la Ortodoxia por espacios de poder, conflicto cuya trama central corrió por los andariveles de la violencia política, "cuyo germen estaba perfectamente instalado en 1972, cuando se debatía la elección de candidaturas en el seno del Movimiento” (p.343) Al respecto, consideramos que afirmaciones de este tipo deberían matizarse en función de una mirada menos monolítica sobre el comportamiento de las organizaciones revolucionarias -en particular aquellas que optaron por participar del juego electoralatendiendo especialmente desde un enfoque histórico a la relación compleja, dinámica y cambiante entre éstas, sus expectativas y acciones, y la acelerada coyuntura política.

Otro trabajo que también atiende al conflicto intraperonista pero limitado al espacio bonaerense es el de Horacio Bustingorry (2015). En su libro Oscar Bidegain. La fugaz experiencia del Pacto Social en la provincia de Buenos Aires, reconstruye la obra de gobierno del mandatario bonaerense, a la luz de las vinculaciones con el programa económico-social aplicado por el FREJULI a nivel nacional. Para el autor, la política socioeconómica llevada a cabo por Bidegain mantuvo coincidencias en términos generales con el Plan Trienal y el Pacto Social implementado desde nación, situación que por lo tanto no explicaría su caída en desgracia, sino más bien la alianza política de éste con los sectores de la Tendencia. Dicho trabajo, al centrarse exclusivamente en la provincia de Buenos Aires y en el derrotero de Oscar Bidegain en su paso por la gobernación es de suma relevancia para nuestra investigación, aportando un detallado y preciso panorama de los principales episodios y conflictos que sellaron la gestión de gobierno, en el marco de su inscripción en la política del tercer gobierno peronista a nivel nacional. No obstante, el énfasis puesto en los aspectos formales de la obra de gobierno y en las medidas económicas emprendidas desde el ámbito institucional, pierde de vista en su enfoque algunos aspectos menos conocidos de las diferentes modalidades de intervención política y programática que la militancia de la Tendencia Revolucionaria 
plasmó en diferentes áreas de gobierno, y su incidencia real -en tanto representó una apuesta alternativa y radicalizada- en la trama de tensiones y practicas represivas que despertaron desde los sectores de la derecha peronista, situación no menor al momento de evaluar las causas que llevaron a la caída del gobierno en el espacio provincial.

Por tal motivo y recapitulando, este conjunto valioso de obras excluye de su órbita de estudio la problemática específica de la transición de sectores ligados a un horizonte de expectativas y prácticas revolucionarias al espacio institucional, en carácter de integrantes de los planteles de gestión ejecutiva y parlamentaria, junto a las tensiones que sus iniciativas y acciones políticas concretas despertaron en el resto de los actores políticos y al interior del propio espacio de la Tendencia. En este sentido, el destacado libro de Mariana Pozzoni (2017) Leales. De la Tendencia Revolucionaria a la Juventud Peronista Lealtad que reconstruye las diversas formas de participación política de las juventudes de la izquierda peronista durante la primera mitad de la década del setenta, constituye un valioso aporte como línea de investigación en tanto el centro de su enfoque no está puesto en las acciones armadas como forma de militancia paradigmática emprendida por los jóvenes revolucionarios de aquellos años, sino en las múltiples iniciativas no armadas. Bajo esta perspectiva, aunque tomando un período más extenso que el de nuestra investigación, la autora logra trazar un mapa de la trayectoria de militancia previa de algunas figuras y agrupaciones que se reconocían parte del espacio político de la Tendencia, destacando su implicación en el trabajo profesional universitario, sindical, barrial, en las movilizaciones y en la protesta social de principios de los setenta y en las actividades de la campaña electoral que llevaron al triunfo del gobernador Oscar Bidegain. Otro aporte significativo de su tesis es la indagación sobre las dificultades que emergieron en el seno de la Tendencia Revolucionaria entre los grupos que finalmente integraron la disidente "JP Lealtad" y Montoneros, en función del peso mayor asignado a las posiciones movimientistas defendidas por los primeros y la línea más "militarista" según la autora- seguida por los segundos. En el esquema de Pozzoni, estas divisiones ya estaban presentes en los orígenes de Montoneros, siendo el grupo movimientista que se incorpora desde las FAP en 1971 el representante más acabado de la línea “política”, que luego devendrá en el corazón de JP Lealtad. Precisamente, esta mirada atenta a las tensiones desatadas al interior de la Tendencia a medida que avanza el proceso político será retomada por nuestra investigación, desde una perspectiva que busca complejizar ese esquema antagónico, matizando los alineamientos y la división dicotómica y conceptual que la autora realiza entre quienes serían los militantes defensores de acciones más 
“políticas" (JP Lealtad) y los que asumieron una posición y prácticas armadas "no políticas" (Montoneros-FAR).

A diferencia de estos postulados, en la presente tesis se busca escapar a estas categorías polares que tienden a excluir dentro de la órbita de la política a las acciones armadas o que sólo consideran la política en su faz institucional. Lejos de establecer un juicio de valor sobre el uso de la violencia en los actores que son objeto de nuestra investigación, se intentará comprender la inserción de estas prácticas dentro de una trama histórica y una lógica política que daba racionalidad y fundamento al conjunto de acciones emprendedias por la militancia revolucionaria, en un contexto determinado. De esta manera, si bien el foco de atención de nuestra tesis estará puesto en las acciones legales/institucionales, dichas iniciativas serán analizadas como parte de un repertorio mayor de prácticas insertas en una estrategia política, la cual incluía como opciones válidas -para los actores estudiados- tanto el uso de la violencia como el activismo no armado.

En una similar línea de investigación a la de Pozzoni encontramos la tesis de Maestría de Horacio Robles (2011), quien estudia la trayectoria de la Juventud Peronista platense desde su creación en 1957 hasta su integración con Montoneros a principios de los setenta. En este trabajo, el autor resalta el peso importante que el trabajo territorial y la movilización barrial ocuparon dentro del repertorio de prácticas radicalizadas impulsadas por los jóvenes integrantes de la Juventud Peronista de la zona, dando cuenta de la heterogeneidad de acciones y apuestas que integraban el accionar de los grupos de la Tendencia y los vasos comunicantes entre ese activismo de base y las organizaciones armadas. Sumado a este aporte, el trabajo de Robles también indaga sobre el acercamiento entre algunos militantes de Montoneros y el gobierno de Oscar Bidegain, línea de trabajo que será retomada y profundizada por nuestra investigación.

Por su parte, María Laura Lenci (1999) en su artículo titulado "Cámpora al gobierno, Perón al poder. La Tendencia Revolucionaria del peronismo ante las elecciones de marzo de 1973", describe la tensión entre dos legitimidades (la democrática y la revolucionaria) que atraviesa el accionar de este actor durante el período. Según la autora, la Tendencia se halló inserta en una lógica dual y a la vez excluyente que implicaba tanto la práctica de la guerra (a través de la lucha armada) como la de la política (a través de su apoyo e inserción en los canales institucionales-partidarios), en el marco de un nuevo contexto político que a partir de las elecciones de marzo de 1973 reintroduce -desde el propio 
gobierno peronista- la legitimidad democrática tradicional pocos meses antes denostada (Lenci, 1999).

En ese sentido, al igual que con el trabajo de Pozzoni (2017) arriba señalado, destacamos la contribución de este tipo de investigaciones al conocimiento y comprensión de la experiencia no unívoca de las organizaciones revolucionarias peronistas, en particular en el contexto de apertura electoral y el tercer gobierno peronista. Asimismo, dichas investigaciones pueden ser complementadas y enriquecidas bajo un enfoque que, a la vez que retome el amplio activismo de las agrupaciones de la Tendencia por fuera de sus prácticas armadas, logre reponer y captar los sentidos y la estrategia política integral que guiaba su accionar, tanto en su modalidad armada como institucional, revisando así los términos dicotómicos, binarios o excluyentes (política vs guerra) en base a los cuales se ha solido caracterizar la posición de los actores en aquel momento.

Por otra parte, al centrarse en la trayectoria y prácticas políticas no armadas de los/as militantes de la Tendencia Revolucionaria que ocuparon cargos en el gobierno provincial bonaerense, para nuestra tesis también son centrales ciertos trabajos que han recuperado como uno de sus intereses- el campo de estudios sobre el Estado y sus agentes. Al respecto, en los últimos años novedosas investigaciones han renovado la atención sobre este fenómeno, desde una perspectiva que indaga en particular el mundo de sus instituciones y actores "desde adentro" (Bohoslavsky y Soprano, 2010). Bajo la premisa de lo que ambos autores han denominado "el rostro humano" del Estado, numerosos trabajos se han enfocado en reconstruir y analizar las acciones de aquellos sujetos "de carne y hueso" que habitan y dan vida al Estado en diferentes coyunturas históricas, atendiendo a sus trayectorias formativas, sus perfiles técnicos y políticos, las expectativas que moldean su intervención en ese espacio, las disputas con otros actores y los límites que la propia dinámica estatal muchas veces les impone en sus proyectos y líneas de acción. Al respecto, los trabajos de Florencia Osuna (2017) sobre el Ministerio de Bienestar Social entre el "onganiato" y la ultima dictadura militar, y el dossier coordindado junto a Martín Vicente (2017) resultan de mucho interés para nuestra investigación, al centrar la mirada en la conformación de redes y elencos políticos gubernamentales y preguntarse por la caracterización precisa de los actores ministeriales. Precisamente, estos aspectos y el enfoque general que toma a las carteras ministeriales como ejes de investigación y estudios de caso, será retomado en los capítulos centrales de nuestra tesis. 


\section{Problema, interrogantes y objetivos de la tesis}

\section{El problema de investigación:}

Tomando como punto de partida los aportes de la bibliografía citada, observamos no obstante la vacancia de estudios que aborden de manera específica y sistemática la problemática de la inserción institucional de la militancia de la Tendencia Revolucionaria del peronismo en la gobernación bonaerense de Oscar Bidegain, analizando de manera concreta sus prácticas de gestión y sus proyectos gubernamentales. Asimismo los enfoques de las investigaciones que, aún sin convertirlo en el centro de su análisis, sí han reparado en el rol jugado por este actor en el período de recuperación democrática, comparten un sesgo interpretativo en el que se distinguen desde el inicio dos lógicas opuestas y excluyentes atravesando su accionar: la de la política en su modalidad formalinstitucional, por un lado (y ocupando un lugar subordinado), y la de la guerra en su versión armada, por otro, encontrando allí un nudo de contradicciones per se que actuaría desde el origen como un factor limitante esencial en la consecución exitosa de dicha experiencia. Desde esa perspectiva se desprende una idea que, casi de modo preconcebido, sostendría la imposibilidad de la realización -e incluso la existencia misma- de un proyecto de gestión encarado por la TR. Esto, en términos epistemológicos, obtura la posibilidad de reconocer analítica y empíricamente en el proceso histórico que nos ocupa, la existencia de otras dinámicas de articulación y funcionamiento de ambas lógicas.

Al respecto, sin negar conceptualmente la existencia de diferencias sustantivas entre la lógica de las prácticas armadas y la lógica de las prácticas institucionales, cada una con su especificidad, en nuestra investigación se pondrá el foco de atención en las apuestas de articulación y compaginación llevadas a cabo por la Tendencia Revolucionaria del peronismo en el gobierno provincial así como en sus tensiones, en el marco de una coyuntura histórica excepcional y abierta a experiencias y formas de la política en donde lo institucional y lo revolucionario no necesariamente fueron pensados -y encarados por los actores del momento- como elementos excluyentes, o por lo menos no en todos los momentos.

Así, nuestra investigación se propone dar cuenta de los dilemas planteados por el nuevo escenario político electoral (que implicó la legalidad del peronismo y los intentos de su institucionalización) para un actor que venía de una práctica de oposición y resistencia al Estado, y en donde las definiciones previas sobre ese mismo escenario asumieron -en distintas formas y grados según las organizaciones- la crítica general contra el sistema 
democrático burgués (leído como una jugada del régimen en sus intentos por vaciar al peronismo de su contenido revolucionario).

Frente a estos posicionamientos ideológicos y dilemas, nuestra investigación analizará de qué manera las agrupaciones de la Tendencia buscaron incidir en la coyuntura política, resignificando la salida electoral y cargando de nuevos sentidos al Estado, la democracia y su participación en ella, asumiendo lugares preponderantes en la estructura institucional y desplegando programas de gobierno en la gestión bonaerense que para muchos resultaron compatibles -aunque no sin tensiones- con los objetivos mayores de transformación social en el marco de una estrategia política revolucionaria.

Asimismo, las expectativas, apuestas y prácticas concretas encaradas por la Tendencia como así también las aspiraciones de autonomía y conducción del Movimiento por parte de algunos de sus grupos- entrarán rápidamente en colisión con el proyecto político reformista de Perón y la potencia de su liderazgo entre las masas, generando tensiones que tendrán repercusiones directas en la trayectoria de los y las militantes que ocuparon cargos en el gobierno provincial.

En este sentido, entonces, la investigación que aquí se desarrolla analizará la dinámica política de un proceso de fuerte y acelerado cambio, protagonizado por los sectores de la Tendencia Revolucionaria que ocuparon cargos en el estado provincial, y los conflictos derivados de su estrategia de conjugar sus aspiraciones revolucionaras dentro del Movimiento Peronista que la impulsó y a través del cual accedió al gobierno. Esto nos llevará también, desde una perspectiva situada en la coyuntura política y atenta a los desfasajes entre las expectativas y el contexto arriba mencionados, a reconstruir los elementos de esa trama política que hicieron ver como posibles y efectivas las acciones y apuestas de compaginación, como así también los tramos de esa coyuntura que en determinado momento empezaron a mostrar señales de profunda tensión para con esas apuestas.

\section{Interrogantes e hipótesis de trabajo}

Tal como mencionamos en la presentación, la radicalización política de amplios sectores de la sociedad civil junto con el accionar de las organizaciones guerrilleras a principios de la década del setenta, derivaron no sólo en un proceso de crisis terminal del gobierno militar sino también en la instauración de un clima de impugnación social generalizada que instaló con fuerza la idea de revolución y las aspiraciones de construcción de un orden socialista. Dentro del conjunto de organizaciones armadas que adscribieron al 
peronismo, la posibilidad de llevar adelante este proyecto se asociaba con el retorno al poder de dicho movimiento político, lo cual implicó desplegar un heterogéneo repertorio de prácticas que iban de la movilización activa y el trabajo político de base al accionar armado. Será precisamente el plan ofensivo de movilización lanzado con la campaña "Luche y Vuelve" en agosto de 1972, protagonizado por los sectores de la Tendencia Revolucionaria, el que forzó la salida del gobierno militar y el llamado efectivo a elecciones, logrando con ello la vuelta del peronismo al poder.

A partir de esta caracterización del contexto político, derivada en gran parte de la bibliografía arriba reseñada, se formulan las siguientes preguntas que actúan como marco analítico orientador de nuestra investigación:

¿Qué lectura realizaron del llamado a elecciones los sectores de la Tendencia Revolucionaria y cuál fue su estrategia frente al nuevo escenario?; ¿cómo articularon, en sus formulaciones ideológicas y políticas, la estrategia revolucionaria y la metodología de la lucha armada con la participación en el proceso electoral, y más específicamente, con la integración al gobierno?

¿Cómo intentaron conjugar, los grupos de la Tendencia Revolucionaria, las prácticas de radicalización y la opción por la violencia política con la posibilidad de participar de un gobierno constitucional democrático? ¿De qué manera influyeron o se reconvirtieron esas metodologías de acción en el desempeño gubernamental de los y las militantes de la Tendencia en el Estado? ¿A partir de qué razonamientos, encuadres y resignificaciones dentro de una estrategia revolucionaria este accionar fue cambiando?

Dentro del espacio provincial bonaerense ¿Cuáles fueron las tensiones que al interior de la Tendencia y dentro del Movimiento Peronista se desplegaron a partir de la incorporación de militantes provenientes de organizaciones político-militares a la estructura de un gobierno constitucional?

¿Qué tipo de vínculos establecieron los militantes de la Tendencia con el gobernador Oscar Bidegain, dirigente histórico de la rama política del peronismo?

¿Cuáles fueron los proyectos institucionales y las acciones concretas de gestión llevadas a cabo desde el Estado?, ¿Cuáles fueron las repercusiones de la ruptura de Montoneros con el líder justicialista entre los militantes de la Tendencia que ocupaban cargos en el gobierno provincial? ¿Qué derroteros políticos siguieron los militantes que ocuparon cargos de gestión ejecutiva en el contexto de enfrentamiento con los sectores de la derecha peronista y frente a las actitudes de disciplinamiento violento tomadas por el propio Perón? 
En relación con nuestro problema de estudio y los interrogantes planteados, cabe señalar algunos supuestos que a modo de hipótesis guían nuestra investigación:

-El destacado papel de la Tendencia Revolucionaria en la vuelta del peronismo al poder inauguró un proceso de marcadas tensiones derivadas de la incorporación de militantes portadores de un ideario revolucionario y de prácticas políticas insertas en una lógica insurreccional al ámbito institucional, en el marco de un gobierno peronista que lejos de incluir en sus objetivos la radicalización del proceso político precedente, buscaba contener la agitación social fortaleciendo la autoridad del Estado (en muchos casos de forma represiva) y poniendo en marcha un programa reformista de alianza de clases.

-El notable desfasaje entre las expectativas y el sentido que debía adquirir el nuevo gobierno para los sectores de la Tendencia Revolucionaria y las prácticas reales que aquél podía y quería llevar a cabo, constituyen un factor central para entender el conflicto desencadenado entre el gobierno nacional -sobre todo durante la presidencia de Juan Domingo Perón- y los gobernadores alineados con la Tendencia.

-La decisión de la Tendencia de participar de lleno en el proceso de apertura democrática se fundaba, en principio, en la caracterización que los sectores del peronismo revolucionario realizaban de esa coyuntura política dentro de una estrategia revolucionaria de más largo alcance, entendiendo al gobierno peronista como una etapa de transición en la que la ocupación de espacios institucionales constituía una táctica efectiva para el fortalecimiento del proyecto estratégico de guerra revolucionaria y construcción del socialismo.

-La amplitud de acciones emprendidas por la Tendencia Revolucionaria (incluyendo actividades que van desde la lucha armada al trabajo político-territorial en los frentes de masas) encuentra sustento por un lado, en el carácter dual de la organización políticomilitar que hegemonizó ese espacio, Montoneros, como también en las diversas agrupaciones y figuras que se referenciaban dentro de ese laxo conglomerado, lo cual permitió poner en práctica múltiples estrategias y practicas en función también del cambiante contexto político.

-Esta misma amplitud se puede observar en las actitudes disímiles y tomas de posición que en diferentes momentos expresaron muchos/as de sus militantes en torno a la predominancia del trabajo político institucional por sobre el accionar militar, y viceversa. -La cercanía del gobernador Bidegain con los sectores de la Tendencia se fue configurando en principio como respuesta defensiva al poder de los sectores de la derecha sindical y política del Movimiento en la provincia, derivando en una alianza de carácter 
táctica que con el correr del tiempo adquirió contornos de mayor afinidad política e ideológica.

-Los lugares específicos y de peso que ocupó la Tendencia en el gabinete provincial (Gobernación, Ministerio Bienestar Social, Ministerio de Asuntos Agrarios, Ministerio de Obras Públicas, Minsiterio de Gobierno) respondían, menos a la puja intrumental por ocupar espacios de poder en función de la lucha que mantenía con la derecha políticosindical, y más a la apuesta por el trabajo político y a plasmar un conjunto de programas y medidas que anticipaban en la práctica el objetivo mayor asociado a la idea de construcción del "socialismo nacional" sostenido por la militancia de izquierda dentro del Movimiento

-El enfrentamiento con Perón pondrá a muchos militantes de la Tendencia ante el dilema de mantener su adhesión y lealtad al líder -garantizándose con ello el vínculo con las masas y la permanencia dentro del Movimiento- o dejar de lado esa opción para llevar adelante su programa revolucionario. La respuesta a esta disyuntiva será lo que definirá la continuación o abandono de la ocupación de cargos institucionales en el gobierno provincial, y su derrotero dentro del Movimiento.

\section{Objetivos de la tesis:}

Como objetivo general nos proponemos contribuir al conocimiento del proceso político del período 1973-1976 a partir del análisis de las prácticas y posicionamientos que adoptó la Tendencia Revolucionaria del peronismo en el marco de su participación institucional en el gobierno de la provincia de Buenos Aires. De este modo buscamos aportar al debate sobre la relación entre violencia y política en función de su historización, en una coyuntura marcada por la aceleración del tiempo político.

Como objetivos específicos podemos mencionar los siguientes:

-Examinar las trayectorias de los grupos de la Tendencia Revolucionaria que ocuparon cargos ejecutivos en el gobierno provincial de Oscar Bidegain.

-Reconstruir y analizar las diferentes estrategias de intervención política de la Tendencia Revolucionaria, y su relación con las demás fuerzas políticas dentro del Movimiento, en la particular coyuntura política de 1972-73.

-Analizar las apuestas de articulación y las tensiones entre el proyecto revolucionario impulsado por la Tendencia y su participación institucional en un sistema definido a priori como "democrático burgués", observando la resignificación que realizaron los 
actores de sus prácticas militantes/institucionales y de la integración en el Estado en ese contexto.

-Caracterizar las diferentes leyes, programas, medidas e iniciativas que intentaron llevar a cabo los militantes de la Tendencia Revolucionaria en diversas dependencias del gobierno de Oscar Bidegain (especialmente bajo la gestión de Floreal Ferrara en el Ministerio de Bienestar Social, la gestión de Guillermo Gallo Mendoza en el Ministerio de Asuntos Agrarios, la de Alberto González en el Ministerio de Obras Públicas y en las Secretarías del Ministerio de Gobierno)

-Analizar las tensiones que generaron las iniciativas de los/as militantes de la Tendencia en el espacio institucional con los sectores de la ortodoxia político-sindical del peronismo, así como con el propio líder del Movimiento.

-Examinar el impacto que tuvieron ciertas controversias y acontecimientos claves de la coyuntura política en las líneas de acción seguidas por la Tendencia Revolucionaria, atendiendo en particular a las tensiones que al interior de este espacio se desplegaron a partir de la ruptura de Montoneros con Perón, como también en función de las diferencias respecto del peso que la apuesta institucional debía tener dentro de la estrategia revolucionaria, y los efectos de la escalada represiva en la continuidad y desarrollo de iniciativas públicas y legales.

\section{Metodología, plan de trabajo y uso de las fuentes}

En líneas generales, nuestra investigación apunta a la reconstrucción de las prácticas y las tensiones políticas experimentadas por la Tendencia Revolucionaria del peronismo a partir de su inserción y trayectoria en el ámbito institucional de la provincia de Buenos Aires en 1973. En tal sentido, consideramos pertinente la aplicación de un enfoque cualitativo orientado a la comprensión integral de nuestro objeto de estudio teniendo en cuenta no sólo los posicionamientos, las acciones y los discursos de los sujetos directamente involucrados (militantes de la Tendencia Revolucionaria que ocuparon cargos institucionales durante la gobernación de Oscar Bidegain) sino también el impacto que los mismos generaron en el espacio político mayor que integraron (Movimiento Peronista). Al mismo tiempo, se espera observar los condicionamientos y disyuntivas que la dinámica política les impone a medida que avanza y se endurece el contexto político del año 1973. Asimismo, si bien en este enfoque se privilegia el análisis de las prácticas en los espacios institucionales (rama juvenil del Movimiento y del Partido Justicialista, áreas de gobierno), se atenderá también a la acción política militante en otros 
ámbitos no gubernamentales (frentes de masas) que se vincularon directamente con aquéllos.

Por su parte, para nuestra investigación creemos importante atender a la conexión de los sucesos políticos desarrollados a nivel nacional y provincial, siendo notables en esta materia los aportes que brindan los estudios regionales. Siguiendo la perspectiva metodológica desarrollada por los trabajos de Gabriela Aguila (2008 y 2015) proponemos aquí adoptar una mirada "extracéntrica", entendida como un enfoque de historia regional que se vincula con el marco nacional, aunque poniendo de relieve en la explicación de los procesos estudiados las particularidades y dinámicas propias de la dimensión provincial (Dalla Corte- Fernández 2001). Esta propuesta de "achicar el foco" (Aguila, 2015) ayudará a enriquecer y profundizar nuestro conocimiento sobre el período 1973-1976, etapa que ha sido generalmente abordada por la historiografía centrando el eje de discusión en el ámbito nacional, y desde allí indagando los procesos provinciales a través de un recorrido unidireccional que los sitúa como epifenómenos subordinados de aquélla. Al respecto, los enfoques realizados desde una escala local/regional permiten reponer elementos que otorgan densidad, mayores grados de complejidad, diferencias y novedades a las explicaciones generales sobre el período, como también las articulaciones e influencias mutuas entre el nivel nacional y provincial, más que las determinaciones unidireccionales de un polo hacia otro (Serna-Pons, 2003).

En este sentido, si bien al estudiar la participación de la Tendencia en la gobernación bonaerense se atenderá a la problemática más amplia de la inserción de cuadros del peronismo revolucionario en el Estado, el caso de la provincia de Buenos Aires a la vez que resulta representativo de esa cuestión general nos permite observar las respuestas particulares y concretas que se dieron a ese proceso en la provincia más importante (en términos económicos, demográficos, electorales y políticos) y en el ámbito gubernamental donde mayor densidad tuvo este fenómeno en todo el país. Para ello será útil tener en cuenta dos cuestiones centrales. Por un lado, la provincia de Buenos Aires fue pensada como el espacio privilegiado para llevar adelante el famoso plan de "trasvasamiento generacional", que consistía en la preparación y adquisición de mayor protagonismo de las generaciones de jóvenes peronistas como futuros dirigentes del Movimiento (Perón, 1971; Urriza, 2004). Esta premisa influyó decisivamente en la conformación de los equipos ministeriales de la gestión de Oscar Bidegain, lo cual se evidenció en la mayor incorporación de militantes de la Tendencia en el Estado, tanto en comparación con el resto de las llamadas "provincias montoneras", como a nivel de la 
administración nacional. Por otro lado, si bien esta experiencia en el gobierno bonaerense fue breve ( 8 meses) permite observar ciertos desfasajes y líneas de ruptura con el proceso nacional, en tanto la salida de Héctor Cámpora de la presidencia en el mes de julio de 1973 -que coincide con el momento de mayor influencia de la izquierda peronista en el Movimiento y el gobierno- no significó el cierre de la participación institucional de la Tendencia en el distrito más importante del país, sino que ésta continuó hasta principios de 1974, aunque en un contexto cada vez más hostil.

En cuanto a la periodización elegida, busca considerar el carácter dinámico y fluctuante de las condiciones sociopolíticas de esta particular coyuntura, expresado en los sucesivos cambios de rumbo que caracterizaron a la política nacional/provincial, y su relación con las líneas de acción seguidas por la Tendencia Revolucionaria. Al respecto, distinguiremos tres momentos que serán abordados a lo largo de diferentes capítulos. El primero va desde mediados del año 1972 hasta mayo de 1973 y está marcado por la fuerte capacidad de movilización y preeminencia política de los sectores juveniles y de izquierda dentro del Movimiento en la campaña por el regreso de Perón al país y el proceso eleccionario de marzo de 1973. Fue en este período cuando se gestó la relación entre el gobernador Bidegain y los militantes de la Tendencia y en el que se pueden observar las diferentes lecturas y estrategias adoptadas por este actor respecto del pasaje de la lucha armada a la acción institucional. El segundo período va desde mayo de 1973 a octubre de 1973 y está signado por la difícil transición desde el clima de radicalización política y social contra la dictadura al orden institucional recobrado por la breve presidencia de Héctor Cámpora. Esta etapa coincide además con el momento de mayores expectativas de la Tendencia y con la puesta en marcha de acciones institucionales conducentes a la construcción del "socialismo nacional". No obstante, con la vuelta definitiva de Perón al país, y más aún a partir de su presidencia, también podrá observarse un declive en el peso de los grupos de la Tendencia dentro del Movimiento y el gobierno provincial, lo cual se evidencia en las sucesivas crisis ministeriales atravesadas por la gestión de Bidegain en esta etapa. Finalmente, el tercer período comprende desde octubre de 1973 a enero de 1974 y estuvo caracterizado por la creciente inestabilidad del gobierno provincial, las repercusiones del "Documento Reservado" que dio inicio a la purga ideológica dentro del Movimiento y, finalmente, la caída de Bidegain y de la mayoría de los militantes de ese espacio político que habían ocupado cargos institucionales, sobre todo tras el intento de copamiento del regimiento militar de la 
localidad de Azul por parte del ERP. Todo lo cual derivó en el ascenso de los sectores de la derecha político-sindical encabezados por el vice gobernador Victorio Calabró.

Sobre la base de esta periodización, se realizará un análisis de las prácticas de la Tendencia Revolucionaria en el ámbito institucional provincial, identificando las diferentes iniciativas y propuestas llevadas a cabo en vistas a dos dimensiones que atraviesan el accionar de nuestro actor. Por un lado, las variaciones en la definición y puesta en práctica de su "línea política" en función de los cambios en las relaciones de fuerza y la incidencia de ciertos sucesos claves del acontecer histórico (llamado a elecciones, regreso definitivo de Perón al país, renuncia de Cámpora, asesinato de Rucci, documento reservado, etc.); observando las tensiones que a su interior se despliegan entre diversos actores. Por el otro, las lecturas, intervenciones y respuestas dadas frente al avance violento de los grupos de la derecha del Movimiento y el claro giro de Perón a favor del cierre de los espacios institucionales controlados por la Tendencia.

Para realizar esta investigación recolectamos diferentes tipos de fuentes. Por un lado, fuentes escritas (documentos y expedientes ministeriales, decretos del Boletín Oficial, discursos políticos, solicitadas y documentos de partidos políticos, organizaciones armadas, agrupaciones sindicales y estudiantiles, programas de gestión de organismos provinciales, materiales internos confeccionados por militantes de la Tendencia en diferentes dependencias públicas, periódicos y revistas). Por otro lado, fuentes orales, especialmente entrevistas a actores involucrados en los procesos investigados, como integrantes de la Tendencia Revolucionaria que desempeñaron cargos en el gobierno bonaerense, o militantes que no ocuparon formalmente cargos institucionales en la provincia pero que fueron testigos y partícipes de estos procesos. La técnica utilizada para la recolección de testimonios fue el método de bola de nieve (Guber, 2004: 137) que consiste básicamente en aprovechar el contacto con un primer entrevistado para establecer luego la comunicación con otros nuevos. Las entrevistas fueron semiestructuradas, es decir, se partió de una guía de preguntas abiertas, algunas de las cuales pudieron abordarse en un primer encuentro y otras en un segundo. La perspectiva central a partir de la cual realicé las entrevistas fue la de considerar que las mismas constituyen una excelente vía para conocer no sólo las trayectorias y prácticas político-institucionales, sino también para comprender el mundo de ideas y sentidos de estos actores en un momento histórico sumamente vertiginoso y marcado por la entrega personal a un proyecto político. 
Con relación a esto, cabe apuntar aquí algunos obstáculos de orden metodológico que se presentaron a la hora de poder reconstruir esta experiencia institucional de la Tendencia Revolucionaria en el año 1973, en lo que fue un período de tiempo realtivamente corto en su duración y fuertemente atravesado en sus interpretaciones posteriores tanto por los conflictos y rupturas al interior del espacio de la militancia revolucionaria, como por los efectos más profundos y traumáticos dejados por la política de exterminio de la ultima dictadura militar.

Por un lado, una dificutad metodológica tuvo que ver con el enfoque general (ya referido en el estado de la cuestión) de muchas de las investigaciones emprendidas en el período post dictadura, y fuertemente influídas por la "teoría de los dos demonios", en las que el tercer gobierno peronista aparece como una experiencia esquiva y oscura para su comprensión. Dificil de recuperar en su complejidad política, sus componentes democráticos y su dimensión no armada, bajo el prisma de la polarización analítica $-\mathrm{y}$ política- de "autoritarismo/democracia" que primó en las reconstrucciones de aquellos años. Así, como señalan Barletta, Lenci y Ramirez (2013) la experiencia del gobierno democrático 73-76 funcionó como una "piedra en el zapato" de la política posterior a 1983, quedando aquélla bajo el velo común del "autoritarismo" y el imperativo de la violencia que habría caracterizado la cultura política de esos años, obstruyendo así la posibilidad de considerar otras dimensiones y aristas de ese proceso histórico.

Esta dificultad no sólo atravesó a los estudios académicos, sino que también estuvo presente en los relatos de parte de su militancia. Tal como vimos, las tesis sobre el “desvío" y la "militarización" de Montoneros tendieron a ocluír -cuando no a negaraspectos centrales de esta experiencia de gobierno, la cual queda reducida -en la mirada retrospectiva de algunos de sus participantes- a un episodio fugaz, o meramente simbólico y dentro del plano de las expectativas y los discursos, más que de las prácticas. Este tipo de registro es el que se encuentra, en particular, en algunos testimonios y reconstrucciones de los y las militantes que rompieron con Montoneros y formaron "JP Lealtad", en los que el paradigma de la militarización y la trasmutación ideológica que habría conllevado la fusión con las FAR, actúan como una tamiz que tiende a minimizar el peso de la apuesta institucional desarrollada en diversos momentos, calificando esa experiencia como "poco significativa" en algunos casos, o como "falsa" e "impostada" en otros.

Esto nos llevó a reflexionar sobre ciertas prácticas y recaudos metodológicos importantes para nuestra investigación, que se vinculan directamente con las características del campo 
de estudios de la memoria del pasado reciente y el abordaje particular del testimonio de los sobrevivientes. Aceptando el carácter subjetivo, individual y selectivo de la memoria -que son singularidades propias del acto de recordar y evocar hechos del pasado desde un contexto e intereses diferentes en tiempo presente (Jelin, 2002; Portelli, 1991 y 2005)reconocemos el valor positivo que brindan estos testimonios, no tanto en su aporte a la consecución de una pretendida "verdad objetiva" y la reconstrucción de los hechos "tal cual sucedieron", sino como discursos que nos permiten adentrarnos en el horizonte de expectativas, subjetividades, emociones y sentidos que en ese momento los sujetos experimentaron y atribuyeron a sus actos, aspectos a los que en muchos casos es difícil acceder a través de fuentes documentales.

En esta dirección, un desafío metodológico al que nos enfrentamos tiene que ver con la aplicación de lo que Franco y Lvovich (2015) denominan un "ejercicio de alerta" o "vigilancia epistemológica" en el abordaje de las fuentes testimoniales, que nos permita distinguir y explicitar las ideas, los debates y los sentidos atribuidos por los sujetos a sus acciones en aquel momento histórico, de las posteriores narrativas, resignificaciones, usos y olvidos que conforman los diferentes "estratos de la memoria social" elaborados sobre esos mismos procesos en períodos posteriores, relatos que muchas veces pueden ser prescriptivos y condenatorios - como en los casos mencionados más arriba- o en otros altamente complacientes y elogiosos.

Frente a estas dificultades y desafíos que nos plantea el trabajo con los testimonios de ex militantes y sus balances políticos, en nuestra investigación se intentará construir una perspectiva que pueda distanciarse tanto del "exceso de empatía" con los protagonistas sus ideas, ideales y proyectos- como también de sus elaboraciones abolutamente críticas (Tortti, 2014). Al decir de Franco y Lvovich (2015) un posicionamiento del investigador/a que logre reconocer, y a la vez saldar, la tensión entre la "empatía" y el "distanciamiento".

Asimismo, teniendo presente que todo testimonio se encuentra atravesado por los filtros de la memoria, y que claramente el paso del tiempo y el contexto de producción intervienen en la construcción de ese recuerdo, en los casos en que las fuentes orales se utilizaron como base de la reconstrucción fáctica éstas se contrastaron con otras fuentes documentales y/o testimoniales, para determinar la veracidad de los hechos relatados (Carnovale, 2007).

En cuanto a las fuentes escritas, a partir de la consulta a las Hemerotecas de la Universidad de La Plata y la de la Cámara de Senadores de la Provincia de Buenos Aires 
accedimos al material periodístico de la época, consultamos el órgano de prensa tradicional de la ciudad de La Plata y que reviste información general de toda la provincia, el diario El Día. También se consultó La Gazeta y El Argentino, ambos de menor tirada y que atienden a cuestiones locales del período a estudiar. A su vez, analizamos diarios de tirada nacional (La Opinión, La Nación, Clarín, La Prensa) para cubrir los principales acontecimientos políticos del período y armar una cronología exhaustiva. Por otra parte, se trabajó con revistas político-culturales de la época, que volcaron en sus páginas variadas referencias al activismo de la Tendencia a nivel nacional y provincial (El Descamisado, El Peronista, La Causa Peronista, Militancia Peronista para la liberación nacional, Ya! Es tiempo de Pueblo, Cristianismo y Revolución, Las Bases, El Caudillo, Alianza). Algunas de estas revistas son mencionadas por la mayoría de los/as militantes como una de las fuentes principales de información y formación política en la época. Parte importante de este material, junto con el diario Noticias perteneciente a Montoneros, se encuentra digitalizado y disponible para su consulta en repositorios on line que fueron de una enorme utilidad por su rápido acceso y consulta. Me refiero a los sitios de internet "El Topo Blindado” y "Ruinas Digitales”. Estos sitios también fueron consultados para acceder a numerosos documentos políticos de las organizaciones de la izquierda peronista, al igual que las recopilaciones realizadas por Roberto Baschetti, Eduardo Luis Duhalde y Eduardo Pérez.

Por otra parte, se consultó el archivo de la Ex -DIPBA (Dirección de Inteligencia de la Provincia de Buenos Aires) que funciona en la Comisión Provincial por la Memoria, y que cuenta con más de 410.000 legajos de hechos y personas, organizados por ficheros temáticos y con un índice automatizado que facilita enormemente el acceso a información de nuestro interés. Este archivo constituye un importante acervo documental sobre procesos sociopolíticos del período estudiado, dado que los legajos creados por la Policía son "mixtos", es decir contienen tanto informes de espionaje policial, como materiales y documentos escritos -que fueron secuestrados u obtenidos en el espacio públicopertenecientes a las agrupaciones de la Tendencia. Al respecto, en nuestro análisis se privilegiaron aquellos documentos originales confeccionados por sus militantes, como así también se consultaron legajos que proveen información de enorme utilidad sobre el Gobierno de Oscar Bidegain, el Partido Justicialista de la Provincia de Buenos Aires, el Partido Justicialista de La Plata, la Juventud Peronista de La Plata, Berisso y Ensenada, la Juventud Peronista de Coronel Pringles, Punta Alta, Saladillo y Bahía Blanca, el 
Operativo Dorrego, los motines carcelarios en la provincia de Buenos Aires a lo largo del año 1973, la renuncia de Oscar Bidegain, etc.

No obstante, debemos señalar ciertos recaudos metodológicos a la hora del trabajo con estas fuentes, en tanto documentos que fueron confeccionados en un contexto represivo, es decir, de violencia por parte del Estado y de posible mentira o delación por parte de las víctimas de esa violencia (Da Silva Catela, 2007). Ello implica tener en cuenta que el contexto de producción de esas fuentes afecta a la información que podemos extraer de algunas de ellas. De esta forma, si bien las fuentes represivas nos permiten conocer acciones realizadas por personas que no sabían que estaban siendo espiadas en el momento en que las realizaban, no podemos dejar de considerar la subjetividad de los sujetos que produjeron esos informes y las lógicas burocráticas que impregnaban las prácticas de inteligencia, creando en muchos casos información "para justificar sus acciones y legar pruebas sobre la concepción del mundo que los guiaba” (Da Silva Catela, 2007: 202).

Por otra parte, se consultó el Boletín Oficial de la Provincia de Buenos Aires, documento que fue clave para la reconstrucción del conjunto de nombramientos, decretos, leyes, disposiciones ministeriales, etc. Esta información luego fue complementada con el examen de diarios de tirada local, provincial y nacional, y los testimonios de nuestros entrevistados. También se consultó el Archivo Histórico de la Provincia de Buenos Aires, y el Fondo documental Floreal Ferrara que se encuentra en el Archivo de la Biblioteca Nacional. Este material fue fundamental para conocer de manera exhaustiva diferentes iniciativas que se desplegaron en el Ministerio de Bienestar Social de la provincia, algunas de las cuales a pesar del corto tiempo que duró la gestión de Ferrara al frente de esta cartera, llegaron a concretarse, siendo representativas de la impronta de transformación y democratización que marcó el paso de los militantes de la Tendencia por el ámbito institucional. A este conjunto de fuentes debemos sumarle los documentos institucionales que algunos/as militantes que se desempeñaron como funcionarios/as del gobierno provincial conservaron de manera personal, junto a material periodístico de la época que nos permitió también reconstruir el impacto público de estas medidas.

\section{Contenido de la Tesis}

En el capítulo I de esta tesis se analiza la evolución y el rol jugado por las agrupaciones de la Tendencia Revolucionaria frente a la apertura democrática y el Gran Acuerdo 
Nacional (GAN), que marcan la salida del gobierno militar de la Revolución Argentina y la posibilidad concreta de la vuelta del peronismo al poder. Se observan las lecturas, los posicionamientos dinámicos y las resignificaciones que acompañan a este actor en el tránsito de la resistencia armada a la coyuntura democrática y las vinculaciones entre ambas formas de la política en función de su estrategia revolucionaria hacia el año 1973.

Las tensiones derivadas de la apuesta electoral (con el armado de listas y candidaturas a nivel nacional y provincial) entre los grupos de la izquierda peronista y los sectores de la derecha político-sindical del Movimiento, junto al desarrollo de la campaña del FREJULI en el verano de 1973, se analizan en el capitulo II, reconstruyendo la dinámica política de disputa al interior del peronismo que determinó el acercamiento entre Oscar Bidegain y los grupos de la Tendencia en la provincia de Buenos Aires.

En el capítulo III se abordan algunas de las discusiones que se dieron al interior de la TR en el momento mismo de la transición gubernamental, sobre el rol específico a ocupar en la nueva etapa. Asimismo, se observan las diferencias que emergieron entre sus aspiraciones y el lugar asignado por Perón de cara al gobierno. Por otra parte, se reconstruyen las trayectorias previas de figuras y grupos de la Tendencia que luego devinieron en experiencias concretas de armado de equipos profesionales para la elaboración de políticas de gobierno, y finalmente el lugar preponderante que sus militantes ocuparon en el organigrama del gobierno provincial.

En el capítulo IV se examinan las prácticas concretas de gestión de la Tendencia en el Ministerio de Bienestar Social a cargo del Dr. Floreal Ferrara, reponiendo los sentidos e imaginarios que guiaron la acción militante en el Estado y su resignificación en el marco del proyecto revolucionario de más largo alcance. Por otra parte, se atiende al impacto que tuvieron los sucesos de la masacre de Ezeiza y la caída del gobierno Cámpora en la apuesta institucional de los sectores revolucionarios del Movimiento, como muestras preocupantes del enfrentamiento con Perón, y las primeras repercusiones de estos hechos al interior de los grupos de la Tendencia.

En el capítulo V se reconstruyen las modalidades de intervención político-institucional de la Tendencia en el Ministerio de Asuntos Agrarios y de Obras Públicas, dando cuenta del alcance de los programas y propuestas encaradas, así como del horizonte de sentidos en torno a la construcción del socialismo nacional que guiaba el accionar de muchos de sus militantes. También se examinan las formas disruptivas de gestión publica encaradas por ellos/as en su nuevo rol de agentes estatales y las tensiones derivadas del "choque" con la lógica burocrática y la inercia propia del Estado. 
A lo largo del capítulo VI se analiza la experiencia del Operativo Dorrego bajo la dirección de los funcionarios de la Tendencia en el Ministerio de Gobierno provincial, vinculando esta línea de trabajo institucional, frentista y territorial con la dinámica política y de disputas que se empiezan a evidenciar de manera abierta al interior del Movimiento y con el propio Perón, examinando en particular la incidencia del Documento Reservado -con la purga ideológica que desató- y su impacto en el proyecto institucional de la Tendencia en la provincia de Buenos Aires.

Finalmente, en el capítulo VII se reconstruyen los principales episodios de la trama política nacional y provincial que llevaron a la caída del Gobernador Bidegain y al cierre de los ensayos institucionales de la Tendencia en el gobierno. Asimismo, se analizan las tensiones y los efectos disímiles que al interior de las agrupaciones de la Tendencia Revolucionaria generó la confrontación con el líder peronista, junto a los diversos derroteros seguidos por algunos de sus militantes luego de la salida de los Ministerios. 


\section{CAPÍTULO I: LA TENDENCIA REVOLUCIONARIA EN \\ LA APERTURA DEMOCRATICA. Actores, estrategias y prácticas frente a la disyuntiva política (1971-1972)}

\subsection{Del ocaso de la Revolución Argentina al despertar de la democracia: el GAN, Lanusse y Perón}

A partir del "Cordobazo", los objetivos trazados por el General Juan Carlos Onganía de posponer para un futuro remoto la emergencia del "tiempo político" se vieron rápidamente conmocionados. La magnitud de aquel estallido social y el protagonismo activo de obreros y estudiantes en la movilización, junto con el ejercicio de acciones violentas como métodos considerados válidos para expresar sus reclamos y enfrentar la represión, erosionaron profundamente la legitimidad del régimen militar a su cargo desde 1966, un gobierno que, además de no poder mostrar certidumbres en el plano económico, exhibía para 1969 notables dificultades para imponer sus decisiones por la sola voluntad de su fuerza (De Riz, 2000:74).

Por su parte, las incipientes organizaciones armadas, en su mayoría todavía en gestación, ${ }^{4}$ percibieron el "Cordobazo" como el inicio de un ciclo altamente favorable en sus proyecciones de cambio radical, en tanto parecía incrementarse la predisposición de la sociedad civil -especialmente de la clase obrera- a lanzarse a acciones violentas, preanunciantes de una situación insurreccional. Como señala Guillermo O’Donnell, los hechos de 1969 en Córdoba "fueron un decisivo estímulo para la formación de diversas organizaciones guerrilleras, entre ellas, las que posteriormente habrían de dominar la escena del campo revolucionario" (1982: 259).

Así, en el nuevo clima político surgido en mayo de 1969, y potenciado además por la seguidilla de alzamientos populares subsiguientes, la preocupación por una posible convergencia entre guerrilla y activismo social comenzó a instalarse como una inquietante amenaza sobre el gobierno castrense, en particular entre quienes se mostraban en desacuerdo con el cierre de todos los canales políticos como única respuesta a estos problemas. El "caso Aramburu” no haría más que profundizar estas tensiones.

\footnotetext{
${ }^{4}$ Hasta ese momento, las Fuerzas Armadas Peronistas (FAP) y las Fuerzas Armadas de Liberación (FAL) eran las únicas dos organizaciones guerrilleras que habían actuado previamente en el contexto del régimen de la Revolución Argentina. Por supuesto, los grupos originarios de las restantes organizaciones (FAR, Montoneros, ERP, Descamisados) ya estaban en pleno desarrollo, pero aún no se habían lanzado públicamente. El Cordobazo precipitó esto.
} 
El 29 de mayo de 1970 -día del primer aniversario del "Cordobazo"-, un comando de la organización armada peronista Montoneros hizo su aparición pública a través de un acto que dislocó hondamente el escenario político: el secuestro y ejecución del Teniente General (RE) Pedro Eugenio Aramburu. Los cargos que esta organización le adjudicó en un "juicio revolucionario" a quien representaba una de las figuras más repudiadas por el conjunto del Movimiento Peronista eran "traidor a la patria y al pueblo" por su responsabilidad directa en los fusilamientos de 1956, por encabezar la represión y proscripción contra el Movimiento, y por profanar el cadáver de Eva Perón. ${ }^{5}$ A estos objetivos iniciales que perseguían una suerte de acción punitiva y de justicia, se sumaban otras dos motivaciones no menores en sus repercusiones políticas frente a la coyuntura. Por un lado, Montoneros buscaba darse a conocer públicamente a través de un hecho espectacular con resonancias en todo el país, que, a la vez -por la elección de la víctimano dejara dudas en cuanto a su identidad peronista. Este acontecimiento, tal como señalan varios autores, marcaría el comienzo ya sin retorno de la presencia de las organizaciones armadas como actores que intervendrán activamente en el espacio público presentándose como una alternativa política más para el acceso al poder (Gordillo, 2003:364; De Riz, 2000: 75; Bartoletti, 2011:33 y Anzorena, 1998:93)

Por otro lado, y en vinculación a esto último, se sumaba el hecho de que Aramburu en los meses precedentes había vuelto a cobrar visibilidad pública a partir de su oposición a la figura de Onganía, intentando propiciar una salida negociada del gobierno militar a través del reconocimiento de los partidos políticos tradicionales -encargados de canalizar la protesta social- y postulándose como candidato para presidir esa transición institucional. Para Montoneros, esta jugada significaba una maniobra espuria del régimen para burlar al pueblo intentando integrar pacíficamente al peronismo al sistema, utilizando para ello a los dirigentes "burócratas" del Movimiento. Una alternativa que -según su comunicadodebían impedir a toda costa en pos de fortalecer la contradicción peronismo antiperonismo y la resistencia armada. ${ }^{6}$

Más allá de las posibilidades concretas de Aramburu de llevar a cabo su empresa política, lo cierto es que, para los sectores de la Tendencia, este plan significaba un intento de acercamiento del régimen a los grupos más “conciliadores" del peronismo, con la clara

\footnotetext{
${ }^{5}$ Montoneros. Comunicado $\mathrm{N}^{\circ} 1$ y Comunicado $\mathrm{N}^{\circ}$ 3. (Baschetti, 1997:50)

${ }^{6}$ Comunicado $N^{\circ} 4$ (Baschetti, 1997:52). El relato oficial de Montoneros sobre este operativo, sus detalles y motivaciones, fue publicado en una nota de Mario Firmenich y Norma Arrostito publicada en la revista La Causa Peronista n $^{\circ} 9$ del 3 de septiembre de 1974.
} 
intención de dividir al Movimiento y vaciarlo del contenido revolucionario que le atribuían, aislando a su ala más radicalizada (Lanusse, 2005:202; Gillespie, 1987:122).

A grandes rasgos esta estrategia prefiguraba el proyecto político que el General Alejandro Agustín Lanusse lanzaría meses más tarde.

Con todo, en sus efectos inmediatos, el asesinato de Aramburu significó el desplazamiento del General Onganía del gobierno y su reemplazo por el General Roberto Levingston. A nivel político, esta situación expresaba las tensiones que atravesaban al régimen militar y su dilema en cuanto a profundizar la revolución por la vía autoritaria o abrir las compuertas hacia una salida democrática (De Riz, 2000:89; Ollier, 1987:41; De Amézola, 1999: 64).

La corta presidencia de Levingston marcó un momento de transición hacia un escenario y una dinámica política cuyas características comenzaron a perfilarse dentro de un horizonte democrático. Fue en esta etapa cuando las fuerzas políticas tradicionales comenzaron a recobrar protagonismo en su exigencia del llamado a elecciones. "La Hora del Pueblo" lanzada en el mes de noviembre de 1970 encarnó la primera estrategia de coalición de diversos -y a la vez rivales- partidos políticos (peronistas, radicales, demoprogresistas, conservadores populares y socialistas) que hicieron públicas sus presiones y denuncias en este sentido. ${ }^{7}$ La declaración en la que se hizo pública la exigencia del llamado a elecciones fue firmada en representación del peronismo por Jorge Daniel Paladino, quien en ese momento era el delegado personal de Perón, y por Ricardo Balbín del Radicalismo, entre otras figuras políticas. La presencia de Paladino en ese lanzamiento -símbolo de la conciliación dentro del peronismo y que condenaba abiertamente a las organizaciones armadas- daba cuenta asimismo del juego de Perón y la anuencia de éste a encarar estas maniobras "intregracionistas", dentro de una estrategia mayor que, como veremos a continuación, no descartaba otras opciones más rupturistas.

Finlamente, la convocatoria de este acuerdo asestó un duro golpe a las inclinaciones autoritarias del régimen, poniendo en evidencia por primera vez desde 1955 el reconocimiento de Perón y el peronismo como interlocutores legítimos dentro del sistema político, de parte de las fuerzas políticas que otrora habían apoyado su proscripción (De Amézola, 1999)

La renuencia de Levingston a aceptar el llamado a elecciones en lo que fue su estrategia de "profundización de la Revolución” agravó aún más la inestabilidad del régimen,

\footnotetext{
${ }^{7}$ El reclamo de la convocatoria a elecciones también fue compartido por otro grupo de fuerzas políticas denominado "Encuentro Nacional de los Argentinos", encabezado principalmente por el Partido Comunista (De Amézola, 1999:70).
} 
situación que implosionó a comienzos del año 1971 a raíz de un nuevo alzamiento popular en Córdoba del que participaron agrupaciones sindicales clasistas y combativas, estudiantes y jóvenes radicalizados y, por primera vez, las organizaciones armadas: el Viborazo (Anzorena, 1998:142; Gordillo, 2003:370).

Frente a esta innegable presión social y política, Levingston dimitió y su lugar fue ocupado por el General Alejandro Agustín Lanusse. El flamante Presidente elegido entre sus pares, asumió el 26 de marzo de 1971 con un claro plan de acción que implicaba un notable giro respecto de sus predecesores en el terreno político.

El principal dilema que Lanusse advirtió y que motivó este cambio de paradigma dentro del régimen, fue la creciente "sensación de amenaza" percibida por las clases dominantes, producto de la creciente conflictividad social que se venía gestando desde el “Cordobazo". Esta situación, a ojos de Lanusse, podía desafiar incluso la supervivencia misma del sistema (capitalista, occidental y cristiano) y el rol central ocupado por las FFAA en su defensa. Para lograr asegurar la persistencia de ese orden, debían abrirse los canales institucionales capaces de encauzar el descontento social y político, lo que necesariamente implicaba asumir el problema de la democracia -que hasta ese momento había sido denostada por los militares- el peronismo y su proscripción.

En esta dirección, Lanusse el 2 de abril -diecisiete días después del Viborazo- declaró rehabilitados los partidos políticos y el 21 de junio se formalizó el proyecto de ley que reglamentaba su actividad. ${ }^{8}$ El 1 de mayo, desde la propia ciudad de Córdoba, anunció también el lanzamiento del Gran Acuerdo Nacional (GAN) prometiendo la convocatoria a elecciones en el corto plazo, y finalmente en septiembre de ese año, se habilitó el reinicio de la afiliación al Partido Justicialista.

No obstante, en su discurso de presentación, Lanusse dejaba en claro cuales serían los términos de su política de transición

\footnotetext{
“Acuerdo Nacional no es contubernio, no es componenda ni pacto con fines electorales. No responde a intereses subalternos; no es una fórmula para alagar demagógicamente a nadie, y no significa volver a cometer errores de un pasado, que entiéndase bien, ya no tienen cabida en nuestro país". (De Riz, 2000: 94)
}

\footnotetext{
${ }^{8}$ Esto se hizo a través de la "Ley Orgánica de los Partidos Políticos" (19.012) que fue elaborada por la Comisión Coordinadora para el Plan Político formada a fines de mayo y presidida por Arturo Morg Roig, Ministro del Interior. La Ley establecía que los partidos tendrían, a partir del 1ero de julio de 1971, un plazo máximo de un año para cumplimentar su proceso de normalización, lo que incluía campaña de afiliación, elecciones internas de autoridades, etc.
} 
Estos reparos tenían la intención de mantener el equilibrio de fuerzas y no despertar mayores tensiones entre los militares renuentes a toda medida aperturista.

Como vemos, si bien el acuerdo implicaba abrir las compuertas de la actividad política partidaria en todo el país, con el peronismo incluido y la promesa de elecciones libres sin proscripciones, una condición indispensable para el éxito de este programa -en especial frente a las presiones de la corporación militar- era lograr el repudio unánime de la guerrilla por parte de todas las fuerzas políticas tradicionales, junto al reconocimiento de la inserción de las Fuerzas Armadas en el futuro esquema de gobierno como ministros de gabinete y hasta la candidatura del propio Lanusse encabezando esa coalición cívicomilitar. Al respecto, señala De Amézola “la solución que Lanusse planteaba, a diferencia de sus predecesores, era esencialmente política: generar una opción que aislara a la guerrilla, atrayendo a los sectores que tenían cierta afinidad ideológica con ella, a participar activamente de la vida política (...) La alianza de amigos y adversarios contra enemigos fue la piedra basal del GAN" (1999:89)

\subsubsection{Perón: del apoyo a las "formaciones especiales" a la reorganización partidaria}

Si bien la incorporación del peronismo en este juego podía ser una apuesta muy costosa, la idea de máxima de Lanusse era lograr el apoyo de una coalición de partidos -en especial el radicalismo- que en una segunda vuelta electoral dieran la victoria al candidato de las Fuerzas Armadas, es decir, él mismo, derrotando al peronismo.

No obstante, uno de los mayores problemas con los que se enfrentó fue que la expectativa depositada en la capacidad de absorción y neutralización de esas tendencias disruptivas por parte de los partidos políticos tradicionales, contrastaba con el creciente predominio de "sus alas de izquierda", en un clima de opinión fuertemente cargado de discursos en torno a la revolución, la nacionalización y el socialismo, y en un contexto de desconfianza y escepticismo creciente por parte de la ciudadanía respecto de la gravitación real de las fuerzas políticas y la salida democrática sin fraudes (Tortti, 1999 y Lenci, 1999).

Por otra parte, dos elementos que analizaremos a continuación jugaron un rol central en el fracaso del GAN tal como fue concebido por Lanusse: la actitud de Perón y su vínculo con las organizaciones armadas en todo este proceso; y el costo político -para Lanusse y el régimen militar- del recrudecimiento de la represión que acompañó la apertura democrática. 
Respecto de Perón, tal como vimos, su lugar en el plan de Lanusse para frenar la guerrilla y la insurrección civil era de vital importancia. El supuesto que acompañaba el final de la proscripción del peronismo, en el ideario de Lanusse, era que, a cambio de esta readmisión en el sistema, el líder justicialista condenaría la violencia armada para dejar sin base de sustentación a las "formaciones especiales" que invocaban su nombre. Sin embargo y en la práctica, las negociaciones con el viejo líder se mostraron mucho más difíciles y distantes de las proyecciones de Lanusse. Como afirma De Riz, "en la medida en que quedaban excluidos del proyecto político tanto los guerrilleros como su jefe político exiliado, la estrategia de Lanusse vino a reforzar el vínculo entre ambos, y de ese modo, convirtió a Perón en el árbitro y protagonista de la salida institucional", (2000:79).

En efecto, el líder justicialista desde Madrid, aprovechando la iniciativa política que la crisis del gobierno militar le brindaba, comenzó a desplegar una estrategia ofensiva y de aliento a todos los sectores de su Movimiento. Su táctica, o lo que algunos llaman "juego pendular", consistía tanto en el estímulo a los grupos más radicalizados del peronismo incluyendo a sus organizaciones armadas - lo cual anulaba uno de los principales objetivos del GAN- como también, el fomento de los sectores moderados en pos de lograr consensos con otras fuerzas políticas para acelerar la salida electoral sin condicionamientos de ningún tipo por parte del régimen.

De esta forma, en los meses que siguieron al lanzamiento del GAN, Perón adoptó un renovado y endurecido discurso en mensajes y comunicados dirigidos a los grupos combativos, alentando su accionar revolucionario. En esta línea se sitúa la carta que dirige a Montoneros el 20 de febrero de 1971 sobre el caso Aramburu, en la que señala estar "completamente de acuerdo y encomio todo lo actuado", al tratarse de "una acción deseada por todos los peronistas", 9 y la larga entrevista concedida ese mismo año al grupo Cine de Liberación, que tendrá una enorme influencia en la militancia juvenil de la época. En ella, Perón realizaba un llamamiento explícito a la juventud, planteando la necesidad de "actualización doctrinaria" y el "trasvasamiento generacional" en su Movimiento, siendo las nuevas generaciones las depositarias directas de esos postulados y quienes tendrían un rol protagónico en esa etapa decisiva. En la misma entrevista caracterizaba también a los grupos armados como "formaciones especiales" que tenían a su cargo "la conducción táctica en el teatro de operaciones", mientras que se reservaba para sí la conducción estratégica. Estas organizaciones venían desarrollando como

\footnotetext{
${ }^{9}$ Carta de Perón a Montoneros, citada en Amorin (2005:154)
} 
método de lucha "la guerra revolucionaria, que es una guerra de guerrillas tanto rural como urbana", siendo una de las vías para derrotar al régimen "si no había otro camino". En otro de sus célebres pasajes citaba también a Mao, el líder de la Revolución Comunista en China, para dar cuenta de su estilo de conducción y la relación con el enemigo, reivindicando también al socialismo como meta hacia el cual marchaba el justicialismo. ${ }^{10}$

Como vemos, este aval explícito de Perón a las organizaciones guerrilleras, si bien quedaba encuadrado en una estrategia más integral de lucha contra el régimen que incluía otras vías como la normalización institucional y partidaria, dio fuerza e ímpetu al desempeño de aquéllas, viéndose fortalecidas y legitimadas en su accionar.

Así, el viejo líder lograba capitalizar sus acciones para presionar al gobierno militar, mostrando que aquéllas estaban bajo su conducción y que, de no haber elecciones, habría revolución, a la vez que con esta "línea dura" mantenía controlados a los sectores colaboracionistas de su propio Movimiento.

Por su parte, y en esta misma dirección, designó a Rodolfo Galimberti como representante oficial de la Juventud Peronista en el Consejo Superior del Movimiento. El vínculo directo que el fundador de las Juventudes Argentinas para la Emancipación Nacional (JAEN) mantenía con la organización Montoneros, fue interpretado como un guiño directo de Perón a las organizaciones armadas y los grupos radicalizados, además de ratificar el lugar por pleno derecho que la juventud combativa se había ganado como cuarta rama del Movimiento y su participación en el juego político (Larraquy-Caballero, 2000:148)

Cabe señalar también que en esta reestructuración del Consejo Superior, el juego de equilibrio pendular que Perón ejercitó se llevó a cabo a través del nombramiento de su mujer, María Isabel Martínez y el Teniente Coronel Jorge Osinde -como delegado de Perón ante la institución castrense-, además de Julián Licastro por la juventud. ${ }^{11}$

En este sentido, y como mencionamos más arriba, la ofensiva de Perón de dar su apoyo explícito a los sectores de la izquierda de su Movimiento, no fue en detrimento de otra maniobra simultánea: la negociación con el resto de los partidos políticos y el

\footnotetext{
${ }^{10}$ Juan Domingo Perón (1971) “Actualización Política y Doctrinaria para la toma del poder”, en Baschetti (1997: 303-339)

${ }^{11}$ Las Bases, $\mathrm{N}^{\circ}$ 2, 7/12/1971, p. 46. Otros nombramientos fueron el de Jorge Gianola como Secretario General y Emma Tacta de Romero por la Rama Política. Osinde era, ya por aquel entonces, un ferviente anticomunista, quien encabezaba las impugnaciones a la Tendencia Revolucionaria. Ver Besoky (2016:199)
} 
fortalecimiento del andamiaje institucional partidario en vistas a lograr el mejor posicionamiento en el escenario electoral.

Para ello, Perón designó a un nuevo delegado personal, Héctor Cámpora, quien a diferencia del anterior, Jorge Daniel Paladino, mostraba un perfil mucho más intransigente y de lealtad indeclinable. ${ }^{12}$ Fue Cámpora el encargado de encabezar las tratativas hacia adentro del justicialismo de cara a la reorganización partidaria, y hacia afuera con otras fuerzas políticas para el horizonte electoral. En este marco, en febrero de 1972, se dio a conocer el lanzamiento del Frente Cívico de Liberación Nacional (FRECILINA) integrado por el peronismo, junto con el Movimiento de Integración y Desarrollo (MID), el conservadurismo popular y otras fuerzas políticas menores.

La dualidad en los guiños de Perón hacia uno y otro vértice del arco político justicialista puede apreciarse en el discurso que acompañó el lanzamiento de esta iniciativa frentista, cuyo objetivo y naturaleza si bien eran de carácter electoral, se presentaba con fines revolucionarios: el FRECILINA no sería sólo un instrumento electoral, sino un vehículo para "la liberación nacional y social" (Bozza, 1999:146).

En sintonía con estas afirmaciones, Perón invitó especialmente a los grupos de la juventud radicalizada a sumarse a este frente, con la finalidad de reunir allí la mayor cantidad de fuerzas heterogéneas bajo un sólo objetivo: presionar a la dictadura para garantizar la institucionalización del país, sin condicionamientos y sin proscripciones (Bozza, 1999:155).

Esta propuesta quedará planteada como un interrogante para los grupos de la Tendencia Revolucionaria, quienes -como veremos más adelante- comenzaron a resolver este dilema a medida que avance la dinámica política del año 1972 y el camino a las urnas comience a ser visualizado como una posibilidad cada vez más concreta.

Con el correr de los meses, Perón endureció su posición frente a Lanusse. En julio de 1972 dio un vuelco en su táctica pasando a un embate directo. Dio a conocer los diálogos de varias entrevistas secretas que había mantenido con enviados del Presidente entre junio de 1971 y abril de 1972 en las que, a cambio de una suma de dinero y los sueldos atrasados como General en retiro, le solicitaban que renuncie a su posible candidatura. Dicha jugada perjudicó directamente a Lanusse, quien había ocultado estas

\footnotetext{
${ }^{12}$ El reemplazo de Jorge Paladino por Héctor Cámpora se vincula con la moderada política de afiliaciones que Paladino había llevado a cabo y la falta de movilización de las bases, siendo por esto mismo blanco privilegiado de las críticas de los sectores más duros del Movimiento. Ver "Reportaje a Galimberti", Revista Panorama, 8/10/1971, citada en Larraquy-Caballero (2000:147).
} 
comunicaciones y sus intenciones acuerdistas frente a los sectores más duros del ejército que mantenían una posición acérrima contra Perón (De Riz, 1981).

Frente a esto, el Comandante en Jefe se vio forzado a modificar su estrategia, pasando del diálogo a una posición ofensiva que desafiaba abiertamente a Perón a volver al país en un plazo muy corto. Las disposiciones que estipulaban esto fueron dos claúsulas limitativas sobre el proceso de institucionalización que culminaría el 25 de mayo de 1973, determinando que: 1) no podrían ser candidatos a las próximas elecciones aquellas personas que no residieran en el país antes del 25 de agosto de 1972, y 2) no podrían serlo quienes desempeñaran cargos a nivel nacional, provincial o municipal después de esa fecha (Nahamías, 2014:160). Si bien estas medidas implicaban la virtual inhibición de Perón como candidato presidencial -quien de retornar al país debía hacerlo en lo inmediato para poder postularse a un cargo electivo-, la decisión implicaba también la autoproscripción de Lanusse como candidato a la presidencia, lo cual significó el fracaso del GAN tal como éste lo había diseñado y el reposicionamiento de Perón en un lugar central de la escena política.

Por otra parte, como mencionamos más arriba, la estrategia de apertura del GAN fue acompañada de un plan represivo contra las organizaciones armadas y las manifestaciones de rebelión popular, situación que en lugar de apaciguar la conflictividad y sumar voces de consenso hacia el régimen, no hizo más que aunar las críticas de la sociedad contra aquél. Entre las nuevas medidas represivas se encuentran la creación de la Comunidad Informativa, dirigida por el Ministerio del Interior, que debía centralizar la información de los diferentes servicios de inteligencia para lograr una represión más eficaz; el control, centralización y ordenamiento de la Policía Federal a cargo del general Cáceres Monié; y por último, la creación en mayo de 1971 de la Cámara Federal en lo Penal para el juzgamiento de la actividad subversiva, cuyos jueces eran conocidos por ignorar abiertamente las marcas de torturas que exhibían los detenidos en las causas del "fuero antisubversivo" (Anzorena, 1998:151).

Si bien la práctica de la tortura no era nueva en el tratamiento represivo dado a los militantes de izquierda (Lenci, 2014), la combinación -y contradicción flagrante- de estas prácticas con un discurso "conciliador" que apuntaba a la "pacificación" del país, generaba enormes rispideces en la opinión pública general, más aún en los casos en que la represión a la protesta social impactaba en amplios sectores de la sociedad civil que no 
necesariamente comulgaban con las organizaciones armadas, pero que, al calor de estos hechos, comenzaron a sublevarse abiertamente contra el gobierno militar. ${ }^{13}$

El punto culminante de esta escalada represiva -y su rechazo por parte de la sociedadllegó con el asesinato de 16 presos políticos y 3 militantes gravemente heridos en la base Aeronaval Almirante Zar de Trelew el 22 de agosto de 1972. "La masacre de Trelew" como se la conoció, desató una ola de indignación generalizada en la población que se solidarizó con los caídos, mas allá de su filiación política, volcando a más contingentes de jóvenes a la movilización y a la militancia radicalizada (Anzorena, 1998:195). ${ }^{14}$

Al respecto, cabe señalar que si la fuga de los presos políticos del penal de Rawson previa a la masacre- permitió verificar el alto nivel operacional alcanzado por las organizaciones armadas que continuaron actuando durante toda esta etapa, los hechos represivos de profunda gravedad que encabezaba el gobierno militar despertaban enormes dudas y resquemores acerca de las "promesas democráticas" y el proceso electoral mismo, circunstancias éstas que actuaron como condicionantes de los grupos de la Tendencia Revolucionaria a la hora definir sus lecturas y posicionamientos respecto de la democracia, la participación legal y la campaña electoral.

Frente a estos niveles inusitados de represión, no es difícil imaginar la creciente incertidumbre y desconfianza que la llamada "institucionalización" del país y la "democracia liberal" despertaban en toda una generación de jóvenes militantes, cuyo ingreso a la vida política se había dado en el marco de la proscripción del partido mayoritario, la sucesión de golpes militares y la anulación de los resultados electorales en las que el peronismo se había consagrado. Como veremos a continuación, para muchos militantes de la Tendencia, la revolución a través de la lucha armada, aún en el marco de la apertura electoral, seguiría siendo una opción sumamente potente.

\subsubsection{La Tendencia Revolucionaria del peronismo en los años 1971-1972}

La coyuntura política analizada previamente, no dejó de tener implicancias y efectos directos en los grupos de la TR, tanto en su configuración como en sus posicionamientos.

\footnotetext{
${ }^{13}$ Los casos mas conocidos de asesinatos fueron los de la pareja de Martins y Zenteno, Maestre y Mesetich, el matrimonio Verd y el de Luis Pujals (Anzorena, 1998:150). Por otra parte, significativas puebladas en Mendoza, Tucumán y General Roca fueron fuertemente reprimidas en este contexto, agudizando el malestar de la población contra los militares. Ver Anzorena (1998:175-76) y Ramírez (2019)

${ }^{14}$ Asimismo, la cuestión del secuestro y desaparición de militantes de izquierda durante el gobierno de Lanusse constituyó un punto clave en este orden. Los casos paradigmáticos por su impacto en la militancia fueron los de Néstor Martins, Nildo Centeno, Marcelo Verd y Sara Palacio de Verd, Juan Pablo Maestre y Mirta Misetich, y Luis Pujals. Ver http://www.elortiba.org/old/notapas1542.html y "Los orígenes de la represión" https://www.pagina12.com.ar/diario/elpais/1-128213-2009-07-14.html
} 
Más allá de que no era el único participante del juego político comandado por Perón, sino que éste la incluía como un elemento más en el escenario de operaciones, durante estos dos años la Tendencia llegó a ocupar un rol central como nuevo actor político que disputaba alternativas de poder y que comenzó a ser visualizado de esa manera por una parte de significativa de la sociedad, en particular por la juventud que hacía su ingreso a la militancia política. Este protagonismo fue el que la convirtió en una pieza clave dentro de la estrategia de retorno de Perón, quien, ante la ofensiva de Lanusse, ya no podía prescindir de ella y sus acciones armadas.

No obstante, en las siguientes páginas analizaremos cómo la participación de los grupos de la Tendencia en esta etapa no se limitó únicamente a cumplir el rol de un "dispositivo táctico" más dentro del plan estratégico de Perón, sino que intervino en el escenario político a partir de sus propias lecturas, intereses y estrategias de largo alcance, utilizando su poder de fuego y de movilización para ver realizados sus objetivos en esta coyuntura.

De esta manera, podemos afirmar que la TR se convirtió en una de los artífices de la salida democrática -en parte por esas mismas acciones- aún cuando dicho horizonte no se encontraba en las expectativas de máxima de muchas de sus organizaciones. Sin embargo, como veremos a continuación, una vez que la perspectiva electoral se materialice, sus respuestas y reacciones frente a esta coyuntura mostrarán un cambio dinámico de su línea político-ideológica, junto a una notable capacidad de adaptación de sus formas organizativas, intentado vincular la vía legal-institucional y la estrategia armada. En este juego habrá grupos que tendrán mayor afinidad con la marcha de los acontecimientos hacia la apertura electoral, quienes en términos generales serán los que posteriormente asumirán lugares en el Estado. En este apartado, nos vamos a ocupar de las trayectorias de militancia de esos grupos en particular y de sus posicionamientos frente a la coyuntura de apertura política.

Ahora bien, ¿de qué grupos hablamos? ¿Quiénes son las organizaciones y militantes que integran el amplio espacio político de la TR en esta coyuntura?

En concreto, hacia el año 1971 la Tendencia Revolucionaria está integrada por diversas organizaciones, grupos y personas que provienen de diferentes recorridos y trayectorias políticas, sociales e ideológicas de radicalización y peronización.

Tal como mencionamos en la Introducción, uno de los actores que conformaban la Tendencia eran las organizaciones armadas que se identificaban como peronistas: las Fuerzas Armadas Peronistas (FAP), las Fuerzas Armadas Revolucionarias (FAR), Descamisados y Montoneros. 
Las FAP hicieron su aparición pública en octubre de 1968, a raíz del intento fallido de establecer un foco guerrillero rural en la localidad tucumana de Taco Ralo que terminó con el apresamiento de sus integrantes (Stavale, 2012:62). Una de las principales características de esta organización es el origen peronista de muchos de sus fundadores, quienes confluyeron en esta experiencia luego de una extensa trayectoria de lucha en la resistencia peronista, en grupos sindicales combativos o en la reorganización de la Juventud Peronista de fines de los '50 y principios de los '60 (Anzorena, 1998:103; Stavale, 2012). ${ }^{15} \mathrm{La}$ "necesidad de pasar a la acción" actuó como un elemento aglutinante de todos sus integrantes, junto a una serie de metas o acuerdos elementales comunes que giraban en torno a: el peronismo entendido como Movimiento de Liberación Nacional; el regreso de Perón y la conformación de una Patria Justa, Libre y Soberana como objetivos; la identificación del imperialismo y la oligarquía como principales enemigos; y la lucha armada como metodología. La caída en Taco Ralo con el apresamiento de sus principales dirigentes y el estallido del Cordobazo colocaron a la organización ante nuevos desafíos tanto en sus definiciones político-ideológicas como en sus prácticas de funcionamiento, que cobraron forma a través del desarrollo de la guerrilla urbana -abandonando el foco rural- y la incorporación de nuevos contingentes de las juventudes universitarias recientemente radicalizadas $\mathrm{y}$ de experiencias sindicales combativas y clasistas (Raimundo, 2004; Stavale, 2012).

Los cambios en la coyuntura nacional a raíz de la apertura política, la vinculación con el movimiento de masas poscordobazo y la recomposición interna con motivo de la detención del grupo originario y el ingreso de nuevos militantes, fueron el marco de una importante reconfiguración de las FAP durante los años 1970-71. Prontamente los acuerdos mínimos iniciales se tensionaron por el desencadenamiento de fuertes discusiones internas y la polarización entre dos líneas que tomaron el nombre de “alternativistas" versus "movimientistas", lo que precipitará la escisión de este último grupo. A grandes rasgos, el debate giraba en torno a los conceptos de la "alternativa independiente" y "clase obrera" que comenzaron a vertebrar la línea político-ideológica del grupo encabezado por el obrero metalúrgico Raimundo Villaflor y el militante Jorge

\footnotetext{
${ }^{15}$ Más específicamente, el grupo original de las FAP estaba integrado por militantes provenientes del Movimiento de la Juventud Peronista (MJP) de Envar El Kadri y Carlos Caride; militantes de Acción Revolucionaria Peronista (ARP) fundada por John W. Cooke como Amanda Peralta y Nestor Verdinelli; otros que venían del Movimiento Nacionalista Revolucionario Tacuara (MNRT) como Jorge Caffati y José Luis Nell; ex activistas del grupo del Vasco Bengoechea que venían del Partido Obrero y se acercan a la Juventud Peronista; y por último algunos curas, seminaristas y militantes cristianos identificados con el Movimiento de Sacerdotes para el Tercer Mundo y el peronismo como Gerardo María Ferrari y Arturo Ferré Gadea, entre otros (Raimundo, 2004).
} 
Caffatti. Esta facción consideraba sólo al proletariado peronista como sujeto revolucionario, y proponía la construcción de una organización política independiente de la "partidocracia" peronista. En contraposición permanecía la postura tradicional que consideraba al Movimiento como el espacio político propio y a Perón como líder indiscutible (Stavale, 2012). Las permanencias de estas diferencias llevaron finalmente a la ruptura del grupo movimientista y su integración con Montoneros y Descamisados. En las páginas siguientes analizaremos con mayor detenimiento la trayectoria de este grupo en vistas a sus posicionamientos respecto de las estructuras del Movimiento y la participación en espacios institucionales.

Desde un recorrido notablemente diferente en su trayectoria de radicalización y peronización, encontramos a las Fuerzas Armadas Revolucionarias (FAR) quienes integraron también la TR en esta coyuntura. Las FAR fueron fundadas por grupos que rompieron con la izquierda marxista a comienzos de los sesenta (el Partido Comunista PC- y el Movimiento de Izquierda Revolucionaria-Praxis -MIR-Praxis-) y que, entre 1966 y 1969, participaron de distintas experiencias guevaristas. En 1970 esos grupos se fusionaron y se presentaron públicamente como FAR con la toma de la localidad bonaerense de Garín en el mes de julio de ese año, dejando pintada en las paredes del pueblo la consigna sanmartiniana que desde entonces los identificaría: "Libres o muertos, jamás esclavos". Al año siguiente asumieron al peronismo como identidad política desde una perspectiva marxista, teniendo al socialismo como objetivo final de su proyecto político. Por esos años la organización logró contar con regionales en distintos lugares del país como Buenos Aires, Córdoba, Tucumán, Santa Fé y Mendoza, y emprendió acciones conjuntas con otras organizaciones armadas peronistas, desarrollando además vínculos con agrupaciones de base. Finalmente, en octubre de 1973 terminaría por fusionarse con Montoneros (González Canosa, 2013).

La particularidad de esta organización -a diferencia de los itinerarios de "peronización" o “izquierdización” del resto de las organizaciones armadas peronistas- es que expresa un "cauce de radicalización política" distinta, aquel que va de la izquierda tradicional y el marxismo al peronismo, proceso que como indica González Canosa (2017) implicó una "doble ruptura" para estos grupos, tanto respecto de sus formas de hacer política abrazando la lucha armada-, como de las tradiciones político-ideológicas de sus partidos de origen, deudoras del pensamiento liberal y profundamente antiperonistas. No obstante dichas rupturas, las "huellas de origen" de la cultura de izquierdas permanecerán en el "estilo de peronización" diferencial de las FAR y en su accionar. En este sentido, la 
organización no abandonó el marxismo, sino que lo reivindicaba como método de análisis para interpretar la realidad nacional y el peronismo, al tiempo que el legado guevarista más allá de las reelaboraciones realizadas- impuso su impronta en las formas de pensar el vínculo con el movimiento social más amplio (Gonzlaez Canosa, 2017). Finalmente, los cambios en la dinámica política nacional con la apertura electoral y el retorno del peronismo al gobierno implicaron ciertas modificaciones en sus planteos políticos iniciales que potenciaron también el acercamiento de posturas con Montoneros, situación que culminará en la fusión de ambas organizaciones formalmente en octubre de 1973.

Por su parte Descamisados, quizás la menos conocida de las organizaciones armadas peronistas que integraron la Tendencia, ${ }^{16}$ expresa un itinerario de radicalización distinto al de las dos organizaciones precedentes. Se trata del proceso de transición hacia la izquierda, peronización y lucha armada que experimentaron diversos sectores laicos del catolicismo postconciliar a mediados de la década del '60 en nuestro país (Campos, 2012). Sus comienzos datan de 1969, cuando varios de sus militantes -jóvenes católicos provenientes de la Juventud Demócrata Cristiana y de la Juventud Peronista- empiezan a plantearse la cuestión de la lucha armada como vía para combatir al gobierno militar de Onganía. Según Castro y Salas (2011), la reunión definitoria en la que se discutió la formación de Descamisados fue un encuentro de centros de estudiantes y coordinadoras del seminario católico de Villa Devoto, en donde se fijaron los ejes político-ideológicos de la organización a través de la definición de la contradicción principal, imperialismo nación, y el rechazo del "foquismo" como metodología, en la medida en que a su juicio implicaba un abandono de los frentes de masas. ${ }^{17}$

La presentación en público de la organización se dio en noviembre de 1970, cuando varios de sus militantes interrumpieron la función en un cine de La Tablada para proyectar un fragmento del film La Hora de los Hornos, realizado por el grupo Cine de

\footnotetext{
${ }^{16}$ Hasta el momento no existen trabajos académicos sistemáticos que reconstruyan por entero la historia de esta organización armada. Sólo contamos con la biografía de uno de sus principales dirigentes, Norberto Habegger, que aborda tangencialmente algunos tramos de la organización (Castro-Salas, 2011) y un artículo de Esteban Campos (2012) que analiza los comienzos de Descamisados como expresión de la transición que hicieron sectores del cristianismo posconciliar a la guerrilla peronista, centrándose más en el grupo originario de la Juventud Demócrata Cristiana que logró erigirse como conducción de la organización.

17 Castro-Salas (2011). Ambos autores desestiman la responsabilidad de Descamisados en el asesinato de Augusto Timoteo Vandor en 1969 a manos del Ejercito Nacional Revolucionario (ENR). Gillespie es quien en su libro sobre Montoneros, señala al ENR como un "sello vacío" utilizado por Descamisados para efectuar acciones armadas cuando aún no estaban dadas las condiciones para dar a conocer su identidad públicamente por las posibles represalias y reacciones adversas (1987:140)
} 
Liberación de Fernando Solanas y Octavio Gettino, en el que Perón elogiaba la lucha armada (Campos, 2012). ${ }^{18}$

$\mathrm{Su}$ programa político presentaba similitudes con el del resto de las organizaciones armadas peronistas, girando en torno al regreso de Perón a través de la guerra revolucionaria y la declaración a favor de la construcción del socialismo nacional (Campos, 2012). ${ }^{19}$ Entre 1970 y 1972 realizaron operativos de propaganda armada, como la voladura del yate "Biguá", que estaba anclado en un muelle del Tigre y pertenecía al Comando en Jefe del Ejército, o el incendio de las instalaciones del Centro Naval de Tigre en septiembre de 1972, un atentado en represalia por la matanza de presos políticos en Trelew.

Si bien Descamisados no llegó a ser una organización que operara a escala nacional, logró un importante anclaje sobre todo en barrios populares del Gran Buenos Aires. Esta fuerte inserción territorial y el trabajo político en los frentes barriales y sindicales, tal como veremos más adelante, fue un elemento distintivo de la organización con importantes resonancias en el derrotero posterior de sus militantes en 1973, ya en otro escenario político y bajo la integración con Montoneros.

Por último, dentro de las organizaciones armadas peronistas que integraban la Tendencia se encuentra Montoneros, que al igual que Descamisados, muestra un cauce de radicalización vinculado a sectores juveniles católicos que en los años '60 emprendieron el paso de la "opción por los pobres” a la “opción por las armas” (Lanusse, 2005).

Como señalamos anteriormente, la organización se dio a conocer públicamente en mayo de 1970 a partir del operativo que terminó con la muerte de Pedro Eugenio Aramburu. Si bien de esta acción participaron sólo los miembros del "grupo fundador", la agrupación desde sus inicios estuvo conformada por 5 grupos provenientes de todo el país, que expresaban en su trayectoria la confluencia de experiencias colectivas de participación en "ámbitos" y "círculos" politizados del catolicismo renovador y su transición hacia el peronismo revolucionario y la lucha armada. ${ }^{20}$

\footnotetext{
${ }^{18}$ Ver "Descamisados: 20 de noviembre de 1970. 'Día de la Soberanía'” En Baschetti (1997:96). En este que es uno de los primeros documentos públicos de la organización se conmemora "la gloriosa gesta de la Vuelta de Obligado" como símbolo de la resistencia del pueblo criollo contra el imperialismo. Se observa así el énfasis en las categorías de imperialismo-nación como formas de contradicción principal y su concepción movimientista al convocar "a todo el pueblo peronista" a encarar "la guerra contra los enemigos de la patria” y "a tomar las armas por el retorno de Perón y el pueblo al poder".

${ }^{19}$ Campos (2012) señala que las referencias al socialismo eran escasas en los documentos de la organización, recurriendo más a la fórmula tradicional del peronismo de "construcción de una Patria justa, libre y soberna" que a la categoría propia de la tradición de izquierda.

${ }^{20}$ Los cinco grupos fundadores eran:1) Grupo Córdoba, cuyos principales referentes eran Luis Rodeiro, Elvio Alberione e Ignacio Vélez forjados en su militancia por los curas rebeldes de la Parroquia Cristo
} 
La organización ya en sus primeros comunicados se declaró como peronista, promoviendo el retorno de Perón y el socialismo nacional como objetivos principales y la lucha armada como metodología para alcanzarlos (Lanusse, 2005:268). Para 1971 Montoneros se vio fuertemente debilitada en su estructura, luego del apresamiento de algunos de sus miltiantes en la toma de La Calera y el trágico desenlace en una pizzería de William Morris, episodios en los que perdieron la vida tres de sus principales líderes (Larraquy y Caballero, 2000:117). ${ }^{21}$ A principios de 1972, la creación en su estructura interna de las Unidades Básicas Revolucionarias (UBR) y el nexo cada vez mayor con la estructura de la JP Regionales, potenció el trabajo político de la organización con las agrupaciones de superficie, lo que provocó un vuelco en su crecimiento e incidencia en importantes sectores de la juventud peronista (Lanusse, 2007).

Las similitudes en cuanto a los criterios estratégicos generales compartidos por estas 4 organizaciones, fundamentalmente la lucha armada como metodología, el peronismo como identidad política y el establecimiento del socialismo como objetivo final, dieron lugar a una experiencia común de acción y debate que las reunió a todas ellas a mediados del año 1971: las Organizaciones Armadas Peronistas (OAP) (Gonzalez Canosa (2014). ${ }^{22}$ No obstante, las diferencias ideológicas de fondo encarnadas en los debates entre la "alternativa independiente" y el "movimientismo", provocaron la disolución de este espacio de coordinación en abril de 1972.

Sin embargo, hacia 1971 las organizaciones armadas no eran las únicas protagonistas e integrantes de la Tendencia Revolucionaria. Los vínculos que aquéllas establecieron -ya sea de manera orgánica, o a través del contacto previo de sus militantes en otros ámbitos

Obrero; 2) el Grupo Santa Fé, bajo el liderazgo de Mario Ernst, María Graciela Roldán y Dora Riestra; 3) el Grupo Reconquista, ligado a Roberto Perdía y los curas Arturo Paoli y Rafael Yacuzzi; 4) el Grupo Sabino Navarro, de José Sabino Navarro, Carlos Hobert y Gustavo Lafluer, y 5) Grupo Fundador, ligado al cura Carlos Mugica, cuyos líderes eran Emilio Maza, Carlos Ramus y Fernando Abal Medina (Lanusse, 2005: 175 y ss).

${ }^{21}$ El 30 de junio, un mes después del secuestro de Aramburu, la organización llevó a cabo la toma de la localidad cordobesa de La Calera. En el momento de la dispersión en las afueras de Córdoba, varios de los integrantes del grupo cordobés fueron heridos de bala y detenidos por la policía, entre ellos, Emilio Maza, Ignacio Vélez y Luis Lozada. A los pocos días, Maza finalmente murió. Por su parte, el 7 septiembre de 1970, Fernando Abal Medina y Carlos Ramus fueron asesinados cuando asitían a una cita de la organización en el local de una pizzería ubicada en la localidad de William Morris. Allí se encontrarían con Luis Rodeiro, Sabino Navarro y Capuano Martínez. La policía, alertada por un vecino, abrió fuego dentro del local, resultando muertos al instante Fernando y Carlos. Luis Rodeiro fue detenido y los dos restantes lograron escapar. Luego de estos hechos que conmovieron a la organización, perdiendo la vida importantes "cuadros fundadores", las FAP dieron refugio y soporte logístico a los restantes miembros de Montoneros que eran perseguidos (Larraquy y Caballero, 2000: 117 y Lanusse, 2005:211)

${ }^{22} \mathrm{En}$ su artículo, la autora señala que inicialmente en base a las posiciones ideologicas sostenidas por las 4 organizaciones, los alineamientos más cercanos se daban entre FAP y FAR, por un lado, al sostener una línea más alternativista, y entre Descamisados y Montoneros por otro, que se ubicaban en la posición movimientista. 
y redes del peronismo revolucionario- con agrupaciones de base y figuras del mundo religioso, sindical, profesional, estudiantil y barrial son fundamentales para comprender tanto la heterogeneidad interna de la Tendencia, como también -y derivado de esto mismo- el crecimiento y dinamismo de este espacio político en la cambiante coyuntura de esos años.

A continuación, nos detendremos en el análisis de tres grupos en particular cuyo itinerario e impronta más "movimientista", será clave en el recorrido posterior vinculado a una mayor inserción institucional. La mirada más focalizada en las etapas previas de su militancia permitirá reponer el contexto, las redes sociales y las discusiones en las cuales estos grupos forjaron su experiencia política concreta, lo que a su vez nos brinda elementos útiles para comprender las formas en que pensaron y sintieron los vínculos entre el peronismo y la lucha armada, entre la democracia y la revolución, y las acciones disímiles que fueron ensayando en la compleja dinámica política que culminó en las elecciones de 1973. De este modo, al destacar estas trayectorias de los años anteriores al gobierno, nuestra intención es reponer ciertas condiciones previas, líneas de acción y perspectivas afines -con muchos matices- que terminarán por definirse y cobrar visibilidad en los acontecimientos de 1973.

\section{-Experiencias de radicalización movimientistas:}

\section{Los "oscuros" de las FAP}

Luego de la caída en Taco Ralo, comienza para las FAP una etapa de consolidación de su estructura urbana, abocándose de lleno al trabajo en las ciudades sin volver a encarar proyectos en el campo. Esta derrota del foco rural, tal como mencionamos previamente, abrió internamente un proceso de profundas transformaciones, tanto por el apresamiento de muchos de los dirigentes del nucleo original, como por el ingreso de nuevos militantes que hacia 1970 fueron incorporando nuevas visiones político ideológicas (Raimundo, 2014). ${ }^{23}$ Estos actores irán delineando una definición crítica respecto de Perón como lider revolucionario, asociado también a una concepción del socialismo que ya no se encontraba ligada a un reparto "más justo" de la riqueza sino a formas socialistas de

${ }^{23}$ Es el caso del grupo Avellaneda, compuesto por militantes obreros que habían participado de la CGT de los Argentinos y muchos también de Acción Revolucionaria Peronista de J.W.Cooke, su líder natural era Raimundo Villaflor, y otro grupo encabezado por Jorge Caffatti, ambos imbuidos con categorías de análisis marxista. (Duhalde y Perez, 2003, p. 62). 
producción. ${ }^{24}$ Dichas ideas encarnaron en la propuesta de la "Alternativa Independiente" (AI) que, como vimos, propiciaba una reafirmación clasista respecto del componente peronista y el repudio absoluto a cualquier articulación con las estructuras sindicales y partidarias del Movimiento, consideradas en extremo "burocratizadas" (Stavale, 2012; Perez, 2003). ${ }^{25}$

Estas definiciones caracterizaron a una de las dos posturas existentes al interior de las FAP. Coexistiendo con ella, de manera cada vez más tensionada, se encontraba el grupo urbano que sostenía una posición más "movimientista", al considerar al Movimiento Peronista como revolucionario en su conjunto y valorando como no prioritaria la diferenciación con la burocracia, en nombre de la unidad. Asimismo, estas ideas iban de la mano de una definición de Perón como único líder y conductor del proceso de liberación nacional, y único interprete de su pueblo (Stavale, 2012: 68), como también de la posibilidad de encarar una alianza con sectores de la burguesía nacional.

Pronto, el grupo movimientista fue denominado como los "oscuros", por parte de los alternativistas o "iluminados" (Gurrucharri, 2001:305) $)^{26}$ y estaba compuesto mayoritariamente por jóvenes universitarios que militaban en agrupaciones estudiantiles peronistas, ${ }^{27}$ docentes que participaron de la experiencia de las Cátedras Nacionales, ${ }^{28} \mathrm{y}$

24“12 preguntas a las FAP”. Cristianismo y Revolución, Nㅜ25, septiembre de 1970. Las definiciones volcadas en esta entrevista resultan muy interesantes ya que allí se dan a conocer por primera vez de manera pública las ideas de la línea "clasista - alternativista". En otro de sus pasajes, caracterizan de insuficiente la lucha llevada a cabo por el peronismo, dada "la existencia de sectores, dentro del movimiento, que aun siguen manteniendo planteos reformistas (esto) se debe a que desde su origen integraron el peronismo sectores de la burguesía nacional que todavía subsisten y a cuyos planteos se adhieren dirigentes sindicales burocratizados. La representatividad de todos estos sectores está hoy en franco retroceso".

${ }^{25}$ Esta línea progresivamente se volverá hegemónica al interior de las FAP, más aún con el lanzamiento del llamado "Proceso de Homogeinización Política Compulsiva" (PHPC) dado en la segunda mitad del año 1971, cuyo objetivo era lograr la "coherencia ideológica" en torno a la visión clasista/alternativista entre los militantes, y acabar definitivamente con el "movimientismo". El lanzamiento de esta iniciativa provocó un fuerte retraimiento de todas las actividades político-militares de la organización, incluida la articulación con los frentes de masas, lo que llevó casi a su parálisis y aislamiento, en un contexto paradójicamente en el que se incrementaba la movilización y politización popular frente a la crisis del gobierno militar y la apertura política. En palabras de Eduardo Pérez "Lo contradictorio del PHPC radicaba en que se intentaba impulsar un proceso destinado a construir la hegemonía de la clase obrera peronista al tiempo que se restringían los contactos con la misma y no se procuraba el desarrollo de frentes" Pérez (2003:78). Conclusiones similares pueden encontrarse en Gasparini (2006) y en los testimonios de Envar El Kadri en Cersósimo (2008) y Anguita y Caparrós (2007 [1998]: 342 y ss.)

${ }^{26}$ Según el autor, el origen de estas denominaciones surge del propio Raimundo Villaflor, cuando ante los argumentos del grupo movimientista que señalaban como incompatible la concepción peronista con un punto de vista clasista, les respondió: “veo todo oscuro". De allí que el grupo alternativista comenzó a llamar a los disidentes "oscuros". También Jorge Gaggero, militante de las FAP del grupo de los "oscuros" señala al respecto: "Los que optamos por una postura movimientista, fuimos denominados "oscuros", se supone que por no haber sido "iluminados" por la teoría del materialismo dialéctico”. En Duzdevich, Raffoul y Beltramini (2015: 74)

${ }^{27}$ Dentro del grupo universitario se encuentran entre otros Alejandro Peyrou y Jorge Gaggero que habían militado en la Facultad de Ciencias Económicas y también en la ARP de Cooke, e ingresan a las FAP en 
también varios ex curas y seminaristas que venían militando políticamente en el peronismo revolucionario haciendo trabajo barrial en villas de San Nicolás y Villa Jardín. $^{29}$

Para todos ellos, la AI y las críticas a Perón implicaban una fuerte ruptura con la identidad peronista desde la cual habían iniciado su militancia política y decidido dar el salto hacia la lucha armada, posiciones que -según ellos- terminaban alejándolos de la clase obrera que buscaban representar y de la movilización popular que brotaba de manera acelerada en ese mismo momento. Algunos testimonios a continuación ilustran el debate de ideas que atravesó a las FAP y las diferencias políticas que terminaron finalmente con la salida del grupo de los "oscuros" y su integración a Montoneros y Descamisados.

En el caso de Alejandro Peyrou, su relato da cuenta de cierta unidad que hasta fines de 1970 nucleaba a los miltantes de las FAP en torno a temas como la vinculación de la organización con las masas y el lugar que ocupaba la lucha armada en esa política

\begin{abstract}
"Nosotros nos ponemos a hacer trabajo de superficie: universidad, gremios ligados a Ongaro, y las villas, porque el centro no era la lucha armada, sino la propaganda armada para marcar presencia política, es decir no estábamos construyendo el ejército revolucionario sino generando acciones militares para despertar la simpatía de la población, repartir juguetes en villa piolín y asaltar un cuartel para conseguir armas, no había una lógica de ejército revolucionario sino una lógica peronista que buscaba organizar a la gente, darle capacidad militar y conducción política, por eso nunca hablamos de la vanguardia, sí estábamos más cerca del brazo armado del movimiento peronista que de la vanguardia revolucionaria, esto es la FAP como conjunto en esos primeros dos años hasta el 70-71"30.
\end{abstract}

Más allá de los debates políticos que surcaron la organización desde sus comienzos, esta "unidad en los hechos, más que en las palabras", según Peyrou, fue interrumpida por la

1968, Leopoldo Halperín que había estudiado Sociología en la UBA y militado en FANDEP, participando junto a Peyrou de la CGTA e incorporándose a las FAP luego del Cordobazo, y Marcela Durrieu que estudiaba en la Facultad de Medicina y se sumó a la organización a fines de 1969. Entrevista de la autora a Alejandro Peyrou, CABA (2012). Pozzoni (2017).

${ }^{28}$ Por su parte, Ernesto Villanueva y Alcira Argumedo formaron parte de las Cátedras Nacionales en la carrera de Sociología y también allí vivenciaron muy de cerca la discusión entre oscuros e iluminados, formando parte del primer grupo. Entrevista a Alcira Argumedo (2008), cedida por Alejandro Peyrou.

${ }^{29}$ Integraban este grupo el cura Jorge Galli, y los seminaristas Eduardo Moreno, José Ledesma y Arturo Ferré Gadea. Lucia Cullen también militaba junto a ellos en Villa Jardín (Duzdevich, Raffoul y Beltramini 2015: 44). Envar El Kadri si bien no participó de esta etapa de las FAP urbanas por su detención, fue uno de los militantes que más se opuso a la línea alternativista, encarnando también el "movimientismo" de los "oscuros" desde la cárcel. Anguita y Caparrós (2007 [1998]: 344)

${ }^{30}$ Entrevista de la autora a Alejandro Peyrou, CABA (2012). Peyrou ingresó a Montoneros luego de la salida del grupo de los "oscuros" de las FAP a mediados de 1971. Fue uno de los responsables políticos de la Columna Sur, teniendo a su cargo la vinculación con el grupo de JP La Plata. Participó como Subsecretario de Asuntos Agrarios durante el gobierno de Oscar Bidegain. Por diferencias políticas con la organización, a principios de 1974 rompió con ésta y se integró a JP Lealtad. Ver capitulo 5. 
influencia del grupo Caffatti y Villaflor, quienes habrían introducido en las FAP una "deformación" del marxismo presente en el pensamiento de Cooke, provocando una extrema ideologización que derivó en diferencias insondables

\begin{abstract}
"A mediados del 70 supongo, entra un nuevo grupo que venía de la ARP, Cafatti, Raimundo Villaflor, ellos tenían una mala versión de Cooke de lo que era el peronismo, deformaron la visión marxista de Cooke sobre el peronismo y decían que la patronal y los obreros estaban adentro de la organización, y te acusaban de 'pequebu'', y que lo peor es cuando el enemigo es el que está adentro de la organización. No podían dialogar con nosotros que eramos los que hicimos esto y ellos vinieron después. Ellos se autodenominan los 'iluminados' y nosotros pasamos a ser los 'oscuros', nos trataban de oscuros, porque no entendíamos de ideología... Eso mezclado con que los montos mataron a Aramburu, esas dos cosas debilitaron mucho a la $P{ }^{\prime \prime 31}$
\end{abstract}

Desde otro lugar, José, ex militante del grupo de los "oscuros", repone las implicancias políticas y de ruptura identitaria que para algunos militantes de las FAP significaba asumir las posiciones alternativistas, llegando a visualizar esto como un cuestionamiento grave a la imagen "cuasi sagrada” de Perón y su rol como único conductor

"Nosotros nos sumamos a las FAP que ya estaban operando militarmente, y no cuestionábamos la violencia porque era la respuesta a una búsqueda permanente de formas de hacer política desde una identidad política proscripta. Entonces nos armamos para el retorno de Perón y el castigo a los represores, y viene este grupo (iluminados) y nos dicen que eso era insuficiente $y$ plantean la Alternativa Independiente. Para nosotros eso era alternativa a Perón"32

En un sentido similar, en el testimonio de Leopoldo Halperín se puede advertir la centralidad que la figura de Perón tenía como punto nodal en los debates introducidos por el grupo alternativista

"En el '71 se empieza a hablar de la AI. Eso era muy grave, porque era peronismo sin Perón. Esto lo habíamos visto toda la vida de nuestra militancia peronista. Nos habíamos matado de risa de Sueldo-Luque, de Paladino, de todos los tipos que venían a hacer peronismo sin Perón, para volver a escucharlo ahora adentro de la organización. Ahi se armó la podrida ...yo estuve un tiempo a la deriva en el '72 y tenía un contacto con Descamisados que estaban procesando su integración en Montoneros, ahi ya había buena parte de los "oscuros" y entré a Montoneros". 33

\footnotetext{
${ }^{31}$ Ibid.

${ }^{32}$ Entrevista de la autora a José, ex militante de las FAP-oscuros. Quilmes (2012).

${ }^{33}$ Leopoldo Halperin, CABA, 2008 (entrevista cedida por Alejandro Peyrou). Leopoldo Halperín militó primero en el ámbito universitario en la carrera de Sociología de la UBA, dentro de la agrupación peronista FANDEP, y luego ingresa a las FAP en el grupo urbano junto a Alejandro Peyrou. Se aleja de la organización armada frente a los debates por la alternativa independiente, y tras un breve paso por Descamisados, ingresa a Montoneros luego de la fusión de ambas organizaciones armadas a fines de 1972. Participó como asesor en la Dirección de Menores del Ministerio de Bienestar Social de la provincia de
} 
Hacia junio-julio de 1971, se produjo finalmente la ruptura formal del grupo de los "oscuros" saliendo de las FAP, muchos luego ingresaron a Montoneros y otros a Descamisados. La afinidad con las posiciones movimientistas que sostenían ambas organizaciones peronistas explica en gran parte esta integración, como así también el impacto y la atracción que despertaban el trabajo con las agrupaciones de superficie y la apertura hacia lo electoral.

\section{Descamisados: Acción Peronista y el grupo de la JP de Vicente López}

La organización Descamisados reunía una rica experiencia de trabajo político, territorial y sindical por parte de sus integrantes, quienes habían transitado el camino que va del catolicismo posconciliar al peronismo revolucionario y la lucha armada. Este activismo desde diferentes agrupaciones de base -presente en las etapas iniciales de radicalización de los y las jóvenes que conformaron la organización- se mantuvo aún luego de que se constituyeran como organización armada con una estructura clandestina.

Noberto Habegger y Horacio Mendizábal, dos importantes dirigentes de la organización, comenzaron a militar en la Juventud Demócrata Cristiana (JDC) a fines de los '50. ${ }^{34}$ Para mediados de los '60 junto a otros compañeros se sumaron a las filas del peronismo, militancia política que combinaron con el activismo universitario y el compromiso social religioso. Una experiencia que marcó a muchos jóvenes católicos del período fue la participación en los Campamentos Universitarios de Trabajo (CUT) organizados por el cura obrero José María Llorens en 1968 (Castro y Salas, 2011:33). El contacto con la situación de explotación y pobreza de las comunidades del interior del país se tradujo luego en un activo trabajo social y político en villas miseria de Vicente López, trabajo que encararon ya bajo una nueva agrupación: Acción Peronista. ${ }^{35}$ Habegger estableció

Buenos Aires, hasta su renuncia en enero de 1974. Por esa misma época, se aleja de Montoneros en ingresa a JP Lealtad.

${ }^{34}$ Norberto Habegger ingresó a la Democracia Cristiana en 1957, y en 1962 fue nombrado Secretario General de la Junta Ejecutiva Nacional de la JDC. Horacio Mendizabal fue responsable de la JDC en Capital Federal en 1962. Flora Castro fue miembro de la Junta Nacional de la DC y Secretaria de Prensa del movimiento femenino del partido en 1964. Jorge Bernetti y Guillermo Gallo Mendoza militaron también en la JDC, luego integrándose a la experiencia de la CGTA. Castro y Salas (2011: 17 y ss)

35 Según el libro de Castro y Salas (2011) “Acción Peronista” era la JP de Vicente López, sus organizadores fueron Habegger, Fernando Galmarini y Socorro Centeno. Al tiempo de establecerse, lograron conectarse con el delegado de Paladino en Vicente López, Teodoro Barbieri, quien según los testimonios era mucho más cercano a la línea combativa de este grupo que a las posiciones conservadoras de Paladino o Remorino por aquél entonces. Estos contactos, a la vez que muestran la tendencia de este grupo a participar en las estructuras "oficiales" del peronismo, propia del movimientismo, permitieron el crecimiento de su trabajo político y territorial en la zona de una forma diferenciada y la publicación de un 
contacto con los núcleos de "viejos" peronistas que militaban en la zona y con el paso del tiempo se organizaron todos juntos como JP de Vicente López, entablando relaciones con dirigentes del Movimiento y extendiendo su trabajo político barrial en Villa Martelli, Olivos y La Matanza. ${ }^{36}$

Las redes en las que confluían los grupos católicos y peronistas combativos llevaron también a su participación en 1968 en la experiencia de la CGT de los Argentinos (CGTA) dirigida por Raimundo Ongaro, que funcionó como un polo de atracción de los jóvenes católicos peronistas. ${ }^{37} \mathrm{Al}$ año siguiente, la profundización de las discusiones en torno al lanzamiento de acciones armadas como forma de lucha más efectiva contra la dictadura militar culminaron en la decisión de conformar la organización político-militar "Descamisados".

El testimonio de Flora Castro citado a continuación, da cuenta de su recorrido de militancia religiosa y social a mediados de los '60 y la articulación con experiencias dentro del ámbito del sindicalismo y el peronismo revolucionario

\footnotetext{
"Yo estaba en Vicente López a cargo de un organismo que dependía de la Iglesia Católica que se llamaba "Campaña mundial de lucha contra el Hambre", lo que hacíamos era trabajo de organización social con gente de la Villa Martelli. Teniamos un jardín de infantes, una cooperativa, trabajábamos con la pedagogía de Paulo Freire y aplicábamos las ideas de Ezequiel Ander Egg de Desarrollo de la Comunidad, que no implicaba una función paternalista ni de beneficencia, sino ayudar a la gente a que se organice, era algo muy de avanzada de organización popular, eso fue durante 5 años. Y a la vez ya se estaban conformando grupos que
}

periódico que llebava el mismo nombre de la organización. Con el tiempo, y luego de los contactos con los nucleos de "viejos" peronistas que militaban allí, se organizaron directamente como Juventud Peronista de Vicente López. Graciela Imaz y Rodolfo Ojea Quintana también se sumaron a este grupo.

${ }^{36}$ Entrevista de la autora a Flora Castro, La Plata (2013). De esa experiencia en Villa Martelli participó también Ricardo Grassi, militante de Descamisados quien más tarde se incoporaría a Montoneros y se integraría al staff de su publicación emblemática: El Descamisado (Grassi, 2015:39)

37 El nacimiento de esta central obrera se vincula al Congreso Normalizador de la CGT realizado el 28 de marzo de 1968, en el cual los gremios combativos y opositores a la línea vandorista y participacionista lograron cesionar con sus delegados y nombrar a una Comisión Directiva presidida por Raimundo Ongaro. Como señala Bozza (2001) la CGTA expresó una ruptura en la columna vertebral de la burocracia sindical peronista. Insinuaba un nuevo tipo de sindicalismo, fogueado en la confrontación, empeñado en un pacto ideológico pluralista, antiimperialista, propenso a una reconstrucción "desde las bases" y promotor de iniciativas de amplia coordinación de luchas sociales y políticas. A poco andar, se convirtió en el principal espacio donde todos los activistas y grupos del Peronismo Revolucionario desplegaron (o intentaron hacerlo) su política de masas. Aunque no reunía a los sindicatos más poderosos del país, la CGTA aglutinaba a una pléyade de formidables dirigentes que le permitieron incidir en protestas populares tan importantes como el Cordobazo, en amplios movimientos huelguísticos que arrastraron a los gremios burocratizados, además de lograr una decisiva penetración y organización en seccionales representativas de los trabajadores del interior del país. 
se reunian con otros fines, grupos más políticos como Acción Peronista, que tenían vínculos con la CGTA, que son el origen de Descamisados" 38

Como así también la línea más "movimientista" en la que inscribían sus prácticas políticas (territoriales y armadas)

"Toda esa organización que habiamos colaborado a formar en el barrio sirvió después a Descamisados, porque ya tenían un grupo con quien hablar en los barrios, un trabajo con las unidades básicas peronistas y contactos con dirigentes sindicales, y ese trabajo político siguió aunque después se volvió un poco más clandestino por las acciones armadas, pero básicamente la idea de toda esa inserción político territorial era para formar cuadros para la organización, para dar la pelea adentro del movimiento peronista" 39

Esta línea movimientista sostenida por Descamisados, junto al persistente arraigo del trabajo político-territorial que mantuvo la organización con las agrupaciones de superficie en paralelo a sus acciones armadas, motivaron el ingreso de militantes "oscuros" de las FAP dentro de sus filas luego del debate con los alternativistas, como también la cercanía y posterior fusión con Montoneros hacia fines de 1972 (Catro-Salas, 2011:40) ${ }^{40}$

\section{La Juventud Peronista de La Plata y la Federación Universitaria de la Revolución Nacional (FURN)}

Hacia principios de los años '70, la Juventud Peronista de La Plata contaba ya con una extensa trayectoria de lucha dentro del Movimiento y una importante base de organización política y territorial en el entramado local-regional. Sus comienzos, por el año 1957, estuvieron ligados a los Comandos de la Resistencia que emprendían acciones de "guerrilla urbana" contra el régimen de la Revolución Argentina, diferenciándose notablemente de lo que consideraban por aquel entonces la actitud "claudicante" de la dirigencia política y sindical tradicional del Movimiento (Robles, 2014). Sus integrantes eran jóvenes peronistas, casi en su totalidad de la clase trabajadora, quienes comenzaron a tener protagonismo en los sindicatos recuperados luego de la intervención que siguió al

${ }^{38}$ Entrevista de la autora a Flora Castro, La Plata (2013). Para una profundización de la temática del comunitarismo católico como política social en los sesenta, ver Giorgi y Mallimacci (2012); Giorgi (20142015) y Ramacciotti (2014).

${ }^{39}$ Ididem.

${ }^{40}$ Sobre las OAP, Amorín (2005:233 y ss) y González Canosa (2014). En su artículo, la autora señala que inicialmente en base a las posiciones ideologicas sostenidas por las 4 organizaciones, los alineamientos más cercanos se daban entre FAP y FAR, por un lado, al defender una línea más alternativista, y entre Descamisados y Montoneros por otro, que se ubicaban en la posición movimientista. 
golpe de estado de $1955,{ }^{41}$ en particular en gremios estatales como ATE, con fuerte llegada en los ministerios provinciales.

La importante capacidad de trabajo de este grupo, con casi 70 miembros, devino rápidamente en su reconocimiento por parte del peronismo local, participando en la organización de actos en la ciudad e impulsando las tareas partidarias y conmemorativas, cuando las condiciones de la proscripción lo permitían en aquél entonces (Pis Diez y Robles, 2018). Así nos relata uno de sus fundadores esta primera etapa de la JP platense:

"Los dirigentes sindicales de primera línea después del '55 habian quedado todos desplazados, presos, entonces muchos que simplemente eran delegados de fábricas o dependencias públicas acceden a la conducción de los gremios. En el'58 y habíamos recuperado ATE y el gremio de la construcción. Éramos setenta personas más o menos, un grupo muy grande, la mayoría del ámbito sindical y unos pocos que habian sido dirigentes del partido previamente. Tomamos contacto, nos reuníamos en la CGT y ahí nació la JP. El 22 de agosto del año '58 hicimos el primer acto político en Plaza Italia, ahi fue que se reunió la fuerza de lo gremial y lo político. Fue la época de Frondizi, ya habian empezado algunos problemas pero acá en la provincia el gobierno estaba a cargo de Alende y teníamos todavía un poco de libertad" ${ }^{\prime 2}$

Esta primera etapa fundacional de la JP platense llegará a su fin en el año 1960, ante la intensa represión aplicada por el Plan CONINTES en la ciudad y el encarcelamiento de la mayoría de sus militantes. ${ }^{43}$ No obstante, si bien estos acontecimientos llevaron lógicamente a un fuerte repliegue, paradójicamente derivaron también en un proceso de renovación del grupo, al calor de las discusiones políticas e ideológicas que la nueva coyuntura internacional con el impacto de la Revolución Cubana despertaba entre los jóvenes peronistas. La injerencia de la figura de Cooke a través de sus lecturas y del contacto directo que entabló con algunos de ellos, que derivó incluso en la realización de viajes a Cuba para adquirir entrenamiento militar (Cháves y Lewinger, 1998:56; Bozza, 2001:141), dieron paso a la construcción de un pensamiento y una identidad peronista cada vez más de izquierda, proceso que culminó con su incorporación al Movimiento

\footnotetext{
${ }^{41}$ Una parte importante de los gremios conducidos por peronistas, e incluso la Confederación General del Trabajo (CGT), fueron intervenidos luego de 1955. Dos años después, en 1957 comenzó el proceso de “normalización” y en agosto de 1957, fue normalizada la CGT platense con una hegemonía de dirigentes peronistas, seguidos de independientes y comunistas (Robles: 2009).

${ }^{42}$ Entrevista de la autora a Babi Praxedes Molina, La Plata (2014)

${ }^{43}$ Haroldo Logiurato, Babi Práxedes Molina, Héctor Enrique Gaite, Horacio Jacinto Cassano, Antonio Wenceslao Lombardi, Diego Miranda, Juan José Bartoletti, Clemente Saavedra, Roberto Mario Carattoli eran los principales referentes del grupo fundador de la JP- LP (Pis Diez y Robles, 2018)
} 
Revolucionario Peronista (MRP) en 1964 conducido por Gustavo Rearte y la asunción de la lucha armada como metodología para la resistencia organizada. ${ }^{44}$

Como resultado de todas estas experiencias de renovación y radicalización, un hecho importante que marcó la historia de la JP de La Plata fue la incorporación del componente estudiantil entre sus filas, proceso que se formalizó en 1966 con la creación de la Federación Universitaria para la Revolución Nacional (FURN). Esta agrupación, la primera de corte peronista dentro de la UNLP, nucleaba estudiantes sobre todo del interior de la provincia que venían a realizar diferentes carreras a la capital y se identificaban con una "línea de pensamiento nacional" y una filiación cada vez mayor con el peronismo. ${ }^{45}$ Las redes políticas y personales que se fueron estableciendo entre los militantes de la JP/MRP de La Plata - muchos de los cuales estudiaban en la UNLP- y los estudiantes de tendencia peronista en la Universidad devinieron en la formación de un "nosotros" que excedía los límites del campo de acción estrictamente universitario para volcarse a otras formas de militancia sindical, barrial y armada. ${ }^{46}$

\footnotetext{
${ }^{44}$ El tránsito hacia una vertiente cada vez más de izquierda dentro del peronismo es señalada por el mismo entrevistado: "Cuando nosotros caemos con el Plan Conintes nos meten presos junto a muchísima gente de Capital. Ahi estaban Rearte, Espina, Rulli y Cacho El Kadri un poquito después, y la relación se estrecha estando presos a través de las conversaciones, de la discusión con ellos. Ya se había producido la revolución cubana, y entre la independencia de Argelia y la revolución cubana se nos había armado un matete que había que resolverlo. ¿y cómo se podía resolver desde el punto de vista nuestro, si no era discutiendo, analizando, leyendo? éramos un grupo que no tenía límites para la lectura, Lenin, Scalabrini y Ortiz, Jauretche (...) Para nosotros la etapa golpista donde algún general iba a aparecer para devolvernos lo que habíamos perdido, se nos había agotado con el intento de golpe de Iñiguez. Entonces dijimos ese el camino no es, ya había surgido en el año '58 el primer grupo guerrillero peronista, el grupo Uturunco, y también habia aparecido Jorge Masetti. Todo ese tipo de cosas fue haciendo cambiar nuestra mentalidad y que a la violencia respondiéramos con una violencia más organizada". Entevista de la autora a Babi Práxedes Molina, La Plata, (2014)

${ }^{45}$ Como señala Lanteri (2009) la Universidad fue un ámbito tradicionalmente hostil al peronismo, dada la tradición liberal reformista que hegemonizaba su gobierno desde 1918. El proceso de prohibición y desperonización que llevó a cabo la Revolución Libertadora en la Universidad reforzó aún más la tendencia reformista de las agrupaciones estudiantiles, quienes se dividían mayormente entre partidarios del radicalismo por un lado, y el amplio espectro de la izquierda por otro. Sin embargo, la revisión crítica que sobre el peronismo emprendieron algunos sectores progresistas y el impacto que la Revolucion Cubana gestó en el mundo de la izquierda tradicional vehiculizaron un paulatino acercamiento entre los grupos de la juventud peronista y algunas agrupaciones reformistas de izquierda de la ciudad, golpeadas ambas duramente por la represión militar del Plan CONINTES a principios de los '60. Este proceso conjunto de socialización y radicalización que desarrollaron los jóvenes peronistas y los estudiantes reformistas de izquierda, fue el terreno fértil a partir del cual, en los años posteriores, comenzaron a surgir en la UNLP diferentes expresiones estudiantiles dentro del arco de la "izquierda nacional" y el peronismo revolucionario. Ver también Pis Diez y Robles (2018). Entre las agrupaciones de izquierda y de la línea nacional en vías de peronización que conformaron la FURN en 1966 se encontraban: Amauta de la Facultad de Medicina, Movimiento de Avanzada de Veterinaria (MAV) -cuyas tres figuras destacadas eran Carlos Miguel, Carlos Bacci y Kenneth Bar Bennett-, y el Movimiento Universitario reformista (MUR) de la Facultad de Derecho.

${ }^{46}$ Producto de la integración de la JP con la FURN se estableció que del total de la dirección de la FURN, la mitad debían ser miembros de la JP, así como la mitad de los miembros de la conducción de la JP debían integrar el MRP. Amato y Bazán (2008:73).
} 
La diversidad de ámbitos y metodologías que reunían los integrantes de la JP-FURN en su militancia se inscribía en una concepción "movimientista" sobre el Peronismo, lo que llevaba a morigerar las tensiones más rupturistas con otros grupos internos y a desplegar una activa militancia dentro de las estructuras del Movimiento. En este marco, si bien reconocían diferencias con otros sectores internos, las mismas no ocupaban -por lo menos en aquel momento- un lugar preponderante. Así lo explica Hugo Bacci, referente de la FURN

"Nosotros no usábamos el término "peronismo de izquierda" sino que decíamos que el peronismo en su conjunto era revolucionario. Nunca dejamos que nos encasillaran en un sector porque creíamos que la división no era correcta. Sí hacíamos la distinción entre un peronismo combativo y uno complaciente, la burocracia sindical, los sectores reaccionarios vs los sectores del pensamiento nacional, es decir si habia sectores revolucionarios, pero siempre hablando del conjunto. En nuestro caso, nosotros éramos la JP en la calle, en la universidad éramos la FURN, trabajábamos todos juntos, yo milité en ambos frentes. En la Universidad queríamos construir un conocimiento que sirva para la liberación de la patria y no uno que contribuyera a la cultura colonial, y también hacíamos mucho laburo en el territorio para generar conciencia y organización " 47

Asimsimo, en un reportaje a la FURN publicado en la revista Primera Plana en agosto de 1972 se detallaban las diferentes formas de participación de esta agrupación en la vida interna del Movimiento, tanto en lo que hacía a tareas de "organización, movilización y doctrinarias" como a las que apuntaban a afirmar una posición política interna "basada en el trasvasamiento generacional, la guerra popular revolucionaria, el socialismo nacional y la solidaridad con las organizaciones armadas peronistas (Montoneros, Descamisados, FAP y FAR)", 48

Estas mismas definiciones y posicionamientos, al calor de los cambios impuestos por la dinámica electoral del año 1972 -y en vinculación con las modificaciones que desarrolló Montoneros en su estructura interna- incidieron posteriormente en la articulación del grupo JP-FURN con dicha organización a finales de ese año.

Al respecto, Gonzalo Cháves, uno de los principales cuadros de la JP platense, describe los contactos y a la vez las diferencias políticas que mantuvieron con las FAP, descartando la posibilidad de integrarse a esta organización armada, a la vez que se acercaban a Montoneros:

\footnotetext{
${ }^{47}$ Entrevista de la autora a Hugo Bacci, La Plata (2012).

${ }^{48}$ Reportaje a la Federación Universitaria de la Revolución Nacional (FURN): "Peronistas que estudian", Primera Plana, No 498, 15 de agosto de 1972.
} 
"la JP de La Plata en el año 63-64 se incorporó al MRP, nosotros asumimos la lucha armada antes de entrar a Montoneros, ya veníamos trabajando mucho y tuvimos relaciones fuertes mucho tiempo con las FAP. El sueño nuestro era ser un comando de la FAP, soñábamos con eso, éramos amigos, conversamos y no se dio. Ellos entraron en una discusión interna y nosotros no la vivimos así, no nos parecía de esa manera. Discutían la alternativa independiente, no trabajaron para el retorno de Perón, no es que estaban en contra, pero no pusieron el cuerpo, cuestionaban el proceso electoral. Decían "ni golpe, ni elección, revolución" y nosotros estábamos armando el retorno de Perón y las listas para presentarnos en las elecciones" $" 49$

En síntesis, la convergencia general entre las distintas organizaciones de la Tendencia anteriormente analizadas (JP/FURN, Acción Peronista/JP Vicente López/Descamisados, "oscuros" de las FAP) sobre cuestiones como la concepción del Movimiento y las formas de superar las diferencias internas; o la posible articulación de una estrategia de guerra popular revolucionaria con otras expresiones de activismo no armado; y la manera de pensar la relación entre las organizaciones guerrilleras y la militancia de superficie -en particular la integración del fenómeno de la juventud radicalizada- explican en gran parte la unificación de todos estos grupos con Montoneros en el transcurso de 1972.

Para comprender las razones que llevaron a esta fusión, es necesario atender especialmente a la política de movilización de la militancia juvenil en los frentes de masas y al interior de las estructuras del Peronismo que desplegó dicha organización, lo que en un contexto que se perfilaba cada vez más hacia la apertura democrática, derivó en su hegemonía dentro del espacio de la Tendencia. Esto mismo, como veremos más adelante, tendrá importantes consecuencias en la configuración político-institucional del peronismo una vez en el gobierno.

\section{Montoneros, las UBR y el fenómeno de la JP Regionales}

Tal como reseñamos previamente, el asesinato de Aramburu fue un hecho profundamente disruptivo en el escenario político nacional y hacia el interior del peronismo, lo que le valió a Montoneros un enorme prestigio entre viejos militantes políticos y sindicales, como también una espectacular atracción en muchísimos jóvenes en proceso de radicalización, deseosos de incorporarse a la organización. El carácter vindicativo y los lazos de identificación y simpatía que produjo este episodio entre los militantes de la JP La Plata es mencionado por uno de nuestros entrevistados:

“De la organización nosotros no sabíamos nada, lo único que nos enteramos por los diarios fue lo de Aramburu. Y como JP-FURN salimos a tirar volantes mariposa dando nuestro apoyo al

\footnotetext{
${ }^{49}$ Entrevista de la autora a Gonzalo Cháves, La Plata (2016)
} 
ajusticiamiento, entonces si vos me preguntas, desde el primer momento fui Montonero, porque estaba de acuerdo con lo que habian hecho, yo y muchos de mis compañeros. Los contactos formales llegaron después" $"$.

Este activismo desde las bases y el creciente anhelo de pertenencia a la organización (Amorín, 2005:152; Jauretche, 1997:54) fueron a su vez potenciados tanto por las definiciones político-ideológicas que Montoneros comenzó a esgrimir en esta etapa (su postura tendencista dentro del Movimiento, aceptando la participación en sus estructuras formales como forma de intentar hegemonizarlo [Lanusse, 2005:259]), ${ }^{51}$ como también por los cambios en su estructura interna, más precisamente, el giro hacia una política de vinculación con el activismo juvenil de superficie a partir del año 1972.

En este plano, a principios de ese año Montoneros creó las "Unidades Básicas Revolucionarias" (UBR) para dar solución a la "necesidad impostergable de crear un puente, un nexo, un nivel intermedio" entre la estructura clandestina de la organización y las agrupaciones sociales y políticas de base, con el objetivo de complementar y enriquecer mutuamente "las dos patas de la lucha popular". ${ }^{2}$ La diferencia con las ya existentes "Unidades Básicas de Combate" (UBC) consistía en que la clandestinidad de las UBR sería "abierta" en el sentido de que los activistas continuarían "insertados en la base" donde militaban, con el fin de organizar y conducir política e ideológicamente la movilización popular en los diferentes frentes de masas, territoriales, fabriles y /o estudiantiles (Lanusse, 2007). ${ }^{53}$

Si bien la creación de las UBR no significaba que Montoneros hubiera abandonado la idea de que la lucha armada era la tarea principal y que los combatientes debían conducir estratégicamente al conjunto, la implementación de este nuevo armado interno brindaba

\footnotetext{
${ }^{50}$ Entrevista de la autora a Hugo Bacci, La Plata (2012). Ver también los testimonios de ex militantes de la JP-La Plata en Amato-Bazán (2008:93).

${ }^{51}$ Montoneros (1972). Documento Interno: Linea Político Militar. En Baschetti (1997:249-270) Lucas Lanuse señala que en este documento se observa el paso de una posición netamente movimientista a otra que es la tendencista.

${ }^{52}$ Montoneros (1972) Memorias del año 71. En Baschetti (1997:371)

${ }^{53}$ En el documento Memorias del año 71, Montoneros realizaba una autocrítica sobre algunas limitaciones que la organización tenía dentro de su estrategia de Guerra Revolucionaria. Allí señalaban como puntos débiles respecto de "las organizaciones de base": "limitación para conducir tácticamente las movilizaciones, subordinándolas a la estrategia de creación y fortalecimiento del Ejercito Peronista; limitación para crear formas organizativas superiores que encuadren a los compañeros que estén en condiciones de cumplir esa tarea". Y dentro de "las organizaciones armadas": "limitación para contar con formas de lucha mas adaptadas a las posibilidades del pueblo (...) necesidad de canales adecuados para incorporar a compañeros dispuesto a integrarse (...) en tareas que van desde el apoyo logístico al combate". La solución que el documento señalaba eran las UBR, que estarían integradas por "compañeros con un mínimo de claridad estratégica y política, de compromiso y decisión (quienes) siguen militando semi clandestinamente en la superficie, como parte de su medio natural, y comienzan a hacerlo clandestinamente en la organización político-militar. En Baschetti (1997:371-372).
} 
la posibilidad de inserción en los espacios legales del peronismo, a través del contacto con la estructura de la JP Regionales y el reconocimiento de sus dirigentes como rama juvenil del Movimiento. Esto mismo aseguraba también canales directos de comunicación con innumerables agrupaciones preexistentes del campo peronista, quienes se sentían fuertemente atraídas por las acciones y la línea política de la organización (Bartoletti, 2011:47; Lanusse, 2007).

Más allá de que la implementación de esta medida dio lugar a controversias dentro de la organización y en principio no recibió un apoyo unánime entre sus filas (Amorín, 2005:156), ${ }^{54}$ lo cierto es que el desarrollo de las UBR se convirtió paulatinamente en el trampolín de su crecimiento hacia los márgenes de la legalidad y la vinculación con las agrupaciones de militantes de base.

Finalmente, la culminación de este fenómeno de identificación entre importantes sectores de la juventud movilizada y Montoneros -y la creciente integración formal entre una y otra- se dio con el lanzamiento de la Juventud Peronista Regionales (JPR) en el mes de julio de 1972, en un acto multitudinario en la cancha de Nueva Chicago ${ }^{55}$ Esta iniciativa de Montoneros buscaba convertir la adhesión política masiva de la juventud en poder organizativo y de movilización propio, lo que se plasmó en la construcción de una

${ }^{54}$ En su libro Amorín señala las diferencias entre aquellos militantes que promovieron las UBR y los que sostenían una posición más de defensa de la estructura clandestina tradicional y cerrada. Según el análisis de este ex militante, la corriente interna de Montoneros que defendió las UBR y el trabajo legal en los frentes de masas, se volvió hegemónica dentro de la organización hasta el año 1974, anteponiendo las actividades políticas legales por encima de las acciones armadas, las cuales no se abandonaban por completo, pero sí se subordinaban. Esta perspectiva, no obstante, también puede ser contrastada con las lecturas que, desde una posición más alternativista, trazaban por aquel entonces los militantes de la Columna Sabino Navarro, para quienes las UBR de Montoneros no representaban un cambio, sino una muestra más de su "militarismo". Para este grupo que finalmente romperá con Montoneros, el trabajo de inserción territorial de la organización tenía sólo un carácter instrumental, al servicio del grupo armado, siendo las UBR meras canteras de reclutamiento de militantes y de recursos logísticos para el aparato militar (Seminara, 2015). Más adelante desarrollaremos las posiciones de esta agrupación.

${ }^{55}$ Los comienzos de esta experiencia se vinculan a la figura de Rodolfo Galimberti, líder de las Juventudes Argentinas para la Emancipación Nacional (JAEN) y a los contactos que Montoneros trabó con él en el año 1971, como parte de su política de vinculación con grupos juveniles peronistas que reivindicaban, aún sin estar encuadrados, el accionar de las organizaciones armadas. Gracias a estos contactos con Montoneros como sugiere la bibliografía citada- Galimberti fue nombrado por Perón como representante de la juventud en el Consejo Superior del MNJ, en el marco de la estrategia del líder justicialista de mostrarse intransigente en sus posiciones frente a Lanusse (Bonasso, 2006:218; Anzorena, 1989; Bartoletti, 2011). Finalmente, en el Acto de Unidad de la Juventud Peronista realizado en la Federación de Box el 9 de junio de 1972, Galimberti junto a las agrupaciones de la Tendencia Revolucionaria lograron hegemonizar el Consejo Nacional de la JP, frente a los sectores de una línea más ortodoxa (Guardia de Hierro, el Frente Estudiantil Nacional-FEN y Comando de Organización-C de O) que se oponían a la lucha armada y al socialismo nacional. La conformación de este espacio, en el que predominaron las posiciones de apoyo abierto a las OAP, culminó un mes después con el lanzamiento de la estructura de la JP Regionales en el acto de Nueva Chicago. "El país se pregunta ¿Qué es la Juventud Peronista?. En El Descamisado, Año 1, $\mathrm{N}^{\circ}$ 8, 10/07/1973, pp.10-12. La Opinión, 28/04/1973 “Antecedentes y tendencias que buscan preponderancia ideológica. La composición de la juventud peronista determina sus propuestas radicalizadas", p. 10. 
superestructura de funcionamiento legal a nivel nacional, conformada por siete regionales, cuya base de apoyo serían los grupos de JP preexistentes con fuerte inserción en el territorio y en los frentes de masas. La dirección de toda esta estructura estaría en manos de un Consejo de las Regionales integrado por Rodolfo Galimberti y cuadros de la organización a cargo de cada uno de esos espacios (Anzorena, 1989:188). ${ }^{56}$

La implementación de esta nueva estructura organizativa dotó a Montoneros de una ingente capacidad de maniobra y presencia política en diversos frentes, al combinar su estrategia de guerra revolucionaria -cuyas tareas fundamentales seguirían recayendo en el accionar armado de las UBC- con una política cada vez más extendida de movilizaciones barriales y la participación a través de la representación de la JP en la superestructura del Movimiento y del partido.

Estos hechos no solo evidenciaban la capacidad de adaptación que mostró la organización ante los desafíos presentados por la cambiante coyuntura política, sino también -en función del enorme poder de movilización que concitó- la posibilidad directa de incidir en el nuevo escenario electoral que se abría.

\subsection{Lecturas y reposicionamientos de las agrupaciones de la Tendencia frente al escenario electoral.}

Como ya dijimos, el avance de las negociaciones en torno al GAN, planteó numerosos interrogantes al conjunto de la militancia inscripta en la Tendencia. ¿Qué hacer? frente a la estrategia aperturista fue la pregunta que dominó el debate político en todas las discusiones de las organizaciones revolucionarias en esa etapa. ¿Se debía resignar la lucha armada y la estrategia revolucionaria para encauzarse en un proyecto político partidario encabezado por Perón?, ¿acaso la integración del peronismo dentro del sistema no significaba - para estos grupos- una contradicción en sí misma, es decir, una renuncia al contenido revolucionario que le asignaban al Movimiento?, ¿qué papel tendrían las organizaciones armadas en el futuro gobierno democrático?, ¿debían apoyar los comicios primero para luego impulsar desde allí formas más radicalizadas de gobierno que se acercaran al objetivo final del "socialismo nacional”?, ¿cuáles serían sus metodologías de acción en el marco de un gobierno peronista elegido por la vía pacífica y el voto popular?.

56 “El país se pregunta ¿Qué es la Juventud Peronista?. En El Descamisado, Año 1, № 8, 10/07/1973, pp.10-12. Este fenómeno de integración de los múltiples grupos preexistentes de la Juventud Peronista a Montoneros no careció de tensiones y dificultades, en particular en aquellas agrupaciones de base que no deseaban perder por completo su autonomía. Ejemplos de esto fueron la JP de Merlo (Salcedo, 2011) y la JP de La Plata que será analizada en el capítulo siguiente. 
Estas y muchas otras preguntas plantearon un dilema no menor a los grupos de la Tendencia Revolucionaria, dilema que interpelaba el seno mismo de sus programas, expectativas, metodologías y formas organizativas. En dicha encrucijada política, como se puede intuir, las tensiones no tardaron en manifestarse, al tratarse de una experiencia política inédita en la cual comenzaban a convivir planteos que descreían de las elecciones como medio efectivo para la toma del poder, con otras posiciones que apostaban a la militancia legal - institucional.

A continuación, analizaremos cómo las organizaciones de la Tendencia, con marchas y contramarchas, ambigüedades y diferencias en su interior, leyeron los desafíos que la coyuntura política les fue presentando a medida que el escenario electoral avanzaba y se mostraba como una opción efectiva para gran parte de la sociedad movilizada que se identificaba con ellas.

\subsubsection{EI GAN y las primeras reacciones generadas}

En líneas generales, desde el comienzo de la presentación del GAN, las organizaciones revolucionarias del peronismo presentaron de manera unánime una posición de desacuerdo. El razonamiento que guiaba este rechazo descansaba en la concepción que a grandes rasgos tenían del peronismo como un movimiento revolucionario, y que como tal no podía plegarse dentro de ninguna estrategia del régimen liberal cuasi-democrático, dado que cualquier intento de integración estaría motivado sólo por el deseo de destruir su potencia revolucionaria. Dicha consideración sobre el GAN como "trampa electoral" se apoyaba también en la idea de que los métodos legales y constitucionales -desde 1955 en adelante- no habían tenido éxito, mientras que la acción directa parecía ser el único medio efectivo para lograr el retorno del peronismo y avanzar en el llamado "socialismo nacional".57

Para ilustar esto, Montoneros en el año 1970 afirmaba en uno de sus primeros comunicados el rechazo total ante un posible escenario electoral, repudiando "las maniobras de los gorilas de adentro y fuera del movimiento que quieren embarcar al pueblo en nuevas y fraudulentas elecciones...porque saben entonces que el queso es grande" y exhortando al pueblo a "unirse a la resistencia armada contra el régimen, sin

57 "Estrategia y Táctica Revolucionarias. Documento presentado al Congreso de Córdoba por la Tendencia Revolucionaria del Peronismo", en Cristianismo y Revolución № 12, marzo 1969. En este documento se explicita la defensa de la vía revolucionaria, es decir la lucha armada, en contra de ilusorias salidas pacifistas electoralistas. 
dejarse engañar por la posibilidad de elecciones, en las que el pueblo seguramente deberá optar entre distintos representantes de la oligarquía". ${ }^{8}$

La apuesta por la lucha armada como necesidad estratégica frente a la "artimaña electoral" del régimen y su complicidad con los "falsos peronistas", se repite en un comunicado de diciembre de 1970.

"La contradicción peronismo-antiperonismo hace utópica toda posibilidad integracionista, porque o no hay elecciones mientras el general Perón viva o hay elecciones sin Perón. Y cualquiera de estas opciones, aunque concurra algún candidato potable disfrazado de peronista, es una nueva burla al pueblo que a esta altura del partido ya no se presta a manoseos." 59

De todas formas, como se desprende de estas declaraciones, la impugnación a las elecciones no parecía ser absoluta, deslizándose la posibilidad de una aceptación de las mismas si Perón fuera el candidato, situación que el régimen no estaba dispuesto a aceptar bajo ningún concepto.

Por esa misma época, encontramos ideas afines en un comunicado de las FAP, descartando de raíz la posibilidad de que el sistema permitiera a Perón y el peronismo retornar al poder, por sus consecuencias anti-sistema:

"Trata la oligarquía, a través de su presidente de turno, de convencer al Pueblo de que va a tener posibilidad de participar en la vida política del país. De sobra sabemos que jamás permitirán la participación del Pueblo con Perón en el Poder, porque esto significaría miles de descamisados en las calles, porque esto significaría la derrota de la oligarquía”. 60

Con otros matices, las FAR, en un reportaje a comienzos de 1971 coincidían en la lectura que posicionaba a la lucha armada como la forma más eficaz de lucha política, en detrimento de los métodos legales como instrumentos para lograr la construcción del socialismo:

"Quienes nos acusan de carecer de nivel politico o de desechar la importancia de la lucha política por haber elegido el camino de las armas, olvidan que esta lucha no es más que la política por otros medios y no cualquier otro medio, sino los más eficaces. Nuestro pueblo apeló a otras posibilidades en el pasado, a todas las que tuvo a mano y le fueron vedadas. No sería necesario quizás recordar que nuestro pueblo ha triunfado en elecciones que fueron miserablemente escamoteadas... esto no quiere decir que nosotros propugnemos la ineficacia o

58 "Montoneros. Comunicado No 4", junio de 1970. Baschetti (1997:54).

59 “Hablan los Montoneros" Cristianismo y Revolución, n 26, Noviembre-Diciembre de 1970

${ }^{60 “ C C o m u n i c a d o ~ d e ~ l a ~ F u e r z a s ~ A r m a d a s ~ P e r o n i s t a s ", ~} 16$ de septiembre de 1970, compilado en Duhalde y Pérez (2003) y Jasinski (2011). 
ilegitimidad de otras formas de lucha política. Pero una organización revolucionaria que pretende responder al mandato de su pueblo de diseñar una alternativa, debe elegir las formas más eficaces de lucha política. Y esto es lo que nosotros hacemos al armar nuestra politica" ${ }^{61}$

Cabe recordar que esta organización se había gestado bajo la convicción de que era imposible alcanzar el socialismo a través de medios pacíficos y que ni el triunfo en las urnas de la Unidad Popular en Chile las había convencido de una posible "vía pacífica" hacia ese sistema (González Canosa, 2017: 9). Esta lectura pesismista de la vía electoral de Salvador Allende y la baja probabilidad de que esa experiencia pudiera ser tomada en cuenta como ejemplo para el conjunto de las organizaciones revolucionarias peronistas, se vincula también con las ideas que permeaban a amplios sectores de la militancia radicalizada por esos años y su rechazo global a las formas tradicionales de la política y la democracia liberal, las cuales se las consideraba no sólo fraudulentas, sino también perimidas

"Lo de Chile no se tuvo en cuenta, no se nos pasó nunca por la cabeza que ese fuera un modelo posible, porque se venía de años de golpes y proscripciones y se creía que nunca iban a dejar al peronismo volver al poder por elecciones. Sí, en todo caso, lo que se pensaba era que si se daba el paso por el gobierno democrático, eso iba ser como un momento de transición, como una etapa previa a la cual le seguiría otro momento, que podríamos asimilar con el de toma del poder efectiva". ${ }^{2}$

Así, el rechazo general a lo que concebían como un nuevo engaño pergeñado por la dictadura, ya fuera por la incredulidad de que el régimen permitiera elecciones libres sin proscripciones y con Perón como candidato, o por el repudio total a una medida cuyo objetivo final era frenar la radicalización social y política para contenerla dentro de los márgenes del sistema de dominación vigente, fueron los sentidos e interpretaciones que primaron durante el año 1970 y los primeros meses de 1971 al interior de la Tendencia.

Estas lecturas y posicionamientos alcanzaron también a los sectores alternativistas de las FAP, quienes sostuvieron el rechazo a la participación electoral primero, y luego directamente la impugnación de los comicios, llamando a votar en blanco durante las elecciones de 1973. Al respecto, en la segunda mitad del año 1971 presentaban la siguiente caracterización de la estrategia aperturista de Lanusse, considerándola como un ensayo del régimen y los sectores dominantes, acompañados por los "traidores" del

\footnotetext{
61 "Reportaje a las FAR: los de Garín" en Baschetti (1997:159)
}

${ }^{62}$ Entrevista de la autora a Flora Castro, La Plata (2013) 
Movimiento, para salvar al sistema neutralizando a las organizaciones armadas y su incidencia directa sobre la clase obrera:

\begin{abstract}
"Surge así el Gran Acuerdo Nacional entre la oligarquía industrial proimperialista, la partidocracia liberal y la burocracia politica y sindical del peronismo. Este Gran Acuerdo tiene un objetivo fundamental: integrar a la clase obrera -base revolucionaria del Movimiento Peronista- a los planes de dominación imperialista. Dos son los medios para conseguirlo: la salida electoral para los acuerdistas y la violencia represiva para los militantes combativos del pueblo." 63
\end{abstract}

Estas definiciones sobre el GAN, se vinculaban estrechamente con la caracterización general que hacían del Movimiento Peronista y la estrategia a darse respecto a sus sectores internos. Para esta corriente de las FAP, la vía correcta lejos de situarse en una lucha intestina al interior del Movimiento (intentar "hegemonizarlo desde adentro"), consistía en lanzar la "Alternativa Independiente" como una herramienta central que desencadenaría el único potencial revolucionario dentro del peronismo, la organización de su clase trabajadora. De esto mismo se desprendía la imposibilidad de encarar cualquier tipo de alianza -ya sea táctica o estratégica- con los sectores de la pequeña y mediana burguesía nacional y aquellos vinculados a la representación político-partidaria en un frente electoral.

Si este tipo de caracterizaciones, como vimos, provocaron la salida de los "oscuros" dentro de las FAP, en paralelo, al interior de Montoneros, también afloraron disidencias internas vinculadas con los mismos debates. Es el caso de la "Columna Sabino Navarro", conformada por un núcleo de militantes que buscaban desarrollar los lineamientos generales del clasismo dentro de la organización. La disidencia y ruptura finalmente de este grupo se dio a mediados del año 1972, a raíz de la elaboración de un documento interno -conocido como "Documento Verde"- en el que presentaban una crítica extensa a la línea político-militar desarrollada por Montoneros en esa etapa. El eje de sus diferencias pasaba tanto por la oposición abierta a la intervención en el juego electoral, como también por la concepción militarista que le atribuían a la organización -en su afán por construir un ejército popular- y a la visión instrumental que Montoneros tendría en relación con los frentes de masas (Seminara, 2015: 37). Tal como explica esta autora, para "los sabinos" las fuerzas antagónicas que el peronismo reunía en su seno -entendidas como contradicciones de clase- volvían irrealizable toda política tendiente a la

63 "Fuerzas Armadas Peronistas: A nuestro Pueblo." Comunicado de las FAP tras el lanzamiento de la operación armada denominada "Aguilucho" en noviembre de 1971. En: Duhalde y Pérez (2003) y Jasinski (2011) 
participación en las estructuras del sistema, sin implicar ello mismo la negación de la estrategia revolucionaria. Ésta solamente podía llevarse a cabo a partir del fortalecimiento de la organización y los intereses de la clase trabajadora, a través del basismo y su inserción en las fábricas. Por lo mismo, y en sintonía con el planteo alternativista de las FAP, rechazaban abiertamente la participación en el GAN, en tanto dicha política significaba un error de carácter estratégico en torno a las necesidades de organización autónoma de la clase obrera y su rol protagónico como sujeto histórico de la revolución (Seminara, 2015:36-38).

Sin embargo, frente a una coyuntura que comenzaba a cambiar de manera vertiginosa, dando muestras de activación y apertura de instancias político-partidarias, las posturas dentro de algunos de los grupos de la Tendencia comenzaron a evidenciar variaciones y matices, cuando no, diferencias notables. No hay que perder de vista que estos reposicionamientos se fueron dando al compás del juego político de estrategias, negociaciones y enfrentamientos que libraron tanto Perón como Lanusse en esta etapa. Será entonces en el marco de estas coordenadas, como veremos a continuación, que algunas organizaciones armadas peronistas y sus agrupaciones de base mostraron paulatinamente signos de adaptación y respuesta -dentro de su lógica política- a estos desafíos, buscando incidir de manera activa en esa coyuntura e intentando conjugar, no sin tensiones, sus planes estratégicos de largo alcance -la guerra popular y prolongada para la toma del poder- con el horizonte democrático e institucional en ciernes.

En efecto, podemos observar que una parte de las agrupaciones de la Tendencia empezaron a manifestar una postura de aceptación de la salida electoral, si eventualmente ésta se concretaba. A la par de la estrategia trazada por Perón, quien en ese contexto impulsaba una ofensiva contra la política de Lanusse tendiente tanto a la reorganización de su Movimiento como a la ampliación de sus alianzas políticas y sociales, algunos sectores de la Tendencia reorientaron sus posiciones previas de rechazo abierto a los comicios, entendiendo esta instancia como una táctica al servicio de una estrategia revolucionaria más amplia que no descartaba con ello la opción de la lucha armada.

En efecto, a principios de 1971 en una carta de Montoneros enviada a Perón vía Galimberti la organización realizaba un análisis sobre la apertura política, calificando como "acertada" la instrumentación de esta opción por parte del líder justicialista. Si bien mantenían su caracterización de la salida electoral como "una trampa, una válvula de escape (para) engañar al pueblo”, no obstante, valoraban de manera positiva este 
escenario en tanto la proscripción obligada del peronismo por parte del régimen, terminaría por desgastar y destruir al sistema en su conjunto (Jauretche, 1997:150). ${ }^{64}$

Desde esta misma lógica, calificaban "como tácticamente acertado el último pacto firmado por el justicialismo, llamado La Hora del Pueblo, porque no sólo le quita al enemigo el caudal de votos peronistas, sino también radicales". Sin embargo y de manera explícita, dejaban en claro el papel subordinado que le asignaban al camino de las urnas y los reparos respecto de confundir esta opción táctica como equivalente a su programa estratégico

\begin{abstract}
"no podemos considerar en nuestra estrategia la toma del poder por el camino de las urnas, porque inexorablemente lo conseguiremos, pero irremediablemente lo perderemos y entonces estamos siempre en la misma; o sea que considerar las elecciones como camino estratégico para la toma del poder es inoperante e incorrecto... lo incorrecto es creer que esta maniobra es un fin en si misma, o sea, que las elecciones sean el camino apto para el retorno del justicialismo al poder...Sobre lo que no abrigamos dudas es sobre la necesidad de mantenernos como opción estratégica, y por lo tanto la absoluta imposibilidad de subordinar nuestro accionar a una opción táctica. En síntesis, no interferiremos al ala política del Movimiento en tanto La Hora del Pueblo es una maniobra útil, y por lo tanto tácticamente acertada, pero nos mantendremos en la actividad señalando la vía armada como único método estratégicamente correcto para tomar el poder" ${ }^{65}$
\end{abstract}

Hasta aquí podemos observar como la posibilidad de aceptar la vía electoral se daba en términos tácticos y encuadrada bajo una estrategia de mayor alcance que era la de guerra integral para la toma del poder. Esta concepción instrumental será una constante por parte de las organizaciones armadas peronistas a lo largo de todo este período e incluso luego de la victoria del 11 de marzo de 1973.

No obstante, sería un error creer que esa nueva posibilidad, que además despertaba simpatías en gran parte de la militancia peronista movilizada, no generaría un impacto en el interior de sus organizaciones y grupos de base, motivando un importante debate en su seno y un cambio en sus modos discursivos y prácticos de intervención política respecto de las elecciones.

\footnotetext{
64 “Carta de Montoneros a Perón”, 9 de febrero de 1971. La carta fue publicada originalmente en el No 9 de La Causa Peronista, del 3 de septiembre de 1974.

${ }^{65}$ Ibid. Amorín en su libro señala: "Los Montoneros consideramos a la Hora del Pueblo no una "treta" sino una táctica. Una táctica a la cual, si bien éramos ajenos, considerábamos correcta en tanto su objetivo apuntaba a aislar y debilitar al enemigo, la dictadura militar. Una táctica desarrollada en el contexto de una estrategia, la guerra integral para la toma del poder - en la cual las acciones armadas eran otro instrumento, desde nuestro lugar muy importante-. Por orta parte, habíamos leido a Perón lo suficiente como para entender que en política siempre hay que sumar, nunca restar" (2005:173).
} 


\subsubsection{El apoyo a la vía electoral: táctica y/o estrategia en los grupos de la Tendencia.}

Gran parte de los testimonios y documentos de las agrupaciones de la Tendencia señalan el año 1972 como una bisagra respecto de las consideraciones esgrimidas ante el panorama electoral.

Si en un principio el apoyo tímido a La Hora del Pueblo se expresaba en el marco de grandes reparos y advertencias acerca de no confundir el carácter estrictamente táctico de esa jugada, el avance de las tratativas eleccionarias dio lugar a ciertas ideas $\mathrm{y}$ posicionamientos de apoyo más explícito, que si bien no implicaban una ruptura con las concepciones estratégicas vigentes, daban cuenta de la creciente importancia que adquirían los métodos legales de lucha para las organizaciones revolucionarias del peronismo en esa coyuntura.

Este salto se dará a partir del lanzamiento de los famosos "Cinco Puntos" que Montoneros adoptó como programa político en la mayor parte de sus comunicados del año 1972, apoyando el proceso electoral y levantando la candidatura de "Perón Presidente". 66

Este vuelco notable a favor de las elecciones, que engarzaba de manera integral con la estrategia de Perón y el lanzamiento del FreCiLiNa por esos meses, permitió además a la organización tender puentes cada vez mayores con la militancia de superficie e integrar sus acciones armadas en el movimiento más amplio de activismo político que la propia coyuntura pre-eleccionaria despertaba. Esto se plasmó, como vimos previamente, tanto en el crecimiento de las UBR durante todo ese año, como en el ascenso exponencial de la militancia de la JP Regionales y su integración a dicha organización.

Por otra parte, cabe señalar nuevamente que esta apuesta por el camino de las urnas, no se pensaba como una opción excluyente, sino que se daba en el marco de una estrategia mayor y una metodología de guerra, que no dejaban de explicitar en sus documentos internos:

"Nuestro objetivo estratégico: la toma del poder por el pueblo para lograr la liberación nacional y la construcción del socialismo. Y como método principal: la guerra revolucionaria total, nacional y prolongada... que necesita de la construcción del ejército popular. El

\footnotetext{
${ }^{66}$ Los 5 puntos eran: 1) Elecciones libres en 1972 en la patria y con Perón como candidato;2) Plena vigencia de la Constitución de 1949; 3)Programa de gobierno revolucionario de nacionalizaciones; 4)Libertad a todos los presos políticos; 5)Supresión de la legislación represiva. Ver "Comunicado de Montoneros: Al Pueblo de la Nación", diciembre de 1971; "Comunicado de Montoneros: A los compañeros trabajadores", marzo de 1972; "Carta abierta de Montoneros y Descamisados: A los Compañeros de la Juventud en el día de los fusilamientos", junio de 1972, disponibles en El Topo Blindado. Ver también Perdía (1997: 110).
} 
concepto de guerra popular es más amplio y correcto que el de la lucha armada, pues corresponde a ésta y a la lucha no armada. Estos diferentes tipos de lucha suponen diferentes métodos y formas organizativas, que a su vez implican distintos niveles de conciencia, pero que deben subordinarse estratégicamente al método principal que es la lucha armada...Lo que debe haber es una organización revolucionaria político-militar peronista, con distintos niveles de encuadramiento que determinan diferentes funciones oformas de hacer la guerra ya sea con métodos armados o no armados. ${ }^{67}$

O en declaraciones de la JP Regionales en el acto de su unidad:

"La unidad en la que estamos empeñados contempla un aspecto táctico, que significa dotar a Perón de una herramienta... a la par que apunta a un objetivo estratégico de más largo alcance, enmarcándose en un programa que supone una estrategia para la toma del poder. Es una unidad que no se hace por que sí...sino que es una unidad de guerra para un objetivo específico que es la continuación y ampliación de la Guerra Revolucionaria". ${ }^{68}$

Con todo, el cambio importante a destacar para nuestra investigación es que estas declaraciones comenzaban a visualizar los métodos legales de lucha como una opción "secundaria" aunque de preponderancia notable, en la coyuntura electoral en la que se desenvolvían y que requería a la vez una respuesta de integración y conducción por parte de las organizaciones armadas

\begin{abstract}
"En cuanto a los métodos revolucionarios secundarios son variados y van desde las acciones paramilitares (atentados con explosivos, sabotajes, etc.) los actos reivindicativos como huelgas, tomas de fábrica, facultades, barrios e iglesias, la lucha callejera, manifestaciones, hechos insurreccionales, hasta la lucha electoral entendida como la movilización popular por sus reivindicaciones, su programa y su líder...si bien los métodos secundarios se subordinan al principal en la estrategia, coyunturalmente alguno de ellos pueden adquirir desde el punto de vista de la conciencia de las masas, mayor peso que el método principal...estos distintos métodos deben articularse a partir de una concepción común y en función del objetivo estratégico" 69
\end{abstract}

Reconociendo así los métodos electorales como acciones de pleno derecho que se incorporaban al repertorio legítimo de prácticas promovidas por las organizaciones armadas peronistas

"Sabemos también que a este enemigo hay que combatirlo de todas las maneras posibles, en todo momento y en todos los frentes para reconquistar el poder... Esta lucha que comprende

\footnotetext{
${ }^{67}$ Montoneros (1972). “Documento Interno: Linea Político Militar”. En Baschetti (1997:249-270)

68 "Declaración del lanzamiento de la JP Regional 2 (Santa Fe) en el acto realizado en la Federación de Box". 9 de junio de 1972. Citada en Anzorena (1989:187). Ideas muy similares pueden observarse en dos reportajes a Rodolfo Galimberti y uno a Ernesto Jauretche, representante de la Juventud en el Comando Táctico del Partido Justicialista por la misma época. Reproducidos en Baschetti (1997:410 y ss).

${ }^{69}$ Montoneros (1972). “Documento Interno: Linea Político Militar”. En Baschetti (1997:262-265).
} 
desde la contienda electoral hasta la acción armada, desde el voto hasta el fusil, que es cotidiana y que se disputa en el ciudad y en el campo, en la fábrica y en la universidad, en el barrio y en la villa, y que se extienden hasta dentro del propio movimiento, contra la traición interna, es la Guerra total o integral...Así desde las agrupaciones de base y las organizaciones politicas hasta las organizaciones político - militares, desde las fabricas hasta los barrios, desde las Mesas de Trabajo del Frente Cívico hasta las acciones militares, debemos unirnos para hacer la guerra y construir el ejercito peronista, porque así reconquistaremos el poder". ${ }^{70}$

Sin embargo, estas diversas metodologías (o formas de la política) que comienzan a marcar el pulso de las declaraciones y prácticas en la etapa inmediatamente previa a la campaña electoral, despertaron algunas tensiones en el interior del conglomerado de la Tendencia.

Al respecto, por un lado, la decisión de participar del juego electoral hizo aflorar resquemores entre algunos sectores que percibían esta iniciativa como una suerte de "desvío" reformista, o "desgaste" de energías, en relación con el objetivo primario de la conformación de un ejército revolucionario

\begin{abstract}
"Existía una controversia política que se arrastraba desde que Montoneros había tomado la decisión de participar en el proceso electoral: Cámpora al Gobierno, Perón al Poder. Decisión que no era compartida por la totalidad de la Organización. De hecho, en los diferentes niveles de conducción, éramos pocos los compañeros que promovíamos con entusiasmo nuestra participación en las elecciones, lo cual implicaba desplazar nuestra prioridad de las acciones político-militares, a las acciones políticas. Muchos tenían dudas y unos pocos estaban en contra...tenían la certeza de que a Perón no lo iban a dejar siquiera tomar el avión. La lucha armada continuaría, ya sea a través de la estrategia de guerra popular prolongada o por la vía insurreccional...Por lo tanto, formar nuevos combatientes era indispensable" $" 11$
\end{abstract}

En definitiva, se puede inferir que esta postura no era más que la prolongación y profundización de la consideración de las elecciones como una táctica al servicio de una estrategia más amplia y que, tal como demuestran los documentos ya analizados, sintetizaba las posiciones dominantes en el seno de las conducciones de Montoneros, Descamisados y FAR.

\footnotetext{
70 “Carta de Montoneros y Descamisados" (junio de 1972). En El Topo Blindado. Y FAR "Documento de Actualización Política" (1972)

${ }^{71}$ Amorín (2005:30-31). En el mismo registro, Perdía (1997:110) también señala que "el planteo de "Péron Presidente" se daba de narices con la consigna que -con mucha fuerza- buena parte de la juventud venía impulsando: ¡Ni votos, ni botas, fusiles y pelotas! Era francamente dificil sostener esta decisión al interior de las organizaciones revolucionarias. Hacerlo significó cargar con las burlas y la crítica feroz de buena parte de los compañeros que habian formado parte de la resistencia combativa. Las FAP nos criticaron abiertamente. Si bien se produjeron algunas rupturas, como la "Columna Sabino Navarro" con base en Córdoba, la mayor parte de los militantes de las distitnas regionales se inclinó por la participación en el proceso electoral"
} 
Más allá de las conducciones de estas organizaciones y sus documentos centrales, a continuación, ahondaremos en los sentidos que les atribuyeron a estas prácticas legales/institucionales aquellos/as militantes que más adelante se involucraron en las tareas de gestión gubernamental provincial. En efecto, generalmente ellos/as fueron quienes comenzaron a pensar la vía electoral y la disputa al interior de las estructuras partidarias ya no necesariamente como un instrumento secundario, sino como un objetivo más sustantivo de acumulación y transformación política.

En el próximo capítulo abordaremos con más detenimiento estas percepciones experimentadas por algunos sectores de la Tendencia Revolucionaria y su influjo en el proceso de las candidaturas y la campaña electoral, lo que a su vez contribuyó a la posibilidad de encarar la tarea institucional dentro del gobierno provincial luego de la victoria del FREJULI el 11 de marzo de 1973. 


\section{CAPÍTULO II: DEL LUCHE Y VUELVE A LA CAMPAÑA ELECTORAL. Internas, candidaturas y juego partidario de la Tendencia en la provincia de Buenos Aires}

Como apuntamos en el capítulo anterior, la salida electoral insinuada en 1970 y lanzada formalmente por el GAN en 1971, en el año 1972 se convirtió en un escenario de disputa concreta. Este año estuvo marcado por la apertura del juego partidario y la rehabilitación del partido justicialista, con el reconocimiento de sus ramas internas, y la conformación de autoridades y listas de candidatos, lo que llevará - luego de años de proscripción e inactividad- a una fuerte competencia interna.

En este marco, en el capítulo analizaremos el rol que jugó la TR en las elecciones internas del Partido Justicialista (PJ) y cómo llegó a participar activamente de la campaña electoral. Consideramos que es importante prestar atención a este proceso de reorganización partidaria para tener en cuenta los alineamientos, las disputas y las tensiones con otros actores del campo peronista (no revolucionario), dado que allí se anuda la trama política de disputas y enfrentamientos que explican el vínculo de la TR con Héctor Cámpora y Oscar Bidegain, y el lugar que luego ocuparon sus militantes en la campaña electoral y el gobierno provincial.

Por su parte, como vimos previamente, ya lanzada la opción electoral los sectores de la Tendencia van a intervenir de lleno en esa coyuntura, apoyando las elecciones como una táctica, es decir, como un medio para otro fin. Esta decisión fue acompañada también de una política por parte de Montoneros de apertura hacia el trabajo de superficie en los frentes de masas bajo la nueva estructura de la JP Regionales, lo que contribuyó a fortalecer los nexos con agrupaciones de base pre-existentes promoviendo su integración a la organización, en un contexto en el que la incertidumbre sobre la realización efectiva de los comicios, y la participación de Perón como candidato fueron una constante durante todo el período.

No obstante, la apuesta por lo electoral no necesariamente se tradujo en una decisión unívoca a favor del trabajo político-partidario, y mucho menos en la renuncia de la opción armada y de su consideración como preponderante en la lucha política.

De esta forma, atenderemos a una doble lógica que comienza a delinearse al interior de la TR, es decir, por un lado, veremos que desde los documentos internos y comunicados públicos de las organizaciones armadas se mantiene como una constante la concepción instrumental de las elecciones, como una táctica y una metodología al servicio de un fin 
mayor. Por otro lado, y como un efecto no buscado de esa apuesta o decisión "secundaria", observaremos cómo a nivel de las prácticas políticas, en ciertos grupos de militantes de la TR, la dinámica de los acontecimientos que la opción electoral desencadena generó ciertos sentidos y acciones en los que la competencia partidaria y la gestión estatal comenzaron a visualizarse como un fin en sí mismo, o como una actividad que valía la pena priorizar en esa etapa, en detrimento del accionar armado.

De allí que analizaremos la presencia de diversas prácticas, sentidos y compromisos involucrados en esta apuesta electoral dentro de la TR, y la insinuación de algunas tensiones latentes durante este proceso previo a la asunción del gobierno, que luego tomarán mayor dimensión una vez que avance el año 1973.

\subsection{Activismo electoral temprano: el caso de JP/FURN de La Plata}

Con el correr del año 1972 el horizonte electoral se fue convirtiendo en una posibilidad cada vez más tangible para todos los actores del campo político, más aún para aquellas fuerzas con aspiraciones directas de participación en la contienda por los votos. Dentro del peronismo, la nueva configuración del escenario político implicó ni más ni menos que la puesta en marcha de los mecanismos institucionales a partir de los cuales poder vehiculizar esa opción. Concretamente esto significó la rehabilitación de las estructuras del Partido Justicialista a nivel nacional, provincial y municipal, con la consiguiente participación -y disputa- de las fuerzas disímiles que integraban el Movimiento y que ahora, tal como vimos previamente, incluía una cuarta rama juvenil, que se sumaba a las tres históricamente reconocidas: femenina, sindical y política (Ladeuix, 2006).

Para algunos grupos de la militancia juvenil peronista adscripta a la Tendencia que contaban ya con un recorrido previo de trabajo político en el frente barrial y universitario, la posibilidad de sumarse y participar de la competencia partidaria no fue en absoluto una opción a subestimar. Al respecto, vale la pena detenerse en la experiencia del grupo JPFURN de la ciudad de La Plata, Berisso y Ensenada, ${ }^{72}$ como un caso representativo de esta activación político-partidaria temprana -nada menos que en una de las JP provinciales más importantes- que tendrá luego su proyección en los lugares preponderantes que ocuparon en las listas de candidaturas, y finalmente su participación gubernamental provincial y local.

\footnotetext{
${ }^{72}$ El radio de influencia de la JP-FURN se desarrollaba en las tres localidades, siendo un grupo unificado.
} Entrevista de la autora a Gonzalo Cháves, La Plata, (2016) 
Las primeras definiciones en esta dirección cobraron fuerza durante los debates que el GAN despertó al interior de esta agrupación hacia fines de 1971 y en el marco de la definitiva reestructuración partidaria que encabezó Héctor Cámpora como nuevo Secretario General del Movimiento Nacional Justicialista (MNJ) y delegado personal de Perón en noviembre de ese mismo año. Una de las iniciativas que diferenció notablemente la gestión de Cámpora de su predecesor Paladino, fue el lanzamiento de una campaña masiva de afiliaciones, con el objetivo de impedir a través de la "fuerza arrolladora de los votos", cualquier intento de proscripción ulterior (Robles, 2009).

Este proceso abierto de normalización partidaria impulsó algunas discusiones significativas en el seno del grupo de militantes de JP-FURN sobre la participación electoral, debates que fueron saldados a favor de una activa práctica de afiliaciones y movilizaciones en apoyo de los candidatos de la Tendencia. A continuación, los testimonios de algunos/as ex militantes permiten identificar las razones que contribuyeron a la apuesta electoral y su vinculación con la línea más movimientista/tendencista que identificaba a este grupo

"el frente electoral es algo a lo que no podemos renunciar, porque es alli donde el peronismo se manifiesta con mayor amplitud y cantidad de gente... a nosotros nos están proscribiendo hace dieciséis años. Ahora se abre un proceso que puede ser tramposo, pero para romper la trampa hay que meterse adentro. Yo digo que a partir de mañana la tarea principal que tenemos todos los que militamos en la JP es ponernos a trabajar en la tarea de afiliación. Aprender a hacer lo que no sabemos hacer" 73

Esta tarea de afiliación, si bien nunca deja de pensarse como parte de un engranaje mayor (un medio/una táctica) en esa coyuntura comenzaba a adquirir un peso "estratégico" (un fin) en la mirada de este grupo, en tanto permitía fortalecer los postulados y el posicionamiento de la Tendencia en la lucha interna del Movimiento, aspectos que se consideraban centrales en las posibilidades del proyecto revolucionario de más largo alcance

“las elecciones no eran el objetivo final porque a través de éstas era muy difícil poder lograr un cambio revolucionario, pero de todas formas nos metimos en esa opción, en ese trabajo, porque estratégicamente eran importantes, participar ahi porque era una buena forma de difusión de nuestra línea política. En ese momento éramos JP, la fusión con Montoneros vino después... hubo acuerdo en integrarnos, como militantes de base sentíamos la necesidad de

${ }^{73}$ Testimonio de Carlos Kunkel en Amato-Bazán (2008:114). Su intervención se dio en el marco de un plenario general de la JP-FURN a fines de 1971, con motivo de adoptar una posición integral frente al GAN. Del mismo plenario participaron Carlos Negri, el Turco Achem y Gonzalo Cháves apoyando esa moción. Ver también Lanteri (2009). 
cambiar los métodos de lucha porque a través de las elecciones había quedado claro que era muy difícil lograr el objetivo de la liberación real y la lucha armada estaba legitimada a nivel mundial con la Revolución Cubana, Argelia. Es decir nosotros íbamos por el cambio, era liberación o dependencia, y creíamos que uniendo ambas cosas íbamos a lograr tomar el poder económico y con todo lo que eso implica, no solo estar en el gobierno. ${ }^{74}$

Una de las consecuencias inmediatas de la aceptación del camino eleccionario por parte del grupo JP-FURN (aun cuando esta opción se daba contemplando la posibilidad de una "trampa", levantando consignas revolucionarias y no descartando la aplicación del accionar armado) fue su escisión. Un grupo minoritario que no aceptó la participación electoral tomó distancia del núcleo universitario original, creando meses más tarde una nueva agrupación estudiantil: el Frente de Agrupaciones Eva Perón (FAEP) que se presentaría públicamente como tal el 26 de julio de 1972 en un acto por el aniversario de la muerte de Eva Perón en la catedral de la ciudad. Dicha agrupación mantendrá a lo largo de 1972 contactos directos con las FAR, adoptando en esa coyuntura una posición más dura y reactiva respecto de la intervención en las estructuras institucionales del peronismo (Lanteri, 2009; Amato-Bazán, 2008:115). ${ }^{75}$

Otra consecuencia derivada de la apuesta eleccionaria fue la competencia por espacios de poder efectivos dentro del Movimiento, a expensas de aquellos sectores tradicionales, fundamentalmente la vieja guardia sindical y política. La estrategia desplegada por el grupo JP-FURN fue el lanzamiento de una campaña masiva de afiliaciones por los barrios, activando locales y unidades básicas que quedaron enroladas bajo la influencia de la Tendencia. Esta tarea fue acompañada por la formación de una agrupación política local que respaldaba dichas acciones, la "Agrupación Teniente Coronel Lorenzo Cogorno", ${ }^{76}$ cuyo objetivo principal era el de disputar directamente a través de candidatos propios (JP-FURN/MRP) los lugares en las listas del partido, en oposición a la facción paladinista local y a la vieja dirigencia peronista vinculada a la ortodoxia sindical

\footnotetext{
${ }^{74}$ Entrevista de la autora a Nora Peralta, La Plata (2012). De familia obrera y peronista, Nora comenzó su militancia formal en el año 1967, cuando ingresó a la Facultad de Veterinaria de la UNLP, encabezando la FURN en dicha casa de estudios. Fue compañera de Carlos Miguel, Mabel Benegas, Pablo Fornasari y Hugo Bacci, y formó parte de la Mesa Directiva de la FURN en el año 1970. Luego pasó a militar en el frente barrial ya como integrante de JP-Montoneros. Su compañero, Raúl Piñeyro, militante de FURN en la Facultad de Derecho, ocupó el cargo de Interventor de la República de los Niños durante el gobierno de Oscar Bidegain.

${ }^{75}$ Ambas agrupaciones FURN y FAEP volverán a unificarse en septiembre de 1973, ya formalmente como Juventud Universitaria Peronista (JUP) en el seno de la UNLP.

${ }^{76}$ Oscar Lorenzo Cogorno, fue Teniente Coronel del Ejército Argentino y uno de los principales referentes militares de la resistencia peronista, junto con el General Juan José Valle. Cogorno encabezó un levantamiento fallido contra el gobierno de la Revolución Libertadora en 1956. Fue fusilado, en La Plata, por estos hechos, junto al General Valle y otros militares y civiles sublevados, aplicándose los decretos de pena de muerte. Ver http://www.robertobaschetti.com/biografia/c/256.html
} 
(Amato-Bazán, 2008:158; Robles, 2009). ${ }^{77}$ La Agrupación Cogorno estaba conformada por miembros de JP-FURN, viejos peronistas ligados al MRP como Horacio Cháves, histórico militante de la resistencia y padre del dirigente de la JP platense Gonzalo Cháves, y otros grupos locales como las "Agrupaciones Gremiales de Base” y la "Alianza de la Juventud Peronista", esta última no encuadrada en la Tendencia pero más cercana a sus posiciones que a la de los grupos de la derecha político-sindical (Cháves-Lewinger, $1998: 43) .^{78}$

Como era de suponer, la determinación de los/as militantes de la Tendencia de participar en la contienda por las candidaturas, llevó a una tensión con la burocracia partidaria local, quien se mostraba reticente sobre todo a aceptar el influjo juvenil portador de mayor autonomía y una capacidad de generar acciones políticas de movilización y organización popular por sí mismas. Esto último se observaba sobre todo en los barrios de la periferia, donde la JP logró una importante cantidad de afiliaciones y el control de decenas de

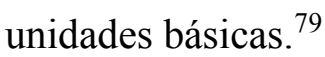

Varios testimonios subrayan el carácter de "hazaña" de esta campaña de afiliaciones y la resistencia que despertó en los viejos "caciques" del partido, con quienes los y las jóvenes debieron negociar sus lugares en las listas:

"la JP y la FURN participan activamente de la campaña, porque claro, cuando uno adhiere a la lucha armada parece que todo eso lo desechara, pero nosotros salimos a afiliar gente a los barrios, y dentro del Movimiento nos miraban raro, ¿estos de izquierda quiénes son? y cuando se hace una reunión por las candidaturas, nosotros vamos como JP a reunirnos con el cabeza de todo el PJ en La Plata que era Amerisse y le mostramos las fichas de afiliación y teníamos más nosotros que todo el resto del movimiento, ahí dijo, no hay nada más que discutir" "80

Esta simultaneidad de la práctica eleccionaria con la vigencia de la lucha armada, sin generar mayores contradicciones, es mencionada por otro entrevistado:

"la agrupación Cogorno se funda a fines del 71 calculo yo, coincide con el ingreso de Cámpora como delegado y cuando ya se veía la apertura. Habíamos dejado el MRP, porque veíamos que eso no avanzaba, había cosas teóricas con las que estábamos de acuerdo, pero no había ni

\footnotetext{
${ }^{77}$ José Carmelo Amerisse, Angel Castellanos y Enrique Cano eran las figuras más tradicionales del peronismo platense que históricamente habían controlado la mesa directiva del justicialismo en la ciudad. Ideológicamente se vinculaban con la línea sindical y ortodoxa de José Rucci. Entrevista de la autora a Babi Molina, La Plata (2014).

${ }^{78}$ Entrevista de la autora a Babi Molina (2014).

${ }^{79}$ Según Robles (2014b) asciende a 31 la cantidad total de Unidades Básicas que quedaron bajo la influencia de JP-Montoneros entre los años 72 y 74, ubicadas todas por fuera del casco urbano platense. Entrevista de la autora a Babi Molina, La Plata (2014).

${ }^{80}$ Entrevista de la autora a Hugo Bacci, La Plata (2012)
} 
desarrollo ni implementación de acciones de propaganda armada... cuando se empieza a ver la posibilidad de participar de las elecciones nos metimos de lleno a afiliar gente, porque la lucha también tenía que ver con eso, una lucha integral. Darla en todos los espacios, como decía Perón, en todo momento y en todo lugar. ${ }^{81}$

Finalmente, la capacidad ejecutiva de la juventud platense, evidenciada en el importante número de afiliados convocados por ellos, ${ }^{82}$ inclinó la balanza a su favor, logrando llegar a un acuerdo con la dirigencia tradicional. La designación de autoridades del partido se hizo en el mes de abril, a través de listas únicas, respondiendo también a la directiva de Perón de evitar las internas abiertas y la necesidad de cumplir con el calendario nacional electoral. Así, los nombres y cargos de la "unidad" fueron: Horacio Cháves como Secretario General, Daniel Naclerio como Secretario de Finanzas, Carlos Negri como Secretario de Prensa y Carlos Rodolfo Ivanovich como delegado suplente del congreso partidario, todos miembros de la JP e incorporados, los dos últimos, luego a Montoneros. Por su parte, Enrique Cano fue designado como presidente y Ángel Castellanos y José Carmelo Amerisse como delegados al congreso provincial (Robles, 2009). ${ }^{83}$

Además de estas designaciones partidarias, los y las jóvenes de la Tendencia obtuvieron lugares destacados en las listas de candidatos: Carlos Negri fue designado como primer diputado provincial; Babi Molina, Aníbal Visus y María Teresa Berardi como concejales por el distrito de La Plata y Raúl Piñeyro, Juan Carlos Martínez y Mirta Achem como suplentes, Stella Maris García como consejera escolar; Amalia Ramella como cuarta senadora provincial. También otros militantes de la JP-FURN oriundos del interior de la provincia figuraron como candidatos en otras secciones electorales: como diputados provinciales Héctor Moreda por Trenque Lauquen, José Tagliafico por Roque Pérez y Raúl Álvarez Echagüe por Almirante Brown, mientras que Carlos Elizagaray y Alberto Mayansky fueron como senadores. Además, Carlos Kunkel, máximo responsable de la JP de La Plata, fue incluido en el octavo lugar en las listas de diputados nacionales. ${ }^{84}$

Este despliegue de prácticas legales dentro de la esfera político partidaria por parte del núcleo JP-FURN fue acompañado por un conjunto de acciones muy activas de agitación

\footnotetext{
${ }^{81}$ Entrevista de la autora a Babi Molina, La Plata (2014)

82 Según el testimonio de Babi Molina y Carlos Bacci, alrededor de 800 fichas nuevas fueron las que llevaron a la reunión con José Carmelo Amerisse, cantidad que motivó el reconocimiento de los jóvenes y su inclusión en el partido por parte de los “jerarcas" justicialistas.

${ }^{83}$ Entrevista de la autora a Babi Molina, La Plata (2014).

${ }^{84}$ CPM - FONDO DIPPBA, División Central de Documentación, Registro y Archivo. Mesa Referencia, Legajo 16223. Carpeta: "Nomina de Autoridades Provinciales". Entrevista de la autora a Babi Molina (2014).
} 
pública y movilización de las bases, que engarzaban con el clima general de radicalización de la militancia juvenil y su lugar preponderante en la creación de las condiciones locales que aseguraron finalmente el retorno del líder en noviembre de 1972.

Al respecto, cabe mencionar como antecedente la visita al país de Isabel Martínez de Perón en diciembre de 1971 y el importante acto organizado por la JP platense en ese marco ya bajo la conducción de Rodolfo Galimberti, flamante representante juvenil del Consejo Superior. El mismo tuvo lugar en la cancha de Defensores Cambaceres en la localidad de Ensenada el 29 de enero de 1972. Precisamente la elección del lugar daba cuenta del creciente peso político y poder de convocatoria que la JP de La Plata, Berisso y Ensenada había logrado alcanzar, en detrimento de otros grupos juveniles dentro del peronismo como el Frente de Estudiantes Nacionales (FEN) y Guardia de Hierro, que mantenían posiciones más ortodoxas y críticas de las "formaciones especiales" y la Tendencia Revolucionaria en general (Larraquy-Caballero, 2000:149). ${ }^{85}$

El acto, que iba a contar con la presencia de Isabel Perón -quien a último momento desistió alegando "cuestiones de salud" - fue una oportunidad inmejorable para que la JPFURN, el MRP, las organizaciones armadas peronistas y las regionales de los gremios combativos afines a la Tendencia (ATE, SUPE y SMATA) exhibieran su poder de adhesión y movilización, en un momento clave de la institucionalización del movimiento y la interna partidaria. ${ }^{86} \mathrm{Al}$ respecto, la puja que libraba la Tendencia con los representantes de la derecha político-sindical se expresó claramente en el discurso de cierre a cargo de Galimberti, quien apuntó contra los "enemigos internos" del Movimiento, "los vandoristas que presentaron reparos al trasvasamiento generacional y a la elección de los 'duros' en el Consejo Superior". Por último, el líder juvenil expresó:

"aceptamos que hay que dejar pasar algunos tránsfugas menores, pero los traidores no pasarán. Si quieren guerra, tendrán guerra, para eso la juventud movilizará su aparato militar... los vamos a aplastar como cucarachas y no va a quedar ni uno solo de los pistoleros a

\footnotetext{
${ }^{85} \mathrm{Ambos}$ grupos se fusionaron en la Organización Única de Trasvasamiento Generacional (OUTG), Anchou (2007) y Cuchetti (2010). La OUTG representaba un espacio político e ideológico en disputa con los sectores de la Tendencia Revolucionaria, constituyendo junto a otros grupos afines (como el Encuadramiento de la JP- los Demetrios) lo que podría considerarse un "centro ortodoxo", que se proponía defender la "pureza" ideológica de la doctrina peronista y la lealtad a Perón y por añadidura a su sucesora Estela Martínez. Denaday (2012) y Besoky (2016).

${ }^{86} \mathrm{Al}$ acto asistieron cerca de 4 mil personas, quienes desbordaron la capacidad del estadio, en su gran mayoría eran militantes y jóvenes alineados con la Tendencia Revolucionaria, quedando por fuera de la organización las figuras y gremios centrales de la burocracia sindical, tales como Lorenzo Miguel y José Ignacio Rucci. Según Amato-Bazán (2008:134) fueron esos dirigentes quienes recomendaron a Isabel no asistir al acto, dado el copamiento del mismo por los grupos de izquierda del movimiento.
} 
sueldo que defienden a sus dirigentes sindicales corrompidos...déjennos tomar la conducción del movimiento, porque la vamos a tomar de todas formas" $" 87$

El encendido mensaje no pasó desapercibido para la cúpula sindical de la UOM, especialmente para Lorenzo Miguel, quien salió en defensa del legado de Vandor pidiendo de inmediato ante el Consejo Superior la renuncia del representante juvenil. En los días siguientes, y ante tal grado de malestar interno, llegaría la disculpa forzada de Galimberti, hecho que sirvió para superar momentáneamente el enfrentamiento entre los dos sectores que se perfilaban como competidores directos en la interna del movimiento: la Tendencia y el sindicalismo ortodoxo (Bonasso, 2010:207)

Las prácticas de movilización que protagonizó la juventud de la Tendencia con una impronta casi insurreccional, se profundizaron en la segunda mitad del año 72 , en el marco del lanzamiento de la campaña "Luche y Vuelve". ${ }^{88}$ Esta convocatoria tuvo como objetivo potenciar la movilización de la militancia juvenil de manera efectiva a nivel nacional, como estrategia de presión contra Lanusse quien por ese entonces había desafiado a Perón a volver al país antes del 25 de agosto. La campaña se lanzó oficialmente en el acto de la JP Regionales en el estadio de Nueva Chicago el 28 de julio, estando presente allí un contingente importante de la JP-FURN, quienes rápidamente respondieron a este llamado convocando a múltiples actos y movilizaciones en la ciudad. ${ }^{89}$

En paralelo a esta decisión de incorporarse a la campaña del "Luche y Vuelve", se conoció la noticia de los fusilamientos ocurridos en la Base Almirante Zar de Trelew, hecho que sacudió hondamente el escenario político nacional, actuando -paradójicamente para el régimen militar- como un potenciador de la militancia juvenil radicalizada y su renovado vínculo con las organizaciones armadas. Por ese entonces, los contactos entre

\footnotetext{
${ }^{87}$ Larraquy y Caballero (2000:150). El Día, 30/01/1972, citado en Robles (2009).

${ }^{88}$ En la biografía del líder de Montoneros, Mario Eduardo Firmenich, varios testimonios señalan que tanto la campaña del Luche y Vuelve como la campaña proselitista del verano de 1973 previa a las elecciones, fue financiada directamente con fondos de la organización producto de un secuestro (Celesia-Waisberg, 2010:134).

${ }^{89}$ Entrevista de la autora a Gonzalo Cháves, La Plata (2016). Entrevista de la autora a Hugo Bacci (2012). En la práctica, la campaña consistió en un recorrido por los principales centros urbanos del país, encabezado por las autoridades del MNJ, comenzando el 25 de agosto en Tucumán y finalizando el 3 de octubre en La Plata. La presencia masiva de la juventud en los actos y movilizaciones terminó por consolidar su promoción política dentro del Movimiento como protagonista indiscutida "de las marchas arrancadas a la dictadura”, que permitieron el regreso de Perón al país. Asimismo la cercanía gestada durante esta campaña sirvió al fortalecimiento de su vinculo con Héctor Cámpora, que terminó por sellarse definitivamente en la reivindicación de la formula “Cámpora al gobierno, Perón al Poder" levantada por los jóvenes de la Tendencia en diciembre de 1972 (Robles, 2009; Lenci, 1999).
} 
la JP-FURN de La Plata, Berisso y Ensenada y Montoneros se encontraban en pleno desarrollo, como parte de la organización de su Columna Sur. A continuación, dos testimonios de ex militantes de Montoneros (uno que venía de las FAP, y otro de JPFURN) permiten comprender elementos decisivos de la trama política que motivaron esa fusión y su particular definición por la militancia local platense:

\begin{abstract}
"Montoneros no paraba de crecer apostando a la salida electoral con los 5 puntos, y sintetizada en la campaña de Luche y Vuelve, no es casual la hegemonía que logra en la variedad de agrupaciones dispersas e inorgánicas hasta ese entonces, que contiene y subsume. Por trayectoria anterior, debieron ser las FAP quienes sintetizaran esa amalgama, pero el ideologismo los desvió de la tarea correcta que sí se dio Montoneros, de apostar a los frentes de masas y considerar la salida electoral como un momento de acumulación política, subordinando las operaciones militares como guerrilla en términos secundarios, como fuerza de hostigamiento a la dictadura de Lanusse ya en retirada. "90
\end{abstract}

Por su parte, Gonzalo Cháves, militante de la JP platense, sintetiza las razones que motivaron la integración a Montoneros en el contexto de la apertura electoral:

\begin{abstract}
"la JP de La Plata en el año 63 se incorporó al MRP, nosotros asumimos la lucha armada antes de entrar a Montoneros, recién entramos en noviembre de 1972. Todo el mundo cree que fue una reunión clandestina, secreta, pero no, hicimos una Asamblea en ATE La Plata, que estaba en la calle 57 entre 12 y 13, planteamos la incorporación y por voto mayoritario se aprobó. Tuvimos relación fuerte mucho tiempo con las FAP. Pero en ese momento en el año 72 ahí hay una articulación con Montoneros y no con FAP, porque Montoneros acepta la salida electoral. La gran decisión que tomó, acertada, es ir por adentro del Peronismo, decir la pelea está acá, sino no se entiende cómo pasó de ser una organización de un puñado de militantes a decenas de miles en tan poco tiempo, fue una acertada histórica que había que trabajar ahí adentro del Movimiento. El armado principal se hizo con un grupo de Montoneros que procedian de Descamisados, Habegger y el cura Soler". ${ }^{91}$
\end{abstract}

En efecto, para el grupo de JP-FURN, y en consonancia con los otros testimonios arriba analizados, la articulación con las organizaciones armadas se veía como natural en tanto muchos de sus miembros ya adherían a la lucha armada, y porque además en su concepción de lucha integral, estaba muy presente la necesidad de contar con todos los métodos (las afiliaciones y las acciones militares) sin descartar ninguno. En este sentido, la fusión con Montoneros se daba más fácil que con el resto de las organizaciones armadas, puntualmente porque para este grupo la salida electoral era un elemento central y Montoneros fue la primera que se definió a favor de esa opción.

El acuerdo entre ambas agrupaciones entrañó el armado de una columna en la ciudad, que estuvo a cargo de cuadros de capital federal, bajo la dirección de militantes de

\footnotetext{
${ }^{90}$ Entrevista de la autora a "Cacho", militante de Montoneros (2016).

${ }^{91}$ Entrevista de la autora a Gonzalo Cháves, La Plata (2016)
} 
Descamisados que se instalaron en La Plata como máximos responsables de Montoneros en la zona. ${ }^{92} \mathrm{La}$ integración se hizo bajo ciertas condiciones especiales por parte del núcleo platense, que ponían en evidencia su trayectoria política y el reconocimiento de ésta por parte de Montoneros: la organización armada se comprometía a no realizar ningún operativo en la ciudad sin la conformidad expresa del grupo JP de La Plata.

Así, los primeros pasos en la articulación efectiva de ambos grupos se dieron en el contexto de la vuelta de Juan Domingo Perón el 17 de noviembre de 1972, cuya estadía estuvo fuertemente marcada por el armado del proceso electoral, con el diseño definitivo de listas y candidaturas, y el lanzamiento de la campaña proselitista.

Como veremos a continuación, este será un momento decisivo para las agrupaciones de la Tendencia, poniendo a prueba su capacidad para desplegar diferentes estrategias orientadas a disputar espacios de poder efectivos en el futuro gobierno, y posicionarse como un actor legítimo dentro de la estructura partidaria frente a sus rivales internos.

\subsection{La reorganización partidaria a nivel nacional: la elección de Cámpora como candidato y los antagonismos ideológicos al interior del peronismo}

Si bien existía una larga trayectoria de enfrentamientos entre los diversos actores del conglomerado peronista, ${ }^{93}$ durante los largos años de prohibición de esta fuerza política, los antagonismos internos tendieron a permanecer en cierto modo "velados" ante la falta de legalidad e institucionalización del Partido Justicialista. Esto que en la práctica inhibió la expresión de dichos conflictos bajo la forma de una competencia directa por ocupar espacios dentro de la estructura partidaria, cambió drásticamente a partir del año 1972 ante la necesidad de llevar a cabo el proceso de normalización partidaria (Ladeuix, 2006; Tocho, 2019)

\footnotetext{
92 La cúpula de Descamisados a cargo de operativizar la fusión estaba integrada por Norberto Habegger, Rodolfo Ojea Quintana, Juan Carlos Alzogaray (el "hippie") y Juan Marcelo Soler. Como responsables políticos de la zona estaban Alejandro Peyrou y Carlos Kunkel. Con la creación unos meses más tarde en el frente sindical de la Juventud Trabajadora Peronista (JTP), Gonzalo Cháves fue nombrado su responsable en la zona. Entrevista de la autora a Alejandro Peyrou, CABA (2012) y Flora Castro, La Plata (2013).

93 Nos referimos fundamentalmente a la disputa entre los sectores "blandos" del sindicalismo, partidarios del diálogo y la conciliación con los gobiernos proscriptivos de turno, posición que encarnó de manera emblemática el dirigente metalúrgico Augusto Vandor y su estrategia del "Peronismo sin Perón", por un lado, y los "duros", agrupados en torno a una combativa camada de dirigentes sindicales peronistas que hacia 1968 con Raimungo Ongaro fundaron la CGTA levantando las banderas intransigentes de la lealtad al líder, por otro. A este sector hay que sumarle claramente los grupos de la juventud radicalizada, que hacia finales de los '60 se identificaron con una línea revolucionaria dentro del peronismo y que asumieron la lucha armada (Bozza, 2001; James, 2010)
} 
Esta operación encomendada por Perón al Secretario General del CSMNJ, Héctor Cámpora, no fue una tarea fácil de encarar, dada la superposición de organismos propios de la historia del peronismo -la arraigada concepción del Movimiento como estructura que integra y a la vez supera al Partido Justicialista- y las relaciones de fuerza cambiantes entre sus diferentes integrantes, gestadas al calor de la proscripción de la rama política y el ascenso en su lugar de otros actores muy activos como el sindicalismo y, más cerca en el tiempo, el creciente influjo de las organizaciones juveniles y las organizaciones armadas (Ladeuix, 2006)

Frente a estos hechos, como veremos a continuación, la tan ansiada reorganización partidaria y la elección de sus autoridades implicó desde el comienzo una serie de conflictos que fueron increscendo en el tiempo, adquiriendo una dinámica de tensiones que llevaron a cambios constantes en la composición de su estructura dirigente y notables actos de violencia en el transcurso de la designación de candidaturas, desgastando notablemente las relaciones entre las diversas ramas del Movimiento y el Partido muchos meses antes de la victoria en las elecciones generales el 11 de marzo.

En efecto, a pesar de la orden dictada por Perón desde Madrid a mediados del '72 que establecía el armado de "listas únicas" en las elecciones internas y llamaba a evitar las confrontaciones entre los dirigentes (Bonasso, 2010:223) las disidencias se hicieron cada vez más evidentes a medida que el proceso de institucionalización del Movimiento avanzaba y que crecían en influencia dentro de la estructura del Partido los sectores "camporistas" y de la juventud radicalizada, ${ }^{94}$ en detrimento de la rama sindical.

Esta contienda tuvo su primera expresión días antes de la fecha límite establecida por Ley (1ero de julio de 1972) para la normalización de los partidos políticos. El 25 de junio en el Hotel Savoy de Capital Federal se llevó a cabo el Primer Congreso Nacional del Partido Justicialista luego de su legalización. En el mismo se debían elegir las autoridades nacionales del partido y consagrar la fórmula presidencial. Siguiendo las directivas de

\footnotetext{
${ }^{94}$ El término "camporismo" es utilizado en la prensa de la época para denominar a aquellos dirigentes de la rama política y del Consejo Superior del MNJ que se mostraron desde el primer momento a favor de Héctor Cámpora como máxima autoridad del PJ primero, y luego como candidato a Presidente por el FREJULI en ausencia de Perón, frente al hostigamiento del sector sindical. Dentro de este grupo se encontraban como referentes Juan Manuel Abal Medina (nombrado Secretario General del MNJ en noviembre de 1972), Rodolfo Galimberti y otros delegados juveniles por la JP y dirigentes como Oscar Bidegain y Obregón Cano entre otros. Pasadas las elecciones del 11 de marzo de 1973, el término comenzó a identificarse cada vez más con una línea de la TR y posteriormente con su gobierno (Bonassso, 2010; Bernetti, 1983; Ladeuix, 2006). La Opinión, 3/11/1972 "El relevo de dirigentes justicialistas implica un importante cambio de táctica".
} 
"Madrid”, Cámpora dividió la conducción del Consejo Nacional del Partido de acuerdo a las 4 ramas del Movimiento, que incluía la rama juvenil. Las tensiones se hicieron evidentes a partir de la puja que los representantes sindicales de las 62 Organizaciones comandados por Rogelio Coria, y acompañados por Lorenzo Miguel y José Ignacio Rucci- iniciaron en torno a los cargos en dicho organismo, pretendiendo obtener para sí la Secretaría General del Partido y negando la representación a la rama juvenil, por considerar que estaba sobredimensionada.

Frente a la determinación de Cámpora de no ceder ante estos reclamos, los sindicalistas se retiraron del cónclave, resolviendo no integrar la conducción del Partido, quedando "vacantes" los tres cargos de secretarios correspondientes a ese sector (Bonasso, 2010:238 y Bozza, 1999:144). ${ }^{95}$ Finalmente, durante el Congreso y ya sin la presencia de los delegados del sector sindical, se proclamó por unanimidad la candidatura presidencial de Juan Domingo Perón.

Podemos adelantar que esta tensión presente en los hechos del Congreso entre los sectores sindicales enfrentados a una parte de la rama política y especialmente a la juventud adscripta a la Tendencia, se convertirá durante los meses siguientes, en la dinámica de funcionamiento de la interna peronista durante el último tramo de su normalización, que incluía la definición de candidaturas para la elección general en todos los niveles. Sumado a esto, y como lo demuestra la orden de Perón arriba mencionada, la extendida actitud del líder justicialista de intentar resolver los conflictos internos a partir del mandato de la verticalidad -elemento central de la doctrina peronista- no favorecía la destreza de la competencia dentro de las diferentes fracciones del peronismo, lo que daba como resultado la conformación de "acuerdos" sumamente inestables basados en la subordinación a su autoridad, más que como resultado de la confrontación y finalmente aceptación de lineamientos políticos comunes (Ladeuix, 2006; Bonavena, 2008; Antúnez, 2015)

\footnotetext{
${ }^{95}$ Verbitsky (1985) agrega que Cámpora fue amenazado con armas de fuego por los matones del ala sindical en el episodio del Hotel Savoy. 1985. El Consejo Nacional del PJ quedó conformado de la siguiente manera: Perón, Presidente; María Estela Martínez, vicepresidente primero; Héctor Cámpora, vicepresidente segundo; Horacio Farmache, secretario general. Oscar Bidegain, Santiago Díaz Ortiz y Celestino Marini, fueron nombrados secretarios por la rama política y estaban alineados en el camporismo. Por la Rama Femenina se nombró secretarias a Esther Fadul de Sobrino (cercana al camporismo y referente del peronismo fueguino), Nelida de Miguel (esposa de Lorenzo Miguel), y Norma Kennedy (referente del CdO). Ernesto Jauretche, Leandro Maisonave y Jorge Llampart, ocuparon las secretarias correspondientes a la Juventud, los tres alineados en la Tendencia y con vínculos con Montoneros. Asimismo se reservaron tres cargos para que los sindicalistas pudieran, con posterioridad al Congreso, integrar la nueva conducción del Partido (Ladeuix, 2006).
} 
Como ejemplo de esta tirantez latente, vale la pena detenerse en algunas escenas y mensajes contrapuestos protagonizados por los jóvenes dirigentes de la Tendencia y el sector sindical, a muy pocos días del retorno de Perón al país, poniendo en evidencia el clima de tensión permanente que existía entre ambas fracciones del Movimiento y las contradicciones en la manera de concebir la apertura democrática y la estrategia política dentro de la cual se insertaba el regreso del líder.

El 10 de noviembre en un acto en la Facultad de Arquitectura y Urbanismo de la UBA, el delegado por la rama juvenil Rodolfo Galimberti, en su discurso frente al público estudiantil, no escatimó críticas hacia el sector sindical acusándolo de traicionar la lucha por la vuelta de Perón al no poner todo el peso de su aparato en la movilización por el retorno, encarnando así la tradición del viejo vandorismo: "No sabemos si la burocracia sindical repetirá la traición de Vandor y Alonso en 1964, cuando no lanzaron el anunciado paro general, durante el primer operativo retorno". Como antítesis de esta claudicación, Galimberti reivindicaba allí el papel de las formaciones especiales y de la juventud como principales fuerzas dinamizadoras del Movimiento, quienes por ese entonces encabezarían -según el delegado juvenil- una estrategia de "colisión directa" contra el régimen. Este relanzamiento de la acción confrontativa a cargo de "milicias juveniles" - hecho que contrastaba notablemente con el tono pacificador asumido por el resto de los dirigentes en referencia al "operativo retorno"- quedó plasmada en la enfervorizada frase que Galimberti utilizó al convocar a la movilización popular hacia el aeropuerto el día de la llegada del líder al país: "los que tengan piedras que lleven piedras, y los que tengan algo más que lleven algo más, y los que no vayan al aeropuerto deben tomar las fábricas, las facultades, los barrios ..." "96

El mismo tono combativo pudo observarse en el acto de cierre del Congreso Nacional de la Juventud Peronista realizado en la ciudad de Santa Fe por esos mismos días. En esta reunión, Galimberti y los sectores más radicalizados de la juventud esgrimieron su parecer acerca del retorno del ex presidente, hecho que calificaban como una “contraofensiva táctica en la guerra prolongada que los enfrenta al sistema” junto con "una mayor conciencia revolucionaria del pueblo y el desgaste de la burocracia sindical que se verá desbordada por sus bases”. A su vez, si bien aceptaban el carácter estratégico del regreso en sí mismo, advierten que "sólo una inserción más profunda de

${ }^{96}$ La Opinión, 11/11/1972. Nueva Plana, Año I, n.6, 28 de noviembre 1972. Como consecuencia de esos dichos, se procesó y dictó una orden de captura contra Galimberti por incitación a la violencia (LarraquyCaballero, 2000:171-172) 
los sectores revolucionarios del peronismo en el seno de la clase trabajadora podrá evitar que los Coria, Rucci y la burocracia sindical puedan capitalizar el regreso de Perón". 97

Por su parte, y en respuesta a estos dichos, las 62 Organizaciones presentaron un documento en el que, además de calificar el retorno de Perón como "prenda para la paz, la unidad y la reconstrucción del país" -únicos objetivos que atribuyen al regreso-, criticaban a los sectores duros del Movimiento que "pretenden convertir el retorno en una bandera de guerra, y que van por el caos, la incitación a la violencia y la desvirtuación de las consignas y los verdaderos objetivos de nuestro líder", llegando a pedir formalmente ante el Consejo Superior la expulsión del delegado juvenil. ${ }^{98}$

Si bien el retorno de Perón el 17 de noviembre significó un punto de inflexión en la historia del Movimiento, condensando una enorme felicidad para todos sus miembros, ${ }^{99}$ el clima de celebración ante la vuelta del líder no impidió el recrudecimiento de las disputas entre sí. En medio de las copiosas negociaciones llevadas a cabo por Perón para el armado del frente electoral, que culminaron con la creación del Frente Justicialista de Liberación (FREJULI) el 12 de diciembre, ${ }^{100}$ la tensión se hizo mayor ante el avance de los sectores "camporistas" en la elección final de las candidaturas y la confirmación explícita del CSMNJ de que la Juventud Peronista participaría de las elecciones, al igual que el resto de las ramas del movimiento, en un 25\% de los cargos (Bonasso, 2010 y Bernetti, 1983).

Frente a esta confirmación, el sector sindical rechazó de lleno la decisión, por entender que el reparto de cargos en partes iguales iba en detrimento del peso que los gremios

${ }^{97}$ La Opinión, 14/11/1972. Según el testimonio de Juan Manuel Abal Medina, estos dichos de Galimberti iban mucho más allá en su intransigencia que la sostenida por algunos miembros de conducción de las organizaciones armadas en los temas de ataque a la burocracia sindical. Esta situación habría deteriorando crecientemente la relación entre Galimberti y Perón, distorsionando asimismo el vinculo con la conducción de las organizaciones armadas en los días inmediatamente previos al retorno (Jauretche, 1997:158)

${ }^{98}$ La Opinión, 15/11/1972.

${ }^{99} \mathrm{El}$ ansiado contacto entre Perón y su pueblo no se dio ese mismo día en el Aeropuerto de Ezeiza, ya que por disposición del gobierno militar el vuelo que lo traía no podía aterrizar allí sino en El Palomar. De esta forma, el encuentro esperado se dio en la quinta de la calle Gaspar Campos en Vicente López, que funcionó como residencia de Perón durante el mes que duró su estadía y que fue colmada por columnas de la JP que actuaron como fuerzas de seguridad.

${ }^{100}$ Las fuerzas políticas que integraban el Frente Justicialista de Liberación eran: el Partido Justicialista (PJ), el Partido Conservador Popular (PCP) siendo su máximo dirigente Vicente Solano Lima, el Movimiento de Integración y Desarrollo (MID) liderado por el ex presidente Arturo Frondizi, el Movimiento Socialista para la Liberación Nacional (MSLN) encabezado por Jorge Selser y el Partido Popular Cristiano (PPC) una de las dos fuerzas en las que se había escindido el antiguo Partido Demócrata Cristiano. (Bernetti, 1983, p. 51) 
habían tenido históricamente en el Movimiento y favorecía a los grupos radicalizados. Así lo explicaba Rogelio Coria a la prensa un día antes de la realización del congreso partidario, señalando que los cargos del justicialismo se distribuirían de manera "tradicional", es decir, entre las tres ramas históricas del movimiento, omitiendo claramente a la juvenil. ${ }^{101}$

Por su parte, los representantes de la JP nucleada en Montoneros en un comunicado de fines de noviembre titulado "Sin Perón no hay pacificación”, afirmaban que el regreso de Perón a la patria era "consecuencia de una mayor claridad en los objetivos perseguidos, fruto de una correlación interna de fuerzas dentro del movimiento que desbordó a los sectores frenadores". Esta nueva correlación, se expresaba ahora en la posibilidad de ocupar lugares en las listas de candidaturas, decisión que lejos de interpretarse como un retroceso en sus planteos estratégicos, serviría para "impulsar una politica revolucionaria dirigida a dar por tierra con todos los intentos, que tanto desde dentro mismo del peronismo -los corias, paladinos, osindes, etc-como fuera de él, aspiran a institucionalizar a un peronismo castrado en sus objetivos revolucionarios". Por esto mismo, proclamaban la candidatura a la presidencia de Juan Domingo Perón, y "para el resto de los cargos electivos en los órdenes nacional, provincial y comunal la necesidad de integración de las listas por un cien por ciento de compañeros de inequívoca trayectoria leal, honesta y revolucionaria, surgidos de las cuatro ramas del movimiento". 102

Finalmente, y más allá de la denominada "noche de las candidaturas" del 13 de diciembre, ${ }^{103}$ la lucha interna cobrará intensidad en el Congreso Nacional del Partido Justicialista reunido el día 15 en el Hotel Crillón, que debía aprobar las candidaturas a

${ }^{101}$ La Opinión 14/12/1972.

102 “Sin Perón no hay pacificación”. Documento de la Juventud Peronista, Nov. 1972 (Baschetti, 1996: 482). El documento estaba firmado por los Consejeros Nacionales por la Juventud en el Partido y el Movimiento (Leandro Maissonave, Jorge Llampart, Ernesto Jauretche, Rodolfo Galimberti y Julián Licastro). Además en la conferencia de prensa en la que se dio a conocer esta declaración estuvieron presentes reconocidas figuras del peronismo "duro" como Raimundo Ongaro, Alicia Eguren y Bernando Alberte.

${ }^{103}$ Por la vigencia de la cláusula del 25 de agosto establecida por Lanusse, Perón quedaba inhabilitado para ser candidato, con lo cual, más allá del ofrecimiento formal en tanto líder y candidato natural, ya empezaban a correrse rumores de todo tipo con respecto a los posibles nombres a ocupar ese puesto. El día 13 de diciembre, justo antes de partir a Paraguay, Perón se reunió en Gaspar Campos con Abal Medina, señalando a Cámpora como su candidato a la presidencia. Por otra parte, Oscar Bidegain fue sindicado como el candidato en la provincia de Buenos Aires, en detrimento de Manuel de Anchorena. Para Córdoba indicó su preferencia por Obregón Cano. Los otros nombres de figuras del peronismo que se buscaban instalar como candidatos presidenciales eran el de JorgeTaiana, apoyado por algunos pocos dirigentes de la rama política y el de Antonio Cafiero promovido por el sindicalismo (Bernetti, 1983:57-60) 
presidente y vice por el FREJULI. Luego de presentar por aclamación la candidatura presidencial de Perón, quien por ese entonces ya se encontraba fuera del país en tierras guaraníes, se desató un duro enfrentamiento entre el grupo que lideraba Juan Manuel Abal Medina integrado por los sectores camporistas, ${ }^{104}$ que proponían la consulta rápida vía télex al líder justicialista y apoyaban la fórmula Cámpora-Solano Lima, frente al grupo de gremialistas y delegados de la derecha peronista (entre otros Norma Kennedy, Brito Lima del CdeO, Manuel de Anchorena del Movimiento Federal y los congresales de Guardia de Hierro) que insistían con la candidatura de Perón y querían enviar una delegación en avión a Paraguay con el fin de entrevistarse directamente con él y poder así negociar una candidatura más cercana al sector sindical. Ante la pérdida de la votación por parte de este grupo, ${ }^{105}$ y sabiendo que quedaba allanado el camino para la proclamación de la candidatura de Cámpora ante la ya anunciada defección de Perón, ${ }^{106}$ los representantes sindicales se retiraron del cónclave formulando graves acusaciones de "entrega" y "arribismo" contra los dirigentes políticos del peronismo "que han mostrado el hambre que le tienen al queso". Por su parte el representante máximo de las 62 Organizaciones, Rogelio Coria, hizo saber que la rama sindical se bajaría de todas las candidaturas. El argumento que utilizaban para justificar esta renovada ortodoxia hacia Perón y la intransigencia frente a la candidatura de Cámpora era que no se debían acatar las proscripciones impuestas por el régimen militar, aunque dicha reacción respondía en verdad a lo que ellos entendían como una pérdida de poder del sector gremial dentro del Movimiento en manos de los sectores que se encolumnaron detrás de Cámpora. ${ }^{107}$

104 Con menos de un mes al mando del MNJ, Juan Manuel Abal Medina era el encargado de conducir el Congreso bajo los lineamientos dados por Perón en la reunión de las candidaturas. Este joven abogado de apenas 27 años de edad y hermano de Fernando, miembro fundador de Montoneros, fue el elegido por Perón para ocupar ese importante cargo, buscando con ello dar una imagen de dureza y cercanía a los sectores radicalizados del movimiento. No obstante, la trayectoria política de Abal Medina se ubicaba dentro del nacionalismo católico junto a Marcelo Sánchez Sorondo, teniendo vínculos con sectores nacionalistas de las FFAA. La Opinión, 3/11/1972, "Nombramiento de Abal Medina como Secretario general del MNJ".

${ }^{105}$ De los 183 delegados presentes, 92 votaron a favor de la opción télex, mientras que 55 respaldaron la iniciativa gremial de enviar una comitiva. El resto se abstuvo. La Opinión, 16/12/72. Para más detalles sobre el Congreso ver Bernetti (1983: 66-67)

106 Sobre la honorifica postulación a Perón y su renuncia, ver Bonasso (2010, p. 336). En ese mensaje leído por Abal Medina, el líder justicialista dejaba expresamente claro que quien debía ocupar su lugar era Héctor Cámpora, siendo su candidatura una maniobra táctica fundamental para derribar, desde adentro del sistema, los planes proscriptivos del régimen. Nueva Plana, 19 de diciembre de 1972. En su testimonio, Juan Manuel Abal Medina señala que tanto él como el grueso de la juventud y la conducción de las organizaciones armadas junto a allegados del delegado personal coincidían en que de no ser Perón candidato, debía ocupar ese lugar alguien lo más cercano a éste, es decir Héctor Cámpora, en Jauretche (1997: 183)

${ }^{107}$ Nueva Plana, 19 de diciembre de 1972. 
Posteriormente y luego del cuarto intermedio dispuesto, el Secretario General de la Unión Obrera Metalúrgica, Lorenzo Miguel, despegándose de la postura intransigente de Coria, avaló la candidatura de Cámpora, que ya había sido aprobada sin los representantes gremiales. ${ }^{108}$ Esta actitud expresaba un verdadero acto de disciplinamiento por parte del líder de la UOM, quien días atrás, junto a José Ignacio Rucci, había apoyado la candidatura presidencial del ex ministro de economía Antonio Cafiero. Al finalizar el Congreso, Lorenzo Miguel declaró que los sindicalistas estaban dispuestos a acatar la verticalidad del justicialismo y, por tanto, la decisión de sus congresales. De la misma manera actuaron los representantes juveniles de la derecha peronista (Brito Lima por CdeO y delegados de otras agrupaciones como Guardia de Hierro y el Movimiento de Bases Peronistas) quienes finalmente, y a su pesar, votaron a favor de la candidatura del ex delegado. ${ }^{109}$

Para concluir, podemos señalar que la aceptación de la fórmula encabezada por Cámpora, si bien implicó un avance muy importante en la finalización del proceso de normalización del justicialismo a nivel de la candidatura presidencial, de ningún modo derivó en el cese definitivo de sus tensiones. Tal como vimos, el llamado de Perón a evitar las disidencias adentro de su fuerza, si bien tuvo su efecto, fue resuelto a partir de una frágil tregua entre los sectores de la burocracia sindical no alineados con Coria (fundamentalmente Lorenzo Miguel y Rucci) y los grupos favorables a Cámpora entre los que se encontraba la juventud de la Tendencia Revolucionaria. ${ }^{110}$ Este momentáneo alineamiento volverá a tensionarse en el marco de la definición de las candidaturas en la provincia de Buenos Aires, blanco privilegiado para los sectores del sindicalismo en sus aspiraciones de recuperar las posiciones de poder perdidas.

\subsection{La interna bonaerense: del enfrentamiento violento a la verticalidad}

Sin duda el clima conflictivo que caracterizó la contienda peronista por las candidaturas a nivel nacional prefiguró ciertas condiciones que incidieron en los diferentes procesos provinciales de cara a las elecciones. Dicho esto, vale la pena considerar el aporte de recientes estudios basados en un enfoque regional que apuntan a "achicar el foco"

${ }^{108}$ De los 150 delegados presentes al momento de la elección, votaron a favor de Cámpora 145 , los 5 restantes fueron en blanco. Ya se habían retirado Coria y su grupo. Ver La Nación 16/12/1972.

${ }^{109}$ La Opinión, 16/12/72 "Héctor Cámpora fue proclamado candidato presidencial por el Congreso Justicialista luego que Perón reiteró su renunciamiento".

${ }^{110}$ La Opinión, 17/12/72 "Brindaron su apoyo a la nominación del delegado de Perón los núcleos juveniles radicalizados". Producto de esta pérdida de poder, Rogelio Coria en enero de 1973 renunció a la presidencia de las 62 Organizaciones peronistas. 
(Águila, 2015) observando las particularidades de ciertos procesos políticos a nivel local, como también las articulaciones e influencias mutuas entre el nivel nacional y provincial, más que las determinaciones unidireccionales de un polo hacia otro (Levi, 2003; SernaPons, 2003). Esto permitirá reconocer la especificidad del caso bonaerense con su propia dinámica del enfrentamiento en esta coyuntura.

Al respecto, podemos afirmar que en los espacios provinciales las disputas por la conformación de los binomios gobernantes y la integración de listas alcanzaron niveles realmente altos de enfrentamiento plasmados no sólo en la utilización de mecanismos legales propios de la vida partidaria (impugnaciones en la justicia electoral, intervenciones, expulsiones) sino también en hechos de violencia directa.

Tal como señala Alicia Servetto (2010) la reorganización partidaria del justicialismo en las provincias fue un proceso notablemente complejo marcado por las duras disputas internas que terminarían por proyectarse sobre los futuros gobiernos constitucionales provinciales. De hecho, se libraron extenuantes luchas para acceder a las diferentes posiciones en las listas para los cargos electivos. En las provincias de Formosa, Córdoba, Mendoza, Santa Cruz y Salta lejos se estuvo de obedecer la directiva de Perón de presentar listas de unidad, enfrentándose dos y hasta tres listas justicialistas por la conducción partidaria provincial y la designación de candidatos a gobernador y vice. Por su parte en la provincia de Tucumán las divisiones al interior del peronismo desencadenaron fuertes impugnaciones de la JP local contra el candidato elegido a gobernador, el ex jefe de la policía Armando Juri, sufriendo éste un atentado en su domicilio (Bonavena, 2009:166). En Catamarca, el Consejo Provincial debió intervenir todas las Juntas Departamentales del PJ y el Congreso Partidario que designó la formula a gobernador y vice (encabezada por Hugo Mott y Raúl Sabath) fue impugnado por el ex gobernador peronista Armando Casas Noblega, dejando como saldo peleas y fricciones muy difíciles de disipar luego de las elecciones (Bonavena, 2009:179). En Misiones, el precandidato a gobernador por un sector del peronismo y apoderado del partido Francisco Ripoll, resultó muerto a balazos por otro afiliado del justicialismo el mismo día en que se realizaba el congreso partidario provincial que elegiría las candidaturas. ${ }^{111}$ Asimismo en la provincia de Santa Fe el enfrentamiento intraperonista desencadenó la constitución de

${ }^{111}$ La Opinión, 16/12/1972 “Agitación en las provincias por las listas peronistas” 
dos congresos paralelos para elegir candidaturas, dejando como saldo la muerte de dos militantes y la detención del presidente de la junta departamental del PJ. ${ }^{112}$

En la provincia de Buenos Aires, el proceso de legalización y rehabilitación del partido junto con la elección de candidaturas recrudeció las tensiones internas del justicialismo, poniendo en jaque - dado el peso gravitante de dicha jurisdicción en el orden político nacional- la postulación electoral del peronismo y la consecución de la campaña.

Las disidencias no eran nuevas, existiendo antecedentes directos de conflictos entre los dos sectores que se perfilaban para disputar la candidatura provincial. ${ }^{113}$ Hacia el mes de junio de 1972 y en el marco del proceso de normalización partidaria, se realizó el primer Congreso Provincial del PJ bonaerense luego de su proscripción, enfrentándose el estanciero Manuel de Anchorena, jefe del derechista Movimiento Federal, ${ }^{114}$ con el delegado nacional por el justicialismo en la provincia de Buenos Aires, el histórico dirigente de la rama política Oscar Bidegain, ${ }^{115}$ quien era apoyado por la conducción del

${ }^{112}$ La Opinión 16/12/1972 “Agitación en las provincias por las listas peronistas” y 17/12/1972 "La crisis nacional peronista agudiza conflictos locales en las provincias".

${ }^{113}$ Ya en el Acto de la JP realizado en la cancha de Cambaceres en enero de 1972 se hicieron visibles los encontronazos entre sectores del sindicalismo ortodoxo y la juventud de la Tendencia (Robles, 2009)

${ }^{114}$ El Movimiento Federal se origina a fines de 1960 a partir de distintos desprendimientos de las organizaciones Tacuara y Guardia Restauradora Nacionalista. Manuel de Anchorena fue su conductor, quien hacia el año 1970 logra la incorporación de su agrupamiento en la estructura del Movimiento gracias a los contactos directos que mantenía con Jorge Osinde, quien le posibilitó el nexo con la cúpula justicialista. Ladeuix (2006). Según Besoky (2012) dentro de este agrupamiento político, en 1969 se funda su rama juvenil, denominada Movimiento de la Juventud Federal (MJF). Con escasa presencia nacional, su base principal fue el interior de la Provincia de Buenos Aires, donde articuló a viejos caudillos locales del peronismo con apoyo juvenil. Tanto Verbitsky (1986) como Larraquy (2007) ubican a los hombres del MJF en el palco en Ezeiza el 20 de junio de 1973. Para junio del ' 73 señala La Opinión que el Movimiento Federal había perdido peso pasando muchos de sus militantes a formar parte de la recientemente creada Juventud Peronista de la República Argentina, en Besoky (2012).

${ }^{115}$ La trayectoria política de Oscar Bidegain, médico cirujano nacido en la localidad bonaerense de Azul, se remonta a una temprana militancia en los grupos del nacionalismo conservador durante la década del '30 (Legión Cívica Argentina, Acción Nacionalista Argentina y la Alianza Libertadora Nacionalista) apoyando luego la Revolución del 4 de junio de 1943 e integrándose al peronismo en 1946, siendo miembro fundador del Partido Peronista de Azul. Durante los dos primeros gobiernos peronistas se desempeñó como Diputado Nacional por la provincia de Buenos Aires y llegó a la presidencia del bloque en 1955. También fue nombrado Tesorero del Consejo Provincial del Partido Peronista en la Provincia de Buenos Aires, e Interventor Reorganizador del Partido Peronista de los Territorios Nacionales de Chaco, Formosa y Misiones. Con el golpe cívico-militar de la "Revolución Libertadora" es encarcelado junto a otros legisladores, condenado por asociación ilícita en el Parlamento y por traición a la Patria al haber votado el Segundo Plan Quinquenal. En los años de la Resistencia, Perón lo designa integrante del Comando Táctico Nacional Peronista, entablando vínculos con John William Cooke, y una estrecha amistad con dirigentes sindicales del ala combativa, como Jorge Di Pascuale, Sebastián Borro, Abelino Fernández, Amado Olmos y Andrés Framini. Posteriormente, en la década del `60, se dedicó a reorganizar la militancia peronista en su ciudad natal. Ya para 1971 ante la legalización del Partido Justicialista es nombrado Delegado para la reorganización del PJ bonaerense y miembro del Consejo Nacional del PJ. Después de su paso por la gobernación bonaerense, en el año 1975 integró el Partido Peronista Auténtico (PPA) junto a Rodolfo Puiggrós y Ricardo Obregón Cano entre otros dirigentes, luego de ser expulsado del PJ. Sufrió amenazas y persecuciones por parte de la Triple A, y finalmente luego del golpe del 24 de marzo de 1976 inició un largo exilió en Roma y Madrid, donde participó activamente de la fundación del Movimiento Peronista 
Consejo Superior del MNJ (Perón, Cámpora, Abal Medina). En aquélla oportunidad la intención del estanciero, secundado por representantes de la derecha peronista como Jorge Osinde y el aparato de la UOM, intentó copar la conducción del Congreso e imponer una lista con gente exclusiva de su agrupación y del sector sindical que respondía a Lorenzo Miguel, como un paso previo a la escalada por la candidatura a gobernador. Finalmente, el apoyo que Cámpora en persona brindó a Bidegain y la mención explícita a respetar la verticalidad que emanaba de los deseos del General Perón, lograron desactivar la maniobra desestabilizadora en ese momento (Bonasso, 2010:231).

Asimismo, durante los actos realizados en el marco de la campaña "Luche y Vuelve", no estuvieron ausentes las menciones acusatorias de traición, falta de lealtad e infiltración ideológica entre representantes de uno y otro bando, siendo elocuente la no intervención de las 62 Organizaciones y de la CGT local en un acto de esta campaña realizado el 3 de octubre en la ciudad de La Plata, en función de la amplia participación de los miembros de la JP local y de la presencia de las agrupaciones armadas Descamisados y Montoneros, quienes criticaron explícitamente a la burocracia sindical. Por su parte, los delegados gremiales calificaron a los sectores de izquierda como "extremistas marxistas infiltrados" (Robles, 2009).

Finalmente, en diciembre de 1972 y luego de haber perdido la pulseada por el candidato propio en el Congreso Nacional del PJ, los sectores de la derecha político-sindical del peronismo volcaron el peso de su fuerza y presión en la elección a gobernador y vice en la provincia de Buenos Aires. De esta manera, la rama sindical dirigida por Rucci y Coria impulsaron la candidatura de Manuel de Anchorena y Luis Guerrero, ${ }^{116}$ este último Secretario Adjunto de la UOM nacional y Secretario General de la seccional Avellaneda, en detrimento del candidato apoyado por la conducción nacional y el propio Perón, Oscar Bidegain. ${ }^{117}$ Por su parte, los sectores de la Tendencia respaldaron la candidatura

Montonero (MPM) como Secretario de la Rama Política. El 15 de diciembre de 1994, en su ciudad natal, falleció a los 89 años por una afección cardíaca. Ver Baschetti (2005), Antúnez (2015), Bustingorry (2015). El Dia, 25/05/1973 "Los mandatarios de nuestra provincia".

${ }^{116}$ Es importante recordar el modelo que Perón había diseñado para las formulas provinciales, consistente en la participación de un dirigente de la rama política en el lugar de gobernador, y uno de la gremial en el de vice.

${ }^{117}$ El apoyo de Perón a Bidegain se fundaba en la estrecha relación que ambos mantenían fruto de la larga participación del segundo en el Movimiento y el Partido, su importante papel durante la resistencia peronista y su encarcelamiento en el marco de la Revolución Libertadora, lo que daba cuenta de su probada lealtad hacia el líder. Además también Bidegain había cumplido un rol destacado en la más inmediata reorganización partidaria como Delegado Provincial del MNJ y Secretario de la Junta Promotora Partidaria Provincial. Por el contrario, Manuel de Anchorena y su grupo eran identificados como sectores oportunistas que jugaban políticamente a favor de Lanusse (Bernetti, 1983; Bonavena, 2009) 
de Bidegain por tratarse del candidato "camporista", sellando así la sintonía con el ex delegado de Perón nacida durante la campaña del "Luche y Vuelve". No obstante, como veremos más adelante, será recién durante el transcurso de la campaña electoral bonaerense cuando se pueda inferir un acercamiento más firme entre la Tendencia y el candidato a gobernador, en función del hostigamiento mutuo que experimentaban desde el sector sindical.

Volviendo a los episodios del Congreso Provincial Justicialista, en éste no sólo se hicieron evidentes las diferencias que separaban a las dos fuerzas en disputa por el control de los cargos y postulaciones, sino también la superposición de esferas de influencia y espacios de decisión que convivían conflictivamente dentro del Movimiento y el Partido, dificultando aún más la posibilidad de lograr decisiones con alto grado de consenso (Ladeuix, 2006)

El sábado 16 de diciembre comenzó a sesionar por la tarde el Congreso Provincial Partidario, en la sede de la UOM de Avellaneda. ${ }^{118}$ A poco de iniciada la reunión se hizo evidente la presión del sector sindical y de la derecha peronista a favor del binomio Anchorena-Guerrero. No obstante, y por pedido de Cámpora, se hizo presente el delegado electoral del Consejo Superior en la provincia de Buenos Aires, el Dr. Alejandro Díaz Bialet, quien fue rechazado en la entrada por militantes del PJ provincial aduciendo que dicho congreso era soberano y por lo tanto no tenían injerencia en él miembros de la conducción central. Posteriormente y ya dentro de un clima de extrema tensión llegó el Secretario General del MNJ, Juan Manuel Abal Medina, quien a pesar de leer una carta de Perón en la que se hacía expresa mención a respetar la verticalidad y acatar sus sugerencias -aunque sin dar nombres propios- fue hondamente abucheado por gran parte de los congresales quienes nuevamente alegaron la naturaleza soberana del cónclave y la reunión del quórum necesario para votar. Ante la creciente crispación del ambiente, Abal Medina se vio obligado a abandonar la sede de la UOM junto a otros congresales, siendo perseguidos por hombres que respondían al gremio metalúrgico, al Movimiento Federal y a la CNU, quienes además de acusarlo de “traidor al movimiento y a Perón”, le propiciaron piedrazos, golpes de puño y disparos de armas de fuego, llegando a herir gravemente a uno de sus acompañantes. Luego de aproximadamente una hora de

118 Según Bonasso (2010:134) la decisión de realizar el Congreso en la sede de la UOM Avellaneda (localidad bajo el control del metalúrgico Luis Guerrero) formó parte de la conspiración que montó Anchorena secundado por Rucci y Osinde para presionar a los delegados y lograr su candidatura. 
disturbios, el Secretario General del Movimiento logró refugiarse en una seccional de la policía, abandonando la localidad acompañado por policías de civil que lo custodiaban. ${ }^{119}$

A pesar de la gravedad de la situación, en la sede de la UOM el Congreso siguió sesionando, ya con un reducido número de congresales - de los 220 iniciales quedaron sólo 146 luego de los incidentes- siendo aclamada por amplia mayoría la fórmula Anchorena-Guerrero, ${ }^{120}$ acompañada por el cántico "Ni yanquis ni marxistas, peronistas" de los simpatizantes de la Juventud Federal y afiliados metalúrgicos que colmaban el recinto.

Ante la muestra clara de desobediencia por parte del sindicalismo y sectores del PJ no alineados con la conducción nacional -quienes a través de la fuerza desconocieron la autoridad de los dirigentes del Movimiento y desestimaron de lleno la candidatura del hombre del "camporismo" en la provincia- el Consejo Superior del MNJ decidió la expulsión de los afiliados Manuel de Anchorena, Luis Guerrero, Tomas Argentino Real, Ángel Castellano, Alberto Armesto y Héctor Aldube por "graves actos de indignidad" y “contravenir las expresas disposiciones del Movimiento y de Perón”. ${ }^{121}$ Asimismo declararon nulo el Congreso, impugnaron las candidaturas e intervinieron el PJ de la Provincia de Buenos Aires. ${ }^{122}$

Sin intimidarse ante lo sucedido y redoblando la apuesta contra la autoridad del ex delegado de Perón y sus allegados, los rebeldes partidarios del Movimiento Federal no acataron la medida de expulsión aduciendo que no tenía validez a nivel del partido, dado que los únicos que podían expulsar o impugnar candidaturas eran los congresos partidarios y no las estructuras paralelas del Movimiento. Asimismo, este sector decidió enviar una comitiva a Paraguay con el objetivo de entrevistarse directamente con Perón y lograr así la aprobación de lo actuado. ${ }^{123}$ Por último y como muestra de la resistencia de este grupo de resignar sus aspiraciones electorales, el día 21 de diciembre se reunieron

119 La Opinión, 17/12/1972 "El candidato bonaerense Anchorena fue expulsado por la conducción peronista" y "Serios disturbios en un congreso justicialista".

${ }^{120}$ De los 146 congresales presentes al momento de la votación, 139 votaron a favor, 6 en blanco y uno anulado. La Nación, 17/12/1972.

${ }^{121} \mathrm{~A}$ los pocos días esta decisión fue ratificada por el Consejo Nacional del Partido Justicialista que alegó que en dicho congreso no se cumplió con la alianza electoral establecida ni con la denominación FREJULI para la presentación de las listas, votándose únicamente por partidarios del PJ sin incluir a candidatos de las restantes fuerzas que integran el frente e incumpliendo la cuota del $25 \%$ de los cargos que les correspondían. La Nación, 19/12/1972. Bonavena (2008: 156)

${ }^{122}$ La Opinión, 19/12/72 "Impugnan en Buenos Aires a Manuel de Anchorena” y "Intervención bonaerense en el justicialismo".

${ }^{123}$ La Opinión, 21/12/72 "Definición en Lima sobre el caso Anchorena" 
nuevamente en un Congreso Partidario - ya sin la presencia de congresales alineados con Cámpora y Abal Medina- en el que ratificaron la candidatura de Anchorena-Guerrero y decidieron a través de un recurso en la justicia electoral intervenir nuevamente el Consejo del PJ Bonaerense (recordemos que éste ya estaba intervenido por decisión del Consejo Nacional del PJ que respondía a Cámpora). ${ }^{124}$ También los congresales decidieron relevar al apoderado del FREJULI de la provincia de Buenos Aires, el abogado René Orsi, ${ }^{125}$ quien hasta ese momento era el acompañante de Bidegain en la formula sostenida por la conducción nacional y con vínculos con la Tendencia revolucionaria, reemplazándolo por Alberto Castellanos, uno de los dirigentes "insurrectos" del PJ expulsado días antes.

Un dato interesante en vistas a la resolución final del conflicto y a las posteriores tensiones internas que conmoverán la gestión de Bidegain, fue la nómina de candidatos a diputados nacionales que aprobaron los congresales "rebeldes", encabezando la misma el Secretario General de la UOM Vicente López, Victorio Calabró, quien hasta ese momento no había figurado entre los nombres que integraban la disidencia bonaerense. ${ }^{126}$ Esta situación no sólo planteaba un problema importante al interior del justicialismo, sino que también amenazaba con quebrar la unidad dentro del sindicalismo peronista y de las 62 Organizaciones, dado que el representante máximo de la UOM Nacional, Lorenzo Miguel, mantuvo su decisión de acatar la verticalidad y sostener la candidatura de Cámpora y Bidegain respectivamente, mientras que sus compañeros directos en la UOM,

${ }^{124}$ La Opinión, 22/12/72 "Los Congresales se alzaron contra Héctor Cámpora”

${ }^{125}$ René Orsi fue legislador durante el primer peronismo y un hombre muy cercano a J.W. Cooke en esa etapa y más adelante, así lo describe Floreal Ferrara en sus memorias (Svampa, 2010:50). Con el golpe de Estado del 16 de septiembre de 1955 fue encarcelado por la Revolución Libertadora. Al finalizar su detención, Orsi integró en los años de la resistencia el Comando Táctico Nacional Peronista junto a Cooke, Andrés Framini, Oscar Bidegain, Héctor Cámpora, Obregón Cano, Delia Parodi y María Granata, entre otros/as. Fue docente en la Facultad de Ciencias Jurídicas y Sociales de la UNLP entre 1973 y 1976. También se desempeñó en la Magistratura como Juez Federal entre los años 1973-1974 cuando ascendió y pasó a integrar la Cámara Federal de Apelaciones de La Plata, cargo que mantuvo hasta 1976. En 1976, por propuesta de María Estela Martínez de Perón, asumió como Interventor de la provincia de Salta, cargo que mantuvo hasta el golpe cívico-militar del 24 de marzo de ese año.

${ }^{126}$ La Opinión, 22/12/72 “Los Congresales de Buenos Aires se alzan contra Cámpora”. No obstante, en esta nota se señala que el acercamiento de Victorio Calabró a Luis Guerrero es puramente circunstancial, respondiendo más a una interna que el metalúrgico de Vicente López mantenía con Lorenzo Miguel en ese momento, quien sí se mostró desde un comienzo proclive a aceptar las candidaturas del camporismo. Por otra parte, la actitud de Lorenzo Miguel se alejaba notablemente de la posición intransigente asumida por otras figuras del sindicalismo, como Rogelio Coria, quien comenzaba a ser sindicado como el sucesor de Vandor al querer representar a las bases obreras peronistas por fuera del PJ y del reconocimiento del propio Perón, situación que podía hacer peligrar todos los lugares reservados al sindicalismo en las listas. 
Luis Guerrero y Victorio Calabró, se alinearon a través de sus candidaturas con la postura de Rogelio Coria, rival de Miguel en la Mesa Ejecutiva de las 62 Organizaciones. ${ }^{127}$

La tensión llegará a su punto más álgido el 26 de diciembre, a sólo cinco días del cierre oficial para la presentación de las listas, cuando resultó herido de bala el dirigente Luis Guerrero al salir de su casa en Avellaneda. Según reportes periodísticos, el atentado contra el líder metalúrgico se lo adjudicó un comando conjunto de las organizaciones armadas Montoneros y Descamisados. ${ }^{128}$

Finalmente, ante la gravedad de los hechos consumados y la profundidad de la crisis en el justicialismo bonaerense, Luis Guerrero decidió bajarse de la candidatura a vice, con lo cual también descomprimía la situación de su gremio y la cúpula sindical, dejándolas en libertad de acción para sostener o no la fórmula encabezada por Anchorena. A cambio de esta medida -que allanaba el camino para lograr un consenso en torno a la candidatura de Bidegain- luego de una reunión entre Abal Medina y Lorenzo Miguel se dispuso como acuerdo transaccional la inclusión de Victorio Calabró como vice en la fórmula a la gobernación, y el cupo de $25 \%$ de los cargos para el sector gremial en las listas de candidatos a diputados y senadores. ${ }^{129}$

Por otra parte ese mismo día y como cierre final del ya conocido repertorio de tensiones, episodios de violencia y finalmente frágiles "acuerdos" centrados en la verticalidad, se dio a conocer un mensaje de Perón en el que felicitaba a Abal Medina por la manera en que había llevado a cabo las negociaciones entre los diferentes sectores del movimiento y descalificaba al hacendado y líder del Movimiento Federal. ${ }^{130}$

De esta manera, como resultado del peso -aunque no sin fisuras- que aún conservaba la voz del líder justicialista para fijar límites a las acciones de rebeldía de parte de sus

${ }^{127}$ La Opinión, 23/12/72 "La cúspide gremial peronista no acierta a definir su ubicación política". La compleja situación que atravesaba el sindicalismo es interpretada en esta nota como un síntoma de su pérdida de poder dentro del movimiento, en favor del camporismo y los grupos de la Tendencia en esa coyuntura.

${ }^{128}$ La Opinión, 27/12/1972 "Resultó herido de bala por un comando armado el dirigente metalúrgico Luis Guerrero". En el atentado también fue herido un familiar de Guerrero, Roberto Lamy, aunque en ambos casos se trató milagrosamente de heridas leves. Si bien la información periodística no es del todo clara, la mención de un comando perteneciente a Montoneros y Descamisados como artífices del atentado resulta verosímil, dado que hacia esa fecha se produce la fusión de ambas organizaciones. Por otra parte es largo y conocido el historial de atentados que contra los jefes sindicales llevaron a cabo las organizaciones armadas, siendo el más renombrado hasta ese momento el asesinato del jefe metalúrgico Augusto Timoteo Vandor en junio de 1969, por la organización peronista Ejército Nacional Revolucionario (Gillespie, 1987: 154)

${ }^{129}$ La Opinión, 28/12/1972 “Acuerdo entre Lorenzo Miguel y Abal Medina”.

${ }^{130}$ La Opinión, 28/12/1972 “Acuerdo entre Lorenzo Miguel y Abal Medina”. 
seguidores, Anchorena y Guerrero presentaron el 2 de enero, día en que vencía la presentación de listas, la renuncia formal a sus candidaturas, subrayando que tomaban dicha medida "en absoluta obediencia a las claras decisiones del General Juan Domingo Perón” y en respuesta a "aquellos eternos traficantes de la baja politiquería en su mezquina intención de colocarnos al margen de una absoluta obediencia a la verticalidad". ${ }^{131}$ Así, sobre el filo del cierre, logró presentarse por el FREJULI la fórmula Bidegain-Calabró como candidatos a gobernador y vice por Buenos Aires.

Por último, y como corolario final de la dimisión aunque no separación total del grupo anchorenista dentro del justicialismo bonaerense, varios hombres de sus filas fueron incorporados a último momento en las listas, ${ }^{132}$ prefigurando un complejo y conflictivo escenario -dadas las contradicciones y actos de violencia que marcaron la internarespecto del apoyo que el sindicalismo brindaría a la futura gestión de Bidegain, quien como veremos a continuación, se recostará cada vez más en los grupos de la Tendencia.

\subsection{La campaña del FREJULI en el verano de 1973 y el lugar de la Tendencia en el triunfo electoral. Tensiones y debates frente al trabajo político partidario.}

Como observamos en los apartados previos, la consagración de Héctor Cámpora como candidato a la presidencia por el FREJULI selló definitivamente la relación de cercanía y apoyo mutuo entre aquél y los jóvenes de la Tendencia. La proximidad creciente que se venía gestando entre ambos desde mediados de 1972 tuvo su expresión final en el voto favorable que los delegados por la JP nucleada en Montoneros le dieron al ex delegado de Perón en el Congreso Partidario, ${ }^{133}$ y también a través de la nueva y emblemática

\footnotetext{
${ }^{131}$ El Día, 3/01/1973 “Tras renunciar Anchorena y Guerrero, se proclamó ayer a O. Bidegain y V. Calabró” ${ }^{132}$ La Nación 3/1/1973 "Resolvieron renunciar Anchorena y Guerrero". Por otro lado, es importante mencionar que más allá de la resolución política del conflicto expresada en la presentación formal de las listas, las desavenencias continuaron por el carril de la justicia electoral a través de las impugnaciones que llevaron adelante partidarios del anchorenismo no conformes con las listas finales elevadas, de lo cual resultó que el FREJULI no pudo presentar candidatos a nivel municipal en 20 distritos de la provincia. El Día, 19/01/1973 "En 20 distritos no fueron oficializadas las listas del FREJULI" y Antúnez (2015:63). Los partidos beneficiados por la ausencia de candidatos del FREJULI en los municipios fueron: partidos vecinales, la UCR, la UCRI y el Partido Conservador.

${ }^{133}$ Nota de Miguel Bonasso en La Opinión, 17/12/72 "Brindaron su apoyo a la nominación del delegado de Perón los núcleos juveniles radicalizados".
} 
consigna levantada por los jóvenes "Cámpora al gobierno, Perón al poder" que se convirtió rápidamente en el slogan que dominó la campaña electoral. ${ }^{134}$

Esta apelación de la Tendencia a favor de las elecciones y del candidato del Consejo Superior ha sido interpretada por algunos autores como un viraje o contradicción respecto de las posiciones y consignas "más revolucionarias y guerreras" sostenidas hasta ese momento (Bartoletti, 2011:63) ejemplificadas en diferentes comunicados de representantes de la JP por esos meses. ${ }^{135}$

Sin embargo, al analizar algunos tramos del Documento de la Juventud Peronista donde se anuncia formalmente la intervención en los comicios, lejos de notar una contradicción o un viraje inexplicable, observamos que se califica dicha apuesta como una "participación crítica", subyaciendo los planteamientos estratégicos y la consideración de las elecciones como una "trampa" y un "proceso viciado" -que significan en realidad un paso previo para otra cosa mayor. Así, en uno de sus pasajes se señala como "principales objetivos políticos y estratégicos el logro de la liberación nacional y la construcción del socialismo nacional mediante la estrategia de la guerra integral”. Más adelante se caracteriza la candidatura de Cámpora como "una fiel garantía [de lealtad] para este proyecto coyuntural" y aclaran que "si bien haremos todo lo que esté a nuestro alcance para obtener el gobierno, sabemos que la cosa no termina ahi”. Por último, califican al proceso electoral como "fraudulento" pero anuncian que participarán del mismo "sin perder de vista sus postulados estratégicos” designando en el $25 \%$ de los cargos a "candidatos leales a Perón". ${ }^{136}$

\footnotetext{
134““Cámpora al gobierno, Perón al poder” Documento de la JP-Montoneros, La Opinión, 21/12/1972; "La Juventud Peronista apoya al Comando Superior" comunicado firmado por la JP de La Plata, Berisso y Ensenada, MRP, Agrupación Cogorno y FURN, El Argentino 19/12/72.

135 Además de los dichos de Galimberti citados previamente en este capítulo, se toma como ejemplo la siguiente declaración de Ernesto Juretche "La JP tiene que constituir una organización que contribuya a fabricar el paraguas de masas bajo el cual las organizaciones que ocupan la primera línea de fuego en la lucha puedan movilizarse como pez en el agua" (Bartoletti, 2011:63)

${ }^{136}$ La Opinión, 21/12/1972 "Nuevo lema de la Juventud Peronista: Cámpora al gobierno, Perón al poder". En el mismo sentido, una idea presente en las solicitadas y documentos de los grupos de la Tendencia durante la campaña electoral es la reafirmación de una doble temporalidad y metodología, acorde a las diferentes etapas de la lucha política: "En la primera semana de febrero sigue habiendo objetivos estratégicos, y también una coyuntura fundamental en lo inmediato: las elecciones. Las elecciones son una táctica del régimen, pero esa táctica le ha sido arrancada por la lucha popular en todas sus formas. Las elecciones son fraudulentas y para el peronismo se efectúan en las peores condiciones...Pero de todos modos es importante, porque la sola perspectiva del triunfo del FreJuLi altera el equilibrio del régimen y pone al peronismo al borde de una experiencia triunfal...cada vez más se avizoran las condiciones para pasar de la etapa de la resistencia cívica a formas de ofensiva. Este pasaje solo será posible con la participación de masas, que debe lograrse a partir de la inserción de la tendencia revolucionaria en su seno”. Editorial, Antropología del 3er Mundo, n 12. Feb/Marzo, 1973 (Baschetti, 1997: 509). Ver también
} 
Asimismo, la persistencia de postulados revolucionarios y de consideraciones que implicaban la continuidad de la lucha armada, aún en el marco del activismo electoral y de la fuerte presencia de la Tendencia en el devenir exitoso de la campaña, será una constante de todo este período (Lenci, 1999; González Canosa, 2018). ${ }^{137}$

Con todo, a nivel de las prácticas que emprenden en esta coyuntura algunos grupos de la Tendencia, cabe destacar la importancia que comienzan a tener para algunos de ellos la ocupación efectiva de lugares en las listas y de cargos en el gobierno. Este compromiso que no es sólo "nominal" sino que -como veremos ejemplificado en el caso bonaerenseinvolucra acciones políticas de organización, movilización y negociación con las restantes fracciones del partido dentro de una lógica institucional, permite comprender ciertos sentidos y expectativas respecto a su futura "militancia en el Estado" ligada a un horizonte de transformación bajo un programa popular y revolucionario.

\begin{abstract}
"Nosotros luchábamos por la liberación y el sistema era el socialismo nacional, ya en el 64 antes de la FURN pensábamos que la salida era la lucha armada y nos preparábamos muy a largo plazo, sabíamos que era necesario el predicamento, crear conciencia, y cuando se acelera el momento había grupos que querían volcar todo al trabajo militar, uno no renegaba de lo militar, pero quería hacer trabajo político de superficie. Habíamos elaborado un documento, Bases para la nueva universidad, que era un proyecto para abrir la universidad al pueblo" ${ }^{138}$
\end{abstract}

En la misma dirección, y tal como deslizaba el documento citado más arriba, el apoyo "crítico" a las elecciones iba acompañado también de la idea de que la ocupación efectiva

\footnotetext{
“Compañero del FREJULI”- Documento de la JP, Febrero de 1973, en el sitio digital El Topo Blindado, y "Documento y Programa. Montoneros", 24 de Febrero de 1973, donde se define al "gobierno popular como una etapa en el desarrollo de la guerra integral" lo que significa que "tanto el sostenimiento del gobierno como la toma definitiva del poder, sólo se garantizará con la constitución del poder militar propio, con el pueblo armado en milicias peronistas, que formarán parte del ejército peronista, cuyos primeros destacamentos son las actuales organizaciones armadas"(Baschetti, 1997: 525)

${ }^{137}$ Para ejemplificar la continuidad discursiva de estos posicionamientos estratégicos e incluso la radicalización de las consignas de campaña, ver "Reportaje a Rodolfo Galimberti. Consejo Superior de la JP” Enero de 1973, donde explica la síntesis de la consigna "Cámpora al gobierno, Perón al poder": "Nosotros diferenciamos gobierno de poder porque sería insensato suponer que las clases dominantes entregarían el poder al pueblo trabajador...tenemos conciencia de que la victoria en las elecciones y la entrega del gobierno no suponen que el poder del estado vaya a ser detentado plenamente por el movimiento popular. La clave de la toma del poder en toda revolución es la síntesis entre las masas y las armas". (Baschetti, 1997:531). En Lenci (1999:185) hay una descripción de los cánticos y consignas a favor del accionar de la guerrilla que se entonaban en los actos de campaña. También ver "Con el Frente al gobierno, con el ejército peronista al poder" Documento de las FAR, previo a las elecciones del 11 de marzo de 1973 (Baschetti, 1997:513). Asimismo, Montoneros y FAR dan a conocer un comunicado conjunto fechado días antes de asumir el nuevo gobierno peronista donde diferencian Gobierno de Poder y plantean como objetivos "la continuación de la formación del ejército peronista, único instrumento capaz de lograr la obtención definitiva de una Argentina Libre, Justa y Soberana, una Patria Socialista”, en El Descamisado, $\mathrm{n}^{\circ} 2,29$ de mayo de 1973 . Consideraciones muy similares se expresan a lo largo del Boletín Interno $n^{\circ} 1$. Montoneros de mayo de 1973(Baschetti, 1997:568).

${ }^{138}$ Entrevista de la autora a Hugo Bacci, La Plata (2012)
} 
de lugares en las listas, en un $25 \%$, actuaría como un "reaseguro" de la política revolucionaria que llevarían a cabo los dirigentes de la JP, inclinando la línea del gobierno en ese sentido y frustrando así los intentos de "integración en el sistema" llevados a cabo por los sectores más reaccionarios y burocráticos del Movimiento.

"Yo era UBC, comencé como UBR y seguí como UBC, como combatiente, no veía mal que el peronismo se presentara a elecciones con Cámpora. Hubo discusiones, lo discutimos con los compañeros que eran más cerrados, más duros, porque era una cosa bastante complicada, si sí, si no, pero yo nunca tuve contradicciones con eso, visto desde el peronismo y desde el movimiento nacional, era un instrumento más de acumulación política, eso yo lo tenía clarísimo. No había que desestimar esa posibilidad... no me hacía ruido el tema de la democracia, porque nosotros teníamos siempre la idea de profundizar, de ir, avanzar, más no nos identificábamos con una democracia liberal para nada, sino como un proceso de avanzar en un programa de justicia social, al socialismo desde el peronismo, porque para nosotros el peronismo era una revolución inconclusa, por eso quisimos ir al gobierno"”, 39

Lo cierto que si para algunos/as militantes la aceleración del proceso electoral implicaba necesariamente la discusión -y la aceptación- de participar directamente en lugares institucionales, sin generar mayores contradicciones o dilemas en tanto prolongación de su militancia revolucionaria en el peronismo, esto no fue asimilado de la misma manera por muchos otros militantes de la Tendencia, incluso por quienes ocupaban lugares de conducción al frente de las organizaciones armadas.

En un pasaje de su libro testimonial, Roberto Perdía, al mismo tiempo que realiza una mirada retrospectiva y autocrítica de la forma efectiva en que se plasmó esta decisión, menciona algunas de las causas que explicarían los límites en la comprensión de esa apuesta institucional por parte de la organización armada en aquella coyuntura:

"Para los cargos electivos, el mismo Perón había planteado que el 25\% de los mismos perteneciera a la JP. Nosotros no supimos ocupar ese porcentaje. Múltiples son las razones por la que no lo hicimos. Habíamos construido nuestra propia fuerza en la resistencia. Hasta hace un año antes la perspectiva electoral no entraba en nuestros planes. Teníamos desconocimiento y desconfianza hacia las estructuras e instituciones de la democracia. Desde el punto de vista ideológico, desvalorizábamos la ocupación de espacios en el aparato institucional. Esto hizo que no volcáramos todo el esfuerzo suficiente en esa dirección. Tampoco quisimos que los compañeros de primera línea de la organización ocuparan cargos...en este sentido había posiciones distintas...otros compañeros optaban por no asumir responsabilidades en el Estado. Sostenian que por su propio carácter había que enfrentarlo hasta crear las condiciones para el nuevo estado revolucionario, por ello preferían mantenerse alejados del mismo...Después

${ }^{139}$ Entrevista de la autora a Mabel Maidana, La Plata (2014). Comenzó su militancia armada en el GEL y de allí pasó a Montoneros en el año 1971. Formó parte del armado inicial de la columna sur de Montoneros en La Plata. Ocupó el cargo de Asesora en el Ministerio de Bienestar Social a cargo de Floreal Ferrara durante el gobierno de Bidegain. Finalmente, a principios de 1974, por diferencias políticas con Montoneros, en particular con los responsables de su zona, se integra a JP Lealtad. 
cuando nos dimos cuenta, quisimos ocupar esos espacios para ejecutar aspectos de nuestro proyecto, pero ya no pudimos". ${ }^{140}$

En la misma línea, pero dentro de un registro más coloquial y a modo de anécdota, Carlos Dante Gullo repone en el siguiente pasaje del libro de Amorín (2007) algunos elementos de la subjetividad política construida por estos jóvenes en aquella época, en la que la imagen asociada a la militancia revolucionaria se alejaba notablemente de los ámbitos de la política "formal" y de "saco y corbata":

"Lo mejor que le podía pasar a un joven era ser militante. Entonces, entre estar militando en la villa, en los barrios, en las columnas o un cargo de diputado, se elegía sin dudar lo primero. Al compañero que se le ofrecía un cargo era como una ofensa...porque todavía no habíamos hecho una síntesis entre lo que era el partido y nuestra práctica como movimiento. El movimiento nos brindaba la posibilidad de estar con la gente en cualquier lugar. Era una tarea de militancia, noble, desinteresada. Lo otro era como de repente te obligan a ponerte corbata, a vestirte de funcionario. Una anécdota: se estaban discutiendo los cargos y le pido a un compañero, Pietragala, que vaya a las reuniones y pelee el $25 \%$ de los cargos que le correspondían a la JP. Aceptó a regañadientes, pero, en lugar de ir a discutir los cargos en el partido, se iba a militar a los barrios. Entonces los otros sectores interpretaron que la juventud no concurría como forma de presionar por más cargos. A la semana me vienen a ver. 'Nos entregamos '...si quieren más cargos estamos dispuestos a darles el 25\% y algunos cargos más. Yo me decía, en qué problemas nos ponen estos tipos, si apenas podemos cubrir el 25\%"141

Si por todas estas razones la militancia institucional no era lo más alentado por la conducción de Montoneros y FAR, no obstante, cabe señalar también que durante esos dos meses (diciembre-enero), la mayor parte de las energías estuvieron dedicadas a la organización de la movilización popular en el marco de la campaña electoral del FREJULI, donde la Tendencia se jugaba nuevamente la posibilidad de afirmar, frente a su

\footnotetext{
${ }^{140}$ Perdía (1997:126). En el mismo sentido, Vaca Narvaja repone "Vos podes llegar al gobierno pero no tener el poder. Fuimos educados en esa concepción y no sólo teóricamente, sino que la experiencia política del peronismo mostraba eso, tuvo el gobierno pero hubo otro poder que lo derrocó sangrientamente. Eso trajo como consecuencia la existencia de una organización política-militar en una etapa democrática y, por lo tanto, una ambivalencia... Un ejemplo: los cuadros de conducción de la organización no entraron como jefes de ningún frente de masas, ni fueron diputados nacionales, ni candidatos. Montoneros mantuvo su conducción al margen de las estructuras institucionales de gobierno. Había una diferencia de gobierno y poder. Éramos conscientes de que se había ganado una batalla, se había dado un paso pero no el definitivo" (Vaca Narvaja- Frugoni, 2002:90). Similares consideraciones también en la biografía de Mario Firmenich (Celescia-Waisberg, 2010:134)

${ }^{141}$ Amorín (2007:297). Expresiones similares se encuentran en las voces de algunos militantes de JP/FURN volcadas en el libro Setentistas (Amato-Boyanosvsky, 2008:160) y en la nota de Nicolás Casullo para $L a$ Opinión, 28/4/73. En ese artículo, el periodista realizaba un análisis del papel preponderante de los grupos de la Tendencia Revolucionaria en la coyuntura electoral, señalando "como un acierto de la JP el apoyo brindado al regreso de Perón, basado en el lema "Luche y Vuelve”, y el aval a la candidatura del Dr. Cámpora. Como errores, quizás el más importante, haya sido la política de no afiliación al Partido, lo que condujo a que la JP no tuviera casi gravitación en la conformación de las listas electorales, cuando quiso finalmente integrarlas".
} 
oponente político interno (el sindicalismo) un lugar preponderante dentro del Movimiento, a la vez que frustrar las aspiraciones proscriptivas del régimen militar.

Así, la decisión de la Tendencia a favor de la participación electoral no se tradujo inmediatamente en la ocupación del $25 \%$ de los cargos en las listas de candidatos del FREJULI, ni en los cargos ejecutivos dentro del gobierno. Si en ese resultado pesó la inclinación de algunos dirigentes de las organizaciones armadas de considerar la actividad política legal como una práctica de menor importancia, también coadyuvó en ésto la oposición y el profundo rechazo -bajo formas violentas- de otros sectores del Movimiento.

En realidad, como veremos a continuación, las candidaturas y cargos de gestión obtenidos por la Tendencia fueron fruto de arduas negociaciones y competencias que debieron librar sus militantes contra las aspiraciones del sindicalismo y la desconfianza de algunas figuras del peronismo tradicional.

Al respecto, en la provincia de Buenos Aires las tensiones observadas durante el proceso de designación de candidaturas se replicaron en el transcurso de la campaña electoral en el verano de 1973. Sin embargo, en ese marco, la tenaz resistencia demostrada por los grupos de la derecha político-sindical del Movimiento contra Bidegain, actuó como un aglutinante entre éste y los militantes de la Tendencia.

En efecto, más allá del apoyo inicial que éstos brindaron a Bidegain en el Congreso provincial partidario -por ser el candidato avalado explícitamente por Perón y Cámporafue en realidad en el transcurso de la campaña electoral cuando se construyó un vínculo político entre ambos, dando como resultado un claro alineamiento de fuerzas entre el futuro gobernador y los jóvenes de la Tendencia.

En este sentido, varias circunstancias y/o motivaciones fueron las que determinaron este acercamiento. Por un lado, tal como señala Manuel Urriza (2004:61), quien ocupó el cargo de Ministro de Gobierno bonaerense desde agosto de 1973, Perón había planeado que fuera la provincia de Buenos Aires el lugar privilegiado donde se llevaría a cabo su famoso proyecto de "trasvasamiento generacional". Esta idea, presentada por el líder durante sus años de exilio en varios mensajes dedicados a la juventud, planteaba que dentro de las filas del peronismo debía darse "un cambio generacional para evitar el 
envejecimiento de su espíritu”. ${ }^{142}$ En la práctica, esto significaba la renovación paulatina de los cuadros dirigentes a manos de la juventud, con el fin de mantener la actualización del Movimiento (Pozzoni, 2017). Según Urriza, Perón le habría dado expresas indicaciones a Bidegain de acercarse a los jóvenes para llevar a cabo esta "prueba piloto" durante su administración (p. 62).

Por otra parte, y desde una dimensión más personal y afectiva pero no exenta de implicancias políticas, debemos mencionar que el círculo íntimo de Bidegain -sus dos hijas y uno de sus yernos- militaban por aquel entonces en la organización Montoneros. ${ }^{143}$

Desde una dimensión política y pragmática, está el hecho de que la cercanía a los jóvenes de la Tendencia le permitía a Bidegain contar con una base de apoyo propia, sobre todo en el marco de la campaña electoral donde se destacaba la fuerte presencia y movilización del aparato sindical en los actos a favor del vice gobernador Victorio Calabró (Nava, 2008; Bonavena, 2009:163). ${ }^{144}$

La misma percepción de la "soledad" del candidato a gobernador, es decir, la falta de una estructura propia a movilizar que apoyara su candidatura y actuara de contrapeso de la del sindicalismo, se encuentra presente en los relatos de los ex militantes de la Tendencia, actuando como una de las motivaciones que incidieron en la búsqueda de vínculos con el dirigente (Antúnez, 2015:89). Esta situación, resultaba una oportunidad valiosísima para acercarle el apoyo de la JP-FURN/Montoneros y lograr de esa manera una inserción directa en futuros cargos de la administración provincial. ${ }^{145}$

${ }^{142}$ Ver Mensaje de Perón "A los compañeros de la juventud”, 23 de febrero de 1971 (Baschetti, 2004, p. 137)

${ }^{143}$ Sus dos hijas, Gloria y Cristina, integraron las filas de la JP-Montoneros y fueron perseguidas por su militancia en el peronismo revolucionario debiendo exiliarse luego del golpe de 1976. Gloria se casó con Daniel Vaca Narvaja, quien militaba en Montoneros y ocupó bajo ese encuadramiento el cargo de Director de la Asesoría Provincial de Desarrollo (ASPRODE) durante la gestión de Oscar Bidegain. Su hermano, Fernando, fue miembro de la Conducción Nacional de Montoneros hasta su disolución. Alejandro Peyrou describe los inicios de la relación con Bidegain por parte de los jóvenes montoneros y la evolución del vínculo político entre ambos: "Yo creo que él era un médico de Azul, prestigioso, de la clase alta de azul, de mentalidad de clase alta de un pueblo, peronista conservador digamos, leal a Peron, se encuentra en ese lugar y Calabró le empieza a patear los tobillos, de paso, Gloria se engancha con Daniel, que era muy importante dentro de la orga, la madre se pone totalmente de acuerdo con la hija, no había tanto ideología primero como sí la cosa personal, después sí, ya en el '76-'77, con el exilio el compromiso de él es total". Entrevista con la autora, CABA (2012)

${ }^{144}$ En líneas generales, los trabajos que estudian los enfrentamientos al interior del peronismo en las denominadas "gobernaciones montoneras", aluden al carácter pragmático de las alianzas, basada en la existencia de afinidades - y necesidades- políticas mutuas, sin implicar ello un vínculo orgánico e ideológico entre la mayor parte de los gobernadores peronistas y el ala izquierda del Movimiento (Servetto, 2010: 201; Antúnez, 2015)

${ }^{145}$ Entrevista de la autora a Hugo Bacci (2012) y testimonio de Carlos Negri, Secretario de la JP de La Plata y Diputado Provincial del FREJULI por la rama juvenil en las elecciones de Marzo de 1973, en Amato- 
El carácter pragmático que se observa del vínculo inicial de los jóvenes de la Tendencia con Bidegain, es ratificado también por las impresiones más personales que los ex dirigentes de JP/FURN recuerdan sobre sus primeros contactos con el futuro gobernador en la instancia preelectoral:

\footnotetext{
"Cuando nos enteramos que va a ser el candidato un grupo de la JP va a reunirse con él dos veces en su casa y le planteábamos nuestras cosas y a veces nos asustaban sus comentarios porque era un nacionalista que hablaba poco de pueblo, digamos...era una buena persona" 146
}

Asimismo, resulta sugestivo el dato que arrojan los diarios de la época sobre la actitud del candidato durante los primeros actos de campaña, quien censuraba los cánticos "subversivos" del público juvenil a favor de las organizaciones armadas y el asesinato de Aramburu, ${ }^{147}$ lo que deja entrever la relativa distancia ideológica que en esta incipiente etapa existía entre el candidato y los jóvenes de la Tendencia. ${ }^{148}$

No obstante, si tomamos en cuenta las tensiones que atraviesan toda la campaña electoral entre la fracción sindical y la juventud radicalizada, agudizadas por el peso del aparato de la CGT/UOM volcado en los actos a favor de Calabró -en una clara señal de presión a Bidegain- y la continuación de importantes hechos de violencia, adquiere entidad la compleja dinámica de enfrentamientos al interior del peronismo que llevaron finalmente al alineamiento político entre el viejo dirigente peronista y los grupos de la Tendencia (Antúnez, 2015).

En relación a la violencia suscitada, cabe mencionar dos episodios notables que dan cuenta del clima beligerante que se vivía durante la campaña electoral en la provincia, entre el ala sindical y la TR.

El primero ocurrió en el mes de enero en Lanús Oeste, donde el candidato a diputado nacional por el FREJULI y Secretario adjunto de la UOM Avellaneda, Julián Moreno, fue baleado -falleciendo en el acto- por un comando revolucionario peronista, quien en su comunicado lo sindicaba como continuador de la línea de Vandor, Alonso, Coria y

Bazán (2008, p. 193). Ambos dirigentes de JP/FURN destacan el papel que jugó la esposa de Bidegain, Antonia "Tony" Moro, en efectivizar esa alianza.

${ }^{146}$ Entrevista de la autora a Hugo Bacci (2012).

${ }^{147}$ El Día, 27/1/1973 "Censuró Bidegain a jóvenes que cantaban estribillos subversivos"

${ }^{148}$ En esta dirección, cabe agregar también el dato de Bonavena (2009, p. 185) quien señala que durante los actos de campaña, Bidegain citaba una frase de Mussolini: "Si avanzo, seguidme; si retrocedo, empujadme; si os traiciono, matadme; si muero, vengadme". La mención a Mussolini en los actos de campaña también fue ratificada en la entrevista a Hugo Bacci. 
Rucci. ${ }^{149}$ El segundo hecho sucedió el 13 de febrero en la localidad de Chivilcoy, en un acto de campaña en el que estuvieron presentes como oradores Rucci y Calabró. Según el relato del diario, al finalizar el evento, se desencadenó un tiroteo entre grupos de la JP y los custodios de Rucci y de otros dirigentes metalúrgicos. En la balacera, resultó herido de muerte el secretario personal y chofer del dirigente cegetista, Luis Bianculli (Graham Yool, 1989:247). ${ }^{150}$

Dicho esto, lo que en un principio se explicaría como una alianza táctica entre Bidegain y la juventud en base a la necesidad mutua de contrarrestar el notable poder del sector sindical en la provincia, con el correr de la campaña -y más aún después de las elecciones- comienza a visualizarse como la gestación de un vínculo más perdurable.

Al respecto, el 27 de febrero en la ciudad de La Plata se llevó a cabo un importante acto de campaña del FREJULI del que participaron Cámpora, Solano Lima y Bidegain. El mismo fue organizado por la JP local, asistiendo aproximadamente 40.000 personas, en su gran mayoría jóvenes de las diferentes agrupaciones de la Tendencia, quienes bajo el cartel de "FAR y Montoneros" sellaron el apoyo y la cercanía con el candidato de Perón en la provincia. ${ }^{151}$

Asimismo, a los pocos días del triunfo electoral del 11 de marzo y como muestra de una mayor afinidad y compromiso en la relación, Bidegain asistió en La Plata a la inauguración de la Casa de la Provincia de la JP, destacándose el mensaje radicalizado de los oradores y su eco en las palabras del gobernador electo. Allí, uno de los militantes de la JP en tomar la palabra fue Carlos Cafferata, quien exhortó a mantener como consigna "la movilización y la lucha para la defensa del triunfo y la construcción del socialismo nacional. Organizaremos el gran ejército del pueblo para la reconstrucción nacional y esto no es una frase sino la convocatoria militante de la juventud". ${ }^{152}$

Luego de las encendidas palabras del delegado de la JP Regional n³ de Córdoba, quien hizo referencia a la extendida consigna de "convertir cada casa y cada barrio peronista en un fortín montonero", habló finalmente Bidegain suscribiendo los dichos de sus antecesores y adelantando aspectos de su futuro gobierno "nos cabe el honor de ser los ejecutores leales y fieles de Juan Perón. Y lo que el pueblo quiere es lo que ustedes

${ }^{149} \mathrm{El} \mathrm{Día,} \mathrm{23/1/1973} \mathrm{"Un} \mathrm{dirigente} \mathrm{gremial} \mathrm{y} \mathrm{candidato} \mathrm{a} \mathrm{diputado} \mathrm{por} \mathrm{el} \mathrm{justicialismo} \mathrm{fue} \mathrm{asesinado} \mathrm{junto} \mathrm{a}$ su chofer". En el episodio también fue herido de bala su chofer, Deheza, quien previamente había sido chofer del dirigente metalúrgico Timoteo Vandor. Julián Moreno había reemplazado a Luis Guerrero en la Secretaria General de la UOM Avellaneda

${ }^{150}$ El Día, 15/2/1973 "Trágico tiroteo luego de un acto justicialista donde habló Rucci".

${ }^{151}$ El Día, 28/2/1973 "El acto de proclamación del FREJULI en La Plata".

${ }^{152}$ El Día 19/3/1973. Mesa "A", Partidos políticos, carpeta 37, legajo n ${ }^{\circ} 271$, JP La Plata- Archivo ex DIPBA/Comisión Provincial por la Memoria. Ver también Nava (2008). 
corean: quiere que la economía esté al servicio social y que vayamos al Estado social, es decir al socialismo nacional". ${ }^{153}$

Sin dejar de lado las diferencias de fondo que pudieran existir con las organizaciones armadas peronistas en torno al significado que cada uno entendía sobre el denominado "socialismo nacional", resulta interesante la incorporación en el discurso del gobernador de esta consigna, señal de una progresiva radicalización en sus dichos y de una más firme alianza política con los jóvenes de la Tendencia.

Finalmente, terminada la etapa de las candidaturas y la campaña electoral, el 11 de marzo de 1973 las elecciones tuvieron lugar, arrojando como resultado un contundente triunfo del FREJULI a nivel nacional y provincial. ${ }^{154}$ Así, el cierre del ciclo histórico de proscripción del peronismo que había comenzado dieciocho años atrás, daba inicio a una etapa de "primavera" para los sectores radicalizados de la juventud peronista, quienes veían próximos sus anhelos de "liberación nacional y social".

Más allá de esta algarabía y sentir triunfalista que condensó la experiencia del momento, los interrogantes que en esta nueva etapa de gobierno se abrían para la Tendencia Revolucionaria eran muchos:

¿Cómo continuaría el proceso de "lucha integral" ahora que el escenario político había cambiado drásticamente y enfrente no estaba el poder militar sino un gobierno peronista que los reconocía como partícipes fundamentales de ese acontecer y les otorgaba un lugar destacado en la estructura gubernamental? ¿Qué pasaría con las acciones armadas y la estructura militar de las "formaciones especiales" una vez que el nuevo gobierno legitimado por el voto popular asumiera el poder? ¿Acaso los militantes de la Tendencia consideraban que habían llegado ellos también al poder, al menos al institucional, y que ese poder se podía ejercer desde el Estado para encarar la reconstrucción y el socialismo nacional? ¿O primaba la idea de que sólo a través “del poder que surge de la boca de un

153 Ibid.

${ }^{154}$ Con un total de 5.982.100 votos la fórmula presidencial del FREJULI alcanzó el 49,58\% del total de votos emitidos. Si bien estos porcentajes no superaban el 50\%, lo que marcaba la necesidad realizar una segunda vuelta, la UCR con la fórmula Balbín-Gamond quedó en segundo lugar (2.584.257 votos, 21,5\% del escrutinio total) decidiendo retirarse del ballotage. Como tercera fuerza, la fórmula Manrique -Martínez Raymonda de la Alianza Popular Federalista obtuvo 1.797.139 votos (14.9\%), luego se ubicaron en cuarto lugar la Alianza Popular Revolucionaria de Alende-Sueldo, y en quinto lugar la Alianza Republicana Federal de Martínez-Bravo. La Opinión, 13/3/73 y 30/3/73. En la provincia de Buenos Aires, la fórmula del FREJULI encabezada por Bidegain-Calabró obtuvo 2.328.213 votos, representando el 50,94 \% del escrutinio total, lo que descartaba también la posibilidad de ballotage. En segundo lugar, se ubicó la UCR con la fórmula García Puente- Vaccarezza, con un total de 939.070 votos (19, 71\%). Asimismo en ambas Cámaras el FREJULI alcanzó la mayoría, al obtener 57 bancas en Diputados, de un total de 92, y 30 en Senadores, de un total de 46. También el FREJULI ganó en 78 de las 121 comunas de la provincia. Datos extraídos de El Día, 13/3/1973 y 30/3/73. Ver Ferrari-Pozzoni (2009) 
fusil" se podría llevar a cabo la real transformación económica y social? Si el peronismo, por su base social -tal como señalaba Montoneros-, era la única fuerza política que podía encarar la liberación nacional y el socialismo, ¿sería posible encarar ese proyecto mediante las elecciones o sólo podía hacerse a través de una revolución armada? ¿qué otros sentidos sobre la "revolución" y la "democracia" comenzaban a ponerse en juego en esa coyuntura?

¿Qué lugar, en ese presente de lucha, le otorgarían a la actividad en el Estado los militantes de la Tendencia que ocuparon cargos en la gobernación de Bidegain? ¿Cómo articularon esas prácticas institucionales con los posicionamientos más estratégicos de Montoneros?

Como veremos en el próximo capítulo, una vez que accedieron al gobierno, las diferentes percepciones respecto de estas cuestiones (prioridad a la lucha política legal o a la lucha política armada) comenzaron a provocar tensiones al interior de la Tendencia, toda vez que para muchos de los y las militantes que ocuparon cargos en el gobierno provincial, las prácticas armadas dejaron de tener prioridad en sus horizontes de expectativas como herramientas útiles y unívocas de transformación, mientras que para otros actores de la Tendencia, aquéllas seguirían siendo la vía principal de acción revolucionaria.

Esta tensión que recorrió la experiencia gubernamental de la Tendencia en la provincia de Buenos Aires dado el lugar preponderante que obtuvieron sus militantes en espacios de gestión, se vio potenciada notablemente ante la resistencia y hechos de violencia ejercidos en su contra por los sectores de la burocracia sindical y política del Movimiento. Por último, a esta disputa habrá que sumar también las fricciones que las metodologías de acción directa y gestión estatal encabezadas por los/las funcionarios/as de la Tendencia despertaron en el líder justicialista, una vez que éste retornó definitivamente al país el 20 de junio de 1973 y asumió en persona la conducción de un gobierno con objetivos políticos muy disímiles a los de la "patria socialista". 


\section{CAPÍTULO III: DE LA RESISTENCIA ARMADA AL DESEMPEÑO INSTITUCIONAL La llegada de la TR a la gobernación provincial}

\subsection{Entre la revolución y la institucionalización: la Tendencia en el gobierno}

Pasada la euforia por el triunfo electoral, los dos meses y medio que transcurren entre las elecciones del 11 de marzo y la asunción del gobierno el 25 de mayo de 1973 constituyen un periodo con una temporalidad propia. En ese corto y vertiginoso espacio de tiempo de apenas 44 días se desarrollaron algunos episodios claves para la TR y su relación con los principales dirigentes del Movimiento Peronista (Perón, Cámpora y Bidegain).

Una dimensión para abordar en el contexto postelectoral es la que refiere a la recuperación del poder del Estado a través de los mecanismos institucionales de la democracia "formal", hecho que obligaba a las organizaciones armadas a realizar ciertos y urgentes- reacomodamientos respecto de su aspiración a conformar una vanguardia armada.

Estas redefiniciones promovidas especialmente por Perón, veremos a continuación, despertaron reacciones dispares entre los grupos de la TR, siendo para algunos un desafío y una oportunidad, a la vez que para otros implicó una notable distancia respecto de sus planes estratégicos y expectativas de conducción política, hecho que tuvo consecuencias directas en el temprano desgaste del vínculo con el líder justicialista.

El siguiente testimonio de Alcira Argumedo, militante de Montoneros y funcionaria del gobierno de Bidegain que luego rompe con la organización político-militar, clarifica estas discusiones que se dieron en el momento mismo de la transición electoral:

"El tema era si había que seguir con la lucha armada, con una politica armada de cuadros, o si era el momento de replegarse y hacer una política de masas. Fue un gran debate que empieza justo en el momento en que las distintas organizaciones se están uniendo, Descamisados con Montoneros y después las FAR con Montoneros. Creo que la pregunta clave era ésa ¿eran formaciones especiales que ya habian cumplido su misión, acabar con la proscripción de la política de masas; o era lógico continuar profundizando o radicalizando la lucha? Lo cual tenía que ver con el papel de Perón ... Mi posición era: 'Ya está, se acabó, no es más legítimo; ahora organización politica de masas' porque pasan a ser protagonistas los sectores populares que tuvieron un papel histórico muy importante en toda la resistencia, aunque en los últimos tiempos parecía que la lucha armada había sido central",155

${ }^{155}$ Entrevista a Alcira Argumedo, CABA, 2008, cedida por Alejandro Peyrou. Alcira Argumedo comenzó su militancia universitaria en el año 1964 en la Tendencia Antiimperialista Universitaria (TAU) de la UBA, posicionada entre la izquierda no vinculada al Partido Comunista y el peronismo. En 1966 fue expulsada de 
Este fue el momento en el que comenzaron a hacerse visibles algunas discusiones centrales sobre el poder y el origen del gobierno y su legitimidad. La tensión que podemos observar entre una concepción revolucionaria más ligada al accionar armado, y otra que hace más hincapié en el peso del trabajo político-institucional con los frentes de masas en la nueva coyuntura política, resultará decisiva para la definición de la continuidad o no de la lucha armada y los alcances del futuro gobierno, problemáticas que tendrán implicancias directas en la marcha de los acontecimientos posteriores.

Al respecto, para algunos integrantes de la TR, el gobierno se había "conquistado" gracias a la lucha revolucionaria encarada bajo diversas formas, en especial, las armadas. (Perdía, 1997; Vaca Narvaja y Frugoni, 2002). Así lo expresa un militante de Montoneros que participó del gobierno provincial y que luego se alejó por diferencias políticas con la organización, quien experimentó de esa manera la victoria en las elecciones:

"Habiamos ganado, pero no era el retorno de Perón. En realidad, a Perón lo habíamos traído nosotros... la mayor parte de las discusiones daban por sentado que la co-dirección era justa. Como después se volcó en las consignas. En una primera fase fue "Cámpora al gobierno, Perón al poder" y luego fue “conducción, conducción, Montoneros y Perón”. La realidad era que se movilizaban decenas de miles de pibes en los barrios y se seguía actuando como si la democracia peronista no existiese. Se seguía operando militarmente” 156

Esa "conquista" debía plasmarse necesariamente en la composición e impronta del nuevo gobierno, al que además de tener que "defender" de los posibles intentos golpistas (recordemos nuevamente la diferencia entre gobierno y poder) debían también "custodiar y controlar de eventuales desviaciones" que impidieran "el cumplimiento de la liberación como etapa de transición hacia la construcción del socialismo nacional". Esto, concretamente para FAR y Montoneros, se lograría sólo a través “del reconocimiento (en el nuevo gobierno) de las estructuras que hagan efectiva la participación de las masas en

la universidad luego de la intervención y se vinculó con la JP de Quilmes, en el barrio Kolinos. Dos años después, con la llegada de Justino O’ Farrell y Gonzalo Cárdenas a la Facultad de Filosofía y Letras de la UBA, reingresó a la universidad y formó parte de las Cátedras Nacionales de la carrera de Sociología, espacio desde el cual se fomentó la incorporación del pensamiento nacional y latinoamericano en los planes de estudio. En 1970 viajó a Madrid donde mantuvo una serie de entrevistas "mano a mano" con Perón. A su regreso, luego de un paso previo por Chile para ver la experiencia de Salvador Allende, se integró a las FAP. Allí transitó el debate interno del grupo, posicionándose en el sector de los “oscuros” y se incorporó a Montoneros, pero sin participar de las acciones armadas. Participó como coordinadora en los Equipos Político - Técnicos (EPT) de la JP y colaboró en la redacción del primer número de El Descamisado (de mayo de 1973), pero desistió de seguir en la revista por no compartir la voluntad de seguir con la lucha armada expresada en sus páginas. Entre agosto de 1973 y enero de 1974 se deseempeñó como Subsecretaria de Cultura en la provincia de Buenos Aires, y se integró a la JP Lealtad luego del asalto del ERP al cuartel militar en Azul. Datos extraídos de la entrevista citada y de Pozzoni (2014:296).

${ }^{156}$ Entrevista a Leopoldo Halperín, CABA, 2008. Cedida por Alejandro Peyrou. 
la resolución de los conflictos nacionales, provinciales y municipales...y por medio de las organizaciones politico-militares. ${ }^{157}$

Debemos señalar que declaraciones como éstas, en las que se expresaba de manera contundente la necesidad de controlar al gobierno con "el pueblo organizado" y la presencia activa de las organizaciones armadas, a través de "la continuidad de la estrategia de la guerra integral... y de las medidas punitivas que establezca la justicia popular", eran publicadas en medios de tirada masiva como El Descamisado, ${ }^{158}$ y no solo en documentos internos de reducido alcance. ${ }^{159}$

Por el contrario, para Perón y muchos otros actores del campo político, lo definitorio en la legitimidad del nuevo gobierno pasaba por el voto mayoritario y la elección popular, más allá de las acciones revolucionarias alentadas en el pasado. ${ }^{160}$ Esta definición implicaba la anulación de las metodologías de acción revolucionaria en la nueva etapa, junto a la afirmación de su rol como único conductor del Movimiento.

En este punto, vale la pena mencionar los efectos que en las observaciones de Perón tuvieron la distancia geográfica y temporal producto de sus largos años de exilio; alejamiento que, como señalan varios autores, habría minado su capacidad para dimensionar la profundidad de los cambios sociales, políticos y culturales que se habían desarrollado en el país durante estos intensos años. En particular, el fenómeno de creciente radicalización y autonomía de la juventud inscripta en organizaciones armadas. Todo lo cual derivó en que, a su vuelta, creyera que solamente con su presencia en el país bastaría para sintetizar la compleja heterogeneidad de fuerzas en el peronismo, disipando

${ }^{157}$ FAR y Montoneros “Apoyar, Defender y Controlar" Comunicado del 24/05/1973 ante la asunción de Héctor Cámpora, en Baschetti (1996:49-51)

${ }^{158}$ El semanario El Descamisado, dirigido formalmente por Dardo Cabo, se publicó desde el 22 de mayo de 1973 hasta su clausura el 8 de abril de 1974, y estuvo destinado principalmente a los militantes de base de los diferentes frentes de masas de Montoneros. Alcanzó una tirada de 100.000 ejemplares semanales, con picos de 200.000 que se vendían en todo el país (Gillespie, 1987:161; Grassi, 2015:26)

${ }^{159}$ FAR y Montoneros “Construir el poder popular”, El Descamisado, Año 1, No 4, 12 de junio de 1973, pp.2-4. En este reportaje, Roberto Quieto agregaba respecto de la nueva línea operacional que seguirían las organizaciones armadas en la etapa democrática, la cual pasaba por: "el señalamiento de los enemigos del Pueblo: el imperialismo, las empresas monopólicas, las oligarquías nativas, los gorilas activos, los traidores del Frente y al Movimiento, los restos de la camarilla militar proimperialista y todos aquellos que conspiren contra el cumplimiento del programa de Liberación. A ellos se los combatirá por todos los medios y en todos los terrenos necesarios, por la acción de masas y la acción armada, tanto de masas como de comando".

${ }^{160}$ En varias notas periodísticas que dio Perón por esta época, se destacan el tono conciliador de sus mensajes y su nuevo rol de "pacificador", bajo un espíritu de unidad y el anhelo de "gobernar para todos los argentinos", muy lejos ya de las consignas más radicalizadas de apenas unos meses atrás. Ver "Mensaje de Juan Domingo Perón" La Opinión, 13 de marzo de 1973; "Precisó el líder justicialista los límites del socialismo nacional", La Opinión, 28 de marzo de 1973; "Mensaje de Perón a los candidatos del ballotage", La Opinión, 8 de abril de 1973; "Con sus instrucciones, Perón desea evitar desviaciones en el FREJULI", La Opinión, 22 de abril de 1973. "Perón ratificó la intención de congelar la reorganización del justicialismo", La Opinión, 29 de abril de 1973. 
las tensiones acumuladas entre los diferentes sectores internos. En esta suposición también estaba la idea de que podría integrar a la TR y sus organizaciones armadas como un partícipe más -y no en un rol de conducción- dentro de su proyecto componedor y de alianza de clases. (Svampa, 2003; Godio, 1985; Gillespie, 1987; Di Tella, 1985; Salcedo, 2011; Grimson, 2018)

A esta reconfiguración política del rol de las "formaciones especiales" se sumaba otra cuestión de orden más pragmático -aunque no exenta de definiciones político-ideológicas en su plasmación- que marcó la transición electoral. Nos referimos a la necesidad operativa de constituir los planteles dirigenciales para completar las carteras ministeriales tanto a nivel nacional como provincial. Punto sumamente importante si tenemos en cuenta que se venía de 18 años de suspensión de la actividad partidaria y de gobierno por parte del peronismo, careciendo así de un equipo funcionarial con continuidad en el Estado que viniera trabajando previamente.

En este sentido, desde el inicio de la etapa de apertura política y reorganización partidaria hacia el año 1971, numerosos grupos de profesionales y técnicos del peronismo asumieron la iniciativa de conformar equipos de trabajo con la idea de presentar diferentes proyectos que pudieran servir de base a futuras políticas públicas, en el caso de que el peronismo llegara nuevamente al gobierno. Dentro de esos grupos, y a los fines de nuestro trabajo, nos interesa reseñar dos experiencias en particular que tuvieron un desempeño destacado en la gobernación provincial y cuyos postulados y profesionales se identificaron con la Tendencia.

El primero de ellos es el Consejo Tecnológico del Movimiento Nacional Peronista (CTMNP). El mismo fue fundado a principios de los setenta, a pedido de Perón, por el por el físico, meteorólogo e intelectual de izquierda Rolando García, quien había sido primer vicepresidente del CONICET y decano de la Facultad de Ciencias Exactas y Naturales de la UBA entre 1957 y 1966, y desplazado de ese cargo en el operativo de La Noche de los Bastones Largos. ${ }^{161}$ El grupo, que incluía a reconocidos especialistas y

${ }^{161}$ Ricardo Rubio, quien participó en el área de prensa y difusión del Consejo Tecnológico sostiene que dicha iniciativa fue promovida por Perón desde el inicio: "En el CT fue importantísima la experiencia, porque en general los que son cuadros intelectuales aparecen cuando aparece el poder o la posibilidad del poder, pero acá cuando Rolando comienza no había nada claro de todo eso, el CT es la única propuesta tecnológica formal de Perón, después viene el Comando de Licastro, y los Equipos Político-Técnicos son posteriores, ahi estuvimos también, pero Perón lo llama a Rolando en 1969, nos cuenta Rolando, lo llama a Puerta de Hierro, Rolando va a ver que quiere y Perón le dice que tiene que empezar a armar los equipos de trabajo y programas porque vamos a ser gobierno, cuando todavía Onganía estaba diciendo que no tenía limite de tiempo su gobierno. En el '70 lo llama de vuelta y ahí Rolando empezó a entender que podía ser realidad esa cuestión. Y ahi se empezó". Entrevista de la autora a Ricardo Rubio, San Miguel (2016). Formalmente, el lanzamiento del Consejo Tecnológico se hizo en julio de 1972, más allá de que se 
profesionales de diversas áreas como Industria, Salud, Energía, Transporte y Comunicaciones, Asuntos Agrarios, Vivienda, Economía y Educación, ${ }^{162}$ adoptó un perfil progresista en sus postulados, ligándose directamente a la TR y a sus programas del Socialismo Nacional (Pozzoni, 2017:46; Dip, 2017:124). Las formulaciones de sus proyectos se publicaron en la colección semanal "Bases para un Gobierno Peronista" que salió entre los meses de marzo y julio de 1973, siendo su último número significativamente el del 19 de julio, una semana después de la renuncia de Héctor Cámpora.

En el primer número que sirve de introducción a esta colección, dedicado al sector Industria, se observan los lineamientos de izquierda que conforman el espíritu del grupo y sus proyectos, al señalar la etapa que se iniciaba como "un período de transición revolucionario en la marcha hacia el Socialismo Nacional" cuyas metas principales debían ser "la liberación del hombre oprimido" y "la participación de toda la sociedad en el proceso que conduzca a la construcción del socialismo nacional”. Al respecto, el sentido estricto que este grupo le asignaba a ese lema apuntaba directamente a una “transformación revolucionaria de la base productiva bajo su estatización” en tanto "sólo el sector nacionalizado puede enfrentar al capital monopólico multinacional”. Asimismo, se advertía que esa política de socialización podría "ser condenada al fracaso si no es conducida por el pueblo mismo, en un proceso de movilización políticamente motivado y con claros objetivos sociales" siendo "imprescindible la creación de nuevas formas organizativas que conduzcan al ejercicio del poder por el pueblo", y señalando a "la juventud de todo el país [como] la garantía de la irreversibilidad del proceso que se ponga en marcha". 163

viniera trabajando en su armado desde mucho antes. Ver Ciencia Nueva, $\mathrm{N}^{\circ} 18$, agosto de 1972 "El Consejo Tecnológico del Movimiento Nacional Justicialista". Agradezco a Sergio Friedeman este dato.

${ }^{162}$ García invitó a varios profesionales de diversas ramas y confió la secretaría al ingeniero Héctor Abrales. Junto a Mario Hernández, Lepanto Bianchi, Carlos Abeledo, Julio Villar, Héctor Recalde, Hugo Di Florio, Enrique Martínez, Ricardo Ferraro, Emilia Ferreiro (esposa de Rolando García), Horacio y Eduardo Bauer, Alberto González, Guillermo Gallo Mendoza, Floreal Ferrara, Ricardo Rubio y Marina Siri, entre otros. Poco después Jorge Taiana quedó a cargo de la vicepresidencia, por pedido de Cámpora, aún cuando sus diferencias con García eran constantes. Ver Bonasso (2010: 215 y 243), "Biografías del peronismo revolucionario: Rolando García" en http://www.robertobaschetti.com/biografia/g/292.html

${ }^{163}$ Consejo Tecnológico del Movimiento Nacional Justicialista "Bases para un programa peronista de acción de gobierno. Industria", $\mathrm{N}^{\circ}$ 1, en www.ruinasdigitales.com, s/f, "Rolando García propone crear un ministerio de Ciencia y Técnica" en La Opinión, 24/03/1973. Ver también Pozzoni (2017: 46). Además de este grupo que logró reconocimiento oficial en las estructuras del Movimiento, por la misma época se creó otro equipo de similares características técnico-profesionales pero ubicado en el otro extremo del espectro político-ideológico peronista, identificado con sectores de la derecha del Movimiento. Fue el denominado Consejo de Planificación del Movimiento Nacional Justicialista (CPMNJ) liderado por Leopoldo Frenkel y Roberto Ares. Este think tank (Denaday 2018) logró también un status formal dentro de la estructura partidaria, incorporando notables figuras de los elencos de la vieja tecnocracia peronista, incluso algunos de 
Como síntesis de la elaboración programática de este grupo se destacaba la idea de que el proceso de liberación que pondría fin a la dependencia estructural de nuestro país, no podría ser alcanzado dentro de los márgenes del sistema capitalista, lo que implicaba un sentido de la transformación mucho más radical que el programa de conciliación de clases y arbitraje del Estado que proyectaba Perón. ${ }^{164}$

Cabe destacar que varios artículos de la prensa en los días posteriores a la elección del 11 de marzo refieren a la "lucha desatada" entre los diferentes equipos de trabajo del FREJULI en vistas a imprimirle su fisionomía al nuevo gobierno. En esa competencia, para la rama económica, señalaban la disputa entre el grupo encabezado por "la vieja guardia peronista" que había dirigido la cartera de economía: el equipo de Alfredo Gómez Morales y Antonio Cafiero, y quien contaría con el apoyo del sindicalismo ortodoxo; un segundo equipo dirigido por Rogelio Frigerio avalado por Arturo Frondizi; y por último el equipo del CTMNP encabezado por Rolando García. Éste sería "la expresión del nuevo peronismo, el de la juventud" cuya "irrupción en la conducción de la economía nacional constituiría una verdadera revolución, mediante la redistribución de los ingresos, la reforma agraria, la nacionalización de los bancos extranjeros y del comercio exterior". 165

El otro grupo que nos interesa reseñar aquí es el de los Equipos Político-Técnicos (EPT) de la Juventud Peronista, cuyo lanzamiento formal se realizó en el mes de abril de 1973, luego de la campaña y el triunfo electoral. En la conferencia de presentación, Alcira Argumedo, figura central de esta experiencia, los caracterizaba como "una instancia más del poder popular gestado desde las bases. Donde lo elaborado no es una asesoría más sino un nuevo canal para la estrategia propia de la Juventud en su camino hacia la patria socialista". Asimismo, Argumedo aclaraba que el retraso en la presentación de las propuestas - más de un mes después de la victoria en los comicios- se debía a que "sobre

ellos con estrechas relaciones con la dictadura de Onganía y Levingston. Entre algunos de los más conocidos se encontraban los dos economistas justicialistas del peronismo tradicional, Alfredo Gómez Morales y Antonio Cafiero, ambos vetados por la cúpula de Montoneros en las reuniones con Perón en abril de 1973 (ver más adelante). Según Denaday, en diciembre de 1972 Hectór Cámpora convocó tanto al grupo de Rolando García y al de Leopoldo Frenkel a participar de reuniones conjuntas con miras a la confección de programas de gobierno. En esas reuniones se habría hecho evidente la hostilidad del grupo del CPM frente al de Rolando García, al atribuirle un plan extremista de estatización general de la economía muy afín a la Tendencia Revolucionaria (Denaday, 2018).

${ }^{164}$ El Consejo Tecnológico del Movimiento Nacional Justicialista, Ciencia Nueva, № 18, agosto de 1972, p. 26. Y Consejo Tecnológico Peronista: "Economía. Prioridad: romper la dependencia", Nueva Plana, N 16, 6/2/1973, pp. 18- 20, citado en Pozzoni (2017:47). Respecto de las diferencias entre estos programas y las definiciones de Perón, ver La Opinión, 28/3/73, "Precisó el líder justicialista los límites del socialismo nacional".

${ }^{165}$ La Opinión, 13/3/1973 "Versiones fidedignas” y La Opinión, 20/3/1973 “El gremialismo y los jóvenes frente al próximo gobierno justicialista". 
la JP recayó el peso de las movilizaciones contra la dictadura militar. Los Equipos Político Técnicos son el producto de esas luchas de las bases y reciben una línea política de esas luchas. No son mera tarea de gabinetes y tecnócratas". 166

Esta úlitma referencia resulta interesante para pensar cómo la incorporación de integrantes de la TR al espacio gubernamental le imprimió ciertas características particulares a su gestión, en las que, si bien el componente técnico-profesional era valorado como un saber y un requisito necesario, se privilegiaba la experiencia política de activismo y militancia en los frentes de masas de la etapa inmediatamente anterior.

Al respecto, este "capital militante" específico (Poupeau, 2007:40-41) ${ }^{167}$ del que gozaban los miembros de la Tendencia devenidos en funcionarios de gobierno, los hacía portadores de un "conjunto de saberes, técnicas, disposiciones" y valores ético-políticos que en el contexto de la época eran sumamente estimados, inclusive más que las credenciales académicas y profesionales que pudieran demostrar (o que al menos debían estar indisociablemente combinadas con ellas). De esta forma, ese conjunto de "saberes $y$ habilidades" adquiridas en el quehacer de la militancia "en el llano" y durante largos años de resistencia a la dictadura, se convertían ahora en insumos claves que moldeaban sus practicas de gestión institucional y, en la percepción de los y las militantes, "garantizaban" la continuidad de su compromiso político revolucionario, ahora en el Estado.

Las siguientes declaraciones de Rodolfo Vittar y Nilda Garré, ambos elegidos diputados por la JP en las elecciones del 11 de marzo ilustran -al igual que las palabras de Argumedo- esa ponderación del "componente militante" en la definición de su rol como miembros del gobierno, y sus funciones:

\footnotetext{
“los activistas obreros, las comisiones internas de fábrica, las delegaciones sindicales de base, el pueblo de barrios y villas, serán convocados y consultados sistemáticamente, para hacer de este parlamento una herramienta. Tienen que convencerse que nosotros, más que diputados, somos militantes".
}

${ }^{166}$ La Opinión, 28/4/1973 "Proyectos de los seis equipos técnico-políticos” y “Creará la Juventud Peronista su propio equipo técnico-político", La Opinión, 24 de abril de 1973.

${ }^{167}$ Para este autor, el capital militante está menos ligado al ejercicio de cargos dirigentes de cierta jerarquía que el capital político, e implica en su estado incorporado: "un conjunto de técnicas, de disposiciones a actuar, intervenir, o simplemente obedecer; recubre un conjunto de saberes y de saber-hacer movilizables durante acciones colectivas, luchas inter o intra-partidarias, pero también exportables, convertibles en otros universos, y, así, susceptibles de facilitar ciertas 'reconversiones"'. (Poupeau, 2007: 40-41). En este sentido, podría pensarse en la trayectoria de los/as militantes de la TR que ocuparon cargos en el Estado como un caso de traslación de ese capital militante al campo de la gestión pública. Un ejemplo del uso y aplicación de estas categorías puede verse en el artículo de Chama, Mauricio y Gonzalaez Canosa, Mora (2011) sobre la participación de militantes de la JUP en la Facultad de Derecho de la UBA en 1973. 
"(el congreso) es un instrumento del pueblo y como tal debe servir para que lleguen las iniciativas desde abajo. Nuestras primeras leyes habrán de convertir en texto jurídico aquello que fue sustancia de las luchas del pueblo en estos 18 años de resistencia. Esos serán los primeros pasos en la marcha hacia el Estado revolucionario" 168

Volviendo a los EPT de la JP, estaban conformados por profesionales de diversas áreas como educación, economía, vivienda, salud, legislación y medios de comunicación, ${ }^{169}$ quienes bajo la premisa de aportar a la reconstrucción nacional y la liberación social, venían elaborando programas de acción en cada una de las ramas mencionadas. Su objetivo principal, según Pozzoni (2015a), era formar cuadros políticos capacitados que pudieran insertarse en el gobierno para operar, desde allí, los cambios esperados. ${ }^{170}$

Entre las propuestas elevadas, para Educación se promovía la organización de los docentes en agrupaciones peronistas, y la de los estudiantes en la JUP, desarrollando proyectos conjuntos "para colocar definitivamente la Universidad junto al pueblo". En el resto de los niveles educativos se planteaba la creación de centros de recreación cultural, producción de audiovisuales y cuadernos populares para las campañas de alfabetización. ${ }^{171}$ Para el área de Economía se planteaban la creación de "Comisiones populares de Control de Precios" que terminarían con la intermediación y el hambre del pueblo. Asimismo, en la lucha contra el imperialismo, se aspiraba a "forjar una economía controlada por la clase trabajadora en todos sus niveles. Esto es: el fin de la

168 Declaraciones de Rodolfo Vittar y Nilda Garré, en "Peronistas en el Parlamento. Nuevo frente de lucha". El Descamisado, $\mathrm{N}^{\circ}$ 0, 8 de mayo de 1973, p. 13. Un trabajo muy interesante para pensar estas cuestiones en un contexto político más reciente y de institucionalización de las políticas de la memoria, es el de Ana Gugliemucci (2011), quien analiza la experiencia de "activismo político" en el Estado que asumieron los integrantes de organismos de DDHH incorporados a los equipos de gestión en el Gobierno de CABA, quienes expresan similares ideas e imágenes al referirse a su tránsito de "militantes políticos" a "funcionarios del gobierno". Por otra parte, es muy interesante la bibliografía de corte sociológico que en los últimos años recupera esta dimensión de los estilos de militancia en la gestión pública, en épocas posteriores y en distintos gobiernos. Por ejemplo, Perelmiter (2016) para el caso de la burocracia kichnerista, y el de Salerno (2019) para el macrismo. Agradezco especialmente a Florencia Osuna los comentarios sobre este tema.

${ }^{169}$ Ibid. Se menciona en esa nota a Pablo Franco como el coordinador del área de Educación, Oscar Sbarra Mitre por Economía, Ignacio Lopatín a cargo de Vivienda, el Dr. Mario Testa por el equipo de Salud, el Dr. Néstor Ladémica por Legislación y Justicia, y Miguel Bonasso por Medios de Comunicación.

${ }^{170}$ Agrega Alejandro Peyrou: "los EPT eran producto de la gran ola, grupos de gente por especialidad que se juntaban para tratar de definir el futuro de la Argentina en cada uno de esos temas, teniendo en mente que había un proceso de apertura política, fue algo muy próximo a la fecha de las elecciones. Lo integraba gente que se habia acercado desde distintas experiencias, había algunos que sí tenían algún grado de encuadramiento y otros menos, pero todos dentro de una línea del peronismo revolucionario... Se lanzan a fines del 72 creo, pero la interna fue mucho antes. Quiero decir que en un contexto de triunfo prácticamente asegurado ahí recién se largan" Entrevista de la autora a Alejandro Peyrou, CABA (2012)

${ }^{171}$ La Opinión, 28/4/1973. Pozzoni (2015a). Para la campaña de alfabetización organizada por cuadros de Montoneros que participaron en la Secretaría de Cultura del Ministerio de Educación en el año 1973 ver Abbattista (2014). También Dip (2018) reconstruye la trayectoria de los docentes e intelectuales que en el año 1973 confluyeron en la experiencia de la Agrupación Docente Universitaria Peronista, con la elaboración de propuestas específicas para la Universidad. 
explotación del sistema". ${ }^{172}$ En Vivienda se consideraba como prioritaria la intervención directa de las bases populares en su construcción, junto a la expropiación y reasignación de las tierras de las villas para acabar con la especulación. ${ }^{173}$ Para Salud, y ante la destrucción del sistema del hospital público legado por la dictadura, se preveía un sistema de autogestión popular en centros ubicados en villas y barrios populares. En Justicia se proponía la conformación de Tribunales Populares en cada barrio y población, elegidos por las bases. Por último, para el área de Medios de Comunicación se anunciaba que a través del aporte del Bloque de Prensa Peronista, la Asociación de Cine Peronista y gente de teatro, se buscaría implementar formas de creación y control popular del área de prensa y comunicación. ${ }^{174}$

Gran parte de estas ideas y propuestas serán las que guíen las políticas desplegadas por los y las militantes de la TR en el gobierno provincial, articulando de modo particular los requerimientos técnicos y específicos de cada área con aquellos valores y saberes prácticos adquiridos en su militancia revolucionaria, tales como el compromiso político, la movilización y el activismo con las bases.

\subsection{De las elecciones al gobierno: los (des)encuentros con Perón.}

Los debates y cuestiones reseñadas cobraron materialidad a partir de los encuentros que se realizaron entre la conducción de las organizaciones armadas y Perón en el mes de abril de 1973. A dichas reuniones convocadas por Perón, primero en Roma y luego en Madrid, asistieron Mario Eduardo Firmenich, Roberto Quieto y Roberto Perdía, junto al flamante presidente electo Héctor Cámpora. Allí, los jefes de Montoneros y FAR presentaron algunas propuestas de trabajo para el nuevo gobierno elaboradas por los

\footnotetext{
${ }^{172}$ La Opinion, 28/4/1973.

${ }^{173}$ Ididem.

${ }^{174}$ Ibid. Un tercer grupo de profesionales y técnicos que cabe mencionar fue el Comando Tecnológico Peronista (CTP) conformado aproximadamente entre fines de 1970 y principios de 1971 en torno a Julián Licastro y José Luis Fernández Valoni, dos ex tenientes retirados del Ejército que se acercaron al peronismo a partir del Cordobazo y fueron considerados por Perón «los tenientes de la revolución». El nombre recuperaba la formación castrense de sus impulsores, que se resumía en la frase de Licastro «los comandos mandan, los consejos aconsejan, asi que nosotros haremos el Comando Tecnológico Peronista para incidir también en la politica general» (Licastro, 2012 y Pozzoni, 2015a;). En la conformación del CTP se encuentran oficiales del ejército y un grupo de profesionales que provenían del Frente Estudiantil Nacional (FEN). Los materiales confeccionados por este grupo se publicaron en el Boletín Informativo Peronista (Denaday, 2018). La trayectoria de Licastro y su grupo se ubicaron con el correr del año 1973, cada vez más hacia el centro del arco político peronista, apoyando indeclinablemente a Perón en el contexto de disputa con los grupos de la Tendencia. Licastro será además quien encabece el proyecto de la Generación Intermedia para la Actualización Política y Sindical a fines de 1973, en detrimento del proyecto del Trasvasamiento Generacional impulsado previamente por los jóvenes de la TR.
} 
grupos de profesionales peronistas ya mencionados: los Equipos Político-Técnicos de la JP y el Consejo Tecnológico Peronista (Perdía, 1997; Celesia y Waisberg, 2010).

Además de estos programas y medidas, los dirigentes de las organizaciones armadas le enseñaron a Perón un listado bastante exhaustivo de personas elegidas por ellos mismos que podrían ocupar cargos de primera y segunda línea en el futuro gobierno. En este famoso organigrama aparecían mencionados desde militantes encuadrados, a técnicos y profesionales muy cercanos y otros aliados, todos identificados en mayor o menor medida con la Tendencia. Entre los nombres postulados figuraban Rodolfo Ortega Peña para el Ministerio de Trabajo, Rolando García (CTMNP) para el Ministerio de Obras Públicas, Guillermo Gallo Mendoza (CTMNP) para Agricultura y Ganadería, Rodolfo Puiggrós y José Hernández Arregui para el Ministerio de Educación, Alcira Argumedo (EPT) en la Subsecretaría de Cultura, Pedro Krostch y Pablo Franco (EPT) en la Subsecretaría de Educación, Esteban Rigui, Eduardo Luis Duhalde y Mario Hernández (CTMNP) para el Ministerio de Justicia, Gustavo Roca y Luis Cerutti Costa como integrantes de la Corte Suprema de Justicia, Hugo Vaca Narvaja (padre de Fernando y Daniel) en el Ministerio de Defensa, Juan Manuel Abal Medina, para el Ministerio del Interior, Mario Kestelboim en la Dirección de Policía de Trabajo, Miguel Bonasso (EPT) y Luis Bernetti (EPT) en la Subsecretaría de Prensa, Carlos Mugica a cargo de la Subsecretaría de Promoción y Asistencia de la Comunidad, Alejandro Peyrou en el Consejo Nacional de Desarrollo (CONADE), Oscar Sbarra Mitre (EPT) a cargo del Ministerio de Hacienda y Finanzas, Ignacio Lopatín (EPT) en la Subsecretaría de Vivienda, Julián Licastro en la Municipalidad de Buenos Aires, y Carlos Groso como Subsecretario General, entre otros. En el mismo documento también se incluían nombres para vetar, es decir, aquellos a quienes consideraban "peligrosos y contrarios a los objetivos del futuro gobierno", tales como Alberto Gómez Morales y Antonio Cafiero para economía, y las figuras sindicales de Oscar Valdovinos, Carlos Maldonado, Norberto Centeno y José Taccone para el área de trabajo, entre otros (Yofre, 2015; Bonasso, 2000; Gasparini, 1999). ${ }^{175}$

Frente a esta escena por parte de los dirigentes Montoneros, quienes -ante tal grado de despliegue de nombres y propuestas- exponían con total franqueza sus aspiraciones a una

175 Entrevista de la autora a Alejandro Peyrou, CABA (2012). Peyrou participó directamente de la confección de la lista. 
“conducción ampliada" entre Perón, Cámpora y ellos mismos, el máximo jefe del justicialismo no ocultó su enojo y preocupación. ${ }^{176}$

Según varios testimonios, Perón, lejos de asegurarles ese lugar preponderante en el control de las decisiones del futuro gobierno, les exigió su reconversión y reintegro a la vida democrática, lo que significaba lisa y llanamente que debían desarmarse (Perdía, 1997:144; Vaca Narvaja, 2002:89; Duzdevich, Raffoul y Betanini, 2015:101). Asimismo, les señalaba que recién al término de su gobierno, y luego de haber dado "muestras probadas" de su reconversión en tareas legales, podrían aspirar a un eficaz trasvasamiento generacional en el Movimiento y la política del país.

Más concretamente y para esa primera etapa, el acotado lugar asignado por Perón para las tareas institucionales a cargo de los jóvenes de la TR sería la Fundación Eva Perón, con el objetivo de darles continuidad a sus actividades desde un rol de organización y promoción social con la comunidad (Perdía, 1997; Amorín, 2005)

Estas diferencias de fondo sobre el lugar de las organizaciones revolucionarias en el nuevo gobierno y los alcances de sus políticas, no sólo no se disiparon, sino que se agravaron al calor de otros acontecimientos ocurridos en el mes de abril en el país.

El más conocido de estos episodios fue la mención pública de Rodolfo Galimberti sobre la conformación de "milicias populares" en el acto de presentación de la Unión de Estudiantes Secundarios (UES), agrupación estudiantil de superficie cuyos militantes de base y dirigentes respondían a Montoneros. En su lanzamiento el 18 de ese mes, Galimberti definió a las milicias como la expresión de "una violencia que ahora debemos ejercer de forma orgánica, porque no podemos pensar que el gobierno popular va a poder llevar adelante su programa de liberación nacional y social si no cuenta con fuerzas que lo apoyen", siendo "la juventud la principal fiadora del contenido revolucionario del proceso destinado a implantar el socialismo nacional" (Larraquy y Caballero, 2000: 184). ${ }^{177}$

El fallido anuncio, con importantes repercusiones en la prensa y críticas de la corporación militar, ${ }^{178}$ se daba además en un contexto político sumamente delicado para el gobierno

${ }^{176}$ Perdía en su libro recuerda este episodio como un momento clave en el comienzo del declive de las relaciones entre la cúpula de Montoneros y Perón, tildando de "excesiva sinceridad" e "ingenuidad política de su parte" el haberle dado a conocer en esos términos la lista de "sus" profesionales (1997).

${ }^{177}$ La Opinión, 21/4/73 "Definen el futuro rol de las milicias juveniles" y 29/4/73 "Perón ratificó la intención de congelar la reorganización del justicialismo"

${ }^{178}$ La Opinión, 29/4/73 “La irritación militar busca la negociación con el nuevo gobierno” y "Afirmó el brigadier Rey que no existirán las milicias populares". "La renuncia de Galimberti. Un golpe de timón" en El Descamisado, Año 1, № 0, 8/05/1973, p.12. Ver también el testimonio de Abal Medina en Jauretche (1997:188) 
peronista próximo a asumir, en tanto la continuidad de acciones por parte de las organizaciones armadas peronistas y no peronistas luego de las elecciones incrementaba las voces contrarias sobre la efectiva entrega del mando desde las FFAA. ${ }^{179}$

Como corolario de esta situación, Rodolfo Galimberti y Juan Manuel Abal Medina fueron citados de inmediato por Perón a una reunión en Madrid, a la que también asistieron Héctor Cámpora y representantes de la derecha del Movimiento como Norma Kennedy (rama femenina), Alberto Campos (intendente electo de San Martín), Manuel Damiano (dirigente del gremio de prensa), el Coronel Jorge Osinde (delegado militar de Perón), Pascual Breglam (representante de la recientemente creada Juventud Sindical Peronista apoyada por Rucci), y el secretario privado de Perón, José López Rega.

Allí, en lo que finalmente resultó un operativo de afirmación de la verticalidad en su Movimiento, Perón decidió el desplazamiento de Galimberti de su cargo en el Consejo Superior, y la orden para Abal Medina de suspender el proceso de reorganización del justicialismo. En la práctica esto significaba un freno concreto al trasvasamiento generacional, es decir, a la presencia de la JP en lugares de representación y decisión cada vez más amplios dentro del Movimiento, y un mensaje claro de disciplinamiento para todo el espacio de la TR. Asimismo, estas decisiones expresaban un deterioro notable de la imagen de Abal Medina y el ascenso de sectores de la derecha peronista que habían

${ }^{179}$ En un comunicado titulado "Por qué el ERP no dejará de combatir", la organización armada daba a conocer su postura frente al nuevo gobierno democrático, ante el pedido público de una tregua que hizo el presidente electo Héctor Cámpora a la guerrilla. Allí declaraban "respetar la voluntad popular" expresada en la victoria del gobierno peronista, al que "no atacarían, mientras éste no ataque al pueblo ni a la guerrilla". No obstante, sí continuarían "combatiendo militarmente a las empresas y las fuerzas armadas contrarevolucionarias". En cuanto a la policía, suspendían "los ataques contra ella a partir del 25 de mayo, mientras ella permanezca neutral y no colabore con el ejército en la persecución de la guerrilla y en la represión de las manifestaciones populares". Ver La Opinión, 11/4/1973 "Confia en una tregua guerrillera el futuro mandatario", y 25/4/1973 "Anunció el ERP que no dejará las armas". Como parte de estas acciones luego de las elecciones, el 25 de marzo el ERP atacó la Central Nuclear de Atucha y el día 30 colocaron una bomba en el Edificio Libertad de la Armada. En el mes de abril realizaron el secuestro del Contraalmirante Francisco Alemán y de un gerente de la firma Kodak. El día 21 de ese mes tomaron el destacamento policial de Ingeniero Maschwitz, y el 26 secuestraron al Comandante de Gendarmeria Jacobo Nacif. Finalmente, el mes se cierra con la ejecución del Contralamirante retirado Hermes Quijada. Duzdevich (2015:102) y Anzorena (1998:214). Como producto de esta ola de atentados, el gobierno militar aún en funciones declaró zonas de emergencia a Buenos Aires, Córdoba, Mendoza y Tucumán con consejos de guerra y juicios sumarios (Graham Yool, 1989:255). Por su parte, y como ya vimos en el reportaje de FAR y Montoneros arriba citado, ambas organizaciones sostenían la continuación de la guerra integral, lo que implicaba el mantenimiento de su estructura militar y los operativos armados. Entre las acciones de las FAR realizadas en esta coyuntura podemos mencionar la ocupación de los tribunales de San Isidro para el pertrechamiento de armas y documentos, el secuestro del presidente de Coca-Cola y el atentado contra un empresario de la empresa Ford. En el caso de Montoneros, el día 4 de abril un comando de esta organización en la provincia de Córdoba ejecutó al Coronel Héctor Alberto Iribarren, y días después secuestraron al presidente de la compañía Nobleza de Tabacos. Duzdevich (2015:103 y 106). Por último, las FAP -Comando Nacional continuaron reivindicando sus planteos de la alternativa independiente y operando militarmente en esta coyuntura, muestra de ello fue el asesinato del secretario general del gremio mecánico de SMATA, Dirk Kloosterman en la ciudad de La Plata, tres días antes de la asunción del nuevo gobierno peronista (Anzorena, 1998:217) 
quedado marginados en la etapa pre-electoral (Larraquy y Caballero, 2000: 187). A decir de Jorge Bernetti (1983:99) "Era el comienzo de la derrota dentro de la victoria... Es allí, en esa reunión, donde queda golpeada la expresión dirigente de la política revolucionaria". ${ }^{180}$

Más allá de estas reflexiones elaboradas a posteriori, cabe incorporar al cuadro de situación otros dos hechos sucedidos durante el mes de abril que a nuestro entender aportaron un mayor grado de tensión por las implicancias políticas -y no meramente discursivas- que tenían sobre el perfil del próximo gobierno, y el esquema de relaciones de fuerza dentro del peronismo.

El primero de ellos fue el lanzamiento de la Juventud Trabajadora Peronista (JTP) el 28 de abril. La creación de esta vital agrupación en el corazón de la clase trabajadora, con sus propuestas antiimperialistas, anticapitalistas y antiburocráticas, actuó como un polo de atracción para los gremios combativos del peronismo (telefónicos, empleados del tabaco, navales, Gas del Estado, Obras Sanitarias, regionales de ATE) así como también para núcleos del Peronismo de Base afín a Raimundo Ongaro y otras agrupaciones peronistas opositoras a las conducciones burocráticas de sus sindicatos. ${ }^{181}$

La JTP representaba una apuesta de Montoneros por cubrir su déficit organizacional en la clase trabajadora, presentándose como una alternativa en oposición a la Juventud Sindical Peronista (JSP) vinculada a la CGT y a la UOM. En poco tiempo, se oirá la consigna: “JTP, la nueva CGT” (Anzorena, 1998:229).

En efecto, esta política de desarrollo de su frente sindical, expresión de la TR en el movimiento obrero, colisionaba de lleno con los intereses de la cúpula de la CGT, decidida en esa etapa a obtener mayores cuotas de influencia y poder en el futuro gobierno. ${ }^{182}$ Por otra parte, la existencia de una organización sindical con objetivos radicalizados en el seno de la clase trabajadora peronista, atentaba a priori contra el programa económico ideado por Perón y su política acuerdista con los empresarios. En este sentido, la actividad de movilización y profundización de los conflictos

${ }^{180}$ Ver La Opinión, 29/4/73 "Perón ratificó la intención de congelar la reorganización del justicialismo" y "La renuncia de Galimberti. Un golpe de timón” en El Descamisado, Año 1, No 0, 8/05/1973, p.12.

${ }^{181}$ La Opinión, 27/4/73 "Intenta la Juventud Peronista organizar a sectores obreros" y El Día 28/4/73 "Constituyóse la JTP. Hubo expresiones contra I. Rucci”. El Descamisado, Año 1, No 0, 8/5/73 "La Juventud Trabajadora Peronista en marcha", p. 2. Entre las propuestas mencionadas en su acto de lanzamiento estaban: libertad a todos los presos políticos y gremiales, nacionalización de empresas, bancos y comercio exterior, aumentos de salarios, control obrero de la producción y dirección de empresas. A esta organización también adhirió el dirigente sindical cordobés Agustín Tosco. Para un análisis de la JTP como política de masas de Montoneros, ver Pacheco (2015) y Lorenz (2007).

${ }^{182}$ El Día, 29/4/73 "Habló Rucci: Hay una sola CGT". La Opinión, 1/4/1973 "El peronismo sindical busca profundizar su participación en el futuro gobierno". 
reivindicativos convertía a la JTP en una amenaza para el Pacto Social (Maceyra, 2004; Page, 1999; Anzorena, 1998). ${ }^{183}$

En vinculación con esto, el segundo hecho que queremos mencionar es el lanzamiento esa misma semana en una conferencia de prensa del denominado "Compromiso de la Juventud Peronista con el pueblo de la patria". ${ }^{184}$ En ese acto, los/as candidatos/as electos/as de la JP a nivel nacional, provincial y municipal, dieron a conocer un decálogo de objetivos y medidas radicalizadas en las que comprometían su accionar durante el próximo gobierno. Los 10 puntos eran:

\begin{abstract}
1) Libertad de todos los presos políticos y gremiales
2) Investigación hasta las últimas consecuencias de los responsables de delitos de persecución, tortura y encarcelamiento a militantes populares, como también de delitos económicos y de los ejecutores de la política imperialista

3) Supresión de todos los tribunales especiales, derogación de la legislación represiva y declaración en comisión de todos los funcionarios y magistrados designados a espaldas del pueblo desde 1955.

4) Impedir la continuidad del funcionariado público responsable de las formas de entrega de la patria y la explotación del pueblo.

5) Denunciar y sancionar a los propios funcionarios del próximo gobierno popular que se aparten de la conducta revolucionaria que les ha impuesto el mandato del pueblo; ejerciendo un control de todos los niveles para evitar claudicaciones y traiciones a dieciocho años de lucha popular.

6) Impulsar el cumplimiento y profundización del programa del FreJuLi, en particular, las propuestas programáticas surgidas de la clase trabajadora en La Falda, Huerta Grande y el programa del 1 de mayo de la CGTA.

7) Propiciar la austeridad en la función pública en los tres poderes del estado y en las Fuerzas Armadas.

8) Socializar las dietas y sueldos de los militantes de la JP que ocupan cargos públicos, canalizando este aporte a través de la estructura orgánica de esta rama del movimiento

9) Trasladar las instancias de decisión política de los cuerpos burocráticos del Estado hacia las bases populares donde se construye el poder organizado del pueblo.

10) Suprimir toda forma de tratamiento entre los militantes del FreJuLi, incluidos los funcionarios, que involucren títulos, aditamentos o prerrogativas propias del sistema. Para la JP el único tratamiento válido es el de "compañeros"." 85
\end{abstract}

Más allá del aspecto declamativo y aspiracional de este documento, junto al hecho no menor de que el rápido deterioro de las relaciones entre la TR y Perón difícultó

\footnotetext{
${ }^{183}$ El Acta de Compromiso Nacional, conocido popularmente como Pacto Social, constituyó el punto más significativo de la política económica del gobierno peronista, desde la presidencia de Cámpora hasta la muerte del general Perón. Este acuerdo firmado el 8 de junio de 1973 entre la CGT, la CGE y el gobierno, buscaba la concertación entre empresarios y trabajadores, a través de un paquete de medidas que incluían la congelación de las reclamaciones salariales, y como contrapartida, el cese de los aumentos de precios. El objetivo perseguido era bloquear el proceso inflacionario, recuperar la capacidad de inversión empresaria y frenar el deterioro en el nivel de vida de los trabajadores. Como parte de estas resoluciones, se proyectaban dos años sin la realización de negociaciones paritarias, razón por la cual el control y restricción de cualquier línea combativa dentro del movimiento obrero eran de vital importancia. Torre (1989:53)

${ }^{184}$ Documento: "Compromiso de la Juventud Peronista con el pueblo de la patria", s/f. El Topo Blindado, citado también en Jauretche (1997)

${ }^{185}$ Suscriben la declaración el Consejo de la Juventud Peronista, delegados de las 7 Regionales de la JP, senadores nacionales, diputados nacionales y provinciales, concejales municipales, consejeros escolares, intendentes municipales.
} 
enormemente las posibilidades de su concreción efectiva, consideramos importante detenernos en esta declaración por varias cuestiones.

En primer lugar, a través de esta propuesta presentada como un "compromiso de todos los dirigentes de la JP" (incluidos los que asumieron cargos ejecutivos y no solo legislativos), se visualizaba el intento real por parte de la joven militancia encuadrada de superar la metodología de movilizaciones que había caracterizado su participación durante la campaña electoral, ligándose además con la práctica de elaboración de proyectos que otros grupos venían desarrollando previamente a nivel más acotado (CTMNJ/FURN/EPT), dándole ahora un reconocimiento mayor.

Es decir, a través de este compromiso, podía observarse la capacidad y las aspiraciones de este actor para desplegar acciones que se encaminarían en la plasmación de proyectos institucionales, inscribiendo su militancia revolucionaria en el espacio gubernamental.

De ahí la alarma que estas declaraciones provocaron en algunos sectores, ${ }^{186}$ en tanto ellas reflejaban un estilo y un programa de gobierno que trascendía la mera irrupción movilizadora, prácticas que si bien habían sido altamente efectivas para ganar las elecciones, no llegaban a canalizarse en otras instancias formales de la política. Este compromiso era un intento en esa vía.

En segundo lugar, el conjunto de medidas reunidas en el documento reflejaba el apoyo a programas económicos y metodologías de acción radicalizadas que, a nuestro entender, constituían la expresión de una TR estructurada políticamente. Es decir, un proyecto y un estilo político asociado a la construcción de la "patria socialista" que ya contaba con diputados/as, senadores y concejales/as, y que gozaba de la simpatía de los equipos electos de varias provincias importantes.

Cabe destacar en este punto, la reivindicación de las propuestas programáticas surgidas en el seno de la clase trabajadora peronista (La Falda, Huerta Grande y CGTA) que rivalizaban directamente con los programas de la CGT y sus representantes actuales (punto 6). Junto a otras medidas que apuntaban a formas organizativas de autogestión popular y que promovían nuevos canales para la toma de decisiones políticas desde las bases hacia el Estado (punto 4 y punto 9); y aquellas que apuntaban, en un sentido performativo, a la construcción de un estilo de ejercicio de la función pública ligada a la idea de "militancia revolucionaria" en el Estado (punto 5, 8 y 10).

186 Mariano Grondona en su columna del diario La Opinión, señala la compleja situación que debería enfrentar el próximo gobierno peronista ante la fuerte presencia de estas "tesis extremas" sobre el cambio y la transformación, desde adentro de sus filas. 
Por último, consideramos relevante recuperar esta declaración en tanto pone de relieve un aspecto que ha sido poco atendido por los estudios del período. Nos referimos a la idea extendida de que las prácticas armadas fueron la expresión dominante de la política revolucionaria en esta época, y que -derivado de esto mismo- la aspiración a ocupar puestos en el aparato estatal por parte de la TR sólo respondía a una mera puja de poder, en función de la lucha que mantenían con los sectores de la derecha del Movimiento. Este tipo de miradas pierden de vista la existencia de prácticas institucionales y proyectos políticos concretos que - tal como los reunidos en este compromiso- tenían la clara intención de gravitar directamente en la política futura del país, empezando por la que asumiría en funciones el 25 de mayo en espacios institucionales de representación y gestión. ${ }^{187}$

\subsection{Bidegain y la Tendencia. Trasvasamiento generacional y gestión provincial}

En la provincia de Buenos Aires, luego de las elecciones asistimos a un período intenso en diálogos y acuerdos cada vez más fructíferos entre el gobernador electo y los militantes de la TR, que afianzaron el vínculo entre ambos de cara a la próxima gestión.

Al respecto, cabe mencionar los mensajes magnetofónicos que Bidegain hace llegar a distintas delegaciones de la JP del interior de la provincia, en los que se observa el rol preponderante de la juventud, tanto como base fundamental de apoyo para su gobierno (dentro del Movimiento), como también en términos de "cantera" para nutrir de militantes a su gestión:

"esto no lo lograremos sólo con el apoyo tumultuoso, sino con la coparticipación en el gobierno que yo he asegurado a la juventud peronista. Ella debe estar bien organizada para asegurar la continuidad del proceso revolucionario que se inicia. Sé que están trabajando empeñosamente en el seno del consejo y del partido, aportando sus perspectivas del futuro... La juventud posibilitó el triunfo del 11 de marzo y debe exigir y apoyar la revolución social por la que tanto han luchado. En Pringles debe abocarse a todas estas tareas de la liberación nacional, que debe ejecutarse en todos los niveles, nacional, provincial y municipal. La muchachada, mujeres y varones, tienen una misión histórica que cumplir a partir del 25 de mayo". 188

\footnotetext{
${ }^{187}$ Una perspectiva similar a la nuestra puede encontrarse en el trabajo ya citado de Pozzoni (2017)

${ }^{188}$ Mensaje de Bidegain a la Juventud Peronista de Coronel Pringles, Mensaje de Bidegain a la Juventud Peronista de Coronel Rosales y Mensaje de Bidegain a la Juventud Peronista de Punta Alta. Abril de 1973. CPM - FONDO DIPPBA, División Central de Documentación, Registro y Archivo: Mesa "A" "Partidos políticos", Carpeta 37, Legajo N 271: JP Coronel Pringles; JP Coronel Rosales.
} 
Por otra parte, fueron numerosas las reuniones que mantuvo Bidegain con altos dirigentes de la organización Montoneros, entre otros, Norberto Habegger, para el armado del futuro gabinete. ${ }^{189}$

Otro episodio que da cuenta de la consolidación de esta relación se llevó a cabo en los primeros días de abril, cuando el mandatario electo visitó a los presos políticos detenidos en la Unidad 9 de La Plata, junto a diputados y senadores electos por la JP, militantes de la TR y abogados defensores miembros de la Asociación de Abogados Peronistas de La Plata (Carlos Negri, Carlos Moreda, Julio Troxler, José Tagliafico, Carlos Elizagaray, Carlos Caferatta, Babi Práxedes Molina, entre otros) haciendo público su compromiso de otorgar tan pronto asumiera el gobierno una amplia amnistía que permitiera su inmediata liberación. ${ }^{190}$

Hasta aquí la proximidad reseñada entre el dirigente peronista y la TR parecía inaugurar una etapa auspiciosa de cara al comienzo de la presidencia de Héctor Cámpora y a las expectativas de avance en el proceso de liberación y construcción de la "patria socialista". No obstante, algunas declaraciones y posicionamientos de los restantes actores del conglomerado peronista -que se sumaban al "descabezamiento" de Galimberti decidido por Perón- cubrían con un halo de oscuridad este horizonte primaveral.

En este sentido se ubican las presiones que a nivel provincial dieron a conocer en un documento político los delegados de la CGT de La Plata (cuyo Secretario General, Rubén Diéguez, fue elegido diputado por la rama sindical y era un hombre muy cercano a Calabró) explicitando su apoyo incondicional al vicegobernador Victorio Calabró -sin mencionar a Bidegain-, quien "asegurará la presencia del movimiento obrero en todas las áreas de decisión y ejecución” en el futuro gobierno, "declaración que tiene el valor de un mandato". ${ }^{191}$

${ }^{189}$ Entrevista de la autora a Flora Castro, La Plata (2013). Entrevista de la autora a Hugo Bacci, La Plata (2012). Entrevista de la autora a Nora Peralta, La Plata (2012). Ver también Castro y Salas (2011:54).

${ }^{190} \mathrm{El} \mathrm{Día,} \mathrm{10/4/1973.} \mathrm{Los} \mathrm{presos} \mathrm{que} \mathrm{se} \mathrm{encontraban} \mathrm{en} \mathrm{el} \mathrm{penal} \mathrm{eran} \mathrm{militantes} \mathrm{históricos} \mathrm{de} \mathrm{la} \mathrm{resistencia}$ peronista, muchos de ellos fundadores de la JP de La Plata y otros que habían caído presos en Taco Ralo: Oscar Doglio, Carlos Flaskamp, Envar El Kadri, Samuel Slutzsky, Edgardo Olivera, David Ramos, Carlos Caride y Sidel Negrín. Por ese entonces comenzaba a discutirse dentro del FREJULI qué hacer con los presos políticos, si otorgarles la libertad a través del indulto, o una ley de amnistía votada por el parlamento. La resolución de esta cuestión, producto de la presión popular y los disturbios ocurridos en la puerta de los penales la noche misma del 25 de mayo, culminó con la sanción de un decreto presidencial de indulto, que legalizaba la situación "de hecho" que ya se estaba viviendo en las cárceles, sin esperar la resolución del congreso que llegaría horas después. Bernetti (1983:117). Anguita y Caparrós (2007 [1998])p. 15). La Opinión, 12/5/1973 "Será difícil elaborar un consenso en torno a la ley de amnistía". Testimonio de Juan Manuel Abal Medina en Jauretche (1997)

${ }^{191}$ El Día, 14/4/1973 "Un documento de tono político difundió el plenario local de la CGT". El tono amenazante de la declaración es muy similar al de Rucci en sus críticas al lanzamiento de la JTP y al "Compromiso de la JP con el pueblo". 
De esta manera, la contundencia de la disputa entre las dos grandes fuerzas que se perfilaban por ganar la hegemonía dentro del Movimiento permite plantear como una hipótesis que esta investigación pretenderá demostrar, que lo que estaba en juego no era únicamente la competencia por ganar espacios de poder dentro del aparato institucional, sino también la posibilidad de llevar a cabo - por uno de sus contendientes- programas y prácticas innovadoras, expresión a la vez de un proyecto político e ideológico alternativo. Situación que a continuación veremos con más detalle en la ocupación de cargos ministeriales por parte de la Tendencia y sus modalidades de gestión.

E1 25 de mayo de 1973 en un clima de efervescencia popular sin precedentes, nutridos contingentes de militantes llenaron las calles del centro de la ciudad provenientes de distintos puntos de la capital provincial y del interior de la provincia. En los alrededores de la Casa de Gobierno y la Legislatura, lugar donde se llevó a cabo el acto de asunción de la fórmula Bidegain-Calabró, la algarabía popular se hizo presente. Allí asistieron de manera separada las columnas de la JP junto a las agrupaciones FURN, FAEP, Unidades Básicas de La Plata, Berisso y Ensenada, activistas gremiales de la Tendencia y militantes de FAR y Montoneros -todas en apoyo al gobernador- frente a delegaciones de la UOM y de otros gremios de la provincia, la Juventud Sindical Peronista, la Agrupación "24 de Febrero" de La Plata y otras, en respaldo del vice. ${ }^{192}$

En esa instancia del armado del gabinete y de la elección de funcionarios, la preponderancia alcanzada por la Tendencia en los meses precedentes, sellada en la alianza con Bidegain, se vieron reflejadas en los lugares destacados que obtuvo en los nombramientos ministeriales.

En relación a esto, Flora Castro, ex militante de Descamisados y esposa de Norberto Habegger, menciona las razones políticas (tanto en los frentes de masas como también a nivel de la estructura armada) que guiaban el trabajo de los dirigentes de la TR y el apoyo a Bidegain:

"Esa inserción territorial digamos fue más para la cuestión política de las elecciones, y para formar cuadros para el gobierno, y también para la organización armada porque bueno... yo no venía a eso, pero si venía Norberto, Ojea Quintana, Soler, ellos hacían todo un trabajo que tenía que ver con la incorporación de cuadros a la JP, JTP, UES, y cuando se vio que se podían presentar a elecciones se pensó en la posibilidad de conseguir un candidato que respondiera a lo que planteaba el peronismo revolucionario. ",193

${ }^{192}$ El Día, 26/5/1973, p. 1. Nava (2008)

${ }^{193}$ Entrevista de la autora a Flora Castro, La Plata (2013). 
En efecto, la creciente cercanía entre Bidegain y la Tendencia se vio reflejada en el armado de los equipos ministeriales, que contaron con un importante número de sus figuras. La llegada de militantes de Montoneros -o personas muy allegadas- en diversas Secretarías y Subsecretarías fue resultado de su nominación por parte de altos dirigentes de esta organización, quienes asesoraron al gobernador para los nombramientos en las reuniones que mantuvieron luego de las elecciones. Así lo menciona uno de los participantes directos de este proceso:

\begin{abstract}
"En esa época la orga me pide que me haga cargo de las vinculaciones de toda la cosa técnica. Ahi estaban el Consejo Tecnológico del Movimiento Peronista que era el grupo de Rolando García, que tenía gente mayor; el Comando Tecnológico de Licastro y después también estaban los equipos de la JP que eran mucho más pendejos. Gallo Mendoza era del grupo de Rolando García, y en algún momento no recuerdo cuándo nos llega el pedido desde La Plata, el cabezón (Norberto Habegger) o Daniel Vaca de algunos nombres para los Ministerios, y yo propongo para Obras Públicas a Alberto González, a Ferrara para Salud y Gallo Mendoza para Asuntos Agrarios". ${ }^{194}$
\end{abstract}

Recordemos que, a nivel nacional, la distribución de cargos en el "equilibrado" gabinete de Héctor Cámpora no había resultado del todo favorable para la Tendencia, quedando sus radios de influencia limitados al Ministerio del Interior (a cargo de Esteban Righi) y el de Educación (en manos de Jorge Taiana), además de tener buenas relaciones con el Ministro de Relaciones Exteriores (Juan Carlos Puig). Si bien la Universidad fue el ámbito de mayor influencia de Montoneros, la presencia de López Rega en el influyente Ministerio de Bienestar Social y la falta de control de los Ministerios de Trabajo y de Economía que articulaban la política eje de Perón plasmada en el Pacto Social (a cargo de Ricardo Otero y José Gelbard respectivamente) generaron críticas y una profunda sensación de insatisfacción en la izquierda del Movimiento (Bernetti, 1984:113 y Gillespie, 1987:165). ${ }^{195}$

\footnotetext{
${ }^{194}$ Entrevista de la autora a Alejandro Peyrou, CABA (2012). El listado de nombres de posibles funcionarios al que hace referencia nuestro entrevistado forma parte del organigrama presentado por Montoneros y FAR a Perón. De esa lista, según Peyrou, que se confeccionó para el nivel nacional, se sacaron luego los nombres para ocupar cargos en las provincias, tal es el caso de las designaciones en Buenos Aires. La participación directa de Montoneros como equipo asesor de Bidegain para los nombramientos es corroborada también por Hugo Bacci y Flora Castro en sus entrevistas. Para un análisis de este documento ver Friedemann (2020) quien analiza la gestión y trayectoria de varias figuras incluídas en el "organigrama montonero" que ocuparon cargos directivos en la UBA durante el año 1973.

${ }^{195}$ Ver también las notas "Versiones fidedignas", La Opinión, 13/3/1973, p. 9, y "El gremialismo y los jóvenes frente al próximo gobierno justicialista", La Opinión, 20/3/1973, p.8 en las que se describe la tensión en el seno del peronismo en cuanto a la fisonomía que tendría el futuro gobierno de Cámpora y el armado de su gabinete.
} 
No obstante, en la provincia de Buenos Aires, la alianza sellada con Bidegain en los meses precedentes, le aseguró a la TR un lugar sumamente destacado entre los cargos electivos y nombramientos ministeriales. A nivel legislativo, varios militantes de la JPMontoneros ocuparon bancas: Carlos Negri, Héctor Moreda, Mario Medina, José Tagliafico y Raúl Álvarez Echagüe lo hicieron en Diputados, mientras que Carlos Elizagaray y Alberto Mayansky en la Cámara de Senadores (Pozzoni, 2017:85). ${ }^{196}$

Por su parte Bidegain, además de nombrar como colaboradores a personas de su círculo íntimo provenientes de Azul, ${ }^{197}$ en cuatro de las seis carteras ministeriales y sus respectivas Secretarías designó en su mayoría a funcionarios con una adscripción directa a la Tendencia: ${ }^{198}$

\section{1) GOBERNACIÓN: Oscar Bidegain}

1.1) Secretaría General: Titular: Leandro Maissonave ${ }^{199}$

1.2) Secretaría de Informaciones y Personal: Titular: Ramón Landajo

1.3) Secretaría Privada: Gloria Bidegain.

Asesor Superior de Gobierno: Daniel Vaca Narvaja ${ }^{200}$

Asesor: Antonio Elizagaray

1.4) Asesoría del Consejo Provincial de Desarrollo (ASPRODE): Titular: Rolando García Subjefe: Eduardo Visus ${ }^{201}$

Asesores: Héctor Oscar Méndez. Enrique Padilla. Guillermo Gutiérrez. ${ }^{202}$

1.5) Dirección de Defensa Civil: Carlos Raúl Villagra

1.6) Secretaría de Informaciones y Personal: Carlos Alberto Collarini ${ }^{203}$

${ }^{196}$ Entrevista de la autora a Babi Molina, La Plata (2014). Asimismo, el "Negro Kuto" Carlos Moreno fue Secretario de Carlos Negri en la Cámara Baja. A nivel nacional, la Tendencia logró hacerse con las diputaciones de Armando Croatto, Carlos Kunkel, Roberto Vidaña, Diego Muñiz Barreto, Jorge Glellel, Aníbal Iturrieta, Rodolfo Vittar, Roberto Vidaña y Santiago Díaz Ortíz, Nicolás Giménez, Juan M. Ramírez, Juana Romero, Nilda Garré y Enrique Sversek.

${ }^{197}$ El Dr. Ricardo Mariátegui fue nombrado Mtro. de Gobierno; el Cnel. Ademar Bidegain, sobrino del Gobernador, ocupó el mando de la Jefatura Policial; el Dr. Felipe Recchi estuvo a cargo de la Fiscalía del Estado y los contadores Juan Cardinal y Néstor Napoleón en el Directorio del Banco Provincia. Ver El Día, 26/05/1973, p. 7.

${ }^{198}$ Este listado se confeccionó en base a información recogida en entrevistas orales, trabajos periodísticos, documentos oficiales y los nombres detallados en la Solicitada "Descalabro en la Provincia" en la que más de 50 funcionarios de la TR hacen pública su renuncia al gobierno de la provincia de Buenos Aires, acompañando la salida de Oscar Bidegain en los últimos días de enero de 1974. Ver "Descalabro en la Provincia". El Descamisado, Año I, No 38 5/02/1974, p.30. CPM-FONDO DIPBA, Mesa "Referencia”, Carpeta Varios Legajo 16223 "Nomina de autoridades provinciales". Decretos varios del Boletín Oficial de la Provincia de Buenos Aires. La Plata. Hemeroteca de la Legislatura Bonaerense.

${ }^{199}$ Fue nombrado delegado por la rama juvenil en el CS del PJ en 1972. Si bien no tenía una militancia previa en grupos de la izquierda peronista, se alineó con la TR. Fue secuestrado y asesinado en Capital Federal, el 28 de marzo de 1975.

${ }^{200}$ Pareja de Gloria Bidegain, luego de la renuncia de Rolando García en agosto de 1973, Daniel Vaca Narvaja asumió como titular de ASPRODE. Junto a él, varias fuentes señalan a Habegger como asesor directo del Gobernador, aunque sin un cargo oficial. Entrevista a Flora Castro (2013). CPM - FONDO DIPBA. División Central de Documentación, registro y archivo. Mesa Referencia, Carpeta Varios, Legajo 16223 , caratulado "Nomina de autoridades provinciales".

${ }^{201}$ Miembro del grupo fundador de FURN en la Facultad de Ciencias Económicas de la UNLP.

${ }^{202}$ Militante de las FAP y director de la revista Antropología 3er Mundo, publicación vinculada a grupos de intelectuales y universitarios de la izquierda peronista a principios de los setenta. 
2) MINISTERIO DE GOBIERNO: Dr. Ricardo Mariátegui

2.1) Subsecretaría de Asuntos Municipales: Ernesto Jauretche ${ }^{204}$

Secretaria: María Casado.

Asesor: Rodolfo Ratti ${ }^{205}$

Inspectores: Hugo Fontenla, Juan C. Lorges. Raúl Busicco

2.2) Jefatura de Policía: Titular: Cnel. Ademar Bidegain

Sub Jefe de Policía: Julio Troxler ${ }^{206}$

2.3) Secretaría de Difusión y Turismo: Titular: Rubén Sergio Caletti207

Asesores: Juan Carlos Ferrari. Andrés Framini ${ }^{208}$

2.4) Radio Provincia: Gustavo Capdevila; Alfredo Oroz y Alfredo Moles

2.5) Servicio Correccional: Dr. Roberto Pettinato 209

Asesor: Ruben Capitanio ${ }^{210}$

\section{3) MINISTERIO DE ASUNTOS AGRARIOS: Ing. Guillermo Gallo Mendoza ${ }^{211}$}

3.1) Subsecretaría de Asuntos Agrarios: Lic. Alejandro Peyrou

3.1.1) Dirección de Relaciones y Difusión: Enrique Albistur

3.1.2) Dirección de Coordinación Agropecuaria: Ricardo Gerardi

3.1.3) Dirección General de Agricultura y Ganadería: Ing. Agr. Gastón Robles ${ }^{212}$

Dirección de Ganadería: Dr. Hugo Bacci

Subdirector: Dr. Kenneth Bar Bennett ${ }^{213}$

Asesores: Gabriel Belo Soler ${ }^{214}$, Carlos Miguel $^{215}$, Carlos Ramos.

\footnotetext{
${ }^{203}$ Militante de Montoneros (secuestrado-desaparecido el $1^{\circ}$ de septiembre de 1977).

${ }^{204}$ Fundador junto a Rodolfo Galimberti de JAEN (Juventudes Argentinas para la Emancipación Nacional), fue elegido delegado por la JP en la conducción del Partido Justicialista en 1972. Luego se incorporó a Montoneros. Su salida de la organización se produce en 1979, en el marco de las críticas a la "contraofensiva estratégica".

${ }^{205}$ Militante de Montoneros

${ }^{206}$ Militante histórico de la resistencia peronista, fue uno de los sobrevivientes de los fusilamientos de José León Suárez ordenados por la dictadura de Aramburu y Rojas en 1956. Participó junto al Mayor Bernardo Alberte de la corriente del Peronismo Revolucionario a finales de los años sesenta. Fue asesinado por escuadrones de la Triple A en septiembre de 1974.

207 Periodista, fue miembro del staff de Cristianismo y Revolución, publicación emblemática sobre el proceso de radicalización, peronización y lanzamiento de la lucha armada por parte de los jóvenes militantes cristianos a fines de los sesenta, ámbito en el cual se originó uno de los grupos fundadores de Montoneros.

${ }^{208}$ Secretario General del Gremio de Textiles, integró el Comando Táctico de la Resistencia Peronista junto a John William Cooke y otras figuras del sindicalismo combativo a fines de los años cincuenta. Fue candidato a Gobernador en la provincia de Buenos Aires en 1962, elecciones que ganó pero que fueron anuladas en el marco de la proscripción del peronismo. Junto a otros viejos sindicalistas del ala dura como Avelino Fernández, Dante Viel, Armando Cabo y Sebastián Borro apoyó a la JP-Montoneros, formando parte de la experiencia fallida del Partido Peronista Auténtico, y sufriendo la persecución de López Rega y la Triple A.

${ }^{209}$ Ver capitulo 7

210 Ver capítulo 7

${ }^{211}$ Ingeniero Agrónomo, fue militante de la Democracia Cristiana junto a Norberto Habegger, e integró el Consejo Tecnológico de Rolando García, participando también como asesor experto en la CGTA. Se incorporó a Montoneros a principios de los setenta. Ver capítulo 5

${ }^{212}$ Ingeniero Agrónomo de Tucumán. Militante de FAR y luego Montoneros. Él y su compañera, Flora Celia Pasatir fueron secuestrados en Campo de Mayo y desaparecidos el 5 de abril de 1976.

${ }^{213}$ Militante del grupo FURN - JP de La Plata

${ }^{214}$ Militante del grupo FURN - JP de La Plata
} 
3.1.4) Dirección de Economía Agraria: Director José Luis Cordeu

3.1.5) Dirección de Enseñanza Agraria: Director Pedro Krotsch

Subdirectora: Lic. Graciela Messina

4) MINISTERIO DE BIENESTAR SOCIAL: Dr. Floreal Antonio Ferrara ${ }^{216}$

4.1) Subsecretaría de Seguridad Social: María Esther Méndez de San Martin ${ }^{217}$ Secretaria: Mabel Maidana ${ }^{218}$

4.1.1) Dirección de Menores: Titular: Hugo Maldonado 219

Subdirector: Arturo Ibarra

Asesores: Eliseo Morales ${ }^{220}$ y Leopoldo Halperín

Subdirección de Educación de Menores: Patricio Ennis

Sanidad: Horacio Laguna

Subdirección de Institutos: Jorge Dellicostas

4.1.2) Dirección de Promoción y Desarrollo de la Comunidad: Flora Castro

Subdirector: Eduardo Flores ${ }^{221}$

4.1.3) Dirección de Servicios Sociales: Amalia Ramella 222

4.2) Instituto de Previsión Social: Titular: Jorge Pereyra ${ }^{223}$

Director: José Barthe

Directora: Marta Chiappe ${ }^{224}$

4.3) República de los Niños: Raúl Piñeyro ${ }^{225}$

5) MINISTERIO DE OBRAS PÚBLICAS: Ing. Alberto Alejandro González 226

5.1) Subsecretaría de Obras Públicas: Titular: Ing. Pablo Escolar 227

5.2) Subsecretaría de Urbanismo y Vivienda: Titular: Arq. Eduardo Raúl Casado 228

${ }^{215}$ Militante del grupo FURN - JP de La Plata, fue nombrado Director del Departamento Central de Planificación de la UNLP durante la gestión del Rector Agoglia en 1973. Participó como autor de las "Bases para una Nueva Universidad". Fue asesinado junto a Rodolfo Achem por un comando CNU en octubre de 1974.

${ }^{216}$ Ver capitulo 4

217 Ver capítulo 4.

${ }^{218}$ Comenzó su militancia revolucionaria en el GEL (Grupo Ejército de Liberación) de La Plata, ingresó a Montoneros en 1971, formando parte del armado de la Columna Sur en el Gran Buenos Aires bajo la dirección de Capuano Martínez. A principios de 1974, por disidencias con la conducción de Montoneros y FAR a raíz del asesinato de Rucci y el documento interno "mamotreto", se va de la organización y se incorpora a la JP-Lealtad.

${ }^{219}$ Dirigente de ATE La Plata, compañero de militancia de Gonzalo Cháves en la JTP-Montoneros.

${ }^{220}$ Fundador del Movimiento de Sacerdotes para el Tercer Mundo (MSTM) y predicador de la Teología de la Liberación en el norte del país, fue detenido por el gobierno dictatorial de A. Lanusse en 1972 dada su militancia peronista y el apoyo a los grupos armados. Luego de su liberación el 25 de mayo de 1973, su amistad con Norberto Habegger y Alejandro Mayol lo ubicaron de lleno en el trabajo con menores en la gobernación bonaerense.

${ }^{221}$ Militante de Montoneros

${ }^{222}$ Militante del grupo JP-FURN de La Plata

${ }^{223}$ Militante del grupo JP-FURN de La Plata

${ }^{224}$ Militante del grupo JP-FURN de La Plata

${ }^{225}$ Militante del grupo JP-FURN de La Plata

${ }^{226}$ Participó del CONADE y del CTMNJ dirigido por Rolando García. En su trayectoria se vinculó a grupos de las FAR, luego integrándose a Montoneros.

${ }^{227}$ Militante de Montoneros. Ver cap. 5

${ }^{228}$ Militante de Montoneros. 
5.3) Subsecretaria de Programación: Lic. Jorge Raúl Blanco ${ }^{229}$

Asesora: Marina Siri ${ }^{230}$

5.4) Secretaría General: Dr. Hugo Di Florio ${ }^{231}$

5.4.1) Dirección de Administración: Rubén Bambrilla

Subdirector: Alejandro Belardone

5.4.2) Dirección de Relaciones Públicas: José Tamarit

Subdirector: Ricardo Rubio ${ }^{232}$

5.4.3) Dirección de Laboratorio de Ensayo Materiales de Investigaciones Tecnológicas (LEMIT): Ing. Roberto Scordato 233

5.5) Entes Autárquicos:

Dirección de Vialidad: Mario Marcovich

Dirección de Energía (DEBA): Ing. Pablo Escolar (director interino)

Ing. Carlos Alberto Frutos

Asesores: Alberto Benamo y Roberto Pereyro

Asimismo, los dos restantes Ministerios (Educación y Economía) que no quedaron bajo la injerencia directa de la Tendencia, sí contaron con la participación de algunos de sus militantes en cargos de segunda línea. En Educación, fueron nombrados Leónidas Lamborghini (hasta agosto de 1973) y Alcira Argumedo en la Subsecretaría de Cultura, entidad que en la Dirección de Coordinación de Servicios Culturales contaba con el trabajo del ex cura tercermundista y amigo personal de Norberto Habegger, Alejandro Mayol (Pozzoni, 2015a). ${ }^{234}$

En el Ministerio de Economía, el Subsecretario de Hacienda fue José Kapeluznik, asesorado por Jorge Bellating, Juan Domingo Plaza y Juan Carlos Conocchiari, todos militantes de JP-Montoneros provenientes del núcleo FURN de La Plata (Amato y Bazán, 2008: 211). ${ }^{235}$

\footnotetext{
${ }^{229}$ Militante de Montoneros.

${ }^{230}$ Militante de Montoneros. Ver cap. 5

${ }^{231}$ Militante de Montoneros, integró el CTMNJ de Rolando García

${ }^{232}$ Militante de Montoneros, integró previamente el CTMNJ y fue responsable del área de prensa y difusión. Ver cap. 5

${ }^{233}$ Militante de Montoneros

${ }^{234}$ CPM - FONDO DIPBA. División Central de Documentación, registro y archivo. Mesa Referencia, Carpeta Varios, Legajo 16223, caratulado "Nomina de autoridades provinciales".

${ }^{235}$ CPM - FONDO DIPBA. División Central de Documentación, registro y archivo. Mesa Referencia, Carpeta Varios, Legajo 16223, caratulado "Nomina de autoridades provinciales". El resto del gabinete lo integraron dirigentes opositores a la línea de la Tendencia. Al mando de la cartera de Educación asumió Alberto Baldrich, cercano a los grupos de la derecha católica. En los años '70 participó como asesor y docente de la Escuela Superior de Conducción Política del Peronismo. Su postulación como Ministro de Educación bonaerense quedó en manos de Perón, en lugar del hombre que Bidegain quería para esa cartera: Rodolfo Agoglia, quien finalmente fue designado Rector Interventor de la UNLP en mayo de 1973 y sostuvo un estrecho vínculo institucional con los cuadros de la Tendencia en el gobierno provincial. Besoky, J.L (2015) y Chávez, F. (2003). En el Ministerio de Economía, asumió el Dr. Ramón Miralles, hombre de la CGE muy cercano a Gelbard y apoyado directamente por Perón para dar respaldo total a su
} 
Del conjunto heterogéneo de figuras y funciones arriba mencionadas, podemos reconocer la existencia de tres grupos más definidos de militantes de la TR que convergieron en la gestión provincial, lo que nos permite realizar, como señalan Osuna y Vicente (2017), una caracterización más precisa de este actor en su función ministerial y de las hibridaciones entre su militancia política y sus saberes profesionales.

En efecto, en cada uno de estos grupos puede observarse, más allá de sus diferencias de origen (grupos católicos posconciliares que se peronizan, peronistas que se radicalizan hacia la izquierda, jóvenes universitarios de clase media que se peronizan) un perfil común que reúne: a) una fuerte identidad política-revolucionaria y un compromiso militante muy marcado; b) una alta formación profesional y técnica puesta al servicio de una causa política, y c) una disposición temprana a intervenir en espacios institucionales, prefigurando así lo que sería un perfil de cuadros político-militantes-gubernamentales. ${ }^{236}$ El primero de esos grupos, el más numeroso, estuvo formado por el núcleo de militantes provenientes de la agrupación estudiantil peronista FURN, ligados directamente a la JP y al MRP de la ciudad de La Plata, Berisso y Ensenada. Este grupo que ocupó lugares importantes en los Ministerios de Asuntos Agrarios y Bienestar Social se caracterizó por la formulación previa en el ámbito universitario de proyectos de gobierno en diferentes áreas, como así también por el trabajo territorial en la zona (creación de Unidades Básicas) y la apuesta temprana por el trabajo político partidario y la disputa dentro de las estructuras del Movimiento. ${ }^{237}$

Un segundo grupo estuvo formado por los militantes montoneros que vinieron desde Capital Federal, muchos de los cuales habían previamente militado en las FAP en el grupo de los "oscuros" e ingresado a Montoneros a mediados de 1971, quienes también

programa económico. La escasa simpatía que Miralles despertó entre la izquierda peronista se hizo palpable el mismo día de su asunción, cuando al momento de la jura de ministros, columnas de la JP-Montoneros y FAR silbaron en su contra. Ver El Día, 26/05/1973, p. 7. Entrevista de la autora a Hugo Bacci (2012). Cabe señalar que ambos ministros permanecieron en sus cargos bajo el gobierno de Victorio Calabró, luego de la renuncia de Bidegain y de todos los cuadros de la TR en enero de 1974.

${ }^{236} \mathrm{El}$ fenómeno de las intersecciones entre el campo intelectual/profesional y el campo político no es un elemento exclusivo de esta experiencia, sino que se desarrolló como una de las características más típicas y distintivas de la época (Sigal, 1991; Terán, 1991). Al respecto, cabe señalar las similitudes con otros grupos de profesionales, por ejemplo los integrantes de la Asociación Gremial de Abogados, quienes no sólo experimentaron por esta misma época un proceso de profunda politización sino que además, comenzaron a reconocerse a sí mismos como “abogados peronistas comprometidos”, llegando a entender su profesión "como un instumento del ideal político", subordinando en algunos casos "la práctica defensista a la lógica de la política radicalizada” (Chama, 2016:119). En nuestro caso, podemos pensar que para la mayoría de los militantes de la Tendencia que ocuparon cargos en el Estado, la definición como militantes del peronismo revolucionario fue la central, anteponiéndose esta condición política a sus funciones profesionales y técnicas, que luego pusieron al servicio de esa causa.

237 Una muestra de las aspiraciones políticas y la proyección de gestión en el ámbito público por parte del grupo FURN se observa en el Documento Bases para la Nueva Universidad, analizado por LanteriMeschiany (2015) y Barletta (2018) 
tenían experiencia previa de militancia en ámbitos universitarios (Cátedras Nacionales, FANDEP), sindicales (CGTA) y profesionales (CTMNP y EPT), ocupando roles destacados en el Ministerios de Asuntos Agrarios, en Obras Públicas y en la Dirección de Menores de Ministerio de Bienestar Social provincial.

Por último, el grupo proveniente de la organización Descamisados, que reunía a militantes del mundo cristiano radicalizado con experiencias previas de trabajo social y territorial en villas miseria (alfabetización y organización comunitaria) y gremial (CGTA), inclinándose también por la línea de trabajo político e inserción en las estructuras del Movimiento.

De esta forma, al observar los lugares específicos que ocupó la TR en el gabinete provincial, junto a la trayectoria y círculos de sociabilidad política previa de muchos de sus militantes, podríamos inferir que detrás de la aspiración de ocupar puestos en el aparato estatal en función de la lucha que mantenían con la derecha político-sindical del Movimiento, se encontraba también - al menos para buena parte de los militantes que hicieron esta experiencia- la pretensión de plasmar un conjunto de programas y medidas de gestión de corte socializante, las cuales, más allá de su breve concreción, permitieron a muchos de sus ejecutores concebir su trabajo en el espacio institucional como una apuesta no reñida con los objetivos revolucionarios mayores, sino como una oportunidad central para cambiar las estructuras "desde adentro". Así lo expresan dos ex militantes de Montoneros que participaron del gobierno provincial:

\footnotetext{
"Nosotros estábamos muy de acuerdo con el trabajo político en la gobernación, con aprovechar esos espacios para generar políticas. Estaba la discusión de qué hacemos con estas estructuras ¿las combatimos o las cambiamos desde adentro? Y nosotros pensábamos que había que cambiarlas desde adentro, pero ésta no era la posición dominante en la organización". ${ }^{238}$
}

Esta consideración positiva, e incluso prioritaria de la contribución que, en su carácter de militantes, podían realizar ahora en la esfera gubernamental desarrollando políticas que venían pensando en sus recorridos previos, es reseñada por Hugo Bacci

“Antes del laburo en el Ministerio nosotros hicimos trabajo barrial en Altos de San Lorenzo y Los Hornos, es decir, repartíamos revistas, abrimos algunos locales antes del gobierno. Después sí tuvimos la oportunidad de participar desde el Estado haciendo

${ }^{238}$ Entrevista de la autora a Flora Castro, La Plata (2013) 
cosas por la gente (...) Ya desde la Universidad veníamos escribiendo sobre problemas nacionales, por ejemplo, en Veterinaria habíamos escrito en contra de la práctica de la Sociedad Rural y de los profesores al servicio de la oligarquí. Sacábamos una revista Patria y Pueblo y un boletín de la FURN sobre temas del país, y ahi escribíamos ideas que teníamos sobre cómo tenían que ser las cosas, que eran propuestas de gobierno. Así que fuimos con esa idea al ministerio... pero ojo, no se pensaba en eso para hacer carrera política como ahora, eso estaba mal visto, sino que se pensaba como una tarea importantísima para avanzar en la reconstrucción del Estado de cara a la liberación nacional. $^{239}$

Desde esta perspectiva, en los capítulos que siguen intentaremos complejizar la lectura presentada por algunos trabajos que, si bien dan cuenta de esta participación institucional, lo hacen mediante un enfoque que no habilita la ponderación concreta de experiencias de trabajo y proyectos políticos de transformación encarados por la TR en la gestión provincial; o cuyo análisis e interpretación se encuentra subordinado a la lógica instrumental que ubica la experiencia de gobierno solamente como un medio para fortalecer el proyecto armado.

A modo de ejemplo de estas interpretaciones, Servetto (2010) explica los conflictos de la interna peronista en las provincias como resultado de la "lucha por espacios de poder condensados en el aparato estatal", y de un enfrentamiento en términos discursivos sobre quien detentaba el monopolio de la identidad peronista: "la lucha se medía en términos morales: leales contra traidores...Aquí no se trató de un enfrentamiento entre dos proyectos; por el contrario, ambos sectores revelaron carecer de proyectos para orientar la acción estatal. Sus preocupaciones se limitaban a reclamar cargos y espacios de poder" (p. 202-203). ${ }^{240}$

En un sentido distinto, a partir de nuestras indagaciones propondremos una mirada renovada de la experiencia de la TR en el gobierno bonaerense, que apunte a considerar sustantivamente su participación en el Ministerio de Gobierno (área eminentemente política donde se juegan las relaciones con todo el entramado de intendencias de la provincia, y que además tiene a su cargo el control de las fuerzas de seguridad), en el Ministerio de Bienestar Social (espacio clave para la promoción de políticas sociales y construcción de poder popular), el de Asuntos Agrarios (ámbito de control de políticas ligadas a la distribución de la tierra y producción y comercialización de alimentos) y en

${ }^{239}$ Entrevista de la autora a Hugo Bacci, La Plata (2012).

${ }^{240}$ En esta misma línea se encuentra el libro de Reato (2008) y de Antúnez (2015). Una perspectiva similar a la nuestra puede encontrarse en el libro ya citado de Pozzoni (2017) 
el de Obras Públicas (esfera a cargo de programas de infraestructura y manejo de recursos sustanciales para el trabajo territorial-barrial) no como producto del azar o sólo como respuesta a la contienda con la derecha político-sindical, sino como una apuesta de militancia en espacios gubernamentales en los que se intentó desarrollar un conjunto de políticas promotoras de las condiciones para la liberación nacional y social.

Con relación a esto, y retomando las ideas presentadas en los capítulos precedentes, en las páginas que siguen intentaremos dar cuenta -a través de casos empíricos y experiencias concretas- de la existencia de dos lógicas de acción política que convivieron y se entrecruzaron, por momentos de manera tensionante, durante toda esta etapa de gobierno al interior de la TR.

Nos referimos, por un lado, a la continuidad de una lógica más ligada al objetivo estratégico de largo plazo y la lucha armada (que requería la conformación de un ejército y el mantenimiento de la estructura militar) aceptando la salida electoral como algo secundario, un medio para otros fines. Y, por otro lado, la presencia cada vez más notoria de una lógica vinculada a la vertiginosidad de la "llegada al gobierno" y la participación en el Estado. Esta lógica se expresó en la experiencia de gestión gubernamental que llevaron a cabo integrantes de la Tendencia y en sus proyectos concretos, implicando concepciones renovadoras sobre los sentidos de la revolución, la democracia y la "militancia en el Estado".

Al respecto, en el próximo capítulo reconstruiremos la experiencia concreta de participación política que llevaron a cabo militantes de la Tendencia en el Ministerio de Bienestar Social provincial, identificando la reelaboración y puesta en marcha de prácticas de trabajo político, social y territorial previas, junto a la implementación de proyectos de gestión encarados ahora desde el espacio institucional y en el marco de la perspectiva de construcción del "socialismo nacional". 


\section{CAPÍTULO IV: LA PARTICIPACIÓN DE LA TENDENCIA EN EL MINISTERIO DE BIENESTAR SOCIAL}

En los capítulos precedentes analizamos la apuesta electoral de la Tendencia con su participación en la reorganización del PJ, la elección de candidaturas y la campaña electoral. En ese proceso observamos no sólo las disputas con otros actores del Movimiento, sino también las ambivalencias y tensiones que esa apuesta generó a su interior. En este capítulo y en los siguientes, analizaremos ya con mayor profundidad la materialización de esa experiencia de gobierno a escala provincial, encarada por algunos grupos de la Tendencia con un perfil de militancia partidaria e institucional previa.

Al respecto, se analizarán las prácticas innovadoras de gestión pública y la ocupación de espacios institucionales significativos por parte de los miembros de la Tendencia en el Ministerio de Bienestar Social; prácticas que a su vez permiten reconocer la heterogeneidad de sentidos en torno al proyecto de construcción de la "patria socialista" sostenido por su joven militancia en el transcurso mismo de esa experiencia.

Por último, se analizará el impacto negativo que ciertos acontecimientos claves de la coyuntura política nacional (Ezeiza, renuncia de Héctor Cámpora) tuvieron en la gestión provincial de Bidegain -en particular en el Ministerio a cargo de Ferrara- y la pérdida de peso político de la Tendencia, avizorando las enormes dificultades que afrontarían ambos actores ante el definitivo giro de Perón a favor de los sectores ortodoxos del Movimiento.

\subsection{La llegada del Dr. Floreal Ferrara al Ministerio de Bienestar Social: "Un ministro revolucionario para una obra revolucionaria"}

Uno de los lazos que vinculan la figura del Dr. Floreal Ferrara con el peronismo revolucionario remite a su temprana y estrecha relación con el dirigente John William Cooke, con quien compartió su militancia en el Comando Superior Peronista a fines de los años '50 y principios de los '60. Otros vínculos significativos en esta adscripción, y por la misma época, fueron la amistad que entabló con los principales referentes del sindicalismo combativo en los años de la resistencia peronista, en los que Ferrara se desempeñó como asesor médico de obras sociales en distintos gremios del ala radical. Por su parte, y de forma paralela, fue su cargo como Profesor en la Cátedra de Medicina Preventiva y Salud Social en la Universidad Nacional de La Plata el espacio específico 
que lo vinculó con los jóvenes militantes de FURN-JP y desde allí su nombre fue sindicado a Bidegain para ocupar el cargo de Ministro de Bienestar Social en la provincia. $^{241}$

En una entrevista realizada en el año 2002, Ferrara describe con detalle las circunstancias en las que se dio su nombramiento en el gabinete y el estrecho vínculo que gestó con la organización Montoneros y los militantes de la JP en su paso por el gobierno:

\begin{abstract}
"Yo en el '73 soy ministro con Don Oscar Bidegain, ese extraordinario tipo que fue un héroe civil poco reconocido. Me sostenían los villeros y la organización montonera. Por eso a todos lados donde yo iba el grito era 'Ferrara montonero, Ferrara montonero'. Y yo no era montonero, pero pertenecía a ese grupo de la juventud y con gran honor de haber pertenecido a ese grupo. Y ese grupo me lleva de candidato. Don Oscar Bidegain nombra a todo el gabinete de ministros menos al de Bienestar Social, como se llamaba anteriormente el Ministerio de Salud. Me llama y me cita en el Hotel Provincial. Ahi me estaba esperando él con dos pibes, dos
\end{abstract}

${ }^{241} \mathrm{Hijo}$ de un obrero y dirigente sindical anarquista, Floreal Ferrara nació en la localidad bonaerense de Punta Alta en 1924. En 1943 se mudó a la ciudad de La Plata para estudiar la carrera de Medicina en la UNLP, obteniendo el título de grado en 1950 y de Especialista en Cardiología en 1953, y Experto en Salud y Desarrollo Económico Social en 1964 por la Facultad Ciencias Económicas (OEA-UBA). Amigo y discípulo de Ramón Carrillo, se identificó con el peronismo revolucionario a través de su amistad con John William Cooke, integrando el Comando Superior Peronista con una labor de denuncia del gobierno de Frondizi ante los acuerdos con los capitales extranjeros, la represión a las huelgas del frigorífico Lisandro de la Torre y de los petroleros de Mendoza, y la aplicación del Plan CONINTES, lo que lo llevó a realizar viajes por distintos países de América Latina. Como resultado de esta acción política, se vinculó también a un grupo de sindicalistas referentes de la resistencia peronista, gestando una relación muy cercana con Avelino Fernández, Sebastián Borro y Andrés Framini, a través de su labor de asesoría en los sindicatos sobre el manejo de las obras sociales, denunciando tempranamente la corrupción de ciertos dirigentes. Como resultado de esta trayectoria, hacia fines de los '60, participó de la experiencia de la CGTA y colaboró en grupos de capacitación técnica como el CTMNJ dentro del área de Salud. Acompañando esta militancia política, Ferrara se abocó a la tarea de desarrollar una concepción integral de la salud pública. En 1959, realizó junto a Milcíades Peña una encuesta sobre la salud mental en Argentina, en las ciudades de Buenos Aires, La Plata, Rosario, Córdoba y Tucumán; un trabajo pionero que sigue siendo recordado en el campo de la psiquiatría. Desde 1957, se desempeñó como docente de la cátedra Higiene y Medicina Social en la Facultad de Medicina de La Plata; y desde 1962, en la cátedra Medicina Preventiva y Social, hasta 1975, año en que fue cesanteado de su cargo de Profesor Titular por cuestiones políticas, siendo perseguido por los escuadrones de la Triple A. En los albores del golpe militar, una patota ingresó a su casa del barrio Las Quintas, en las afueras de La Plata, destrozando sus pertenencias e incendiando su biblioteca, lo que provocó una crisis cardíaca en su esposa, Dora Roggeri, quien fallece luego trágicamente. En dos oportunidades, 1973 y 1987, ocupó el cargo de Ministro de Salud en la provincia de Buenos Aires. En los años '90 reinició su carrera docente en la Universidad de San Martin y de Lomas de Zamora. Participó también de la fundación de la Central de Trabajadores Argentinos (CTA) con Víctor de Gennaro y German Abdala, y del Polo Social junto a Luis Farinello. En el año 2010 falleció de una afección cardíaca a los 85 años de edad. Ver Svampa (2010:59 y ss), Arrúa (2014), Biblioteca Nacional Mariano Moreno (Argentina), Departamento de Archivos, Fondo Floreal Ferrara (AR-BNMM-ARCH-FF). La relación entre Ferrara y los jóvenes de FURN-JP es señalada por varios de nuestros entrevistados. Por su parte, Alejandro Peyrou menciona a Ferrara como parte de las figuras que se postularon para cargos oficiales desde la organización Montoneros, dada su pertenencia al peronismo revolucionario y su participación en los equipos técnicos del peronismo. Carlos Flaskamp, militante de las FAR, destaca que a principios de los '70 Ferrara figuraba en una lista de médicos cercanos a las organizaciones guerrilleras con los cuales se podía contar en casos de emergencia. Ver Biografias del Peronismo Revolucionario: Floreal Ferrara http://www.robertobaschetti.com/biografia/.

https://www.pagina12.com.ar/diario/dialogos/subnotas/144143-46341-2010-04-19.html ¿Por qué Floreal Ferrara? Militante social de la salud", y https://www.pagina12.com.ar/diario/dialogos/21-144143-2010-0419.html "Entrevista inédita a Floreal Ferrara. La salud es la solución del conflicto". 
monto, y entonces me dice: "Acabo de leer su último libro y me parece muy importante para mi gobierno, pero más importantes son las preguntas que quieren hacerle estos dos muchachos". Uno de ellos me dice: “¿Vos estás dispuesto a seguir manteniendo una actitud revolucionaria en el gobierno como lo dice el libro?". "Totalmente, si es mi vida", le digo. El otro pibe me pregunta: “¿Sos capaz de defender tu pertenencia a nuestra organización?”. “Por supuesto”. Entonces Oscar Bidegain me dice: "Bueno, usted es el Ministro de Bienestar Social”. ${ }^{242}$

La escena retratada por Ferrara sobre su designación en el Ministerio da cuenta de varios elementos significativos para nuestra tesis. Por un lado, confirma la presencia sustantiva de integrantes de la organización Montoneros desde los primeros días de asunción del gobierno -y aún antes- no sólo acompañando al gobernador en los primeros pasos de su gestión sino participando directamente en la elección de su gabinete, de lo que se puede inferir la estrecha confianza que Bidegain había depositado en esos militantes.

Por otro lado, permite visualizar que la elección de esos funcionarios respondía a un criterio político-ideológico que era a la vez amplio y restrictivo: amplio en el sentido de que, tal como señala Ferrara, él no era un militante encuadrado orgánicamente en Montoneros ni en ninguna otra de las organizaciones armadas peronistas, sin embargo, su trayectoria política lo situaba dentro de ese espacio común y vasto de la Tendencia Revolucionaria en esa coyuntura. Y restrictivo en tanto su designación estaba supeditada a la identificación y compromiso con el cumplimiento de ciertas medidas y "actitudes revolucionarias" que debían mantenerse en la gestión gubernamental. Esto mismo deja entrever la presencia -en el imaginario de los cuadros de Montoneros- de una ambivalencia o "tensión productiva" (y no una dicotomía entre la que había que optar) entre la esfera institucional y los objetivos estratégicos mayores. Tensión que podía morigerarse si se garantizaba que los cargos ejecutivos quedaran en manos de dirigentes con probadas posiciones revolucionarias.

Acompañando a Ferrara en su labor estuvieron Norberto Habegger y Daniel Vaca Narvaja, quienes desde la gobernación asesoraban directamente a Bidegain y mantenían reuniones seguidas con el ministro, haciendo de nexo entre la organización, sus militantes-funcionarios/as y el gobierno. Junto a ellos dos, Flora Castro, militante del grupo originario de Descamisados, ocupó el cargo de Directora de Promoción y Desarrollo de la Comunidad, participando Amalia Ramella (militante de FURN-JP) y los curas tercermundistas Eliseo Morales y Rubén Capitanio en el área de Acción Social. También quien fuera compañero de militancia cristiana de Habegger, el ex cura

242 "La única salida es la revolución. Entrevista a Floreal Ferrara". La Pulseada, Año 1, № 3, junio 2002. Resaltado nuestro. El libro al que se hace referencia en la cita es Medicina de la comunidad, editado en 1971. 
Alejandro Mayol, lo hizo desde la Subsecretaría de Cultura para el área de Menores a cargo del Ministerio. Jorge Pereyra, militante de FURN/JP-Montoneros fue nombrado en la Secretaría de Previsión Social, mientras que Nora Peralta (fundadora de FURN en Veterinaria) y su esposo, Raúl Piñeyro (FURN Derecho/JP-Montoneros) estuvieron a cargo de la "República de los Niños", institución que a los pocos días de iniciado el gobierno quedó bajo el control del ejecutivo provincial como resultado de la ocupación del predio que efectuaron los militantes de la Tendencia.

Como sabemos, la modalidad de "las tomas" se extendió rápidamente durante los primeros días del gobierno peronista, tanto a nivel nacional como provincial. A continuación, nos detendremos en el análisis de algunos de estos episodios en la ciudad de La Plata, que tuvieron como protagonistas al Ministro de Bienestar Social y a los militantes y funcionarios/as de la Tendencia, como expresión del tipo de prácticas específicas que experimentaron durante la gestión estatal.

\subsubsection{La República de los Niños y el fenómeno de las tomas: cruce de tiempos y metodologías de acción política en el ámbito institucional}

Tal como han señalado diversos/as autores/as (Nievas, 1999; Abbattista y Ramírez, 2011; Svampa, 2003; Gordillo, 2001) una de las escenas que mejor condensan el clima de efervescencia popular que caracterizó los primeros días de la "primavera camporista" fue el fenómeno de las tomas.

Éste consistió en una "ola de ocupaciones" de diversos lugares de trabajo, principalmente aquellos vinculados a la administración pública, a lo largo de todo el país. Si bien los agentes y objetivos de las tomas, tal como veremos a continuación, fueron muy diversos, en su conjunto la metodología de acción directa que las caracterizaba se convirtió rápidamente en uno de los mayores desafíos que tuvo que afrontar el gobierno de Héctor Cámpora a nivel nacional.

En el epicentro de este fenómeno se encontraba ni más ni menos que la cuestión de la definición de las "formas válidas de intervención política" en el naciente gobierno democrático, en un momento en el que si bien ya se encontraba en vigencia el nuevo orden constitucional y representativo (legitimado por el voto popular) aún persistían fuertes componentes de la movilización popular y la acción insurreccional de la etapa inmediatamente anterior (Abbattista y Ramírez, 2011).

En definitiva, en el contexto de una sociedad altamente movilizada y con fuertes expectativas de cambio, las tomas representaron un enorme reto para el gobierno en su 
búsqueda por "encauzar" esas energías (las formas radicalizadas de la política) hacia mecanismos más tradicionales y/o previsibles de interacción y control (Svampa, 2003; Abbattista y Ramírez, 2011). Reto que se volvió mayor cuando esas prácticas fueron motorizadas por la militancia adscripta a la Tendencia que ahora formaba parte del gobierno, y visualizaba en ellas una herramienta eficaz para la construcción de la "patria socialista".

La gobernación de Bidegain no estuvo exenta del desafío que planteó este movimiento colectivo. Por el contrario, la ciudad de La Plata, capital de la provincia y sede de las autoridades provinciales se convirtió en el epicentro de una sucesión de tomas en hospitales, centros educativos, fábricas, radios, el teatro provincial y diversas reparticiones públicas, que pusieron de manifiesto el impulso y la fuerte disposición de la sociedad hacia una participación más activa en diversos ámbitos de su cotidianeidad. Apenas una semana de comenzado el gobierno, el domingo 3 de junio, se llevó a cabo la ocupación de la República de los Niños, dirigida por contingentes de la JP de La Plata, Berisso y Ensenada, quienes movilizaron en micros a miles de niños y jóvenes de las UB de la zona controladas por la Tendencia, junto a las recién creadas "Comisiones ProDefensa del triunfo" de la región. ${ }^{243}$

El objetivo de la toma, según sus protagonistas, era devolver el contenido social, cultural y cívico que en su momento había inspirado la creación del predio por parte de la Fundación Eva Perón, dejando sin efecto la concesión en manos privadas que hasta ese momento tenía la explotación del lugar. La ocupación serviría de vehículo para la intervención del Ministerio de Bienestar Social de la provincia, organismo que se haría cargo de la gestión del inmueble hasta su definitiva expropiación. ${ }^{244}$

Un dato no menor de la movilización es que, junto a la amplia militancia de base de la JP, participaron también funcionarios provinciales y dirigentes de la Tendencia, convocados

\footnotetext{
${ }^{243}$ El Día, 4/6/73, "Fueron ocupadas las instalaciones del País de los niños en Gonnet”. Desde su inauguración en noviembre de 1951, el nombre original del establecimiento fue República de los Niños. El predio comenzó a construirse dos años antes, en 1949, sobre las tierras expropiadas del «Swift Golf Club», propiedad de la Compañía frigorífica Swift de Berisso. A partir de los gobiernos militares de la Revolución Libertadora, en el año 1962 bajo la intervención del general Francisco Imaz, se cambió el nombre de República por el de "País de los Niños". Si bien el nombre República se vuelve a instalar con el retorno del peronismo al gobierno en 1973, en el diario El Día la siguen llamando "País de los Niños". Asimismo, durante la última dictadura militar, el predio pasó a estar en manos de la Municipalidad de La Plata, cuya explotación se otorgó a manos privadas, en este caso a la empresa Zanón que tenía la concesión del parque de diversiones Italpark. Finalmente, con la recuperación democrática en 1983 se votó a favor de la recuperación estatal de la República de los Niños bajo gestión municipal.

${ }^{244}$ Entrevista de la autora a Nora Peralta (2012) participante de la toma y compañera de Raúl Piñeyro, quien fue nombrado Interventor de la República de los Niños por el gobierno de Bidegain. El Día, 4/6/73, "Fueron ocupadas las instalaciones del País de los niños en Gonnet". Según la crónica del diario, más de 5000 personas participaron de esta toma.
} 
especialmente para concretar la ocupación y expropiación del predio. A tales efectos, se hicieron presentes la Subsecretaria de Seguridad Social, María Esther Méndez San Martín, acompañada por Flora Castro como Directora de Promoción y Desarrollo de la Comunidad, Amalia Ramella como Directora de Servicios Sociales, los diputados provinciales Carlos Negri y Héctor Moreda, el diputado nacional Carlos Kunkel, y el delegado de la Regional 1 de la JP Carlos Cafferata, quienes refrendaron el acta de ocupación. Incluso de la toma participó también la esposa del gobernador Bidegain, María Antonia Moro, aunque aclarando que lo hacía a título personal. Por último, Raúl Piñeyro, militante de JP-Montoneros La Plata fue nombrado su Interventor. ${ }^{245}$

En el comunicado que elaboraron los dirigentes de la JP explicando las razones de la toma mencionaban, entre otras, el mal estado de las instalaciones, las onerosas tarifas y la incongruencia que esto significaba para un predio que debía estar al servicio del pueblo y no del lucro.

Por su parte, se señalaba la continuidad de este tipo de acciones, dado que ellas representaban "el modo más eficaz de afianzar la participación popular en el futuro gobierno (siendo) la recuperación de la República una de las plataformas de lanzamiento de las Comisiones Pro-Defensa del triunfo constituidas para actuar mancomunadamente con las autoridades populares". ${ }^{246}$

Estas Comisiones, organizadas por la militancia barrial de la JP, se habían lanzado con el objetivo de actuar como puntos de apoyo, control y defensa del gobierno peronista a nivel local, canalizando asimismo las inquietudes de la población y ampliando las instancias de

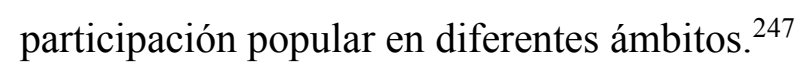

Esta iniciativa se desarrollaba en consonancia con el accionar de las recientemente creadas "Juntas Vecinales de Consumidores" (JUVECO), cuyo fin era apoyar la política de precios máximos fijada por el poder ejecutivo nacional en el marco del Pacto Social. ${ }^{248}$ En su despliegue, las JUVECO reunían a vecinos y vecinas de todos los barrios, quienes se organizaban para impedir las actividades de acaparamiento, especulación y artificial desabastecimiento promovido por algunos empresarios y miembros de la cadena de

${ }^{245}$ El Día, 4/6/73, "Fueron ocupadas las instalaciones del País de los niños en Gonnet”. Entrevista de la autora a Hugo Bacci (2012). Recordemos que Ferrara aún no había asumido formalmente al frente de Bienestar Social, por eso no participó de esta acción y sí otros/as funcionarios/as del Ministerio.

${ }^{246}$ Idem.

${ }^{247}$ Entrevista de la autora a Babi Molina (2014).

${ }^{248}$ Decreto del PE provincial, no 32/73. El Día, 2/6/73 "Fueron creadas en la provincia las Juntas Vecinales de Consumidores" 
comercialización, actuando a la vez como dispositivo inmediato de control de los precios máximos fijados por el gobierno. ${ }^{249}$

Más allá del alcance real y el accionar efectivo que lograron estas iniciativas (las Comisiones y las Juntas), lo que es difícil de estimar, cabe destacar que ambas gozaban del apoyo oficial, lo que expresaba el profundo activismo y movilización que atravesaba a importantes sectores de la sociedad y los intentos por parte de la TR de formalizar esa participación popular desde el Estado, a través de la creación de nuevas instancias y mecanismos institucionales que tendían a acortar las distancias entre "pueblo" y "gobierno".

Volviendo a la toma de la República de los Niños, finalmente, como resultado de la ocupación e intervención del predio, a los pocos días el acta de expropiación fue ratificada por un decreto del Poder Ejecutivo bonaerense que dispuso la caducidad de la concesión privada y la gestión provincial del inmueble por parte de funcionarios/as de la Tendencia (Abbattista y Ramírez, 2011).

Entre las actividades desarrolladas a partir de ese momento por los jóvenes ocupantes, en su mayoría militantes de JP y la UES, se destacan las tareas de reconstrucción, pintura y puesta en funcionamiento de los principales edificios y del tren que recorría el predio, junto a la organización de juegos, festivales y actividades totalmente gratuitas para los niños que asistían al comedor. Por otra parte, según el testimonio de varios/as militantes, existió también un repertorio de prácticas innovadoras, que se despliegan casi de manera improvisada al calor del vertiginoso proceso de tomas y asunción de la función pública, las cuales revelan en parte el contenido ideológico que guiaba el accionar de los militantes de la Tendencia en el Estado (contribuir a la construcción de la patria socialista) y la posibilidad, aún abierta, de implementar modalidades de gestión institucional alejadas de los parámetros tradicionales y jerárquicos

\footnotetext{
"Empezaron a llegar chicos de todos lados y se les daba de comer a todos. La plata se iba sacando de cualquier lado. En la República no teníamos un peso, no había presupuesto pautado, y bueno dijimos ¿qué hacemos? todos empezamos a socializar el sueldo. Los que trabajamos ahi decidimos que cobrábamos lo mismo, y había meses que ni cobraba porque
}

${ }^{249}$ En varias notas de El Descamisado se describen las tareas realizadas por estas Comisiones de control de precios y comercialización. Ver "Canasta familiar: Defenderse, movilizarse, no dejarse robar". $E l$ Descamisado, N $5,19 / 6 / 73$, p. 10. "Van a cobrar lo que Cámpora dijo, ni un peso más", El Descamisado, $\mathrm{N}^{\mathrm{o}} 3$, p. 5 . 
dejaba toda la plata para comprar cosas, alimentos para los pibes, materiales, la pintura, porque todos esos gastos no estaban dentro del presupuesto" 250

Como se observa, la toma de la República de los Niños constituyó uno de los eventos donde se expresaron las nuevas formas de intervención política de la militancia aglutinada en la Tendencia en esta coyuntura. En ella se materializaron los nuevos ritmos, metodologías y sentidos de la política puestos en juego por este actor, en los que la urgencia por llevar a cabo transformaciones de envergadura y poner fin al "continuismo" de la dictadura, se articulaba con prácticas de acción directa y una fuerte presencia del actor popular en la gestación de esas acciones y en el sentido de esos cambios. Todo esto bajo el paraguas de la participación institucional de sus militantes en el gobierno, quienes alentaban estas acciones como una forma de aportar y fortalecer el proyecto del "socialismo nacional". 251

En este sentido, podemos afirmar que estos episodios de acción colectiva permiten evidenciar los intentos por conjugar las "metodologías revolucionarias" con las nuevas funciones gubernamentales asumidas por los militantes de la TR, ampliando los límites de la democracia representativa otrora denostada, hacia nuevos horizontes de participación e intervención social.

Esta experiencia, no exenta de complejidades, desató todo tipo de voces detractoras desde sus primeros pasos, dentro mismo del gobierno peronista. El siguiente testimonio permite vislumbrar las tensiones que atravesaron los/as militantes de la TR durante este proceso, y su significado respecto del contenido y el sentido de la nueva etapa que se abría:

"Para nosotros era fundamental alentar la movilización popular, que la gente de los barrios y los villeros se involucren y participen directamente en las acciones del gobierno, porque era nuestra manera de llevar adelante un programa revolucionario, que no era distinto al del FreJuLi en lo programático, pero sí en la metodología ...todo eso se hizo evidente con la vuelta de Perón y la caída de Cámpora" 252

Si la toma de la República de los Niños puso en escena una de las modalidades de la “política revolucionaria" encarada por la Tendencia en la nueva etapa del gobierno

\footnotetext{
${ }^{250}$ Entrevista de la autora a Nora Peralta, La Plata (2012). La experiencia de la socialización de los sueldos también es comentada por Hugo Bacci. En el documento analizado en el capítulo anterior también se menciona la socialización de las dietas de los funcionarios y representantes de la JP.

251 Entrevista de la autora a "Cacho", militante de Montoneros (2016). Entrevista de la autora a Nora Peralta (2012), Hugo Bacci (2012) y Babi Molina (2014). También expresiones de este tipo pueden encontrarse en Jauretche (1997) y Perdía (1997).

${ }^{252}$ Entrevista de la autora a Nora Peralta, La Plata (2012).
} 
democrático, cabe señalar que existieron también otros casos de ocupaciones que, si bien no respondían tan claramente a un plan predefinido o a una dirección centralizada, reproducían también una lógica de acción directa, expresando la fuerte inclinación de las bases para intervenir en la cosa pública.

Este fue el caso de numerosas tomas realizadas durante los primeros días de junio por los trabajadores de hospitales, centros educativos y dependencias públicas, quienes ocuparon sus lugares de trabajo con el objetivo común de asegurar la efectiva salida de los funcionarios de la dictadura y apoyar a las nuevas autoridades nombradas por el gobierno popular de Oscar Bidegain, al que reconocían como propio (Abbattista y Ramírez, $2011){ }^{253}$

Como mencionamos más arriba, tanto la toma de la República como este otro tipo de ocupaciones, despertaron rápidamente las críticas de numerosos actores del campo político y económico, alarmados ante la falta de "orden" y el incumplimiento de los "procedimientos tradicionales" en la metodología de la acción política que estos episodios representaban. Así lo manifestaron en diversos comunicados la Cámara de Comercio e Industria de la ciudad de La Plata y la Federación Médica de la Provincia de Buenos Aires (FEMEBA), repudiando estos hechos que consideraban un peligroso precedente "que ponía en juego la vigencia del estado de derecho", en tanto desconocían "el acatamiento y respeto de las normas jurídicas en vigencia" y "exponían a la metodología de la acción directa a todo el cuerpo social y a sus órganos". 254

Pero también la gestión de Ferrara tuvo que afrontar esta modalidad de intervención política desde los sectores sindicales alineados con el vicegobernador Victorio Calabró. El 13 de junio, apenas tres días de asumido en el cargo, cerca de 2000 afiliados del Sindicato de Salud Pública de la Provincia (con representantes y delegaciones de toda la región) realizaron una manifestación al Ministerio de Bienestar Social con el objetivo de pedir al flamante ministro la adopción de medidas que asegurasen la efectiva participación de los trabajadores en la conducción de la política sanitaria oficial, por medio de los sindicatos. El reclamo concreto de los dirigentes sindicales era "el cogobierno del ministerio por parte de los trabajadores a través del sindicato, su órgano representativo”. Acompañando esta demanda, según la crónica periodística, expresaron

${ }^{253}$ Entre las reparticiones públicas que fueron producto de este tipo de tomas podemos mencionar el Hospital Neuropsiquiátrico Melchor Romero, el edificio del rectorado de la UNLP, DEBA, el Hospital de Niños, el Instituto de Seguridad Social de la provincia, varios Departamentos de la Facultad de Humanidades, el Hospital San Martín y el Colegio Nacional, entre otros.

${ }^{254}$ El Día , 6/06/1973 "La Cámara de Comercio critica la ocupación del País de los Niños", citada en Abbattista y Ramirez (2011). 
también su identidad partidaria peronista y su "lealtad incondicional hacia el líder de las mayorías Juan Domingo Perón", sin hacer referencias al gobernador Bidegain como había sucedido hasta el momento en las tomas precedentes. Al enterarse de esta presencia, el Ministro decidió salir a la calle a dialogar con los manifestantes. Desde las escalinatas del Ministerio, Ferrara agradeció la presencia de los trabajadores y realizó un racconto de las luchas populares que habían sido necesarias para que "el pueblo, por medio de sus representantes legítimos, retornara al ejercicio del poder”. Luego agregó que "esta revolución es de los pobres" y que para poder realizarla "ustedes tienen que defender mi jerarquía y apoyar los lineamientos trazados por una de las personalidades más rectas que tiene el peronismo en este momento: el gobernador doctor Oscar Bidegain”. Finalmente manifestó que se comprometía al cogobierno con los trabajadores y con todas las expresiones del pueblo, e invitó a los presentes a movilizarse a Ezeiza en los próximos días para recibir a Perón. ${ }^{255}$

Ante este intento de toma del Ministerio, que implicó la demostración de fuerza por parte de uno de los sindicatos que se definía abiertamente en contra de Bidegain y los sectores de la TR, resulta sugestivo el modo en que Ferrara intentó articular la demanda de mayor participación de los trabajadores sin plantear una polarización u antagonismo abierto con el actor sindical que sabía contrario a su línea política, apelando a la defensa de "su jerarquía" y la del propio gobernador como representantes legítimos de los intereses populares y de los trabajadores en el gobierno provincial (Abbattista y Ramírez, 2011).

Esta estrategia de no confrontación directa con el sindicalismo ortodoxo en la provincia, supo neutralizar momentáneamente el conflicto con una de las fuerzas que, como veremos más adelante, allanarían en muy poco tiempo el camino para la caída de Cámpora primero, y para la del propio Ferrara después.

\subsubsection{Experiencias innovadoras y/o ¿revolucionarias? en el área de salud, desarrollo social y minoridad}

\section{El ámbito de la salud}

Que la gestión de Ferrara se iniciara con medidas de este tipo llevadas a cabo por grupos de la TR, en las que la metodología de acción directa y el espíritu contestatario se ligaban de lleno con las formas de radicalización y movilización propias de la etapa anterior no resulta casual, en tanto coincidían con la concepción que el propio Ministro tenía sobre el

${ }^{255}$ La Gaceta, 13/6/73 “Concentración frente a Bienestar Social”, y El Día, 14/6/73 "Los agentes de Salud Pública expresaron su aspiración de poder coparticipar en la gestión del ministro de Bienestar Social”. 
trabajo en el área pública en salud y los mecanismos de la toma de decisiones en el ámbito institucional y social.

Ya desde los años '60 y a lo largo de su importante labor intelectual, Ferrara se destacó por sus postulados progresistas en el campo de la medicina comunitaria y por un enfoque multidisciplinar en torno a la atención de la salud. Estas ideas plasmadas en sus investigaciones implicaban una nueva forma de concebir la medicina en relación con disciplinas sociales como la sociología, la antropología y la psicología social. ${ }^{256}$

La propuesta se basaba en una crítica al concepto de adaptación en la definición de salud, privilegiando a la comunidad como centro de su organización. Podríamos decir que sus ideas giraban en torno a tres ejes: 1) La idea de atención médica integral comunitaria. En este punto, el centro estaba puesto en la idea de atención de la salud, no en la enfermedad (las endemias o epidemias) fundamentalmente a partir de una visión integral de la salud y el hombre (en tanto ser biológico, social, económico, etc.) que remite necesariamente para su estudio a lo multidisciplinar; 2) Esto desemboca en la conformación de equipos de salud interdisciplinarios en los establecimientos comunitarios, donde tanto el médico, el psicólogo, el antropólogo, el enfermero y el trabajador social ocupan un lugar destacado; y 3 ) La participación activa de la comunidad en la decisión de los programas de atención médica y la organización de la salud (Arrúa, 2014).

En coincidencia con estas nociones, una de las principales propuestas que intentó desplegar Ferrara en el área de salud bonaerense consistió en un novedoso plan de descentralización de la atención sanitaria, a través de la formación de Hospitales de comunidad y su instalación en barrios periféricos y zonas marginales de toda la provincia. Estas "pequeñas unidades de salud participativa" como él las llamaba, contarían con el trabajo de un equipo interdisciplinario de profesionales y trabajadores de la salud (médicos, antropólogos, psicólogos, enfermeros, trabajadores sociales) y con un consejo de la comunidad integrado por los habitantes de la región, que tendría intervención directa en la toma de decisiones y el manejo de la institución. ${ }^{257}$

Precisamente este aspecto de la organización comunitaria y la participación popular en todos los niveles de la atención médica "que implican tanto el trabajo, la planificación,

${ }^{256}$ Ferrara, F. (1965) "En torno al concepto de salud" en Revista de Salud Pública, La Plata, No 8. Ferrara, F. (1966) Desarrollo y bienestar argentino. La Plata, Renacimiento. Y Ferrara, F.; Acebal, E.; Paganini, J. (1971) Medicina de la comunidad. Buenos Aires, Intermédica.

${ }^{257}$ Ministerio de Bienestar Social. Subsecretaría de Salud Pública. Dirección de Atención Medica. Biblioteca Nacional Mariano Moreno (Argentina), Departamento de Archivos, Fondo Floreal Ferrara (AR-BNMM-ARCH-FF). 
la ejecución, la evaluación y el control de la acción sanitaria por parte del pueblo", ${ }^{258}$ constituían una pieza importante del programa que Ferrara venía diseñando para el área de Salud dentro del CTMNJ de Rolando García, considerando esta modalidad de funcionamiento horizontal y asambleario la mejor vía para contrarrestar el enorme proceso de desmantelamiento y burocratización que azotaba la atención hospitalaria en la provincia desde hacía 18 años atrás. Esta situación, según señaló el Ministro en conferencia de prensa el día mismo de su asunción, era "el producto directo del alejamiento durante años de los sectores populares del poder”, cuestión que sólo se revertiría "a través de la participación popular, que es sin duda la mejor manera de terminar con la burocratización de la democracia, e iniciar una democracia funcional y real", 259

Asimismo, esta dimensión participativa, popular y anti jerárquica que Ferrara caracterizaba como "una obra revolucionaria" estaba presente en otros campos de su plan de acción, por ejemplo, en la asignación y manejo de los recursos financieros necesarios para solucionar estos problemas, y en la prioridad de la atención pública por sobre la privada en las dedicaciones de los miembros de la corporación médica:

"La medicina privada será respetada pero no será la que más impulsaremos. La prioridad será el fortalecimiento de la atención pública y gratuita con una dedicación full time de los profesionales del hospital público...La reconstrucción nacional se hace con plata. Si logramos una reforma impositiva que ponga justicia en la redistribución de la riqueza en la provincia de Buenos Aires, tendremos el refuerzo necesario para solventar la penosa situación de los hospitales públicos. Además, contamos con la participación popular, no con dinero, pero sí con su trabajo, sus ideas y esfuerzo" 260

"El presupuesto puede ser una cosa para el gobierno de una oligarquía, pero es una cosa muy distinta para el gobierno del pueblo. Los padecimientos hospitalarios no se corrigen construyendo comedores para médicos y otras instalaciones superfluas. Nada se arreglará con tener tres grandes automóviles al servicio de cada funcionario, ni una legión de sirvientes para servirnos. En el gobierno popular se cuidará que la austeridad republicana sea cierta y esté al servicio de los más necesitados ",261

${ }^{258}$ El Día, 10/06/1973 “Asumió ayer el ministro de B. Social, Dr. Floreal Ferrara”. La Gaceta, 10/6/1973 "Ministro revolucionario para una obra revolucionaria". Ver Luis Bruschtein, entrevista a Floreal Ferrara http://www.pagina12.com.ar/2001/01-03/01-03-05/pag14.htm

${ }^{259}$ El Día, 10/06/1973. También La Prensa, 10/6/1973 y 25/07/1973. Ver “Bases para un programa peronista de gobierno, Salud/2", Consejo Tecnológico del Movimiento Nacional Justicialista, Buenos Aires, mayo de 1973.

${ }^{260}$ La Prensa, 25/7/1973 "Pasarán a jurisdicción provincial hospitales municipales bonaerenses"

${ }^{261}$ El Día, 25/7/1973. En relación con el tema, ya en la primera semana de gobierno se dispuso a través de un Decreto provincial (8899/67) la limitación del uso de automóviles oficiales y la puesta en venta de los vehículos sacados de circulación -más de 200-, con el fin de hacer efectivo el mandato de austeridad y utilizar los fondos recaudados para el equipamiento de nuevas ambulancias para los servicios asistenciales de la provincia. Ver El Día, 1/06/1973, p.7 
Este corrimiento de la institución médica como centro de las políticas del área, poniendo en su lugar a la salud como preocupación principal del Estado y a la comunidad con su organización y su acción, iban de la mano de otro de los ejes de la política sanitaria que se intentó desarrollar desde el Ministerio: el impulso y fortalecimiento del hospital público, a través de la unificación del sistema de atención médica en toda la provincia -en detrimento de la atención privada- y la propuesta de provincialización de los hospitales municipales. ${ }^{262}$

El vector de estas propuestas giraba en torno a la garantía por parte del Estado de la prestación gratuita de la salud a los sectores más desfavorecidos a través de la creación de un Seguro Social que garantizara una efectiva e igualitaria cobertura médica, desde la niñez hasta la ancianidad. Esta iniciativa sería acompañada por la creación de un Seguro Lácteo para todos los menores de 10 años, en especial para aquellos de las zonas de emergencia sanitaria, a través de la provisión de leche por el Estado provincial y nacional. ${ }^{263}$

Un punto substancial del programa de Ferrara -el que más controversias y a la vez expectativas despertó- fue su política de lucha contra el monopolio y extranjerización de la industria farmacéutica, "que nos va dar muchos dolores de cabeza, pero no debemos olvidar que forma parte del proceso de liberación nacional, porque ahi están las empresas multinacionales y los intereses internacionales", planteando como horizonte de mediano plazo la nacionalización de la producción y comercialización de medicamentos, lo que implicaba en la práctica una dura batalla contra los capitales extranjeros que controlaban el sector (Bustingorry, 2015). ${ }^{264}$ Para ello, el Ministerio firmó un convenio con la UNLP a fin de elaborar un proyecto conjunto que diseñara la implementación de una política nacional de medicamentos, propuesta que luego sería elevada a Nación. ${ }^{265}$

\footnotetext{
${ }^{262}$ La Gaceta, 24/7/73 "Pasarán a la provincia los hospitales municipales".

${ }^{263}$ El Día, 19/7/1973, “Una extensa visita al IOMA realizó el titular de B. social” y El Día, 25/07/1973 "Anunciose en la provincia un sistema unificado de servicios hospitalarios y la creación de un seguro social". Decreto No 3562/73, Poder Ejecutivo de la Provincia de Buenos Aires, en Barba, F. y Massey (1987:141). La implementación de la provincialización de los hospitales municipales se programaba para principios de 1974, una vez que el nuevo presupuesto así lo permitiera, junto con la construcción de dos nuevos establecimientos en La Matanza y Florencio Varela.

${ }^{264}$ El Día, 10/06/1973 “Asumió ayer el ministro de B. Social, Dr. Floreal Ferrara” y El Día, 25/07/1973 "Anunciose en la provincia un sistema unificado de servicios hospitalarios y la creación de un seguro social".

${ }^{265}$ La Opinión, 25/7/1973 "La situación sanitaria en Buenos Aires". La Nación, 25/7/1973 "Política sanitaria para Buenos Aires"
} 
Empero, esta política de corte estructural apenas si pudo llegar a plantearse, debido tanto a las duras resistencias que despertó en las corporaciones médicas como así también a la línea más reformista que desde el ámbito de Nación se emprendió para el área de medicamentos. ${ }^{266}$ En este último caso, la participación de Ferrara en la Comisión Nacional de Medicamentos duró un suspiro, a raíz del enfrentamiento con el Ministro de Bienestar Social de la Nación, José López Rega (Svampa, 2010:70; Bustingorry, 2015:89).

Como dijimos, los directivos de las entidades médicas más importantes de la provincia, la Federación Médica de Buenos Aires (FEMEBA) y la Agremiación Médica Platense (AMP) no ocultaron su descontento con la orientación del proyecto sanitario centrado en el hospital público y la participación popular impulsada por Ferrara. Las críticas se hicieron públicas ya desde los primeros días de iniciada su gestión, en contra de los nombramientos realizados en el marco de las tomas y de lo que consideraban la pérdida de autonomía del sector y una política "demagógica" a favor de las "clases proletarias" en detrimento de los intereses de los médicos. ${ }^{267}$

Esta tensión llegó a plasmarse en varios telegramas enviados a Bidegain, al propio Ferrara y a las presidencias de las Cámaras de Diputados y Senadores, en los que dichas entidades reclamaban la reincorporación de agentes médicos dejados de lado por razones políticas e ideológicas (aquellos que tenían vínculos directos con la dictadura militar), poniéndose en estado de alerta ante la situación de "caos" y asamblea permanente dentro de los hospitales. ${ }^{268}$

Por citar un ejemplo de esto, en el Hospital de Quilmes, las principales resistencias a las medidas de corte popular y participativo que allí se implementaron provinieron de los

266 Tanto en el documento Bases para un programa peronista de gobierno ya citado, como en el discurso de asunción de Oscar Bidegain, la política de nacionalización de la industria de medicamentos en todos sus niveles ocupó un lugar destacado. No obstante, a nivel nacional no se avanzó demasiado en ese sentido. Desde la Secretaría de Salud, al mando del Dr. Domingo Liotta, dependiente del Ministerio de Bienestar Social a cargo de López Rega, sí se sancionó en septiembre de 1974 la Ley No 20.748 del Sistema Nacional Integrado de Salud que, si bien reconocía como deber y garantía del Estado la financiación y responsabilidad de la prestación del servicio de salud para toda la población, no avanzaba específicamente en el área de la producción y comercialización nacional de medicamentos. Ver Di Tella (1983: 186) y Ierace (2013).

${ }^{267}$ Ya! Es tiempo del Pueblo. No 6, 3/08/1973 "Los Médicos contra el pueblo”, p 13

${ }^{268}$ El Día, 1/6/1973 “Solicitose la reincorporación de médicos separados de la función pública por razones ideológicas”, El Día 22/6/1973 “A los concursos de la carrera médico-hospitalaria refiriose FEMEBA”, El Día, 30/6/1973 "Dos asambleas realizará hoy la Fed. Médica de la Provincia”, La Opinión, 26/7/1973 "Alcances de las transformaciones en la estructura sanitaria bonaerense", El Día 16/08/73, "Diversas inquietudes gremiales planteó la Federación Médica a las autoridades provinciales", $L a$ Gaceta,16/8/1973“FEMEBA expuso sus criterios sobre la política sanitaria”. 
profesionales que ocupaban cargos jerárquicos y otros que integraban el Consejo Médico Asesor, quienes junto con las "Damas de Beneficencia" controlaban -hasta el 25 de mayo de 1973- la gestión interna y financiera del establecimiento. Luego de la asunción de Ferrara al frente del Ministerio, en una asamblea encabezada por los trabajadores del hospital, la Agrupación 17 de noviembre perteneciente a Sanidad y miembros de la JP, JTP y el Movimiento Villero, se decidió realizar la toma del establecimiento, nombrando nuevas autoridades y la conformación de una Mesa de Trabajo y Reconstrucción que llevaría adelante un programa de transformación de la atención sanitaria brindada a la comunidad. Parte de las medidas dispuestas por este nuevo órgano de gestión fueron: establecimiento de la gratuidad de la atención sanitaria y entrega de remedios a los pacientes (en contraposición a la atención paga y las prestaciones privadas vía mutuales que solían realizar los médicos en la gestión anterior); supresión de todos los aranceles en los consultorios externos y en internación; prohibición de que los médicos perciban en horarios de trabajo otros honorarios que no sean los que correspondían por su labor en el establecimiento público; disolución del Consejo Médico Asesor y reasignación de sus honorarios para el mejoramiento de la atención a los pacientes más necesitados; establecimiento de una guardia pediátrica permanente; eliminación de los intermediarios (alimentos, insumos, placas radiográficas, etc); uso del comedor gratuito por los familiares de los pacientes, etc. ${ }^{269}$

Este notable cambio en la atención del hospital fue destacado por varios pacientes y familiares de la comunidad, que fueron entrevistados por un semanario: “Antes no nos dejaban ni acercar a las camas, cobraban hasta la sopa y una radiografía salía más cara que en una clínica. Ahora nos atienden gratis y podemos las madres comer en el comedor, con los doctores". ${ }^{270}$

A propósito de esto, Ferrara recordaba el impacto que las nuevas formas de participación popular despertaban en los miembros jerárquicos de la corporación médica "se gobernaba por una asamblea ...el tema de la participación frecuentemente es tumultuoso. Vos ibas a los centros de salud y estaban los borrachos, los locos, los perros, los chicos. Estaban todos, era una asamblea peronista. Entonces eso es muy dificil de aceptar", ${ }^{271}$

\section{La subsecretaria de seguridad social y el trabajo con la comunidad}

\footnotetext{
${ }^{269}$ Ya! Es Tiempo de Pueblo, № 6, 3/8/1973" El pueblo definede su propia salud"

${ }^{270}$ Ya! Es Tiempo de Pueblo, No 6, 3/8/1973" El pueblo definede su propia salud"

271،La única salida es la revolución. Entrevista a Floreal Ferrara”. La Pulseada, Año 1, No 3, junio 2002
} 
El reconocimiento de la intervención popular como un elemento clave del proyecto de gestión que impulsó la TR desde el Ministerio se reflejó también en los programas encarados desde la Subsecretaría de Seguridad Social. Esta dependencia estuvo a cargo de María Esther Méndez San Martín, una mujer nombrada por Bidegain y ligada al peronismo histórico, quien, por su edad y trayectoria previa, podía -a primera vistaparecer poco adepta a conciliar con la impronta radicalizada de la juventud. ${ }^{272}$ No obstante, al igual que sucedió con el gobernador, su relación con los jóvenes militantes de Montoneros rápidamente se volvió muy estrecha. Al respecto, el relato de Mabel Maidana, integrante de Montoneros que ingresó a la Subsecretaría en mayo de 1973, permite conocer algunos aspectos más "políticos" de las funciones y el quehacer cotidiano en el Ministerio llevado a cabo por algunos/as militantes de la TR, y el vínculo gestado con aquellos/as funcionarios/as que no eran identificados a priori como parte de ese colectivo:

\begin{abstract}
"Yo estaba a cargo de una UBR que hacía trabajo territorial en Villa Montoro, bien en las afueras de La Plata, un barrio que tenía muchos paraguayos, a mí me encantaba estar con la gente, por eso la orga me manda a la Subsecretaria de Seguridad Social, como una especie de guardia rojo para vigilar a María Esther San Martin, mi rol era bien político, no técnico. Ella era peronista de una línea más tradicional, pero estuvo de acuerdo con lo que pensábamos y haciamos. Hasta terminó prestando su casa para reuniones de la conducción de la orga, reuniones muy importantes, o sea que su apoyo fue total, era una persona de confianza. $Y$ bueno, mi función entonces era ver qué pasaba ahí con la subsecretaria, atendía gente, veía que pasaba, que querían, derivaba, esa era mi tarea, ver qué firmaba, cómo lo firmaba, era aplicar el criterio político. ${ }^{273}$
\end{abstract}

Bajo la órbita de esta Subsecretaría estuvo la Dirección de Promoción y Desarrollo de la Comunidad a cargo de Flora Castro, junto a la Dirección de Servicios Sociales en manos de Amalia Ramella, encargadas de llevar adelante programas con un fuerte contenido participativo y social en el territorio.

Una de estas iniciativas fue el Proyecto de Formación de Centros de Promoción de la Comunidad. Dicho proyecto consistía en la creación de nuevos Centros Comunitarios en zonas rurales, barrios populares y villas miseria de toda la provincia, junto a la reconversión de los "viejos" centros heredados de la administración militar saliente. ${ }^{274}$ En

${ }^{272}$ Durante el primer peronismo, ocupó un lugar destacado primero en la Dirección de Asistencia Social (Ex Sociedad de Beneficencia) y luego en la Fundación Eva Perón, de quien su marido, el médico Armando Méndez San Martín, fue su Director General y posteriormente Ministro de Educación en 1950, sucediendo en el cargo a Oscar Ivanissevich.

${ }^{273}$ Entrevista de la autora a Mabel Maidana, La Plata (2014).

${ }^{274}$ De los 64 Centros de Promoción vigentes al inicio de la gestión de Bidegain, solamente 4 eran de gestión provincial directa, 30 se gestionaban en coordinación con los municipios y los 30 restantes estaban 
ellos trabajarían asistentes sociales, profesores y maestros, personal de maestranza y particularmente los habitantes del barrio y la comunidad.

Este programa buscaba fortalecer los mecanismos de participación directa de los sectores populares en la organización, administración y funcionamiento diario de esas instituciones sociales, dejando de lado las tradicionales prácticas paternalistas $\mathrm{y}$ fraudulentas que habrían caracterizado la política de beneficencia de la gestión anterior. $^{275}$

En la práctica, la concreción de estos centros sirvió para dar anclaje y reconocimiento institucional a las acciones asamblearias y a las demandas cooperativistas impulsadas por la militancia barrial y juvenil previa, de muy activa participación durante la campaña electoral y organizada formalmente a partir de mayo de 1973 a través del Movimiento Villero Peronista (MVP) (Camelli, 2018). ${ }^{276}$

Precisamente, una de las reivindicaciones más caras a la militancia villera, y que cobró impulso en la provincia a través del Programa de Centros Comunitarios, fue la política de radicación de villas, que consistía en el reconocimiento de derechos sobre las tierras donde se asentaban los villeros, y la posibilidad de mejoras en sus viviendas. Esta política planteaba tanto el rechazo a los programas previos de erradicación de las villas (que implicaban el traslado entero de la población) como el reconocimiento del trabajo y los esfuerzos realizados por cada una de las familias asentadas en esos barrios y sus viviendas (Camelli, 2018). ${ }^{277}$

Bajo el nombre de "Transformación villera por participación popular" se inició un Plan de Cooperativas de Construcción de Viviendas, elaborado juntamente con el MVP, e integrado por las familias villeras, quienes tendrían a su cargo las tareas de planificación, edificación y reconstrucción tanto del establecimiento público (el Centro Comunitario propiamente dicho) como de las viviendas populares. Los materiales eran aportados de

en manos de Instituciones Civiles Privadas tales como el Rotary Club o Instituciones Religiosas, que administraban directamente los fondos recibidos desde el gobierno provincial. Dirección de Promoción y Presupuesto. Ministerio de Bienestar Social. Proyecto Comunitario. Mayo-octubre de 1973. Materiales de archivo cedidos por Flora Castro.

${ }^{275}$ Entrevista de la autora a Flora Castro (2013). Entrevista de la autora a Mabel Maidana (2014).

${ }^{276} \mathrm{La}$ autora señala tres procesos convergentes en la formación del MVP en 1973. En principio, la experiencia organizativa de larga data con que contaba el sector villero al momento de creación del $M V P$; por otra parte, el final de la proscripción del peronismo, que permitió conjugar identidad política con militancia territorial en las villas; $y$, por último, la confluencia del sector villero con otros actores políticos como el MSTM y Montoneros en un momento del país de activa participación política (Camelli, 2018).

${ }^{277}$ El Día 11/7/1973 "Serán analizados los problemas de los villeros de la Provincia”. "Congreso Nacional Villero. Villeros Peronistas, unidos y organizados hacia la libración”, en El Descamisado, Año I, N²4, 30 de octubre de 1973, pág. 13. 
forma gratuita por la gobernación (a través del Ministerio de Obras Públicas), mientras que la mano de obra era aportada por la comunidad residente en las villas. ${ }^{278}$

De esta forma, como destaca Camelli (2018) se lograba dar respuesta a dos demandas sumamente importantes para la comunidad villera. Por un lado, se intentaba dar solución al problema del desempleo particularmente fuerte en este sector. Por otro, la construcción cooperativa de las viviendas permitía resolver el déficit habitacional que aquejaba desde siempre a muchos de sus miembros.

Así, la organización de los villeros en estas empresas populares estimulaba no sólo su participación directa en la resolución del problema urbano referente a sus barrios, sino que les brindaba un canal institucional directo para expresar sus reivindicaciones y negociar sus demandas en la esfera estatal.

Finalmente, un elemento no menor de esta política en términos de su contenido "revolucionario", era el hecho de que la propia organización cooperativa permitía contrarrestar las ganancias de las empresas constructoras capitalistas. De este modo, como señala Camelli (2018) se superaban las demandas sectoriales inherentes a las villas para enmarcarlas dentro de un proyecto político transformador de más amplio alcance en términos económicos y de la puja con el capital concentrado del sector inmoviliario.

En la conferencia de prensa que se realizó con motivo del lanzamiento de este programa, el Ministro Ferrara se refería en primer lugar al contenido participativo y popular de la iniciativa

\footnotetext{
"la intervención directa de los villeros en el gobierno del pueblo se hará mediante la formación de esas cooperativas de trabajo, que tienen por finalidad construir las viviendas que el pueblo reclama en las villas de emergencia, y asimismo defender el derecho que tiene cada trabajador a levantar su propia casa. Estas "empresas” estarán integradas, administradas y dirigidas por los propios villeros. Y el gobierno deberá aportar los elementos necesarios para su concreción" 279
}

En la conferencia se anunció además la conformación de una Coordinadora Interministerial integrada por las Subsecretarías del Ministerio de Asuntos Agrarios, de Obras Públicas y de Bienestar Social, encargada de accionar todo lo vinculado a este proyecto. Además, Flora Castro, Directora de Promoción y Desarrollo de la Comunidad

${ }^{278}$ Ya! Es Tiempo de Pueblo, № 10, "Organizados desde cada villa, cada manzana, cada pasillo", p. 10 y "Villeros Peronistas. Impulsar las empresas populares", p. 13.

${ }^{279}$ El Día, 18/7/1973 "Coparticipación de villeros en un programa de vivienda”. 
sería la encargada de articular directamente con los delegados y representantes del MVP. ${ }^{280}$

Muchas de las tareas que se desarrollaban en los Centros de Promoción y que eran impulsadas formalmente por los/las funcionarios/as de la Tendencia como parte de su política gubernamental, retomaban en parte y a una escala mayor, la experiencia previa de trabajo político que muchos/as de ellos/as habían desarrollado en el ámbito territorial o universitario, antes de integrarse formalmente a Montoneros, percibiendo ahora frente a la apertura de espacios institucionales la posibilidad de plasmar desde el Estado ciertas medidas y programas asociados a los objetivos de Reconstrucción y Liberación Nacional. Al respecto, resulta interesante para pensar ciertas líneas de continuidad en las trayectorias y prácticas de algunos/as militantes que participaron del gobierno de Bidegain, las impresiones que sobre esta experiencia de trabajo institucional nos brindan dos de sus protagonistas, quienes lejos de ver dicha apuesta como "reformista" o alejada de los objetivos revolucionarios de más largo alcance, la entendían como una instancia importante en el avance del proyecto de construcción de la "patria socialista":

\begin{abstract}
"La posibilidad de la apertura que se dio con el peronismo había que aprovecharla, ganar espacios en lo político, por eso no fue sólo con Bidegain, también Martínez Baca, Obregón Cano, Cepernic y otros con los que se intentó insertar y trabajar dentro de las estructuras de gobierno. Yo que habia trabajado mucho antes con la gente en el barrio, tenía mucha inserción en Villa Martelli, y cuando se forma el gobierno y hay posibilidades de trabajar, de tener cargos, Norberto me preguntó qué me gustaría hacer, y yo le dije algo relacionado con trabajo con las villas que era lo que yo hacía ... yo dije que sí porque lo que hicimos desde las bases lo podíamos hacer desde arriba"281
\end{abstract}

En el mismo sentido, Mabel Maidana, militante de Montoneros que también trabajó junto a Flora Castro en la Subsecretaria de Seguridad Social, señala la conexión entre diferentes espacios por los que transitaban los/as militantes de la Tendencia (el barrio/la organización/el Estado) articulando su experiencia de trabajo político-territorial con las funciones de gestión, y el lugar destacado de la organización en la línea de las políticas públicas que se implementaban y que "volvían a las bases"

\footnotetext{
${ }^{280}$ Ibid. Entrevista de la autora a Flora Castro, La Plata (2013). Ver también El Descamisado "Congreso Nacional Villero. Villeros Peronistas, unidos y organizados hacia la libración", Año I, N²4, 30 de octubre de 1973, pág. 13.

${ }^{281}$ Entrevista de la autora a Flora Castro (2013). Gran parte de las actividades de alfabetización y promoción de la comunidad que Castro desarrolló a partir de 1973 desde el Ministerio, retomaban la experiencia de trabajo barrial que venía realizando desde el año 1968 en Vicente López, como integrante de la Campaña de "Lucha Contra el Hambre" a cargo de la Comisión Católica Argentina. Este trabajo se ligaba de lleno con su militancia cristiana en vías de radicalización, primero en Acción Católica, y luego en la Democracia Cristiana, donde conoció a su futuro marido Norberto Habegger. Ver Diana, M. (2013:364).
} 
"A mi la orga, mi responsable el Tosco Ojea Quintana, me dice que tengo que ir al ministerio, después mi responsable pasa a ser el Hippie Alsogaray, y todos dependiamos de Habegger. Norberto tenía relación con Daniel Vaca Narvaja que se termina casando con Gloria Bidegain, y Norberto era el encargado de la conexión de la organización en la gobernación, Norberto estaba prácticamente siempre en la gobernación. Lo interesante además es que había acuerdos políticos con la dirección del ministerio que estaba en manos de Ferrara, y teníamos reuniones con él, iba Norberto también y se acordaban políticas, ver qué política, con qué dirección, había una participación real en las decisiones. Ferrara era un tipo muy abierto para eso. Y lo interesante es que había insumos para el trabajo barrial, yo llevaba recursos para la UBR que conducía, veíamos qué cosas necesitaba la gente, muy al estilo cubano. Es decir, se vinculaban las políticas públicas con la política nuestra y con el trabajo nuestro en el barrio, con la vida cotidiana en la UBR". ${ }^{282}$

Esta vinculación entre el trabajo territorial en las UB y las políticas públicas desarrolladas bajo la mediación de la Tendencia, es mencionado por otro entrevistado, quien subraya la circulación por diversos ámbitos propia de la experiencia de participación gubernamental de los/as militantes-funcionarios/as, articulando distintas formas de acción política en su vida laboral y cotidiana

"Yo acompañé como jefe de asesores a Floreal Ferrara en la provincia de Buenos Aires, pero todos seguíamos laburando en dos lugares, en el barrio y en el Ministerio. Eran 24hs de laburo, era un laburo frenético”. ${ }^{283}$

En este cruce entre política revolucionaria y gestión institucional que los testimonios permiten evidenciar, podemos identificar también -además de la circulación entre distintos espacios (el ministerio, el barrio, la organización)- la convergencia de distintas políticas que se van a fusionar en la experiencia concreta de gobierno. Es decir, una política pública "inspirada” en prácticas, sentidos y modos de construcción de la política territorial llevada a cabo previamente en las UBR, que luego bajo la órbita y los recursos del Ministerio, volvía transformada al barrio.

“Esa era nuestra política, bien de gestión popular y organización barrial. Era aplicar
conceptos básicos que se manejaban sobre politica social y que ya veníamos trabajando en los
barrios, teorizar no teorizábamos demasiado. No es que la orga bajaba un programa de
gestión institucional específico para el área de Acción Social. Si existió eso yo no lo vi, pero
había una atmósfera de ideas, un clima de ideas muy similar que no necesariamente tenías que
sentarte a discutirlo, más entre los que veníamos del peronismo se compartían ideas generales
sobre la política social y de distribución. Y estaba Ferrara que para nosotros era una garantía.

282 Entrevista de la autora a Mabel Maidana (2014)

${ }^{283}$ Entrevista a Leopoldo Halperín, CABA, 2008 (cedida por Alejandro Peyrou) 
Viendo como habían dejado todo en ese momento, teníamos más la idea de avanzar en la reconstrucción nacional" 284

En torno a este último punto que señala nuestra entrevistada, también en muchos testimonios de los/las militantes funcionarios/as aparece casi de manera solapada, la existencia de una tensión entre las temporalidades de la revolución (con sus propios ritmos, recursos y metodologías) y los tiempos y mecanismos inherentes a la acción cotidiana en el gobierno, bajo una dinámica estatal y burocrática que no siempre resultaba fácil de compatibilizar.

Precisamente, algo de este registro podemos encontrar en el mensaje que el propio Ferrara trazaba para su gestión el día mismo de su asunción:

"Tengo la felicidad de decir que voy a ser ministro de una revolución. A diferencia de las anteriores esta es una revolución que hace el pueblo, sin armas, con paz y con trabajo. $Y$ estamos seguros de que nuestras complicaciones, serán problemas coyunturales, porque en lo estructural no tenemos dudas. Sabemos perfectamente lo que quiere el país, porque seis millones de votos así lo expresan. El problema está en lo coyuntural, en resolver lo de hoy, lo urgente, lo urticante" 285

Esta tensión entre los objetivos de largo plazo y las urgencias y el tipo de tareas que son indispensables en la gestión gubernamental del día a día, la observaremos en el caso particular de la Dirección de Menores.

\section{El área de Menores:}

Dentro del Ministerio de Bienestar Social, gran parte de estas premuras y de lo contingente se vinculaba con la necesidad de aplicar una política específica para el área de Menores, sector que se encontraba en un estado de abandono y falta de asistencia de todo tipo. Al respecto, luego de asumir, Ferrara realizó una visita a varios Institutos de Menores de la provincia. Según las notas periodísticas que cubrieron el hecho, en la recorrida se encontraron elementos de castigo y tortura utilizados por parte del personal, lo que se sumaba a las condiciones pavorosas de hacinamiento y suciedad. En albergues con capacidad para 70 niños llegaban a residir 225 menores. Por otra parte, la falta de

${ }^{284}$ Entrevista de la autora a Mabel Maidana, La Plata (2014)

${ }^{285}$ El Día, 10/06/1973, p 3 y 7. Menciones similares en torno a los tiempos particulares de la gestión gubernamental y las tareas específicas que la función pública implicaba en el día a día, pueden observarse en el testimonio de Envar El Kadri en Anguita y Caparrós (2007 [1998]):364) y en el de Nicolás Casullo (2007 [1998]:371). 
asistencia sanitaria, alimenticia y educativa, según los diarios, eran realmente apremiantes. $^{286}$

Frente a esta situación tan acuciante, Ferrara nombró a cargo de esta Dirección como su Interventor a Hugo Maldonado, ex militante de las FAP “oscuros" y en ese momento Secretario General de ATE La Plata. ${ }^{287}$ Este nombramiento se realizó a pesar de las fuertes presiones que -incluso a punta de pistola- recibió el Ministro en su despacho por parte de algunos miembros de la derecha peronista que buscaban imponer hombres propios al frente de este área. Por el contrario, Ferrara designó a figuras ligadas a la Tendencia, como los curas tercermundistas Eliseo Morales y el ex sacerdote Eduardo Flores, ambos de relación muy cercana con Norberto Habegger y Flora Castro, y a Leopoldo Halperín quien había militado en el sector "oscuro" de las FAP junto al mencionado Maldonado. ${ }^{288}$

Al referirse al estado pavoroso y de emergencia en que se encontraban los establecimientos de menores y los niños residentes allí, Ferrara señaló "Todo esto es producto de la política que llevaron a cabo quienes no sintieron al país, al pueblo y a la niñez como propia. Esto es reflejo de un país ocupado 18 años por un ejército, esto es testimonio de un país que hay que liberar". 289

Desde dicha repartición se impulsó una política progresista en términos de prácticas de encierro, en coordinación con los funcionarios a cargo de la República de los Niños. Luego de que la gestión de ese predio quedara en manos del Ministerio de Bienestar Social, se puso en marcha un programa que se denominó "Recuperación para la Liberación Peronista" que permitía el traslado y la residencia de 23 menores en dicho establecimiento bajo un régimen de libertad y condiciones laxas de control y vigilancia. En el marco de este programa, se estipuló la realización de actividades de desarrollo psico-cultural, que incluían el aprendizaje de diversos oficios según los intereses de cada

\footnotetext{
${ }^{286}$ El Día, 19/6/1973 "A la política a emprenderse con relación a la minoridad aludió el ministro de B. Social" y El Día 30/6/1973 "Declaración de emergencia del Área de Menores".

${ }^{287}$ Boletín Oficial de la Provincia de Buenos Aires, Decreto n 353, 15/6/1973.

${ }^{288}$ Flora Castro y Floreal Ferrara dan cuenta de las presiones de personas de la derecha peronista por quedarse con el control de esta Dependencia en vistas a las posibilidades de realizar un manejo fraudulento de los recursos financieros. Svampa, M. (2010:74). Entrevista de la autora a Flora Castro, La Plata (2013). ${ }^{289}$ La Gaceta, 30/6/1973 "Menores debe ser declarado de emergencia provincial". Ferrara relata la conmoción del cura Eliseo Morales al constatar la situación de extrema vulnerabilidad de los menores y el abuso y animadversión de miembros de la derecha peronista por quedarse con el control de los Institutos: "Morales, que era un tipo respetadísimo, me decía: "Floreal, no se pueden contener estos hombres, no se pueden contener. Hay que sacarlos a todos. ¿Y cómo los vamos a sacar, nos van a hacer una revolución?”. Era así. En los hospitales fue así también, pelear por la apropiación de los negocios. Y había otra cosa abajo, más oscura (el abuso sexual) de los chicos y las chicas. Y bueno, me pareció una cosa muy dramática". Svampa, (2010:74)
} 
uno de los menores; la práctica de deportes con asesoramiento de profesionales; el desarrollo de un plan de alfabetización acelerada con ingreso a escuelas de enseñanza media o técnica, y la estimulación de la expresión en todas sus manifestaciones (arte, música, letras, etc). Este aspecto estuvo a cargo del ex cura Alejandro Mayol, encargado del área de Coordinación de Servicios Culturales de la Subsecretaría de Cultura que articulaba con Bienestar Social.

Como parte de la organización de esta política de integración social para los jóvenes y de apertura de los institutos de menores, se preveía la elección de delegados entre los mismos residentes, quienes tendrían la representatividad y actuarían de nexos entre la Dirección de Menores y la Dirección de la República de los Niños. En el marco de su estadía en el predio, los jóvenes además realizarían tareas de reparación, pintura y puesta en funcionamiento de oficinas y dependencias muy deterioradas. ${ }^{290}$

Acompañando esta experiencia de apertura de las instituciones de encierro, se llevó a cabo en articulación con el Ministerio de Asuntos Agrarios un programa de trabajo en tierras públicas que estaban bajo la Dirección de Menores. Allí se enseñarían diversas actividades ligadas a la horticultura, la ganadería y la lechería, con el doble objetivo de iniciar a los jóvenes en un oficio, y a su vez lograr un autoabastecimiento de alimentos evitando así la intermediación comercial. ${ }^{291}$

También en el marco de las políticas de la niñez, se realizaron dos iniciativas que, si bien se vinculaban con aspectos más recreativos y de entretenimiento, no obstante, contenían y recuperaban algunas reivindicaciones culturales muy significativas para los sectores más postergados. La primera consistió en un Programa de Turismo Infantil, realizado por la Dirección de Promoción y Asistencia a la Comunidad en coordinación con la Secretaría de Turismo a cargo de Sergio Caletti, en el que se brindaba de forma gratuita el traslado y la estadía para vacacionar en Chapadmalal durante una semana a más de 1000 niños de villas de emergencia del Gran Buenos Aires, otorgándoles también ropa, calzado, abrigo y asistencia sanitaria (Pozzoni, 2017). ${ }^{292}$

La segunda iniciativa tuvo lugar en el marco de los festejos por el día del niño. Instrumentando la política de intervención de la comunidad en la cosa pública, semanas

${ }^{290}$ Entrevista de la autora a Nora Peralta, La Plata (2012). El Día, 26/07/1973 "Menores tutelados residirán en la República de los Niños" y La Gaceta 26/7/1973, "Vivirán en el País de los Niños menores tutelados". El proyecto era una prueba piloto que se extendería luego hacia todos los institutos de menores de la Provincia. Los dos primeros contingentes llegaron desde Gonnet y Almirante Brown.

${ }^{291}$ Entrevista de la autora a Hugo Bacci, La Plata (2012). Barba, F. y De María, M. (1987:142). El Día, 25/7/1973, "Convenio entre Asuntos Agrarios y Bienestar Social por alimentos en hospitales e institutos".

${ }^{292}$ La Gaceta, 18/7/1973 "Vacaciones para niños de villas de emergencia”. Entrevista de la autora a Flora Castro, La Plata (2013). 
antes de la celebración que tuvo lugar los primeros días de agosto, funcionarios/as del Ministerio de Bienestar Social junto a militantes barriales de la Tendencia nucleados en distintas Unidades Básicas de la JP, convocaron a la gente de los barrios para que expresaran sus ideas sobre los festejos, de modo que estas demandas fueran luego canalizadas directamente a través del accionar del gobierno.

Entre las iniciativas reunidas, se decidió llevar a cabo una "Fiesta de la Infancia: Compañera Evita” en la República de los Niños, de la que participaron más de 15.000 menores provenientes de los institutos de menores de la provincia y de los barrios populares de La Plata, Berisso y Ensenada. Además del Gobernador Bidegain y el Ministro Ferrara, grupos de la JUP y la UES participaron de la jornada ayudando en la organización y traslado de los contingentes infantiles y asistiendo a las actividades recreativas tales como teatro de títeres, partidos de futbol, suelta de globos, reparto de golosinas y juguetes, paseo en el trencito, etc. ${ }^{293}$

Por último, también desde el área de Coordinación de la Subsecretaría de Cultura, que dependía formalmente del Ministerio de Educación, pero articulaba sus actividades con el Ministerio de Bienestar Social, se llevó a cabo un destacado "Plan de Movilización Cultural”. El mismo fue lanzado el 19 de julio en el Salón Dorado de la Gobernación, contando con la presencia de Bidegain, el Ministro de Educación Alberto Baldrich, el Ministro Floreal Ferrara y los funcionarios de la Subsecretaría de Cultura, Leónidas Lamborghini, Alcira Argumedo y Alejandro Mayol, entre otros.

El programa presentaba a la cultura como un elemento central para la liberación, elemento que debía expresarse a través de "la autogestión popular, anteponiendo esta participación descentralizada y con fuerte intervención desde las bases a la ejecución centralizada desde el mercado liberal extranjerizante". ${ }^{294}$

Bajo la idea de que en nuestras latitudes la opción en el terreno de la educación y la cultura pasaba por "coloniaje o liberación", se fomentaba la creación de Centros Culturales en los barrios, con el fin de generar polos de atracción cultural y de recreación de niños y adolescentes a través de diversas prácticas artísticas como el teatro, la música y las artes plásticas. En su plasmación, el programa apuntaba a la difusión de artistas bonaerenses en espacios no tradicionales del territorio provincial, como fábricas y clubes de barrio, con la idea de llevar el arte y la ciencia a los lugares de trabajo y desde el seno del pueblo mismo (Bustingorry, 2015:97).

${ }^{293}$ El Día, 6/8/1973 "Animados y muy concurridos actos hubo con motivo de la celebración del día del niño", La Gaceta, 5/8/1973 “Actos en el día del niño".

${ }^{294}$ La Gaceta, 20/7/1973 "Se puso en marcha el plan de movilización cultural" 
En el marco de este programa tuvo lugar también la experiencia del "Tren Cultural" que recorría los municipios más alejados de la provincia para exhibir teatro de títeres y proyectar películas y que, en articulación con el Ministerio de Bienestar Social, también realizaba tareas de vacunación y control odontológico (Pozzoni, 2017: 79). ${ }^{295}$

\subsection{Primeras voces de alarma: Ezeiza y la renuncia de Cámpora}

Las medidas arriba analizadas permiten dar cuenta de la existencia de un conjunto ambicioso de políticas con eje en la participación y organización de los sectores populares que los/as funcionarios/as de la TR intentaron llevar adelante desde los primeros días de gestión. No obstante, los alcances reales de su implementación deben medirse también a la luz de las fuertes presiones ejercidas en su contra luego de la llegada definitiva de Juan Domingo Perón al país.

Además de los conflictos desatados durante la campaña electoral y las acciones de fuerza - ya reseñadas- por parte de la derecha sindical para presionar a Ferrara a pocos días de su asunción, un hecho significativo de la trama política del enfrentamiento intra peronista en la provincia de Buenos Aires y antes de los sucesos de Ezeiza, se desarrolló el día 9 de junio en el acto que se realizó para recordar a los caídos de José León Suarez en 1956. Ese día el gobernador Bidegain acompañado por funcionarios de la Tendencia y una gran concurrencia de militantes de JP-Montoneros, rindieron homenaje a los militantes peronistas asesinados por la Revolución Libertadora. Del acto participaron también el General Raúl Tanco (sobreviviente de los fusilamientos), la viuda del coronel Juan José Valle y el dirigente sindical Oscar Framini. La ceremonia que transcurrió en horas de la tarde consistió en unas palabras de homenaje de los asistentes, acompañadas por una ofrenda floral llevada por el gobernador. No obstante, y a poco de empezar -según la crónica periodística- comenzaron a escucharse los cánticos rivales de la "Patria Socialista" vs la "Patria Peronista" entre las columnas mayoritarias de la JP- Montoneros y FAR enfrentadas a las de la Juventud Sindical Peronista (JSP) y de la Coordinadora de la Juventud Peronista de Vicente López, también partícipes del acto. Finalmente, luego de varios encontronazos y refriegas, los incidentes más graves de desataron cuando un grupo de la JSP comenzó a disparar a un grupo de militantes que levantaban una bandera de FAR y Montoneros (Bonasso, 2010:505). El saldo de estos episodios fue un muerto y

${ }^{295}$ El Día, 21/7/1973 "Fue puesto en marcha el Plan de Movilización Cultural bonaerense”. 
cinco personas heridas de bala. Según el diario El Día, la víctima fatal era un trabajador del sindicato de textiles, Aldo Rubén Romano. ${ }^{296}$

Las palabras del gobernador luego del tiroteo, pidiendo casi a modo de súplica la unidad de todos los peronistas, expresaban de manera notable la tensión política del momento y la profunda preocupación, a sólo diez días del retorno definitivo de Perón, ante la posible repetición de estos hechos de violencia. ${ }^{297}$

Precisamente con motivo de la organización del arribo inminente del líder justicialista, el gobernador Bidegain dispuso la creación de una Comisión Provincial de Recepción, a cargo del Secretario General de la Gobernación, Leandro Maissonave. Esta Comisión sería la encargada de coordinar juntamente con la Comisión Nacional de Recepción los preparativos del histórico acto. ${ }^{298}$ Es de destacar que a pesar de los intentos de Juan Manuel Abal Medina por garantizar un espacio de representación a la JP en dicha comisión, sus miembros fueron excluidos de la misma, quedando el control de ésta en manos del Ministerio de Bienestar Social de la Nación y miembros reconocidos de la derecha peronista como el Cnel. Jorge Osinde, Norma Kennedy y Alberto Brito Lima, además del Secretario General de la CGT, José Ignacio Rucci. Asimismo, Abal Medina, quien integraba la Comisión, fue excluido de las reuniones, sufriendo un dudoso accidente el día previo al regreso. La misma suerte corrió el Subjefe de la Policía Bonaerense, Julio Troxler, quien fue marginado completamente de la organización a pesar de que el acto central se realizaría en su jurisdicción (Perdía, 1997:167; Jauretche,1997:198; Amato y Bazán, 2008:215, Bonasso, 2010:513; Anguita-Caparrós, (2007 [1998]:108). ${ }^{299}$

${ }^{296}$ El Día, 11/6/1973 “Graves incidentes entre sectores antagónicos peronistas en José León Suárez. Hubo un muerto y cinco heridos"

${ }^{297}$ El Día, 10/6/1973 "Con la presencia del gobernador se honró a los muertos en los sucesos del 9 de junio de 1956" y El Día, 11/6/1973 "Graves incidentes entre sectores antagónicos peronistas en José León Suárez. Hubo un muerto y cinco heridos". Los mensajes del gobernador exhortando a la unidad, conciliación, pacificación y disciplinamiento de todos los peronistas se multiplicaron en los días subsiguientes, con motivo de la organización del acto multitudinario del 20 de junio. Ver El Día, 13/6/1973 "Bidegain envió un mensaje al pueblo de la provincia" y El Día, 19/6/1973 "Al pueblo de la provincia de Buenos Aires"

${ }^{298}$ El Día, 13/6/1973 "Al pueblo de la provincia de Buenos Aires. A las cuatro ramas del MNJ en la provincia".

${ }^{299}$ Dos días antes del arribo de Perón, en una reunión de la Comisión Organizadora, Norma Kennedy mantuvo una fuerte discusión con Troxler y Maissonave (representantes de la Comisión Provincial) al sostener la versión sobre un supuesto complot de la izquierda peronista para asesinar al líder justicialista. Asimismo, luego de ocurridos los hechos del 20 de junio, en un canal de televisión Kennedy ratificó estos dichos e hizo responsable directamente al Gobernador Bidegain de la seguridad del acto. Como respuestas a estas acusaciones el SubJefe de la Policía Bonaerense en conferencia de prensa dijo que en aquella reunión se había establecido que el área de responsabilidad de la Policía Bonaerense no abarcaba la zona del palco y sus adyacencias, jurisdicción que estaba reservada expresamente a la Comisión Nacional organizadora del acto. El Día, 28/6/1973, Amato y Bazán (2008: 216) 
Finalmente, el 20 de junio, el tan ansiado encuentro de Perón con sus seguidores se vio frustrado ante los hechos de violencia que marcaron a fuego ese trágico día y la historia del Movimiento Peronista de allí en más. Si bien los sucesos de aquella jornada han sido reconstruidos por una amplia bibliografía de variada interpretación, ${ }^{300}$ menos conocido es el impacto que estos hechos tuvieron en la trama política de la provincia de Buenos Aires y el inestable equilibrio gubernamental que desencadenó hacia adelante.

Al respecto, debemos mencionar primero el peligro que en el transcurso mismo de la jornada corrió el propio Bidegain junto a su mujer y otros funcionarios del gobierno (Ernesto Jauretche y el diputado nacional Carlos Kunkel) amenazados por grupos de la derecha peronista entre los que se encontraban custodios de Victorio Calabró, debiendo refugiarse de las balaceras durante varias horas en el Hotel Internacional y luego abandonando de urgencia el lugar en una avioneta provincial sin la autorización de la torre de control. Esta negativa daba cuenta del control que sectores de la derecha peronista habían logrado en puestos estratégicos durante aquella jornada (Bonasso, 2010:505; Amato y Bazán, 2008; Bustingorry, 2015).

Pese a estos hechos de notoria gravedad, sumado a las víctimas fatales que dejó el trágico episodio, ${ }^{301}$ las investigaciones que inmediatamente se llevaron a cabo desde el gobierno provincial encabezadas por el subjefe de la Policía Bonaerense, Julio Troxler (y que dieron como responsables directos al encargado de la seguridad del acto, Jorge Osinde, y los grupos que estaban bajo su órbita) fueron desestimadas completamente. ${ }^{302}$ Más aún,

${ }^{300} \mathrm{El}$ libro de Horacio Verbistky "Ezeiza" inaugura un abordaje sobre los hechos de violencia que sucedieron en las inmediaciones del aeropuerto de Ezeiza el 20 de junio de 1973. Allí la interpretación que se sostiene es que se trató de una "matanza organizada", una "masacre" planificada por la derecha peronista responsable de la organización del acto y de la seguridad en el palco. Esta interpretación canónica ha sido replicada por otros estudios (Bonasso, 1997; Anguita y Caparrós, 2007 [1998]; Gillespie, 1987; Flaskamp, 2002 ; entre otros). Por otra parte, en los últimos años han aparecido otras interpretaciones, menos extendidas, que cuestionan la utilización del término "masacre", y ponen el foco en la responsabilidad de la conducción de Montoneros al "exponer a personas inocentes" a la reacción de los sectores de derecha a cargo de la seguridad del acto. Esta perspectiva es sostenida por el artículo "Ezeiza, 20 de junio de 1973" de Samuel Amaral (2010). También en parte de la bibliografía testimonial puede rastrearse esa misma interpretación, como en el libro de Duzdevich, Raffoul y Bettanin (2015) y en los testimonios del artículo de Anchou (2012).

${ }^{301}$ Según los cálculos volcados en el libro de Verbitzky, las víctimas fatales fueron 13 en total, y alrededor de 350 los heridos. Sólo 73 de esos pudieron ser identificados. De ellos, más del cincuenta por ciento pertenecían a la columna Sur de Montoneros y FAR, quienes habían quedado atrapados en la balacera entre el palco y el hogar escuela. La JP de La Plata sufrió dos muertes directas: Raúl Obregoso y Antonio Quispe. Ver Amato y Bazán (2008: 229) y Carnagui (2016).

${ }^{302}$ Las investigaciones iniciadas por Troxler a pedido de Esteban Righi rápidamente fueron desestimadas, no pudiendo hacer valer los cargos esgrimidos contra el ex coronel Jorge Osinde y los grupos que estuvieron bajo su dirección (Juventud Sindical Peronista, el Comando de Organización, la Concentración Nacional Universitaria, la Alianza Libertadora Nacionalista y otros grupos independientes de la JP), siendo esto una muestra acabada de la debilidad política que ya por esos días comenzaba a tener el Presidente Héctor Cámpora y su núcleo más cercano de dirigentes, Bustingorry (2015:38). Por ese entonces, Osinde ocupaba el cargo de Subsecretario de Deportes de la Nación, dependiente del Ministerio de Bienestar Social 
en los días subsiguientes, las acusaciones públicas de figuras reconocidas de la derecha peronista culpando a la "juventud infiltrada" y al gobernador por tales incidentes fueron increscendo. Tal fue el caso de las declaraciones de Norma Kennedy en un canal de televisión acusando a Bidegain y al Ministro Ferrara de prestar automóviles oficiales para uso de francotiradores, a las que se sumaron las denuncias del diputado nacional Rodolfo Arce sobre supuestas armas pertenecientes a la Policía Bonaerense que habrían sido utilizadas en Ezeiza, ${ }^{303}$ y las palabras de Victorio Calabró el día 23 de junio en un acto en Arrecifes organizado por la UOM local, en donde el vicegobernador responsabilizó a "la extrema izquierda infiltrada en el movimiento" por lo sucedido en Ezeiza, señalando, además que

\begin{abstract}
"Después del discurso del General Perón, nadie tiene ya derecho a equivocarse, ya que la única doctrina que tiene el pueblo se llama justicialista (...) y que a los trotskistas y comunistas se los reconoce por el olor, por lo que ningún peronista se va a equivocar (...) Ahora todos saben perfectamente quienes son nuestros enemigos y todos los hombres que ocupamos un puesto dentro del gobierno debemos limpiar nuestro movimiento primero, el gobierno mismo, y después el país de esos infiltrados "304
\end{abstract}

Si bien estas acusaciones fueron respondidas inmediatamente por sucesivos comunicados de parte de la JP Regionales-Montoneros-FAR, el PJ de La Plata, la JP de La Plata, Berisso y Ensenada y otras agrupaciones, ${ }^{305}$ brindando muestras de apoyo unívocas a Bidegain y señalando a los verdaderos responsables de la "masacre", se hacía evidente que dichos mensajes no alcanzaban a revertir el tenso clima institucional del momento, y el durísimo golpe que en términos políticos no sólo los hechos de Ezeiza, sino sobre todo las palabras de Perón al día siguiente, significaron para la Tendencia.

En efecto, en su duro mensaje del día 21, el líder justicialista, alejado ya de las consignas revolucionarias del trasvasamiento generacional y el socialismo nacional, apuntó contra "los infiltrados del movimiento", aludiendo de esta manera a "los muchachos que

a cargo José López Rega, quien había delegado en él la seguridad del Acto de Ezeiza. Osinde permaneció en la Subsecretaría de Deportes hasta mayo de 1974, momento en que fue enviado como embajador a Paraguay (Besoky, 2016:292). Ver El Día, 28/06/1973 "Réplica del secretario Gral. de la gobernación Maissonave a dichos de Norma Kennedy".

303 El Día, 19/7/1973, "Se formularon aclaraciones en torno a la tenencia de armas de la policía bonaerense"

304 “Calabró responsabilizó a la extrema izquierda por los episodios de Ezeiza”. El Día, 24/06/1973, p. 3.

305 El Día, 26/6/1973 Solicitada: “Ante la masacre de Ezeiza” FAR y Montoneros. El Día, 23/6/1973 Solicitada: "El que ataca a un compañero se está pasando a las filas del enemigo" JP La Plata, Berisso y Ensenada, Comisiones Defensa del Triunfo, UES, JUP y Agrupaciones Gremiales Peronistas. En el mismo sentido se ubicó tambien la conferencia de prensa de los representantes de la JP Regionales junto a los diputados de la Tendencia Armando Croatto y Carlos Kunkel. El Descamisado, Año I, N 6. 26/06/1973 p. 6. 
levantan banderas revolucionarias". Era la primera vez que Perón hablaba públicamente de infiltrados que pretendían copar el Movimiento, lo que implicaba un áspero descargo que apuntaba la mayor responsabilidad de los hechos a la TR.

Además, en su discurso, la definición ideológica y doctrinaria que daba del Movimiento Peronista no dejaba lugar a dudas:

\begin{abstract}
"Nosotros somos justicialistas, levantamos una bandera tan distante de uno como de otro de los imperialismos dominantes (...) Los peronistas tenemos que retornar a la conducción de nuestro movimiento. No hay nuevos rótulos que califiquen a nuestra doctrina y a nuestra ideología. Somos lo que las veinte verdades peronistas dicen. No es gritando 'la vida por Perón' que se hace patria, sino manteniendo el credo por el cual luchamos",306
\end{abstract}

Por otra parte, y tomando las palabras que la derecha peronista solía utilizar para referirse a los militantes de la JP como “marxistas infiltrados en el Movimiento", lanzaba la siguiente advertencia:

"Los que ingenuamente creen que pueden copar nuestro movimiento o tomar el poder que el pueblo ha conquistado se equivocan. Por eso deseo advertir a los que intentan infiltrarse en los estamentos populares que por ese camino van mal (...) a los enemigos embozados, encubiertos o disimulados les aconsejo que cesen en sus intentos, porque cuando los pueblos agotan su paciencia hacen tronar el escarmiento". ${ }^{307}$

Así, sin hacer una sola referencia a la Comisión de Recepción Nacional encargada de la organización y seguridad del acto, el mensaje de Perón apuntaba directamente a la TR. Tal como señala Svampa (2003:404) aquel discurso "despejó de toda ambigüedad y estableció un corte, cuya sustancia difería notablemente de aquel que esperaban los sectores juveniles y las organizaciones armadas peronistas".

En ese contexto, las palabras del líder justicialista no hicieron más que agudizar las tensiones al interior de su Movimiento, dando vigor a los sectores de la derecha en su ofensiva por recuperar y acrecentar espacios de poder dentro del gobierno. Así, y como corolario de toda esta situación, las presiones cada vez más duras de José López Rega y la burocracia sindical dieron como resultado, el día 13 de julio, las renuncias del Presidente Héctor Cámpora y su vice Solano Lima, quedando el gobierno en manos de Raúl Lastiri, yerno de López Rega. ${ }^{308}$

\footnotetext{
${ }^{306}$ El Día, 22/6/1973 "No hay nuevos rótulos para nuestra doctrina ni para nuestra ideología, dijo Perón"

${ }^{307}$ Ibid. El Día, 23/6/1973 “Tuvo amplio eco político el mensaje que pronunció Perón”

${ }^{308}$ Además de Cámpora, renunciaron también el Ministro del Interior, Esteban Righi y el Ministro de Relaciones Exteriores, Juan Carlos Puig, ambos considerados el "ala izquierda" del gabinete nacional. En los días siguientes el avance decisivo de la derecha se efectivizó también en las remociones en el Consejo
} 
Como un mensaje premonitorio y hasta amenazador, dos días antes, el vicegobernador de Buenos Aires en declaraciones al diario Clarín durante un acto en la provincia de Corrientes sostenía que "estando Perón en el país nadie puede ser presidente de los argentinos más que él" y agregó que Cámpora "debe brindarle al Gral. Perón lo que le corresponde". La sugerencia directa para que Cámpora dimitiera iba acompañada también de una crítica solapada al Gobernador Bidegain al puntualizar que "hay mandatarios provinciales disfrazados de peronistas que también deben ser barridos", 309

Estas declaraciones de Calabró en Corrientes, fueron además refrendadas el día 12 en una reunión que mantuvo con representantes de la CGT regional y de las 62 Organizaciones, para coordinar las medidas de movilización del día siguiente, a fin de lograr la inmediata salida de Cámpora. ${ }^{310}$ Entre los conceptos que formuló en esa reunión, expresaba además que con la presidencia de Perón se solucionaría un gran problema de orden políticoideológico: "Negar y dudar que nuestro gobierno necesita una limpieza profunda sería de tontos. Darles obras de las que tiene Perón en sus manos a muchos de los gobernadores sería un pecado, porque serían ellos los que las llevarían a cabo con ideologías que no son justicialistas". ${ }^{111}$ Estas declaraciones van a concitar el apoyo de varios sectores sociales y políticos que se expresaron en esa dirección en comunicados y solicitadas los días siguientes. ${ }^{312}$

La renuncia de Cámpora y el peso de las acciones del aparato sindical en la provincia no hicieron más que agudizar el clima de inestabilidad en el gobierno y los rumores de dimisión de Bidegain. Esto se evidenció en la decisión de ambas Cámaras Legislativas de quedar en estado de sesión permanente ante una posible renuncia del gobernador y una hipotética intervención provincial.

Un nuevo alineamiento de fuerzas dentro de la rama política del peronismo bonaerense comenzaba así a perfilarse, en tanto muchos diputados y senadores del FREJULI a partir

Superior del Movimiento (con la salida de Abal Medina) y la paralización de la institucionalización, sumado a la incorporación de sectores juveniles de la derecha en detrimento de los de la TR. Besoky (2016:215)

${ }^{309}$ El Descamisado, Año I, N 9, 17/7/1973 “El 13 de julio”, p. 28. El Día, 13/7/1973 "El vicegobernador exhortó a movilizarse en apoyo de Perón" y 14/7/1973 "Recientes declaraciones del vicegobernador habrían hecho que se adelantara el proceso"

${ }^{310}$ El Día, 13/07/1973, "Dispuso estado de movilización el plenario de secretarios generales de la CGT regional".

${ }^{311}$ El Día, 13/7/1973 “El vicegobernador exhorto a movilizarse en apoyo de Perón”. Nava (2008).

${ }^{312}$ El Día, 14/7/1073 Solicitada: "Perón al gobierno y al poder". Entre quienes manifiestan su adhesión públicamente se encuentran las agrupaciones "Renovación” y "24 de febrero", "Agrupación Unidad del Movimiento Justicialista de La Plata", la CGT regional y el bloque de las "62 organizaciones"; varios legisladores del FREJULI (Arturo Ares, Justiniano, Atanasoff, Antonio Vives); la Agrupación "Mesa Ortodoxa" de la $3^{\text {a }}$ sección electoral; La Juventud Obrera Peronista sección 5ta., y la Unión de Trabajadores Gastronómicos; SUPE y otros. Nava (2008) 
de este momento dejaron de expresar su apoyo a Bidegain y comenzaron a respaldar a Calabró en sus críticas a la política del gobernador y los sectores de la TR, lo que iba en consonancia con el giro de Perón luego de Ezeiza. ${ }^{313}$

Frente a estos hechos de extrema gravedad institucional, la noche misma del viernes 13 de julio Bidegain dirigió un mensaje al pueblo la provincia de Buenos Aires en el que desmintió las versiones sobre su posible renuncia, reafirmando además sus muestras de lealtad incondicional hacia el conductor del Movimiento y su absoluta "identificación con la verticalidad de la conducción y el ideario del General Perón (...) una vez más declaro ante el pueblo de la provincia de Buenos Aires: con Perón todo, sin Perón, nada".314 Esta proclama de acatamiento a las directivas del líder y el tono pacificador de su mensaje fue repetido al día siguiente, en un improvisado discurso que el gobernador emitió frente a los contingentes de la JP-Montoneros y FAR que se movilizaron hasta la casa de gobierno para manifestarle su apoyo. ${ }^{315}$ Entre las agrupaciones que se congregaron durante la tarde del sábado 14 estaban presentes FURN, FAEP, JP-La Plata, JUP Regional La Plata, Agrupación no docente peronista de La Plata, UES, Unidad Básica de los Héroes de Trelew y Unidad Básica Luís Fernando Abal Medina. Además de las muestras de adhesión a Bidegain exhibidas en carteles y pancartas, no faltaron los cánticos críticos a las figuras de Rucci, López Rega, Osinde y Calabró. Asimismo, se leyeron mensajes de apoyo emitidos por la JP de Coronel Rosales, Punta Alta y Tres Arroyos, expresando su total apoyo a Cámpora “quien demostró ser el más leal de los leales, y el único que cumplió con los preceptos de la campaña electoral de 'Perón al poder'”, y al compañero Bidegain “quien fue el hombre designado por Perón en la provincia por su lealtad a la clase trabajadora y al socialismo nacional", 316

En los días subsiguientes, Bidegain continuó desmintiendo en declaraciones públicas los rumores de su renuncia y de conflictos con el vice. ${ }^{317}$

${ }^{313}$ La Gaceta, 28/7/1973 “Otras versiones sobre la situación en la Provincia”, y Clarín, 28/8/1973 "Se operarían cambios en el gobierno bonaerense"

${ }^{314}$ El Día, 13/7/1973 "Bidegain dirigió un mensaje al pueblo de la provincia de Buenos Aires".

${ }^{315}$ El Día, 14/07/1973 “Ante una concentración frente a la sede del poder ejecutivo hablo el Gobernador”. En un tramo del discurso, Bidegain expresa: "Compañeros: a Perón tenemos que ayudarlo, tenemos que apuntarlarlo, firmemente, reflexivamente, porque el jefe tiene que sortear la animosidad y el resquemor de aquellos que se sienten heridos en sus privilegios. Que esa colaboración que Perón espera de todos nosotros y de todo el pueblo, cualquiera fuese su militancia, sea constructiva, sea pacifica y solidaria, sea amistosa entre nosotros los que integramos el Frente Justicialista de Liberación y el Movimiento Nacional Peronista... Yo he dicho: con Perón todo; sin Perón nada. Y esa es la consigna. Estar con Perón no es solamente vivar su nombre, es seguir sus ideas, acompañarlo en la tarea, dar todo para que él triunfe". Ver CPM-DIPBA, Mesa DS, Varios, Legajo $N^{\circ} 851$

${ }^{316}$ Ibid. CPM-DIPBA, Mesa DS, Varios, Legajo $N^{\circ} 851$

${ }^{317}$ El Día, 18/07/1973 "El Gobernador desautorizó ayer versiones sobre su renuncia o una intervención a la Provincia". 
Si bien ese horizonte parecía disiparse momentáneamente, la salida de Cámpora de la presidencia y la constatación de que la TR era el único actor que se movilizaba en su apoyo -en un momento en el que Perón se recostaba sobre los grupos de la burocracia sindical y política y desautorizaba abiertamente a la juventud radicalizada - planteaban un panorama sumamente sombrío de cara a su poder y el lugar primordial de los funcionarios de la Tendencia en su gobierno. Los conflictos con el sector sindical en los meses venideros no harían más que agravar esa situación.

\subsection{La crisis de agosto}

Como mencionamos previamente, los episodios del 20 de junio y la caída de Cámpora repercutieron directamente en la provincia. Una primera muestra de esto fue la renuncia del Secretario General de la Gobernación, Leandro Maissonave, representante de la JP en el gobierno bonaerense. Su salida los últimos días del mes de julio estuvo vinculada directamente a las presiones que figuras de la derecha peronista realizaron en su contra, producto de las denuncias que Maissonave había dirigido hacia Jorge Osinde como responsable máximo del tiroteo en Ezeiza. ${ }^{318}$ Asimismo, la negativa de Perón a recibirlo en una audiencia en la residencia de Gaspar Campos, en un trato diametralmente opuesto al otorgado a Calabró, actuó como un detonante de su salida del gobierno. ${ }^{319}$

A nivel ministerial, la situación de inestabilidad y hostigamiento que comenzaron a transitar los/las funcionarios/as de la Tendencia fue increscendo. En el caso particular de Bienestar Social, los sucesivos atentados y hechos de violencia que sufrió Ferrara en su domicilio y en el Ministerio, volvieron casi insostenible su posición dentro del gobierno provincial. ${ }^{320}$

${ }^{318}$ El Día, 27/7/1973 "Renunció el Secretario Gral. de la Gobernación”. El Día, 28/07/1973 “Divergencias entre el gobernador y el vice”. Crónica, 28/7/197 "Crisis en la provincia: pese a desmentidos, más versiones". En todas estas notas periodísticas la salida de Maissonave sería una muestra de las conflictivas relaciones entre Bidegain y Calabró, lo que profundizaría las versiones de una inminente crisis ministerial y hasta una posible renuncia de Bidegain.

${ }^{319}$ El Día, 26/7/1973 “Victorio Calabró participó de una reunión con López Rega en Gaspar Campos”.

${ }^{320}$ Flora Castro relata que en varias oportunidades Ferrara junto a ella y a otros compañeros debieron salir corriendo del Ministerio debido a los recurrentes ataques y amenazas realizadas por miembros de la CNU. Entrevista a Flora Castro, op. cit. Carnagui (2016) analiza la relación directa entre la CNU y Calabró, producto de la animadversión mutua que sentían hacia Bidegain y su vínculo con la TR. Según este autor, cuadros de CNU pasaron directamente a ocupar cargos en la provincia una vez que Calabró asumió como gobernador. A los hechos arriba descriptos se sumaban las presiones a punto de pistola que personas ligadas a la derecha peronista realizaron en el despacho de Ferrara, a fin de lograr su nombramiento en la Dirección de Menores. También relata el propio Ferrara en una entrevista que su casa del barrio Las Quintas, en las afueras de La Plata, fue "visitada" varias veces por enviados de López Rega. Svampa, M. (2010:73). 
A este cuadro de vulnerabilidad hay que sumar el hecho, no menor, de que el área específica de salud y bienestar social bonaerense mantenía una relación muy conflictiva con su par de nación, en manos de José López Rega.

En efecto, ya en la primera reunión de Ministros del área de salud de todo el país realizada en el Hotel Savoy, Ferrara escuchó como Isabel Perón se refería a él como el "ministro trosko", debiendo salir raudamente del lugar frente a la intimidación recibida por los custodios de López Rega. ${ }^{321}$

Otro episodio grave que retrata las presiones desestabilizadoras que enfrentaron Ferrara y los militantes de la Tendencia fue la ocupación de la sede de la Zona Sanitaria VIII (Mar del Plata) por integrantes de la Juventud Sindical Peronista (JSP), Comando de la Resistencia Peronista (CRP) y Comando de Organización Peronista $(\mathrm{CdeO})$ el día 8 de agosto, con el objetivo declarado de "frenar la infiltración marxista en dependencias provinciales", haciendo responsables directamente de esos hechos al Gobernador de la provincia, al Ministro Ferrara y al Subjefe de la Policía bonaerense, Julio Troxler. Esta medida de fuerza contó además con el aval de los dirigentes de la CGT local, quienes exigieron la renuncia del director-interventor Dr. Andrés Cabo -nombrado por Ferrara-, alegando que en dicha repartición sanitaria "no se manejaban asuntos vinculados con el rubro salubridad, y sí muchas actitudes y prácticas extranjerizantes”. A raíz de la toma, cuatro dirigentes de estas organizaciones fueron detenidos por los disturbios que ocasionaron, lo que provocó el llamado a un "estado de alerta" por parte de la regional de trabajadores y la convocatoria a un paro general de no mediar la liberación inmediata de los detenidos. El conflicto terminó finalmente con la destitución del Interventor Andrés Cabo y la liberación de los ocupantes, en un hecho que marcaba la difícil situación política y los límites concretos que la TR comenzaba a experimentar dentro del gobierno en esa coyuntura (Bustingorry, 2015:90). ${ }^{322}$

\footnotetext{
${ }^{321}$ En el libro de Maristella Svampa (2010) Ferrara describe una escena por demás elocuente del grado de impunidad y violencia con el que se manejaban López Rega y sus allegados en el Ministerio: "Fui una vez al Ministerio de Bienestar Social, ;y sali horrorizado! ¡Era una cosa de locos, estaban las armas a la vista! La Triple A ejercía sobre nosotros una influencia realmente nefasta. Me acuerdo que yo voy a la primera reunión de ministros (de Bienestar Social): está Isabel en el centro; está López Rega al lado mío y yo como ministro de la primera provincia, más allá la Tacta de Romero que era la ministra de Bienestar Social de Corrientes. E Isabel pregunta: “Ché, ¿cuál es el trotsko? ¡YY yo estaba ahi!! ¡Era yo! Y en ese momento veo entrar corriendo a mi chofer que era un tipo formidablemente amigo y me dice: "vamos doctor, ni me pregunte, vamos! Y me arrancó de la mesa, lo van a matar, lo van a matar, jtírese al auto!" Y me pegaron en el techo... iEn la primera reunión nacional de Ministros de Bienestar Social en el Hotel Savoy! (Svampa, 2010:72)

${ }^{322}$ El Día, 10/8/1973 "La ocupación de un organismo sanitario marplatense derivó en una situación conflictiva" y 11/08/1973 "Fue aceptada la renuncia del interventor de la zona sanitaria de Mar del Plata"
} 
El desencadenante último en el clímax de tensión que se desarrolló con el sindicalismo se dio también a principios de agosto, a raíz de un atentado que sufrió el diputado provincial y Secretario General de la CGT regional La Plata, Rubén Diéguez, quien además era un estrecho colaborador del vicegobernador.

Según las crónicas periodísticas, Diéguez fue herido de bala en una pierna a raíz de un confuso episodio que el sector sindical presentó como un atentado atribuido directamente a los grupos de "infiltrados" dentro del Movimiento. ${ }^{323}$ Cabe destacar que el propio Ministro de Trabajo de la Nación, Ricardo Otero se hizo presente en el domicilio de Diéguez junto a Calabró, dirigiendo severas críticas hacia el Gobernador Bidegain, señalándolo como "máximo responsable de encontrar y condenar a los culpables". 324

En respuesta a estas acusaciones, se publicó una solicitada titulada "La conspiración en marcha: Diéguez simula el atentado”, firmada por la JP de La Plata, Berisso y Ensenada; Miembros de la Junta del PJ de La Plata; Comisiones de Defensa del triunfo y Consejo de Unidades Básicas (La Plata, Berisso y Ensenada); JTP; Agrupaciones Gremiales Peronistas; JUP La Plata; JUP Mar del Plata -Bahía Blanca; UES La Plata; UES Mar del Plata -Bahía Blanca; Consejo provisorio de la Juventud Peronista de la Provincia de Buenos Aires, en la cual se desmentían las denuncias y se calificaba el episodio como un “autoatentado", perpetrado por el mismo Diéguez, Calabró y la CGT en connivencia con las patronales para desestabilizar al gobierno popular de Oscar Bidegain. ${ }^{325}$

No obstante estas declaraciones, las palabras emitidas por el Ministro Otero y las acciones del propio Calabró dieron lugar a una campaña de persecución ideológica contra los militantes de la Tendencia en la administración provincial, campaña que nuevamente

${ }^{323}$ El Día, 2/8/1973 "Atentaron contra el secretario de la CGT local. Paro por 24hs en La Plata, Berisso y Ensenada". Detalles de lo que habría sido este "autoatentado" de Diéguez, según la denuncia de la TR, se pueden encontrar en la nota publicada en la Revista Ya! Es tiempo de Pueblo, N 9, 24/8/1973, "Buenos Aires: se cierra el cerco", p. 10-11.

${ }^{324}$ El Día, 2/8/1973 "El titular de Trabajo, Sr. Otero visitó al dirigente herido y formuló severas declaraciones". Otero, en declaraciones a la prensa luego de visitar a Diéguez, señaló que: "esto se investigará hasta las últimas instancias y los culpables tendrán el castigo que se merecen, quiero señalar que es el gobierno, y en el caso del atentado contra Diéguez, el gobernador, quien debe arbitrar las medidas necesarias para garantizar las vidas de los habitantes y mas aún de las personas expuestas a estas contingencias", agregando que "esto no se arregla con custodias personales, sino con medidas de fondo que el gobierno debe adoptar sin demoras". A su vez, el mismo Diéguez en una entrevista acusó y responsabilizó de este hecho al gobierno provincial, ya que para éste el atentado "no constituye un hecho aislado, sino que es la consecuencia de una permanente deformación de lo que viene efectuando el Poder Ejecutivo provincial en cuanto a la política a seguir". Por su parte, el dirigente sindical Antonio Balcedo fue quien más lejos llegó en el ataque a Bidegain, al declarar públicamente que “el gobernador tendría que renunciar a su cargo (porque) no puede ni debe desconocer que desde importantes áreas de su propio gobierno se ataca a los hombres del movimiento obrero, inclusive a los que integran el Movimiento justicialista Nacional". El Día, 2/8/1973 "Múltiples expresiones de repudio" y "Formuló declaraciones el Sr. Rubén Diéguez”. El Día, 4/8/1973 “Las dos Cámaras Legislativas repudiaron ayer el atentado contra R. Diéguez".

${ }^{325}$ El Día, 3/8/1973. Solicitada "La conspiración en marcha: Diéguez simula el atentado" 
ponía el foco en la "inminente” renuncia del gobernador y una posible intervención federal. ${ }^{326}$

Si bien estas presiones no tuvieron ese desenlace en lo inmediato, sí obligaron a Bidegain a realizar una reestructuración de su gabinete, en el que Ferrara ya no contaba con un lugar. $^{327}$

En un principio, las maniobras desestabilizadoras tuvieron como resultado la puesta a disposición de Bidegain de las renuncias de todos los miembros de su gabinete. No obstante, las que finalmente resultaron efectivas fueron las del Ministro de Bienestar Social, Floreal Ferrara; el Subjefe de la Policía Bonaerense, Julio Troxler; el titular de la Asesoría Provincial de Desarrollo, Rolando García ${ }^{328}$ y el Subsecretario de Cultura, Leónidas Lamborghini, ${ }^{329}$ todas figuras ligadas a la Tendencia. También acompañaron

${ }^{326}$ Incluso en varias notas periodísticas se menciona el abordaje de este enfrentamiento en altas esferas del gobierno nacional, dado el grave nivel de conflictividad política que acarreaba. Allí se menciona una reunión que habrían mantenido Bidegain y Calabró con Benito Llambí (Ministro del Interior) y el titular de la SIDE Brigadier ( $\mathrm{Re}$ ) Alberto Morello. Éste último sería quien habría aportado pruebas de "la infiltración marxista en el gobierno bonaerense". En estos informes se sindicaba como "agentes infiltrados" a los ministros de Obras Públicas, Asuntos Agrarios y Bienestar Social, y a Julio Troxler como un "militante de los grupos más extremos del peronismo". También se acusaba a Bidegain de contar en su gobierno con la colaboración directa de miembros de JP, Montoneros y FAR y de "prestar apoyo logístico a través de recursos provinciales" a dichas organizaciones. Ver Crónica, 28/7/197 "Crisis en la provincia: pese a desmentidos, más versiones". Gaceta 28/7/1973 "Otras versiones sobre la situación en la provincia". Clarín, 28/7/1973 "Se operarían cambios en el gobierno bonaerense". También se mencionaba que en dicha reunión Llambí y Calabró habrían presionado a Bidegain para que realice cambios en su gabinete, incorporando "auténticos peronistas". Los rumores de renuncia de Bidegain se incrementaron también luego de una reunión que los delegados regionales de la CGT de Avellaneda, San Martín, Zona Norte, Quilmes, Morón, Zárate y La Matanza llevaron a cabo en la ciudad de La Plata, mostrando su apoyo a Diéguez y Calabró. Renuncia que nuevamente fue desmentida por el Secretario de Prensa, Sergio Caletti. La Nación, 9/8/1973 "Reúnense en La Plata delegados de la CGT".

${ }^{327}$ El Descamisado N ${ }^{\circ}$ 12, 7/08/1973, p.29. Clarín, 15/8/1973 "La situación bonaerense". La Prensa, 18/8/1973 "Crisis de Gabinete en Buenos Aires", El Día, 18/8/1973 "Restructuración del gabinete provincial". En todas las notas se habla de que el gobernador pidió las renuncias a todos sus colaboradores a fin de realizar una reorganización ministerial que le permitiera al gobierno provincial estar más acorde a las necesidades y la tónica política a nivel nacional.

${ }^{328}$ Luego de su corta participación en el gobierno de Bidegain, Rolando García sufrió amenazas y persecución por parte de la Triple A, partiendo al exilio en México en el año 1974 junto a toda su familia. Allí se radicó definitivamente y continuó con su carrera como docente e investigador en la Universidad Autónoma de México (UNAM) hasta su muerte en el año 2012. Héctor Abrales y Mario Hernández, dos de sus más íntimos colaboradores en el Consejo Tecnológico, fueron detenidos y desaparecidos.

${ }^{329}$ Reconocido periodista, ensayista, poeta y militante del peronismo de la resistencia. Una de sus obras más conocidas fue su poema titulado "Las patas en la fuente" (1965) haciendo referencia a los obreros que coparon la Plaza de Mayo el 17 de Octubre de 1945 para rescatar a Perón, obra que creó en respuesta a la expresión "aluvión zoológico" que el diputado radical Sanmartino había usado para hablar del peronismo. Por su militancia peronista y combativa, Lamborghini fue guionista del programa radial "El Toto te la canta justa" en 1973, creado en apoyo a la campaña elctoral del Frente Justicialista de Liberación Nacional (FREJULI). Tras su breve paso por la Subsecretaría de Cultura de la provincia de Buenos Aires, se exilió en México junto a su familia en 1977. http://www.robertobaschetti.com/biografia/1/269.html y https://www.lanacion.com.ar/cultura/murio-leonidas-lamborghini-un-poeta-de-la-parodia-nid1199336/ 
esta salida el Ministro de Gobierno, Ricardo Mariátegui, a quien se recriminaba falta de celeridad para atemperar los conflictos internos dentro del gobierno. ${ }^{330}$

Este repliegue de los lugares y funciones ocupadas por militantes de la TR en el ámbito provincial provocaron un freno en la continuidad de las políticas impulsadas en el área de Bienestar Social, en tanto en dicha cartera se nombró a Carlos Bocalandro, dirigente afín a la línea ortodoxa, quien desestimó las medidas implementadas por el Ministro saliente y mantuvo un nulo contacto con los/las funcionarios/as de la Tendencia. ${ }^{331}$

Si bien luego de estas renuncias la crisis institucional parecía disipada, la posición de Bidegain y de los grupos de la TR en la provincia de Buenos Aires quedó muy debilitada. Como veremos a continuación, su permanencia en los meses siguientes al frente de otros espacios de gestión importantes, como el Ministerio de Asuntos Agrarios y el de Obras Públicas revelará nuevamente las dificultades y tensiones, cada vez más agudas, entre las aspiraciones de la militancia por desarrollar un proyecto alternativo dentro del peronismo, y las posibilidades concretas de su realización en una coyuntura cada vez más adversa.

De hecho, el rechazo de Perón de forma abierta a estas acciones encaradas desde el ámbito institucional situará a los militantes de la TR en una enorme disyuntiva, que los obligará a elegir entre la continuación de su proyecto revolucionario, o el abandono de éste en función de la lealtad al líder.

\footnotetext{
${ }^{330}$ El Día, 21/08/1973 “Concretóse en la víspera el alejamiento de los ministros de Gobierno y Bienestar social”, y El Día, 23/8/1973 “Otras renuncias fueron aceptadas en el ámbito oficial de la provincia”. El Descamisado $\mathrm{N}^{\circ} 15,28 / 08 / 1973$, p.26

${ }^{331}$ El Ministro entrante planteó una política sanitaria y de bienestar social alineada con las disposiciones de Nación. En tal sentido dio lugar a las quejas realizadas por las corporaciones de profesionales médicos en contra de la reestructuración hospitalaria de Ferrara que privilegiaba la atención pública. También se dio marcha atrás con las intervenciones en zonas sanitarias y nombramientos, reincorporando a los profesionales que cumplían funciones antes de 1973. Entrevista a Flora Castro, op. cit. El Día, 18/8/1973 "Restructuración del gabinete provincial". Bustingorry (2015:91).
} 


\section{CAPITULO V: LOS "MINISTERIOS ROJOS"332 El caso de Asuntos Agrarios y Obras Públicas}

\subsection{La Tendencia y la cuestión agraria: el problema de la tierra y su concentración}

Como mencionamos en el capítulo tres, la gestión del Ministerio de Asuntos Agrarios recayó en manos de diversos grupos de militantes de la TR, quienes contaban con una experiencia previa de trabajo técnico y especialización profesional tanto en la Universidad como en otras agencias públicas y ámbitos políticos.

En primer lugar, quien fue nombrado como Ministro, el Ingeniero Agrónomo Guillermo Gallo Mendoza, había trabajado en el Consejo Nacional de Desarrollo (CONADE) en los años sesenta, combinando esa labor con su militancia en las filas de la Democracia Cristiana, espacio en el que entabló amistad con Norberto Habegger y Flora Castro (Castro-Salas, 2011). Años más tarde, ya en su tránsito al peronismo de izquierda, participó junto a ellos dos de la experiencia de la CGT de los Argentinos (CGTA), asesorando a Raimundo Ongaro en temas de política agropecuaria ${ }^{333}$ y vinculándose también con Alejandro Peyrou que militaba en las FAP “oscuros”. En 1971, desde un grupo de estudio especializado en temas agrarios (el Instituto de Estudios Sociales-IES), se incorporó al Consejo Tecnológico del Movimiento Nacional Justicialista (CTMNJ) dirigido por Rolando García, elaborando en dicho espacio un conjunto de materiales sobre políticas públicas para el sector que luego serían retomadas por diferentes agrupaciones integrantes de las Ligas Agrarias. Al año siguiente, de la mano de Alejandro

\footnotetext{
332 Bajo esa denominación, la revista El Caudillo, vocera de los sectores ultras de la derecha peronista, acusaba en sus páginas a los Ministros y funcionarios de la TR de estar llevando a cabo "una aberrante campaña de adoctrinamiento marxista" en la provincia, señalando además la "nefasta influencia de los elementos puestos por la Tendencia" sobre todo en los "Ministerios Rojos de Asuntos Agrarios y Obras Públicas", situación que para el semanario debía llegar a su fin con la urgente "intervención federal en la provincia". El Caudillo de la Tercera Posición, Año 2, N 8, 4/01/1974.

${ }^{333}$ Algunos de los puntos del programa de la CGTA que se dio a conocer el $1^{\circ}$ de mayo de 1968 sobre temas agrarios eran: La propiedad de la tierra como función social; intervención de los trabajadores en la administración de las empresas y distribución de bienes; nacionalización de los sectores básicos de la economía (comercio exterior, bancos, petróleo, electricidad, siderurgia, frigoríficos); elimincacion de los monopolios, profunda reforma agraria con exporpiaciones; etc (Gallo Mendoza, 2010:43) y Bases para un Programa Peronista de Gobierno, No5, mayo de $1973 . \quad$ En http://www.ruinasdigitales.com/revistas/ProgramaDeGobierno05.pdf
} 
Peyrou ingresó a Montoneros, y desde allí es nominado para sumarse al gabinete de Oscar Bidegain. ${ }^{334}$

Por su parte, Alejandro Peyrou quien estuvo a cargo de la Subsecretaría de Asuntos Agrarios, había iniciado su militancia peronista como estudiante en la Facultad de Ciencias Económicas de la UBA donde se recibió de Licenciado en Economía. Participó también como ayudante en las denominadas "Cátedras Nacionales" de la carrera de Sociología en el año 1966, vinculándose paralelamente con la ARP de Cooke. Desde allí, en 1967 se incorporó a las FAP, y al año siguiente participó como Secretario Coordinador de los equipos técnicos de la CGTA. Finalmente, luego de las divergencias con los sectores "alternativistas" de las FAP, se integró a Montoneros en 1971, siendo uno de los que confeccionó el organigrama de cuadros político-técnicos para integrar el gobierno de Cámpora. Junto a él, otros compañeros de estudio, práctica profesional y militancia se sumaron al Ministerio de Asuntos Agrarios en la provincia, tales como José Luis Cordeau a cargo de la Dirección de Economía Agraria y Ricardo Gerardi en la Dirección de Coordinación Agropecuaria. ${ }^{335}$

Al frente de la Dirección de Ganadería estuvo el Médico Veterinario Hugo Bacci, quien había sido miembro fundador de la agrupación peronista FURN en la UNLP e integrado también la JP de La Plata, Berisso y Ensenada. Con él se sumaron a la labor en el Ministerio otros compañeros de militancia en la Facultad de Veterinaria de la UNLP, que ocuparon cargos relevantes: Kenneth Bar Bennett fue nombrado Subdirector de Ganadería, mientras que Gabriel Belo Soler y Carlos Miguel fueron nombrados asesores de esta área. Los cuatro se incorporaron a Montoneros luego de la fusión de JP/FURN a fines de 1972. Desde allí, participaron activamente de la campaña electoral, reuniéndose en varias oportunidades con Bidegain.

El siguiente testimonio de Hugo Bacci da cuenta del itinerario de preparación profesional con el que contaba el grupo FURN/JP antes de llegar al gobierno, y la articulación de esos saberes y prácticas con su militancia peronista más vasta

${ }^{334}$ Entrevista a Guillermo Gallo Mendoza disponible en http:/www.youtube.com/watch?v=NcLwLQFjVGs 20/07/2014. Entrevista a Alejandro Peyrou (2012). Hugo Bacci también corrobora la postulación de Gallo Mendoza como Ministro de Asuntos Agrarios por parte de la organización Montoneros, señalando además que él mismo participó de las reuniones en las que grupos de JP-Montoneros revisaban los curriculums y antecedentes de los posibles candidatos y su opción favorable hacia Gallo Mendoza, dado su perfil más "militante" y no tecnócrata-desarrollista. Entrevista a Hugo Bacci (2012).

${ }^{335}$ Entrevista de la autora a Alejandro Peyrou, CABA (2012) 
“Desde la universidad veníamos escribiendo sobre problemas nacionales, por ejemplo, en veterinaria habiamos escrito en contra de la práctica de la Sociedad Rural y de los profesores al servicio de la oligarquía, es decir criticábamos un modelo de zootecnia al servicio del imperialismo, nocivo para el país. En la revista Patria y Pueblo publicamos varios artículos sobre estos problemas, ideas que eran propuestas de gobierno peronista. Así que cuando llego al Ministerio no lo hago solo, sino con todo un equipo muy grande de compañeros, con muy poca experiencia administrativa" ${ }^{36}$

Como también permite observar el sentido de "responsabilidad política" comprometida en la participación ministerial, desempeño que se entendía casi como una extensión natural e ineludible de su militancia en otros campos

"A mí me llamaron para ir de director de ganadería, isi yo nunca había sido empleado ni en un kiosco! ir a un ministerio de director provincial era una responsabilidad enorme imagínate, pero no se podía renunciar a esa obligación, era asumir un rol militante en el gobierno, era militancia por la liberación de la patria (...) no se pensaba eso como ocupación de cargos políticos para hacer carrera política, eso estaba mal visto, sino que se pensaba como una tarea insoslayable para avanzar en la reconstrucción del Estado, para empezar y de ahí avanzar. ${ }^{337}$

Un registro similar de este compromiso político cuasi obligatorio, aunque de tono más crítico, puede observarse en el testimonio de Peyrou respecto de la vertiginosidad de los tiempos políticos y la precipitación de la tarea gubernamental para estos grupos, carentes -según la percepción del entrevistado- de la preparación y acumulación política necesaria para desempeñar esas funciones:

\footnotetext{
"Veníamos de un régimen que había vaciado todo, habia un abismo inmenso, yo pensaba que nosotros no estábamos en condiciones de asumir, no teníamos densidad social que nos permita subir al gobierno pensaba, pero sí que el gobierno era una plataforma para subir para obtener esa densidad social... ¿si no tenemos un ingeniero mayor de 40 años para nombrar, cómo vamos a hacer la socialización de los medios de producción?" 338
}

\footnotetext{
${ }^{336}$ Entrevista de la autora a Hugo Bacci, La Plata (2012).

337 Ibid.

338 Entrevista a Alejandro Peyrou (2012) Gallo Mendoza también hace referencia a la baja edad que tenían los jóvenes que ingresaron al Ministerio: "Primero cuando arribamos la decisión que se tomó fue la de pedirle la renuncia a todos los directores que había porque era muy clara la inclinación que tenían con la dictadura militar y con las organizaciones de grandes productores agropecuarios, que venía de la dictadura militar, es decir había un funcionariado que era parte orgánica de los grupos más concentrados, entonces llevamos gente joven que había trabajado con nosotros en el IES, que eran recibidos de hacía un año ponele, de 25, 27 años, y asumieron las direcciones". Entrevista a Guillermo Gallo Mendoza disponible en http://www.youtube.com/watch?v=NcLwLQFjVGs 20/07/2014.
} 
La presencia de militantes de la TR que contaban con un saber especializado en el área de asuntos agrarios derivó rápidamente en que actuaran como asesores directos de Bidegain para estos temas. ${ }^{339}$

Dicha temática ya había estado presente en las declaraciones públicas que el gobernador había realizado a lo largo de la campaña electoral y en el acto de asunción de mando. Así hacía referencia al problema de la tierra y la baja productividad agraria en la provincia de Buenos Aires el 25 de mayo de 1973, en su discurso inaugural frente a la Asamblea Legislativa:

\begin{abstract}
"Nuestros objetivos inmediatos consisten en: 1) aumento de la productividad rural; 2) racionalidad de las explotaciones; 3) mano de obra plenamente ocupada. Dada la magnitud del problema y su relación con la tierra y sus poseedores, quiero ratificar ahora nuestro respeto a la propiedad privada mientras se mantenga en función social, establecida justicieramente mediante el control estatal de su productividad". ${ }^{340}$
\end{abstract}

La cuestión del respeto a la propiedad privada sólo si cumplía su función social había sido sostenida por Bidegain en reiteradas oportunidades. Estas declaraciones del gobernador se fundaban en la idea de que el problema de la tierra y del estancamiento de la productividad no se debía a la carencia de una política crediticia favorable hacia el sector, el deterioro de los precios o la escasez de mano de obra, sino a la conducta egoísta de los grandes propietarios que ponían el interés individual por encima del interés social. En este sentido, Bidegain postulaba que "la tierra debía estar en manos de quien la trabaja", dejando abierta la posibilidad para posibles "expropiaciones a latifundios improductivos y su fracción y entrega a los verdaderos trabajadores". ${ }^{341}$

Por otra parte, postulaba como prioridad en su política agropecuaria la ayuda al productor minifundista despojado o con tierras insuficientes, a través de la compra por parte del Estado de tierras privadas improductivas, y su concesión a éstos. Asimismo, aquellas tierras que no cumplieran con los niveles adecuados de producción y rendimiento serían gravadas con un impuesto adicional. ${ }^{342}$

\footnotetext{
339 Entrevista de la autora a Hugo Bacci, La Plata (2012)

${ }^{340}$ El Día 26/05/1973. "Tomaron posesión de sus cargos el Gobernador Oscar Bidegain y el Vice Victorio Calabró."

${ }^{341}$ El Día 24/02/1973 "Reportaje a Bidegain”. El Día18/03 “Adelantó Bidegain aspectos básicos de su futura labor oficial". Ver también Bustingorry (2015)

${ }^{342}$ Ibid. Los ejes de la política agraria provincial seguían a grandes rasgos los lineamientos trazados por la política agropecuaria nacional bajo la dirección del Ingeniero Agrónomo Horacio Giberti, a cargo de la Secretaría de Agricultura y Ganadería de la Nación. Precisamente, una de las principales medidas
} 
Así, sobre la base de este diagnóstico y con el objetivo de dar solución a esos problemas se inició la gestión de Gallo Mendoza y los funcionarios de la TR al frente del Ministerio de Asuntos Agrarios. ${ }^{343}$

\subsubsection{Política agraria y social: las Unidades Básicas de Producción y Solidaridad Social}

Uno de los ejes de la política agropecuaria y de tierras implementada por Gallo Mendoza y su equipo fue la creación de las denominadas Unidades Básicas de Trabajo, Producción, Comercialización y Solidaridad Social. Las mismas consistían en la puesta en producción de predios pertenecientes al patrimonio provincial y su concesión para la explotación conjunta a familias sin tierras o campesinos minifundistas, con el doble objetivo de ayudar a los pequeños productores a alcanzar una mayor capacidad productiva, y a la vez realizar una producción con sentido social. Este programa fue implementado a través de la firma de un convenio entre los Ministerios de Asuntos Agrarios y el de Bienestar Social, dado que la variada producción que se realizaría en esos predios (horticultura, tambo, engorde de novillos para faena, entre otros) se destinaría a diversas instituciones dependientes del área de Bienestar Social (hospitales, institutos de menores, escuelas y asilos de ancianos), siendo su excedente comercializado a través de las vías normales en beneficio de los minifundistas. ${ }^{344}$

orientadas por esta Secretaría fue la sanción de la Ley de Impuesto a la Renta Normal Potencial de la Tierra $\left(\mathrm{N}^{\circ} 20.538\right)$, que gravaba a todas las tierras libres de mejoras o aquellas que produjesen a una rentabilidad menor a la estipulada por el gobierno, con el fin de terminar con la ociosidad productiva y lograr niveles de explotación eficientes, desalentando así las tenencias improductivas y combatiendo la especulación. Dicha Ley, en la práctica, jamás pudo ser aplicada por la enorme resistencia que opusieron las entidades agropecuarias de alcance nacional (Sociedad Rural Argentina, Federación Agraria Argentina y Confederaciones Rurales Argentinas) y provincial (Confederación de Asociaciones Rurales de Buenos Aires y La Pampa -CARBAP), y el desacuerdo por parte de sectores internos del peronismo identificados con aquéllas. Otra política fundamental de esta Secretaría que acompañaba la sanción de la ley del IRNP, fue el proyecto de Ley Agraria, que también fue duramente resistido y nunca llegó a tratarse en el Congreso. Finalmente, en octubre de 1974 luego del reemplazo de Gelbard por Gómez Morales en el Ministerio de Economía, Giberti fue presionado para dejar su cargo. Una vez producida su renuncia y la de todo su equipo, el proyecto de Ley Agraria pasó al olvido y se postergó indefinidamente la aplicación del IRNP. Lattuada (1986) Markler (2005) Rougier y Fiszbein (2006) y Gárgano (2015).

343 Según Gallo Mendoza, desde el IES venían trabajando específicamente en estos temas con los datos del INDEC sobre el censo nacional agropecuario del año 1969, que les permitió tener un panorama certero de la situación de concentración de la tierra en la provincia y el sector.

344 Ver Boletín Oficial de la Provincia de Buenos Aires, La Plata, Decreto 3570/73 que aprueba el convenio entre los Ministerios de Bienestar Social y Asuntos Agrarios para la creación de las "Unidades Básicas de Solidaridad Social". Por caso, en la localidad de Pehuajó, ambos ministerios dieron lugar a la creación de la Colonia Agrícola Nueva Plata, en donde se organizó la instalación de un asilo de ancianos para trabajadores rurales. La Nación, 15/7/1973 "Proyéctase un asilo rural para ancianos". También, El Día, 25/7/1973 "Convenio entre los ministerios de Asuntos Agrarios y Bienestar Social por alimentos en hospitales e institutos". 
Por otra parte, a través de este tipo de unidades, se buscaba fomentar desde el Estado la producción asociativa, estableciendo para su funcionamiento un sistema de rotación en la conducción y dirección de dichas organizaciones, "para que todos los integrantes puedan capacitarse en las funciones directivas". ${ }^{345}$

Una de estas Unidades Básicas de Producción y Solidaridad Social se desarrolló en la Colonia Las Banderitas en el predio del Parque Pereyra cerca de la ciudad de La Plata. Allí, además de establecerse familias que emprendieron la explotación conjunta de las tierras fiscales bajo contratos de arrendamiento firmados con el gobierno provincial, ${ }^{346} \mathrm{se}$ llevó a cabo una experiencia de trabajo con adolescentes provenientes de Institutos de Menores de la Provincia, quienes bajo la dirección de funcionarios del Ministerio de Bienestar Social, realizaron actividades de horticultura y tambo con la finalidad de aprender un oficio, pasando a residir de forma permanente en el predio bajo un régimen laxo de vigilancia y control. ${ }^{347}$ Otras experiencias de entrega de terrenos fiscales y su puesta en producción bajo formas asociativas por familias campesinas desposeídas se desarrollaron también en la Colonia El Mate en el Partido de Trenque Lauquen, ${ }^{348}$ la Cooperativa de Trabajo y Producción Agropecuaria Evita en Laguna de los Padres, y la Cooperativa de Pesca en Guaminí para promover la actividad de pequeños pescadores, contra la competencia y presiones de las empresas monopólicas del sector, y en la Colonia Pehuajó, entre otras. ${ }^{349}$

345 El Día, 13/08/1973 "Creación de las unidades agrarias de solidaridad social en la provincia”.

346 Noticias, 29/12/1973 "Regularizan tenencia de tierras". Los contratos de arrendamiento firmados con las familias de poseedores tenían una duración de 5 años, pagándose un canon anual (muy inferior al valor del mercado) al ministerio y estipulándose previamente el tipo de producción a desarrollar en el predio.

${ }^{347}$ Entrevista a Hugo Bacci, op. cit. Esta modalidad de formar cooperativas de trabajo y producción social se repitió también en las localidades de 25 de Mayo, 9 de Julio, Lavallol, Torquinst, Zonas del Delta, San Pedro, Bahía Blanca y Mar del Plata. Ver El Día, 13/08/1973 "Creación de Unidades de Solidaridad Social en la Provincia". El Dia, 21/10/1973 "Fue inaugurada en Mar del Plata una Unidad Básica de Producción" ${ }^{348}$ En cuanto al funcionamiento de las Unidades Básicas de Producción y Comercialización, Bacci señala: "había colonias agropecuarias que venían de la época del gobierno de Allende. En esas colonias, en la de Trenque Lauquen, había chacareros que tenían su tierra que la habían recibido de la expropiación, pero además tierras que eran del estado que estaban abandonadas, entonces se anotaban los hijos de los chacareros para que se repartan esas tierras. Y nosotros vimos que habia 300 anotados y que no se podia repartir de esa manera entonces hicimos un plan de utilización en conjunto de esas 300 hectáreas desde el estado. Se recuperó el casco, se hicieron producciones de alimento, verduras, hortalizas y para vender eso que primero se vendía barato en la colonia, y luego el excedente la JP de Trenque Llauquen formó una cooperativa de consumo pensada para no perjudicar al pequeño comerciante tampoco, sino que lo hacíamos parte, le llevábamos los productos, y la JP se encargaba de la distribución de esa producción" Entrevista a Hugo Bacci (2012)

${ }^{349}$ El Día, 31/12/1973 "Crearan una cooperativa en una colonia de Trenque Lauquen”. Noticias, 31/12/1973 "Iniciativas del Ministro Provincial", p. 16. El Día, 15/02/1974 "Efecturá Asuntos Agrarios una revisión total de la adjudicación de tierras" y "Anulacion de cesión de hectáreas en Pereyra", y El Dia, 21/02/1974 "Gestión de los adjudicatarios de tierras de Lincoln recientemente recuperadas por el Estado". En la Colonia de Trenque Lauquen se creó además una Cooperativa de Comercialización y Consumo, siendo la JP de la zona la encargada de distribuir la producción. Entrevista a Hugo Bacci (2012). 
Cabe señalar que esta política de distribución de tierras públicas y su puesta al servicio de los sectores más débiles de la cadena productiva en el agro (que sí pudo efectivizarse a través de la firma de un decreto provincial No 3570) formaba parte de un Proyecto de Ley Agraria más integral, que se presentó a principios de la gestión de Bidegain pero que nunca llegó a tratarse en la Legislatura provincial. Dicho proyecto planteaba un programa más radicalizado en términos del régimen de tenencia de la tierra, estipulando límites concretos y restricciones a la propiedad privada, con el objetivo de garantizar la función social de la tierra y la de los productores, lo que implicaba posibles expropiaciones a terratenientes absentistas del sector. ${ }^{350}$

Una de las razones que explica su falta de apoyo y tratamiento en la Legislatura se encuentra en las fuertes presiones que en su contra desplegaron las corporaciones rurales provinciales y nacionales, incluso antes de la asunción del gobierno de Bidegain. Al respecto, el 1 de abril de 1973, en una nota del diario El Día, se aludía a las intensas críticas y señales de alarma que entre los voceros de CARBAP y la SRA había despertado un borrador de proyecto de reforma agraria para la provincia de Buenos Aires, ideado según la nota- por dirigentes "izquierdistas" de la democracia cristiana, en clara alusión a Gallo Mendoza y su equipo. En la nota además se mencionaba que una de las mayores preocupaciones entre las corporaciones estaba motivada por lo que consideraban una política que "propicia la disolución o reemplazo de las actuales estructuras de representación gremial agropecuaria por otras distintas, por razones políticas".351 Como veremos a continuación, estos reparos y advertencias de los grupos concentrados del sector se confirmarían con la implementación del Parlamento Agrario y el conjunto de políticas que los funcionarios de la TR promovieron desde el Ministerio.

\subsection{2 "La tierra para quien la trabaja": El Parlamento Agrario}

En el mes de agosto de 1973, en el partido de Lincoln tuvo lugar por primera y única vez una experiencia de participación inédita de las bases y de democratización de las voces en torno a la cuestión agraria y el acceso a la tierra y su producción, con el reconocimiento oficial del Estado provincial y bajo el auspicio de los funcionarios del Ministerio de Asuntos Agrarios: el Parlamento Agrario.

\footnotetext{
${ }^{350}$ Una copia del Proyecto original de Ley Agraria tal cual fue presentado en el año 1973 se encuentra disponible en Gallo Mendoza (2010:146 y ss)

${ }^{351}$ El Día, 01/04/1973 "Preocupa a sectores rurales un supuesto plan de reforma agraria”. Entrevista a Guillermo Gallo Mendoza disponible en http://www.youtube.com/watch?v=NcLwLQFjVGs 20/07/2014.
} 
Bajo la consigna "El Agro en pie por la liberación nacional", más de cinco mil campesinos miembros de las Ligas Agrarias del Noreste Argentino, las Ligas Agrarias Bonaerenses, las Ligas Agrarias Entrerrianas, el Movimiento Rural de La Rioja, los Sindicatos Rurales, Las Ligas Tamberas de Córdoba y los nucleamientos de pequeños productores de cuencas lecheras, de cultivos intensivos y miembros de las Juventudes Agrarias, se reunieron con el objetivo de debatir acerca del régimen de tenencia de la tierra, el sistema de producción y las dificultades estructurales que atravesaban al sector como resultado del imperio de los grandes terratenientes aliados con los capitales extranjeros, los monopolios comerciales y una política impositiva que no castigaba la ineficiencia e improductividad de los más poderosos. ${ }^{352}$

La finalidad del Parlamento fue sintetizar en un documento que recogiera las opiniones de todos los nucleamientos de pequeños productores y trabajadores agrícolas sin tierras, las demandas y las políticas que deberían ser implementadas para dar una respuesta superadora a los problemas de estos actores en particular (Gallo Mendoza, 2010:255).

El Parlamento deliberó en Lincoln, bajo la presencia del Ministro de Asuntos Agrarios bonaerense y su gabinete, y la asistencia de legisladores nacionales y provinciales de la TR que fueron especialmente invitados. Entre las conclusiones que reunía el documento final, surgidas de las diferentes exposiciones de los representantes de las Ligas, se apuntaba a la consecución de medidas radicales tales como una Reforma Agraria Integral; la nacionalización del comercio exterior con la participación de los trabajadores a través de sus organizaciones representativas (gremios, cooperativas) para su control; la promoción de una redistribución de la población en el territorio nacional mediante la creación de nuevas fuentes de trabajo; la descentralización de las industrias elaboradoras de la materia prima instalándose en los sitios de producción (en particular la instalación de frigoríficos regionales); la promoción de las formas cooperativas de trabajo y su enseñanza en las escuelas rurales, y fundamentalmente; la creación de un organismo

${ }^{352}$ El Descamisado, № 16, 4/09/1973 "Lincoln: La tierra debe ser de los que la trabajan". Ya! Es Tiempo de Pueblo, $\mathrm{N}^{\circ}$ 10, 30/08/1973 "El interior contra la oligarquía" pp.27- 28. El Día, 28/08/1973, "Varios temas analizó en la ciudad de Lincoln el parlamento agrario", p. 2. Para el fenómeno de las Ligas Agrarias ver Militancia Peronista, Año 1, no 17 4/10/73 "Chaco: ¿qué son las ligas agrarias", p.26, también Anzorena (1998: 176). Una experiencia casi idéntica a la del Parlamento Agrario en Lincoln se desarrolló en la provincia del Chaco, también a principios de agosto, durante el Congreso de las Ligas Agrarias Chaqueñas, reuniendo a las principales agrupaciones de campesinos y minifundistas. Si bien las Ligas no tenían representación político partidaria formal, sus principales delegados se referenciaban en el espacio de la TR, y en oposición a la Federación Agraria. Ver Ya! Es tiempo de Pueblo, №7, "El despertar de los campesinos", p. 2-6. 
estatal central que controlara todo el proceso de producción, industrialización y comercialización a nivel nacional (Gallo Mendoza, 2010:258). ${ }^{353}$

En relación con el régimen de tenencia de tierras, el documento consideraba:

- Que el derecho a la tierra es un derecho natural e inalienable del pueblo

- Que las tierras agrarias deben ser para quienes la trabajan

- Que el actual régimen concentrado de tenencia de la tierra es el responsable del estancamiento de la sociedad argentina, y, a la par, causa principal del despoblamiento y empobrecimiento del interior del país

- Que el problema argentino debe ser enfocado teniendo en cuenta las experiencias positivas de otras reformas agrarias realizadas en América Latina

(...) Todo lo expuesto demuestra que es necesario realizar en el país una verdadera justicia agraria. Concretamente, creemos que no son suficientes las leyes que tiendan a incrementar la productividad de la tierra y el trabajo solamente. Exigimos que se instrumente en el país una legislación que cambie la estructura agraria mediante la sustitución del régimen de latifundio y minifundio, por un sistema justo y eficiente de propiedad, tenencia, uso y explotación de la tierra, fundado en la equitativa distribución de la riqueza.

(...) Como pautas orientadoras de la politica de reforma agraria sostenemos las siguientes:

- Expropiación de todas las tierras de capitales extranjeros

- Expropiación de todas las tierras de capitales mixtos, ya que bajo esta forma se enajenaron vastas superficies de los mejores suelos del país. 354

Tal como mencionamos más arriba, los planteos más radicalizados dentro del conjunto de demandas expresadas por los participantes de la asamblea agraria no pudieron ser realizados por el gobierno bonaerense. ${ }^{355}$ No obstante, desde el Ministerio se emprendió

${ }^{353}$ Ya! Es Tiempo de Pueblo, $\mathrm{N}^{\circ} 10,30 / 08 / 1973$ "El interior contra la oligarquía” pp.27- 30.

354 Ibid. Gallo Mendoza (2010:282)

${ }^{355}$ Tanto Gallo Mendoza, como Bacci y Peyrou señalan las fuertes resistencias y presiones que la actuación de las Ligas Agrarias Bonaerenses y los planteos de una política de expropiaciones sin indemnización despertaron entre las corporaciones que representaban a los grupos más concentrados del sector agropecuario como CARBAP y SRA, pidiendo luego del Parlamento Agrario la renuncia del ministro y su equipo en varias ocasiones. Por su parte, las críticas también provenían desde la Federación Agraria, en tanto el movimiento de las Ligas y la experiencia del Parlamento de Lincoln le disputaron a dicha entidad la representatividad directa de los pequeños productores dentro del campo bonaerense (Entrevista a Hugo Bacci, 2012; Entrevista a Alejandro Peyrou, 2012 y Entrevista a Guillermo Gallo Mendoza disponible en http://www.youtube.com/watch?v=NcLwLQFjVGs 20/07/2014). A nivel nacional, la oposición directa de estas entidades gremiales se manifestó también en el bloqueo del proyecto de Ley Agraria presentado por la Secretaría de Agricultura de Giberti, el cual nunca pudo ser sancionado. Ver Lattuada (1986); Makler (2005) y Lázzaro (2017) La Nación, 15/10/1973 “Analiza CARBAP la situación del Agro”, 18/10/1973 "Reunión de CARBAP", y 19/10/1973 "Estabilidad para el agro pide CARBAP”. En estas notas se recogen las principales declaraciones que los representantes de CARBAP realizaron en el congreso anual de la entidad realizado en el mes de octubre. La crítica mordaz a la política agropecuaria llevada a cabo en 
una política de recuperación de tierras fiscales (según el balance presentado por Bidegain a seis meses de su gestión, se recuperaron en total más de 10.000 hectáreas de tierras) ${ }^{356}$ y su puesta a disposición de la población campesina más desprotegida, incentivando otras modalidades de producción ligadas a tipos de explotación cooperativa y trabajo asociativo, y a través de canales de comercialización directos que evitaban la intermediación y su consiguiente especulación y suba de precios. Precisamente en el mes de enero en la localidad de Lincoln, el Ministerio de Asuntos Agrarios hizo entrega efectiva de 175 hectáreas de tierras ubicadas en la Colonia Bayauca a la Cooperativa de Trabajo y Producción General San Martín, perteneciente a Ligas Agrarias Bonaerenses. En dicho predio funcionaría una Unidad Básica de Producción y Comercialización, y se preveía también la instalación de una Unidad Básica de Capacitación Agraria que serviría para la formación y aprendizaje tanto de los peones rurales como de los menores provenientes de institutos de la región. ${ }^{357}$ También, y como una herramienta para elevar la productividad de estos emprendimientos en manos de campesinos minifundistas, se firmaron diversos convenios con la Universidad en los que se establecía un programa de capacitación y ayuda para la aplicación de conocimientos técnicos y recursos provistos por profesionales de la Facultad de Agronomía, la Facultad de Ciencias Económicas y la Facultad de Veterinaria de la UNLP. ${ }^{358}$

A la par de estas iniciativas, otras medidas fueron promulgadas desde el Ministerio como parte de su política integral de tierras y beneficio a los sectores más débiles en la cadena

Buenos Aires puede observarse en los discursos allí presentados, los cuales caracterizaban las medidas de Gallo Mendoza como "un ataque al agro que pareciera que apunta a la postración del campo ... y a la destrucción de todo un sistema de vida", lo que obligaba a este sector a emprender "una larga y dura batalla para defender no sólo la producción agropecuaria, sino también los principios fundamentales que hacen a la esencia misma de la nacionalidad argentina".

356 Noticias, 2/12/1973 “Tierras para forestación", p.10. En esta nota se informa la recesión del contrato de arrendamiento de más de 10 mil hectáreas de tierras fiscales en la zona del Delta a empresas y productores privados en función de la anomalía presentada en los contratos (firmados entre 1969 y 1970), el abandono de las tierras y la falta de cumplimiento de lo normado. Esta medida también es relevada en una solicitada del gobierno de Bidegain en la que se enumeran las políticas efectuadas durante el año de gestión. El Día, 14/12/1973, "Mejor que prometer es realizar". P. 4

${ }^{357}$ El Descamisado, n ${ }^{\circ} 32$, p. 31-32. Noticias, 22/12/1974 “Entregan tierras a cooperativas”, p. 7. El Día, 10/01/1974 "Reglamentóse el funcionamiento de las cooperadoras creadas en establecimientos de Asuntos Agrarios".

${ }^{358}$ El Día, 03/07/1073 "Firmáronse convenios de cooperación para el desarrollo agropecuario bonaerense" y 20/07/1973 “Asuntos Agrarios y la Facultad de Agronomía firmaron un acuerdo de cooperación técnica". Ver también Boletín Oficial de la Provincia de Buenos Aires, La Plata, Decreto 5157/73 que aprobó el convenio con la Facultad de Ciencias Económicas de UNLP para realizar actividades de interés vinculadas al sector agrario de la provincia. Es importante señalar que en la Universidad de La Plata, bajo la gestión del Rector Agoglia, la TR gozó de un lugar privilegiado en los cargos y programas desempeñados, ocupando lugares de relevancia en el gobierno de la universidad y en numerosas unidades académicas. Ver Lanteri, M. y Meschiany T. (2015). 
de producción y comercialización. Entre otras podemos mencionar: la creación de un Consejo Provincial de Acción Cooperativa; ${ }^{359}$ la reglamentación y aplicación efectiva del Código Rural (Ley 7616); ${ }^{360}$ la implantación de un Seguro Agrícola Integral para los productores afectados por las inundaciones ${ }^{361}$ y la estipulación de un precio único para la leche (Decreto 3573). ${ }^{362}$ Asimismo, se presentaron en la Legislatura numerosos proyectos, que no llegaron a tener tratamiento: la Creación del Fondo Provincial de Colonización; ${ }^{363}$ la creación del Libro Ganadero; 364 la Ley de Impuesto Único Provincial a los Inmuebles Rurales; ${ }^{365}$ y la creación de la Junta Provincial de la Papa, ${ }^{366}$ entre otros.

\subsubsection{Un "socialismo sui generis"}

${ }^{359}$ Boletín Oficial de la Provincia de Buenos Aires, La Plata, Decreto 3572/73. Esta medida reforzaba la formación de cooperativas de trabajo y producción social. El Día, 20/10/1973 “Concretóse la creación del Consejo Provincial de Acción Cooperativa"

${ }^{360}$ Boletín Oficial de la Provincia de Buenos Aires, La Plata, Decreto 5013/73. Bacci señala que ni bien se hicieron cargo del Ministerio, encontraron casos de explotación de trabajadores rurales en condiciones de semiesclavitud, a los cuales se mejoró su situación a través de la firma de contratos de aparcería. Entrevista a Hugo Bacci (2012). Entrevista a Guillermo Gallo Mendoza disponible en http://www.youtube.com/watch?v=NcLwLQFjVGs 20/07/2014. Ver El Dia, 25/07/1973 "Firmáronse contratos de aparcería con trabajadores rurales de Olmos".

${ }^{361}$ El Día, 14/12/1973 "Mejor que prometer es realizar". Solicitada del Gobierno de Bidegain. En relación con esto, debemos mencionar que en el mes de agosto grandes inundaciones en el centro oeste de la provincia habían afectado a numerosos distritos rurales y su producción, declarándose la emergencia agropecuaria en la zona afectada. Ver capítulo 6.

${ }^{362}$ Entrevista a Hugo Bacci (2012). El entrevistado señala que en aquella época existían dos precios para la leche, uno para consumo, más caro, y otro para uso industrial, a pesar de que la leche era la misma, entonces desde el Ministerio decidieron unificarlos. Las empresas más importantes del rubro (Mastellone y Mendicrim) eran las que medían la leche y establecían el precio por kilo de grasa butirométrica, aprovechándose del productor al que le pasaban un punto o dos menos por kilo para pagarle menos. Finalmente, y luego de un congreso en Chivilcoy donde juntaron a los pequeños productores con Mastellone y Mendicrim, lograron unificar un precio único para la leche, colocando inspectores oficiales que median la leche y obligaban a las empresas a pagar lo que correspondía al productor. Asimismo, se impusieron multas por la leche adulterada. Según Bacci, Mastellone se entrevistó con Gelbard exigiéndole la renuncia de Gallo Mendoza y su equipo. Ver Bustingorry (2015:75)

363 Gallo Mendoza (2010: 245)

364 Noticias, 29/11/1973, "Las vacas tendrán una Ley (Sobre el libro ganadero)". Gallo Mendoza (2010:226). La Nación, 18/10/1973 “Aprobó proyectos el gabinete de Buenos Aires"

365 Gallo Mendoza (2010:240)

${ }^{366}$ El Día, 18/10/1973 "Varias iniciativas agropecuarias consideró el gabinete bonaerense" y 22/11/1973 "Encontradas opiniones acerca del proyecto de creación de la Junta Provincial de la Papa". Gallo Mendoza (2010: 249). La falta de tratamiento en la Legislatura de todos estos proyectos, respondía a la debilidad que los representantes de la TR tenían en el parlamento provincial, en donde la correlación de fuerzas dentro del movimiento peronista nunca fue mayoritaria para este sector, menos aún luego de la salida de Cámpora en el mes de julio (Ferrari-Pozzoni, 2008). Ya vimos también que, en el mes de agosto, en medio de la crisis institucional que atravesó el gobierno de Bidegain con fuertes rumores de su renuncia, Gallo Mendoza era mencionado por la prensa y los sectores sindicales como "numero puesto" en la purga del gabinete. Si bien la reestructuración del gobierno provincial en esa oportunidad no alcanzó al ministro de asuntos agrarios y sí a otras figuras de la TR, la pérdida de poder que en su conjunto comenzó a tener este sector dentro del gobierno y el movimiento en favor del ala sindical y política de la derecha, resultó cada vez más evidente. En los próximos capítulos analizaremos con más detenimiento este declive. 
Acompañando el desarrollo de estos programas específicos de política agraria, cuyos mecanismos de implementación transitaron los canales más formales e institucionales decretos del ejecutivo, disposiciones ministeriales, proyectos de ley-, también existió un conjunto más heterogéneo y espontáneo de prácticas políticas y modalidades de gestión, que condensaban en su realización cotidiana aspectos relevantes de una sociabilidad política-institucional de corte popular, en la que se fusionaban elementos de la sensibilidad peronista con el ideario del "socialismo nacional".

Una de estas experiencias consistió en la socialización de los sueldos que percibían los militantes de la Tendencia. Así lo relata Hugo Bacci, Director de Ganadería del Ministerio de Asuntos Agrarios:

\begin{abstract}
"En ese tiempo un subsecretario cobraba 900 pesos aproximadamente, por decirte algo, que era una fortuna, y el que servía café cobraba 120, una diferencia tremenda, entonces resolvimos cuánto necesitaba un matrimonio con dos hijos para vivir, hicimos la cuenta, 160 pesos, entonces cuando cobrábamos se ponía toda la plata junta y un chofer cobraba 160 y un subsecretario 160. Así que socializábamos el sueldo, nunca nadie nos dijo que teníamos que hacer eso, sino que fue una práctica que nació allí, ni sé cómo, pero surgió ahi. Era un socialismo sui generis" ${ }^{367}$
\end{abstract}

En la misma línea de esta medida se ubican la socialización de viáticos y dietas; ${ }^{368}$ la eliminación del uso privado de los autos oficiales; la reglamentación del horario de los choferes por turnos de 8 hs; la eliminación de relojes y fichajes para controlar el tiempo de llegada y salida del personal administrativo; la conformación de bolsas de trabajo para facilitar el ingreso de personas desocupadas o humildes en el Ministerio; la utilización únicamente de la palabra "compañero" para el trato de los militantes que ocupaban cargos públicos -más allá de que poseyeran títulos profesionales-; la realización de fiestas y asados gratuitos para todo el personal y sus familias; la remodelación del camping del Ministerio y su puesta al servicio de los trabajadores; la creación de una guardería para los hijos de los empleados, etc. ${ }^{369}$

${ }^{367}$ Entrevista de la autora a Hugo Bacci, La Plata (2012)

368 Ibid. Sobre la relación con los choferes del Ministerio Bacci recuerda: "Cuando íbamos al interior se daba lo mismo, nos daban viáticos, hotel 5 estrellas, y a ellos les daban sólo para una pensión, entonces nosotros íbamos todos juntos a un hotel 3 estrellas por decirte algo, es decir se juntaba toda la plata de los viáticos y se gastaba en lo mismo y si sobraba se repartía. Lo mismo para la comida, no íbamos nosotros a comer al restaurante de lujo y ellos a un bodegón, íbamos todos al mismo lugar, término medio. $Y$ trabajábamos de viernes a domingo en esos lugares del interior de la provincia.

${ }^{369}$ El Día, 12/10/1973 "En Punta Lara celebróse el día del empleado agrario". Ibid. Ya vimos como en el "Compromiso de la JP con el pueblo de la patria" analizado en el capítulo 3 se trazan lineamientos similares para los candidatos electos de la JP en los niveles nacional, provincial y municipal. 
Si bien este repertorio de prácticas no se encontraba formulado previamente en ningún programa de gestión formal, su ejecución permite acercarnos al conjunto de ideas y representaciones que moldeaban las formas de participación en el Estado de estos/as militantes. Es decir, una experiencia política en la que el cuestionamiento a los resortes tradicionales de autoridad y a las formas jerárquicas en la toma de decisiones se efectivizaba a través de la construcción de una relación más horizontal, participativa e igualitaria con los empleados del ministerio, prolongando en cierto modo en el escenario gubernamental el clima de activismo social y movilización popular propio de la metodología de resistencia de la etapa anterior.

\section{2 "Convertir nuestro lugar de trabajo en una trinchera de lucha". La gestión de}

\section{Alberto González en el MOP}

Tal como mencionamos en el capítulo tres, en el Ministerio de Obras Públicas (MOP), un conjunto nutrido de militantes de la TR ocupó los principales cargos y secretarías. A la cabeza de esta dependencia estuvo Alberto Alejandro González, cuya trayectoria lo ubica en espacios de formación y militancia muy similares a los de su par en Asuntos Agrarios y al Jefe de ASPRODE, Rolando García. González, oriundo de Misiones, se recibió primero como Agrimensor en 1957 y luego como Ingeniero Civil en 1959 en la Facultad de Ciencias Matemáticas de la Universidad del Litoral. En la década del sesenta y luego de ocupar cargos públicos en Misiones y Santa Fe, se trasladó a Capital Federal, profundizando sus estudios en el área de Comunicaciones y Transporte y participando como asesor del ente estatal CONADE para la región metropolitana. Su militancia en el peronismo revolucionario y su labor docente en la Facultad de Ciencias Exactas de la UBA lo llevó a entablar una estrecha amistad con Rolando García, participando del armado de las propuestas del CTMNJ desde su inicio. Concomitante a este desempeño, su militancia orgánica en Montoneros por esos mismos años lo posicionó de lleno como un cuadro político y técnico destacado para la asunción de roles de gestión pública en el contexto de 1973.370

Junto a él, otros compañeros de militancia en el CTMNJ y en Montoneros fueron designados en las principales secretarías del MOP. Al frente de la Subsecretaría de Obras

${ }^{370}$ El Día , 1/6/1973 "Nombran Ministro de Obras Públicas en la Provincia al Ing. Alberto A. González” y El Día, 2/6/73 "Prestó juramento el titular del Ministerio de Obras Públicas, Ingeniero Alberto A. González” y Entrevista de la autora a Marina Siri, San Miguel (2017) 
Públicas estuvo el Ingeniero Pablo Escolar, mano derecha de González y principal responsable político de Montoneros en el Ministerio. El Arquitecto Eduardo Casado fue nombrado en la Subsecretaría de Urbanismo y Vivienda, mientras que Jorge Raúl Blanco en la de Programación. Osvaldo Hugo Di Florio estuvo en la Secretaría General, Silvio Peist en la Dirección de Vialidad y Hugo Roberto Scordato ocupó la Dirección de Investigaciones Tecnológicas. Alejandro Belardone fue nombrado Subdirector de Administración, mientras que José Tamarit y Ricardo Rubio estuvieron al frente de la Dirección de Relaciones Públicas y Prensa, junto a Carlos Collarini en Información y Personal. ${ }^{371}$

Si bien la presencia de militantes de la TR fue muy significativa dentro del MOP, la cobertura de casi todos los cargos implicó un desafío enorme, no sólo por la cantidad de espacios a ocupar, sino también por el tipo de tareas específicas que la labor estatal requería. Así lo destaca uno de nuestros entrevistados:

\begin{abstract}
"el organigrama fue un quilombo, me quería morir porque yo no estuve nunca en la función pública, lo que manejaba Obras Públicas de Buenos Aires en ese entonces era descomunal, la cantidad de gente que se necesitaba para cubrir las áreas, vialidad, energía, transporte, vivienda ¿cómo llenábamos la planta? porque nosotros veníamos de la experiencia militante, territorial, universitaria y villera o sindical, era otro tipo de militancia y formación ¿sabes la cantidad de lugares y profesionales que hay que rellenar? y nos faltaban. ¿A quién tenemos? pregunto, $y$, uno dice yo conozco un estudiante amigo...llamálo, no en las conducciones, pero sí en niveles más de abajo, tenían que haber sido todos militantes orgánicos, pero no los teníamos. Esas eran las condiciones. ${ }^{372}$
\end{abstract}

A este desafío que implicaba asumir funciones en la gestión pública, en términos de contar con una cantidad notable de militantes portadores de saberes técnicos específicos, se sumaba también el desafío ya visto en el caso de otro ministerio, de aprender una lógica diferente a la exclusivamente militante. Más concretamente, una lógica vinculada al manejo cotidiano de la "cosa pública" y del Estado en su faceta más burocrática (los insumos, los expedientes, el memo, etc.) que, si bien puede transformarse, aun así, contenía su propia dinámica y una impronta que muchas veces resultaba desconocida para la militancia forjada en otros espacios.

${ }^{371}$ CPM - FONDO DIPPBA, División Central de Documentación, Registro y Archivo: Mesa "DS": "Nómina de autoridades provinciales". Entrevista de la autora a Ricardo Rubio, San Miguel (2017). Entrevista de la autora a Sergio D., La Plata (2017). Boletín Oficial de la Provincia de Buenos Aires, Decreto 342 y 344, 348, 349, 350 y 365. 15/6/1973 sobre nombramientos a funcionarios del MOP

${ }^{372}$ Entrevista de la autora a Ricardo Rubio, San Miguel (2017). 
"Por ejemplo, algo básico, ¿cómo se pide un insumo a otro departamento? nosotros no sabíamos. Y eso en un momento politico tan acelerado era mucho más complicado, eso es parte también del desarrollo de la politica popular institucional que tuvimos que aprender y llevar a cabo porque no tuvimos dos siglos en el poder" ${ }^{\prime 373}$

Volviendo a los lugares que ocupó la TR en el Ministerio, una atención especial merece el caso de los nombramientos en la Dirección de Energía de la provincia de Buenos Aires (DEBA), un ente autárquico bajo la órbita del MOP. Allí, en su sede central el día 12 de junio, 250 trabajadores iniciaron una "toma" del establecimiento, con el objetivo de “asegurar la entrada de las autoridades que la gobernación disponga”. Esta acción fue conducida por la "Agrupación Peronista de trabajadores de DEBA", integrada a la JTP y la TR, que se enfrentaba a la conducción de la sección local del Sindicato de Luz y Fuerza. ${ }^{374}$

Vale la pena citar algunos tramos de las declaraciones que presentaron los trabajadores con motivo de esta acción, la que ubicaban como parte de una política revolucionaria situada desde su labor cotidiana en el Ministerio para la etapa de reconstrucción nacional:

"En este momento histórico de llegada al gobierno, debe darse en todos los niveles una estructura política de masas, es decir, que, en cada lugar de trabajo, se hagan escuchar todas las voces, desde el peón hasta el directivo. Sabemos que, reunidas las opiniones populares, el único tribunal es el interés revolucionario, y así el proceso será irreversible.

Ante la necesidad de dar una respuesta a esta coyuntura queremos recodar que no basta con un día ir a votar; que no basta con ganar el gobierno, sino que es necesario ahora ganar el poder, y ello sólo lo lograremos comprometiéndonos cada uno de nosotros en convertir nuestro lugar de trabajo en una trinchera de lucha, desde donde todos hablaremos y seremos escuchados.

Para superar la crisis del país, debemos superar la estructura que le dio origen y para ello debemos determinar cuáles son las fuerzas interesadas en el cambio que necesita nuestra sociedad, y cuáles son los que se oponen al cambio por ser beneficiarios de la situación actual. Nosotros queremos una política revolucionaria; nadie pretende objetivos ambiciosos pero inalcanzables; tampoco queremos plantear objetivos mínimos ya que eso sería una política oportunista y meramente reformista. La política que consideramos revolucionaria es la que tiende a crear el hombre nuevo, consciente de que el poder también debe pasar por sus manos y ser capaz de asumir esa responsabilidad.

¿Cuáles son entonces los pasos, métodos, técnicas y tareas que nos permitirán avanzar a fin de lograr la participación de todos los trabajadores en el proceso de liberación?: obtener la ruptura de la burocracia establecida mediante la consulta permanente con todos los sectores de trabajo y a todo nivel, a fin de elaborar juntos una política energética bajo los principios revolucionarios que plantea esta etapa de Reconstrucción Nacional", 375

\footnotetext{
373 Ibid.

374 Archivo de la Ex DIPBA, mesa de referencia, legajo N 15979. Tomo 7.

375 El Día, 14/6/1973 "Designóse interventor interino en DEBA"
} 
Varias cosas importantes se desprenden de este comunicado. Por un lado, se replica la idea ya analizada en otros capítulos de que la democracia "formal" y el triunfo electoral no bastan para garantizar las medidas de fondo necesarias para avanzar en el camino de la liberación. Sin embargo, en esta declaración se observa que la separación entre "gobierno" y "poder" ya aludida, lejos de presentarse como dos momentos bien diferenciados que responden a objetivos distintos - siendo el gobierno una instancia "reformista" y subordinada a un fin mayor- es resignificada a la luz de la coyuntura institucional, encontrando una vía de articulación directa entre una instancia y otra. Es decir, desde su perspectiva, la participación activa del pueblo trabajador en la gestión del Ministerio sería la garantía para lograr la conquista efectiva del poder. De esta manera, lo que podría pensarse a priori como una política reformista del Estado burgués, en este comunicado, toma el significado de ser un momento, una parte integrante de la política revolucionaria (en relación con la totalidad del proceso de liberación) al originarse en la voz y participación de todos los trabajadores.

Por otra parte, de la mano de esta percepción de la instancia gubernativa como un momento sustancial en el camino hacia la construcción del "hombre nuevo", aparece también explicitado el mandato del compromiso indeclinable que deben asumir los y las militantes con esas tareas y responsabilidades que el momento histórico les reclama, lo que en el planteo del comunicado lleva directamente al enfrentamiento con los sectores de la burocracia sindical peronista en el marco del gobierno recién asumido.

En efecto, la acción de la toma fue conducida por una agrupación identificada con la Tendencia y se resolvió finalmente con la designación del Subsecretario de Obras Públicas, Pablo Escolar, como interventor interino del organismo.

Esta medida que fue resistida por el sindicalismo ortodoxo, ${ }^{376}$ reflejó en ese momento el "triunfo" en la correlación de fuerzas que la TR obtuvo al inicio del gobierno provincial, situación que como veremos más adelante, se verá debilitada en muy pocos meses.

\subsubsection{Hacia una estructura política de masas en el MOP: las Mesas de Trabajo y las Comisiones de Respuesta Inmediata (CERI)}

Como parte de esta demanda de modificaciones en la estructura de poder del MOP que implicasen transformaciones sustantivas en su dinámica de funcionamiento y toma de decisiones, en el mes de agosto se llevaron a cabo dos medidas significativas al respecto.

${ }^{376}$ El Día, 19/6/1973. “Quehacer sindical. La ocupación de DEBA ha motivado declaraciones” 
Por un lado, hacia el interior del Ministerio, se puso en marcha la creación de las denominadas Mesas de Trabajo que buscaban potenciar una intervención más activa de los trabajadores en la formulación y discusión de propuestas sobre políticas públicas, y en la toma de decisiones sobre diversas cuestiones de la vida interna del MOP. Estas mesas funcionarían en cada una de las divisiones del Ministerio, y serían integradas por un Coordinador -elegido por votación directa- y todos los trabajadores del sector. Su modalidad sería de debate y asamblearia, elevándose las propuestas de mayoría y minoría -si las hubiese- a una Mesa de Trabajo Central, que a su vez elevaría las propuestas a las autoridades máximas del MOP. ${ }^{377}$

En los considerandos de su creación, se hace referencia a la necesidad de realizar "una revisión de la concepción sobre la política laboral imperante durante el régimen anterior, ya que ésta resulta incompatible con el criterio que debe presidir las relaciones de colaboración entre todos los agentes del ministerio", siendo uno de los pilares de la política popular actual "la participación activa de todos los agentes, cualquiera sea su jerarquía o nivel, en la elaboración de las normas que han de organizar esta comunidad de trabajo". 378

A tal efecto, se disponía la creación de Mesas de Trabajo que permitan "la participación masiva del personal para proponer criterios respecto de los problemas más urgentes” permitiendo a las autoridades "aplicar los lineamientos de la política social popular con absoluto conocimiento de causa y teniendo en cuenta las inquietudes del personal". 379 Algunos aspectos más subjetivos del funcionamiento cotidiano de esta política laboral son explicados por un ex funcionario de MOP y militante de Montoneros:

"sobre las Mesas de Trabajo, recuerdo que cuando entré al Ministerio nunca había tenido experiencia institucional, no sabía cómo manejarme con los empleados de planta, parecía que había que dar órdenes de hierro...no, nosotros nos acercamos, hablamos, abrimos canales de participación directa. Si yo no sabía cómo hacer un pedido a los proveedores, por ejemplo, y me di cuenta de que quienes sí tenían esa experiencia burocrática eran los empleados del ministerio, entonces ellos saben cómo se hace un despacho, etc".

Nuevamente aparece aquí la necesidad de los/las militantes funcionarios/as de contar con un saber-hacer propio de la gestión pública (la experiencia burocrática) que no estaba entre sus conocimientos y prácticas previas, es decir entre el "capital militante" que traían consigo. Una de las formas de responder a este desafío, siguiendo el testimonio de

377 CPM - FONDO DIPPBA, División Central de Documentación, Registro y Archivo Mesa "B”, Carpeta 4, Legajo N 27, folio 85, 89-90.

378 Ibid

${ }^{379}$ Ibid 
nuestro entrevistado, fue a través de la transformación misma de las formas internas de gestión estatal en un sentido más democratizador e igualitario

"Pero porque además de las cuestiones prácticas y del funcionamiento cotidiano de la gestión, había una cuestión ideológica, que desde el ministro para abajo era compartida por todos los compañeros, una cuestión de evitar el autoritarismo y el servilismo, para nosotros todos eran pares. "380

La segunda iniciativa que se implementó, esta vez dirigida a fortalecer y acelerar el vínculo hacia afuera con la comunidad, fue la creación de la Comisión Ejecutiva de Respuesta Inmediata (CERI). ${ }^{381}$ Esta nueva dependencia tenía la función de receptar los pedidos que los distintos grupos de la JP de La Plata y del gran Buenos Aires realizaban, recogiendo a su vez los reclamos de sus bases barriales sobre temas de infraestructura en general (Robles, 2014b).

Estos Comité de Gestión Inmediata comenzaron a funcionar en Vialidad, DEBA y demás dependencias, siguiendo la política ya implementada en otras áreas ministeriales. Entre los fundamentos de su creación, se señalaba que la medida respondía a la obligación por parte del ejecutivo provincial de "hacer efectiva la participación de todos los trabajadores en la conducción de los distintos organismos de gobierno”, representando "el primer paso para desarrollar los mecanismos institucionales y las formas organizativas que faciliten la intervención de los trabajadores en la conducción de la entidad, asumiendo claras y directas responsabilidades". Además, se menciona también que dicha modalidad de gestión de trabajo "quedará definitivamente incorporada a la práctica de esta comunidad a través de una futura Ley Orgánica, una vez perfeccionado su funcionamiento". 382

El funcionario y militante de Montoneros que estuvo a la cabeza de la CERI fue Eduardo Casado, quien además de ser el Subsecretario de Urbanismo y Vivienda, contaba con una reconocida militancia entre los activistas juveniles de la región platense. Lo acompañaba en esta labor un staff de representantes de las distintas áreas del MOP, quienes recibían

\footnotetext{
${ }^{380}$ Entrevista Ricardo Rubio, San Miguel (2017). Marina Siri, militante de Montoneros con funciones en el MOP, comparte similares impresiones sobre el vínculo horizontal y hasta personal gestado con los trabajadores del Ministerio: "No encontramos hostilidad en los trabajadores de planta, en absoluto. Es más, incluso también tuvimos la adhesión y el compromiso militante de algunos de ellos, en mi caso del chofer, no era militante él y después cuando nos fuimos del Ministerio, sacamos clandestinamente todas las fotos que teníamos en la oficina para que no quedara en manos de los otros. Las sacamos y él se las llevó a su casa y las escondió ahí corriendo mucho riesgo porque estábamos vigilados... mirá hasta donde estaba metido él". Entrevista de la autora a Marina Siri, San Miguel (2017)

381 El Día, 5/10/1973 "Ya funciona el Comité de Gestión Inmediata en el ente Vial". ${ }^{382}$ Ibid.
} 
las peticiones y las elevaban a las dependencias respectivas. En ellas se evaluaba la factibilidad, se proveía de dirección técnica y, sobre todo, de recursos y materiales necesarios que el MOP tenía a disposición en sus depósitos, lo que facilitaba la rápida implementación de las demandas (Robles, 2014b). Parte de las obras realizadas por esta Comisión consistieron en la colocación de asfalto y arreglo de calles, la extensión de la red cloacal y de los desagües, tendido eléctrico en zonas marginales, etc.

Asimismo, no debemos subestimar el impacto positivo que este tipo de políticas institucionales tuvieron en la población de los barrios más carenciados, quienes veían luego de años de abandono por parte de los gobiernos militares- la concreción de sus demandas. Y, todo ello, a través de mecanismos que potenciaban el involucramiento directo de la comunidad en la resolución de sus problemas, sin apelar a las formas más jerárquicas y clientelares de intervención social del peronismo histórico (Robles, 2014b). El siguiente testimonio de un militante de Montoneros que trabajó junto a Eduardo Casado ejemplifica parte de las acciones llevadas a cabo:

\footnotetext{
"Te puedo dar un ejemplo de la política pública revolucionaria que hicimos desde el MOP, llevamos el agua potable a los barrios, que no la pudimos desarrollar del todo porque nos fuimos antes, pero hay muchos barrios que hoy tienen agua potable gracias a nosotros. ¿Cómo funcionaba? Establecimos trabajo voluntario asociado al Ministerio, incluso los propios funcionarios fueron a cavar zanjas junto con los compañeros barriales de la JP para colocar los caños, los ingenieros también fueron, Eduardo Casado y Pablo Escolar. Había un proceso revolucionario desde las instituciones, respetando las instituciones. Nosotros (JP-Montoneros) poníamos el trabajo voluntario, sacamos los técnicos de las oficinas y los llevamos al territorio, y abrimos los galpones y los corralones donde había de todo, el estado puso el material y las máquinas, y la gente ponía el trabajo voluntario y en muchos barrios hicimos eso. ${ }^{383}$
}

Aquí, en el relato de los y las militantes que participaron de la gestión institucional vemos aparecer nuevamente la cuestión del tránsito por diferentes lugares. En el siguiente apartado veremos cómo esta lógica de circular por diversos espacios (el barrio, la oficina, el Ministerio, la organización armada) -que a priori podrían ser pensados como espacios en tensión con sus propias prácticas y finalidades- implicó, para sus protagonistas, la posibilidad de encarar una apuesta de compaginación de diversas prácticas en el ejercicio mismo de su militancia revolucionaria.

\subsubsection{Militancias múltiples: el estado, el barrio y la organización}

${ }^{383}$ Entrevista de la autora a Ricardo Rubio, San Miguel (2017) 
Tal como se destaca en el testimonio citado más arriba, la imbricación de los diferentes ámbitos de militancia y la asunción de diversas y simultáneas responsabilidades en manos de los/as militantes/funcionarios/as fue una característica de este tipo de experiencias de participación institucional.

De esta manera, medidas de corte "reivindicativo" como el zanjeo para la red cloacal o la provisión de agua potable podían ser redefinidas por esta franja de militantes como parte de una politica pública popular al servicio de un objetivo mayor: la construcción del socialismo nacional. Esta era la visión de varios/as militantes de Montoneros que participaron del gobierno, sin "abandonar" su presencia barrial y su encuadramiento dentro de la organización

"había una articulación directa con JP de los barrios, se movía mucho la militancia en el territorio y viniendo a trabajar con nosotros. No había un plan superior a ese, sino fortalecer la articulación que ya existía, básicamente se acercaban los compañeros, venían y se llevaban cosas que necesitaban. Yo me acuerdo que lo que llegaba a mi secretaría todo lo trabajamos para los barrios, y conocía a muchos militantes y mas allá de mi función, yo me moví como militante en poner la estructura del ministerio al servicio de lo que se podí, y se puede mucho desde lo institucional, a veces pienso que si no hubieran matado a tantos compañeros eso habría continuado y hoy tendríamos otros cuadros politicos." 384

Apoyándonos en los testimonios, podemos observar que se propiciaba una forma amplia de militancia en la que la intervención en el Estado y en el barrio se entrelazaban, formando un circuito que iba del territorio al Ministerio, y de allí, a través de políticas púbicas populares, nuevamente al barrio con el objetivo de fortalecer la construcción de poder popular desde y para la organización.

"Yo complementaba el trabajo en el ministerio con el trabajo en la UBR, hacía las dos cosas, iba al barrio siempre, y los recursos del ministerio iban a los barrios, llevábamos cosas que necesitaba la gente, esa era la concepción. En la UBR "Evita Montonera" hacíamos trabajo politico, haciamos charlas, había muy buena predisposición de los vecinos, había reuniones de discusión política y se llenaba, organizábamos reuniones, partidos de fútbol, bailes, discutíamos las políticas del gobierno, teníamos que explicar por qué eran esas politicas, qué pasaba, saber qué pensaban, la idea era formar de a poco pequeños cuadros digamos, era gente muy humilde pero interesada en lo que estaba pasando". 385

En este sentido, y en vinculación con otros casos analizados previamente, podemos observar cómo estas políticas públicas populares trascendían su carácter más usual, en tanto no sólo eran promovidas desde el Estado "para el pueblo", sino que se concebía que

\footnotetext{
${ }^{384}$ Entrevista de la autora a Ricardo Rubio, San Miguel (2017)
}

${ }^{385}$ Entrevista de la autora a Mabel Maidana, La Plata (2014) 
debían ser hechas y decididas "con la activa participación del pueblo". Y, para ello, como vimos, el Estado debía transformar sus propias lógicas internas de funcionamiento, democratizando sus prácticas de gestión y "llevando los técnicos de las oficinas al barrio", lo que desafiaba las tendencias al cierre y el encorsetamiento propio de las instituciones burocráticas que cuentan en su interior con un plantel de técnicos y expertos en la función pública. ${ }^{386}$

Este pasaje por una y otra instancia de la acción política militante, vivida casi de forma natural por los funcionarios de la TR, es también relatada por Ricardo Rubio

\begin{abstract}
"No existió la tensión de participar de una estructura burguesa formando parte de una organización revolucionaria. En Montoneros eso se tenía más claro, pero la experiencia que te puedo contar es la que pasé yo que vengo del CTMNJ, quizás en otros fue distinto. Pero a la conducción le hacía ruido participar del Estado, porque yo sentí que de alguna manera se liberaron un poco a los compañeros que se hicieron cargo de la parte institucional, ahí tuvimos autonomía, a mi no me vino a poner los galones nadie. De hecho, la participación de nuestro salario la compartíamos con los lisiados, con el Frente de Lisiados Peronistas, porque yo era el responsable político de Pepe Poblete. Había otros compañeros que si aportaban a la estructura más orgánica, pero yo no". 387
\end{abstract}

Algunas consideraciones interesantes se desprenden de este testimonio. Por un lado, se observa la predisposición de parte de la militancia que venía de ámbitos legales dentro del Movimiento, por ejemplo, el CTMNJ, a participar de la experiencia gubernamental sin mayores contradicciones ideológicas o políticas. Por otro lado, no deja de resultar significativa la tensión entre ese posicionamiento general alentado por la organización, y la forma concreta en que luego esa experiencia institucional se llevó a cabo.

Para nuestro entrevistado, esa tensión se expresó a través del grado notable de autonomía del que gozaron y ese margen amplio de acción (ese “dejar hacer" de la conducción), entendiendo ésto como una desatención que la dirigencia de Montoneros manifestó en ciertos momentos.

No obstante, observamos como esa situación podía derivar en una revalorización de esa práctica política institucional por parte de los/as militantes que efectivamente ocuparon cargos en el Estado (en la medida en que cada acción es resignificada como parte, ya misma, de la revolución) más aún cuando esa práctica implicaba no sólo medidas de corte distributivo hacia los sectores populares, sino también acciones que se construían con

\footnotetext{
${ }^{386}$ Weber, M. "Parlamento y Gobierno en el nuevo ordenamiento alemán”, en Escritos Políticos (Tomo I), Folios Ediciones, México, 1984

387 Entrevista de la autora a Ricardo Rubio, San Miguel (2017)
} 
ellos y apuntaban directamente contra el poder de grandes empresas asociadas con la dictadura de Lanusse. El siguiente caso es ilustrativo de todo esto.

\subsection{3. "Por el camino de la reconstrucción y la liberación nacional": El caso del dique de Paso de las Piedras}

Un episodio que marcó la agenda del MOP con fuerte impacto político, poniendo la gestión de Alberto González y su equipo en la mira de la prensa nacional, fue el del Dique Paso de las Piedras ubicado en la localidad de Bahía Blanca. Esta obra, iniciada durante la gestión del gobierno militar de Lanusse, estaba destinada a mejorar la provisión de agua para consumo doméstico y para el complejo industrial de toda la región a través del aprovechamiento del río Sauce Grande, mediante la construcción de una represa y un acueducto. ${ }^{388}$

En el marco de su inauguración parcial en el mes de diciembre de 1972, se habían generado denuncias sobre deficiencias que presentaban las instalaciones, lo que dio lugar al compromiso -no cumplido- por parte de las autoridades militares de llevar a cabo las modificaciones requeridas en un plazo no mayor a 20 días.

Finalmente, tras la asunción del nuevo gobierno en mayo de 1973, la constatación del incumplimiento de esas mejoras dio lugar a la visita de funcionarios del MOP en el lugar, a raíz de la escasez de agua que seguía aquejando a la población bahiense y su cordón industrial. Dichas inspecciones, de las que participaron Pablo Escolar y el director de Obras Sanitarias de la provincia, Carlos Raimondi -también militante de la TRderivaron en la realización de estudios técnicos por parte de los equipos del MOP que dieron como resultado la comprobación de severas fallas hídricas y filtraciones en la construcción del dique, lo que en un futuro no muy alejado podía derivar incluso en la inundación de la ciudad de Bahía Blanca. ${ }^{389}$ Según la mención de los estudios indicados,

388 La Nación 9/08/1973 “Sin solución rápida en Paso de las Piedras”. El Dia, 10/8/1973 “Estúdianse deficiencias del dique de Paso de las Piedras".

${ }^{389}$ La Nación, 8/08/1973 "Estudios para una represa en Buenos Aires", El Dia, 10/8/1973 "Estúdianse deficiencias del dique de Paso de las Piedras". Entrevista de la autora a Ricardo Rubio (2017). En su testimonio, este funcionario y militante de Montoneros agrega que "Lanusse lo inauguró muy rápido, antes que entremos nosotros al gobierno, hizo todo a los rajes, utilizando otra técnica de las que se acostumbraba, y al poco tiempo se empezó a salir toda el agua por abajo, porque no hicieron los estudios del suelo debidos, y se podía inundar la ciudad de Bahía Blanca por completo. Nosotros estudiamos todo eso con mucho detenimiento, paramos todas las obras y lo cerramos, y ahí descubrimos que en realidad el dique debía estar emplazado un quilómetro y medio más arriba, pero como era muy costoso no lo hicieron y tampoco los estudios de suelo, hicieron todo rápido, y cuando salta esto empezaron a moverse para coimear al ministro y se fueron con las manos vacías porque Alberto en ese sentido era inflexible, y los 
que además derivaron directamente en una denuncia del gobierno provincial a la empresa privada adjudicataria de la obra, gran parte del problema se originaba en la ubicación del dique, construido "en un territorio no apto lo suficientemente para llevar a cabo lo que se conoce técnicamente como sifonaje” y cuyas perforaciones no cumplían con los requisitos de profundidad mínimos, además de utilizar un método inadecuado para el drenaje de las tierras, entre otras deficiencias técnicas notorias (Bustingorry, 2015:86). ${ }^{390}$

Como resultado de esta investigación emprendida por los funcionarios de la TR del MOP, trabajadores del dique nucleados en la JTP bajo la conducción de Roberto "Tito" Bustos -Secretario General de Unión Obrera de la Construcción y militante de Montonerosemprendieron la ocupación del complejo y sus instalaciones, con el objetivo de detener la obra y exigir una solución inmediata a estos problemas. La toma fue secundada por los funcionarios Escolar y Raimondi, quienes procedieron a la incautación de las maquinarias y prohibieron el acceso de los directivos de la empresa, asegurando por otra parte a los obreros que su fuente de trabajo estaría garantizada a partir de ese momento por el gobierno provincial, quien tomaba en sus manos la continuidad de la obra. ${ }^{391}$

Tales medidas fueron oficializadas a través de un decreto del ejecutivo provincial que rescindió el contrato con la empresa adjudicataria, sin indemnización de parte del estado. Asimismo se preveía la aplicación de sanciones económicas en tanto la denuncia también contemplaba el fraude de la empresa, en connivencia con los funcionaros de la dictadura saliente, por sobreprecios en el costo de los materiales y en las formas de adjudicación de la licitación. ${ }^{392}$

Finalmente, en los considerandos del decreto de rescisión, se establecía que "el gobierno popular no puede ser cómplice de las falencias morales, administrativas y técnicas de los funcionarios de turno que tuvieron injerencia en el proyecto y ejecución de la obra" apuntando además "el compromiso ineludible de satisfacer el derecho inalienable de la población de contar con el servicio de agua potable...continuando la obra a través de la

denunciamos, hicimos una conferencia de prensa con Caletti trabajamos juntos en la denuncia, por eso nos odiaban".

${ }^{390}$ El Dia, 10/8/1973 "Estúdianse deficiencias del dique de Paso de las Piedras".

391 La Nación, 10/08/1973 "Ocupáronse obras de un dique bonaerense".

392 Decreto 1674/73 Boletín Oficial de la Provincia de Buenos Aires. El Día, 11/8/1973 "La Provincia rescindió el contrato para la construcción de la presa y del embalse de Paso de las Piedras". La Nación, 11/08/1973 "Intervinieronse obras en Paso de las Piedras" 
acción estatal, que redundará positivamente en el Programa de Reconstrucción y Liberación Nacional", 393

Las implicancias de la medida fueron varias. Por un lado, encarnaba a nivel del gobierno peronista provincial el cumplimiento con las pautas programáticas pensadas para esa etapa. Esto se traducía concretamente, como vimos más arriba, en el reconocimiento de derechos primarios y la provisión de servicios públicos básicos -como el agua potablepara los sectores más postergados, quienes habían padecido durante décadas el abandono y la desidia de los gobiernos proscriptivos y antipopulares. A su vez, esta política "reparatoria" iba asociada -en contraposición- a la imagen del manejo fraudulento y los negociados de la dictadura militar, prácticas que eran profundamente repudiadas y que se encontraban en las antípodas de la concepción sobre el ejercicio de la función pública que primaba entre los y las militantes de la TR.

Por otro lado, desde el nivel de la organización Montoneros, este caso en particular representaba en cierto modo la posibilidad de avanzar en la concreción de objetivos mayores desde la instancia del gobierno, vinculados directamente a la gestión estatal de recursos estratégicos y el quite de ese poder al capital privado. Al respecto, esa yuxtaposición de esferas de la práctica militante, guiada por un objetivo estratégico común, es explicada por una de sus protagonistas:

\footnotetext{
"Hay cosas que por ahi no responden orgánicamente a las estructuras o canales que corresponden a las de un Ministerio, por ejemplo, con lo del tema dique Paso de las Piedras. Fue muy importante porque el gobierno de Bidegain decidió tomar las riendas en el asunto y manejarlo desde Obras Públicas. Ahi había un negociado tremendo del gobierno de Lanusse y en este tipo de casos había cosas que se manejaban... es decir, a lo mejor yo no tenía que ir por el ministerio, pero viene Escolar con Prenso (Ricardo Rubio) y me dicen vas vos con el chofer del ministro a capital, te damos los contactos en cada diario donde tenés que ir a plantear la cuestión de Paso de las Piedras, y uno de los contactos era Verbistky en Clarín, que ya era compañero, y me acuerdo que me mandan casi como clandestinamente con el chofer. Es decir, como que las cosas no se manejaban por los canales oficiales del ministerio, estábamos en esta tensión permanente entre lo que es una estructura oficial burguesa, y una forma de manejar la política desde una perspectiva diferente. Porque a lo mejor ellos no podían mandar a hacer ese trabajo a quien le correspondía en la jerarquía ministerial ¿me explico? sino que se tenía que confiar en los militantes". 394
}

La trascendencia de este caso, junto al alto perfil de algunos funcionarios de la TR directamente comprometidos en su cometido, dio lugar nuevamente a fuertes presiones de sectores de la derecha peronista hacia el ejecutivo provincial para forzar renuncias a nivel

\footnotetext{
393 Ibid.

${ }^{394}$ Entrevista de la autora a Marina Siri, San Miguel (2017)
} 
ministerial. Las presiones aludidas, es importante destacar, se daban en el marco de una coyuntura política a nivel nacional cada vez más inestable para la TR en el gobierno, que involucró un plan de "depuración" dentro del Movimiento Peronista encabezado por los grupos de la ortodoxia legitimados por Perón. Más precisamente, nos referimos a las órdenes de disciplinamiento interno impartidas por Perón en una reunión a principios de octubre que contó con la presencia de los gobernadores y miembros del CSMNJ. Las directivas allí dadas se conocieron bajo el nombre de "Documento Reservado". En el próximo capítulo analizaremos con mayor detenimiento las implicancias de esta medida para la TR.

Bajo este telón de fondo, a mediados de octubre el Subsecretario de Obras Públicas, Pablo Escolar, debió renunciar a su cargo acompañado por otros funcionarios del MOP. ${ }^{395} \mathrm{Su}$ conocida militancia en Montoneros, el vínculo directo con las agrupaciones de la JTP, el estímulo a las acciones directas y a la participación de los trabajadores en el MOP, y el despliegue de políticas que afectaban intereses de sectores empresarios, fueron las razones que lo colocaron en el blanco de los ataques. ${ }^{396}$

Con relación a esto, en una solicitada de apoyo que los trabajadores del MOP publicaron en los diarios días después de su renuncia, puede leerse la mención directa al papel desempeñado por Escolar en el caso del dique de Paso de las Piedras como motivo de su obligada salida del organismo. Allí se afirma que "la forma en que el MOP resolvió este caso constituye un muy mal precedente para las grandes empresas", siendo la renuncia del funcionario Escolar "la excusa de quienes en realidad están en contra de lo que se ha realizado en 120 días de gestión...una política de participación del personal en todos los niveles, que rompe con los mecanismos de poder y privilegio de sectores al servicio de lo antinacional". Además de apuntar directamente al contenido radicalizado de sus políticas, se mencionaba también que esta medida formaba parte "del lanzamiento de una histérica caza de brujas" protagonizada por sectores "profundamente reacios a las politicas nacionalistas y al compromiso con el pueblo". 397

\footnotetext{
${ }^{395}$ El Día, 18/10/1973 “Otras dos renuncias fueron aceptadas en el ámbito bonaerense”.

396 Entrevista de la autora a Babi Molina, La Plata (2014). Entrevista de la autora a Sergio D. (2017) y Entrevista de la autora a Ricardo Rubio (2017).

${ }^{397}$ El Día, 15/10/1973 "Solicitada: Renuncia de un funcionario. Quienes y por qué la quieren”. La firman Coordinadora de agrupaciones peronistas del MOP. Agrupación de trabajadores peronistas de Vialidad. Agrupación de trabajadores peronistas de DEBA. Agrupación de trabajadores peronistas de Obras Sanitarias. Agrupación de trabajadores peronistas de Obras Públicas - JTP.
} 
La remoción de Escolar marcó un punto de inflexión en el activismo de la TR en el MOP, hecho que puso cada vez más en claro el declive general que comenzó a tener este sector en el seno del Movimiento. No obstante, como veremos en el próximo capítulo, la profundización del enfrentamiento con sectores de la derecha peronista, y con el propio Perón, en los últimos meses de 1973, no significaron el abandono de las iniciativas institucionales. Por el contrario, este desafío se traducirá en el intento por desarrollar nuevas estrategias desde el gobierno provincial. El Operativo Dorrego fue una muestra de ello. 


\section{CAPITULO VI: APUESTAS FRENTISTAS DESDE EL MINISTERIO DE GOBIERNO. EI Operativo Dorrego}

Durante el mes de octubre tuvo lugar una de las experiencias más destacadas del gobierno de Oscar Bidegain y que despertó todo tipo de reacciones: El Operativo Dorrego. ${ }^{398}$ El mismo fue convocado para hacer frente a las fuertes lluvias y posteriores inundaciones que azotaron las localidades del centro oeste de la provincia desde el mes de junio, ${ }^{399}$ participando militantes de la Juventud Peronista (JP)-Montoneros en asociación con sectores del Ejército. La iniciativa lanzada desde el Ministerio de Gobierno provincial se desarrolló entre los días 4 y 23 de ese mes, y contó entre sus principales organizadores con funcionarios/as del ejecutivo bonaerense todos/as integrantes de la Tendencia, e implicó la movilización de 800 militantes de la JP en tareas de reconstrucción y trabajo comunitario en las zonas afectadas.

Si bien de modo parcial, la literatura académica sobre el tercer gobierno peronista ha reparado en este episodio de características particulares desde diferentes enfoques. Algunos trabajos se han limitado a señalar el carácter excepcional y fallido del Operativo como ensayo de trabajo conjunto entre militares y civiles con el objetivo político de lograr una supuesta "unión de todos los argentinos", destacando asimismo las consecuencias perjudiciales de aquel contacto para la militancia de la JP, en función de la información que facilitó para la posterior represión llevada a cabo por la dictadura militar (Verbitsky, 2006; Díaz y Vega, 2009; Besoky 2011).

Otros estudios han analizado el Operativo en el marco de las internas y el derrotero propio de las Fuerzas Armadas (Fraga, 1988; Rouquié, 1982), o desde el universo de las tradiciones de izquierda -en particular las organizaciones guerrilleras ERP y Montonerosy su vínculo con la cuestión militar (Caviasca, 2011 y 2018).

Estas contribuciones, no obstante, han omitido poner en diálogo el Operativo con la estrategia política más amplia que desarrolló la TR a partir de la coyuntura electoral, y con la experiencia institucional concreta ensayada en la provincia de Buenos Aires.

\footnotetext{
${ }^{398} \mathrm{Su}$ nombre oficial fue Plan Provincial de Reconstrucción Gobernador de Buenos Aires Coronel Manuel Dorrego.

${ }^{399}$ El Dia, 4/7/73 "Medidas para las áreas bonaerenses inundadas”. El Día, 30/7/1973 "El gobernador recorrió zonas del oeste afectadas por la inundación”. El Descamisado, Año 1, No 12, 7/8/1973 "Una verdadera catástrofe nacional".
} 
En este capítulo analizaremos el Operativo Dorrego en articulación con la dinámica de intervenciones político-institucionales que llevó a cabo la TR en el espacio bonaerense durante la segunda mitad del año 1973, dando cuenta -aquí también- de los intentos de la militancia por realizar acciones desde el ámbito gubernamental que contribuyeran a su proyecto revolucionario.

Asimismo, es importante no perder de vista que este hecho se produjo en una coyuntura sumamente adversa para el conjunto de la izquierda peronista a nivel nacional y provincial, pero aún abierta a la posibilidad de encarar distintas apuestas de trabajo político territorial con la intención de incidir en las relaciones de fuerza al interior del Movimiento Peronista.

En este sentido, como veremos a continuación, el Operativo Dorrego se convirtió hacia fines de 1973 en la última propuesta de envergadura institucional llevada a cabo por Montoneros en el gobierno de Bidegain, combinando en su despliegue el trabajo desde las estructuras del Estado con un conjunto de prácticas políticas no armadas en el territorio, dentro de una estrategia frentista que buscó fortalecer la alianza con otros actores en el marco de la ofensiva de la derecha peronista.

Cabe señalar también que el Operativo sirvió para dejar al descubierto ciertas definiciones ideológicas y alineamientos políticos muy significativos para la trama política subsiguiente -ubicando definitivamente a Bidegain junto con la TR y sectores nacionalistas del Ejército por un lado, enfrentados a Perón y los sectores ortodoxos de la rama política y sindical, por otro-, incidiendo de lleno en lo que fue la rápida "caída en desgracia" del gobernador y en el marginamiento definitivo de la TR en el estado provincial.

\subsection{El contexto: La cruzada contra el "enemigo interno" y las reacciones de la Tendencia}

Como vimos en los capítulos precedentes, la "masacre de Ezeiza" y la renuncia de Héctor Cámpora a la presidencia de la Nación representaron dos momentos claves del quiebre de las relaciones entre Perón y los grupos radicalizados de su Movimiento, y el inicio de la ofensiva de los sectores ortodoxos por recuperar los espacios de poder perdidos (Merele, 2016). Las fuertes advertencias del líder justicialista al día siguiente de su arribo, tal como señala Marina Franco, marcaron 'la línea entre el 'orden' y el 'desorden' que el peronismo en el poder admitiría” de allí en más (Franco, 2012: 47). Este episodio, junto 
con el alejamiento forzado de Héctor Cámpora ya remitido, fueron percibidos por el conjunto de la Tendencia como un freno al poder de movilización y acción política que la militancia revolucionaria venía ejerciendo en el gobierno, anunciando el nuevo realineamiento de fuerzas dentro del peronismo a favor de los sectores de la ortodoxia política y sindical.

El impacto de este proceso en la provincia de Buenos Aires, tal como analizamos en el capítulo 4, derivó en una marcada crisis institucional a principios de agosto, y finalmente en la renuncia de importantes funcionarios ligados directamente a la TR.

Con el correr de los meses, se puede observar la profundización de esta línea, desplegándose a nivel nacional un conjunto de medidas y disposiciones que apuntaron directamente a recortar el poder político y de movilización de las organizaciones de la izquierda peronista dentro del partido y el gobierno, cuando no, a erradicar definitivamente y en forma violenta su inclusión misma en el Movimiento.

Las razones que explicarían este giro notable de la política de Perón en contra de los grupos más radicalizados, tal como señalan varios autores, se vincula directamente con el nuevo escenario de concertación económico-social que el líder buscó imponer desde su llegada al país, a través de la implementación del Pacto Social. Dicha estrategia -tal como vimos en el capítulo 3- necesitaba para su cabal funcionamiento del apoyo de los grupos tradicionales del sindicalismo ortodoxo, quienes -a cambio de la moderación en sus demandas- pujaban por incrementar su poder corporativo en detrimento de las dirigencias más combativas, y por esto mismo, disfuncionales a los planes de Perón: concretamente las organizaciones nucleadas en la TR (Torre, 1989; Godio, 1986; Maceyra, 2004; Anzorena, 1998).

Como prueba de esta política de exclusión podemos mencionar la reunión que Perón mantuvo con los gobernadores peronistas a principios de agosto, en la que adelantó los ejes de su estrategia futura. Allí, el líder justicialista explicitó que su propósito mayor era "poner de acuerdo a todos los argentinos", tarea política que se lograría sólo "dentro de la ley" y bajo el sumo cuidado de no "sacar los pies de plato, porque entonces tendremos el derecho a darles con todo". La referencia iba dirigida a las organizaciones armadas, las cuales no serían aceptadas bajo ningún concepto en su futuro gobierno: "No admitiremos la guerrilla, porque yo conozco perfectamente el origen de esa guerrilla" (citado en Servetto, 2010:194). En la misma línea, se encuentran también el conjunto de instrucciones tomadas por el Consejo Superior del Movimiento Nacional Justicialista que 
disponían la clausura de todos los Ateneos, Agrupaciones y Unidades Básicas que no hubieran sido reconocidas oficialmente por la rama política de ese Consejo, lo que en la práctica implicaba la supresión y el rechazo de las agrupaciones de la Tendencia y su imposibilidad de competir dentro del partido, asegurando así el control de los sectores de la derecha político sindical en las estructuras del Movimiento. Precisamente, esta disposición en aquel momento significó la desarticulación de la Agrupación Evita de la Rama Femenina recientemente organizada. ${ }^{400}$

Estas medidas se complementaron con otras de similar orientación, como el proyecto de conformar una JP contraria a la de la Tendencia (la Juventud Peronista de la República Argentina- JPRA) y con plena representación en el CSMNJ; la designación de López Rega como intermediario directo entre Perón y los grupos juveniles; la nominación de Julio Yessi al frente de la Rama Juvenil; la destitución de Juan Manuel Abal Medina de su cargo de Secretario General; el pedido y finalmente renuncia del Rector Interventor de la UBA, Rodolfo Puiggrós; entre otras (Franco, 2012; Besoky, 2016 y Merele, 2017)

Si estas resoluciones buscaron aislar a la TR debilitando su representatividad en los órganos oficiales del Movimiento, otras dos leyes importantes del período (Ley de Asociaciones Profesionales y Ley de Prescindibilidad) apuntaron directamente contra la hegemonía de los sectores radicalizados en el movimiento obrero y el Estado. La primera, enviada al Congreso en el mes de octubre, implicó el recorte de experiencias antiburocráticas y basistas a través del fortalecimiento de las estructuras tradicionales del aparato sindical, lo que despertó una ola de manifestaciones y plenarios de discusión lanzados por la JTP que fueron duramente reprimidos. ${ }^{401}$ La segunda, sancionada en noviembre, fue un proyecto que surgió originalmente para poner fin al "continuismo" de los funcionarios legados por la dictadura militar pero que rápidamente fue reconvertida para llevar adelante despedidos de una gran cantidad de funcionarios y trabajadores estatales vinculados a la Tendencia. ${ }^{402}$ Los objetivos finales de todo este engranaje, como señala Servetto, no eran otros más que "la depuración ideológica, la desmovilización politica y el disciplinamiento de los actores sociales" (Servetto, 2010: 196).

\footnotetext{
${ }^{400}$ Ver "La depuración y los anhelos de las bases". Militancia, Año 1, No 20, 25/10/1973, p. 8.

401 "Contratapa". El Descamisado. Añol, No 24. 30/10/1973.

${ }^{402}$ Una tercera y muy polémica Ley sancionada finalmente en enero de 1974 pero enviada al Congreso en esta misma época fue la Reforma del Código Penal, fuertemente resistida por la Tendencia y que derivó en la renuncia de 8 de sus diputados al Congreso de la Nación. Ver próximo capítulo.
} 
Por último, en función de sus implicancias políticas y de la caza de brujas que habilitó en las administraciones provinciales, no podemos dejar de mencionar el denominado "Documento Reservado". El mismo fue presentado en una reunión con gobernadores y vices convocada por Perón el 1 de octubre y firmada por el CSMNJ, destinada a los delegados del Movimiento Nacional Justicialista en las provincias. Dicha "orden reservada" sancionaba el mandato de "depuración ideológica" dentro del Movimiento en vistas a lograr una próxima gestión bajo la "más estricta y pura ortodoxia peronista".

Si bien las alusiones a la lucha contra la "infiltración" venían siendo una constante desde Ezeiza en adelante, la novedad ahora radicaba en que era el propio Perón quien oficializaba el inicio de la "purga" entre sus seguidores, en nombre de la ortodoxia y el verticalismo, apuntando asimismo a los sectores juveniles como los más vulnerables a esta "penetración ideológica". Como parte de las directivas emanadas de este documento, se estipulaba el inicio de un "estado de guerra permanente contra la infiltración marxista que sufría el Movimiento Nacional Justicialista", haciendo un llamamiento directo al esclarecimiento y definición pública de todos sus integrantes en favor de la doctrina Justicialista. ${ }^{403}$

Bajo este registro de guerra interna, se establecía también la urgencia de que las administraciones provinciales y municipales se ajustasen " $a$ los propósitos y desenvolvimiento de esta lucha, ya que a ellos les compete la principal responsabilidad de resguardar la paz social...haciendo actuar a todos los elementos de que dispone el Estado para impedir los planes del enemigo para reprimirlo con todo vigor" (Merele, 2016:49), señalamiento por demás amenazante para la gestión de Bidegain y el resto de los gobernadores asociados a la TR. ${ }^{404}$

Inicialmente, la reacción de las organizaciones nucleadas en la Tendencia ante estos sustanciales reveses consistió en la demostración pública de su capacidad de movilización, con el objetivo de tomar contacto directo con el líder y medir fuerzas con los otros sectores del Movimiento. Esto es lo que sucedió tempranamente en la movilización del 21 de julio a la residencia de Gaspar Campos para "romper el cerco"

${ }^{403}$ La Opinión 2/10/1973 "Drásticas instrucciones a los dirigentes del Movimiento para que excluyan todo atisbo de heterodoxia marxista: el Documento Reservado"

${ }^{404}$ Tanto en la revista El Descamisado como en Militancia se pueden observar las críticas inmediatas que la aparición de esta "orden reservada” produjo en las agrupaciones de la TR. Ver “¿Y esto qué es?”. El Descamisado, Año 1, No 21, 9/10/1973. p.2 "Perón presidente”. Militancia, Año 1, Nº19. 18/10/1973. Pp. 4-7, y “Semana política: el terror blanco y las exigencias del pueblo”. Militancia, Año 1, No18. 11/10/1973. pp 4-6. 
que separaba a Perón de su pueblo, y en la del 31 de agosto frente a la sede de la CGT nacional en apoyo de su candidatura presidencial. ${ }^{405}$

No obstante, la contestación del líder justicialista ante estos sucesos fue contundente: en el primer caso, decidió recibir sólo a una mínima delegación y nombró como su interlocutor a José López Rega; en el segundo, avaló la intervención de patotas de la UOM y de la CGT nacional en la conducción regional cegetista de Salta, en manos de Armando Jaime, reconocida figura del sindicalismo combativo (Gasparini, 1998: 62; Lapolla, 2005: 242)

Debemos recordar que el aumento en la capacidad de movilización de la Tendencia no fue proporcional a su representación en los cargos ejecutivos y en las listas. Si bien, como ya analizamos, la movilización de sus agrupaciones había sido muy importante durante el “Operativo Retorno" en la segunda mitad del año 1972, y durante toda la campaña electoral de principios de 1973, este poder no se tradujo en la obtención de lugares mayoritarios dentro de las listas (rama política, sindical, femenina y juvenil) obteniendo un porcentaje menor de la representación total (Vaca Narvaja y Frugoni, 2002:89; Perdía, 1997:148).

Por otra parte, esta metodología de acción directa fue desautorizada cada vez con mayor virulencia por Perón luego de su regreso, agravándose aún más con el asesinato del Secretario General de la CGT, José Ignacio Rucci, ocurrido tan sólo dos días después de las elecciones que lo consagraron como presidente por tercera vez. Este hecho, de profundas implicancias políticas, con el correr de los días fue adjudicado a la organización Montoneros, ${ }^{406}$ desatando una ola de intimidaciones, persecuciones, atentados contra locales y asesinatos de militantes de la izquierda peronista en los meses siguientes (Franco: 2012; Merele: 2016)

A esta altura de los acontecimientos, comenzaban a evidenciarse para la TR los límites de un accionar que apelaba a la movilización -por fuera de las estructuras institucionales del partido y el estado- como respuesta inmediata para contrarrestar los embates de la

\footnotetext{
${ }^{405}$ Montoneros utilizó la "teoría del cerco" como primera explicación ante el comportamiento crítico de Perón hacia ellos. Según esta teoría, el líder justicialista se encontraba senil y cercado por personajes siniestros como López Rega y la misma Isabel, quienes impedían su contacto con las masas y el fiel conocimiento de la realidad. Gillespie (1987:182). Según los datos de este autor, Montoneros en su momento de mayor crecimiento logró movilizar más de 150.000 personas durante los actos de 1973 (Gillespíe, 1987:170).

406 Para diferentes referencias sobre la autoría de Montoneros en el asesinato de Rucci ver Gasparini (2007:91), Bonasso (2001:141), Anguita y Caparrós (2007 [1998]: 326 y 327), Celesia-Waisberg (2010: 164), Reato (2008), Peyrou (2008)
} 
ortodoxia político sindical y del propio jefe del Movimiento. Como veremos a continuación, con el lanzamiento del Operativo Dorrego esa capacidad de convocatoria y movilización se intentó articular con una estrategia política de mayor alcance desde el gobierno provincial, proyectándose en una alianza con sectores nacionalistas del Ejército para la conformación de un Frente de Liberación Nacional.

\subsection{Política frentista: militares y militantes “codo a codo" por la Reconstrucción Nacional}

Con la llegada del peronismo al poder, la relación entre Montoneros y las Fuerzas Armadas (FFAA) experimentó un cambio notable. Según el relato de uno de sus principales miembros, los contactos entre la organización y figuras importantes del Ejército comenzaron a ser fluidos ya en los primeros meses de 1973, llegando incluso a acercarle a Perón en las reuniones que mantuvieron en Roma y Madrid, los nombres de varios militares (Cesio, Dalla Tea y Carcagno) como posibles candidatos para conducir la fuerza (Perdía, 1997:141).

La vinculación que Montoneros promovía con este actor -que hasta ese momento había sido uno de sus principales enemigos- respondía a la lectura política que realizaba la organización de la nueva coyuntura abierta en 1973. En esta lectura, visualizaban como positivo un acercamiento a las FFAA tanto por ser una institución del Estado en la que eventualmente podrían "introducir" su línea política, como en especial para menguar lo que entendían como una posición sectaria y antipopular de esta institución que podría devenir en un nuevo golpe contra el gobierno peronista. Así lo expresaba uno de sus cuadros de conducción:

\footnotetext{
"restablecida la soberanía popular, entendimos - a diferencia del ERP- que ya no había razones para continuar la lucha armada ni para el enfrentamiento con las FFAA (...) era necesario generar lazos de solidaridad que pusieran límites a sus tendencias elitistas. Creíamos que de esa manera alejábamos los riesgos de los golpes de estado y favorecíamos esa interrelación necesaria entre la sociedad y sus instituciones militares (Perdía, 1997:174)
}

Por otra parte, Montoneros desde de sus posicionamientos ideológicos, definía como contradicción principal el enfrentamiento entre Imperio-Nación, en lugar de BurguesíaProletariado, y la concepción de un Frente de Liberación Nacional (FLN) policlasista bajo el liderazgo de la clase obrera que actuaría en el proceso de lucha antiimperialista. Por tanto, esta línea ideológica habilitaba de lleno la posibilidad de establecer acuerdos 
con otros actores, más aún con los sectores nacionalistas de la corporación militar. ${ }^{407}$ Muestra de ello fueron las declaraciones que brindaron los principales dirigentes de FAR y Montoneros en una conferencia de prensa en el mes de junio de 1973. Allí, además de definir los términos de la contradicción principal como "liberación" o "dependencia", destacaron la importancia de forjar alianzas con todos los sectores identificados con el objetivo de la emancipación. En este sentido, se planteaba que "las FFAA son un actor que debe integrarse al proceso de reconstrucción y liberación nacional”, cuyos integrantes "deben comprender que si se encierran en sus cuarteles bajo la consigna de un supuesto profesionalismo, lo único que conseguirán será aislarse del pueblo". ${ }^{408}$

Así también lo señalaba un miembro de la conducción nacional, Fernando Vaca Narvaja, a raíz del Operativo Dorrego y las expectativas en torno a la ampliación de la base social y política del FLN:

"Hasta antes del '73 era impensable que nosotros estuviéramos trabajando en un tema social con los militares. Pero esto luego, de alguna manera, reflejaba la intencionalidad política de Montoneros respecto de la situación del pais: la conformación de un Frente de Liberación Nacional que incluyera a las Fuerzas Armadas". 409

Por otra parte, experiencias en el plano internacional y especialmente latinoamericano, en las que generales del Ejército encabezaban gobiernos de reformas radicales en un sentido popular y antiimperialista, abonaban también a una mirada permeable y no monolítica sobre las FFAA como actor político, y a gestar potenciales vínculos con sus sectores progresistas. La experiencia más temprana de Nasser en Egipto, así como la de Velasco Alvarado en Perú, Torres en Bolivia y Torrijos en Panamá, fueron seguidas muy de cerca

\footnotetext{
407“"Boletín Interno no 1. Primera quincena de mayo de 1973 - Montoneros" (Baschetti, 1996:568-616). En este documento, en el punto 3.2.3.2 denominado Nuestro Plan de Ataque, se plantea, entre otras formas de organización de masas política y militar, "la constitución de un ejército regular del FLN a partir de sectores militares que hoy adhieren al Frente, de la captación ideológica para el MLN de la oficialidad joven (hasta capitán), suboficiales y tropa". Como así también la "organización de las milicias populares con la preparación de una estructura de combate y una estructura de logistica de apoyo y mantenimiento". 408“"Conferencia de Prensa. FAR y Montoneros, junio de 1973" (Baschetti, 1996: 75 y ss). Sobre las tradiciones peronistas de izquierda que influyeron en la concepción de Montoneros y su relación con las FFAA, ver Caviasca (2018).

${ }^{409}$ Vaca Narvaja y Frugoni (2002: 227). El dirigente montonero asimismo relata que la organización ya venía realizando trabajo político dentro de las FFAA, con aquellos sectores que protagonizaron levantamientos dentro de la Escuela de Mecánica de la Armada, o en cuarteles de Corrientes y el litorial el mismo 17 de noviembre de 1972, día del retorno de Perón. Para el caso de Julio Cesar Urien, guardiamarina que se sublevó en la Escuela de Mecánica de la Armada e ingresó a Montoneros ver Anguita y Caparrós (2007 [1998]: 609). Luego de esta experiencia Urien se incorporó a la Secretaría Militar de Montoneros y ofició contactos entre la organización y los militares.
} 
por la conducción de Montoneros, ejerciendo una influencia en todo el amplio espectro de la izquierda peronista (Nercesián, 2014:189-210). ${ }^{410}$

En paralelo a esta estrategia frentista planteada por Montoneros, al interior de las FFAA a principios de 1973 se sucedieron importantes cambios y realineamientos que resultaron favorables para este acercamiento.

La debilidad y crisis que sobrevino a las corrientes más liberales y antiperonistas dentro del Ejército luego del fracaso del GAN de Lanusse, dieron lugar a la ascendencia de un grupo de militares que adscribían a una línea de apertura democrática, nacional-populista, encarnada en un "profesionalismo comprometido" con el nuevo proceso político (Rouquié, 1982). Con centro en el V Cuerpo del Ejército en Bahía Blanca, el Coronel Carlos Dalla Tea, el Coronel Juan Cesio y el General Jorge Raúl Carcagno, aparecían como los principales representantes de estas posiciones, y más proclives al diálogo con los grupos radicalizados del peronismo.

Según el cumplimiento de una ley no escrita dentro de la fuerza militar, la designación de Jorge Carcagno como Comandante en Jefe del Ejército, al ser el más joven de los Generales de su división, determinó el pase a retiro de los ocho colegas más antiguos que él. De acuerdo al historiador Alain Rouquié, el nuevo comandante pertenecía, como Perón, al cuerpo de Infantería y reducto "colorado", lo que significó un duro golpe para la camarilla "azul" de la Caballería que dominaba el ejército desde 1960, la cual sufrió una especie de depuración. Según sus palabras "era el fin de una época, nuevas relaciones cívico militares tomaban forma, mientras que en el ejército se modificaban las relaciones entre las armas" (Rouquié, 1982: 296-297). ${ }^{411}$

\footnotetext{
${ }^{410}$ Un ejemplo de la influencia del Gobierno de Velasco Alvarado con su política de reforma agraria y nacionalización de recursos estratégicos puede observarse en las notas periodísticas de varias revistas de la izquierda peronista, por mencionar solo algunas: "A los enemigos les cortaremos las manos con nuestros machetes", Revista Ya! Es tiempo del pueblo $\mathrm{N}^{\circ}$ 6, 3 de agosto de 1973, p.10 y "La liberación que intenta Perú" Revista Ya! Es tiempo del pueblo No 9, 24 de agosto de 1973, p. 19. Referencias positivas al Gobierno de Torres se encuentran en "Bolivia. La hora del cambio de guardia" en El Descamisado año 1, $\mathrm{N}^{\circ} 1,22$ de mayo de 1973, p.3, y al Gobierno de Torrijos "Unidos o Dominados" en El Descamisado año 1, $\mathrm{N}^{\circ}$ 13, 14 de agosto de1973, p. 9, y "Torrijos. Un general peronista" en El Descamisado, año $1 \mathrm{~N}^{\circ}$ 16, 4 de septiembre de 1973 .

${ }^{411}$ Ver también Bernetti (1983:166). Según Bonasso, la elección de Carcagno corrió por cuenta de Perón, siendo ésta una opción intermedia entre una terna que por derecha postulaba al militar López Aufranc y por izquierda al Coronel de Inteligencia Dalla Tea, lo que hubiera significado el pase a retiro de más de 40 Generales. Opción finalmente descartada frente a las posibles reacciones que dicho descabezamiento podría generar en el cuerpo castrense. Bonasso (1997:450).
} 
Si bien los antecedentes de Carcagno no eran demasiado auspiciosos de cara al vínculo con sectores del campo revolucionario peronista, ${ }^{412}$ con el paso del tiempo éste y sus allegados dieron muestras no sólo de la aceptación de la salida electoral, sino también de la cercanía con el proyecto de Cámpora, a través de contactos fluidos con Juan Manuel Abal Medina sostenidos en la etapa de transición electoral (Bernetti, 1983: 127).

De acuerdo con el testimonio de Rodolfo Galimberti, el plan de Carcagno consistía en avanzar sobre los puestos de conducción del Ejército con el objetivo de llevar adelante una política antiimperialista, que revirtiera la persistente hegemonía de la doctrina de Seguridad Nacional en la Fuerza. Asimismo, según el exdelegado juvenil, también le habría sugerido a Montoneros meses antes del Operativo "formar una milicia nacional para desarrollar una política de fronteras, una versión similar al Operativo Dorrego, pero a nivel nacional" (citado en Bernetti, 1983:169).

Precisamente, en su discurso de asunción como jefe castrense, Carcagno dio muestras de sus posiciones políticas al reconocer que "el pueblo es el único depositario de la soberanía” y que, de ahora en más, correspondía al Ejército "honrar sus armas, para contribuir a la unión de todos los argentinos, sin distinción de credo político o de postura ideológica". ${ }^{413}$ Palabras que iban en concordancia con el rol democrático y popular que el presidente Héctor Cámpora le asignaba a las FFAA en la nueva etapa constitucional, y de la política anti represiva que el Ministro del Interior Esteban Righi encaraba en la Policía Federal por la misma época (Bernetti, 1983: 125).

Dentro de este marco, la relación de la nueva cúpula militar con la dirección de Montoneros comenzó a incrementarse. Los primeros contactos a principios de 1973 se habían realizado a través de militantes de la JP ligados al Sindicato de la Construcción en Bahía Blanca, lugar donde Carcagno y su Estado Mayor ejercían funciones. Luego de su asunción ya como Jefe del Ejército, las reuniones entre ambas conducciones se volvieron

\footnotetext{
${ }^{412}$ Carcagno había participado en la represión al Cordobazo como Jefe de la IV Brigada de Infantería Aerotransportada, y también en el accionar contra Montoneros a raíz de la toma de la localidad cordobesa de La Calera. Según Perdía, Carcagno le habría confesado que luego del Cordobazo se prometió hacer todo lo posible para que nunca más el ejército estuviera enfrentado con el pueblo. Perdía, (1997: 207).

${ }^{413}$ Reportaje de Carcagno para el diario La Opinión, citado en Besoky (2012). Otro hito destacable fue la posición que Carcagno sostuvo en la X Conferencia de Ejércitos Americanos, a principios de septiembre en Venezuela, en la que junto con la delegación de Perú, se manifestó a favor de una política de defensa continental antiimperialista, proponiendo incluso la "creación de organismos de coordinación militar entre ejércitos de Latinoamérica que excluyan a los EEUU”. Esta declaración fue acompañada del pedido de retiro de las misiones norteamericanas y francesas instaladas en nuestro país desde hacía quince años en la propia sede del comando del arma. La actuación de Carcagno en esta Conferencia recibió una destacada cobertura por parte de la revista El Descamisado. Ver "Se acabó la época en que los yanquis nos metían dos hembras en la cama". El Descamisado, Año 1, n 17, 11 de septiembre de 1973, p. 29.
} 
más regulares, con el objetivo -según el testimonio de Perdía- de lograr acuerdos políticos para el pos gobierno frente a una eventual muerte de Perón (Perdía, 1997: 206).

Montoneros impulsó este plan debido al conocimiento del grave deterioro de la salud de su líder. Así lo señala Perdía en su libro:

"Sin Perón existía el riesgo de que los sectores identificados con las viejas políticas, que controlaban la mayor parte de los mandos efectivos, intentaran una nueva aventura golpista. Por ello promovimos un encuentro secreto con Carcagno y su Estado mayor [...] la implicancia del acuerdo se limitaba a procurar un mayor equilibrio en el poder y evitar las acechanzas e intentos hegemónicos que pudiera hacer López Rega, a partir de su influencia sobre Isabel" (1997: 206-207). ${ }^{414}$

Estas ideas convergían asimismo con la desconfianza de Carcagno y sus allegados respecto de López Rega y el peso influyente del sector sindical en el gobierno, situación que podía poner en peligro la continuidad de la línea popular nacionalista al interior de la corporación militar, ante el posible fallecimiento del presidente de la Nación. En palabras del historiador Rosendo Fraga sobre el pronóstico elaborado por el Jefe del Ejército:

"Perón difíilmente terminaría su periodo de gobierno por razones de salud. A su desaparición se produciría un vacio de poder que debería ser llenado por un frente conformado por el Ejército y el peronismo a través de su ala más dinámica que eran los sectores juveniles quienes serían los dueños del peronismo en el futuro. Por esa razón, era necesario establecer una alianza entre el ejército y la JP, para asegurar el futuro de la Nación y evitar que el país se precipitara en un caos tras la desaparición del Presidente" (Fraga, 1988:61). ${ }^{415}$

Más allá de esta convergencia táctica entre la conducción de Montoneros y Carcagno, en lo que sería una posible "salida a la peruana" como horizonte de mediano plazo ante un eventual vacío de poder, ${ }^{416}$ existieron otras iniciativas que se plasmaron en el campo político inmediato, concretamente en el territorio, y cuyas repercusiones condicionaron en gran medida el futuro de la TR en el espacio institucional provincial y el derrotero mismo del gobierno de Bidegain.

${ }^{414}$ La información sobre el creciente deterioro de la salud de Perón provenía de los contactos directos que Montoneros tenía con el Dr. Jorge Taiana a través de su hijo, militante de la organización.

415 Ver también Perdía (1997: 207).

${ }^{416}$ Se denominaba de esa manera a la línea militar que ponía eje en el antiimperialismo y en la defensa nacional y latinoamericana contra el avance del capital monopólico extranjero. Esta posición fue la que encabezó la delegación de Perú en la X Conferencia de Ejércitos Americanos de 1973. Ver Caviasca (2011) y Nercesián (2014). Ver ¿Qué pasa con los milicos? En El Descamisado, Año 1, № 30, 11 de diciembre de 1973 , p.2-3. 


\subsection{Intervención en el territorio: El Operativo Dorrego y su impacto en la interna peronista}

La idea de llevar a cabo un accionar conjunto entre Montoneros y las FFAA a partir de la conformación de brigadas de trabajo, estuvo presente en las conversaciones entre ambos actores hacia la primera mitad del año 1973. Precisamente fueron las inundaciones que azotaron a distintas localidades del centro oeste de la provincia de Buenos Aires las que brindaron la ocasión oportuna para consolidar esa iniciativa. ${ }^{417}$

Si bien el operativo fue presentado como una idea lanzada por el gobernador Bidegain convocando al Ejército y a las "Juventudes Políticas" en general a participar conjuntamente de las tareas de reconstrucción, ${ }^{418}$ lo cierto es que tanto la Conducción de Montoneros -en las figuras de los jefes de la Juventud Peronista Regional 1, Juan Carlos

Dante Gullo y Juan Carlos Añon- como los militantes de la TR que participaban como funcionarios del gobierno provincial, fueron quienes estuvieron al mando del mismo. Al respecto, a fines de julio desde el gobierno provincial se decidió conformar una Comisión Interministerial para la Zona de Emergencia ${ }^{419}$ que estaría a cargo de estas actividades, siendo además del Ministro de Gobierno, Manuel Urriza, los funcionarios y militantes de Montoneros Norberto Habegger (asesor privado de gobierno), ${ }^{420}$ Ernesto Jauretche (Subsecretario de Asuntos Municipales), Alejandro Mayol (Director de Coordinación de Servicios Culturales) y Alejandro Peyrou (Subsecretario de Asuntos Agrarios) quienes

${ }^{417}$ El Día, 30/6/1973 “El Gobernador recorrió las zonas del oeste afectadas por la inundación”. El estado de emergencia agropecuaria se prorrogó por el Ejecutivo Nacional hasta el 31 de diciembre de 1973 en 16 de los 18 partidos afectados. Diario Mayoría, 28/9/73, p.6.y El Descamisado, $N^{o}$ 12, 7/8/1973, p.17.

418 Ver Solicitada "Al pueblo de la Provincia de Buenos Aires" convocando al Operativo Dorrego. Diario El Día, 28 de septiembre de 1973, p. 6. Según Perdía “El Operativo aparecía como una respuesta a la convocatoria original realizada por el Gobernador Bidegain, pero nosotros ya teníamos contactos con sectores del ejército, lo planificamos con el Estado Mayor de modo que hubiera garantías, que no hubiera incidentes". En el mismo sentido Urriza sostiene que un pedido previo de los jefes militares fue que los campamentos de los soldados y los civiles de la Juventud Peronista estuvieran separados, aunque podían diariamente realizar formaciones conjuntas de izar la bandera, y que además los dirigentes de la JP se comprometían a no hablar de política con los soldados, aunque sí podrían discutir temas políticos con los oficiales. Urriza (2004:74).

419 Decreto 1137/73, Boletín Oficial de la Provincia de Buenos Aires.

${ }^{420}$ Según su esposa y compañera de militancia Flora Castro, Norberto Habegger fue quien estuvo al mando del Operativo: “Aparecía Dante Gullo pero el que supervisó y manejó todo en helicóptero fue Norberto, él era el responsable de hablar con Harguindeguy (...) en el acto del cierre del operativo en la localidad de 25 de Mayo, ahí fue un destape porque él que era para todo el mundo Ernesto Gómez, y ahí habló como Norberto Habegger de Montoneros. Yo estuve en ese acto de cierre en el palco." Ernesto Gómez era el nombre con el que Habegger figuraba como funcionario de la Gobernación. Entrevista de la autora a Flora Castro, La Plata (2013). 
tendrían la dirección política y técnica del operativo. ${ }^{421}$ Así lo señala uno de sus participantes:

"A nivel del Ministerio de Asuntos Agrarios, de gestión política desde el gobierno digamos, eso (el Operativo) chupó todas las energías mías y de alrededor, si bien no fue una politica institucional agropecuaria o de obras públicas de carácter tradicional, fue el episodio politico más importante de la JP en esos años, lamentablemente no hubo tiempo ni condiciones para hacer más". 422

Además de los lugares preponderantes en esta Comisión, otros espacios y áreas de la estructura institucional provincial encabezadas por militantes de la Tendencia intervinieron directamente en el Operativo, volcando recursos profesionales, técnicos y materiales. Desde el MOP se pusieron a disposición equipos mecánicos para drenar la zona afectada y reacondicionar el terreno, junto con el tendido de cañerías para garantizar la provisión de agua potable. También se proveyó de materiales para la construcción de viviendas y recuperación de edificios públicos como escuelas y hospitales, y se realizaron estudios conjuntos entre este organismo y el Ministerio de Asuntos Agrarios para la elaboración de un diagnóstico sobre las condiciones del suelo y el uso del agua en la cuenca el río Salado, haciendo un cálculo aproximado de las pérdidas ocasionadas en términos de cultivos y hacienda. ${ }^{423}$

Por otra parte, en sintonía con la política llevada a cabo en otros lugares, se promovió la conformación de cooperativas para la construcción de viviendas y consumo, en las localidades de Roque Pérez y Pehuajó, en las que el MOP aportaba materiales, maquinaria y recursos. ${ }^{424}$ Asimismo, desde el Ministerio de Bienestar Social a cargo del área de salud provincial, se dispusieron recursos para la prestación de servicios médicos, odontológicos y de vacunación. Dos altos funcionarios y ex militantes de Montoneros dan cuenta de las expectativas y objetivos en torno al Operativo, y el carácter diferenciado que revestía la participación de algunos militantes:

${ }^{421}$ El Descamisado, Año 1, № 20, 2/10/1973, p. 21. Entrevista de la autora a Flora Castro (2013).

${ }^{422}$ Entrevista de la autora a Alejandro Peyrou (2012)

${ }^{423}$ Entrevista de la autora a Ricardo Rubio (2017). Para el trabajo en el territorio se dividió la región en 4 zonas operativas: zona 1: partidos de Bragado, 9 de Julio, 25 de Mayo y Saladillo, con 2.300 soldados y 400 miembros de JP. Zona II: partidos de Carlos Casares, Pehuajó, Bolivar y General Alvear, con 1152 soldados y 300 miembros de JP. Zona III: partidos de Junín, Lincoln, General Viamonte y General Pinto, con 300 soldados y 50 miembros de la JP. Zona IV: partidos de Trenque Lauquen y Carlos Tejedor, con 192 soldados y 50 miembros de la JP. Urriza (2004:80)

${ }^{424}$ En la localidad de Roque Pérez el diputado provincial del FREJULI y militante de la Tendencia, José Tagliafico, oriundo de esa región, fue quien llevó a cabo la iniciativa local. Ver CPM-FONDO DIPBA, Mesa Referencia, legajo 16070, p. 126. 
“del Operativo Dorrego participamos de la logística y difusión, yo fui como integrante del ministerio por la parte de prensa y difusión, y estuve en la reunión en la que explicó el Coronel Albano Harguindeguy, también estuvo el Ministro de Obras Públicas, Alberto González, y fuimos logística en muchas cosas. Otros compañeros del Ministerio fueron directamente en calidad de militantes convocados por la orga. Fue un emprendimiento muy ambicioso para unificar a las Fuerzas Armadas con nosotros dentro de un proyecto politico. Nosotros levantamos la política del pueblo en armas, porque no hay seguridad ni defensa posible de la patria si no hay pueblo en armas, y el Operativo formaba parte de esa idea", ${ }^{425}$

Esta amplitud en el modo de intervenir en el Operativo, ya sea como funcionarios desde la estructura de los Ministerios, o en carácter de militantes por el territorio y la organización, es destacada también por Alejandro Peyrou:

"Yo no participé directamente del Operativo, pero el Ministerio (Asuntos Agrarios) aportaba lo que tenía para ese emprendimiento. Puso máquinas, recursos y gente en cada localidad (...) la verdad es que no teníamos demasiadas expectativas sobre la conversión de los militares al proyecto de liberación nacional, pero creíamos que podía ayudar a ampliar la base social y política del Frente de Liberación Nacional y al aislamiento del enemigo que era el imperialismo". ${ }^{426}$

La expresión del proyecto nacionalista y antiimperialista que el Operativo encarnaba para la militancia se expresó también en el nombre elegido para esta iniciativa. Según fuentes testimoniales, la designación del Operativo fue postulada por los dirigentes de la JP, quienes al evocar la figura mártir del caudillo federal Manuel Dorrego, buscaron unir y legitimar históricamente las luchas por la soberanía nacional realizadas en el pasado con las batallas dadas en el presente. ${ }^{427}$

El llamado para la participación de la militancia se realizó desde la Conducción de Montoneros -en algunos casos- y también desde los responsables de la Juventud Peronista

\footnotetext{
${ }^{425}$ Entrevista de la autora a Ricardo Rubio (2016). Con respecto a la participación de empleados públicos en el Operativo, el Gobierno de la provincia emitió el Decreto $\mathrm{N}^{\circ}$ 3051/73 facultando a los empleados de la administración pública para hacer uso de una licencia extraordinaria -con goce de sueldo $-\mathrm{y}$ sumarse voluntariamente a las tareas de recuperación de la zona afectada. Boletín Oficial de la Provincia de Buenos Aires, octubre de 1973.

${ }^{426}$ Entrevista de la autora a Alejandro Peyrou (2012). Similar definición brinda Hugo Bacci (2012)

427 "Dorrego era el Coronel del pueblo que enfrentó al imperialismo y que dio su vida por la causa nacional y popular, para nosotros fue toda una reivindicación histórica, y que además a los militares les dijera algo, en contra de una lectura liberal de la historia que siempre favoreció a Lavalle" Testimonio de Juan Carlos Dante Gullo en "¿Codo a codo? Operativo Dorrego”. Documental del Programa Jóvenes y Memoria para la Comisión Provincial por la Memoria, La Plata, 2007. Disponible en: https://www.youtube.com/watch?v=ZgDghtNKVbM. La imagen de Dorrego como mártir de la causa nacional formaba parte del relato que Montoneros construyó sobre la historia política nacional, desde la independencia hasta el siglo XX, trazando una línea de continuidad entre las luchas antiimperialistas conducidas por San Martín, Rosas y Perón. Esta narrativa "revisionista" se oponía a la lectura "liberaloligárquica" fundada por Mitre en el campo de la historia tradicional. Un ejemplo de esta configuración puede verse en "Hablan los Montoneros" en Cristianismo y Revolución, $\mathrm{N}^{\circ}$ 26, pp 11-14.
} 
en cada una de las 7 Regionales de todo el país. En total participaron 800 jóvenes (en su mayoría contingentes de la JP Regional 1), y por el lado del Ejército 4000 soldados (la mayoría conscriptos seguidos de oficiales de las distintas Unidades del Primer Cuerpo del Ejército con jurisdicción en provincia de Buenos Aires). ${ }^{428}$

En cuanto a la convocatoria y difusión interna del Operativo entre las distintas regionales, podemos identificar diversas razones que intervinieron en la decisión de los militantes de participar, algunas vinculadas a los objetivos planteados al interior de cada zona por sus responsables, y otras más ligadas a la jerarquía que tenían dentro de la organización (militante de superficie, aspirante, oficial).

En el caso de algunos militantes, las motivaciones para sumarse al Operativo pasaron más por el compromiso con el trabajo comunitario y como una vía de fortalecimiento ideológico y ascenso dentro de la organización

\begin{abstract}
"Omar era el más entusiasta de los militantes que habiamos conseguido reclutar en el barrio, por eso decidimos elegirlo a él para que representara a la Maestre (Unidad Básica) en el Operativo Dorrego. Teníamos la esperanza de que esa experiencia fuera vital para consolidarlo ideológicamente y que en poco tiempo se convirtiera en un cuadro barrial; entonces nuestro trabajo habría alcanzado el éxito" 429
\end{abstract}

En otros, la participación estaba directamente vinculada al contacto y trabajo de inteligencia que pudieran hacer con las FFAA, en el marco de la estrategia frentista de la organización:

\begin{abstract}
"Los responsables de la Juventud Peronista de la Regional I llevaron un documento mimeografiado que fijaba pautas para la discusión de los militantes con cuadros del ejército en todos sus niveles: oficiales de media y alta graduación, suboficiales y tropa. La charla giraría, según el documento, sobre el rol del ejército en las distintas etapas de la Historia, como ejército liberador en algunas coyunturas, como opresor en otras. También llevaron un cuadernillo en el que podía leerse, completo, el discurso que el Comandante General, Raúl Carcagno, pronunció en Caracas ante los jefes de ejércitos de todo el continente americano. ${ }^{430}$
\end{abstract}

Para otros, la intervención en el Operativo se relacionaba con las expectativas y el posible desarrollo de milicias armadas:

\footnotetext{
${ }^{428}$ Testimonio de Juan Carlos Dante Gullo, en “¿Codo a codo? ...” op. cit. Urriza (2004:77). Además de la división en 4 zonas de emergencia que abarcaba varias localidades, para el trabajo operativo en el territorio la JP dispuso la creación de Unidades Básicas de Reconstrucción Nacional (UBRN) las cuales constituían la estructura operativa y de coordinación. Dentro de cada una UBRN, existían grupos de trabajo de diez integrantes cada uno (Díaz y Vega, 2009)

${ }^{429}$ Asuaje (2004:173).

${ }^{430}$ Soriano $(2015: 165)$
} 
"Una directiva nacional se transmitía en formas diferentes. A mi zona llegó como una tarea de milicia. Pensar que ibas al Operativo Dorrego a realizar una tarea de milicias junto a los milicos, que ibas a confraternizar con ellos y ique los ibas a infiltrar! ...la tarea real fue de discusión entre nosotros, formación de cuadros y tareas conjuntas. ${ }^{431}$

A través de estos testimonios -junto con el de Ricardo Rubio citado más arriba- se puede observar la doble lógica que atravesó esta experiencia para la militancia revolucionaria de la Tendencia. Una lógica política que apelaba por un lado a la planificación y despliegue de sus militantes/funcionarios desde las estructuras del Estado en el marco de la realización de un programa de reconstrucción nacional; y otra lógica política que no abandonaba sus proyecciones estratégicas y que veía al Operativo como un posible escenario donde consolidar alianzas sustantivas con las FFAA y ensayar prácticas ligadas a la formación de un ejército popular revolucionario.

De todos modos, más allá de las diferentes directivas emanadas desde los órganos de conducción y de las expectativas dispares que despertó entre sus participantes, lo novedoso de la experiencia fue la envergadura de la movilización que implicó en el territorio, reuniendo por primera vez a militantes de la JP de distintas zonas para encarar conjuntamente las tareas de "reconstrucción nacional". 432

Fue esta movilización inédita la que permitió la articulación de diferentes grupos de trabajo, por ejemplo, entre los militantes de la JP del Oeste -conformada por los residentes directos de la zona afectada- y los contingentes de la JP del resto del país, en particular de la Regional I.

Precisamente, una de las primeras acciones encaradas en la región en los meses de junioagosto antes del Operativo, fue la conformación de "Mesas de trabajo comunitario, información y discusión” a cargo de las JP de Pehuajó, Bragado, Bolívar y 25 de Mayo, en las que se promovía el contacto y la comunicación directa con los damnificados por las inundaciones, quienes acercaban allí sus demandas y obtenían información técnica y política, además de servir de canal directo para elevar esas demandas a los organismos provinciales. A esta estructura de Mesas de Trabajo ya establecidas se sumarían, por

431 Testimonio de Pancho (seudónimo) oficial de las Fuerzas Armadas Revolucionarias (FAR). Entrevista citada en Díaz y Vega (2010). Recordemos que más allá de la fallida mención de Rodolfo Galimberti sobre la conformación de "milicias populares" en abril de 1973, recién en el año 1975 se consolidó el sistema de milicias en la estructura interna de Montoneros. Gillespie (1987:229).

${ }^{432}$ Hasta ese momento, la práctica habitual en las tareas de reconstrucción era que los militantes de la JP desarrollaran ese accionar en el ámbito mismo donde residían. 
ejemplo, los contingentes de la JP de La Plata, que arribaron a la zona una vez lanzado el Operativo en el mes de octubre. ${ }^{433}$

Esta experiencia de trabajo de las JP locales replicaba la política de participación popular e intervención de la comunidad en todos los niveles de la toma de decisiones públicas que, como vimos, fue una constante en la gestión de la TR en el gobierno provincial.

Por esto mismo, es interesante también examinar el tratamiento y la atención pormenorizada que recibieron del servicio de informaciones secreto dependiente de la policía de la provincia de Buenos Aires. En los informes remitidos por los agentes de las delegaciones regionales, se observa un seguimiento a la actividad de los militantes de la JP-Montoneros desde los meses de junio-julio en las denominadas "comisiones de defensa" encargadas de coordinar las actividades de asistencia a los damnificados, detallando la profesión y pertenencia institucional y política de cada uno de sus miembros. ${ }^{434}$ Dichos informes continúan incrementándose en los meses siguientes, volcándose una detallada caracterización sobre los aspectos "gremial", "político", “estudiantil” y "subversivo" de las personas que participaron de estas actividades (Jäkel y Farace, 2016). Por mencionar algunos ejemplos significativos, en el informe de la localidad de Carlos Casares del mes de julio se menciona que muchos vecinos "se quejan de que la comisión de ayuda a los damnificados está infectada de comunistas", acompañando dichas referencias con recortes de periódicos locales en los que se denuncia de manera alarmista el desembarco de "militantes de izquierda" provenientes de todo el país. ${ }^{435}$

Otro caso para destacar es el de la localidad de 25 de mayo, donde tuvo lugar el acto de cierre del Operativo, con informes muy detallados que dan cuenta de las actividades desarrolladas por los efectivos militares, los militantes de la Juventud Peronista y los empleados municipales y provinciales, señalando la preocupación por el posible contacto entre los dos primeros. Por último, desde la Unidad Regional Nº10 en Pehuajó, se

\footnotetext{
${ }^{433}$ El Descamisado, Año 1, No 12 del 7/8/1973, p. 15. CPM-Fondo DIPBA, Mesa de Referencia, Legajo 16.070, p. 221.

434 "Panorama de las inundaciones 25 de Mayo", sin lugar y fecha, en CPM - FONDO DIPBA, Mesa Referencia, Legajo 16.070, p. 74-76.

${ }^{435}$ CPM - FONDO DIPBA. Mesa Referencia, Legajo 16.070, p 44. Tal como señalan Jäkel y Farace (2016) la referencia a personas consideradas "comunistas" atraviesa todo el lenguaje de los Informes del Servicio Secreto de Inteligencia de la Policía, más allá de tratarse de personas cuya adscripción política no pertenecía al Partido Comunista en concreto. En la mayoría de los casos es un mote ambiguo que refiere a rumores y sospechas de "izquierdistas" sobre militantes de distintas tradiciones políticas. "El sujeto impreciso al que alude esta categoría habla de cómo la institución ha definido históricamente al "otro" subversivo por antonomasia, siempre referido como "comunista" o "izquierdista", tópicos que a su vez deben ser interpretados en el marco del vocabulario de Guerra Fría y de las diferentes doctrinas de seguridad del período”. Ver Marengo (2015)
} 
confeccionó el informe más completo, con una cronología de los hechos para cada una de las localidades que abarcaba esa delegación (Pehuajó, Carlos Casares, Bolivar y Carlos Tejedor) desde el momento en que se instalaron los miembros de la JP hasta el día en que partieron con destino a la ciudad de 25 de mayo donde se realizó el acto de cierre del Operativo. Al respecto, en ese informe se reseñan todas las actividades realizadas por los integrantes de JP- Montoneros que arribaron a cada localidad y que fueron recibidos por los militantes de las distintas JP y Unidades Básicas "locales". En la crónica se detalla la realización por parte de estos contingentes de varios actos y fogones, con motivo de los festejos por la asunción de Perón a la presidencia y por el "Día de la Lealtad" peronista el 17 de octubre, ocasión en la que se levantaron consignas a favor de "FAR y Montoneros", "Yanquis hijos de puta" y "Evita Montonera", entre otras.

Un dato pintoresco descripto en el informe fue el ocurrido en Pehuajó, donde jóvenes identificados con las insignias de FAR y Montoneros "izaron en el mástil de la plaza central la bandera argentina conjuntamente con la de los Montoneros, para luego desconcentrarse, sin que se produjeran desórdenes", hecho que -según el informe- habría causado "un principio de encono en la población local, dado que es inusual estos tipos de acontecimientos". Por último, el escrito repara en los brazaletes de Montoneros que llevaban varios de los jóvenes y en las máquinas fotográficas de alta calidad que poseían algunos de ellos, lo que supondría algunas actividades de inteligencia que éstos habrían llevado adelante por esos días. En relación a esto último, el informe culmina con la mención a una publicación del periódico "El oeste" de Carlos Casares titulada “¿Pensarán volver?”, en la que se alude de manera inquietante a la toma de fotografías a varios edificios públicos y funcionarios por parte de los jóvenes militantes. ${ }^{436}$

Al cabo de 20 días de trabajo, el Operativo finalizó con un acto de cierre en la localidad de 25 de Mayo y arrojó como resultado la reparación y limpieza de 29 kilómetros de canales urbanos, la construcción de 1200 metros de canales de desagote, la colocación de 390 caños de cruces de calles así como la refacción de escuelas, hospitales, cementerios, viviendas rurales y la asistencia médica y social al conjunto de la población afectada. ${ }^{437}$

${ }^{436}$ CPM - FONDO DIPBA, Mesa Referencia, Legajo 16.070, pp 233-238.

437 El Día, 23/10/1973 "Al Pueblo de la Provincia de Buenos Aires-Gobierno de la Provincia de Buenos Aires" Solicitada ante el cierre del Operativo Dorrego. Esta experiencia de trabajo político territorial y de compromiso con la "reconstrucción" fue replicada por la Juventud Peronista Regionales, ya sin el Ejército como contraparte, en los meses siguientes, a través de diversos operativos de trabajo voluntario en numerosas localidades y villas miseria de las provincias de Buenos Aires, Formosa, Santa Fe y Salta que involucraron la movilización de miles de jóvenes, a pesar de la oposición ministerial directa de José López Rega. Por ejemplo, durante el mes de octubre tuvo lugar en la Regional IV el denominado "Operativo Formosa", cuyo objetivo fue la reparación de viviendas, construcción de escuelas y hospitales en esa 
No obstante, en términos de las repercusiones políticas, el saldo lejos estuvo de ser favorable para la TR y su experiencia institucional pues aceleró las tensiones con los sectores de la derecha y el propio Perón.

Retomando algunas cuestiones planteadas al comienzo del capítulo, el Operativo dada su envergadura y despliegue (movilizando centenares de militantes de la JP en el territorio provincial) desafiaba las disposiciones trazadas en el "Documento Reservado", acrecentando las presiones dirigidas contra el gobernador Bidegain y la militancia de la Tendencia.

Como un ejemplo de la ofensiva desatada contra Bidegain, son sintomáticas las amenazas que el primer mandatario bonaerense recibió desde las páginas Alianza, publicación de grupos de la extrema derecha peronista nacionalista. ${ }^{438}$ Allí en el número del 4 de octubre, se lanza un ultimátum contra Bidegain, a quien se acusa de "inundar de cuanto cipayo marxista hay en la ciudad de La Plata y sus alrededores la gobernación", situación que habilitaba a estos sectores a "defender al Caudillo y fulminar a los idiotas y marxistas. Como en Ezeiza. Es responsabilidad nuestra y somos responsables de que esto se cumpla". ${ }^{439}$

Asimismo, el 29 de octubre, unos días después del cierre del operativo, en la misma publicación se encuentra una extensa nota titulada "Operativo Dorrego: Payasada con malas intenciones”. En sus párrafos se observa el objetivo de rescatar a la institución militar por las buenas intenciones que guiaron su accionar en las tareas de reconstrucción y pacificación nacional, no obstante, se acusa abiertamente a su comandancia de prestarse al juego de la "camarilla infiltrada” en el Movimiento, calificando al Operativo como "una maniobra magistral para crearle problemas al General Perón con las Fuerzas Armadas, facilitando al mismo tiempo el adoctrinamiento marxista del ejército en el

provincia. Asimismo, durante todo el mes de noviembre se lanzó el "Operativo 17 de noviembre" en diferentes barrios del Gran Buenos Aires, que comprendía la reparación de calles, construcción de escuelas y unidades sanitarias, limpieza de zanjas, desagües y blanqueo de paredes, junto a un desfile y festival musical hecho por los vecinos y militantes de la JP. También se llevó a cabo la difusión de una campaña contra la diarrea estival, de la que participaron miembros de la Agrupación Evita, el Movimiento Villero Peronista y profesionales de la salud y equipos móviles sanitarios de la provincia. En enero de 1974 la JP realizó otros dos operativos, el primero fue el "Operativo Estanislao López" en Santa Fe, organizado por la Regional 2 y el segundo fue el "Operativo Güemes" en Salta conducido por la JP junto con la UES para ayudar y organizar a las poblaciones del sur de la provincia (Gillespie, 2008:254) y "Culminó la campaña de la JP. Demostración práctica de 'reconstrucción nacional' en Almirante Brown”, Diario Noticias, $18 / 12 / 73$.

${ }^{438}$ Para un análisis pormenorizado de esta publicación y de la biografía de su director, Juan Queraltó, ver Besoky, J.L (2016)

439 Alianza, 4/10/1973 "Bidegain y Ragone no son más aliancistas" 
nivel experimental". Luego de acusar directamente a Bidegain como responsable político de dicho plan, en compañía de funcionarios "ultraizquierdistas" como el ex cura Alejandro Mayol y Sergio Caletti, se pasa a denunciar a Carcagno por "haber convertido eventualmente al ejército en objeto de adoctrinamiento clasista y botín de guerra de enfrentamientos facciosos". Lejos de considerar el accionar del jefe militar como un "error", se ultima a terminar con "los agentes del caos", tarea que en el caso de los grupos civiles que participaron (los militantes de la JP) "resultaría relativamente sencilla rastreando su pista". 440

Un dato no menor que debemos subrayar en cuanto a la difícil posición de la TR en esa coyuntura, y que contribuyó a la política de aislamiento y persecución de la que fue blanco, fue la decisión de Perón de no asistir al acto de cierre del Operativo Dorrego en la ciudad de 25 de Mayo, aun cuando en declaraciones a los medios tanto Carcagno como Bidegain expresaron que sí lo haría.

La situación de extrema vulnerabilidad del Gobernador Bidegain y los grupos de la Tendencia en el Movimiento Peronista y simultáneamente en el Estado, se vio reflejada en las palabras de Juan Carlos Dante Gullo en la conferencia de prensa que la JP Regionales brindó en el cierre del Operativo, en respuesta a la cruzada desatada en su contra encabezada en la provincia por el vice gobernador Victorio Calabró:

\footnotetext{
"Esta tarea es una de las tantas pruebas que desde hace 18 años la juventud viene dando en cuanto a la ortodoxia y la lealtad que hoy algunos exigen. La juventud ha puesto su sangre para echar a la dictadura militar. La historia también es clara en cuanto a la lealtad y la ortodoxia tardía demostrada por otros sectores que hoy, cuando todo viene fácil, pretenden erigirse en dueños del movimiento y se arrogan la tarea depuradora. Estos depuradores eran los mismos que entregaron al movimiento desde la traición y se largaron como lobos a capturar despachos luego del triunfo (...) Hoy vemos desde las vicegobernaturas cómo se ha armado una conjura que opera en todo el país para sacar de sus cargos a los gobernadores que han sido elegidos
}

\footnotetext{
${ }^{440}$ Alianza, 29/10/1973 “Operativo Dorrego: payasada con malas intenciones”. Acompañando las amenzas directas al gobernador, durante el mes de octubre se desarrollaron al menos tres atentados que si bien no tuvieron relación directa con el Operativo, visualizan el grado de violencia desatado contra la militancia revolucionaria y que tuvieron gran repercusión en los medios de la Tendencia. El primero fue el asesinato del militante histórico de la resistencia peronista Constantino Razzetti, en la ciudad de Rosario, quien días antes había manifestado públicamente sus críticas a los grupos de la derecha sindical. Fue la primera víctima de un grupo precursor de la Triple A en esa ciudad. El segundo fue el ametrallamiento del local "Ateneo 20 de Junio", ubicado en la ciudad de Buenos Aires, hiriendo a varios militantes que habían asistido con sus hijos a una reunión festiva en el marco de las elecciones. El tercero fue en la provincia de Formosa, durante un acto convocado por la Regional IV de la JP, en el que fueron heridos de bala dos militantes producto del ataque de miembros de la Juventud de la República Argentina, según el informe policial. Baschetti (s/f), Militantes del peronismo revolucionario uno por uno, RAZZETTI, Constantino. Disponible en http://www.robertobaschetti.com/biografia/r/42.html. El Día, 16/10/1973 "Una severa declaración difundió la Juventud Peronista Regional 1". El Día, 18/10/1973 "Varios heridos fue el saldo del choque entre dos grupos de la Juventud Peronista en Formosa".
} 
por la voluntad del pueblo con decretos de un consejo provisorio que dice de ahora en adelante quien es peronista y quien no (...) La JP seguirá firme en el proceso de reconstrucción y liberación conducido por Perón, y se opondrá a cualquier intento de destrucción y desorganización del movimiento peronista". ${ }^{441}$

Como podemos observar, además del uso común -aunque en sentido contrario- que los sectores de la TR realizaban de las categorías de "lealtad" y "ortodoxia" desde la vuelta de Perón, para reafirmar su compromiso y pertenencia al peronismo frente a sus detractores internos, las alusiones críticas al Documento Reservado por la "acción depuradora" que habilitó y la ofensiva contra la militancia revolucionaria que en esos momentos estaban llevando a cabo los sectores reaccionarios del Movimiento es muy clara, incluso en el corazón de las gobernaciones.

Finalmente, los primeros días de diciembre - y como una confirmación del cierre total en las posibilidades de encarar un proyecto conjunto entre Ejército y los grupos de la Tendencia desde el gobierno- Perón negó los ascensos correspondientes a los altos mandos y firmó el pase a retiro del propio Carcagno, Cesio y el resto de los militares que se habían mostrado bien predispuestos al diálogo y acercamiento con la JP (Franco, 2012: 66; Gillespie, 1987: 200-201).

Así, con esas medidas, quedaba clausurado el horizonte proyectado por la militancia de la TR sobre una posible alianza con los sectores progresistas del Ejército como contrapeso efectivo para el avance de la derecha dentro y fuera del Movimiento.

441“"Comunicado de la JP ante el cierre del Operativo Dorrego". CPM-FONDO DIPBA, Mesa Referencia, legajo 16071, p.165. "Firme en la reconstrucción nacional". Comunicado de la JP, JTP y JUP. El Descamisado, Año 1, N¹, 30/10/1973. 


\section{CAPÍTULO VII: LA DESARTICULACION DE UNA EXPERIENCIA}

\subsection{Perón presidente: la ofensiva derechista contra la TR se radicaliza}

Tal como referimos en el capítulo anterior, la dinámica política que se desarrolló en los últimos tres meses de 1973 estuvo marcada por la profundización de los aspectos más represivos de la disputa al interior del peronismo.

En esta particular coyuntura, en la que el último gran objetivo cohesionador del heterogéneo Movimiento - "Perón presidente"- había sido finalmente alcanzado, comenzaron a evidenciarse de manera acelerada los efectos de una acción represiva contra la militancia de la TR a través de la configuración de un entramado estatal y paraestatal que tenía por objetivo perseguir y aniquilar a sus referentes (Franco, 2012). Esto significó no solamente la resistencia violenta del sindicalismo tradicional y de los grupos de la derecha de aceptar la hegemonía de la Tendencia en las decisiones del gobierno provincial, sino la disposición misma desde la conducción del Movimiento y el Estado (bajo la presidencia de Perón) de cerrar drástica y definitivamente el ciclo de la “juventud maravillosa” y la expresión del peronismo revolucionario en el ámbito gubernamental.

Si bien no son las únicas claves explicativas a nivel coyuntural, es necesario reponer tres hechos sucedidos en estos meses para entender el clima que envuelve la elección de Perón y las posiciones de la Tendencia en ese contexto. En primer lugar, el 6 de septiembre el ERP atacó fallidamente el Comando de Sanidad del Ejército en Capital Federal $^{442}$ y a fin de mes fue declarado ilegal en medio de duras condenas contra la actividad guerrillera en su conjunto. ${ }^{443}$ En segundo lugar, el día 11 se produjo el golpe de Estado en Chile, que acabó con la experiencia del gobierno socialista de la Unidad Popular y cerró el cerco sobre la frágil democracia argentina. Por último, el día 25 fue ejecutado el máximo dirigente de la CGT José Ignacio Rucci; atentado que fue convertido por Perón y la derecha una justificación directa para desatar a gran escala dentro del

${ }^{442}$ En esa acción resultaron detenidos once de sus militantes y fallece el Teniente Coronel Raúl Duarte Hardoy.

${ }^{443}$ Por medio de un decreto del Poder Ejecutivo, el ERP fue puesto fuera de la Ley el 24 de septiembre. Ese mismo día, el General Miguel Angel Iñiguez fue nombrado Jefe de la Policía Federal. Este personaje que había sido emisario de Perón en 1971, era conocido por su filomilitarismo y por defender la no prescindencia de las FFAA en el proceso electoral, además de asignarles un rol clave y salvacionista en la lucha contra la "amenaza del comnunismo". (Bozza, 1997:153 y Besoky, 2016:198) 
Movimiento y el Estado, una cruzada contra los grupos y figuras de la izquierda peronista (Abbattista y Tocho, 2012).

A propósito de esto, cabe citar aquí las declaraciones que Perón realizó a la prensa pocos días antes de su asunción como presidente de la nación. En un reportaje, titulado "No al Marxismo", y que el periódico Alianza reproduce en su número del 4 de octubre, el mandatario no dejó lugar a dudas sobre su posición ante la guerrilla, los sucesos de Chile y la lucha antimarxista que encabezaría desde su gobierno. Ante la pregunta del periodista sobre las organizaciones guerrilleras, el líder justicialista señalaba sin tapujos

\footnotetext{
“conozco sus orígenes, sus objetivos y sus métodos. Conozco los propósitos de los marxistas, quienes sabiendo no poder medrar en el marco de las leyes, intentan conseguir el poder con la violencia. De todas maneras, estoy seguro que domaremos a la guerrilla. Chile nos ha enseñado muchas cosas: o los guerrilleros dejan de perturbar la vida del país o los obligaremos a hacerlo con todos los medios de que disponemos, los cuales no son pocos. Las vicisitudes chilenas cerraron la única válvula de seguridad que tenían los guerrilleros argentinos, a mi parecer se ejercitan acá para operar en otros lados, su cerebro se encuentra en Cuba... A Cuba le advierto que no haga lo mismo que en Chile, porque en Argentina podría desencadenarse una acción bastante violenta. La guerrilla molesta y daña la vida política y económica del país, pero aquí no tendrá éxito. Si insiste sucederá lo mismo que en Santiago, donde la responsabilidad del golpe no fue de los militares sino de los guerrilleros" ${ }^{\prime 444}$
}

En cuanto a las tendencias ideológicas presentes en la juventud, en la misma nota Perón sentenciaba que "mientras algunos hablan de socialismo, nosotros hablamos de justicialismo. Somos decididamente antimarxistas" agregando que lo sucedido en Chile “demuestra que Allende cayó por su propio sectarismo, víctima de su política tendiente al exceso. Nosotros aplicaremos la ley de los contrapesos". ${ }^{445}$

Efectivamente, al calor de estas premisas y "contrapesos" el 12 de octubre Juan Domingo Perón inició su tercera presidencia. Bajo esta lógica, debemos detenernos en el despliegue de algunas medidas represivas en el escenario nacional que afectaron directamente el desempeño y la relación de fuerzas de la TR a nivel general.

Por un lado, corresponde mencionar la aplicación en la administración pública nacional de la ya mencionada Ley de Prescindibilidad. La sanción de esta medida en el mes de noviembre -que fue avalada en el Congreso con mayoría de votos del FREJULI- tenía como objetivo la desvinculación en el ámbito de la administración pública de aquellas

444 “Perón: No al Marxismo". Alianza, 4/10/1973.

445 Ibid. 
personas consideradas como "traidoras" a la causa justicialista, lo que a esa altura apuntaba directamente a los empleados y funcionarios militantes de la Tendencia. ${ }^{446}$

Por otro lado, como es sabido, las medidas destinadas a la "depuración" no se restringieron a la administración pública, sino que se aplicaron también al interior del Movimiento Justicialista primero, luego a la Universidades Nacionales, y finalmente a las gobernaciones afines a la Tendencia, a través de su intervención.

En cuanto al Movimiento Justicialista, un ejemplo cabal de esta ofensiva fueron las denuncias y sanciones contra dos de los dirigentes más representativos del peronismo histórico, vinculados a su ala izquierda: Héctor Cámpora y Ricardo Obregón Cano. La intimación llegó por el Consejo Superior del MNJ luego de un acto realizado en la ciudad de Córdoba y organizado por la JP, en conmemoración por el 17 de octubre. Concretamente la denuncia del CSMNJ acusaba a ambos dirigentes de haber recaído en faltas graves y muestras peligrosas de "deslealtad" al haber enviado adhesiones al mencionado acto, en el cual se habrían realizado declaraciones ofensivas contra el líder justicialista. Asimismo se intimaba a que en el plazo de $48 \mathrm{hs}$ se retractaran púbicamente, so pena de ser expulsados del Movimiento y del partido. ${ }^{447}$

El repudio a estas amenazas llegó en el editorial de El Descamisado del 30 de octubre, firmado por Dardo Cabo, volcando una enérgica defensa de Cámpora y del gobernador cordobés, y explicando las verdaderas razones de esa persecución:

"La campaña depuradora aparece, así como un recurso del poder sindical y su aparato político conexo. La purga tal como ha sido planteada, no tiene otro propósito más que encubrir con la defensa de la “ortodoxia justicialista” el ataque a los sectores más combativos del peronismo" 448

${ }^{446}$ El Día, 16/10/1973 “Ley de despidos. Sería considerada mañana en la Cámara Baja” y 26/10/1973 "Diputados aprobó el Proyecto sobre Prescindibilidad, que ahora pasa al Senado". Cabe señalar que los intentos fallidos de extender esta medida en la provincia de Buenos Aires, producto de la negativa explícita que realizó Bidegain respecto de su eventual aplicación, dieron lugar a un increscendo de la tensión entre el gobernador y Perón. Ver El Día, 7/11/1973 “Sobre prescindibilidad de empleados públicos” y 14/11/1973 "Reiteróse que el gobierno bonaerense garantizará la estabilidad del empleado público". En esta nota se transcriben las declaraciones que Bidegain realizó frente a los representantes sindicales de ATE, y a su Secretario General, Hugo Maldonado, desmintiendo los rumores sobre una posible aplicación de esta medida y una ola de despidos.

447 El Día, 25/10/1973 “Intimación a Cámpora y Obregón Cano” y 26/10/1973 "Respondieron Obregón Cano y Cámpora a la intimación del Movimiento Peronista". La denuncia fue acompañada por solicitadas de la Juventud Sindical Peronista y de las 62 Organizaciones en las que pedían la renucia del primer mandatario cordobés.

${ }^{448}$ El Descamisado, Año 1, № 24, 30/10/1973 “Intimación a Cámpora y Obregón Cano. El Consejo ataca a los leales" 
Un comentario que a esta altura del análisis no se puede eludir, es la notable ausencia de referencias públicas -en El Descamisado en particular- sobre la responsabilidad de Perón, como conductor del Movimiento, en todas estas medidas condenatorias de figuras de la Tendencia y sus políticas. A continuación veremos que esta posición acrítica hacia el líder justicialista, acompañada por el señalamiento de los sectores sindicales y políticos burocratizados del peronismo como los "únicos" culpables -y que como vimos en el capítulo anterior tuvo su expresión máxima en la "teoría del cerco" y en el silencio respecto del "Documento Reservado"- comenzará a modificarse, tanto en las intervenciones públicas como en las discusiones internas de la TR a medida que la política represiva se radicalice y no deje lugar para segundas interpretaciones.

En cuanto a las Universidades, que fue uno de los espacios donde la Tendencia ocupó mayores lugares, la depuración vino de la mano del corrimiento de los rectores interventores nombrados durante el gobierno de Cámpora, asociados al peronismo revolucionario. En el caso de la UBA, tempranamente en el mes de octubre las presiones de grupos nacionalistas y de la derecha peronista, acompañados por el poder desestabilizador de López Rega, obligaron a la renuncia de Rodolfo Puiggrós al frente de esa institución, en medio de denuncias que calificaban su gestión como "cueva de bolches" (Abbattista, 2019; Friedemann, 2015) ${ }^{449}$ En el caso de la Universidad Nacional del Sur (UNS) el rector interventor Víctor Benamo (referente de la Tendencia a nivel local y muy cercano al dirigente de la JTP Roberto Bustos) había sido nombrado en el marco de las tomas de junio de1973. Tras sucesivas persecuciones, amenazas y hasta un atentado con explosivos realizado por los grupos locales de CNU en su propia casa, renunció a su cargo a mediados de 1974 (Ladeuix, 2014). ${ }^{450}$ Muy similar fue el caso de la Universidad Provincial de Mar del Plata. El rector interventor nombrado durante la presidencia de Cámpora fue el sociólogo Julio Aurelio, reconocido por su militancia en la izquierda peronista en la Universidad. Su designación, avalada por el gobernador Bidegain, fue cuestionada severamente en el mes de octubre por grupos de la derecha

449 El Descamisado, Año 1, N²1, 9/10/1973, p. 7. La Nación, 2/10/1973 "La renuncia de Puiggros pidióse". También desde la revista Militancia se publicaron enérgicos repudios contra esta medida. Militancia, Ano I, N 17, p. 8 "La universidad en la mira".

${ }^{450}$ Según Ladeuix (2014) en el mes de octubre Víctor Benamo de la UNS y el Ing. Vila, decano de la Facultad Regional de la UTN, estuvieron a punto de renunciar a sus cargos a raíz de la ofensiva ortodoxa que se hizo sentir con fuerza en los claustros universitarios y el avance de diversas agrupaciones ultraderechistas. Finalmente, en aquella oportunidad, la movilización activa de la Asociación de Docentes Universitarios Peronista y la Asociación de Trabajadores Universitarios, quienes tomaron la sede del rectorado de la UNS, y el apoyo de los militantes de la UES que promovieron la toma de las escuelas medias dependientes de la universidad, lograron frenar esas desvinculaciones. 
peronista (Juventud Sindical Peronista, CdeO y delegados de las 62 Organizaciones) quienes en una reunión con el Ministro de Educación de la provincia, Alberto Baldrich, exigieron la renuncia de Aurelio por "haber entregado el mando y poder de la universidad a sectores abiertamente enrolados en el marxismo, en todas las formas que este adquiere en la lucha universitaria, actuando como focos subversivos". 451 Finalmente, a principios de 1974 Aurelio abandonó la rectoría de la universidad provincial. Sugestivamente, fue nombrado como su sucesor el Dr. Pedro José Arrighi (quien más tarde sería interventor en la Universidad de La Plata y el último Ministro de Educación del gobierno de Isabel Perón), fuertemente vinculado a los grupos nacionalistas y a la derecha peronista. Apunta Ladeuix (2014) que, durante su gestión, los miembros de la CNU recuperaron espacios de poder dentro del claustro estudiantil y no docente, incorporándose como empleados en distintas dependencias de la Universidad, situación que también se replicó en la UNLP. Precisamente, en la Universidad de La Plata el desplazamiento del rector Agoglia, quien mantenía fuertes vínculos con la TR y parte de sus equipos de gobierno estaban integrados por militantes de JP-Montoneros, llegó en marzo de 1974, ante los ataques de grupos de CNU que asediaron esa casa de estudios. $^{452}$ Los signos más graves de esta violencia desatada contra la militancia revolucionaria en la UNLP se dieron luego de la muerte de Perón, con la colocación de una bomba en el comedor universitario y el secuestro y asesinato de Rodolfo Achem y Carlos Miguel, artífices del proyecto institucional generado por la TR para la Universidad (Lanteri y Meschiany, 2015; Carnagui, 2015; Barletta, 2018).

Por último, las intervenciones provinciales. Este mecanismo, tal como analiza Servetto (2010) fue utilizado por el gobierno de Perón primero, y luego por el de su sucesora María Estela Martínez, para desalojar a aquellos gobernadores "díscolos", que no eran funcionales a los objetivos de orden y disciplinamiento requeridos por el poder central, ocupando sus lugares representantes "más confiables" de la derecha política y sindical. En el fondo, tal como señala Servetto (2010), lo que se buscaba con estas intervenciones era "desplazar a los sectores disruptivos y liquidar los bastiones de poder del peronismo revolucionario” (p. 208).

Bajo esta lógica, a principios de noviembre de 1973 fue intervenida por el Poder Ejecutivo la provincia de Formosa y sus autoridades electas destituidas. Esta modalidad

${ }^{451}$ El Mundo, 9/10/1973 "Una ofensiva antimarxista".

${ }^{452}$ La renuncia de Agoglia se dio también en el marco de su desacuerdo con algunas disposiciones de la nueva Ley Universitaria, que generó todo tipo de críticas desde los sectores de la TR (ver más adelante, p. 266) 
se repitió al año siguiente con las provincias de Córdoba, Mendoza, Santa Cruz y Salta. El caso de Buenos Aires, que bien podría haber sido alcanzada por esta política, asumió características propias, tal como analizaremos en los próximos apartados.

\subsubsection{La sublevación de los guardiacárceles: ¿un intento de golpe?}

Puntualizando en la situación de la provincia de Buenos Aires, los últimos meses de 1973 fueron de extrema vulnerabilidad para el gobierno, desenvolviéndose una dinámica de denuncias y ataques desestabilizadores que pusieron a Bidegain y a la militancia de la TR al borde de la dimisión.

Particularmente, la situación que agudizó los conflictos internos y marcó un punto de inflexión en la crisis provincial tuvo que ver con una ola de motines y levantamientos por parte de agentes del servicio penitenciario bonaerense en distintas unidades carcelarias durante los meses de noviembre y diciembre.

La presencia de conflictos al interior de las cárceles no era un dato nuevo para el gobierno de Bidegain. Desde los primeros meses de su gestión, se habían desencadenado diversos motines entre los presos "comunes", incentivados por el clima de movilización de la sociedad en general y del activismo que los detenidos por razones políticas habían venido desarrollando, en especial entre los meses de marzo y mayo de 1973, lo que finalizó con su liberación. ${ }^{453}$

En el caso los presos "comunes", el auge de las tomas en reparticiones del Estado junto con las expectativas de cambio que también para ellos abría el final de la dictadura y la llegada de nuevos funcionarios a cargo del servicio penitenciario -ahora bajo un gobierno de signo peronista- avivó el reclamo por un conjunto de medidas y el reconocimiento de derechos postergados.

Como señalan Lenci y Malacalza (2009) casi a la par de la ola de tomas de edificios públicos, puede observarse el surgimiento de una ola de motines y acciones colectivas por parte de los y las detenidas, quienes puertas adentro de las cárceles aprovecharon la coyuntura de la asunción de un gobierno popular para visibilizar sus demandas.

${ }^{453} \mathrm{El}$ estudio de los/as presos/as políticos y su liberación en las jornadas de Mayo de 1973 ha sido reconstruído de manera considerable por la bibliografía testimonial y académica. Ver Garaño y Pertot (2007), D’Antonio (2016), Bonasso (2001) y Anguita y Caparrós (2007[1998]), entre otros. 
Es importante mencionar que este conjunto de acciones de protesta -reclamos por las condiciones de encierro, celeridad en los trámites judiciales, conmutación de penas, mejoras en la alimentación, atención médica y en el trato del personal penitenciario, etc. cuyo pico máximo se dio entre los meses de junio y julio, coincidieron con el nombramiento por parte de Bidegain del Prof. Roberto Petinatto como nuevo Jefe del Servicio Correccional de la provincia de Buenos Aires. ${ }^{454}$

Éste llevó a cabo un conjunto de reformas y medidas innovadoras en políticas de encierro que ayudaron a gestar un contexto favorable para la formulación de demandas por parte de los reclusos (Lenci y Malacalza, 2009; Bustingorry, 2015). A modo de ejemplo de las significativas medidas que implementó Petinatto, podemos mencionar: la modificación en el régimen de detención y en las condiciones de los detenidos en un sentido más humano y acorde a las reglas mínimas de tratamiento de los reclusos fijadas por la ONU; la modificación del régimen de trabajo carcelario con el reconocimiento de aportes jubilatorios; retribución salarial para los presos igual que cualquier trabajador fuera de la cárcel; acceso de los detenidos a los medios de comunicación; reducción de penas a partir de los días de trabajo y buena conducta; no admisión de menores en las cárceles; levantamiento de los castigos que cumplían los detenidos; eliminación de alambres que separaban a los detenidos de sus familiares en los locutorios de visitas, entre otras. ${ }^{455}$

La política carcelaria progresista encarada por dicho funcionario -que se encontraba en sintonía con el conjunto de medidas de ampliación de derechos y de fuerte corte democrático que marcó el proyecto político de la TR en el gobierno- despertó enérgicas críticas, más si pensamos en el carácter extremadamente jerárquico y disciplinatorio que atraviesa a la institución penitenciaria y sus agentes. Tal es así que, en el contexto de la

\footnotetext{
${ }^{454}$ Roberto Petinatto había sido designado por Perón como Director Nacional de Institutos Penales durante sus dos primeras presidencias. Luego de 1955 debió exiliarse por la persecución del gobierno militar. La información sobre las demandas de los/las detenidos/as puede consultarse en la cobertura del diario El Día sobre los motines carcelarios, de los meses de junio y julio de 1973.

${ }^{455}$ En varias notas de El Descamisado se reivindica la política penitenciaria llevada a cabo por el gobierno de Bidegain y la gestión de Petinatto, detallándose las reformas que se implementaron ni bien asumió. “Cárceles: ¿Escuelas de delito o de reeducación?, El Descamisado, Año 1, nº 8, 10/7/1973. Y “¿A quién se la quieren contar? El Descamisado, Año 1, No 13, 14/8/1973. Una de las personas nombradas por Petinatto que desempeñó un papel muy destacado por su cercanía con los presos, actuando incluso de mediador en los conflictos, fue el joven seminarista Rubén Capitanio, quien desde hacía tiempo venía denunciando los vejámenes que sufrían los detenidos en las cáceles de Olmos y Sierra Chica, motivo por el cual el gobierno militar le había prohibido su entrada a los penales. Con la asunción de Petinatto al frente del Servicio Penitenciario, Capitanio actuó como asesor directo en asuntos carcelarios, representando a los presos.
} 
crisis política del mes de agosto de 1973, Petinatto debió renunciar a su cargo junto con los otros funcionarios de la Tendencia en el gabinete. ${ }^{456}$

No obstante, la particularidad de este caso radica en que su lugar fue ocupado por el Coronel Norberto Ugolini, ${ }^{457}$ quien lejos de distanciarse de las políticas de su antecesor, las profundizó. Así, el flamante Jefe del Servicio Correccional, quien dependía del nuevo Ministro de Gobierno de la provincia, Manuel Urriza, derogó la vigencia del Estatuto que regía los nombramientos y ascensos del personal del servicio penitenciario, e inició un conjunto de sumarios administrativos contra oficiales denunciados por "robo, malversación de fondos públicos, exacciones ilegales, irregularidades administrativas y aplicación de malos tratos en perjuicio de los internos" entre otros delitos, acciones que terminaron con la destitución de los agentes denunciados. ${ }^{458}$

En respuesta directa a estas medidas -que desafiaban la tradicional autoridad y jerarquía de las fuerzas de seguridad- a fines de noviembre los agentes penitenciarios de las unidades carcelarias de Olmos, Sierra Chica, Bahía Blanca, Mercedes, San Nicolás y la $\mathrm{N}^{\circ} 9$ de La Plata ocuparon dichas instalaciones, en lo que definieron como un "autoacuartelamiento" para repudiar las causas iniciadas en su contra. Además exigían el restablecimiento del Estatuto derogado y pedían la renuncia de los funcionarios nombrados "arbitrariamente" por Ugolini, quienes -según los insurrectos- no cumplían con la idoneidad, formación y antigüedad adecuada para ocupar esos cargos. ${ }^{459}$

La reacción de Ugolini al día siguiente fue contundente. En lugar de rectificar sus medidas, las confirmó relevando a los jefes, subjefes y jefes de las guardias armadas de las unidades sublevadas. Asimismo, según la prensa, “ordenó al personal del servicio penitenciario, cuyos jefes se encuentran en rebeldía, abandonar las unidades $y$

\footnotetext{
${ }^{456}$ ¿A quién se la quieren contar? El Descamisado, Año 1, № 13, 14/8/197.

${ }^{457}$ En el segundo gobierno de Perón, el Coronel Ugolini encabezó la resistencia contra el intento de golpe pergeñado por el General Menéndez en 1952, tomando la base de Punta Indio. Actitud que replicó durante el bombardeo a la Plaza de Mayo el 16 de junio de 1955. Ese mismo año, en septiembre, actuó en la defensa de la Base Naval de Río Santiago. Luego del derrocamiento del peronismo, el gobierno militar le formuló 34 cargos, de los que no pudo probar ninguno, aunque la carrera de Ugolini dentro de las FFAA quedó truncada. Noticias 28/12/1973, p.5.

458 Noticias, 28/11/1973 “Los guardias tomaron las cáceles".

${ }^{459}$ El Día, 29/11/1973 "Persiste el conflicto en cuatro unidades penitenciarias de la provincia”. Y Noticias, 28/11/1973 "Los guardias tomaron las cárceles". En el petitorio de los oficiales que tomaron el penal de Sierra Chica se hacía referencia a los "elementos marxistas" que se encontraba muy próximos a Ugolini, tales como el seminarista Rubén Capitanio y el Mayor Eduardo Zavala, pidiendo su dimisión.
} 
presentarse a disposición de la Jefatura del Servicio, disponiéndose la inmediata destitución y retiro absoluto de quienes no cumplieran con dicha orden". ${ }^{60}$

Por su parte, en conferencia de prensa el gobernador Bidegain, el Ministro Urriza y el Jefe de la Policía bonaerense, Coronel Ademar Bidegain, expresaron su total apoyo a las políticas de Ugolini, ratificando su procedimiento y comprometiéndose a llegar hasta las últimas consecuencias contra los autoacuartelados. ${ }^{461}$

La gravedad de este conflicto que planteaba muestras inquietantes de rebelión por parte de los jefes de las fuerzas de seguridad provincial y ponían en el ojo de la tormenta nuevamente al gobierno de Bidegain, no dejó de tener repercusiones a nivel político dentro de la interna del peronismo.

Una de las cuestiones a considerar es que estos sucesos se dieron -como vimos en el apartado anterior- en un contexto de fuerte ofensiva "antisubversiva" de los sectores de la derecha peronista, y que ya el mecanismo de intervenciones federales por el gobierno central se había puesto en marcha en la provincia de Formosa.

Por el lado de la JP, las manifestaciones de apoyo al Jefe del Servicio Correccional se formularon a través de los medios y una solicitada. La lectura que allí hacían de estos sucesos era que los mismos respondían a "motivaciones políticas" y no "gremiales” de parte de los "sublevados...acostumbrados a un régimen basado en la corrupción la represión y las torturas, donde se trabajaba poco y se hacian grandes negociados". Asimismo declaraban que "en el fondo lo que se busca es conspirar contra Perón y el gobernador, creando las condiciones para el caos mediante la alteración del orden y la seguridad". ${ }^{462}$

Estas declaraciones iban en el mismo sentido que las formuladas a la prensa por el propio Ugolini, quien interpretó los acuartelamientos como "un nuevo plan de provocación contra el gobernador Bidegain...una acción impulsada por grupos que tratan de crear malestar en la provincia, para justificar la intervención federal". 463

Un dato interesante que complejiza aún más el cuadro de situación es que, tal como observan Lenci y Malacalza (2009), en algunas unidades penales los presos comunes

\footnotetext{
${ }^{460}$ El Día, 30/11/1973 “Agravóse el conflicto en el Servicio Correccional”. Noticias, 30/11/1973 "Relevan a guardiacárceles sublevados”.

461 Ibid.

${ }^{462}$ El Día, 5/12/1973 "La Juventud Peronista ante el conflicto en las cárceles”.

${ }^{463}$ El Día, 30/11/1973 “Agravóse el conflicto en el Servicio Correccional”
} 
apoyaron públicamente la posición de Ugolini contra la "rebelión" de los oficiales superiores del servicio. Por ejemplo, en la Unidad de Olmos, según el diario Noticias:

"el sacerdote Rubén Capitanio, delegado y coordinador de los internos en las cárceles de la provincia, entregó a la prensa un documento de los internos, en que éstos acusan a los oficiales sublevados de disfrazar sus verdaderos objetivos: 'hacer fracasar los planes justicialistas y volver al trato inhumano'". 464

Otro caso similar es el de la Unidad 9 de La Plata, donde los reclusos presentaron un comunicado en adhesión a Ugolini, criticando la postura de los guardiacárceles amotinados. En dicho comunicado, los presos declaraban que "se intenta volver al régimen inhumano que debieron soportar los presos a lo largo de 18 años e interrumpir la politica del gobierno popular en materia carcelaria. "465

Más allá de estas muestras de apoyo, la reacción de los sectores de la derecha peronista no se hizo esperar, actuando en algunos casos en abierta consonancia con los agentes amotinados. El caso de la sublevación de los guardicárceles del penal de Sierra Chica es el más notorio. Allí, la toma del penal -que duró en total 19 días- estuvo bajo el mando del Prefecto Mayor Mario García, quien además de enfrentarse a Ugolini con hechos de violencia directa realizados por sus hombres cuando éste intentó ingresar al penal, ${ }^{466}$ denunció al Jefe el Servicio Correccional de entregarle armas a grupos civiles vinculados a la JP (un supuesto "Comando 9 de Junio") para atacar a los agentes sublevados en otras unidades carcelarias. ${ }^{467}$

Las implicancias políticas de esta denuncia llegaron hasta la esfera nacional, cuando el diputado de la derecha peronista Rodolfo Arce defendió al Prefecto García y elevó ante el Congreso de la Nación la misma imputación contra Ugolini, extendiéndola hacia el gobernador Bidegain a quien acusaba de ser el responsable de la "entrega de 250 escopetas Itaka a grupos civiles marxistas para iniciar una persecución contra peronistas...generando un clima de terror en la provincia", ${ }^{468}$

${ }^{464}$ Noticias, 2/12/1973 "Continúa la rebelión carcelaria”.

${ }^{465}$ Noticias, 1/2/1973 "Cabecillas guardiacárceles estaban en la coima", citado en Lenci y Nazar (2009)

${ }^{466}$ El Día, 30/11/1973 "Agravose el conflicto en el Servicio Correccional"

${ }^{467}$ El Día, 3/12/1973 "El personal de Sierra Chica se mantiene autoacuartelado" y El Día 4/12/1973 "Sierra Chica: subsiste la situación de resistencia". Ver Bustingorry (2015:107)

${ }^{468}$ El Día, 5/12/1973 "Grave acusación contra el gobierno de la provincia". Alianza, 10/12/1973 "Rodolfo Arce en acción"; El Día, 12/02/1974 "Arce reiteró sus denuncias sobre la entrega de armas". Militancia peronista para la liberación, $\mathrm{N}^{\circ} 27,13 / 11 / 1973$, "Semana política" p. 5 
Parte del entramado de inteligencia secreta y las supuestas pruebas en las que se fundaba esta denuncia podemos analizarlas en un grupo de documentos denominado "Sobre la Lucha Antisubversiva" que forman parte del Fondo Documental Olegario Becerra, quien fue diputado por el FREJULI en $1973 .{ }^{469}$ En este archivo se encuentran una serie de documentos (algunos confeccionados por Becerra y otros sin referencias de sus autores) fechados a fines de ese año sobre la supuesta "Infiltración y acción marxista en la gobernación de Buenos Aires", tal como se lee en su encabezado. En su contenido se hace un raconto de las presuntas actividades llevadas a cabo por altos funcionarios del gobierno, con la anuencia de Bidegain, a quienes califican de "elementos indeseables y marxistas", entre otros: Troxler, Maissonave, la esposa del gobernador Tony Bidegain, su hija Gloria y su pareja Daniel Vaca Narvaja. Concretamente, se los acusa de ser los organizadores de los tiroteos en Ezeiza, sindicando a Troxler y Maissonave como los responsables directos de haber entregado armas a la JP y la JUP. ${ }^{470}$ Asimismo se repasan las principales amenazas "marxistas" en cada uno de los Ministerios. ${ }^{471}$

Puntualmente nos interesa destacar, para el Ministerio de Gobierno, el extenso informe que se realiza sobre la situación del Servicio Correccional y en las cáceles. Se habla del accionar de una brigada compuesta por miembros de la JP que "dominaría" a Ugolini -a quien se presenta como "un peronista honesto"- presionándolo para que entregue las armas. Entre los mencionados se encuentran el diputado Carlos Negri como propiciador

469 Olegario Becerra (1911-1992) militó en la Unión Cívica Radical desde 1929. Fue Presidente Fundador del Instituto Radical de La Plata, colaboró en la creación del Movimiento de Intransigencia y Renovación (MIR) y fue uno de los fundadores de la Unión Cívica Radical Intransigente. En 1958 ingresa a la cámara baja como diputado y luego del golpe de estado de 1962, es nombrado como presidente interino de la misma. En 1972 formó parte del Frente Justicialista de Liberación Nacional. Becerra también fue docente en la Universidad Nacional de La Plata, en la Universidad del Salvador y en la Universidad Católica Argentina. Escribió distintos libros sobre política e historia. Biblioteca Nacional Mariano Moreno (Argentina), Departamento de Archivos, Fondo Olegario Antonio Becerra (AR-BNMM-ARCH-OAB). Documentos Lucha antisubversiva. Agradezco a Juan Besoky la cesión de este material.

${ }^{470}$ Desconocemos quien es el autor puntual de este documento (grupos de inteligencia de la policía, grupos civiles de la derecha peronista, etc) pero muy probablemente por el tipo de descripciones que se hacen, se trate de un informe que se haya confeccionado como parte de las directivas del Documento Reservado. Por su parte, las categorías de "elementos subversivos" e "infiltrados de izquierda o marxista" que recorren todo el documento son muy similares al lenguaje utilizado en las revistas de la derecha peronista como $E l$ Caudillo o Alianza.

${ }^{471}$ Para el Ministerio de Asuntos Agrarios se menciona que existe allí un grupo muy activo de jóvenes de extrema izquerida, protegidos por el Ministro Gallo Mendoza. En cuanto al MOP se califica como un "nido de marxistas" y particularmene a Escolar como "un guerrillero que estuvo con el Che Guevara". El Minsiterio de Educación se describe como una entidad más aligerada de elementos marxistas, aunque cuenta con algunas personas peligrosas como la Subsecretaria de Cultura, Alcira Argumedo. Sobre el Ministerio de Bienestar Social se señala que fue "baluarte del marxismo" durante la época de Ferrara, y que fue bastante purgado por la gestión de Bocalandro, aunque persisten elementos muy activos en la Dirección de Menores y en la Republica de los Niños, definido como un "centro de adoctrinamiento de teorías marxistas". Biblioteca Nacional Mariano Moreno (Argentina), Departamento de Archivos, Fondo Olegario Antonio Becerra (AR-BNMM-ARCH-OAB). Documentos Lucha antisubversiva 
de los Comités de Presos, el oficial Eduardo Zabala y el seminarista Rubén Capitanio, quienes serían los instigadores de la rebeldía de los reclusos contra los agentes penitenciarios. ${ }^{472}$

Por su parte, también encontramos varios panfletos firmados por el Personal de la Policía de la provincia de Buenos Aires, fechados en el mes de noviembre, que reproducen las mismas ideas, agregando el mote de "seudoguerrilleros" a los diputados Negri y Kunkel, y de "asesinos como Caride, actual secretario de la Princesa Gloria Bidegain, Doglio, Ferrari y Villagra y demás marxistas infiltrados en el Gobierno de la provincia”. El panfleto, de circulación interna entre el personal policial, termina con la siguiente leyenda: ¡Camaradas!: nuestra misión es la de asegurar Paz y Tranquilidad al pueblo y a su gobierno... lo que no significa la protección de los delincuentes infiltrados en el mismo.- Distribúyalo entre sus camaradas". ${ }^{473}$

Más allá de la veracidad de la información presente en estos documentos, nos interesa mostrar con ellos el clima de persecución, hostigamiento y alto grado de virulencia que se cernía contra Bidegain y la militancia de la TR en el gobierno hacia fines de 1973. Es decir, ese entramado de informes secretos, panfletos llamando a la insubordinación de las fuerzas de seguridad contra las autoridades del gobierno y las denuncias públicas contra el gobernador y sus funcionaros realizadas por otros miembros del partido justicialista no hacían más que potenciar el clima de desestabilización que efectivamente las prácticas insurrectas de los agentes del servicio penitenciario estaban promoviendo en ese momento.

Finalmente, si bien la situación en las cárceles bonaerenses logró ser controlada a mediados de diciembre, ${ }^{474}$ el saldo negativo que esta crisis institucional dejó para Bidegain fue considerable. A los pocos días, el Coronel Ugolini pidió licencia, aduciendo razones de salud, lo que en los círculos de las fuerzas de seguridad fue visualizado como un triunfo de los "revoltosos". ${ }^{475}$

\footnotetext{
${ }^{472}$ Biblioteca Nacional Mariano Moreno (Argentina), Departamento de Archivos, Fondo Olegario Antonio Becerra (AR-BNMM-ARCH-OAB). Documentos Lucha antisubversiva

${ }^{473}$ CPM- FONDO DIPBA, Mesa DS, Varios, Legajo N 8774

${ }^{474}$ La recuperación del control en el penal de Sierra Chica por parte de las autoridades provinciales marcó el final de esta seguidilla de acciones rebeldes por parte de los guardiacárceles. García, principal líder de la revuelta fue suspendido, al igual que el resto de los cabecillas del movimiento a quienes se puso en disponibilidad sin goce de sueldo hasta que los sumarios administrativos y judiciales se sustancien (Bustingorry, 2015: $110 \mathrm{y} \mathrm{ss).}$

${ }^{475}$ Noticias, 28/12/1973 "Reasumiría el Coronel Ugolini”. Otra dimisión importante del gabinete en el marco de esta crisis fue la renuncia del Secretario de Difusión y Turismo, Sergio Caletti. El Día,
} 
El desgaste que en la autoridad del gobernador provocaron estos hechos, y la imagen de soledad que remitían -apuntamos aquí que ningún miembro del gabinete nacional se reunió o hizo declaraciones a favor del gobernador y sus ministros durante todo el conflicto- preanunciaban la situación de extrema vulnerabilidad política para él y la TR en las semanas siguientes.

\subsection{Dilemas y quiebres hacia adentro de la TR: el mamotreto y el origen de los}

\section{leales.}

En el corazón de esta convulsionada coyuntura, varios hechos que se desenvolvieron entre los meses de octubre y diciembre merecen nuestra atención desde la perspectiva de las prácticas e intervenciones públicas de la TR, como así también las repercusiones que dentro de su militancia produjeron ciertos debates políticos trascendentales.

En principio, un acontecimiento con una fuerte carga simbólica y política, fue la comunicación pública del "Acta de Unidad" entre FAR y Montoneros el 12 de octubre, nada menos que el mismo día de la asunción de Perón. ${ }^{476}$ Sabemos que el proceso de convergencia entre ambas organizaciones venía de mucho antes (González Canosa, 2013), siendo por demás sintomática esta presentación formal en un momento político de fuertes cuestionamientos hacia este sector dentro del peronismo, lo que puede leerse como un mensaje hacia el afuera -y hacia el interior de la militancia - de mostrarse unidas y potenciadas para contrarrestar esos embates.

Precisamente las discordancias entre la TR y el flamante presidente de la nación comenzaron a ganar espacio en las páginas de las publicaciones más representativas de este conglomerado. Por ejemplo, en el editorial de El Descamisado del $\mathrm{N}^{\mathrm{o}} 22$, con una crítica solapada, Dardo Cabo hacía hincapié en que "sólo hubo 100 mil asistentes al acto de asunción”, en comparación con los millones de personas reunidas en Ezeiza, lo que

11/12/1973 "El Secretario de Difusión y Turismo renunció a su cargo". Al poco tiempo de la renuncia de Ugolini, el seminarista Rubén Capitanio también debió abandonar su cargo como defensor de los derechos de los internos en las unidades carcelarias. En el año 1975 se ordenó finalmente como sacerdote en la ciudad de La Plata, sufriendo en ese contexto la persecusión de los grupos parapoliciales él, su padre y su hermano. El 4 de julio de 1976 luego del asesinato de los cinco curas Palotinos, el Arzobispo de La Plata (Antonio Plaza) le avisó que debía abandonar la ciudad porque lo iban a matar. Se instaló en la provincia de Neuquén, gracias a su amistad con el Obispo Don Jaime De Nevares, quien fue defensor de las Madres y familiares de víctimas del terrorismo de estado en esa provincia, lugar donde Capitanio se radicó definitivamente y ejerció como sacerdote hasta la actualidad. Ver su reportaje "Vine a Neuquén por 3 meses que se conviertieron en 30 años" http://w1.lmneuquen.com.ar/06-03-15/n regionales 13 .asp

${ }^{476}$ Documento “Acta de Unidad de FAR y Montoneros". Baschetti (1996:240) 
demostraba la distancia que existía entre el líder y las masas en ese momento. Acto seguido, resaltaba positivamente que ese 12 de octubre había tenido lugar un encuentro que permitía "reiniciar el diálogo entre Perón y su pueblo", dando cuenta del proceso de marginación que estaban experimentando los sectores revolucionarios del peronismo. Asimismo, en el editorial se asumía "el deber de controlar y someter a asamblea popular" la marcha del gobierno que se iniciaba. Agregamos también que en esa misma edición se denunciaba la campaña de macartismo y violencia desatada en el propio Movimiento, destacándose las agresiones de las bandas de la CNU y del CdeO contra militantes de la JUP durante la desconcentración del acto de asunción (Abbattista y Tocho, 2012). ${ }^{477}$

La capacidad de convocatoria de Perón también fue cuestionada por la línea editorial de Militancia, señalando la cantidad notablemente menor de asistentes a la movilización en comparación con los actos del 25 de Mayo de 1973 y de Ezeiza de ese mismo año. Insistían, por otra parte, en la necesidad de profundizar el análisis y hacer una autocrítica desde la izquierda del peronismo, debido a que los acontecimientos "los habian tomado 'por sorpresa',". ${ }^{478}$ La sagaz lectura de la coyuntura que hace el equipo de Militancia -de las revistas más críticas a Perón en el marco de la Tendencia- puede sintetizarse en el siguiente párrafo:

\footnotetext{
"Desde la unidad básica del barrio o la villa hasta las superestructuras del movimiento o los organismos del gobierno, pasando por las luchas sindicales o universitarias, viven cada vez más la realidad de que el peronismo no es uno en cuanto a definiciones ideológicas, objetivos políticos y métodos de lucha, sino que en su seno existen básicamente dos proyectos que chocan constantemente (...) Y no se trata de que haya infiltrados. De lo que se trata es que hay dos politicas que nunca podrían juntarse en la misma bolsa porque apuntan hacia objetivos distintos, patean para lados opuestos. Y esto es lo importante: no son diferencias de métodos, de que unos son apresurados y violentos y los otros pacíficos y maduros, son diferencias ideológicas y politicas de fondo. Las diferencias están en la forma de ver la realidad que se quiere cambiar y en el modelo de sociedad por la que se lucha" 479
}

\footnotetext{
${ }^{477}$ El Descamisado, Año 1, N²2, 16/10/1973 "Se reinició el diálogo entre Perón y su pueblo".

${ }^{478}$ Militancia, Año 1, №19. 18/10/1973 "Perón presidente", citado en Abbattista y Tocho (2012)

${ }^{479}$ Ibid. Para un análisis pormenorizado de la revista Militancia Peronista para la Liberación ver la Tesis Doctoral de Mariela Stavale (2018). En su investigación, la autora define a la revista como expresión política y cultural de las corrientes más "alternativistas" del peronismo revolucionario y de las organizaciones que optaron por el "peronismo de las bases", planteando contrapuntos y críticas cada vez más duras hacia la figura de Perón -en particular a partir de la dirección que tomaba el gobierno peronista de 1973- y a las posiciones más "movimientistas" de Montoneros y la JP, aún cuando los consideraban “compañeros" del espacio político de la TR y disputaban con ellos la agenda de ese conglomerado.
} 
A propósito de estas diferencias, que comenzaban a cobrar visibilidad en la escena política de manera cada vez más violenta, debemos señalar la existencia de un documento interno de Montoneros y FAR que circuló hacia fines del año 1973 entre los responsables de las agrupaciones de base, y que tuvo repercusiones significativas en la vida interna de su militancia.

El documento, conocido con los nombres de Mamotreto o La Biblia, ${ }^{480}$ recogía las principales líneas que la Conducción Nacional había elaborado en torno al proceso político luego de las elecciones y al posicionamiento de la organización en esa coyuntura, explicitando también las razones y fundamentos de su conflictiva relación con Perón (Bartoletti, 2011, Salcedo, 2011; Pozzoni, 2017).

Su importancia para nuestro análisis radica en que allí, por primera vez en un texto de discusión interna, se expresaban de manera taxativa las profundas (y hasta el momento veladas) contradicciones que existían entre su proyecto y el del líder del Movimiento. Como veremos a continuación al analizar algunos de sus pasajes, las definiciones allí volcadas tendrán su correlato en la práctica, en una merma del apoyo brindado desde la Conducción a las prácticas institucionales que se venían desarrollando en el gobierno provincial que, por otra parte, encontraban cada vez menos espacio político para desenvolverse en el marco de la aguda represión que se cernía en su contra.

El documento comenzaba con una autocrítica respecto del "pensamiento político que hemos tenido en lo que va de este año", haciendo referencia a la "teoría del cerco" adoptada en junio de 1973. Esta teoría se habría sustentado -según el documento- en un "pensamiento mágico acerca de lo que es Perón y de su relación con las masas", muestra del "infantilismo político" de la organización, que los habría llevado a lecturas simplificadas de una "realidad objetiva que es más compleja", 481

Parte de la complejidad que se buscaba esclarecer tenía que ver con la caracterización que hacían del proceso iniciado el 25 de mayo, el cual tendría ciertos "vicios o limitaciones congénitas" que harían imposible avanzar hacia una opción revolucionaria sin llevar a fondo las contradicciones internas y a "una situación de fractura" dentro del Frente de Liberación Nacional (FLN). Uno de los vicios mencionados era el propio "sistema demoliberal" a través del cual se había llegado al gobierno, el cual impedía "asumir la ofensiva estratégica en un proceso revolucionario" dado que por sus características

${ }^{480} \mathrm{Si}$ bien este texto nunca se ha publicado de forma completa, se puede realizar un análisis de su contenido a través del Documento "Charla de la Conducción Nacional de Montoneros ante las agrupaciones de los frentes-1973" que recogía gran parte de sus planteos. Baschetti (1996: 258-311).

${ }^{481}$ Baschetti (1996:258-259). 
prohibía "una gran acumulación de poder (militar) y la centralización del mismo", necesario para derrocar a las fuerzas enemigas. Otro vicio de origen del proceso político era la constitución misma del FLN, que al estar integrado por "elementos del sistema anterior" (los partidos demoliberales y la estructura económica capitalista) no podía atentar contra sus propios intereses, es decir "tender a acumular poder y centralizar poder para conducir el proceso revolucionario e introducir un sistema de transición que desemboque en el socialismo". Esto derivaba en la situación contradictoria de contar con un FLN formado por elementos políticos anteriores y "pretender a la vez desarrollar un proceso de liberación dentro de la estructura capitalista sin producirle modificaciones a la infraestructura económica y a la superestructura política para que pueda ser un proceso de transición". ${ }^{482}$

Para contrarrestar esta situación y profundizar el proceso revolucionario antiimperialista lo que implicaba llegar lo suficientemente preparados al punto de fractura- era necesario “lograr la suficiente acumulación válida de poder, que es la del poder militar en última instancia: es decir el poder decisorio para conquistar los poderes político y económico. Y la acumulación de poder militar es el poder del pueblo, el Ejército del Pueblo". 483

Acompañando estas observaciones que marcaban el rumbo próximo a encarar, se hacía también una revisión de la propia imagen de Perón que habían sostenido hasta ese momento, y de las diferencias no sólo políticas sino ideológicas que los separaban en esa nueva etapa.

\footnotetext{
“Hemos hecho nuestro propio Perón, más allá de lo que realmente es. Hoy está aquí, Perón es Perón y no lo que nosotros queremos (...) la ideología de Perón es contradictoria con nuestra ideología porque nosotros somos socialistas. La conducción estratégica de Perón es unipersonal, es el conductor, y nosotros los cuadros auxiliares. Eso es contradictorio con un proyecto de vanguardia, en donde la conducción estratégica la ejerce una organización, no un hombre" 484
}

Al mismo tiempo, en ese documento interno señalaban los peligros de hacer explícita estas divergencias entre la militancia de base, en función del costo político que ello podría ocasionar por la pérdida del apoyo popular y la adhesión masiva a su proyecto dentro del peronismo:

\footnotetext{
${ }^{482}$ Idid, pp 264-265

483 Ibid, p. 279.

${ }^{484}$ Ibid, p. 277.
} 
"Sería estúpido de nuestra parte pelearnos con Perón por la ideología...no por eso nos vamos a ir del peronismo, no tiene el más mínimo sentido porque compartimos el proyecto estratégico que formula Perón [su programa nacional y antiimperialista] aunque nosotros vayamos más allá, $y$ porque el peronismo es obligadamente el movimiento de masas por el cual pasa inexorablemente la revolución. Es decir pretender desarrollar una revolución por fuera del peronismo, por contradicciones ideológicas con Perón, es absurdo, terminaríamos, ahí sí, en el PCR", ${ }^{485}$

Así, llegaban al apartado “Nuestra Organización”, donde reconocían su responsabilidad por no haber adoptado una posición clara respecto a si constituían una "vanguardia" o una "formación especial" (recordemos que esta segunda opción implicaba que el líder podía disolverlas cuando lo creyera conveniente, a diferencia de la primera que consistía en una estructura militar permanente que tiene en sus manos la implementación estratégica), esto -según el documento- había llevado a la "confusión en nosotros mismos, en nuestras propias fuerzas, a partir del 25 de Mayo, acerca del rol y la actividad que nos cabe". Ahora ese proyecto político-ideológico se expresaba de manera unívoca y sin titubeos: "no disolverse, sino lograr la conducción del Movimiento Peronista para transformarlo en Movimiento de Liberación Nacional total, es decir, que eso constituya una herramienta política-militar que desaloje a los elementos que distorsionan la esencia del Movimiento de Liberación Nacional en el peronismo". ${ }^{486}$ Estos elementos eran fundamentalmente la burocracia sindical y política.

Si bien es imposible medir el grado de recepción e impacto real que tuvo este documento interno, varios testimonios analizados en la bibliografía lo sindican como uno de los principales causantes de la ruptura del sector que pasará a llamarse "JP Lealtad" (Pozzoni, 2017; Mingrone, 2010; Salcedo, 2011; Duzdevich, Raffoul y Beltramini, 2015). ${ }^{487}$ El nombre de esta agrupación que se escinde formalmente de Montoneros a principios de $1974,{ }^{488}$ remitía a tres de los tópicos centrales puestos en debate en el

${ }^{485}$ Ibid, p. 293. Las dificultades para explicitar sus diferencias con Perón entre la militancia barrial pueden observarse en el estudio de caso de Horacio Robles (2011).

${ }^{486}$ Ibid, p. 283

${ }^{487}$ Otro de los hechos rememorado por los militantes de JP Lealtad como determinante del alejamiento del espacio de la TR es el asesinato de José Ignacio Rucci, atribuido a Montoneros (Pozzoni, 2015b). Ya en febrero de 1974, otro acontecimiento que incidió en la ruptura definitiva fue la negativa de Montoneros a participar de las "Reuniones de los jueves", una serie de encuentros convocados por Perón hacia los distintos sectores de la rama juvenil para fijar directivas tendientes a su unificación. La negativa presentada por los representantes de la JP, JTP, JUP y Montoneros a participar de esas reuniones se vinculó con la inclusión en la lista de invitados de grupos que consideraban no representativos del sector juvenil, como los miembros de JPRA, $\mathrm{CdeO}$ y CNU, responsables directos de atentados y provocaciones en contra de los locales y militantes de la Tendencia (Pozzoni, 2015b y Besoky, 2016).

${ }^{488}$ La solicitada que hizo pública la ruptura de este grupo y la presentación formal de la nueva agrupación se tituló "Al Pueblo Peronista. La conducción de Montoneros es Perón" y fue publicada el 14 de marzo de 
mamotreto: continuar reivindicando el liderazgo incuestionable de Perón; rechazar la noción de vanguardia y la lucha armada en el marco de su gobierno; y supeditar todo proyecto alternativo dentro del peronismo a los mandatos del líder. Como un cuarto elemento explicativo de la ruptura de "los leales" se menciona en la bibliografía el impacto "negativo" que habría tenido dentro de Montoneros la fusión con las FAR, ejerciendo una predominancia la ideología marxista por sobre la peronista. ${ }^{489}$

Cabe señalar que esta interpretación crítica sobre el contenido del Mamotreto y el supuesto "viraje marxista" de la organización ante la unión con las FAR, representaron en aquel momento las lecturas que realizaron ese grupo de militantes que formaron JP Lealtad, existiendo dentro de la TR otras agrupaciones y colectivos por fuera de Montoneros (como los vinculados a la revista Militancia) que presentaron sentidos profundamente críticos sobre el rol de Perón y la marcha de su gobierno en esa misma coyuntura (Stavale, 2018).

1974. Ver Duzdevich, Raffoul y Beltramini (2015:214). Los principales referentes de JP Lealtad fueron el sacerdote Jorge Galli y Eduardo "Negro" Moreno. En torno a ellos se nucleó un grupo considerable de militantes provenientes de las columnas de Capital Federal, Oeste (Gran Buenos Aires) y Nordeste (provincia de Bs. As., ex Columna Artigas) y unidades básicas de las columnas Sur y Norte (ambas del Gran Bs. As) quienes coincidían en las críticas a la Conducción Nacional de Montoneros por lo que consideraban "un cambio inconsulto en su línea politico-militar" vinculado a la reciente fusión con las FAR, lo que había llevado a cuestionar el liderazgo de Perón y a "enfrentarse al proyecto del Conductor" a través de una postura vanguardista y militarista de la organización. Señala Pozzoni (2015b y 2017) que la efímera vida de esta nueva agrupación se vinculó a lo que varios de sus militantes caracterizaron como el "no lugar político" que atravesó ese espacio, tensionado por las dificultades a la hora de poder desarrollar un proyecto político propio, más allá de los designios de Perón y de las diferencias y antagonismos con su organización madre. Por su parte, la casi inmediata muerte del líder eclipsó toda posibilidad de crecimiento ulterior, lo que se sumó a las tensiones que surgieron entre "los leales" a raíz de la defensa de Isabel como su sucesora y conductora del Movimiento, posición que no era compartida por todos sus miembros.

${ }^{489}$ En la mirada retrospectiva de algunos militantes de Lealtad, dos elementos aparecen de forma recurrente como causantes de la ruptura con Montoneros: la inversión de roles respecto de la relación tradicional con Perón -que a su vez era atribuida a una cuota importante de "arrogancia juvenil" e "inmadurez política" de los miembros de la Conducción Nacional-; y el impacto de la fusión con las FAR. El siguiente testimonio de Alejandro Peyrou es ilustrativo de estas miradas: "Pensá en esta situación, Perón estaba ahí arriba y él era un General -pensá en términos militares- y ustedes muchachos son una formación especial, están para tal cosa, el que maneja soy yo, yo soy el padre eterno, y una parte de la tropa dijo no, nosotros somos la vanguardia revolucionaria. ¿Pero cómo? si ustedes son las formaciones especiales... nosotros en un momento cantábamos 'Perón vuelve' y ahi pasamos a cantar 'conducción, conducción, Montoneros y Perón'... Imagináte que vos tenés 74 años, sos General, estuviste proscripto 18 años, el hecho imposible de aceptar para la oligarquía sos vos, Perón, y viene un grupo de chicos que tienen ¿sabés cuánto de militancia? Y dicen, no no, nosotros somos los que conducimos. El planteo fue cambiando y la presencia de las FAR fue muy importante para eso, los de la " $R$ " no eran peronistas... El mamotreto yo no lo leí, porque los documentos que circulaban por capital no eran los de Buenos Aires, pero era un giro hacia una posición marxista leninista que busca reforzar la organización. En febrero del 74 me voy a Lealtad. En realidad, Lewinger me echa por diferencias ideológicas, me dicen que me separan de la orga por diferencias ideológicas". Entrevista de la autora a Alejandro Peyrou (2012). Similares consideraciones se pueden encontrar también en las entrevistas citadas de Halperín (2008) y Argumedo (2008) y en el libro de Duzdevich, Raffoul y Beltramini (2015). 
Volviendo al documento, el peso de los principios político-ideológicos que contenía provocó ciertas incomodidades y tensiones en el grueso de la militancia de la TR que desempeñaba funciones en el Estado. Sin embargo, no hay que olvidar que esas definiciones teóricas se daban en un contexto represivo sumamente álgido -como analizaremos más adelante- en el que los cursos de acción posibles dentro de las estructuras del gobierno se "angostaban" cada vez más.

Por un lado el texto planteaba abiertamente no sólo que Perón no iba a encabezar el proceso revolucionario en el continente, sino que además, frente a la estrategia del imperialismo, era quien "buscaba la negociación con los países del cerco", ofreciendo la disolución de Montoneros “como prenda de paz".490 Por el otro, la salida que se propiciaba para encarar este desafío, como vimos, ya no hacía hincapié en el trabajo político dentro del Estado y las estructuras "demoliberales" (para transformarlas en la etapa de transición), sino en el fortalecimiento de la "vanguardia" y su estructura militar, que pasaban a adquirir nuevamente un rol preponderante.

Estas formulaciones que pueden parecer algo abstractas y lejanas, sin embargo, tuvieron su expresión concreta en ciertos planteos hechos por los responsables de Montoneros a los/as militantes que participaban de la gobernación de Bidegain. Al respecto, Flora Castro relata ciertas actitudes por parte de algunos cuadros de jerarquía dentro de la organización que denotaban un "menosprecio" del trabajo institucional que venían desarrollando en el Ministerio

\footnotetext{
"Norberto (Habegger) estaba muy de acuerdo con el trabajo político en la gobernación, con aprovechar esos espacios para generar políticas, pero había peleas con otros cuadros de la organización. Hubo cuestionamientos hacia mí y a todos los que estábamos haciendo este tipo de trabajo. Un día, antes de fin de año, vinieron y nos preguntaron si estábamos haciendo prácticas de tiro... Pero oíme, yo no entendía nada, porque yo estaba diez horas trabajando en la dirección, los expedientes, salía con el ministro ¿cuándo iba a practicar?, ¿qué tiene que ver? Yo dije que no estaba de acuerdo y lo discutí mucho, y se paró momentáneamente ese cuestionamiento, pero eso quiere decir que había otros que no pensaban así. Es más, incluso a mi en un momento me cuestionaron el trabajo en las villas porque era "reformista". Eso vino desde la gente joven con poca experiencia previa en la política y en el territorio". ${ }^{491}$
}

\footnotetext{
490“Charla de la Conducción Nacional de Montoneros ante las agrupaciones de los frentes-1973" (Baschetti, 1996:277-278). Asimismo, en este pasaje del documento que titulan "Perón nos ofrece como prenda de negociación" se afirma que "Todas las medidas ultimas del Consejo Superior, de los distintos gobernadores, vicegobernadores contra determinados gobernadores, los discursos del propio Perón, tienden o expresan ese intento de hacernos desaparecer como proyecto; tal vez no como individuos, no lo necesitan; si desaparecernos como proyecto es suficiente. Si nos disolviéramos, si entregáramos las armas abandonaríamos todo nuestro proyecto, ahi por supuesto no habría ningún problema en que por ejemplo, los compañeros de la JP estuvieran en el Consejo Superior".

${ }^{491}$ Entrevista de la autora a Flora Castro, La Plata (2013)
} 
En el mismo sentido, Nora Peralta recuerda las diferencias que comenzaron a manifestarse dentro de la organización entre quienes venían -o eran percibidos como portadores- de una identidad "más peronista", atribuyéndoles también una actitud "complaciente" con el líder justicialista, frente a quienes comenzaban a articular de manera más abierta sus críticas y divergencias de fondo con Perón

\begin{abstract}
"Nosotros hablábamos de socialismo nacional no como un proceso a lo ruso o vietnamita, sino como un proceso local a través del peronismo, o el peronismo como motor de eso. Y yo identificaba a Perón con ese objetivo, nunca le tuve desconfianza, quizás porque mi familia, mi cuna es peronista y por eso pude entender todo eso, la conducción pendulante del viejo y esas cosas... y también que algunos errores cometimos nosotros porque el viejo se calentó mucho. Por esta actitud de no desconfiar de Perón a mi marido [Raúl Piñeyro] y a mí nos tildaron de 'ortodoxos' dentro de la organización y un poco nos dejaron solos". 492
\end{abstract}

Las tensiones arriba reseñadas ilustran el momento político de extrema complejidad que atravesaba la militancia de la TR a fines de 1973 y principios de 1974. Uno de los polos que más tensiones condensaba era, sin dudas, la ofensiva violenta que se ejercía desde la derecha del Movimiento y el propio Perón hacia la juventud radicalizada. No resultaba nada fácil para los y las jóvenes peronistas que habían levantado la bandera de la lucha por la vuelta del líder y el compromiso con la liberación de la patria, asistir ahora al conjunto de medidas represivas que se cernían en su contra, desde ese mismo gobierno popular que habían jurado defender hasta sus últimas consecuencias.

Sin embargo, en el vértice opuesto y actuando como otro núcleo de tensiones, no debemos subestimar el peso de aquel tipo de formulaciones y diferencias al interior de la organización, las cuales tendían a debilitar los sentidos compartidos -entre los y las militantes que apostaron al trabajo legal- respecto de la importancia de la intervención política y el fortalecimiento de la lucha en esos espacios para la construcción de la "patria socialista".

Podemos arriesgar aquí que esos planteos que cuestionaban la "utilidad" de dichas iniciativas en esa coyuntura, minaban en cierto modo la fuerza y las expectativas de quienes encaraban la tarea político-institucional como parte central de su militancia peronista y su contribución al proyecto revolucionario de más largo alcance. Lo que en algunos casos podía implicar incluso un conflicto interno respecto de su decisión de

492 Entrevista de la autora a Nora Peralta, La Plata (2012) 
seguir o no en la organización Montoneros. Quizás, en estos cuestionamientos de la Conducción Nacional hacia el trabajo "reformista" que llevaban a cabo parte de sus compañeros/as en la gobernación, comenzaba a escribirse también un párrafo significativo del capítulo final de la experiencia de TR en el Estado.

\subsection{Los sucesos de Azul: la renuncia de Bidegain y el ocaso del proyecto institucional}

\section{de la Tendencia.}

El 14 de diciembre, casi a la par de la finalización del conflicto en las cárceles, el gobierno de la provincia de Buenos Aires publicó una gran solicitada en El Día, el principal diario de la provincia. ${ }^{493} \mathrm{Su}$ título era "Mejor que prometer es realizar: Provincia de Buenos Aires, 6 meses de reconstrucción”. Allí se volcaba un resumen pormenorizado de la obra de gestión que se venía desarrollando desde el 25 de mayo, que había terminado -afirmaba el documento- con el "desolador panorama de caos y desorganización encontrado en el aparato estatal" para iniciar "con paso firme y seguro el proceso de Reconstrucción Nacional en la Provincia". ${ }^{494}$

La publicación, que cubría la totalidad de las páginas 4 y 5 del diario, proyectaba en su descripción una profusa actividad estatal que atendía principalmente a las necesidades de los sectores populares más postergados en todas sus dimensiones (vivienda, salud, economía, educación, cultura) a la vez que daba cuenta del avance en políticas que recortaban el poder de los grupos más concentrados de la economía. El mensaje que se buscaba dar era el de un gobierno popular fuerte, activo y consustanciado con los mandatos del General Perón.

Sin embargo, esa imagen de estabilidad y seguridad -como veremos a continuación- será puesta en cuestión y tristemente contrastada con la cadena de hechos que de manera vertiginosa se sucedieron en el mes y medio que transcurrió entre esa publicación y los hechos de Azul que terminaron en la renuncia del gobernador y el equipo de la TR.

Como afirman Abbattista y Tocho (2012) ese "verano caliente del '74" -que debe su nombre al acelerado recalentamiento del clima político que allí se desató- condensó una serie de acontecimientos claves para comprender la dinámica política del período 1973-

${ }^{493}$ El Día, 14/1/1973. "Solicitada del Gobierno de la Provincia de Buenos Aires”.

494 Ibid. 
1976, en particular el devenir de la TR y el fracaso de sus proyectos ante un espiral de violencia cada vez más acuciante.

Para analizar esta coyuntura en la provincia de Buenos Aires, nuevamente es necesario tomar en consideración el juego de influencias y repercusiones mutuas que se dan entre el espacio nacional y provincial. Es decir, observaremos el impacto y la significación de algunos acontecimientos del orden nacional que potenciaron las tensiones al interior del peronismo y que tendrán sus efectos directos en la gobernación de Bidegain. Como también, la incidencia que tuvieron algunos hechos producidos en la provincia de Buenos Aires en la agudización de la política represiva que el gobierno central desató contra el conjunto de la militancia de la TR y las organizaciones armadas.

\section{El Acta de Seguridad Nacional y las Reformas al Código Penal}

A fines de diciembre tuvieron lugar dos anuncios por parte de Perón que marcaban los ejes de la futura política nacional. El día 21 se presentaron, por un lado, los lineamientos de su política económica para los próximos años de gobierno, lo que se conoció como "Plan Trienal". Por otro lado, esa misma tarde, el segundo anuncio directamente vinculado con el primero se llevó a cabo en un acto presidido por Perón y el Ministro del Interior, Benito Llambí, comunicando la firma del Acta de Seguridad Nacional entre el Presidente, el gabinete de ministros y los gobernadores provinciales, con el fin de crear un marco de garantías desde el Estado para los empresarios y las inversiones locales y extranjeras. El blanco de este conjunto de medidas apuntaba directamente a la destrucción de la guerrilla en todo el país. Las palabras de Llambí esa tarde así lo reflejan: "no hay fronteras para el terrorismo, el crimen alevoso y la subversión, no habrá fronteras para reprimirlos y erradicarlos". ${ }^{495} \mathrm{El}$ Acta, entre otras medidas, extendía la jurisdicción de la Policía Federal a fin de que pudiera actuar en forma inmediata en cualquier lugar del país en que se considerara necesario, a solicitud de los gobernadores provinciales o cuando mediaran instrucciones del Ministro del Interior. Se disponía también el empleo de la Gendarmería para custodiar las fábricas. Por otra parte, se condenaba la portación de armas, los secuestros y extorsiones, y se recomendaba tener "mayor precaución y severidad [con] los tráficos de drogas, armas y literaturas que instruyan en la subversión y el caos" dado que las mismas "responden al deseo de crear estados de angustias

\footnotetext{
${ }^{495}$ El Día. 22/12/1973 "No habrá fronteras para reprimir el terrorismo, dijo el ministro Llambí”.
} 
colectivos (sic) que no se compadecen de la realidad que construye el país día a día" (Abbattista y Tocho, 2012). ${ }^{496}$

En aquella reunión se dispuso también la creación de un Consejo de Seguridad Nacional, y se comunicó que obtuvo media sanción en la Cámara de Senadores el proyecto de reformas al Código Penal presentado por el Poder Ejecutivo. También se anunció que el día 7 de enero, se presentaría en la Cámara de Diputados para su sanción definitiva.

El nuevo código adquiría un carácter aún más restrictivo que la legislación lannusista, endureciendo las penas para la portación de armas y las acciones armadas, y creando nuevas figuras delictivas como la de "asociación ilícita" denunciadas como ambiguas y persecutorias por la oposición y la militancia revolucionaria del peronismo, viendo con suma preocupación este incremento de la capacidad represiva del Estado (Franco, 2012; Besoky, 2016). Atrás en el tiempo y de manera paradójica, quedaba la promesa cumplida por el gobierno popular de Héctor Cámpora de terminar con la legislación represiva, que había sido uno de sus lemas de campaña. ${ }^{497}$

Ante la disconformidad con estas reformas, los diputados de la Tendencia se reunieron con Perón para plantearle sus objeciones sobre algunos artículos de la ley. En el fallido encuentro -que iba a ser a puertas cerradas- el Presidente los esperó frente a las cámaras de televisión y entre otras cosas les planteó que sus reparos en realidad correspondían a

\begin{abstract}
"un problema interno del bloque. Cuando se está en el bloque se acepta lo que el bloque haya decidido en conjunto (...) Nadie está obligado a permanecer en una fracción política. El que no está contento, se va. En ese sentido, nosotros no vamos poner el menor inconveniente. Quién esté en otra tendencia diferente de la peronista lo que debe hacer es irse. En ese aspecto hemos sido muy tolerantes con todo el mundo, lo que no es lícito diría es estar defendiendo otras causas y usar la camiseta peronista (...) El que no está de acuerdo se va. Por perder un voto no nos vamos a poner tristes".498
\end{abstract}

Frente a esta muestra inequívoca del apoyo de Perón a la nueva ley represiva, y su “invitación" a los representantes de la juventud a "sacarse la camiseta peronista" y abandonar el Movimiento, los ocho diputados (Carlos Kunkel, Armando Croatto, Jorge

\footnotetext{
${ }^{496}$ Ibid. Para un análisis más detallado consultar el trabajo de Marina Franco (2012:68).

${ }^{497}$ Las críticas de la JP- Montoneros hacia las reformas del código penal fueron presentadas en varias notas y comunicados publicados en El Descamisado. "A la juventud argentina. Solicitada de la JP-Consejo Nacional" El Descamisado, Año 1, No 36, 22/1/1974. "Solo la organización y la movilización del pueblo nos dará la liberación. La represión solo nos dará la dependencia. Montoneros, Comunicado". El Descamisado, Año 1, Nº36, 22/1/1974

498“"Perón clarifica: 'Quién esté en otra tendencia diferente a la peronista, lo que debe hacer es irse'. Entrevista con diputados peronistas opuestos a las reformas al Código Penal". Residencia de Olivos, enero de 1974. Reproducción textual del diálogo en Baschetti (1996:396-407).
} 
Glellel, Anibal Iturrieta, Rodolfo Vittar, Roberto Vidaña, Santiago Díaz Ortíz y Diego Muñiz Barreto) renunciaron a sus bancas, siendo aprobada la reforma al Código Penal al día siguiente con 128 votos a favor y 62 en contra. A pesar de su dimisión, que significaba hacerse a un lado, los ocho diputados fueron expulsados también del Movimiento por el Consejo Superior. ${ }^{499}$

La realidad comenzaba a mostrarse implacable para la Tendencia. Los hechos desatados en Azul lo confirmarían.

\section{La precipitación de los acontecimientos: el accionar del ERP en Azul}

En el marco recientemente señalado de profundización del aparato represivo y de marginamiento de los representantes de la TR en el Congreso y el Movimiento, en la noche del sábado 19 de enero se produjo el intento de copamiento de la Guarnición Militar de la localidad de Azul, por parte de la "Compañía Héroes de Trelew" de la guerrilla guevarista del ERP.

El ataque fallido, del que participaron entre 100 y 120 combatientes de dicha organización, se realizó contra una de las unidades del ejército más importantes del país el Regimiento 10 de Caballería Blindada y el Grupo de Artillería Blindada 1- quienes movilizaron rápidamente sus efectivos para derrotar a los guerrilleros. Tras horas de combate, el saldo de dicho operativo finalizó con la muerte del jefe de la Guarnición, Coronel Camilo Gay, su esposa y un conscripto. Además, tres oficiales resultaron heridos y el Coronel Jorge Ibárzabal fue tomado como rehén de la organización armada durante 10 meses. El ERP tuvo dos combatientes muertos y otros dos heridos. ${ }^{500}$

La magnitud de este hecho tuvo repercusiones políticas múltiples y profundas. Al día siguiente, el Presidente Perón vestido con su uniforme de General, dirigió al país un

\footnotetext{
499“Primero la patria, luego el movimiento, después los hombres". Solicitada. Ocho diputados de JP renuncian a sus cargos para no avalar medidas represivas del ejecutivo. Baschetti (1996:407-409)

${ }^{500}$ El Día, 21/1/74 "Sangriento ataque extremista a la guarnición militar de Azul”. Clarín, 18/1/2018 "Giro institucional: homenaje del ejército en el aniversario de un ataque guerrillero de 1974". En esta nota periodística del año 2018 se recuperan los hechos del año '74 a raíz del cambio que en políticas de la memoria y homenajes a las FFAA marcó el gobierno de Mauricio Macri respecto de sus anteriores. Entre los familiares de los militares que participaron de ese acto homenaje a las "víctimas del terrorismo subversivo" se encontraba la hija del Coronel Ibárzabal, Silvia, vicepresidenta de AFAVITA (Asociación de Familiares y Amigos de víctimas del Terrorismo) grupo que en el presente impulsa la consigna de "memoria completa" en contraposición al lema emblemático de "memoria, verdad y justicia" consagrado por los organismos de DDHH y las políticas de juzgamiento a los crímenes de lesa humanidad impulsados por los gobiernos de Néstor Kichner y Cristina Fernández. Para un análisis desde el campo historiográfico sobre el debate de una "memoria completa" propuesta por ciertos trabajos periodísticos en sintonía con la demanda de los grupos cercanos a las FFAA, ver Campos (2009 y 2012).
} 
colérico mensaje de repudio transmitido en cadena nacional. Sus palabras, con un tono amenazante, apuntaban directamente como uno de sus responsables al gobernador de la provincia de Buenos Aires:

\begin{abstract}
"Hechos de esta naturaleza evidencian elocuentemente el grado de peligrosidad y audacia de los grupos terroristas que vienen operando en la provincia de Buenos Aires ante la evidente desaprensión de sus autoridades (...) No es por casualidad que estas acciones se produzcan en determinadas jurisdicciones. Es indudable que ello obedece a una impunidad en la que la desaprensión e incapacidad lo hacen posible, o lo que sería aún peor, si mediara, como se sospecha, una tolerancia culposa (...) Pero todo tiene su límite. Tolerar por más tiempo hechos como el ocurrido en Azul, donde se ataca una institución nacional con los más graves procedimientos, está demostrando palmariamente que estamos en presencia de verdaderos enemigos de la patria, organizados para luchar en fuerza contra el Estado, al que además infiltran con aviesos fines insurreccionales" ${ }^{\circ 01}$
\end{abstract}

El Presidente dejó en claro que su único objetivo de gobierno sería de ahí en más "aniquilar cuanto antes al terrorismo criminal", convocando al conjunto de los partidos políticos, trabajadores sindicalizados y miembros del Movimiento a movilizar todos sus recursos en pos de salvar la patria, la República, el Estado y sus instituciones. Finalizó su discurso diciendo: "Ha pasado la hora de gritar Perón; ha llegado la hora de defenderlo". 502

Como han señalado Franco (2012) y Merele (2016), con este discurso Perón echó por tierra las diferencias entre las organizaciones armadas ERP y Montoneros, igualándolas en sus objetivos desestabilizadores para con el gobierno constitucional y confluyendo en la figura del "enemigo subversivo" al que había que combatir por todos los medios. ${ }^{503}$

${ }^{501}$ El Día, 21/1/1974 "Perón formuló un llamado al país e hizo cargo al gobierno de la provincia". Noticias, 21/1/1974 "Perón: enérgico mensaje por los hechos de Azul"

${ }^{502}$ Ibid. La respuesta de Montoneros a las virulentas palabras de Perón llegó a la semana siguiente en el editorial de El Descamisado del 29 de enero. Allí se dirigían al líder con un tono desafiante y crítico, interpelándolo directamente por sus dichos y acciones: "Queremos, General, saber en qué podemos ayudarlo. Pero saberlo de usted mismo, en la plaza de Mayo. Usted dialogando con todos nosotros, como antes, donde nosotros también le podamos decir nuestras cosas. A nosotros no nos dan porque el ERP golpea. No hay relación. Nos dan porque para los matones de la derecha peronista amparada en el gobierno, nosotros somos más enemigos que el imperialismo. La cosa es que nosotros queremos una revolución. Queremos llegar al socialismo nacional -que Usted nos marcó como camino-, queremos que se concrete el frente de liberación nacional -que Usted anunció para esta etapa-y ellos quieren destruirlo". “Cómo y de quien lo defendemos, general”. En: El Descamisado, Año I, No 37, 29/1/74. p. 2-3.

${ }^{503}$ Marina Franco (2012:244) señala que el intento de copamiento en Azul por parte del ERP significó un punto de inflexión en el avance de la salida represiva, en tanto "puede verse con claridad la articulación entre la 'depuración' del peronismo y la 'guerrilla marxista', fundidas ahora en un mismo enemigo interno". Merele (2016) por su parte, consigna muy bien que este desplazamiento tendrá sus consecuencias también en un mayor endurecimiento de la política de seguridad del gobierno peronista. Una muestra de ello fue el nombramiento de los comisarios Alberto Villar y Carlos Margaride como máximos Jefes de la Policía Federal, quienes habían sido exonerados de la fuerza por el gobierno de Cámpora dados sus oscuros 
Por otra parte, al vincular directamente el accionar de los grupos guerrilleros con la gestión de Bidegain, el líder justicialista forzaba directamente su dimisión.

En efecto, este duro mensaje, que habilitaba el pasaje a un ataque abierto, fue aprovechado de manera inmediata por el conjunto de los sectores opositores a la TR. Por ejemplo, el Bloque de los Diputados y Senadores del FREJULI en la provincia de Buenos Aires (donde la representación de la Tendencia ya estaba fuertemente debilitada y cuestionada) apenas unas horas después del discurso de Perón, envió un ultimátum a Bidegain notificándole que de no renunciar en 24 horas le iniciarían juicio político para destituirlo. ${ }^{504}$

Por su parte, las autoridades del Partido Justicialista de La Plata se sumaron también al pedido de dimisión. Estas intimaciones no hacían más que potenciar la información presente en los principales diarios del país acerca de la inminente intervención federal en la provincia de Buenos Aires. ${ }^{505}$

Esta salida, la de la intervención federal, no era la más conveniente para los intereses del sector sindical, en tanto implicaba el desplazamiento también del vicegobernador Victorio Calabró. Por ello mismo, la regional de la CGT en un plenario resolvió solicitar a Bidegain "en bien del Movimiento Justicialista, que presente inmediatamente su renuncia”, y llamó a una fuerte movilización para proclamar la asunción de Calabró. ${ }^{506}$ Asimismo, la CGT nacional se declaró en estado de alerta permanente y asamblea. Por su parte, la CGT y las 62 Organizaciones de La Plata, Berisso y Ensenada exigieron en un comunicado la inmediata renuncia del gobernador, plegándose al pedido de los legisladores y miembros del PJ. ${ }^{507}$

antecedentes como partícipes en la lucha contra la represión política y la guerrilla durante el gobierno de Onganía.

${ }^{504}$ El Día, 22 /1/74 "Los bloques legislativos del oficialismo están a favor del juicio político". Entre los legisladores que más fervientemente se pronunciaron en contra de Bidegain se encontraban el titular de la Cámara de Diputados, Raúl Lázaro Roca, el diputado nacional José Amerise, el jefe del bloque de Senadores Carlos Gastaldi y el diputado nacional Alberto Stecco. Sin embargo, como apunta Bustingorry (2015) las posiciones en el bloque del FREJULI no eran unánimes, el diputado provincial por la Tendencia, Raúl Alvarez Echagüe, hizo pública su disconformidad con el dictamen, extendiendo su posición al resto de sus compañeros de la JP en el recinto. No obstante, a esa altura, la posición de la Tendencia era muy minoritaria. En total, 35 diputados y 27 senadores del FREJULI en la provincia firmaron la declaración pidiendo la renuncia del gobernador.

${ }^{505}$ La Opinión, 22/1/74 "Se considera probable la intervención federal en la provincia de Buenos Aires". $E l$ Día, 22/01/74 "El P.E. nacional enviaría al congreso el proyecto para la intervención de la provincia". La Nación, 22/010/74 "Intervención o una solución intermedia". En todos los casos se menciona también que la intervención federal podría alcanzar a la provincia de Córdoba.

${ }^{506}$ El Día 22/1/1974 "La central obrera dispuso estado de alerta y dio a conocer una declaración"

507 "La central obrera dispuso estado de alerta y dio a conocer una declaración" El Día 22/1/1974 p. 3 
Por último, sumándose a la feroz campaña contra Bidegain, en las páginas del $E l$ Caudillo, el Secretario General de la JPRA de la provincia de Buenos Aires, Gabriel Cigna, convocaba al pase a la clandestinidad de su organización para cumplir con el mandato que Perón les había dado (en su mensaje del día 20 de enero) de enfrentar abiertamente a los infiltrados. Así lo expresaban en el siguiente comunicado publicado en la revista:
"Ante los hechos por todos conocidos se resuelve:
1. cumplir a sangre y fuego la orden del jefe del Movimiento en cuanto a que debemos 'movilizarnos y ponernos decididamente al servicio del orden'.
2. volver a la clandestinidad en todo el territorio de la provincia de Buenos Aires e iniciar todo tipo de hostilidades hasta derrumbar a la camarilla marxista y a su titere Bidegain.
3. declarar asimismo zonas conflictivas a los territorios de Córdoba y Mendoza.
4. considerar bajo el delito de traición a todo aquel integrante del Movimiento que no colabore en esta lucha y actuar en consecuencia.
¡Perón o muerte! ¡viva la patria!’"508

Finalmente, y a pesar de la movilización organizada por la JP hacia la Casa de Gobierno provincial para pedirle a Bidegain que no dimitiera, ${ }^{509}$ el martes 22 por la noche, el gobernador y parte de su gabinete presentaron sus renuncias, las que fueron aprobadas por la Legislatura provincial los días siguientes. Con esta decisión, quedó allanado el camino para la asunción de Victorio Calabró, ${ }^{510}$ con lo que se evitó la intervención

508 “Creer, obedecer y combatir por Perón” en El Caudillo, Año 2, №11, 25 de enero de 1974, p. 19, citado en Besoky (2016:226). Similares amenazas se encontraban en volantes y comunicados de otros grupos de la derecha peronista, como el llamado "Comando Coronel Arturo Gay" y el grupo "Concentración de la Juventud Peronista de la provincia de Buenos Aires" (CNU), en los que anunciaban que "no vamos a perdonar ni a un solo comunista. Va correr mucha sangre...quienes se sientan argentinos, que salgan a la calle a expulsar al gobernador Bidegain y a su familia. Llegó la hora de echar a los comunistas que manejan el gobierno de la provincia de Buenos Aires". Ver Noticias, 23/1/1974 "JPRA anuncia la pena de muerte" y La Razón, 23/1/1974.

${ }^{509}$ CPM-Fondo DIPBA. División Central de Documentación, Registro y Archivo, Mesa “A” Carpeta 37, Legajo 271 Folio 111. Según el diario Noticias, la movilización alcanzó cerca de 5000 manifestantes. El informe del Servicio de Inteligencia de la Policía de la Provincia de Buenos Aires arroja la suma de 1.300 manifestantes, quienes entonaban canciones en apoyo a Bidegain tales como "Bidegain corazón, sos el hombre de Perón" y "Bidegain, sos leal, no tenés que renunciar". Por el contrario, para El Día, los integrantes de JP-Montoneros no superaban los 200 asistentes. Para Hugo Bacci y Nora Peralta el impacto que tuvieron los hechos de la localidad de Azul, los agarraron desprevenidos. Según sus testimonios, muchos militantes de la JP/JUP que eran del interior, se encontraban de vacaciones en sus localidades de origen, eso les habría jugado en contra para movilizar una gran cantidad de gente. Entrevista Hugo Bacci (2012) y entrevista a Nora Peralta (2012). Ver Noticias, 22/1/1974 "Bidegain vería a Perón".

${ }^{510} \mathrm{La}$ decisión de Calabró de no renunciar y tomar el mando del poder ejecutivo en la provincia se vio fortalecida por el apoyo directo que obtuvo de Perón, quien aceptó reunirse con el vicegobernador y con representantes de la Mesa Nacional de las 62 Organizaciones por esos días, a la vez que le negó la audiencia a Bidegain. Éste, a pesar de solicitar una reunión con el Presidente, sólo fue recibido en la Casa Rosada por Solano Lima y Benito Llambí, quienes le transmitieron la directiva de que debía dejar su cargo. Noticias, 26/1/1974 "Los legisladores tratan hoy la renuncia de Bidegain”. El Día, 26/01/1974 "Integróse el nuevo gabinete". 
federal en la provincia y los sectores del peronismo ortodoxo alcanzaron los principales cargos en el aparato gubernamental. ${ }^{511}$

Cabe señalar que no todo el gabinete de Bidegain renunció sino sólo los ministros, subsecretarios y asesores ligados directamente a la TR y de mayor confianza con el gobernador. De esa manera, los ministros salientes fueron Urriza (Gobierno), Gallo Mendoza (Asuntos Agrarios) y González (MOP), mientras que Baldrich (Educación), Miralles (Economía) y Bocalandro (Bienestar Social) permanecieron en sus cargos. También elevó su renuncia el Jefe de la Policía, Cnel. Ademar Bidegain. Como Ministro de Gobierno de Calabró asumió Alberto Rocamora, dirigente del peronismo ortodoxo quien hasta ese momento se desempeñaba como Secretario de la Cámara Nacional de Diputados. En el caso de Asuntos Agrarios y Obras Públicas asumieron respectivamente Pedro Goin y Alberto Liberman, hombres del círculo de Ramón Miralles, Ministro de Economía y opositor a Bidegain. ${ }^{512}$

\section{Descalabro en la Provincia}

Tal como señalamos, luego de las enérgicas críticas de Perón hacia Bidegain, la renuncia de éste y sus ministros era un hecho inminente que sólo debía formalizarse con el correr de los días. ${ }^{513}$ Con todo, esta situación no dejó de plantear dilemas y discusiones en el

\footnotetext{
${ }^{511}$ Asi recuerda un militante y funcionario de la TR el paso de Calabró por la provincia en 1973 y la centralidad de Perón en su ascenso a la gobernación, una vez que le soltó la mano a Bidegain: "Calabró es un tipo que no estuvo en ninguna reunión de gabinete, era el dueño de los juegos y los prostíbulos, fue terrible, no fue nunca a una reunión de gabinete en todo el año, no podía hacer otra cosa mientras Perón no dijera otra cosa. El único que podía sacarlo a Bidegain era Perón. Pero luego de lo de Rucci ahí la cosa cambió con Perón, habilitó una caza de brujas al interior de los ministerios. Ese es Calabró, apenas pudo nos metió la pata con todo". Entrevista de la autora a Ricardo Rubio (2016).

${ }^{512}$ El Día, 26/01/1974 "Integróse el nuevo gabinete".

${ }^{513}$ Luego de la renuncia, Bidegain y su familia se instalaron nuevamente en su ciudad natal de Azul. Cabe apuntar que, en su derrotero político posterior, lejos de verse debilitado el vínculo con la TR, éste se vio fortalecido participando de importantes iniciativas políticas que lo tuvieron como protagonista. Por caso, Bidegain participó del lanzamiento de la Agrupación del Peronismo Auténtico (APA) y del Partido Peronista Auténtico (PPA) el 11 de marzo de 1975. Este espacio promocionado por Montoneros, nucleaba a ex gobernadores de la TR (Obregón Cano, Martínez Baca, Cepernic) y dirigentes políticos y sindicales de la línea combativa (Andrés Framini, Armando Cabo, Sebastián Borro, Arnaldo Lizaso y Avelino Fernández) que venían sosteniendo severas críticas al gobierno de Isabel Perón y buscaban reencauzar el movimiento peronista y el gobierno bajo las banderas populares votadas el 11 de marzo de 1973. En septiembre de 1975 Bidegain integró además el Movimiento Peronista Auténtico (MPA) formando parte de su Consejo Directivo. En 1976, luego del golpe, el gobierno militar pone en interdicción todos sus bienes suspendiendo también el pago de sus haberes jubilatorios. El calvario vivido ante estas medidas y por la persecución de los grupos de tareas, obligan a Bidegain y su familia a exiliarse en Roma, destino donde en abril de 1977 participa junto a Mario Firmenich y Obregón Cano del lanzamiento del Movimiento Peronista Montonero (MPM), organizado en ramas. Las autoridades del Consejo Superior del MPM estaban integradas por: Mario Firmenich como Secretario General; Gonzalo Cháves por la Rama Sindical; Oscar Bidegain y Obregón Cano por la Rama Política; Lidia Massaferro y Adriana Lesgart por la Rama Femenina; Rodolfo Galimberti y Manuel Pedreira por la Rama Juvenil; Rodolfo Puiggrós por la Rama de Profesionales, Intelectuales y Artistas y Osvaldo Lovey por la Rama Agraria. Además se constituyeron dos
} 
seno de los y las militantes de la Tendencia que participaban como funcionarios/as del gobierno, profundizando en ciertos casos las diferencias políticas que se venían dando internamente en los meses previos.

Puntualmente, un eje de la discusión pasaba por la decisión de abandonar la gestión pública para continuar la lucha y el proyecto estratégico en otros frentes -posición que apoyaba la Conducción de Montoneros- o, apostar a cierto repliegue en el Estado que permitiera frenar el avance de la derecha en un gobierno que aún consideraban "propio" y por el que creían que valía la pena -según la percepción de los entrevistados/as- seguir peleando por la hegemonía en esos espacios.

Esta fue la postura de Hugo Bacci, para quien el respeto a la figura de Perón encabezando el gobierno, y su propia adscripción peronista alineada con las posiciones más "movimientistas", implicaban un límite respecto del tenor de las críticas emanadas a Calabró y las posiciones que se encaminaban hacia una ruptura abierta:

\begin{abstract}
"Desde Montoneros nos vinieron a proponer que sacáramos una solicitada en contra de Calabró renunciando en masa. Yo no estaba de acuerdo porque Perón seguía en el gobierno, no podíamos enfrentar al gobierno peronista, porque, aunque a Calabró no lo queríamos porque era un hijo de puta, era el gobernador que quedaba y que había nombrado Perón, y bueno, al final ganó la posición más combativa, por presiones de poder se sacó la solicitada. Yo estaba en contra de esas posturas, de ir al choque porque se debilitaba a Perón. Finalmente se vota a favor de la solicitada en contra de Calabró $y$ en Asuntos Agrarios votan y deciden unánimemente renunciar todos los que habíamos asumido en mayo. Fue un acto de protesta esa renuncia. ${ }^{, 514}$
\end{abstract}

La línea más "movimientista" que el testimonio de Bacci revela, en su disposición a seguir reconociendo a Perón como máxima autoridad del Movimiento, fue sostenida también por Bidegain, para quien la "lealtad" al líder se tradujo -en esa coyuntura- en la decisión de su propia renuncia indeclinable

"Bidegain no era el que fue después, era un peronista total leal a muerte a Perón. Y Perón cuando dice lo que le dice [por el discurso del 20 de enero] nosotros le decimos que no renuncie, que tiene que haber un costo político. Y él nos dice: al único que no le digo que no es

secretarías que quedarían en manos de militantes de Montoneros: la de Relaciones Exteriores, a cargo de Fernando Vaca Narvaja, y la de Prensa y Difusión, compartida por Miguel Bonasso y Juan Gelman. Ver Gillespie (1987:252-257, 296) y Movimiento Peronista Montonero, “Documento de Roma”, abril de 1977, disponible en: http://eltopoblindado.com/opm-peronistas/montoneros/montonerosexilio/movimientoperonista-montonero-documento-de-roma/

${ }^{514}$ Entrevista de la autroa a Hugo Bacci, La Plata (2012) 
a Perón. Y eso fue terrible porque muchos queríamos seguir librando la batalla desde adentro, hasta las últimas consecuencias" ${ }^{515}$

La misma disposición a continuar militando en la esfera gubernamental y el reparo a las críticas que en ese momento se agudizaban contra el conductor del Movimiento son mencionadas por Sergio D., un ex militante de Montoneros que trabajó en el MOP

\begin{abstract}
"Nosotros veíamos que nos estaban dando muy duro, internamente yo sentía muchas críticas y rabia, pero así y todo creía que teníamos que seguir gobernando, darlo todo ahí. Después uno analiza fríamente y se da cuenta de errores que cometimos, disputarle la conducción a Perón fue un error. Yo traté de evitar las críticas a Perón, pero había muchos compañeros y compañeras que lo criticaban abiertamente. A mí no me gustaba tampoco que insultaran a Isabel porque era insultar a Perón”. 516
\end{abstract}

A pesar de estas tensiones internas, que en muchos casos fueron vividas por los y las militantes que ocuparon cargos como el comienzo de una derrota política para el proyecto de la "patria socialista" desde el gobierno, la firma y publicación de la mencionada solicitada marcó el final de esa experiencia en el Estado.

En ese documento, firmado por más de 50 funcionarios/as de la TR del gobierno provincial, ${ }^{517}$ además de realizar una caracterización de Bidegain y su gobierno como "ejemplo de lealtad incondicional a Perón, al Pueblo y a los objetivos de Reconstrucción y Liberación" (en contraposición a "Calabró y la camarilla de la $U O M$ ” que representaban la traición de esos mismos intereses y ahora encabezaban el gobierno provincial) declaraban:

"Por eso renunciamos a nuestros cargos públicamente, como siempre hemos actuado y actuaremos; porque en el peronismo no caben círculos ni camarillas. Nos comprometimos a luchar por los objetivos de reconstrucción y liberación nacional enunciados por el propio General Perón, y lo haremos desde el llano, como corresponde a leales soldados peronistas dispuestos a servir hasta el fin, porque como dijo la compañera Evita 'El peronismo será revolucionario o no será ${ }^{\prime,}, 518$

\footnotetext{
${ }^{515}$ Entrevista de la autora a Ricardo Rubio, San Miguel (2016). Hugo Bacci refiere de forma similar a la "lealtad" incondicional que Bidegain mantuvo con Perón hasta su fallecimiento el 1 de julio de 1974.

${ }^{516}$ Entrevista de la autora a Sergio D., La Plata (2016)

517“Descalabro en la provincia”. Solicitada. El Descamisado, Año 1, N³8, 5 de febrero de 1974, p. 30. Explica Marina Siri que quienes se desempeñaban como asesores/as políticos/as o secretarios/as privados/as, como era su caso, no firmaron la solicitada, sino sólo los que ocupaban puestos de dirección. Entrevista de la autora a Marina Siri, San Miguel (2016)

518“Descalabro en la Provincia" Solicitada. El Descamisado, Año 1, N 38, 5/02/1974, p.30. (resaltado nuestro).
} 
Con este mensaje, en el que reafirmaban su compromiso de continuar la lucha por un peronismo revolucionario (anteponiendo una lealtad mayor a la figura de Evita y su mandato, antes que a la de Perón) pero ahora desde nuevos -o viejos- espacios, culminaban así su participación en el gobierno.

\section{La despedida de los Ministerios y la "vuelta al llano"}

La salida de los Ministerios y el cese de sus funciones en el gobierno bonaerense es rememorada con suma nostalgia por la mayoría de los entrevistados/as de la TR que ocuparon cargos de gestión el estado provincial.

En gran parte, los testimonios recogidos refieren al final de esta experiencia como un momento crítico, que implicó profundos cambios tanto en el acaecer de sus vidas y labores cotidianas, como también -en algunos casos- en su disposición a la militancia revolucionaria en esa coyuntura y el replanteamiento de ciertas posiciones ligadas a su adscripción a Montoneros y la lucha armada.

No obstante, la heterogeneidad en las trayectorias posteriores y en el devenir de los y las militantes dentro de la organización o fuera de ella, vuelve esquiva toda posibilidad de generalizaciones o de trazar un patrón unívoco.

En el caso de los/as militantes del Ministerio de Obras Públicas que acompañaron la renuncia de Alberto González, éstos/as pudieron realizar una "asamblea de despedida" con los trabajadores de esa dependencia, oportunidad en la que leyeron un mensaje explicando las razones de su alejamiento de la función pública. En el mismo destacaban los avances que en tan solo 8 meses de gestión habían podido llevar a cabo, "trabajando unidos en el común objetivo de la reconstrucción y la liberación nacional, tarea que iniciamos entendiendo que la participación del personal en la conducción y control es un derecho y un deber que tienen todos los trabajadores que eligieron el gobierno popular el 11 de marzo". 519 También se recordaba como uno de los mayores logros la institucionalización de las Mesas de Trabajo y los Comités de Gestión, los inicios de las obras de la guardería y la redistribución más justa de la Ley 6021, entre otros. ${ }^{520}$ Por último señalaban que el alejamiento de la función pública implicaba sólo un cambio de las áreas de trabajo, manteniéndose intacto el objetivo de luchar por la liberación de la

${ }^{519}$ CPM- FONDO DIPBA, Mesa B, carpeta 4, Legajo N 27, folio 85, 89-90.

${ }^{520}$ En la primavera del año 1973 se logró una de las reivindicaciones históricas de los trabajadores del MOP, que consistió en la repartición en forma proporcional de la bonificación de la Ley 6021, que ya cobraban los profesionales universitarios y que se extendió a los no universitarios. 
patria. Firmaban el mensaje el Ministro de Obras Públicas, Alberto González, el Subsecretario de Obras Públicas, Roberto Scordato, el Subsecretario de Programación, Jorge Raúl Blanco y el Subsecretario de Urbanismo y Vivienda Eduardo Casado.

Ricardo Rubio y Marina Siri recuerdan vívidamente aquella jornada de despedida, que en su caso marcaba un punto de quiebre con Perón, no así con el peronismo ni con

\section{Montoneros}

"Fueron muy famosas las asambleas cuando renunciamos, todos los empleados del Ministerio participaron, nos pedían que nos quedáramos y nos aplaudieron cuando nos fuimos, estaban todos, nunca vi una asamblea tan participativa. Ahí esa tensión con Perón la vivi muy fuerte junto con muchos compañeros, eso no se puede negar, y en ese momento con mucha bronca, nosotros nos fuimos, nos retiramos de la gobernación. Fue algo que se repitió ya de manera masiva en la Plaza el lero de mayo". ${ }^{221}$

"Yo pasé por varias etapas. Un poco lo que vivimos en ese momento, sobre todo los que nos hicimos peronistas de jóvenes no viniendo de familias peronistas...porque vuelvo a mirar a Perón con sentimientos muy encontrados y críticos, después vino la etapa de los milicos, y luego y a con la democracia vuelvo a encontrarme con el Perón más estratégico, es decir nunca vamos a poder entender y lo hablamos siempre, cómo Perón bancó a la Triple A y esas cosas, pero bueno, la tensión siempre va a estar y va a ir de un lado a otro". 522

Si bien ambos militantes no compartían la decisión de la cúpula de Montoneros de alejarse de la función pública, esta divergencia política no implicó su ruptura o alejamiento de la organización. Por el contrario, continuaron su militancia de manera clandestina desempeñando distintas tareas tanto en el país como en el exilio. Así evocan con cierta cuota de orgullo su trayectoria dentro de Montoneros en los años posteriores a su paso por la gobernación, a pesar de estas diferencias y de lo que consideran, a la distancia, cierta "degradación" de su participación interna en función del mayor peso que ganaron los cuadros más "militaristas"

\footnotetext{
"Más allá de no haber entendido la postura de la Conducción, nosotros seguimos peleando desde nuestro ámbito, peleando pero adentro, con una enorme disciplina, de hecho participamos de la contraofensiva ${ }^{, 523}$
}

"Nosotros cuestionamos la estrategia del sur, desde el método a la táctica y estrategia de la Columna sur donde estábamos. A fines del 76 nosotros planteamos un período crítico de discusión con nuestro responsable, la dimos, pero sin dejar de respetar todo y con absoluta

\footnotetext{
${ }^{521}$ Entrevista de la autora a Ricardo Rubio, San Miguel (2016)

522 Entrevista de la autora a Marina Siri, San Miguel (2016)

${ }^{523}$ Entrevista de la autora a Marina Siri, San Miguel (2016) Marina y su compañero, Ricardo Rubio se exiliaron en Suecia en 1978 y allí formaron parte del Movimiento Peronista Montonero (MPM). Retornaron al país en 1979 y también en 1980 en el marco de la Contraofensiva Estratégica. Para un análisis pormenorizado de esta experiencia ver el excelente trabajo de Confino (2018).
} 
disciplina y solidaridad con nuestros compañeros. Como éramos de la logística, siempre fuimos opuestos a la tendencia armamentística, y con una orientación muy política, estuvimos en lugares siempre de riesgo, y sin embargo por otro lado estábamos en la parte de logística, que era una cosa muy cerrada y muy sensible en construir la seguridad de los compañeros de la Conducción, cubrimos las citas nacionales, los compañeros de la Conducción nos tenían una absoluta confianza, y los que nos cortaron la relación de crecimiento interno fueron los de la tendencia militarista de bajo nivel". ${ }^{524}$

En el caso del Ministerio de Bienestar Social, Flora Castro recuerda con tristeza el retroceso que en materia de políticas sociales implicó la llegada de Bocalandro al Ministerio, siendo esta regresión profundizada luego con la asunción de Calabró

\begin{abstract}
"Ya después de la salida de Ferrara, fue mermando la cosa. Ahí asume Bocalandro que era un viejo baboso, nada que ver con Ferrara. Bidegain le dijo que a las tres personas que habia puesto Montoneros (que éramos Amalia Ramella en Acción Social, Jorge Pereyra en el Instituto de Previsión, y yo) y María Esther Méndez que era nuestra jefa, no nos podía tocar. El viejo nos tuvo que aguantar, pero no se metía. Nosotros teníamos relación directa con la esposa de Bidegain y cualquier cosa que pasaba se la comunicábamos a ella. Si hubiésemos estado cuatro años sí podríamos haber cambiado mucho más, pero cuando yo me fui a todo eso (los Centros de Promoción y Desarrollo para la Comunidad) se dio marcha atrás, Bocalandro siguió con Calabró y en mi área asumió una mujer grande puesta por los metalúrgicos y nada que ver". 525
\end{abstract}

En un registro similar, Nora Peralta describe el cambio sustancial que significó la llegada de Calabró a la gobernación y la persecución desatada contra su marido por su actuación en la República de los Niños como funcionario de la Tendencia

“Me acuerdo dos anécdotas del trabajo con chicos menores y de Eliseo Morales el cura que
trabajaba con Habegger. Bueno, primero algunos pibes después de que nos fuimos de la
gobernación, se escaparon de los Hogares e Institutos y se fueron a vivir con Eliseo, por la
inmensa tarea que él había hecho con ellos. La segunda anécdota más amarga es que los pibes
habían roto algunas cosas y maquetas de aviación en la república de los niños, y Raúl mi

${ }^{524}$ Entrevista de la autora a Ricardo Rubio, San Miguel (2016)

${ }^{525}$ Entrevista de la autora a Flora Castro, La Plata (2013). Tras su separación de Norberto Habegger, Flora fue secuestrada por un grupo de tareas en junio de 1977, siendo liberada luego de unos meses. Finalmente, se exilió en México junto a su hijo Andrés (quien había permanecido bajo el cuidado de su tía y su abuela durante el secuestro de su madre) hasta su regreso con el final de la dictadura. Fue Directora de Educación de Adultos en la Provincia de Buenos Aires durante la Gobernación de Antonio Cafiero, entre 1987-1991. Por su parte, Norberto Habegger, luego de la caída de Bidegain fue Subdirector del diario Noticias y participó de la formación del Partido Peronista Auténtico (PPA) en 1975, agrupación política de la TR que integró Oscar Bidegain. Después del golpe militar de marzo de 1976 permaneció en el país coordinando el trabajo político de algunos grupos de militantes del área federal, luego de la salida del país de la Conducción Nacional de Montoneros a fines de 1976. En abril de 1977, estuvo a cargo de la Secretaría de Organización de la Rama Política del Movimiento Peronista Montonero (MPM). El 3 de agosto de1978 fue secuestrado por un escuadrón del Plan Cóndor en Río de Janeiro, siendo trasladado luego a Buenos Aires a un centro clandestino dependiente del Ejército. Hasta la fecha continúa desaparecido. Ver http://www.cels.org.ar/especiales/plancondor/\#tuna-asociacion-ilicita-para-reprimir-opositores 
compañero no lo denuncia, porque si no se iba a venir abajo el trabajo con los pibes. Sostener el trabajo de menores en combinación con la República era muy dificil, porque los pibes venían de institutos, había mucha reticencia. Raúl no lo denuncia y el que se hace cargo después de la República, uno que puso Calabró, éste si denuncia esos destrozos, y por eso Raúl tiene pedido de captura por incumplimiento de funcionario público. Le inician un sumario y le piden la captura y lo exoneran, después de eso él jamás pudo reingresar a la administración pública a trabajar". 526

Para ambas militantes, el cese de su participación en ámbitos legales y las dificultades cada vez mayores de sostener la militancia clandestina en el marco de la represión inusitada, marcaron el final de su inscripción formal dentro de la organización

"Con el golpe nos destinan a Rosario clandestinamente, lejos de nuestra familia. Antes ya habíamos estado clandestinos, pero cerca de la familia... pero bueno yo siempre tuve muchas diferencias politicas con la lucha armada, y venía de una formación cristiana, imagínate, y más allá de que racionalmente entendía que la lucha armada era la única forma de vencer al enemigo, que la revolución, etc., ya cuando nos tenemos que ir clandestinos a Rosario yo ya no quise, no me banque la clandestinidad y no quería someterlo a Andrés, nuestro hijo, a eso. Ahí en el 76 nos separamos". 527

\begin{abstract}
“Cuando estaba todavía Calabró empezó la persecución muy fuerte con las patotas que mataron a Achem y Miguel en La Plata, tuvimos que dejar corriendo nuestra casa y nos fuimos saltando la medianera, no pude ni agarrar los documentos, eso fue a fines del 74 justo antes de que naciera nuestro hijo, lo tuve a escondidas en una clínica del barrio la cumbre en la que no estuve ni registrada. En esa época sentíamos que la presencia de los que venían de la izquierda (FAR) era fuerte en las decisiones y en la línea que se bajaba desde la Conducción. Luego nos fuimos a vivir al Gran Buenos Aires, a Villa Tesei, seguimos militando pero ya más por nuestra cuenta". 528
\end{abstract}

El caso del Ministerio de Asuntos Agrarios permite observar también trayectorias disímiles entre quienes se desempeñaron como funcionarios. Para Alejandro Peyrou, ya a fines de 1973, las desavenencias con la Conducción de Montoneros por el enfrentamiento con Perón y la supuesta orientación marxista prevaleciente en la organización a partir de

526 Entrevista de la autora a Nora Peralta, La Plata (2012). En cuanto a la trayectoria del cura tercermundista Eliseo Morales, luego de la renuncia a su cargo como asesor en el Ministerio de Bienestar Social, continuó su trabajo con niños y adolescentes en la parroquia del barrio de Wilde. Allí sufrió la persecución de la dictadura militar, siendo detenido y torturado por un grupo de tareas y luego, gracias al reclamo que se elevó en la Argentina desde diversas partes del mundo, fue puesto a disposición del Poder Ejecutivo y posteriormente liberado, volviendo a su trabajo como cura obrero y a la lucha por la defensa de los detenidos-desaparecidos. En la década del 90 fue candidato a diputado provincial por Buenos Aires en el Frente Grande (FG) de Fernando "Pino" Solanas. Falleció en el año 2001. http://www.robertobaschetti.com/biografia/m/271.html

${ }^{527}$ Entrevista de la autora a Flora Castro, La Plata (2013)

${ }^{528}$ Entrevista de la autora a Nora Peralta, La Plata (2012) 
la incorporación de las FAR, marcaron su alejamiento inmediato, lo que significó la renuncia a su cargo provincial incluso antes de los hechos de Azul, integrándose rápidamente a la JP-Lealtad. ${ }^{529}$

Por su parte, Hugo Bacci -quien quedó a cargo de la Subsecretaría del Ministerio luego de la renuncia de Peyrou- recuerda los lazos tejidos con trabajadores y miembros del sindicato en función de una identidad peronista compartida y del vínculo con Perón, más allá de las diferencias políticas con Calabró

\begin{abstract}
"En Asuntos Agrarios se hizo una asamblea para ver que hacíamos. A mi me ofrecieron quedarme porque había compañeros que tenían buena relación con Calabró y pidieron para que nos quedáramos, pero yo no acepté. Acaté con mis reservas lo que la organización había decidido. Ya veníamos teniendo roces con la gente de capital, porque era diferente la experiencia de ellos de la nuestra (JP La Plata). Ellos venían a "hacer de funcionarios" y nosotros seguíamos siendo militantes, había cierta soberbia del porteño que se notaba en las decisiones y en las jerarquías, los que venían de capital nunca se hicieron cargo de las consecuencias de vivir en La Plata luego de la renuncia y con la represión que se desató acá con la CNU'.530
\end{abstract}

Esta distancia percibida por Bacci respecto de la manera de encarar la tarea en el Ministerio entre los que venían de JP La Plata/FURN y "los de capital”, se profundizó luego en las diferencias políticas que tanto él como algunos de sus compañeros mantuvieron con la Conducción. Estas fundamentalmente pasaban por la idea de seguir apostando a la militancia de superficie y no debilitar el vínculo con las masas dentro del peronismo, en un contexto en el que Montoneros decidió su vuelta a la clandestinidad y el repliegue de los frentes políticos y de las Unidades Básicas, con el reordenamiento de sus militantes en estructuras de combate (Gillespie, 1987:217; Salas, 2007; Pastoriza, 2006)..$^{531}$

\footnotetext{
${ }^{529}$ Entrevista de la autora a Alejandro Peyrou (2012). Su militancia se diluyó en 1975, luego de la desintegración de JP Lealtad. Peyrou es una de las voces más críticas con la conducción de Montoneros, calificando la trayectoria de la organización en 1974 como "delirio más atroz" (Duzdevich, Raffoul y Beltramini, 2015:256). En el año 2013 participó como testimoniante en la causa por el asesinato de José Ignacio Rucci, incriminando a la organización. Esta causa fue encabezada por los hijos del dirigente sindical para quienes se trataría de un caso de "lesa humanidad". Ver https://www.clarin.com/politica/funcionario-cancilleria-montonero-admitio-rucci 0 rJDKHDBjPXl.html

${ }_{530}$ Entrevista a Hugo Bacci (2012). Luego de su salida del Ministerio de Asuntos Agrarios y bajo la persecución feroz desatada por las bandas de la CNU en La Plata, Bacci y su familia se exiliaron en Panamá hasta el final de la dictadura.

${ }^{531}$ Entrevista a Hugo Bacci (2012). Entrevista a Babi Molina (2014). En el caso de Molina que ejercía su cargo como Concejal de la JP en La Plata, las diferencias se hicieron notables cuando se negó a renunciar ante el pedido de Montoneros de clandestinizarse y pasar al frente armado. Sostuvo su cargo en la concejalía de La Plata hasta el 24 de marzo de 1976. Muy similar a esta trayectoria es la de Carlos Negri, quien se opuso -luego de los episodios de la caída de Bidegain- a dejar su banca como diputado provincial
} 
No obstante, otros derroteros también pueden encontrarse en los y las militantes del mismo grupo oriundo de la JP-FURN La Plata. Por caso, Gonzalo Cháves y su compañera Amalia Ramella continuaron dentro de la organización de manera cada vez más activa, militando en la JTP clandestinamente, luego conformando el MPM -junto con Bidegain- en el exilio y retornando al país en 1979 en el marco de la Contraofensiva. Así recuerda Cháves la transición que se vivió en el frente sindical con la renuncia de Bidegain y la llegada de Calabró, etapa que significó la ruptura definitiva de antiguos códigos de convivencia y lazos compartidos entre los dirigentes peronistas, más allá de sus diferencias:

\begin{abstract}
"En un momento, aún con los opositores internos más ortodoxos existían códigos, después se rompieron, la Triple A rompió todos los códigos. Cayó el gobierno de Bidegain y nos llamaron otra vez para conversar, los dirigentes del sindicato, Balcedo por SOEME, West Ocampo en SANIDAD y Rodríguez en FOETRA, y dijeron 'bueno ahora cambió la situación, nosotros estamos en el gobierno, ustedes en la oposición ¿qué necesitan? ', estaba eso todavía. Nosotros les dijimos ¿qué diálogo vamos a hacer con ustedes si nos están persiguiendo? nos tirotearon ayer en el local de JTP en San Justo, nos tirotearon el local acá... En principio díganle al gobernador que pare la represión. No pararon un comino, y nos dijeron 'bueno, vayan a hablar con Calabró'. Fui yo con un compañero que estaba en la JUP y Calabró nos recibió, pero vimos que no había diálogo, no quería saber nada, era toda una ficción. Y de ahi en más fue empeorando todo". ${ }^{332}$
\end{abstract}

La desarticulación de la experiencia de gobierno que llevó a cabo la Tendencia en la provincia de Buenos Aires no fue más que un eslabón -aunque de los más importantesde la regresión superlativa que a nivel de las estructuras del Movimiento y el Estado sufrió el conjunto de la militancia peronista revolucionaria, entre los meses de febrero y julio de 1974.

Este fue el resultado de la acción “depurativa” y violenta que Perón habilitó en su contra, con la intención de acabar con su influencia en todos los ámbitos en los que aún tenía

del FREJULI y se mantuvo en ese cargo hasta el golpe militar. Más allá de estas diferencias con la organización, ninguno de los tres militantes provenientes del núcleo JP-La Plata se integró a JP-Lealtad.

${ }^{532}$ Entrevista de la autora a Gonzalo Cháves, La Plata (2016). El 7 de agosto de 1974 un comando de la Triple A dirigido por Aníbal Gordon ingresó a La Plata en busca de Gonzalo Cháves. Al no encontrarlo en su casa, persiguieron a su familia. Hallaron a su padre de 64 años y a su hermano Rolando de 28 años, asesinándolos de manera inmediata. El cadáver de Horacio Cháves fue arrojado sobre la vereda del local de la Juventud Peronista, en pleno centro de la ciudad. El raid continuó en la casa del Gringo Carlos Pierini, reconocido dirigente sindical de SUPE con fuertes vínculos con la TR, quien fue asesinado por 24 impactos de bala en un descampado en las afueras de La Plata. También, ese mismo día, un comando paramilitar ingresó en la casa de Luis Macor, militante de la JUP, quien apareció muerto con más de 14 impactos de bala en el arroyo El Gato cerca de Punta Lara. 
cierta injerencia. A modo de ilustración, y sólo teniendo en cuenta algunos de los acontecimientos más significativos, podemos mencionar:

Los encuentros del Presidente en la Quinta de Olivos, durante el mes de febrero, con grupos de la juventud ortodoxa (JPRA, CdeO, CNU y JP Lealtad) en los que les ordenó “purificar el Movimiento para detener la infiltración”, legitimando así el accionar violento de muchos de ellos, ${ }^{533}$ el derrocamiento de Obregón Cano y Atilio López en la gobernación de Córdoba el 27 de febrero; ${ }^{534}$ la promulgación de la Ley 20.654 (o "Ley Taiana") que prohibía el proselitismo político partidario "o de ideas contrarias al sistema democrático que es propio de nuestra organización nacional” en el ámbito de la universidad; ${ }^{535}$ la renuncia forzada del gobernador de Mendoza Alberto Martínez Baca y la intervención de la provincia por el poder central; ${ }^{536}$ la clausura de la publicación $E l$ Descamisado, por "incitar a la subversión y a la destrucción del orden constitucional”; el secuestro y tortura de 5 militantes de la Tendencia; ${ }^{537}$ y el asesinato el 11 de mayo del cura tercermundista Carlos Mugica por escuadrones de la Triple A; $;^{538}$ entre otros.

\footnotetext{
${ }^{533}$ En estas reuniones dirigió una crítica implacable a la JP Regionales, planteando que la misma "no era justicialista" y que estaba viviendo un proceso de infiltración política y de deslizamiento ideológico, y que se había terminado la hora de "los que quieren seguir peleando", porque iban a quedar fuera de la ley. Insistió además en que desde el gobierno "sabian que eran cualquier cosa menos justicialistas", y que si él fuera comunista se iría al PC y no se quedaría ni en el partido ni en el Movimiento Justicialista (Besoky, 2016). Ver "Perón habla a la Juventud Peronista. Primera reunión. 7 de Febrero de 1974" publicado por la Secretaría de Prensa y Difusión de la Presidencia. Disponible en: http://www.ruinasdigitales.com/discursosde-peron-1972-1974/

534 Ese día se produjo el hecho conocido como el Navarrazo, cuando el Jefe de la Policía de Córdoba, Antonio Navarro, destituyó a las autoridades electas, con el apoyo de la burocracia política y sindical del peronismo, grupos de la Juventud Sindical Peronista y de sectores de las Fuerzas Armadas. La respuesta del gobierno nacional ante estos gravísimos hechos fue la de declarar la intervención de la provincia, sin reponer a las autoridades legítimas depuestas ni procesar a Navarro (Servetto, 2010:97).

${ }^{535} \mathrm{La}$ puesta en vigencia de esta Ley, que daba inicio una nueva etapa, abrió la oportunidad para "renovar" las autoridades en aquellas Universidades en que todavía la TR mantenía gravitación, achicando así su margen de maniobra (Abbattista, 2019).

${ }^{536}$ Martínez Baca había llegado al gobierno mendocino con un $70 \%$ de votos a favor, y una fuerte impronta política y discursiva alineada con los postulados de la izquierda peronista. Prueba de ello fue el amplio programa de reforma educativa que intentó llevar a cabo y que despertó la intransigencia de todo el arco político-ideológico conservador. La argumentación principal utilizada por el frente opositor para llevar a cabo el juicio político fue la irregularidad en la gestión de las Bodegas y Viñedos Giol, en la que estaba involucrado su hijo. Solamente un grupo de 10 diputados de la Tendencia se pronunciaron en contra del juicio, formando un nuevo bloque, encabezado por el diputado Eduardo Molina. A los pocos días, todos ellos fueron expulsados del Partido Justicialista por "indisciplina partidaria, y agravio grave al movimiento y a su jefe, al mostrar subordinación a la denominada Tendencia Revolucionaria, directamente excomulgada del orden partidario por el teniente general Juan Perón”. (Servetto, 2010: 124)

${ }^{537}$ El 17 y el 19 de abril fueron secuestradas dos parejas de militantes que, a su manera, representaban un emblema de la lucha contra la dictadura previa: Eusebio Maestre (hermano de Juan Pablo Maestre) y su mujer Luisa Galli, embarazada de tres meses; y Alberto Camps (sobreviviente de la masacre de Trelew) junto a su mujer, Rosa Pargas, embarazada de ocho meses. Las dos parejas sufrieron toda clase de torturas y poco después fueron blanqueados como detenidos de la Policía Federal (Abbattista y Tocho, 2012). Además, el 25 de ese mes fue secuestrada María Liliana Ivanoff, de la Agrupación Evita de Monte Grande,
} 
Para finalizar, y como una síntesis en tono dramático de las profundas tensiones que atravesaban a la TR, cabe citar aquí un extenso fragmento del editorial titulado "Por qué somos peronistas" que salió publicado en El Descamisado $N^{\circ} 39$ del 12 de febrero de 1974. Allí la Tendencia interpelaba explícitamente a Perón por las impugnaciones que éste venía realizando sobre su pertenencia legítima al Movimiento y la lucha por el socialismo que en tiempos pasados él mismo había sabido alentar entre la juventud radicalizada, y que hoy parecía repudiar abiertamente, al igual que había terminado haciéndolo con su participación en el gobierno

“Fue él quien nos marcó el camino del socialismo nacional. Alli están los libros, las cartas, la película donde él lanza la propuesta (...) nosotros vamos a seguir siendo leales a esas banderas, que por otra parte son las que nos mostró Perón para que lo siguiéramos"

“Ayer éramos los muchachos y éramos saludados por el jefe del movimiento con emoción por nuestra lucha, se honraban nuestros muertos y ahora, por ser como Perón dijo que tenían que ser los peronistas, nos señalan que hay otros partidos socialistas donde podemos ir si queremos. ¿Por qué no nos dijeron eso antes, cuando peleábamos, que nos pasáramos a otros partidos? ¿Dónde estaban estos que nos tirotean y que preparan los atentados para eliminarnos cuando había que pelear contra Lanusse?"

"Pero este movimiento es nuestro y en él nos vamos a quedar. Nos empujan de adentro y nos llaman desde afuera, pero iminga!, la vamos a pelear desde adentro. Esa es nuestra mejor muestra de lealtad a la clase trabajadora, al pueblo, al movimiento peronista y a la patria (...) de aquí nadie tiene derecho a echarnos, ya ahora no nos despide nadie,"539

Como puede observarse, lo que estaba en juego ni más ni menos en este mensaje era el reconocimiento y la habilitación para la participación política de las organizaciones de masas de la Tendencia en cualquier ámbito dentro del Movimiento Peronista. Tal como señalaban, la lucha por las banderas del socialismo nacional finalmente la seguirían dando dentro del peronismo, aunque ya no dentro del gobierno. Aunque esa ya es otra historia.

mientras realizaba pintadas convocando a la Plaza para el $1^{\circ}$ de mayo. Su cuerpo apareció con signos de violación y torturas y la responsabilidad se atribuyó a un grupo del CdeO (Grammático 2011: 104).

${ }^{538}$ Además de la pérdida profunda que en términos afectivos y simbólicos representó el asesinato del Padre Mugica para la militancia juvenil peronista, el hecho generó complicaciones mayores para la Tendencia ya que la Triple A no reivindicó este accionar como propio y hubo quienes, desde la prensa, se lo atribuyeron a Montoneros (Celesia y Waisberg, 2010: 186).

539 “Por qué somos peronistas" En: El Descamisado, Año 1, №39, 12/02/1974. pp.2-3 


\section{CONCLUSIONES}

El retorno a la democracia el 10 de diciembre de 1983, que dio inicio al gobierno radical de Raúl Alfonsín, abrió la posibilidad para el regreso a nuestro país de los/as militantes exiliados/as. En ese marco, Oscar Bidegain y Ricardo Obregón Cano emprendieron su vuelta. No obstante, no sería una tarea fácil. La policía aeronáutica a instancias del Juzgado Federal en lo Criminal y Correccional $N^{\circ}$ 6, a cargo del juez Siro de Martini, ordenó la inmediata detención del ex gobernador de Córdoba. La captura respondía a la aplicación del famoso Decreto $\mathrm{N}^{\circ}$ 157/83 firmado por el presidente Alfonsín días antes, ordenando el juzgamiento a las cúpulas guerrilleras (este decreto fue acompañado por otro equivalente, el 158/83, que dictaminaba el juzgamiento a los integrantes de las tres primeras Juntas Militares, en sintonía con la narrativa oficial de "los 2 demonios" que se volvió hegemónica durante esos años). Luego de la detención de Obregón Cano, el mismo juez pidió el arresto inmediato del ex gobernador de Buenos Aires el 21 de diciembre. Desafiando la orden policial, Bidegain acompañado por su mujer, logró escapar antes de su detención y salir nuevamente al exilio, estableciéndose en Madrid durante 6 años. Finalmente, la aplicación de los indultos que promovió el gobierno de Carlos Saúl Menem (Decreto $N^{\circ} 1003$ ), en diciembre de 1989, posibilitó su regreso definitivo al país, radicándose en su ciudad natal.

Tal como explicaba la orden de su detención fallida en 1983, los cargos que se le imputaban (integrante de asociación ilícita, instigación pública a cometer delitos, apología del crimen, entre otros) tenían vinculación directa con su participación como miembro de la conducción del MPM en el exterior. ${ }^{540}$ Más allá de estos elementos que remitían a su trayectoria política y su exposición pública en el tiempo más reciente, consideramos también que para su comprensión en términos históricos es necesario bucear en aquellos acontecimientos de más larga duración que, en los primeros años setenta, configuraron su militancia en el peronismo revolucionario y su vínculo con la Tendencia. En ese sentido, esta tesis constituye un aporte al conocimiento de esa historia

\footnotetext{
${ }^{540}$ En 1979 Bidegain fue invitado por el Parlamento Europeo para participar de una Conferencia Interparlamentaria Europea y Latinoamericana realizada en Roma, acusando a la dictadura militar por los crímenes que estaba llevando a cabo en nuestro país. Al año siguiente, participó en representación del MPM (rama política), en Suiza, como miembro informante ante el Tribunal Permanente de los Pueblos "Lelio Basso", denunciando la violación fundamental de derechos humanos que sufría el pueblo argentino a través de secuestros, torturas, desapariciones de personas y asesinatos cometidos por el régimen militar.
} 
de más larga duración y cuyo epicentro se gestó en la experiencia del gobierno bonaerense de 1973.

De esta manera, a lo largo de los capítulos que conforman esta tesis hemos reconstruido y analizado la participación de militantes de la Tendencia Revolucionaria del Peronismo en la gobernación de Oscar Bidegain durante el año 1973, con el objetivo de iluminar aspectos particulares y poco conocidos de un proceso sumamente complejo que implicó la inserción de integrantes de organizaciones armadas y militantes del peronismo revolucionario como funcionarios/as del Estado. Dicha investigación se realizó tomando como caso de estudio la provincia de Buenos Aires, no solamente por su gravitación demográfica, política y electoral en la historia nacional, y por representar además una de las denominadas "gobernaciones montoneras" en la coyuntura analizada, sino también porque fue en dicho ámbito gubernamental donde mayor desarrollo alcanzó la experiencia institucional de la Tendencia Revolucionaria a nivel de Ministerios y Secretarías. Esta condición nos ha permitido conocer en profundidad la multiplicidad de proyectos e iniciativas -muchas de ellas concretadas y otras meramente enunciadas- que se intentaron llevar a cabo, junto a los imaginarios y expectativas que guiaron esas acciones y la trayectoria político-institucional de sus protagonistas.

Este intento por estudiar y comprender la dificultosa institucionalización de la militancia de la Tendencia Revolucionaria en el Movimiento Peronista y en el Estado, implicó para nuestra investigación analizar no sólo la conflictiva relación con Perón y los grupos antagónicos de la derecha, sino también y fundamentalmente, abordar las tensiones que ese proceso desencadenó al interior de este amplio conglomerado en el que convivieron por momentos, de manera más articulada y fluida, y por otros, de manera más dificultosa y compleja- lógicas de acción política disímiles, aunque concebidas como parte de un mismo proyecto revolucionario (la construcción del socialismo nacional).

Al respecto, esta tesis incluso cuando su objeto central versa sobre las prácticas no armadas de los grupos de la TR, ha buscado como un ejercicio metodológico primordial alejarse de aquellos enfoques que realizan un enjuiciamiento -por lo general negativo, condenatorio y extemporáneo- del uso de la violencia política por parte de la militancia revolucionaria en los años setenta. Lejos de emitir un juicio de valor sobre esas acciones, muchas veces caracterizadas como "irracionales", "desquiciadas" y "extremas" y fuera de la órbita de la política formal (entendida solo en su dimensión institucional), esperamos que esta tesis haya podido también reponer el entramado de ideas y sentidos compartidos, 
y el conjunto de hechos y prácticas que, en aquella coyuntura histórica, generaron las condiciones de posibilidad para llevar a cabo esa metodología, pensada como una opción válida y racional para los individuos y organizaciones comprometidos en ellas.

En este sentido, una de las ideas fuerza que atravesó el conjunto de esta tesis, y que motorizó en gran parte nuestra investigación, fue poder visibilizar la lógica integral del conjunto amplio, multifacético y plural de formas de la política encaradas por la Tendencia Revolucionaria en un momento vertiginoso y cambiante de nuestra historia reciente, el de la transición de la etapa de resistencia armada contra la dictadura y el post Cordobazo, a la gestión en el Estado bajo un gobierno peronista. De allí que nuestra investigación haya abordado en primer lugar, y a modo introductorio, aquella primera etapa de resistencia armada, para dedicarnos luego a ese pasaje a la esfera estatal, lo que implicó enormes desafíos para militantes con saberes, prácticas y lógicas de militancia forjadas en aquel periodo anterior. Aun así, como vimos, ambas lógicas políticas convivieron -con diversos énfasis- durante el gobierno de Bidegain.

Como dijimos, bajo esta doble dimensión de análisis en donde la política no armada se volvió un eje central de nuestro trabajo, no obstante, pudimos observar también las estrategias de articulación con las prácticas armadas que las organizaciones políticomilitares nucleadas en la TR trazaron dentro de un programa revolucionario de más largo alcance. Así, demostramos que en la lógica de los actores que estudiamos, ambas dimensiones (la militar y la institucional) lejos de presentarse como polos dicotómicos y excluyentes per se, en realidad constituyeron dos instancias complementarias de la lucha política que contribuían -con diferentes grados de valoración y de acuerdo a los perfiles de militantes en cuestión- a un mismo fin, y a las que apelaron con diferentes énfasis según las lecturas que realizaban de la cambiante coyuntura, como también en función de sus trayectorias y círculos previos de militancia y los distintos elementos que pesaron en la configuración de su identidad peronista revolucionaria.

Ahora bien, el análisis de lo que hemos llamado intentos de compaginación de ambas lógicas políticas -que cobró forma en la experiencia institucional de la TR en el gobierno provincial- no implicó dejar de lado en nuestro abordaje las múltiples tensiones que en su devenir se desarrollaron. De esta forma, reconstruimos también las notorias dificultades, dilemas y tensiones de todo tipo que el pasaje a la esfera institucional y la militancia en el Estado despertaron al interior de la TR, en particular entre aquellos grupos que sostenían como prioritaria y estratégica la continuidad de la lucha armada y la idea de vanguardia. 
Con respecto a esto, un elemento clave para nuestra tesis fue captar las reelaboraciones y los sentidos concretos que la opción institucional tuvo -en el transcurso mismo en que esta experiencia de gobierno se desarrollaba- para muchos de sus protagonistas. Esta valoración positiva de su militancia en el Estado, incluso considerada por algunos/as funcionarios/as como "revolucionaria" (es decir, ya no como un medio o una herramienta para, sino, como "parte misma" de la revolución en ciernes) agudizó las tensiones con aquellas posiciones que habían considerado, desde el inicio, a las prácticas institucionales como una táctica más al servicio de un objetivo mayor (la conformación de un ejército para la toma del poder). Al respecto, a lo largo de esta tesis pudimos observar el difícil equilibrio -y el dilema que significó para muchos de sus protagonistas- la coexistencia de estas dos lógicas políticas al interior de la Tendencia en el marco de un gobierno democrático y bajo el liderazgo de Perón en el país. Precisamente esa coyuntura y una dinámica política que se volvió cada vez más adversa y represiva para el conjunto de los sectores radicalizados fueron, a nuestro entender, los elementos que agudizaron profundamente esas tensiones llevándolas casi al punto de su ruptura hacia fines de 1973.

Por otra parte, abordar de manera integral tanto estos ensayos de articulación de lógicas dispares como sus tensiones, llevó necesariamente a considerar como un elemento central la rica y a su vez compleja heterogeneidad presente en el conjunto de organizaciones, grupos y referentes que integraron este espacio político. Examinar pormenorizadamente esa notable diversidad -que va desde las organizaciones armadas peronistas a las agrupaciones de militantes orientadas al trabajo de superficie, pasando por un conjunto de actores individuales con diversos anclajes en el peronismo revolucionario- constituyó una pieza clave y un trampolín para poder comprender la pluralidad de iniciativas y respuestas que a lo largo del tiempo desplegaron sus integrantes, considerando también los elementos aglutinantes que en términos políticos e ideológicos dotaron de unidad de sentido a ese espacio y a las acciones inscriptas en él por parte de sus militantes, poniendo en diálogo prácticas que a priori podrían pensarse como contradictorias. $\mathrm{O}$, dicho en otras palabras, la riqueza en términos políticos - no exenta de tensiones- de albergar un repertorio de prácticas no sólo armadas desde las cuales pensar e intentar construir un horizonte revolucionario.

Tomando en cuenta estas consideraciones, y siguiendo la línea de análisis arriba señalada tendiente a rastrear las diversas formas de la política y sus lógicas puestas en juego por la TR en el pasaje que va de la etapa insurreccional a la gestión en el gobierno, a 
continuación, destacaremos las principales claves del itinerario analizado a lo largo de la tesis.

Uno de los temas claves que atravesó las lecturas, debates y posicionamientos de la TR a principios de los años setenta fue sin duda el de la apertura electoral y la posibilidad de que el peronismo accediera nuevamente al gobierno. El horizonte democrático habilitado por el GAN, como vimos, había sido "arrancado" al régimen militar por el accionar conjunto de las organizaciones armadas y el extendido movimiento de radicalización social y política presente en amplios sectores de la sociedad civil.

La centralidad que la lucha armada y las metodologías de acción directa adquirieron en ese contexto contribuyeron, paradójicamente, al llamado a elecciones, objetivo "reformista" que no se encontraba en las aspiraciones de máxima de ninguna de las organizaciones político-militares peronistas. Precisamente, las lecturas de rechazo a la llamada "trampa electoral" fueron las que predominaron durante los años 1970-71 en el conjunto de agrupamientos que integraban la Tendencia. Con diferentes matices, observamos un posicionamiento que iba del descreimiento absoluto a que el régimen permitiera elecciones libres sin proscripciones y con Perón como candidato, al repudio total a una medida cuyo objetivo final, según se consideraba, era frenar la radicalización y "vaciar" al peronismo de su contenido revolucionario. Como trasfondo de estas ideas se encontraba también la fuerte creencia de que los métodos legales de lucha-desde 1955 en adelante, tantas veces ensayados y frustrados- no constituían la vía correcta, mientras que las distintas formas de movilización popular y la lucha armada parecían ser los únicos medios efectivos para el retorno del peronismo al poder y avanzar en el llamado "socialismo nacional".

Sin embargo, los cambios de la coyuntura política, al compás de la estrategia trazada por Perón con el lanzamiento del FRECILINA -que implicaba la revitalización y un mayor protagonismo de las estructuras legales del peronismo- y las muestras de consenso que el escenario electoral despertaba en gran parte de la población, promovieron un reposicionamiento en la mayoría de las organizaciones de la TR en el año 1972, revelando una significativa capacidad de adaptación (política y organizativa) ante el desafío electoral en ciernes.

En este sentido, el programa de los "Cinco Puntos" que Montoneros presentó ese año apoyando la candidatura de Perón y el lanzamiento de la JP Regionales, constituyeron los 
signos más notables de esta nueva disposición a la participación y disputa en las estructuras legales del Movimiento, y los intentos de capitalizar políticamente a su favor las elecciones. Al respecto, también observamos como una constante de todo el período incluso luego del triunfo del 11 de marzo de 1973- que la aceptación de la salida electoral en los documentos e intervenciones públicas de las conducciones de las organizaciones armadas que encabezaron esta apuesta, se expresó siempre en los términos de una táctica al servicio de una estrategia revolucionaria más amplia, la cual seguía apostando en el mediano y largo plazo a la necesidad de construir un Ejército popular que asegurara la marcha efectiva hacia la "patria socialista".

No obstante, observamos que esta concepción instrumental de las elecciones, en la práctica, lo que habilitó fue la integración y a la vez la promoción -como métodos revolucionarios secundarios- de un repertorio amplio de acciones políticas de corte más legal e institucional que venían desarrollando diversos grupos de la TR en los frentes de masas. Ahora bien, esta preponderancia que comenzaron a adquirir los métodos legales de lucha política no dejó de despertar tensiones en su seno. Tal como vimos, en algunos casos la decisión de participar del juego electoral fue vista con cierto resquemor, percibiendo en ello una suerte de "desvío reformista" en relación con el objetivo primario de la conformación de un ejército revolucionario para la toma del poder. Por otra parte, como pudimos evidenciar, existieron otros militantes de la Tendencia que de manera muy temprana mostraron mayor predisposición hacia la militancia en espacios institucionales, siendo mayormente quienes más tarde se involucraron en las tareas de gestión gubernamental provincial. Para estos grupos, que fueron claves en nuestra investigación, la vía electoral y la disputa al interior de las estructuras partidarias se convirtieron ya no en un instrumento secundario y menor, sino en un objetivo más sustantivo de acumulación y transformación política.

Para poder comprender cómo se fueron construyendo esos sentidos proclives a la apertura electoral y su posterior "afinidad electiva" con la participación institucional, fue necesario retrotraernos a las etapas iniciales de la militancia de tres grupos en particular: JP-FURN, “oscuros” de las FAP y Descamisados. El enfoque más pormenorizado en sus itinerarios previos, más allá de los matices analizados en cada uno de los grupos, lo que nos permitió observar fue la presencia de una línea más "movimientista" en sus definiciones político-ideológicas que será clave en su recorrido posterior vinculado a la función gubernamental. En este sentido, incluso cuando los tres grupos pusieron en 
práctica la lucha armada, su concepción sobre el Peronismo como "revolucionario en su conjunto" -que implicaba morigerar las tensiones más rupturistas con otros grupos internos- y su disposición a desplegar una activa militancia de base en los frentes de masas y hacia adentro de las estructuras formales del Movimiento, explican su mayor permeabilidad hacia una posible articulación entre la estrategia de guerra popular y prolongada y otras expresiones de activismo no armado.

Por otra parte, la postura "tendencista" que Montoneros asumió en 1972, aceptando la participación en las estructuras del Movimiento como forma de intentar hegemonizarlo, y el giro hacia una política de vinculación con el activismo juvenil de superficie, constituyen los elementos que motorizaron la unificación de todos estos grupos en el transcurso de ese año, y las claves para comprender la preponderancia que Montoneros adquirió en el espacio de la TR y en el futuro gobierno.

Precisamente, un momento muy significativo de este itinerario al que atendimos particularmente fue el proceso de armado de candidaturas y la campaña electoral. En esta instancia, reconstruimos la intervención temprana y activa que el grupo JP-FURN llevó a cabo a través de una práctica extendida de afiliaciones y promoción de candidatos propios en las listas que competían dentro del partido, lo que a nivel local/regional dotó a dicha agrupación de una notable capacidad de organización y presencia política territorial, y una proyección hacia la gestión gubernamental. Con todo, un elemento que se destacó en nuestro análisis es que esta fuerte determinación de intervenir en la puja dentro del partido, se conjugó con su apoyo a la lucha armada y su integración a Montoneros. En este sentido, lejos de ser vivido como un proceso signado por lógicas contradictorias o excluyentes, tratamos de evidenciar el tipo de coherencia y racionalidad que, en aquella coyuntura, los sujetos le otorgaron a la diversidad de sus prácticas militantes.

En concreto, para este grupo de militantes de la TR, en principio la apuesta institucional se pensó como parte de un engranaje mayor (un medio/una táctica) dentro de una concepción de lucha integral que apelaba a distintos métodos. De allí también que cobra sentido la fusión con Montoneros en ese mismo momento, en tanto organización armada que primero se definió a favor de la opción electoral.

Sin embargo, tal como se dejó de manifiesto en nuestro trabajo, la experiencia y la práctica política del juego institucional -en relación también con los cambios en el contexto político nacional- promovieron una modificación del lugar "secundario" 
asignado a esta apuesta. En una coyuntura marcada por la reorganización partidaria y la competencia con sectores rivales del peronismo por ganar lugares en las listas y cargos en el futuro gobierno, la militancia legal comenzó a adquirir, para estos/as militantes, un peso "estratégico" - en detrimento del accionar armado- en tanto permitía fortalecer la línea política de la Tendencia dentro del Movimiento, acrecentando las posibilidades de realizar el proyecto revolucionario de más largo alcance. Esto reveló que, lejos de percibir esa ambivalencia como una dicotomía insalvable entre la que había que optar, los actores vivieron el proceso como una tensión productiva de la cual emergió el intento de fusionar lo institucional con lo revolucionario.

En este marco y atendiendo al desarrollo de la dinámica política nacional y provincial, dimos cuenta del rol protagónico que jugó la TR en las elecciones internas del Partido Justicialista (PJ) y cómo llegó a participar activamente de la campaña electoral. Atendiendo a las disputas y las tensiones desencadenadas con otros actores del campo peronista, reconstruimos el escenario político de enfrentamientos internos que motivaron el vínculo de la TR con Héctor Cámpora y Oscar Bidegain, y el lugar que ocuparon sus militantes en la campaña electoral y el gobierno provincial. Concretamente en la provincia de Buenos Aires, la tenaz resistencia demostrada por los grupos de la derecha político-sindical hacia la candidatura de Bidegain, actuaron como aglutinante entre éste y los militantes de la Tendencia. El carácter pragmático observado en la relación inicial de ambos actores -para contrarrestar el notable poder del sector sindical en la provinciaadquirió relieves más sustantivos luego de las elecciones, convirtiéndose los grupos de la TR en la principal "cantera" de militantes para cubrir los cargos en el gabinete conformado por el gobernador.

En esta línea, pudimos reconstruir las experiencias previas, sumamente significativas, de dos grupos que ocuparon roles destacados en el gobierno provincial, integrados por profesionales y técnicos inscriptos en la TR (el CTMNP y los EPT de la JP) que venían elaborando proyectos con una alta calificación, los cuales sirvieron de base para las futuras políticas públicas que aspiraban a desarrollar en la gestión gubernamental. Ambos grupos, más allá de sus diferencias generacionales y de orígenes, tenían en común la disposición temprana de sus integrantes a intervenir en espacios institucionales, lo que se combinaba con un marcado compromiso militante y posicionamiento revolucionario, plasmado en la idea de que su experticia profesional debía ponerse al servicio de una causa política más elevada. Precisamente una característica o perfil distintivo de muchos 
de ellos fue su "capital militante", que fue ponderado como un insumo clave junto con sus habilidades técnicas en su desempeño institucional; condición política que a su vez actuaba como garantía de su desempeño revolucionario el Estado. Esa reconversión de valores, habilidades y saberes prácticos adquiridos en su militancia previa (el compromiso y la entrega política, la movilización callejera, diversas formas de acción directa y el activismo con las bases entre otras cuestiones vinculadas a ese "saber hacer") en articulación con su recorrido institucional y la práctica de elaboración de proyectos, marcaron la experiencia de gestión de los/as militantes-funcionarios/as de la Tendencia en el gobierno provincial.

Ahora bien, tal como observamos, las consecuencias de este proceso no fueron menores teniendo en cuenta diversos planos de análisis. A nivel metodológico y del enfoque privilegiado en nuestra investigación, abordar esta experiencia implicó tomar distancia del paradigma historiográfico que ha considerado a las prácticas armadas como la expresión unívoca y dominante de la política revolucionaria de los años setenta, sentido que -como hemos visto- subyace incluso en aquellos estudios que han reconstruido la participación de la TR en las "provincias montoneras". Si para estos trabajos, la aspiración a ocupar puestos en el Estado respondía únicamente a la lucha de poder que mantenían con los sectores de la derecha del Movimiento, y/o al objetivo de obtener recursos que fortalecieran la estrategia militar, sin encontrar otras motivaciones políticoideológicas sustantivas, en nuestra investigación pudimos dar cuenta del desafío y el intento real por parte de algunos grupos de la Tendencia de inscribir su militancia radicalizada en el espacio gubernamental, canalizando a través de instancias más formales de la política sus aspiraciones y prácticas revolucionarias.

Esto significó atender particularmente a los lugares estratégicos que ocuparon en el gabinete provincial -con la intención de gravitar directamente en la línea del nuevo gobierno- y al conjunto de programas de corte socializante que buscaron desarrollar, los cuales permitieron a muchos de sus ejecutores concebir su trabajo en el espacio institucional como una apuesta no reñida con los objetivos de transformación mayores. A nuestro entender, esas prácticas y medidas que procuraron poner en marcha -con mayor éxito algunas, y otras solo meramente enunciadas- fueron expresión de un proyecto político e ideológico alternativo asociado a la idea de la "patria socialista" encarada desde el gobierno. 
Esto nos lleva a la otra dimensión de análisis privilegiada, referida a la reconstrucción de la dinámica política de los grupos de la Tendencia y su desempeño en el Estado, proceso que resultó profundamente negativo para este actor en términos de las relaciones de fuerza dentro del Movimiento, toda vez que esas expresiones radicalizadas en el gobierno entraron en abierta contradicción con los planes de Perón.

Las experiencias concretas impulsadas desde la gestión de los diferentes Ministerios bonaerenses así dan cuenta. En el caso del Ministerio de Bienestar Social, la reconstrucción empírica que llevamos a cabo reveló, por un lado, un abundante número de políticas y medidas proyectadas para el área de salud y acción social, fundadas en la concepción de la organización comunitaria, la intervención popular en todas sus etapas, el fortalecimiento de la gestión pública por sobre la privada y una modalidad asamblearia y anti jerárquica en la toma de decisiones y en la distribución y uso de los recursos.

Por otro lado, acompañando esos proyectos, observamos también las diversas estrategias puestas en juego por los/las militantes-funcionarios/as en su búsqueda por dotar de un “contenido revolucionario" su participación en el Estado. En esta vía, visualizamos los intentos por trasladar al espacio gubernamental un conjunto de prácticas y disposiciones democratizantes que venían de la etapa de radicalización previa, las cuales servirían de afluentes a las políticas institucionales. Concretamente la movilización popular y la acción directa, el activismo territorial, la organización comunitaria, el trabajo con las bases y una dinámica de participación horizontal no fueron abandonados, sino que se promovieron y reelaboraron como pilares de las políticas públicas implementadas, dándole a esas prácticas ahora un cauce institucional bajo la perspectiva de construcción del "socialismo nacional".

Esto que pudimos observar en particular en el contexto y la metodología de las tomas y en gran parte de las políticas sociales impulsadas, constituyó a nuestro entender el ensayo por compatibilizar las "metodologías revolucionarias" con las nuevas funciones gubernamentales asumidas por los/as militantes de la TR, ampliando los límites de la democracia representativa hacia otros horizontes de participación y transformación social en que la propia noción de democracia adquiría renovados sentidos. Por ejemplo, en torno a la cuestión de la transformación social y el trastrocamiento de las estructuras del poder económico vigente, logramos reponer también el conjunto de políticas diseñadas desde el Ministerio para abordar este tema (reasignación de los recursos financieros, plan de nacionalización de medicamentos, etc.) pero que apenas lograron esbozarse dadas las 
profundas resistencias que se levantaron en su contra, provenientes no solo de las corporaciones médicas y farmacéuticas, sino desde el propio gobierno. Los episodios de Ezeiza, la renuncia de Cámpora y la salida de Ferrara y otros destacados funcionarios de la Tendencia en el gabinete se inscriben precisamente en ese registro, poniendo de manifiesto las diferencias de fondo que existían -en términos político-ideológicos y de las metodologías utilizadas- entre las aspiraciones revolucionarias de la militancia en el gobierno, y los sectores de la derecha peronista encabezados por el vice gobernador y el propio Perón.

A pesar de estos duros reveses, algo que también nuestra tesis puso de relieve fue la persistencia por parte de los grupos de la Tendencia que continuaban al frente de los Ministerios de avanzar en la realización de lo que alguno de nuestros protagonistas definió como "políticas públicas revolucionarias". En este sentido, como mencionamos, la experiencia concreta de la gestión derivó en un proceso de resignificación de la instancia gubernamental y de las potencialidades de su militancia en ese ámbito, comenzando a percibir el entrecruzamiento de ambas lógicas (la revolucionaria y la institucional) como una vía efectiva en la promoción de políticas para la liberación nacional y social.

Esa visualización de su desempeño en el gobierno como un momento sustancial o parte integrante y prioritaria de la política revolucionaria misma se expresó en las distintas iniciativas encabezadas por los/as militantes de la Tendencia en el gabinete, aún luego de la salida de Ferrara. En efecto, a pesar de transitar un contexto nacional que viraba cada vez más hacia la derecha del espectro político peronista (el documento reservado y las prácticas de persecución violenta son una muestra de ello), la gestión de este grupo de funcionarios/as en los Ministerios de Obras Públicas, Asuntos Agrarios y en el de Gobierno constituyen ejemplos claros del intento sistemático de avanzar en esa línea, incluso cuando los desafíos de llevar a cabo estas prácticas institucionales derivaron en tensiones de distinto orden.

En principio, podemos mencionar una tensión de orden práctico que atraviesa de modo general la experiencia de la labor en los Ministerios, que tiene que ver con el desajuste entre las temporalidades más extensas de la revolución, y los ritmos, saberes y mecanismos inherentes a la acción cotidiana en el Estado, junto a las urgencias a las que había que dar respuesta. Al desconocimiento de la dinámica estatal y burocrática, con sus propios habitus y disposiciones, se sumaba la necesidad de atender rápidamente a las 
demandas apremiantes que surgían de los sectores más postergados. Esta imposición de un tiempo corto y vertiginoso en el que había que aprender saberes desconocidos que eran fundamentales para poder accionar todos los resortes de la maquinaria estatal constituyó un desafío notable para los/as militantes-funcionarios/as de la Tendencia, al que dieron respuesta de un modo particular y expresivo también de los sentidos y metodologías llevados al Estado desde su militancia revolucionaria. Tal como señalaron varios de nuestros entrevistados y como se pudo observar en los documentos analizados, un pilar en la resolución de estas dificultades fue la creación de instancias de participación efectiva de los/as trabajadores, promoviendo una sociabilidad políticoinstitucional horizontal y alejada de las jerarquías y formas autoritarias de gestión de la cosa pública. A su vez, esta disposición al interior de la dinámica ministerial buscando romper la lógica burocrática y la distancia entre funcionarios/as y empleados/as se replicaba hacia afuera, en las modalidades de gestación y concreción de las políticas públicas mismas, las cuales recuperaban como un eje central la concurrencia activa de las bases y la intervención popular como elementos sustantivos del proyecto de liberación. En la vivencia de los protagonistas, esta experiencia significó el intento no sólo de llevar el "Estado al barrio", sino también "el barrio al Estado" como una forma de trasladar el activismo de base y el repertorio de prácticas de lucha de su militancia anterior. Esta trasformación de la dinámica estatal nos llevó también a plantear la cuestión del espacio y la circulación por diferentes ámbitos por parte de los/as funcionarios/as militantes, como una dimensión singular a la que atender. En este ir y venir del barrio al Ministerio y de la oficina a la Unidad Básica, lejos de visualizar una bifurcación insalvable entre esos espacios y sus funciones, lo que observamos nuevamente es la posibilidad de conjugar distintas metodologías, revelando una disposición democratizante en las prácticas de gestión gubernamental. Este desafío a la "propensión al cierre" propia de toda institución burocrática se vio reflejado en el conjunto vasto de medidas que hacia adentro del funcionamiento del Estado y fuera de él desplegaron los/as militantes de la TR, transformando en un sentido más igualitario y democrático las estructuras de poder. El Parlamento Agrario, la política de autogestión de base, las Mesas de Trabajo, las expropiaciones de tierras y empresas, la política carcelaria, por recuperar solo algunos casos, son una muestra de ello.

Estas dificultades de orden práctico que se dieron en el transcurso mismo de la gestión, fueron canalizadas de un modo sumamente productivo por la militancia en el gobierno, tal como analizamos. No obstante, en nuestro trabajo fue capital atender a otro tipo de 
tensiones que de manera simultánea y en retroalimentación, resultaron profundamente corrosivas en sus efectos sobre esta experiencia, al punto de llevarla a su declive y desarticulación.

Nos referimos, por un lado, a la exacerbación de las contradicciones entre la TR y Perón. Como observamos detenidamente en los últimos capítulos de esta tesis, las diferencias políticas e ideológicas entre ambos actores comenzaron a cobrar relieves cada vez más violentos, en particular durante la presidencia de Perón, etapa en la que se desató una campaña represiva y depuratoria con el objetivo perseguir y desplazar a los referentes de la Tendencia. Esta ofensiva reaccionaria, fue desplegada plenamente durante su mandato, trastocando aceleradamente el escenario en que se desarrollaban las iniciativas de la militancia radicalizada en el gobierno.

Una de las ideas que esta tesis sostiene, y que esperamos haber demostrado, es que las formas disruptivas de gestión estatal encabezadas por la Tendencia en el gobierno provincial se encuentran en la base de esa acción depurativa y persecutoria que llevó finalmente a su expulsión del ámbito institucional. Al respecto, consideramos que nuestra investigación ha permitido recuperar con base empírica algunos de los sentidos puestos en disputa por este actor sobre la democracia popular, la participación institucional de la militancia revolucionaria, la orientación de las políticas estatales y la posibilidad de construcción del socialismo nacional desde el Estado, todo lo cual contribuye a explicar tanto como las acciones armadas- el proceso que llevó a que los militantes de la Tendencia fueran el blanco de la acción represiva.

Esta ofensiva violenta que se ejercía desde la derecha del Movimiento y el propio Perón, fue vivida de manera muy tensionante por la militancia radicalizada. Tal como se analizó en los testimonios y documentos, no era nada fácil para los y las jóvenes militantes que habían levantado la bandera de la lucha por la vuelta del líder, asistir al conjunto de medidas represivas que se cernían en su contra desde un gobierno peronista que habían jurado defender hasta sus últimas consecuencias. No obstante, la heterogeneidad ya señalada en la composición de los grupos que integraban la TR ha impedido realizar definiciones taxativas sobre este punto. Como vimos, algunos/as militantes que participaron de la gestión provincial, vivieron estas acciones como un punto de inflexión y quiebre en el vínculo con Perón, no así con el peronismo y su militancia revolucionaria. Para otros/as integrantes de la Tendencia, las críticas hacia el líder justicialista encontraban un límite en el peso que su figura seguía teniendo en la construcción de su 
identidad peronista, como en lo que entendían un "exceso de arrogancia" y "provocación" por parte de Montoneros en sus aspiraciones desmedidas por la conducción del Movimiento. Esta reacción que en ciertos casos rozaba la justificación, la observamos en el núcleo de militantes que rompieron con Montoneros a principios de 1974 y fundaron JP-Lealtad (en particular los ex - oscuros de las FAP). Con otros matices, la disconformidad con las críticas que la cúpula de la organización armada realizaba de manera abierta a Perón y la agudización del enfrentamiento la observamos también en un grupo no menor de militantes de la JP-FURN que, si bien no se alejaron de Montoneros en ese momento, vivieron con mucha angustia y pesar las discrepancias con el líder y el alejamiento de su participación en el gobierno peronista.

Precisamente estas diferencias en las reacciones de la militancia de la Tendencia ante la coyuntura represiva y la figura de Perón, se articulan con el otro nudo de tensiones al que esta tesis atendió de manera especial, y que a nuestro entender -no con el mismo peso que las políticas represivas, pero sí de manera significativa- también contribuyeron a debilitar internamente la apuesta institucional de la Tendencia. Nos referimos concretamente al peso que fueron ganando las posiciones a favor de la estrategia armada. Una de las manifestaciones más claras en este sentido, a nivel de la línea política y las discusiones ideológicas que habilitó, fue la presentación del Mamotreto. Las definiciones volcadas en ese documento (la noción de vanguardia, la lucha armada como metodología principal y la conformación de un ejército como postulado estratégico) si bien no eran nuevas, comenzaron a cobrar en aquel contexto un renovado espesor, que propiciaba el vuelco hacia el fortalecimiento de la estructura militar y las acciones armadas en detrimento del sostén y apuntalamiento del trabajo político dentro del Estado. Como hemos visto a lo largo de esta tesis, esa lógica armada que concebía de manera instrumental la participación en las elecciones y el gobierno, nunca había sido desestimada. Sin embargo, a la luz de las oportunidades que la democracia brindaba y la participación de amplios sectores de la militancia de la Tendencia en el gobierno, esos postulados se habían visto morigerados sobre todo a nivel de las prácticas y en el imaginario de muchos de los militantes que efectivamente ocuparon cargos en el gobierno. En ese contraste entre las expectativas, las representaciones y las acciones que los/as militantes-funcionarios/as desplegaron en su labor en el Estado, y los lineamientos que en un sentido opuesto la conducción de Montoneros volcaba en ese documento, se debe medir el impacto real y profundo que la desestimación de la apuesta institucional tuvo para los/as militantes que protagonizaron esa experiencia. A su vez, como correlato de las definiciones que en ese 
documento se clarificaban, encontramos el despliegue de un conjunto de acciones y cuestionamientos que los responsables de Montoneros realizaron a los/as militantes que participaban de la gobernación de Bidegain. Entre las actitudes mencionadas, encontramos desde un "dejar hacer" leído como muestra de la falta de interés y apoyo que las iniciativas de gestión concitaban, al "menosprecio" abierto por el trabajo institucional tildado de "reformista" por algunos cuadros de jerarquía dentro de la organización, quienes acompañaban esas críticas con la presión por poner en marcha prácticas armadas. Este accionar que desalentaba la experiencia gubernamental cuestionando su "utilidad" a los fines revolucionarios, terminó socavando internamente la fuerza y las expectativas de quienes experimentaban la tarea político-institucional como parte central de su militancia peronista y revolucionaria, lo que en algunos casos derivó en un conflicto interno respecto de su decisión de seguir o no en la organización Montoneros.

Otorgar una atención especial a esta tensión interna, sin embargo, no implicó en nuestra investigación desestimar el peso mayor y determinante que las contradicciones políticas de fondo con Perón y la ofensiva represiva tuvieron en la renuncia de Bidegain y la expulsión del conjunto de la militancia revolucionaria de los espacios gubernamentales. No obstante, podemos arriesgar también que esa tensión latente entre ambas lógicas políticas, al calor de un contexto cada vez más adverso para las expresiones radicalizadas dentro del gobierno, terminó por definirse a favor de los grupos que dentro de la Tendencia habían concebido desde siempre la lógica armada como la expresión principal y más efectiva de la lucha política.

Por último, esta investigación reveló que los 8 meses de gobierno de Oscar Bidegain en la provincia de Buenos Aires, constituyeron un momento complejo y rico en experiencias y tensiones de todo tipo que atravesaron a la militancia peronista revolucionaria durante el transcurso del primer año del tercer gobierno peronista. Puntualmente, dimos cuenta de los distintos procesos que confluyeron en el protagonismo de la Tendencia Revolucionaria en el espacio institucional bonaerense, mostrando que su relevancia en la dinámica política general del período fue mucho más allá de su accionar armado. En ese devenir analizamos la emergencia de prácticas institucionales que lejos de anclarse en una lógica cerrada, jerárquica y burocrática, apuntaron desde una concepción revolucionaria al fortalecimiento del poder popular, la descentralización de la cosa pública, la horizontalidad en la toma de decisiones y las prácticas de autogestión, por citar las más destacadas. Ahora bien, también nuestro trabajo reveló que esas prácticas 
confluyeron con otra lógica que, como muestran los ejemplos arriba señalados, apuntaba a la centralización del universo militante y de las decisiones y prácticas plurales de los grupos de la Tendencia, atentando contra la autonomía de esas acciones divergentes. Bajo este enfoque, esperamos entonces que este trabajo haya podido contribuir a ampliar el marco de reflexión sobre las distintas expresiones de la política revolucionaria en los años setenta, observando las orientaciones disímiles que esta praxis tuvo al interior de la militancia peronista dentro y fuera de Estado, reparando particularmente en las "otras prácticas", las no armadas, que también se inscribieron en ese horizonte de trasformación radical de los años setenta, más allá de su obturación y derrota política. 


\section{FUENTES Y BIBLIOGRAFIA}

\section{FUENTES:}

\section{Entrevistas}

- Hugo Bacci, La Plata, 2 de abril de 2012 (entrevista de la autora)

- Nora Peralta, La Plata, 1 de mayo de 2012 (entrevista de la autora)

- Alejandro Peyrou, CABA, 11 de noviembre de 2012 (entrevista de la autora)

- “José” ex militante de las FAP-oscuros. Quilmes, diciembre de 2012 (entrevista de la autora)

- Flora Castro (dos sesiones), La Plata, 22 de junio de 2013 y 18 de julio de 2013 (entrevista de la autora)

- Mabel Maidana, La Plata, 10 de julio de 2014 (entrevista de la autora)

- Babi Práxedes Molina, La Plata, 16 de junio del 2014 (entrevista de la autora)

- “Cacho" ex militante de Montoneros, agosto de 2016 (entrevista de la autora por mail)

- Gonzalo Cháves, La Plata, 10 de abril de 2016 (entrevista de la autora)

- Sergio D., La Plata, 3 de octubre de 2016 (entrevista de la autora)

- Ricardo Rubio, San Miguel, 17 de diciembre de 2016 (entrevista de la autora)

- Marina Siri, San Miguel, 17 de diciembre de 2016 (entrevista de la autora)

- Néstor Ronconi, Ensenada, 1 de mayo de 2017 (entrevista de la autora)

- Alcira Argumedo, CABA, 2008 (entrevista cedida por Alejandro Peyrou)

- Leopoldo Halperin, CABA, 2008 (entrevista cedida por Alejandro Peyrou)

- Guillermo Gallo Mendoza, julio de 2014 (entrevista de Guillermo Caviasca) disponible en: http://www.youtube.com/watch?v=NcLwLQFjVGs Fecha de consulta: 2/5/2018

\section{Documentos citados:}

- Documento de la Juventud Peronista "Sin Perón no hay pacificación". Noviembre de 1972. En Baschetti, Roberto (1996: 482).

- Documento de la Juventud Peronista, “Compañero del FreJuli”- Febrero de 1973. Disponible en Centro de documentación de las organizaciones político-militares argentinas "El topo blindado": http://eltopoblindado.com/.

- Solicitada del Gobierno provincial convocando al Operativo Dorrego: "Al pueblo de la Provincia de Buenos Aires". El Día, 28 de Septiembre de 1973, p. 6. 
- Comunicado de la JP, JTP y JUP "Firme en la reconstrucción nacional". El Descamisado, Año 1, N¹, 30/10/1973.

- Documento de la Juventud Peronista "Compromiso de la Juventud Peronista con el pueblo de la patria", s/f. Disponible en Centro de documentación de las organizaciones político-militares argentinas "El topo blindado": http://eltopoblindado.com/.

- Solicitada de la JP-Consejo Nacional “A la juventud argentina.” El Descamisado, Año $1, \mathrm{~N}^{\circ} 36,22 / 1 / 1974$.

- "Solo la organización y la movilización del pueblo nos dará la liberación. La represión solo nos dará la dependencia. Montoneros, Comunicado”. El Descamisado, Año 1, N³6, $22 / 1 / 1974$

- Decreto $\mathrm{N}^{\circ}$ 3050/73 Boletín Oficial de la Provincia de Buenos Aires, La Plata, Hemeroteca de la Legislatura Bonaerense sobre la creación de las "Unidades Básicas de Solidaridad Social"

- Decreto $\mathrm{N}^{\circ}$ 3051/73. Boletín Oficial de la Provincia de Buenos Aires. La Plata. Hemeroteca de la Legislatura Bonaerense.

- Decreto No 5132/73 Boletín Oficial de la Provincia de Buenos Aires. Hemeroteca de la Legislatura Bonaerense, La Plata, sobre la creación de las Juntas Vecinales de Consumidores.

- Decreto 5157/73 Boletín Oficial de la Provincia de Buenos Aires, La Plata, que aprobó el convenio con la Facultad de Ciencias Económicas de UNLP para realizar actividades de interés vinculadas al sector agrario de la provincia.

- Decreto 3572/73, Boletín Oficial de la Provincia de Buenos Aires, La Plata que promovía la formación de cooperativas de trabajo y producción social.

- Decreto 5013/73, Boletín Oficial de la Provincia de Buenos Aires, La Plata, sobre la reglamentación del Estatuto del Peón en la provincia de Buenos Aires.

- Decreto 342 y 344, 348, 349, 350 y 365 del 15/6/1973 Boletín Oficial de la Provincia de Buenos Aires, sobre nombramientos a funcionarios del MOP

- Descamisados "20 de noviembre de 1970. 'Día de la Soberanía'” En Baschetti, Roberto (comp.) (1997). Documentos 1970-1973. De la guerrilla al gobierno popular, La Plata, Editorial de La Campana, p. 96

- Descamisados y Montoneros “A los Compañeros de la Juventud en el día de los fusilamientos", junio de 1972. Disponible en Centro de documentación de las organizaciones político-militares argentinas "El topo blindado": http:/eltopoblindado.com/. 
- "Descalabro en la provincia". Solicitada. El Descamisado, Año 1, N³8, 5 de febrero de 1974, p. 30

- "Drásticas instrucciones a los dirigentes del Movimiento para que excluyan todo atisbo de heterodoxia marxista: el Documento Reservado", La Opinión 2/10/1973.

- Documento de la Juventud Peronista "Nuevo lema de la Juventud Peronista: Cámpora al gobierno, Perón al poder” (1972). La Opinión, 21/12/1972, p.13.

-Fuerzas Armadas Peronistas (FAP), "12 preguntas a las Fuerzas Armadas Peronistas”, 1970 en Cristianismo y Revolución, No 25.

-Fuerzas Armadas Revolucionarias (FAR) "Documento de Actualización Política”, 1972. En Baschetti, Roberto (1997) De la guerrilla peronista al gobierno popular. Documentos 1970-1973, De la Campana, Buenos Aires.

-Fuerzas Armadas Revolucionarias (FAR) “Aportes críticos de las Fuerzas Armadas Revolucionarias al "Documento Base para la Reactualización de la Línea Político-Militar. En Baschetti, Roberto (1997) De la guerrilla peronista al gobierno popular. Documentos 1970-1973, De la Campana, Buenos Aires.

- Fuerzas Armadas Revolucionarias (FAR) "Con el Frente al gobierno, con el ejército peronista al poder" Documento previo a las elecciones del 11 de marzo de 1973. En Baschetti (1997, p. 513).

- FAR y Montoneros “Apoyar, defender y controlar”. Comunicado del 24-5-73 ante la asunción del Dr. Héctor Cámpora. El Descamisado, No 2, 29/5/1973, p. 3.

- FAR y Montoneros. “Conferencia de Prensa Junio de 1973”, Baschetti, Roberto (comp.) (1996). Documentos 1970-1973. De la guerrilla al gobierno popular, La Plata, Editorial de La Campana.

- FAR y Montoneros (1973), “Acta de la unidad", en Baschetti, Roberto (comp.) (1996). Documentos 1970-1973. De la guerrilla al gobierno popular, La Plata, Editorial de La Campana.

- Montoneros. “Comunicado N 1" y “Comunicado No 3". En Baschetti, Roberto (1997) De la guerrilla peronista al gobierno popular. Documentos 1970-1973, De la Campana, Buenos Aires, p.50

- Montoneros. "Comunicado No 4", junio de 1970. En Baschetti, Roberto (1997) De la guerrilla peronista al gobierno popular. Documentos 1970-1973, De la Campana, Buenos Aires. P. 54

- Montoneros "Hablan los montoneros" (1970) en Cristianismo y Revolución, no 26, Noviembre-Diciembre de 1970 
- Montoneros "El llanto del enemigo" (1971) en Cristianismo y Revolución, № 28.

- Montoneros “Al Pueblo de la Nación”, diciembre de 1971. Disponible en Centro de documentación de las organizaciones político-militares argentinas "El topo blindado": http:/eltopoblindado.com/.

- Montoneros “A los compañeros trabajadores”, marzo de 1972. Disponible en Centro de documentación de las organizaciones político-militares argentinas "El topo blindado": http:/eltopoblindado.com/.

- Montoneros, "Línea político-militar" (1972), en Baschetti, Roberto (1997), De la guerrilla peronista al gobierno popular. Documentos 1970-1973, De la Campana, Buenos Aires pp. 249-270

- Montoneros "Memoria del año 1971. Informe especial” (1972), en Baschetti, Roberto (1997), De la guerrilla peronista al gobierno popular. Documentos 1970-1973, De la Campana, Buenos Aires, pp. 363-373

- Montoneros "Documento y Programa”, 24 de Febrero de 1973. En Baschetti, Roberto (1997: 525)

- Montoneros "Boletín Interno N 1” (1973, 1era. quincena de mayo), Baschetti, Roberto (1997). De la guerrilla al gobierno popular. Documentos 1970-1973, La Plata, Editorial de La Campana, pp. 568-616

- Montoneros “Construir el poder popular”. El Descamisado No 4, 12/06/1973, pp 2-4.

- Montoneros "Charla de la Conducción Nacional de Montoneros ante las agrupaciones de los frentes-1973” En Baschetti, Roberto (1996) De la guerrilla peronista al gobierno popular. Documentos 1970-1973, De la Campana, Buenos Aires pp. 258-311.

- Movimiento Peronista Montonero, "Documento de Roma”, abril de 1977, disponible en: http://eltopoblindado.com/opm-peronistas/montoneros/montonerosexilio/movimientoperonista-montonero-documento-de-roma/

- Perón, Juan Domingo (1965), “Carta de Juan D. Perón a la Juventud Peronista. Octubre de 1965", en Baschetti, Roberto (1998), Documentos de la Resistencia Peronista 19551970, Punto Sur, Buenos Aires.

- Perón, Juan Domingo (1971). “Carta a Montoneros del 20 de febrero”. En Añoran, José (2005). Bs.As. Catálogos, p.154

- Perón, Juan Domingo (1971), “Actualización política y doctrinaria para la toma del poder” junio, julio y octubre. En Baschetti, Roberto (1997), De la guerrilla peronista al gobierno popular. Documentos 1970-1973, De la Campana, Buenos Aires, pp. 303-339 
-Tendencia Revolucionaria del Peronismo "Estrategia y Táctica Revolucionarias". Documento presentado en el Congreso del Peronismo Revolucionario en Córdoba. Cristianismo y Revolución $\mathrm{N}^{\circ}$ 12, marzo 1969.

\section{Documentos de inteligencia}

CPM - FONDO DIPPBA, División Central de Documentación, Registro y Archivo:

- Mesa “A” "Partidos políticos", Carpeta 37, Legajo N 271: JP Coronel Pringles; JP Coronel Rosales; JP La Plata; JP Quilmes; FREJULI; MNJ Órgano Superior

- Mesa "A" "Partidos políticos", La Plata 1 era. Movimiento Justicialista; JC del Movimiento Justicialista.

- Mesa “B”, Carpeta 4, Legajo N 27, folio 85, 89-90.

- Mesa "DS" "Renuncia Dr. Bidegain".

- Mesa “DS”, Varios, Legajo N 8774

- Mesa “DS”, Varios, Legajo N 851

- Mesa "Referencia". Legajo 16223 "Nómina de autoridades provinciales"

- Mesa “Referencia”, Legajo 16070, “Operativo Dorrego”, p. 44, p. 74-76, p.126, p. 221. P. 233-238

- Mesa "Referencia", Legajo 16071, p.165 - "Comunicado de la JP ante el cierre del Operativo Dorrego".

Documentos Lucha antisubversiva. Biblioteca Nacional Mariano Moreno (Argentina), Departamento de Archivos, Fondo Olegario Antonio Becerra (AR-BNMM-ARCH$\mathrm{OAB})$.

\section{Documentos de reparticiones gubernamentales:}

- "Dirección de Promoción y Presupuesto. Proyecto Comunitario". Ministerio de Bienestar Social. Mayo-octubre de 1973. Material cedido por Flora Castro

- "Ministerio de Bienestar Social. Subsecretaría de Salud Pública. Dirección de Atención Medica". Biblioteca Nacional Mariano Moreno (Argentina), Departamento de Archivos, Fondo Floreal Ferrara (AR-BNMM-ARCH-FF).

\section{Archivos, hemerotecas y centros de documentación consultados}


CPM-DIPPBA: Comisión Provincial por la Memoria- Fondo Dirección de Inteligencia de la Policía de la Provincia de Buenos Aires, División Central de Documentación, Registro y Archivo.

Hemeroteca de la Legislatura de la Provincia de Buenos Aires.

Hemeroteca de la Biblioteca Nacional, Mariano Moreno.

Hemeroteca de la Biblioteca Dardo Rocha, Universidad Nacional de La Plata.

El Topo Blindado, Centro de Documentación de las Organizaciones Político-Militares Argentinas. Archivo digital: http://eltopoblindado.com/

Ruinas Digitales, Archivo digital: http://www.ruinasdigitales.com/

\section{Documentos publicados:}

Baschetti, Roberto (1996), De la guerrilla peronista al gobierno popular. Documentos 1973-1976, Buenos Aires, Editorial De la Campana, Vol. I

Baschetti, Roberto (1997), De la guerrilla peronista al gobierno popular. Documentos 1970-1973, De la Campana, Buenos Aires Documentos 1970-1973, La Plata, Editorial De la Campana, Vol. I y II

Baschetti, Roberto (1998), Documentos de la Resistencia Peronista 1955-1970, Punto Sur, Buenos Aires.

Duhalde, Eduardo y Pérez, Eduardo. (2003), De Taco Ralo a la alternativa Independiente. Historia documental de las Fuerzas Armadas Peronistas y del Peronismo de Base, Tomo I, Bs As, Editorial De la Campana.

\section{Publicaciones periódicas consultadas}

\section{Diarios}

Clarín, 1973

Crónica, 1973

El Argentino, 1972

El Día, 1971-1974

La Gaceta, 1973

La Nación, 1973

La Opinión, 1972-1973

La Prensa, 1973

Noticias, 1973-1974 


\section{Revistas}

Alianza (1973)

Antropología 3er Mundo (1973)

Bases para un Programa Peronista de acción de gobierno (1973)

Controversia (1979-1981)

Cristianismo y Revolución (1966-1971)

El Caudillo de la Tercera Posición (1973-1974)

El Descamisado (1973-1974.

El Peronista (1974)

La causa peronista (1974)

Las Bases (1971-1972)

Militancia peronista para la liberación (1973-1974)

Nueva Plana (1972)

Primera Plana (1972)

Ya! Es tiempo del pueblo (1973)

\section{BIBLIOGRAFIA CITADA:}

-Abbattista, María Lucía (2019) Justicialismo y cultura en la Guerra Fría: El retorno de Oscar Ivanissevich al Ministerio de Cultura y Educación (Argentina 1974-1975) (Tesis de posgrado). - Presentada en Universidad Nacional de La Plata. Facultad de Humanidades y Ciencias de la Educación para optar al grado de Magíster en Historia y Memoria. Disponible en: http://www.memoria.fahce.unlp.edu.ar/tesis/te.1801/te.1801.pdf --(2014) "Que todos los chicos se metan, opinen, intervengan. Un estudio sobre El diario de los Chicos, publicado por el Ministerio de Cultura y Educación de la Argentina (1973-1974)", en VII Jornadas de Trabajo sobre Historia Reciente, Universidad Nacional de La Plata, La Plata.

-Abbattista, María Lucía y Ramírez, Ana Julia (2011) "Las tomas en la ciudad de La Plata. Aportes al estudio de la dinámica política durante el gobierno de Héctor Cámpora", ponencia presentada en las XIII Jornadas Interescuelas / Departamentos de Historia, Catamarca, 2011.

-Abbattista, María Lucía y Tocho, Fernanda (2012). El verano caliente del '74: La Tendencia Revolucionaria del peronismo entre la asunción de Perón y el aniversario del 
'triunfo popular'. VII Jornadas de Sociología de la UNLP, 5 al 7 de diciembre de 2012, La Plata, Argentina. Argentina en el escenario latinoamericano actual: Debates desde las ciencias sociales. EN: Actas. La Plata: UNLP-FAHCE. Disponible en: http://www.memoria.fahce.unlp.edu.ar/trab_eventos/ev.1658/ev.1658.pdf

-Acha, Omar (2010) "Dilemas de una violentología argentina: tiempos generacionales e ideologías en el debate sobre la historia reciente", en $V$ Jornadas de Trabajo sobre Historia Reciente, Universidad Nacional de General Sarmiento, Buenos Aires.

-Águila, Gabriela (2008) Dictadura, represión y sociedad en Rosario, 1976-1983. Bs. As., Prometeo.

(2015) "Las escalas de análisis en los estudios sobre el pasado reciente: a modo de introducción". Avances del Cesor12: 91-96.

-Águila, Gabriela; Santiago Garaño y Pablo Scatizza (coords.) (2016). Represión estatal y violencia paraestatal en la historia reciente argentina: Nuevos abordajes a 40 años del golpe de Estado. La Plata: UNLP-FAHCE (Estudios/Investigaciones; 57). Recuperado de: http :// www . libros . fahce . unlp . edu . ar / index . php / libros / catalog / book /63

-Altamirano, Carlos (2001) Bajo el signo de las masas, Bs As., Ariel.

(2001) Peronismo y Cultura de Izquierda. Bs. As. Temas Grupo

Editorial.

-Amaral, Samuel (2010). «Ezeiza, 20 de junio de 1973», en Todo es historia, Bs. As, $\mathrm{N}^{\circ} 518$, septiembre, pp. 6-21.

-Amaral, Samuel y Plotkin, Mariano (1993) Perón del exilio al poder. Bs As., Cántaro.

-Amato, Fernando y Boyanovsky Bazán, Christian. (2008) Setentistas. De La Plata a la Casa Rosada, Bs. As., Sudamericana.

-Amorín, José (2005) Montoneros, la buena historia, Bs. As., Editorial Catálogos.

-Anchou, Ángeles (2007). "De marxistas a peronistas: los militantes del FEN y la conformación de la OUTG". Actas de las XI Jornadas Interescuelas/Departamentos de Historia. Departamento de Historia. Facultad de Filosofia y Letras. Universidad de Tucumán, San Miguel de Tucumán.

-Anchou, Ángeles (2012) “'Compañera, ¿cómo hago para volver a Jujuy? ': testimonios de ex militantes del Frente Principal de la Juventud Peronista "Trasvasamiento Generacional" sobre la movilización a Ezeiza por el segundo retorno de Juan Perón - 20 de junio 1973”. Actas del Tercer Congreso de Estudios sobre el Peronismo (1943-2012)- 
Red de Estudios sobre el Peronismo- Universidad Nacional de Jujuy 18-19-20 octubre 2012.

-Anguita, Eduardo y Caparrós, Martín (2007 [1998]). La Voluntad. Bs. As. Planeta.

-Antúnez, Damián (2015) Caras extrañas. La Tendencia Revolucionaria del Peronismo en los gobiernos provinciales (Buenos Aires, Córdoba, Mendoza, Santa Cruz y Salta, 1973-1974). Bs.As. Prohistoria

(2015) "El peronismo en los municipios bonaerenses de 1973-1976".

Coordenadas, II (1), 84-121

-Anzorena, Oscar (1998) Tiempo de violencia y utopía. 1966-1976., Bs. As, Ediciones del Pensamiento Nacional.

-Arrúa, Néstor (2014) "Floreal Ferrara: itinerario intelectual, política y docencia universitaria entre 1957 - 1975”, en revista Escenarios, FTS/UNLP, La Plata, No 21.

-Asuaje, Pastor (2004) Por algo habrá sido. El futbol, el amor y la guerra. Buenos Aires, Nuestra América

-Barba, Fernando y Demaría, María Elena (1987) La Provincia de Buenos Aires 19101987, La Plata, Archivo Histórico de la Provincia de Buenos Aires.

-Barletta, Ana María, director. (2010) La política y sus formas. Argentina 1973-1976 / H542. (Proyecto de investigación). UNLP. FaHCE. Centro de Investigaciones Socio Históricas.

-Barletta, Ana María (2018) "Apuntes sobre un legado invisibilizado: Universidad y peronismo en la UNLP, 19721974" en Colección Nuevas Bases Para La Reforma Universitaria. Volumen 4. IEC-CONADU. Recuperado de: http :// iec . conadu . org . ar / files / publicaciones /1540404666_ la plata -1972-1974. pdf

-Barletta, Ana, Lenci, Laura y Ramírez, Ana Julia (2013) "Democracias en pugna: un intento de recuperar los sentidos perdidos", Cuestiones de Sociología, N 9, La Plata.

-Barletta, Ana y Lenci, M. Laura (2000) "Politización de las ciencias sociales en Argentina. El caso de la revista Antropología 3er. Mundo", en la sección "Dossier: Revistas de la Nueva Izquierda" en la Revista Sociohistórica. Cuadernos del CISH, Facultad de Humanidades y Ciencias de la Educación, UNLP, $\mathrm{N}^{\circ} 8$.

-Barletta, Ana y Cernadas, Jorge (2006) "Argentina, 1973-1976: de la "Democracia Integrada" al Terrorismo de Estado", en Revista Matériaux pour l'histoire de notre temps, Bibliothéque de Documentation internationale contemporaine, Université de Nanterre, París, Francia, № 81 Enero-Marzo. 
-Bartoletti, Julieta (2011) Montoneros: De la movilización a la Organización. Rosario, Laborde Libros.

-Baschetti, Roberto (2005) Oscar Bidegain. Cronología de un patriota. Disponible en: http://www.robertobaschetti.com/pdf/OSCAR\%20BIDEGAIN.pdf

-Baschetti, Roberto (s/F) Biografias del Peronismo Revolucionario: Floreal Ferrara Disponible en: http://www.robertobaschetti.com/pdf/biografial

-Bernetti, Jorge Luis (1983) El peronismo de la victoria. Bs. As., Legasa.

-Besoky, Juan Luis (2011) "Hacia la convergencia cívico-militar: el operativo Dorrego". Ponencia presentada en lasIX Jornadas de Sociología de la UBA, Buenos Aires, 2011.

(2012). Adiós Juventud...: Juan Domingo Perón y el fin de la

Tendencia Revolucionaria. VII Jornadas de Sociología de la UNLP, 5 al 7 de diciembre de 2012, La Plata, Argentina. Argentina en el escenario latinoamericano actual: Debates desde las ciencias sociales. EN: [Actas]. La Plata: UNLP-FAHCE.

(2016). La derecha peronista: Prácticas politicas y representaciones (1943-1976). Tesis de posgrado. Presentada en Universidad Nacional de La Plata. Facultad de Humanidades y Ciencias de la Educación para optar al grado de Magíster en Historia y Memoria. Disponible en: h $\mathrm{t} \mathrm{t}$ : // w w w . m e m o ria .f a h c e . u nlp . e d u . $\mathrm{ar} / \mathrm{t}$ e sis / t e $1280 / \mathrm{te} .1280$. p d f

-Bohoslavsky, Ernesto y Germán Soprano (2010) "Una evaluación y propuestas para el estudio del Estado en la Argentina” en Bohoslavsky, Ernesto y Germán Soprano (comp.). Un Estado con rostro humano. Funcionarios e instituciones estatales en Argentina (de 1880 a la actualidad). Buenos Aires: UNGS y Prometeo Libros.

-Bonasso, Miguel (1997) El presidente que no fue. Los archivos secretos del peronismo. Bs.As. Planeta.

(2000) Diario de un clandestino. Buenos Aires: Planeta.

-Bonavena, Pablo (1998) Orígenes y desarrollo de la guerra civil en la Argentina (19661976). Bs.As. Eudeba.

(2009) “Guerra contra el campo popular en los '70: Juan Domingo Perón, la depuración ideológica y la ofensiva contra los gobernadores" en Izaguirre, Inés Lucha de clases, guerra civil y genocidio en la Argentina 1973-1983, Bs. As, Eudeba.

-Bozza, Juan A. (1999) “Las artes del asedio y la negociación. Perón y el lanzamiento del Frente Cívico de Liberación Nacional”, en Pucciarelli, Alfredo (ed.), La primacía de la política. Lanusse, Perón y la Nueva Izquierda en tiempos del GAN, Buenos Aires, Eudeba 
(2001) "El peronismo revolucionario. Itinerario y vertientes de la radicalización, 1959-1969”, Revista Sociohistórica. Cuadernos del CISH N 9-10

(2006) "El peronismo revolucionario. Corrientes y experiencias en la radicalización sindical (1958-1969). En Cuestiones de Sociología $\mathrm{N}^{\circ} 3$.

-Bustingorry, Horacio (2015) Oscar Bidegain. La fugaz experiencia del Pacto Social en la provincia de Buenos Aires. La Plata. Publicaciones del Archivo Histórico de la Provincia de Buenos Aires

-Calveiro, Pilar (2005) Política y/o violencia. Una aproximación a la guerrilla de los años 70, Bs. As, Editorial Norma.

-Camarero, Hernán, Pozzi, Pablo y Schneider, Alejandro (2000) De la Revolución Libertadora al menemismo. Historia social y política argentina. Bs. As. Imago Mundi.

-Campos, Esteban (2009) “¿Es posible una memoria completa? Acerca de olvidos y reacciones conservadoras en la narrativa histórica de los '60/'70 (2006-2009)", en Revista Afuera. Estudios de crítica cultural, Año IV, n.7 (noviembre de 2009). Disponible en: http://www.revistaafuera.com/NumAnteriores/pagina.php?seccion=Articulos\&page=07. Articulos.Campos. htm\&idautor $=151$

(2012) “'Venceremos en un año o venceremos en diez, pero venceremos“. La organización Descamisados: entre la Democracia Cristiana, el peronismo revolucionario y la lucha armada" PolHis. Revista del Programa Interuniversitario de Historia Politica, Buenos Aires. Volumen $\mathrm{N}^{\mathrm{o}}$ 10, segundo semestre 2012, pp. 133-145

(2012) "Una crítica a la ideología de la "memoria completa", a propósito de Juan Bautista Yofre y la narrativa histórica en 'Volver a matar'". Primeras Jornadas de la Revista Conflicto Social - 27 y 28 de octubre de 2012 (2016) Cristianismo y revolución. El origen de Montoneros

Violencia, politica y religión en los 60 . Edhasa.

-Camelli, Eva (2013) Politicidad villera. El Movimiento Villero Peronista, 1973-1976, Tesis de Doctorado, Facultad de Ciencias Sociales, UBA.

-Camelli, Eva (2018) "Revolución y socialismo nacional en las villas setentistas de Buenos Aires: expropiación de tierras, radicación de villas y empresa popular”. Revista Encuentros Uruguayos Volumen XI, Número 1, julio 2018 pp.: 45 - 58

-Carnagui, Juan Luis (2016) Nacionalistas, católicos y peronistas. Auge, afianzamiento y reconfiguración de la Concentración Nacional Universitaria (CNU) La Plata, 1955 - 
1974. Tesis de doctorado en Historia. FAHCEUNLP. En Memoria Académica. Recuperado de: http :// www . memoria . fahce . unlp . edu . ar / tesis / te .1255/ te .1255 . pdf

-Carnovale, Vera (2007) “Aportes y problemas de los testimonios en la reconstrucción del pasado reciente en la Argentina", en Franco, M. y Levín, F. Historia Reciente, Bs. As. Paidós.

(2011) Los Combatientes. Historia del PRT-ERP, Bs. As. Siglo XIX.

-Castro, Flora y Salas, Ernesto (2011) Norberto Habegger. Cristiano, Descamisado, Montonero. Bs. As. Colihue.

-Casullo, Nicolás (2008) Peronismo. Militancia y crítica (1973-2008). Bs. As. Colihue.

-Cavarozzi, Marcelo (1983) Autoritarismo y democracia (1955-19796). Bs As. CEAL.

-Caviasca, Guillermo (2009) Dos caminos, PRT-ERP y Montoneros en los setenta, Bs. As., Editorial cooperativa El río suena.

(2011) "La cuestión militar y las organizaciones guerrilleras argentinas" Cuadernos de Marte. Revista latinoamericana de sociología de la guerra. Año I, Nro. 2 octubre.

(2017) La hipótesis Carcagno. Militares y guerrilleros en los setenta.

Bs.As. Punto de Encuentro.

-Celesia F. y Waisberg, P. (2010) Firmenich. La historia jamás contada del jefe montonero. Aguilar.

-Cersósimo, Facundo (2008) Envar El Kadri. Historias del peronismo revolucionario. Buenos Aires: Ediciones Colihue.

-Chama, Mauricio (2016). Compromiso político y labor profesional: Estudios sobre psicólogos y abogados en los primeros setenta. Ensenada: UNLP. FaHCE. (Entre los libros de la buena memoria ; 4) Disponible en: http://www.memoria.fahce.unlp.edu.ar/libros/pm.407/pm.407.pdf

-Chama, Mauricio y González Canosa, Mora (2011) “Universidad, política y movimiento estudiantil: la Intervención de Kestelboim y el rol de la Juventud Universitaria Peronista en la Facultad de Derecho de la UBA (1973-1974)", en Revista Conflicto Social, Instituto de Investigaciones Gino Germani, FSC / UBA. Volumen Nº 5, junio 2011.

-Cháves, Gonzalo y Lewinger, Jorge (1998), Los del 73. Memoria Montonera, De la Campana. 
-Confino, Hernán (2018) La Contraofensiva Estratégica de Montoneros. Entre el exilio y la militancia revolucionaria (1976-1980). Tesis de Doctorado-Universidad Nacional de General San Martín

-Cucchetti, Humberto (2010) Combatientes de Perón, herederos de Cristo. Peronismo, religión secular y organizaciones de cuadros. Buenos Aires, Prometeo.

-D’Antonio, Débora (2016) La prisión en los años 70. Historia, género y política. Bs.As. Biblos.

-Dalla Corte, G. y Fernández, S. (2001). Lugares para la Historia. Espacio, Historia Regional e Historia local en los estudios contemporáneos, UNR, Rosario.

-De Amézola, Gonzalo (1999) "El caso del realismo insuficiente. Lanusse, La Hora del Pueblo y el Gran Acuerdo Nacional", en Pucciarelli, Alfredo (edit.). La primacía de la política. Lanusse, Perón y la Nueva Izquierda en tiempos del GAN, Buenos Aires, Eudeba

-De Marinis, Hugo y abalo Ramón (2005) Mendoza Montonera. Memorias y sucesos durante el gobierno de Martínez Baca. Bs.As. Corregidor

-Denaday, Juan Pedro (2018) No todo fue violencia: un think tank en el retorno de Perón. El caso del Consejo de Planificación del Movimiento Nacional Justicialista (19701973). Tesis de Maestría, Posgrados en Historia, Departamento de Estudios Históricos y Sociales, Universidad Torcuato Di Tella. Recuperado de: https :// repositorio . utdt . edu / bitstream / handle / utdt /11053/ MHIS _2018_ Denaday . pdf ? sequence $=1 \&$ isAllowed $=\mathrm{y}$

-De Riz, Liliana (1981) Retorno y Derrumbe. Bs. As., Hyspamerica. (2000) La política en suspenso: 1966-1976. Bs. As., Paidós.

- Diana, Marta (2013) Buscando el Reino. La opción por los pobres de los argentinos que siguieron al Concilio Vaticano II, Planeta.

-Díaz, Gabriel y Vega, Sergio (2009) “Operativo Dorrego (1973). La institucionalidad fallida" en Voces recobradas. Revista de Historia Oral (27), pp. 26-37.

-Dip, Nicolás (2017) Libros y alpargatas: la peronización de estudiantes, docentes e intelectuales de la UBA (1966-1974). Rosario: Prohistoria.

-Di Tella, Guido (1983) Perón-Perón. Bs.As., Sudamericana.

-Duzdevich, Aldo, Raffoul, Norberto y Beltramini, Rodolfo (2015) La Lealtad. Los Montoneros que se quedaron con Perón. Bs. As. Sudamericana.

-Esquivada, Gabriela (2009). Noticias de los Montoneros. La historia del diario que no pudo anunciar la revolución. Buenos Aires: Sudamericana. 
-Ferrara, Floreal (1965) "En torno al concepto de salud” en Revista de Salud Pública, La Plata, $\mathrm{N}^{\mathrm{o}} 8$.

-Ferrara, F.; Acebal, E.; Paganini, J. (1976) Medicina de la comunidad. Buenos Aires. Intermédica, ( $1^{\text {o }}$ edición 1971)-Ferrari, Marcela y Pozzoni, Mariana (2008) "La legislatura bonaerense (1973-1974): otro espacio de conflicto entre la derecha y la izquierda peronistas". Actas de las V Jornadas de Sociología de la UNLP.

(2009) "De la interna a la legislatura: los enfrentamientos en el peronismo bonaerense ,1973-1976”. Actas de las XII Jornadas InterescuelasDepartamentos de Historia, San Carlos de Bariloche.

-Flaskamp, Carlos (2002) Organizaciones político-militares. Testimonio de la lucha armada en la Argentina (1968-1976), Ed. Nuevos Tiempos, Bs. As.

-Fraga, Rosendo (1988) Ejército: del escarnio al poder (1973-1976). Buenos Aires, Planeta,

-Franco, Marina (2005) "Reflexiones sobre la historiografía argentina y la historia reciente de los años '70”, Nuevo Topo. Revista de Historia y Pensamiento Crítico, $\mathrm{n}^{\mathrm{o}} 1$. (2012) Un enemigo para la nación. Orden, violencia y "subversión”. 1973-1976. Bs.As. FCE

-Franco, Marina y Lvovich, Daniel, "Historia Reciente: apuntes sobre un campo de investigación en expansión” en Boletín del Instituto de Historia Argentina y Americana “Dr. Emilio Ravignani” N47, 2017.

-Friedemann (2015) "La Universidad Nacional y Popular de Buenos Aires (1973-1974). Una reforma universitaria inconclusa". Tesis doctoral. Facultad de Ciencias Sociales, Universidad de Buenos Aires.

(2017) "De las Cátedras Nacionales (1967-1971) a la Universidad Nacional y Popular de Buenos Aires (1973-1974). Experiencias configuradoras de institucionalidad universitaria". Sociohistorica, 39, e026. https://doi.org/10.24215/18521606e026

-Friedemann (2020) "Peronismo y sectores medios. Del "gabinete montonero" a la Universidad de Buenos Aires (1973-1974)”. Páginas. Revista digital de la Escuela de Historia de la Facultad de Humanidades y Artes - Universidad Nacional de Rosario. Vol $13, \mathrm{~N}^{\circ} 31$ (en prensa)

-Gallo Mendoza, Guillermo (2010) La marcha al campo. Propuestas para contribuir a superar la desocupación estructural, Bs. As., Fundación Patagonia Tercer Milenio.

-Garaño, Santiago y Werner, Pertot (2007) Detenidos Aparecidos. Presas y presos políticos desde Trelew a la dictadura. Bs.As. Editorial Biblos 
-Gasparini, Juan (1999). Montoneros. Final de cuentas. Editorial De La Campana

-Gil, Germán ([1989] 2018) La izquierda peronista. Transitando los bordes de la revolución (1955-1974). Bs.As. Prometeo

-Gillespie, Richard (1987) Soldados de Perón. Los Montoneros, Grijalbo.

-Gilman, Claudia (2012) Entre la pluma y el fusil, debates y dilemas del escritor revolucionario en América Latina, Buenos Aires, Editorial Siglo XXI, 2012.

-Giorgi, Guido (2014-2015), "En los pliegues de la planificación del Onganiato: el comunitarismo como política estatal”, en Anuario IEHS, No 29 y 30, pp.159-175.

-Giorgi, Guido y Mallimacci, Fortunato (2012), "Catolicismos, nacionalismos y comunitarismos en política social. Redes católicas en la creación del Ministerio de Bienestar Social de Argentina (1966-1970)", en Cultura y Religión, Vol.1, Nº 6, Iquique, pp. 113-144

-Godio, Julio (1986) Regreso, soledad y muerte, Bs. As, Hyspamerica.

-González Canosa, Mora (2013) Las Fuerzas Armadas Revolucionarias. Orígenes y desarrollo de una particular conjunción entre marxismo, peronismo y lucha armada (1960-1973). Tesis de Doctorado. Doctorado en Ciencias Sociales. Universidad de La Plata, La Plata, 2013a. Disponible en: http://www.memoria.fahce.unlp.edu.ar/tesis/te.808/te.808.pdf

(2014). "Las "Organizaciones Armadas Peronistas" [OAP]: Un análisis comparativo de los [re] posicionamientos de las FAR". En: Tortti, María Cristina; Chama, Mauricio; Celentano, Adrián, Dir. La nueva izquierda argentina (1955-1976): Socialismo, Peronismo y Revolución, Rosario Prohistoria.

(2017) "Libres o muertos, jamás esclavos". Marxismo, peronismo y lucha armada: las Fuerzas Armadas Revolucionarias en la Argentina de los primeros setenta (En línea). Tempo e Argumento, 9(22): 364-395. Disponible en: http://www.memoria.fahce.unlp.edu.ar/art_revistas/pr.8993/pr.8993.pdf -(2018) “¿Democracia y/o Revolución? Las Fuerzas Armadas Revolucionarias frente a la coyuntura electoral: los comicios, la revolución y la lógica instrumental (Argentina, 1972-1973)" (En línea). Izquierdas, (38): 164-189. Disponible en: http://www.memoria.fahce.unlp.edu.ar/art_revistas/pr.8952/pr.8952.pdf

-González Canosa, Mora y Tocho, Fernanda (2018) “Introducción”. Dossier: Más allá de Montoneros: los otros peronismos revolucionarios de los setenta. En historiapolitica.com. ISSN sección Dossier 2618-415x 
-Gordillo, Mónica (2001) Actores, prácticas, discursos en la Córdoba combativa: una aproximación a la cultura política de los '70. Córdoba, Ferreyra Editor.

(2003) "Protesta, rebelión, movilización: de La resistencia a La Lucha armada, 1955- 1973" en: James, Daniel (Dir.). Violencia, Proscripción y Autoritarismo. Colección Nueva Historia Argentina, Tomo IX, Sudamericana, Bs. As, 2003

-Grammático, Karin (2011) Mujeres montoneras. Una historia de la Agrupación Evita, 1973-1974, Buenos Aires: Ediciones Luxemburg.

-Grassi, Ricardo (2015). Periodismo sin aliento. La revista que cubrió el conflicto y la ruptura de Perón con Montoneros. Buenos Aires: Sudamericana.

-Grimson, Alejandro (2018) ¿Qué es el peronismo? de Perón a los Kirchner, el movimiento que no deja de conmover la política argentina. Bs.As. Siglo XXI

-Guglielmucci, Ana (2011) “Compromiso y técnica en la configuración del campo laboral de los derechos humanos en el gobierno de la ciudad de Buenos Aires". Revista del Museo de Antropologia, № 4.

-Gurucharri, Eduardo (2001) Un militar entre obreros y guerrilleros. Buenos Aires. Colihue.

-Horowicz, Alejandro (2005) Los cuatro peronismos. Bs.As. Edhasa

-Ierace, V. (2013) "El Sistema Nacional Integrado de Salud, hacia una revalorización". Epidemiología y Salud, Vol 1, p. 31-34.

-Itzcovitz, Victoria (1985) Estilo de gobierno y crisis política (1973-1976). Bs. As. CEAL

-Izaguirre, Inés (2009) Lucha de clases, guerra civil y genocidio en la Argentina 19731983, Bs. As, Eudeba.

-James, Daniel (1990) Resistenciae Integración. El peronismo y la clase trabajadora argentina. 1946-1976, Bs. As. Sudamericana.

(DIR) (2003) Violencia, proscripción y autoritarismo (1955-1976), Tomo IX

Colección Nueva Historia Argentina, Bs. As., Sudamericana.

-Jauretche, Ernesto (1997) No dejes que te la cuenten. Violencia y política en los 70.

Colihue.

-Jelin, Elizabeth (2002) Los trabajos de la memoria, Madrid, Siglo XXI. 
-Jasinski, Alejandro (2011) Entre el alternativismo y el movimientismo. Disidencias en Montoneros y las FAP ante la apertura electoral en los primeros años setenta.

-Ladeuix, Juan Iván (2006) “Entre la institución y la práctica. La normalización y las candidaturas del Partido Justicialista en la provincia de Buenos Aires, 1972 - 1973”. Jornadas II "La politica en Buenos Aires. Siglo XX. Centro de Estudios de Historia Política (USAM), Ciudad de Buenos Aires, 22 y 23 de junio de 2006.

- (2014) Perón o muerte en la aldea. Las formas de la violencia política en espacios locales del interior bonaerense. 1973 - 1976. Tesis de Doctorado en Historia. Universidad Nacional de Mar del Plata. Facultad de Humanidades -Lanteri, Magdalena (2009) "Los pasos previos". El largo proceso de conformación de la JUP en la Universidad Nacional de La Plata (1960-1973). XII Jornadas Interescuelas/Departamentos de Historia. Universidad Nacional del Comahue, San Carlos de Bariloche.

-Lanteri, Magdalena y Talia Meschiany (2015). "Bases para la nueva Universidad. La UNLP entre 1973 y 1976”. Ponencia presentada en XI Jornadas de Sociología. Facultad de Ciencias Sociales, Universidad de Buenos Aires. Disponible en: http :// cdsa . aacademica . org /000-061/922. pdf

-Lanusse, Lucas (2005) Montoneros. El mito de sus 12 fundadores, Bs. As., Vergara. (2007) “Caer y volver a levantarse. La situación de Montoneros entre fines de 1970 y comienzos de 1972”. Jornada Académica: Partidos armados en la Argentina de los setenta. UNSAM- Disponible en http:/historiapolitica.com/datos/biblioteca/lanusse j.pdf

-Lapolla, Alberto (2005) Kronos: Historia de las luchas y organizaciones revolucionarias de los años setenta. Volumen II: La esperanza rota (1972-1974). La Plata, de la Campana.

-Larraquy, M. y Caballero, R. (2000) Galimberti. De Perón a Susana, de Montoneros a la CIA, Bs. As., Aguilar.

-Lenci, María Laura (1998) “La radicalización de los católicos en la Argentina. Peronista, cristianismo y revolución (1966-1971), en Revista Sociohistórica. Cuadernos del CISH, N 4. La Plata: FAHCE - Editorial Al Margen.

(1999) “Cámpora al gobierno, Perón al poder. La tendencia revolucionaria del peronismo ante las elecciones del 11 de marzo de 1973" En: Pucciarelli, Alfredo (editor) La primacía de la política: Lanusse, Perón y la nueva izquierda en tiempos del GAN. Bs. As. Eudeba. 
(2014) "Violencia, política y terrorismo de Estado (1955-1983)" en Barreneche, Osvaldo. Historia de la provincia de Buenos Aires, Tomo 5: del primer peronismo a la crisis de 2001. Buenos Aires: Edhasa; Gonnet: UNIPE: Editorial universitaria, Pp. 209-236.

-Lenci, Laura y Malacalza, Laurana (2009) “Una mirada desde el género a los motines en las cárceles de la provincia de Buenos Aires en el año 1973”. Ponencia presentada en las XIII Jornadas Interescuelas. Departamentos de Historia. San Carlos de Bariloche.

-Licastro, Julián (2004) Mi encuentro con Perón. Memorias e ideales. Bs.As. Lumiere.

-Lorenz, Federico (2007) Los zapatos de 'Carlito'. Una historia de los trabajadores navales de Tigre en la década del setenta, Bs. As., Grupo Editorial Norma.

(2013) Algo parecido a la felicidad. Una historia de la lucha de la clase trabajadora durante la década del setenta (1973-1978), Buenos Aires, Edhasa.

-Maceyra, Horacio (2004) Cámpora, Perón, Isabel, Bs. As., Editores de América Latina.

-Manzano Valeria (2017) La era de la juventud en Argentina. Cultura, política y sexualidad desde Perón hasta Videla. Buenos Aires: Fondo de Cultura Económica.

-Marchesi, Aldo (2019) Hacer la revolución. Guerrillas latinoamericanas de los 60 a la caída del muro. Bs.As. Siglo XXI

-Marengo, María Eugenia (2015). Lo aparente como real: Un análisis del sujeto "comunista" en la creación y consolidación del servicio de inteligencia de la policía de la Provincia de Buenos Aires (1930-1962). La Plata: Universidad Nacional de La Plata. Facultad de Humanidades y Ciencias de la Educación. Disponible en: http://www.memoria.fahce.unlp.edu.ar/libros/pm.374/pm.374.pdf

-Marín, Juan Carlos (1996) Los hechos armados, Argentina 1973-76. La acumulación primitiva del genocidio. Bs.As. La Rosa Blindada/ P.I.CA.SO.

-Melón Pirro, Julio César (2009) El peronismo después del peronismo. Resistencia, sindicalismo y política luego del 55, Bs. As., S. XXI.

-Merele, Hernán (2017). La depuración ideológica del peronismo en General Sarmiento, 1973-1974: Una aproximación al proceso represivo durante los años setenta constitucionales a partir del caso de Antonio Tito Deleroni. La Plata: Universidad Nacional de La Plata. Facultad de Humanidades y Ciencias de la Educación; Posadas: Universidad Nacional de Misiones; Los Polvorines: Universidad Nacional de General Sarmiento. (Entre los libros de la buena memoria ; 8) Recuperado de http://libros.fahce.unlp.edu.ar/index.php/libros/catalog/book 
(2016) "El Germen genera sus propios anticuerpos". La "depuración" interna peronista y el proceso represivo entre 1973-1976.En Gabriela Aguila Dossier. Represión estatal y paraestatal en la historia reciente argentina. Disponible en: http://www.historiapolitica.com/datos/biblioteca/represionestatal_merele.pdf

-Mingrone, Luciana (2010) "Pelearle a María. Disidencias en Montoneros (19721976)", ponencia presentada al Segundo congreso de Estudios sobre el peronismo (1943-1976), Tres de Febrero. Disponible en http://redesperonismo.com.ar/archivos/CD2/Mingrone.pdf

-Monasterolo, E., y Pittaluga, R. (Eds.) (2017). Formas de la política. Experiencias de activismo en el pasado reciente. Argentina (1969-2010). Santa Rosa, EdUNLPam. Disponible en http://www.unlpam.edu.ar/images/extension/edunlpam/QuedateEnCasa/formas-de-lapolitica.pdf

-Nava, Agustín (2008) “El gobierno de Bidegain 1973-1974. Crónica de una caída anunciada". Actas de las V Jornadas de Sociología de la UNLP.

-Nahmías, Gustavo (2013) La batalla peronista. De la unidad imposible a la violencia política, 1969-1973, Buenos Aires, Edhasa.

-Nercesián, Inés (2014) “La izquierda peronista y los gobiernos nacionalistas de la región”. En: Tortti, C., Chama, M. y Celentano, A. (coord.) La Nueva Izquierda argentina (1955-1976). Socialismo, peronismo y revolución. Prohistoria.

-Nievas, Flabián (1999). “Cámpora: primavera-otoño. Las tomas”. En A. Pucciarelli (editor), La primacía de la política. Lanusse, Perón y la Nueva Izquierda en tiempos del GAN (págs. 351-393). Buenos Aires: EUDEBA.

-Noguera, Ana (2013). "La participación de las mujeres en la lucha armada durante los tempranos setenta. Córdoba. 1970-1973”, Taller (Segunda Época), Revista de Sociedad, Cultura y Política en América Latina, 2, 2, pp. 10-23.

-Oberti, Alejandra (2015), Las revolucionarias. Militancia, vida cotidiana y afectividad en los setenta. Buenos Aires: Edhasa.

-Oberti, Alejandra y Pittaluga, Roberto (2006), Memorias en montaje. Escrituras de la militancia y pensamientos sobre la historia, Buenos Aires: El cielo por Asalto.

-O’Donnell, Guillermo (1977) "Estado y Alianzas en la Argentina, 1956-14976”, Desarrollo Económico, № 64, (enero-marzo), pp. 523-554.

(1972) Modernización y Autoritarismo. Bs.As. Paidós. 
crisis. Bs. As. Paidós.

-Ollier, María Matilde (1986), El fenómeno insurreccional y la cultura política. 19691973, CEAL, Bs. As.

(1989) Orden, poder y violencia (1968-1973), CEAL, Bs. As.

-Osuna, Florencia (2017) "El Ministerio de Bienestar Social entre el onganiato y la última dictadura (1966-1983). Análisis de la estrategia de intervención social del Estado en la historia argentina reciente", Estudios Sociales del Estado - volumen 3, número 6, pp. 41 a 65, segundo semestre de 2017 - ISSN: 2422-7803

-Osuna, Florencia y Vicente, Martín (2017) "Estudios sobre Ministerios. Actores, políticas y problemas de abordaje entre el primer peronismo y la última dictadura" en Estudios Sociales del Estado - volumen 3, número 6, pp. 1 a 10, segundo semestre de 2017 - ISSN: 2422-7803

-Pacheco, Julieta (2014) "Montoneros a la luz de su programa". Revista THEOMAI Estudios críticos sobre Sociedad y Desarrollo. № 29, primer semestre, 2014.

-Page, Josepth (2000) Perón. Una biografía. Buenos Aires: Sudamericana.

-Pastoriza, L. (2006) «La «traición» de Roberto Quieto. Treinta años de silencio». En: Revista Lucha Armada, No 6. Buenos Aires.

-Perdía, Roberto (1997) La otra historia. Testimonio de un jefe montonero, Bs.As. Grupo Ágora.

-Perelmiter, Luisina (2016) Burocracia plebeya. La trastienda de la asistencia social en el Estado argentino. San Martín: Universidad Nacional de San Martín.

-Peyrou, Alejandro (2010) "Lealtad”. Anuario Lucha Armada en la Argentina, Año 5, Buenos Aires.

-Pis Diez, Nayla (2018) Universidad, política y radicalización en el posperonismo: el caso de la Universidad Nacional de La Plata y su movimiento estudiantil reformista (1955-1966) (Tesis de posgrado). - Presentada en Universidad Nacional de La Plata. Facultad de Humanidades y Ciencias de la Educación para optar al grado de Doctora en Ciencias Sociales. Disponible en: http://www.memoria.fahce.unlp.edu.ar/tesis/te.1678/te.1678.pdf

-Pis Diez, Nayla y Robles, Horacio (2018). "El movimiento juvenil platense entre la radicalización política y la represión estatal: el impacto de la Revolución Cubana y el plan Conintes en la Juventud Peronista y el reformismo de izquierda (1959-1962)". X Jornadas de Sociología de la UNLP, 5 al 7 de diciembre de 2018, Ensenada, Argentina. 
EN: Actas. Ensenada: Universidad Nacional de La Plata. Facultad de Humanidades y Ciencias de la Educación. Departamento de Sociología. Disponible en: http://www.memoria.fahce.unlp.edu.ar/trab_eventos/ev.11695/ev.11695.pdf

-Portantiero, Juan Carlos (1977), "Economía y política en la crisis argentina”, Revista Mexicana de Sociología, Vol. 38:21, abril-junio, págs. 531-565.

-Portelli, Alessandro (1991). "Lo que hace diferente a la historia oral". En: Sschwarztein, Dora, William Moss, Alessandro Portelli, Ronald Fraser y otros. La historia oral. Buenos Aires: CEAL, pp. 36-53.

(2005). "El uso de la entrevista en Historia Oral". Anuario 20(2003-2004). Rosario: Escuela de Historia, Facultad de Humanidades y Artes, Universidad Nacional de Rosario.

-Poupeau, F. (2007) "El capital militante. Intento de definición”, en Poupeau, F., Dominación y movilizaciones. Estudios sociológicos sobre el capital militante y el capital escolar, Ferreyra Editor, Córdoba, pp. 37-44.

-Pozzoni, Mariana (2014) Proyectos, ideas y prácticas políticas de las juventudes peronistas de izquierda en el contexto de la cultura política argentina. Provincia de Buenos Aires, c. 1970- 1976. Tesis de Doctorado, Universidad Nacional de Mar del Plata. (2015a) "La participación político-técnica de la izquierda peronista en el ministerio de educación bonaerense (1973-1974)". En ESTUDIOS - No 34 (Juliodiciembre 2015) pp. 119-137

-(2015b) "Los orígenes de la Juventud Peronista Lealtad: los "soldados de Perón” (1973- 19749)"Cuadernos del CLAEH, Montevideo, №101, 2015, pp. 33-61

(2017) Leales. De la Tendencia Revolucionaria a la Juventud Peronista

Lealtad. Bs. As. Imago Mundi.

-Pozzi, Pablo y Schneider, Alejandro (2000). Los setentistas. Izquierda y clase obrera. 1969-1976. Bs. As. Eudeba.

-Pozzi, Pablo (2006) "Para continuar con la polémica sobre la lucha armada" en Revista Lucha Armada, $\mathrm{N}^{\mathrm{0}}$ 5, febrero/abril.

-Pucciarelli, Alfredo (comp.), (1999) La primacía de la política. Lanusse, Perón y la Nueva izquierda en tiempos del GAN, Bs. As., Eudeba

-Raimundo, Marcelo (2004), "Izquierda peronista, clase obrera y violencia armada: Una experiencia alternativa”, en Sociohistórica, No 15-16.

-Ramacciotti Karina (2014) "Políticas sanitarias, desarrollo y comunidad en la Argentina de los años sesenta” Rev. Ciencias de la Salud. 2014;12(1):93-113. 
-Ramírez, Ana Julia (2019) “A 50 años del Cordobazo... Pensar las "puebladas” en la Argentina de los años setenta". Aletheia, 9(18), e003. https://doi.org/10.24215/18521606e003

-Ramírez, Ana Julia y Viguera, Aníbal (2006) "La protestation sociale dans les trois dernières décennies du XXe. Siècle”, en Revista Matériaux pour l' histoire de notre temps, Bibliothèque de Documentation Internationale Contemporaine, Université de Nanterre, Francia, № 81 (ISSN 0769 - 3206), enero-marzo

-Reato, Ceferino (2008) Operación Traviata. ¿Quién mató a Rucci? La verdadera historia. Bs. As. Sudamericana.

-Robles, Horacio (2009) “La Plata en las vísperas montoneras: una reconstrucción de las condiciones sociales y políticas de la masificación y radicalización política de la JP platense y su articulación con Montoneros (1970-72)". Cuestiones de sociología, 5/6, 339-367.

- (2011) Radicalización política y sectores populares en la Argentina de los '70. La Juventud Peronista (JP) y su articulación con Montoneros en los barrios periféricos de la ciudad de La Plata. Tesis de Maestría en Ciencias Sociales, FaHCE, UNLP, La Plata. Disponible en línea en: http:/www.memoria.fahce.unlp.edu.ar/tesis/te.437/te.437.pdf

(2014a) "Desamparo y responsabilidad política: La conformación de la Juventud Peronista (JP) platense entre 1955-1958". VIII Jornadas de Sociología de la UNLP, 3 al 5 de diciembre de 2014, Ensenada, Argentina. EN: Actas. La Plata: UNLP. FAHCE. Departamento de Sociología.

(2014b). "La retaguardia revolucionaria: Una descripción de la estructura de unidades básicas controlada por la juventud peronista y Montoneros en los barrios populares de la ciudad de La Plata [1972-1974]”. EN: Tortti, María Cristina; Chama, Mauricio; Celentano, Adrián, dir. La nueva izquierda argentina [1955-1976]: Socialismo, peronismo y revolución. Rosario: Prohistoria.

-Rot, Gabriel (2016) "Un balance de los estudios sobre las Organizaciones Político Militares argentinas” en Archivos, $\mathrm{N}^{\circ}$ 9, septiembre de 2016, pp. 33-53

-Rouquié, Alain (1982) Poder Militar y Sociedad Política en la Argentina, 1943-1973, Vol II, Bs. As., Emecé.

-Rougier, Marcelo y Fiszbein, Martín (2006). La frustración de un proyecto económico. El gobierno peronista de 1973-1976, Buenos Aires: Ediciones Manantial. 
-Salas, Ernesto (2007) "El errático rumbo de la vanguardia montonera", en Lucha Armada,

Año 3, No 8, pp. 32-41.

-Salcedo, Javier (2011) Los Montoneros del barrio. Bs.As. EDUNTREF

-Salerno, Agustín (2019) Una nueva derecha embarrada: perfiles de gestión PRO en torno a la cuestión social de la ciudad de Buenos Aires (2007-2015). Sociohistórica, (44): e083.

Disponible en: http://www.memoria.fahce.unlp.edu.ar/art revistas/pr.11023/pr.11023.pdf -Sarlo, Beatriz (2001) La batalla de las ideas (1943-1973) Bs. As., Ariel.

-Seminara, Luciana (2015) Bajo la sombra del ombú. Montoneros Sabino Navarro, historia de una disidencia. Bs.As. Imago Mundi

-Serna y Pons (2003) "En su lugar. Una reflexión sobre la historia local y el microanálisis" Contribuciones desde Coatepec, enero-junio 2003/vol. II N4. UNAM.

-Servetto, Alicia (2010) 73/76: El gobierno peronista contra las "provincias montoneras", Bs. As., Siglo XXI.

-Sigal, Silvia (1991), Intelectuales y poder en la década del sesenta, Puntosur, Buenos Aires.

-Sigal, Silvia y Verón, Eliseo (2004) Perón o muerte. Las estrategias discursivas del fenómeno peronista, Bs.As., Eudeba.

-Slipak, Daniela (2015) Las revistas montoneras. Cómo la organización construyó su identidad a partir de sus publicaciones, Buenos Aires, Siglo XXI.

-Soriano, Osvaldo (2015) “El Operativo Dorrego”, en Artistas, locos y criminales, Buenos Aires, Seix Barral.

-Stavale, Mariela (2012). Las Fuerzas Armadas Peronistas y su experiencia alternativa (1964-1979) [en línea]. Trabajo final de grado. Universidad Nacional de La Plata. Facultad de Humanidades y Ciencias de la Educación. En Memoria Académica. Disponible en: http://www.memoria.fahce.unlp.edu.ar/tesis/te.705/te.705.pdf (2017) “'Las aventuras de Tendencio' en la revista Militancia Peronista para la Liberación: humor gráfico para la disputa peronista de los años 70" en Izquierdas. Una mirada histórica desde América Latina, Instituto de Estudios Avanzados de la Universidad de Santiago de Chile, N³5, 2017, pp. 1-30

(2018) Las revistas "Militancia Peronista para la Liberación" y "De Frente con las Bases Peronistas": una propuesta "alternativa" para la identidad política del peronismo revolucionario, 1973-1974 (Tesis de posgrado). - Presentada en Universidad 
Nacional de La Plata. Facultad de Humanidades y Ciencias de la Educación para optar al grado de Doctora en Ciencias Sociales.

-Svampa, Maristella (2003) "El populismo imposible y sus actores, 1973-76” en James,

D. (DIR) Violencia, proscripción y autoritarismo (1955-1976), Tomo IX de la Colección Nueva Historia Argentina, Bs. As., Sudamericana.

(2010) Certezas, incertezas y desmesuras de un pensamiento político.

Conversaciones con Floreal Ferrara. Buenos Aires, 2010.

-Taiana, Jorge (2000) El último Perón. Testimonio de su médico y amigo. Buenos Aires, Planeta.

-Terán, Oscar (1991), Nuestros años sesentas. La formación de la nueva izquierda intelectual en la Argentina, 1956-1966, Puntosur, Bs. As.

-Terán Oscar (2006) “Década del 70: violencia de las ideas”, Revista Lucha Armada, No 5, Bs.As.

-Tocho, Fernanda (2011) "La interna peronista y sus repercusiones en torno a la definición de la candidatura bonaerense. 1972-1973.” XIII ${ }^{\circ}$ JORNADAS INTERESCUELAS / DEPARTAMENTOS DE HISTORIA, Catamarca. Agosto, 2011.

(2012a) "Relaciones peligrosas. Oscar Bidegain, la Tendencia

Revolucionaria y el peronismo: de la apertura democrática al inicio de la obturación política". VI JORNADAS DE TRABAJO sobre HISTORIA RECIENTE, Universidad Nacional del Litoral, Santa Fe. Agosto, 2012

(2012b) "Las esperanzas y el principio del fin. El rol de la Tendencia

Revolucionaria en el gobierno de Oscar Bidegain en la provincia de Buenos Aires, desde la candidatura a la renuncia de Cámpora". Tercer Congreso de Estudios sobre el Peronismo (1943-2012)”, Universidad Nacional de Jujuy. Octubre, 2012

(2014) “Los 'otros setenta': un recorrido por la experiencia de la Tendencia

Revolucionaria del Peronismo en la gobernación bonaerense (1973-1974)" en Aletheia. Revista de la Maestría en Historia y Memoria de la FaHCE, volumen 4, número 8, abril. (2015) "El desafío institucional: las prácticas políticas no armadas de la Tendencia Revolucionaria del Peronismo en el Ministerio de Asuntos Agrarios de la provincia de Buenos Aires (1973-1974)" Sociohistórica. Cuadernos del CISH, FaHCE, UNLP, $N^{\circ} 35,2015$, pp. 1-22.

(2018) "No solo lucha armada. El Operativo Dorrego y la participación institucional de la Tendencia Revolucionaria en la provincia de Buenos Aires”, en: Encuentros Uruguayos. Revista Digital de la Facultad de Humanidades y Ciencias de la 
Educación, Universidad de la República, Montevideo. Vol XI, Núm 1. http://www.encuru.fhuce.edu.uy/images/revistas/numero11/07-Tocho.-FINAL-.pdf

-(2019) "La Tendencia Revolucionaria del Peronismo en la apertura democrática. Un acercamiento a las experiencias de radicalización "movimientistas" y su posicionamiento frente a la salida electoral (1971-1972). Actas de las XVII Jornadas Interescuelas/Departamentos de Historia, Universidad Nacional de Catamarca, 2 al 5 de octubre de 2019.

-(2020) "La interna del Partido Justicialista en la provincia de Buenos Aires y papel de la Tendencia Revolucionaria en la campaña electoral (1972-1973)". Actas y Comunicaciones UNGS - IV Jornadas de Historia Reciente del Conurbano bonaerense - I Jornadas de Historia Reciente de la Provincia de Buenos Aires Código ISSN No 26184621.

-Torre, Juan Carlos (1989) Los sindicatos en el gobierno peronista. 1973-1976, Bs. As. CEAL.

-Tortti, María Cristina (1999) "Protesta social y Nueva Izquierda durante el Gran Acuerdo Nacional”, en Pucciarelli, Alfredo (ed.) La primacía de la política. Lanusse, Perón y la Nueva Izquierda en tiempos del GAN, Eudeba, Buenos Aires.

(2009) El "viejo" partido socialista y los origenes de la "nueva izquierda" (1955-1965). Buenos Aires: Prometeo Libros.

(2014) "La nueva izquierda argentina. La cuestión del peronismo y el tema de la revolución", en Tortti, María Cristina; Chama, Mauricio; Celentano, Adrián, dir. La nueva izquierda argentina [1955-1976]: Socialismo, peronismo y revolución. Rosario: Prohistoria.

-Vaca Narvaja, Fernando y Frugoni, Gustavo (2002) Fernando Vaca Narvaja. Con igual Ánimo. Pensamiento político y biografía autorizada, Bs. As., Colihue.

-Urriza, Manuel (2004) El Perón que conocí. Buenos Aires, Ediciones Continente, 2004.

-Verbitsky Horacio (1985) Ezeiza, Bs. As., Contrapunto.

-Vezzetti, Hugo (2006) Pasado y Presente. Guerra, dictadura y sociedad en la Argentina, Bs.As., Siglo XXI.

(2009) Sobre la violencia revolucionaria. Memorias y olvidos, Bs. As.,

Siglo XXI.

-Viano, Cristina (2011). "Pinceladas sobre las relaciones de género en la nueva izquierda peronista de los primeros años '70", Revista Temas de mujeres, 7, pp. 233-252. 
-Weber, Max. 1984 "Parlamento y gobierno en el nuevo ordenamiento alemán”, en Escritos políticos (Tomo I). México, Folios Ediciones.

-Yofre, Juan Butista (2015) Puerta de Hierro. Los documentos inéditos y los encuentros secretos de Perón en el exilio. Buenos Aires. Sudamericana. 